INVENTING EDEN:

\title{
PRIMITIVISM, MILLENNIALISM, AND THE MAKING OF NEW ENGLAND
}

\author{
Zachary McLeod Hutchins
}
A dissertation submitted to the faculty of the University of North Carolina at Chapel Hill in partial fulfillment of the requirements for the degree of Doctor of Philosophy in the Department of English and Comparative Literature.

\section{Chapel Hill}

2010

Approved by:

Philip Gura

Reid Barbour

Laurie Maffly-Kipp

Timothy Marr

Mary Floyd-Wilson

Eliza Richards 
(C) 2010

Zachary McLeod Hutchins

ALL RIGHTS RESERVED 


\begin{abstract}
ZACHARY McLEOD HUTCHINS

Inventing Eden: Primitivism, Millennialism, and the Making of New England (Under the Direction of Philip Gura)
\end{abstract}

Seventeenth-century exegetes described Eden as a three-fold paradise because they believed that Adam and Eve lived in "an external garden of delight," possessed incorrupt physiologies, and enjoyed intellectual, spiritual, and social perfections before the Fall. Accordingly, the dissertation is organized thematically, treating the ways in which New England colonists sought to mold their lands, bodies, minds, language, souls, and social spheres after the pattern provided in Eden. Chapter one traces the transition of terms used to describe the New England landscape from the present "paradise" of John Smith to the "hideous and desolate wilderness" of William Bradford and the prospective "Paradise" of Cotton Mather. Chapter two outlines programs of physiological reform, as colonists like Anne Bradstreet disciplined their physical bodies and ministers like Edward Taylor regulated the ecclesiastical body's consumption of communion in order to achieve humoral temperance - the somatic and spiritual state of Adam and Eve in Eden. Chapters three and four document Francis Bacon's influence on educational and linguistic aspirations in New England. I argue that because the encyclopedic knowledge and divinely denotative language of Adam were believed to be inseparably linked, Leonard Hoar's plans to turn Harvard into the world's first experimental laboratory in chemistry situated at a university and John Cotton's attempt to model the language of the Bay Psalm Book after the lingua humana of 
Eden should be understood as related endeavors, companion contributions from New England to the Baconian project for the instauration of prelapsarian intellectual perfections. Chapter five examines the ways in which ministers of the Great Awakening presented Adam and Eve to their congregants as types of Christian conversion, and chapter six details the process by which theories of natural law distilled from Genesis became the basis for colonial rebellion and republican government through the influence of Oceana, James Harrington's vision of an idealized, edenic republic. Spanning two centuries and surveying the works of major British and American authors from George Herbert and John Milton to Jonathan Edwards and Benjamin Franklin, Inventing Eden is the history of an idea that irrevocably altered the theology, literature, and culture of early modern New England. 
For my very own Eve, a mother who knows. 


\section{ACKNOWLEDGMENTS}

No one, sadly, volunteered to write this dissertation for me, but many contributed their time, talents, and other assets so that I could write more cogently and more quickly than I ever would have been able to on my own. Much as I would like to I cannot name all of those who helped me to learn and write about Eden — time and space will not permit. But the following individuals simply must be mentioned; without them this study would not exist in anything like its current form.

My first debt is to Janet Garrard, who persuaded me that such a work was possible. The Brigham Young University Office of Research and Creative Activities allowed me to pursue the dreams that she awakened by financially supporting the mentorship of Steve Walker, whose wisdom continues to be a source of strength. David Shields and the anonymous readers for Early American Literature, who reviewed the essay has since become Chapter 5, were enormously generous in their treatment of undergraduate writing, and their patient feedback continues to shape my understanding of how to write for the academy. After I thought I had learned to write, Eliza Richards-who reads more carefully than anyone I know - taught me to revise, for which I am deeply grateful. Reid Barbour never allowed me to rest on my laurels, and the breadth of this study is a testament to both the capacious curiosity he constantly exudes and his willingness to tutor me on the finer points of seventeenth-century British culture. Laurie Maffly-Kipp introduced me to a world outside of English department readings lists and understood the point of this study before anyone else, 
even myself. Mary Floyd-Wilson deserves a special note of thanks for being patient enough and honest enough to persistently point out the flaws in early drafts until I was ready to listen to her invaluable critiques and for introducing me to the Folger Institute, where David Hall, Laura Lunger Knoppers, and the members of our seminar on "Forms of Religious Experience in the $17^{\text {th }}$-Century British Atlantic World" provided feedback that dramatically influenced this project's trajectory. The Americanist Writing Group at the University of North Carolina at Chapel Hill also provided helpful feedback on early drafts of several chapters; Angie Calcaterra and Kelly Bezio did more than anyone had a right to expect in making that group's work possible. The friendship of Tim Marr was a pleasant surprise to a young graduate student; I hope that someday I will learn to imitate his endless enthusiasm and knack for asking just the right question. My final and largest academic debt is to Philip Gura. His scholarship brought me to Chapel Hill and laid a groundwork for all that follows in this study; his expertise opened doors and books that I never would have found on my own; and his unflagging support gave me a reason to hope that I might someday succeed. I will always be his student.

Even with all of this intellectual firepower behind me, I could never have completed this dissertation without the support of family and friends, who made it possible for me to spend hours in solitude without worrying overmuch about what was happening outside of my office. I thank my father- and mother-in-law, Jerry and Nancy Ogarek, for making sure I had the proverbial "five hundred pounds and a room of my own." I thank Akram and Jodi Khater for their friendship and seemingly unbounded optimism. I thank my brother Richard for setting the bar so high and then daring me to jump. I thank my parents, Kenneth and Priscilla, for finding the courage to be interested in my work and for raising me in the New England 
Puritan tradition. I thank my sons: Kenneth MacLeod for staying asleep while we shared an office/nursery; David Hyrum for his uplifting hugs; and Gabriel Ogarek for his energetic invitations to leave it all behind and play at the end of each day. But most of all, I thank my wife and muse, Alana. She is both the reason I write and the reason I stop writing, the summum bonum of my life. 


\section{TABLE OF CONTENTS}

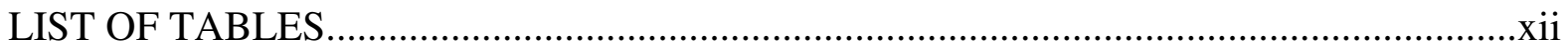

INTRODUCTION

Edenic Past, Edenic Future: The Turn from Primitivism to Millennialism.....................3

The Limits and Labor of Eden: Separating the Ideal from the Idyllic..........................17

Invention: Discovery, Interpretation, and Innovation................................................31

Intellectual Roots, Cultural Fruits: Grounding Intellectual History..............................37

Inventing Eden: Methods and Materials...................................................................45

\section{CHAPTERS}

I. FINDING PARADISE, INVENTING WILDERNESS: THE GEOGRAPHICAL POSSIBILITIES AND AGRICULTURAL REALITIES OF COLONIAL NEW ENGLAND.....................................................56

Finding Paradise: “The More I Looked, the More I Liked It."....................................59

Cultivating Wilderness: Importing English Order and Invention.................................83

Confronting Failure: The Inward Turn....................................................................102

II. A BODY UNEMBARRASSED: HUMORAL EMPOWERMENT AND ASPIRATIONS TO EDENIC TEMPERANCE.............................................111

Other-Fashioning: The Limits of Humoral Empowerment.......................................119

Engendering Edenic Temperance: The Sexing of Medicine.......................................123

Embarrassed By Sin: Humoral Correctives for Ecclesiastical Intemperance.............139

The Humoral Inheritance: Pauper to Printer..............................................................156 
Edenic Body, American Identity...

III. THE WISDOM OF SOLOMON: ADAM, EVE, AND BACON'S LEGACY IN NEW ENGLAND

New England as New Atlantis: Cotton's Epistemological Mandate.

The Aims of a College: Harvard's Place in the Paradisiacal Tradition 180

The Wisdom of Anne Bradstreet: Imitating Elizabeth, Outdoing Solomon

An Edenic Enlightenment: The Science of Mather and Edwards

IV. TRANSLATIONS OF EDEN: HEBREW, HERBERT, AND THE NEW ENGLAND INTEREST IN LINGUISTIC PURITY.

Entering The Temple: Two Paths Back to Paradisiacal Purity. .226

"In the Beginning Was the Word": The Plain Language of the Bay Psalm Book.

"Make my Leaden Whittle, Metall Good": Edward Taylor and the Alchemy of Eden.

Paradise Lost, Paradise Regain'd: The Eighteenth-Century Move to Milton.

V. FROM ADAM'S INNOCENCE TO EVE'S REGENERACY: ALTERNATIVE MODELS AND MORPHOLOGIES OF CONVERSION IN EARLY MODERN NEW ENGLAND. 279

Exemplary Pilgrims: Seventeenth-Century Narratives of Conversion.......................289

First Stirrings: Preparing for the New Birth in New England.....................................300

Labor and Delivery: Edwards, Eve, and the New Birth............................................314

The After Birth: Eve's Impact on Edwards and the Awakenings................................322

VI. 'OUT OF CHAOS AND CONFUSION': THE BELATED CREATION AND ANTICIPATED FALL OF HARRINGTON'S EDENIC REPUBLIC 328

Declaring Eden: Jefferson, Grotius, and the Natural Law Tradition. 330

The Architecture of Eden: Right Reason and Republican Government .344 
A Snake in the Garden: Portents of the Fall.

The Conclusion of the Whole Matter: Vanity of Vanities, All is Vanity.

.400

\section{APPENDICES}

A. A COMPENDIUM OF NEW ENGLAND FLORA AND FAUNA

CATALOGUED IN ACCOUNTS OF THE 1620s AND 1630s.....

B. A COLOR-CODED ETYMOLOGICAL AND SYLLABIC ANALYSIS OF THREE PSALTERS.

BIBLIOGRAPHY. 


\section{LIST OF TABLES}

Table 1: Words Per Psalm..........................................................................................253

Table 2: A Comparative Analysis of Three Versions of the $23^{\text {rd }}$ Psalm.............................254

Table 3: Etymological Composition of the Bay Psalm Book..........................................255

Table 4: A Comparative Analysis of Three Psalters' Etymological Roots.........................257 


\section{INTRODUCTION}

When Christopher Columbus first arrived in the New World, he found that on the island of Española the indigenous people "all go naked, men and women, as their mothers bore them, although some women cover a single place with the leaf of a plant or with a net of cotton which they make for the purpose." Columbus eventually comes to understand both the nakedness and the strategic covering of these "Indians" in biblical terms, converting their foreign customs and the fecundity of the land into symbols of Eden. ${ }^{2}$ By the time of his third voyage to the West Indies, Columbus had developed new theological and geographical theories to account for the edenic character of Española and the surrounding islands. He postulated that the globe was shaped like "a very round pear, which has a raised stalk ... or like a woman's nipple on a round ball": the Eastern Hemisphere from which he sails is spherical, like the bottom half of a pear; the Western Hemisphere of the New World tapers inward and upward, culminating in a mountain that protrudes from the earth's surface like the stem of a pear; and Columbus believed that the garden of Eden was located on top of that

\footnotetext{
${ }^{1}$ Christopher Columbus, The Four Voyages of Columbus, ed. Cecil Jane, Vol. I, (New York: Dover Publications, 1988), 6.

${ }^{2}$ Edmundo O'Gorman traces the process by which Columbus's empirical experiences are converted into subjective realities and concludes that "neither things nor happenings are something per se; their being (not their existence) depends on the meaning given to them in within the framework of the image of realtity valid at a particular moment" (Edmundo O'Gorman, The Invention of America, [Bloomington: Indiana University Press, 1961] 51). Because Columbus discovered a new—or unknown world—-"within a world which, by definition allowed no such possibility," this new world was understood as a remnant of an already known "new world"Eden (69). Tzvetan Todorov likewise remarks on the pre-determined nature of Columbus's discovery of Eden: "The interpretation of nature's signs as practiced by Columbus is determined by the result that must be arrived at" (Tzvetan Todorov, The Conquest of America, trans. Richard Howard, [New York: Harper \& Row, 1984], 22).
} 
mountain. Columbus's theory contradicts both the "authoritative accounts and the

experiments which Ptolemy and all the others have recorded concerning this matter" of world geography and "all the learned theologians [who] agree that the earthly paradise is in the East," yet he maintained that Eden was located in the New World. ${ }^{3}$

Although Columbus was certain that Eden's presence had a tempering influence on the surrounding climate and population, with fresh water from the four rivers that he believed flowed out of the garden pushing back the salt water of the ocean, he refused even to attempt to ascertain the validity of his theory. He did not seek Eden itself because he did not believe "that the summit of the extreme point is navigable, or water, or that it is possible to ascend there, for I believe that the earthly paradise is there and to it, save by the will of God, no man can come." Columbus exhorted Ferdinand and Isabella to send additional colonists to harvest the edenic resources and convert the innocently "simple" inhabitants of the New World, but he did not presume that his discovery will allow humanity to re-enter Eden in all its prelapsarian splendor. Instead, he thought of himself as "the messenger" of God whose arrival in the New World fulfilled the apocalyptic prophecies of Isaiah, by whose mouth God "spake so clearly of these lands ... affirming that from Spain His holy name should be proclaimed to them." "For Columbus, as Djelal Kadir notes, "the progress of the soul was no longer toward a Golden Age of yore but in an investment in the features of futurity, whether Elysian fields or Arcadian eutopias." Columbus expounded on his millennial vision for the

\footnotetext{
${ }^{3}$ Columbus, The Four Voyages II.30, 36, 28.

${ }^{4}$ ibid, II.36, I.78, II.2-4.Though Columbus does not identify the specific verses in Isaiah to which he is referring, his Book of Prophecies highlights chapter fifty-one of Isaiah repeatedly, where God promises "to make her desert as a place of pleasure and her wilderness as the garden of the Lord" and indicates that the "islands shall look for me and shall wait patiently for my arm" until "the earth shall be worn away like a garment" (Christopher Columbus, The Libro de las Profecías of Christopher Columbus, trans. Delno C. West and August King, [Gainesville: University of Florida Press, 1991], 175). This introduction, like Columbus's descriptions of the New World, conflates the themes of origin and ending, Eden and Judgment, when the righteous would enjoy a paradisiacal state and the wicked would be thrust down to Hell.
} 
future of this edenic New World in the Book of Prophecies, establishing a link between Eden and eschatology from the very beginning of what we now call American literature that was reaffirmed and revisited throughout the following four centuries by American—and New England-authors from Cotton Mather to Herman Melville. ${ }^{5}$

\section{Edenic Past, Edenic Future: The Turn from Primitivism to Millennialism}

While the edenic and eschatalogical themes of Columbus, Mather, and Melville are widely acknowledged, intellectual historians have recently called into question the continuity of this apocalyptic tradition, and Reiner Smolinski complains that historians of religion and literary scholars alike have projected the eschatological focus of Mather and Melville "back into the motivation of the first settlers [of New England] and thus read the literature of this transmigration in light of its later manifestation." There simply is no evidence, Smolinski suggests, that "millenarian ideology informed the Puritan exodus during the first wave of emigration, because such issues did not become pronounced until a full decade after the first wave of settlers had arrived in New England." ${ }^{6}$ Others have argued that the central incentives

\footnotetext{
${ }^{5}$ Djelal Kadir, Columbus and the Ends of the Earth, (Berkeley: University of California Press, 1992), 3. The apocalyptic bent of American literature is the subject of Douglas Robinson's American Apocalypses. While Robinson assumes that "the very idea of America in history is apocalyptic," this study challenges that assertion's simplicity and illustrates the ways in which American apocalypticism is inextricably linked to primitivist priorities. Understanding this initial link between Armageddon and Eden reveals a shift in the significance of the apocalypse; whereas seventeenth- and eighteenth-century writers looked forward to the event as a transformative experience that would lead to a physical and spiritual renewal of the community, Robinson suggests that by the middle of the nineteenth century, apocalyptic meditation "becomes too efficacious, too likely to intiate a transformation that will endanger the collective vision of the community." While the apocalyptic literature of the nineteenth and twentieth centuries that Robinson surveys may function as "betrayals of mankind's holiest self-conceptions, expressions of a diseased lust for racial suicide," the first expressions of an American apocalyptic tradition were anything but - they were the means by which mankind's holiest self-conceptions were realized, not betrayed. See Douglas Robinson, American Apocalypses, (Baltimore: Johns Hopkins University Press, 1985), xi, xv, 3.

${ }^{6}$ Reiner Smolinski, “Apocalypticism in Colonial North America," in The Encyclopedia of Apocalypticism, Vol. 3, ed. Stephen J. Stein, (New York: Continuum, 1998), 37; Reiner Smolinski, General Introduction to The Kingdom, the Power, \& the Glory, ed. Reiner Smolinski, (Dubuque: Kendall/Hunt, 1998), xii.
} 
for emigration to New England were economic and not eschatological, but the primary motivation of Puritans who left their England homes for the Bay Colony could not have been a desire for wealth. As Howard Russell notes,

an unemployed spinner or weaver of woolens or even an enterprising London merchant might be led by alluring reports into adventuring in a new country, [but] it would ordinarily take more than a year or two of poor markets or low income to uproot country gentlemen such as [John] Winthrop or [John] Endecott, or yeomen and husbandmen with fertile lands, ancestral rights, and assured position in Essex, Norfolk, Lincoln, or Middlesex. ${ }^{7}$

Neither eschatology nor economic necessity can fully explain the Puritan emigration; instead, the Puritan exodus should be understood primarily as an extension of the Protestant Reformation, a movement to restore Christianity to an original state of purity in an environment free from the creeping influence of papacy.

T. D. Bozeman has shown that the Puritan emigration was a movement intended to reverse "the decline of centuries but one that also curved back to restore contact with originals and return Christianity to its primitive foundations. In this context, 'reformation' (or 'restoration' or 'restitution'), describing the distinctive task of Protestant Christians until the approaching end of the world, was distinguished by the prefix $r e-$, signifying directedness toward the first and best." The texts produced by Puritan emigrants in the 1630 s reflect a "sustained preoccupation with moral and primitive purity"; the colonists looked to the past for a model of individual and ecclesiastical innocence, to biblical history—not to a glorious millennial future. ${ }^{8}$ Bozeman and others identify the early Christian church of the first and second centuries as the central influence on Puritan aspirations to primitive purity, but the innocence of Eden was, arguably, an even more important standard for Winthrop and the first

\footnotetext{
${ }^{7}$ Howard S. Russell, A Long, Deep Furrow, (Hanover: University Press of New England, 1976), 28.

8 Theodore Dwight Bozeman, To Live Ancient Lives, (Chapel Hill: University of North Carolina Press, 1988), 18,7 .
} 
wave of Puritan colonists to cross the Atlantic. After all, as the assembled divines of the Massachusetts Bay Colony pointedly told John Cotton during the Antinomian Controversy: to have "the Image of God in Adam renewed in us" was the entire point of the Puritan errand into the wilderness. ${ }^{9}$

\section{From Edenic Innocence...}

The desire to make the Bay Colony specifically, and New England generally, into an exemplary society is one that has long been recognized by scholars of American literature. Sacvan Bercovitch, among others, argues that Puritan theology in New England-even during the 1630s—revolves around "a prophetic vision that unveils the promises, announces the good things to come, and explains away the gap between fact and ideal," between the current state of New England's churches and "millennial expectations, for America first and then the world." 10 Those who emphasize the eschatological character of 1630s theology point, with Bercovitch, to John Winthrop's foundational sermon, “A Modell of Christian Charitie," as an early manifestation of millennial fervor. But Bozeman argues forcefully and persuasively that Winthrop's call to "be as a Citty vpon a Hill" is not the "climax or conclusion to Winthrop's principal arguments. [The words] occur, instead, in passing, in the midst of a paragraph that commences with and proceeds to other and thematically more central matters."11 Winthrop's sermon clearly revolves around the idea of establishing an ideal society, but the central image of that society in the "Modell" is not the millennial New Jerusalem encoded as a "Citty vpon a Hill" or even the primitive Christian church: it is Eden.

\footnotetext{
${ }^{9}$ John Cotton, Sixteene Questions of Serious and Necessary Consequence, in The Antinomian Controversy, 1636-1638, $2^{\text {nd }}$ ed, ed. David D. Hall, (Durham: Duke Univerity Press, 1999), 51.

${ }^{10}$ Sacvan Bercovitch, The American Jeremiad, (Madison: University of Wisconsin Press, 1978), 16, 42.

${ }^{11}$ John Winthrop, “A Modell of Christian Charity,” in Winthrop Papers, Vol. 2, ed. Stewart Mitchell, (Boston: Massachusetts Historical Society, 1931), 295; Bozeman, To Live Ancient Lives, 92.
} 
Describing the community which he plans to establish at the Bay, Winthrop exhorts church members to acquire the love that bound their first parents together in the garden of Eden and that will allow them to enjoy a paradisiacal social unity in New England. Winthrop explains that as it was for Adam and Eve before the Fall, so too is it

between the members of Christ, each discernes by the worke of the spirit his owne Image and resemblance in another, and therefore cannot but loue him as he loues himself: Now when the soule which is of a sociable nature findes any thing like to it selfe, it is like Adam when Eue was brought to him, shee must haue it one with herselfe this is fleshe of my fleshe (saith shee) and bone of my bone shee conceiues a greate delighte in it, therefore shee desires nearness and familiarity with it: shee hath a greate propensity to doe it good and receiues such content in it, as feareing the miscarriage of her beloued shee bestowes it in the inmost closett of her heart, shee will not endure that it shall want any good which see can giue it, if by occasion shee be withdrawne from the Company of it, shee is still looking towardes the place where shee left her beloued, if shee heare it groane shee is with it presently, if shee finde it sadd and disconsolate shee sighes and mournes with it, shee hath noe such ioy, as to see her beloued merry and thriueing, if shee see it wronged, shee cannot beare it without passion, shee setts noe boundes of her affeccions, nor hath any thought of reward, shee findes recompence enoughe in the exercise of her loue towardes it. ${ }^{12}$

The sheer length of Winthrop's encomium on Eve's marital affections indicates that the edenic pattern she represents is more central to Winthrop's conception of the Bay's future than his brief reference to Christ's sermon on the mount and the image of a city on a hill. But Eve is not the only exemplary inhabitant of Eden, and in his sermon Winthrop returns to other images and attributes of the garden repeatedly; even when he introduces alternative models of Christian charity from outside the garden, he takes pains to connect them to Eden.

Winthrop does identify the early Christian church as a group that collectively attained the charity originally possessed by Eve. Because the primitive Christian church abolished private property, a product of the Fall, and because the believers, like Adam and Eve, "were of one heart and of one soul: neither said any of them that ought of the things which he

\footnotetext{
${ }^{12}$ Winthrop, “A Modell of Christian Charity,” 290-91.
} 
possessed was his own; but they had all things common," Winthrop understands their selflessness as an antitype to edenic charity. In describing the early Christian church, Winthrop calls attention to God's promise that "such as haue beene most bountifull to the poore Saintes ... shalt be like a watered Garden, and they shall be of thee that shall build the old wast places," implicitly referencing God's promise in Isaiah that he "will make her wilderness like Eden, and her desert like the garden of the Lord." ${ }^{13}$ Winthrop points out that "Adam in his first estate was a perfect modell of mankinde in all theire generacions, and in him this loue was perfected," making Adam a type of all the regenerate, of every individual who achieved the love that he possessed naturally in Eden. More conventionally, Winthrop also describes Adam as a type of Christ; when charity "is thus formed in the soules of men it workes like the Spirit vpon the drie bones Ezek. 37. [7] bone came to bone, it gathers together the scattered bones or perfect old man Adam and knits them into one body againe in Christ whereby a man is become againe a liueing soule. ${ }^{\prime 14}$ Adam and Eve provide the climactic examples of charity in Winthrop's sermon, and Eden is the "Modell" after which he urges his listeners to pattern their own lives.

The edenic aspirations that Winthrop outlines in his "Modell" are characteristic of the earliest Puritan preaching in New England. In his Parable of the Ten Virgins, Thomas Shepard reflects on the spiritual state of the New England elect "whom God hath called out of the world, and planted in his Church" and asks, "What hath the Lord done, but opened the way to the Tree of life, and let you into Paradise again?" As Jesper Rosenmeier notes, the difference between Adam in Paradise and Shepard's renewed Christian in New England is one of degree only: 'Those that are renewed to Adams image in their measure, have according to that measure, power to act; ... for he had power so to do

\footnotetext{
${ }^{13}$ Acts 4:32; Winthrop, "A Modell of Christian Charity," 287-88; Isaiah 51:3.

${ }^{14}$ Winthrop, "A Modell of Christian Charity," 290.
} 
... Adam had a Law of Divinity, whereby he being a cause by Counsel, was enabled by God to carry himself toward his end. Now, we are renewed to that image in part. ${ }^{, 15}$ Shepard's belief in an "individual and collective renewal of man in Adam's image" became "official doctrine" in New England, but he was not the only—or even the most prominentpreacher in New England, and other ministers invoked the edenic motif in their sermons for different purposes. ${ }^{16}$

Whereas Shepard — and the vast majority of his contemporaries in the 1630s—viewed Eden solely as a model for the restoration of spiritual innocence, Cotton was one of the few preachers who saw in Eden a physical pattern of a millennial future even before civil unrest in England during the 1640s prompted eschatological excitement among Puritans on both sides of the Atlantic. Eden was, for Cotton, a pattern of the new heavens and the new earth that would be physically restored in the millennium when God "would come to repaire decayed nature." ${ }^{17}$ Given the importance of the edenic model to the primitivist aspirations that were replaced by widespread millennial fervor in the 1640s, it was, perhaps, inevitable that when "Puritan thinkers became interested in the millennial idea, they tied it firmly to [their original] primitivist priorities. The expected age of fulfillment was understood in several senses as the climax of Protestant restoration, the finally triumphant reversion to primordial conditions." ${ }^{18}$ By the midpoint of the seventeenth century, the millennial Eden of Cotton had replaced the primitive Eden of Shepard, and ministers who believed that the edenic perfections described in Genesis would be restored to the earth prior to the impending

\footnotetext{
${ }^{15}$ Thomas Shepard, The Parable of the Ten Virgins, (London: J. Hayes, 1660), 5; Jesper Rosenmeier, "New England's Perfection: The Image of Adam and the Image of Christ in the Antinomian Crisis," The William and Mary Quarterly 27.3 (1970): 441.

${ }^{16}$ Rosenmeier, "New England's Perfection: The Image of Adam and the Image of Christ in the Antinomian Crisis," 440.

${ }^{17}$ John Cotton, The Way of Life, (London: M.F., 1641), 164.
} 
apocalypse promised in Revelation had appropriated the paradisiacal rhetoric of preachers with primitivist priorities. The prospect of recapturing the prelapsarian perfections enjoyed by Adam and Eve motivated both the primitivist and the millennial movements in the seventeenth century, providing an illusion of eschatological continuity to modern critics in the late 1970s and early 1980s. Eden was the ideal to which early modern New England looked as a pattern of primitive purity during the 1630s and as a model of millennial perfection in the late seventeenth and eighteenth centuries; it is the theological touchstone that united two otherwise incompatible visions for New England's future.

\section{...to English Eschatology}

Cotton's conflation of Genesis and Revelation, of the beginning and end points of sacred time and sacred text, was the product of a slow evolution in Protestant apocalyptic thought from the Catholic starting points of Columbus. ${ }^{19}$ In the sixteenth and early seventeenth centuries, apocalyptic interpretations were primarily derived from three books of scripture: Daniel, Revelation, and the apocryphal Prophecy of Elias. ${ }^{20}$ Sixteenth-century Protestant exegetes found in these texts a prophetic vision and timetable for what they then

\footnotetext{
${ }^{18}$ Bozeman, To Live Ancient Lives, 18.

${ }^{19}$ My discussion of English apocalypticism is significantly indebted to the magnificent work of Katharine R. Firth, who traces the evolution of the apocalyptic tradition in Britain from its Catholic origins into the 1640s, when she suggests that Joseph Mede makes the last original and significant contribution to the tradition for several centuries. For more on the topic, see her discussion of The Apocalyptic Tradition in Reformation Britain (Oxford University Press, 1979). Bryan Ball's A Great Expectation (E. J. Brill, 1975) and Ernest Lee Tuveson's Millennium and Utopia (University of California Press, 1949) and Redeemer Nation (University of Chicago Press, 1968) also provide thorough overviews of the development of millenarian thought, Ball in England and Tuveson more generally. For an overview of the quest to regain paradise that ranges from ancient to modern, see Charles L. Sanford, The Quest for Paradise, (Urbana: University of Illinois Press, 1961).

${ }^{20}$ The Prophecy of Elias was the product of a third-century Midrash, and while it was considered a questionable source by many sixteenth-century Protestants, Revelation was also treated with considerable skepticism. Revelation was not initially accepted by Luther, and it was damned by faint praise from Calvin, who noted only that "it should not enjoy the same authority as the gospels." By the mid seventeenth century, this group of texts was enlarged to include Canticles; both Thomas Brightman and John Cotton delivered commentaries on the apocalyptic tradition in commentaries on Canticles. See Firth, The Apocalyptic Tradition in Reformation Britain, 5, 9.
} 
understood to be historical events. Luther and other early German reformers firmly tied the contemporary papacy to the figure of the Antichrist in the Revelation of John, and exiles from England, including John Bale and John Foxe, likewise identified late medieval and Renaissance popes as a collective representation of the Antichrist. After making this connection between the papacy and the Antichrist, Protestant exegetes typically adopted one of two positions with regards to the millennium: they either understood the millennial period to be an already-passed thousand-year interval that began with Christ's birth, when Satan was bound, and that ended with the papal corruption which signaled his release and an imminent descent into the final war preceding Judgment Day; or they understood it as a future interval of peace, prosperity and ecclesiastical purity that would follow the destruction of Rome, a time when Satan's power would be severely limited or eliminated that would precede the Second Coming. ${ }^{21}$ Those who embraced the latter view were known as postmillennialists. The Second Helvetic Confession (1564) discouraged the postmillennial position among Protestants, particularly inasmuch as their "belief in an approaching Golden Age" produced expectations of a material kingdom and temporal perfection, but Katharine Firth notes that "a significant minority" maintained their belief in a period of millennial perfection that would precede Christ's return to earth. $^{22}$

\footnotetext{
${ }^{21}$ Though he was originally a believer in a future millennium, Bale ultimately argued that the thousand year period was an historical reality that began with the birth of Christ. Foxe, on the other hand, believed that the millennium had begun with the ascension of Constantine and ended around 1300 AD. The important point of continuity in this tradition is the identification of the millennium as an historical and not a future event.

${ }^{22}$ Firth, The Apocalyptic Tradition in Reformation Britain, 148. Crawford Gribben explains that postmillennialists were divided into two different camps: "John Alsted's The Beloved City (1643) advanced a postmillennial reading of Revelation which included a physical first resurrection. John Cotton's The Churches Resurrection (1642) was also a postmillennial apologetic, but advanced an allegorical reading of the first resurrection: "the first Resurrection was the rising of men from spirituall death to spirituall life." It is this second position advocated by Cotton that most closely concerns us both because Cotton was a New Englander whose influence on millennial thought was immense and because the practical establishment of Eden could be accomplished by the church with a minimum of divine intervention if the resurrection were understood to be a
} 
For those late sixteenth-century thinkers who did look forward to the promise of "a new heaven and a new earth" after the impending battle of Armageddon or who expected a postmillennial future, Eden assumed importance as an historical model of the physical and spiritual perfection they anticipated. ${ }^{23}$ Early English apocalyptic thinkers who, like Bale, thought of the millennium as a future event strove to avoid being identified as chiliasts, radical reformers who worked to hasten the millennium by "the slaughter of the ungodly or by the withdrawal of the elect into a separate community," and so avoided the topic of physical, temporal perfection. Instead, without "denying that the renovation of the creation would be physical as well as spiritual, [they] sought to lay ... emphasis on the spiritual renovation of God's glory." ${ }^{24}$ However, Michael Fixler notes that by the end of the sixteenth century Hugh Broughton and Thomas Brightman had connected the millennial hopes of Bale and Foxe to "the faith of the godly in their nation" and turned English apocalypticism to a more temporally grounded hope "in a future Golden Age which would see not only the perfection of religion but also the completion of knowledge"- a specifically English recovery of the mastery that Adam enjoyed over the physical world in the garden of Eden. Indeed, Brightman is the source of theological innovations that made it possible for Cotton and other New Englanders to imagine a millennial Eden: he approached John's Revelation "armed with an indefatigable love of invention" and national identity, assured that Eden's

\footnotetext{
figurative or spiritual change instead of a physical one. See Crawford Gribben, The Puritan Millennium, (Milton Keynes: Paternoster, 2008), 27-28.

${ }^{23}$ Revelation 21:1. Because this study encompasses the seventeenth and eighteenth centuries, all biblical references are from the King James Version of the Bible unless otherwise noted. While the Geneva Bible was more influential in the early seventeenth century, the Authorized Version soon replaced it as the standard biblical text in New England.

${ }^{24}$ Firth, The Apocalyptic Tradition in Reformation Britain, 10, 56.
} 
past perfection was presently possible for the English people. ${ }^{25}$

Brightman was a Bedfordshire clergyman of little renown whose works were published posthumously and whose contribution to English eschatology was accordingly widely recognized only after his death in 1607 . His primary contribution to the apocalyptic tradition of Bale, Foxe, and Broughton was the invention of a system of panes and counterpanes in which the seven churches of Ephesus, Smyrna, Pergamos, Thyatira, Sardis, Philadelphia and Laodicea to whom John's Revelation is addressed are read as "a Type of all the Churches amonge the Gentiles." More specifically, Brightman identifies the church in Laodicea as a type of the English church: "The Counterpaine (I say) of Laodicea, is the third reformed Church, namely: Our Church of England."26 God's approbation for the English church, Brightman argues, is manifest in the physical abundance England has enjoyed under Elizabeth, an abundance that seems to come without strife or undue labor as

lawes are in force, iudgment is executed, euery man enioyeth his owne, iniuryes are repressed, all reproachfull dealinge in word or deede is curbed in, the Nobilitie is honoured, the Cominaltie fall hard to there worke, good learning flourisheth, handicraftes are exercised, Cities are gorgeously sett out, riches are increased, our youth growth vp infinitely, the feildes abound with corne, the pastures with cattell, the mountaynes with sheepe. What neede many wordes?

But Brightman's typology does more than simply acknowledge God's providence. He innovates by transcending the limitations of history and scripture and entering the realm of prophecy with the claim that the utopian conditions he describes will transform those "that shall keep themselues pure from the corruptions of these tymes, and shall not forsake theire first loue" into "the true and free denizens of this holy Church, [who] shall haue liberty and

\footnotetext{
${ }^{25}$ Michael Fixler, Milton and the Kingdoms of God, (London: Faber and Faber, 1964), 39; Firth, The Apocalyptic Tradition in Reformation Britain, 175, 166.

${ }^{26}$ Thomas Brightman, A Revelation of the Revelation, (London: 1615), 124, 125.
} 
power to eate of Christ who is that true tree of life in the mids of this newe Eden." ${ }^{27}$ In Brightman's mind, the coming millennium will bring physical prosperity and spiritual perfection to England, returning members of the church of England and eventually all the world to the spiritual perfections and physical ease of Adam's prelapsarian paradise. Brightman's primary contribution to English eschatology is his identification of the immediate future and the English nation as the promised time and location in which millennial prosperity would be realized, an assertion that converted the study of apocalyptic scripture from an exercise in typology to an experiment in prophecy and that allowed believers to work towards the promised end in a new Eden.

In addition to shortening the expected timetable of those with postmillennial hopes, Brightman emphasized the connection between Genesis and Revelation, between the primeval and millennial in scripture, a theme upon which his contemporaries and successors also seized. By the end of the sixteenth century, connecting biblical prophecies to historical events "had become very standard stuff indeed. Interest was rapidly turning to either end of the pattern: to Genesis and to the Apocalypse."28 Like Brightman, Walter Ralegh sought to unify the events at either end of the Bible's sacred timeline; in his History of the World, he postulates that "after the consummation of this world, there shall be a new heaven and a new earth, without any new creation of matter." Ralegh describes the fallen earth's final end in terms of its beginning, moving "from Creation to restoration or renovation, not to judgement and destruction." 29 Thinkers who expected an imminent restoration of the terrestrial perfections that existed before the Fall turned toward Genesis and the Garden of Eden as the

\footnotetext{
${ }^{27}$ ibid, 127, 51 .

${ }^{28}$ Firth, The Apocalyptic Tradition in Reformation Britain, 158.
} 
most reliable sources of information on the conditions they would encounter in the coming millennium.

Even as Eden assumed importance in the early seventeenth-century as a model for the imminent millennial future predicted by Brightman and Joseph Mede, whose indirect influence on New England theologians is detailed by Jeffrey Jue, it continued to serve as an interpretive lens for explorers striving to understand and communicate the natural abundance of the New World to readers in England. ${ }^{30}$ Seventeenth-century promotional tracts advertising the economic possibilities of the New World touted the edenic character of lands far north of the West Indies, and John Smith's first description of the land that he names New England contains the obligatory references to Adam, Eve, and Eden. Despite its northern location, Smith contends that New England's climate "is as temperate and as fruitfull as any other paralell in the world"; the country is "as God made it, when he created the world," and if settlers will only follow the example of "Adam and Eve [who] did first beginne this innocent worke, To plant the earth," they will realize its potential and reap the physical and spiritual rewards of their predecessors. ${ }^{31}$ In New England Smith offered an Eden ready for planting to those colonists unwilling to wait for Brightman's prophecies to be fulfilled in Old England.

Contemporary theories about the genealogical origins of the New World's inhabitants

\footnotetext{
${ }^{29}$ As quoted in Firth, The Apocalyptic Tradition in Reformation Britain, 181; Firth, The Apocalyptic Tradition in Reformation Britain, 182.

30 Jue argues that Mede's influence on New England theology was mediated by Thomas Goodwin, who was, unlike Mede, an advocate of the congregational way. Goodwin made Mede more palatable to Cotton, John Davenport, and Edward Johnson. See Jeffrey K. Jue, Heaven Upon Earth, (Dordrecht: Springer, 2006), 175209.

${ }^{31}$ John Smith, “A Description of New England," in Captain John Smith: Writings with Other Narratives of Roanoke, Jamestown, and the First English Settlement of America, ed. James Horn, (New York: Library of America, 2007), 141-42, 170.
} 
only strengthened its association with Eden. In 1611, Broughton conjectured that the Indians were part of the lost ten tribes of Israel, making public record of a theory that had circulated since Columbus first set eyes on the New World. Commenting on perceived linguistic similarities between Hebrew and Native American dialects, which he imagined to be a corrupted derivative of the true Hebrew that had descended from Adam to the Israelites, and on Hebrew's superiority to Greek as a devotional language, Broughton notes in passing that the "Tongue of Adam which continued in Hebers faithfull, not in Iocktanes house, whẽce both Indians are: this hath admiration of height in wisdome."32 He takes for granted the assumption that the reader agrees that the Indians are in fact part of "Iocktanes house," descendants of Joktan and the remnants of a lost biblical tribe. Broughton's passing reference was more fully developed in 1650 by Thomas Thorowgood, who likewise affirmed that "the Jewes did Indianize, or the Indians doe Judaize, for surely they are alike in many, very many remarkable particulars." More importantly, Thorowgood argues, "if they bee Iewes, they must not for that be neglected," because the conversion of the Jews — and therefore the Indians-was understood to be a necessary precondition of the millennium by seventeenthcentury exegetes. ${ }^{33}$ As Richard Eburne put it, "this is a worke that must be done before the end can be." ${ }^{34}$ Before Brightman's edenic millennium could arrive in England, the

\footnotetext{
${ }^{32}$ Hugh Broughton, A Require of Agreement, (Middelburg: 1611), 77.

${ }^{33}$ Thomas Thorowgood, Ievves in America, (London: W. H., 1650), A3. Johann Heinrich Alsted explains this sequence of events and the part that Native Americans played in it. He notes that the conflicts between different Christian sects has already begun the process "on the one side of converting the Indians, on another of converting the Jews, and Turks." The conversion of both the Indians, who were believed to be the descendants of the lost ten tribes of Israel, and the Jews, who were the remnant of the remaining houses of Judah and Benjamin, would prompt the millennium: “...in the first place those ten Tribes, which were carried away by the Assyrians, shall be converted, to whom afterwards the Tribes of Judah, and Benjamin shall joyn themselves" and then "this Church, gathered together of Jews and Gentiles, shall be freed from the persecutions of their enemies." See Johann Heinrich Alsted, The Beloved City (London: 1643), 8, 9.

${ }^{34}$ Richard Eburne, A Plaine Pathway to Plantations, (London: G. P., 1624), 7.
} 
inhabitants of an edenic New World needed to be converted, and quickly_-before Jesuit missionaries, the emissaries of the Antichrist, got to them.

The connections drawn between Eden and the New World, between Eden and the millennium, naturally led some to speculate as to whether the millennium might come to fruition in the New World, where a pre-existing edenic climate and the presence of a people whose conversion would make the millennium possible might expedite the prophesied transition to prelapsarian perfection. While "considering our English Plantations" and New England in particular, William Twisse asked Mede in a letter, "Why may not that be the place of New Jerusalem?" Eburne agreed that "towards the end of the world, the true Religion shall be in America," and George Herbert expressed a poetic certainty that "the Church shall thither westward fly" (259). ${ }^{35}$ As a refuge for religious dissidents who anticipated the end of the world, New England harbored the eschatological hopes of seventeenth-century Puritan colonists in the midst of Indians whose conversion was a precondition to their own millennial future and in a landscape understood in the terms of Eden's natural abundance and temperate climate. Furthermore, because the first inhabitants of New England strove to obtain the "moral and primitive purity" exemplified biblically in Eden and the apostolic church, the Puritans might be said to have looked backward to Eden as a model and forward to Eden as a goal even as they lived in "Massachusetts, which is the Paradise of all those parts." 36 To seventeenth-century Puritans, "the biblical world of saving origins was comprehended as an order of completed perfection. The realm of sacred pattern was closed, all-sufficient,

\footnotetext{
${ }^{35}$ William Twisse, "Fourth Letter to Mr. Mede," in Joseph Mede, Works, (London: James Flesher, 1664), 979; Eburne, A Plaine Path-VVay to Plantations, 7; George Herbert, "The Church-Militant," in The Complete English Poems, ed. John Tobin, (New York: Penguin, 2004), 186. Mede, of course, specifically condemned the American continent as a land given over to the devil; for a discussion of colonial reaction to Mede's position, see Reiner Smolinski, General Introduction to The Kingdom, the Power, \& the Glory, ed. Reiner Smolinski, (Dubuque: Kendall/Hunt, 1998), x-xii.
} 
timeless; it was not relative to times, places, and changes of history. Subject to no alteration, it held full and equal jurisdiction in any present hour." ${ }^{, 37}$ For Bay Colony settlers in the seventeenth century, Eden was an historical reality, a certain millennial and heavenly futurity, and a present possibility.

\section{The Limits and Labor of Eden: Separating the Ideal from the Idyllic}

Since I have used the word utopian to describe Brightman's depiction of Elizabethan England as an edenic paradise and the word paradisiacal to characterize the millennial rhetoric of Cotton, it seems both appropriate and necessary to define the possibilities and limitation of these and other terms as well as their relationship to the Eden that I claim early modern New Englanders sought to invent. Winthrop and his fellow colonists had no intention of reentering or replanting the physical garden that their first parents had inhabited any more than Columbus did. Instead, they wanted to create an ideal society that would allow them to enjoy the physical and spiritual benefits that Adam and Eve experienced in Eden.

Although Adam and Eve are well represented in the written record of early modern New England, other biblical figures are regularly compared to Adam and Eve's prelapsarian perfection or endowed with edenic attributes, and their appearance in the literature of this period will also be understood as part of the attempt to reinvent Eden in New England.

\footnotetext{
${ }^{36}$ Bozeman, To Live Ancient Lives, 7; Smith, “A Description of New England,” 149.

${ }^{37}$ Bozeman, To Live Ancient Lives, 17. While the "advent of modernity constructed a new vision of time as linear, ordered, progressive, and teleological," time was a circular construct in the early modern period, as illustrated by the patterns of biblical typology, in which Old Testament events were re-enacted in the New Testament. This typological understanding of time made it possible to understand the understand the initial creation of the world and Eden as a type of the Second Coming and the millennium, when there would be a new heaven and a new earth. In this way, typology plays the function that Dana Luciano ascribes to grief in the nineteenth century, when emotion "defended [time's nonlinearity] against the increasingly rapid pace of progress by providing avenues of return to the sacred truths that both preceded and exceeded history as such." See Dana Luciano, Arranging Grief, (New York: New York University Press, 2007), 2.
} 
Enoch, for example, "walked with God after he begat Methusaleh three hundred years, and begat sons and daughters: And all the days of Enoch were three hundred sixty and five years: And Enoch walked with God: And he was not; for God took him" into heaven. In a discussion of Enoch's walk with God, Benjamin Colman asks, "Will God in very deed walk with us on earth? Behold Heaven, and the Heaven of heavens cannot contain him? How pleasant this must be, to walk with GOD? Such was Eden, the Garden of God, in man's first state; and such is the Paradise of God above., ${ }^{38}$ For Colman, Enoch's experience attests to the truth that edenic ideals are still achievable in a fallen world, and he urges his congregation to prepare themselves for the heavenly paradise by imagining and then emulating Enoch's earthly attainment of paradisiacal purity. By imitating Enoch's walk, Colman's congregation could ground their edenic aspirations in a standard of post-lapsarian attainment, and other biblical figures serve similarly as models for emulation. Colman notes that Elijah was translated in the same manner and for the same reasons as Enoch; elsewhere he points out that Moses, like Adam, spoke with God "face to face, as a man speaketh unto his friend." Because of his interaction with deity, "Moses face shone in the Mount with God, [as] did Adam's in the Garden of God." ${ }^{39}$ The description of Eden in Genesis provides a pattern after which early modern New Englanders could model their own ideal society, but preachers helpfully identified other, additional scriptural examples that successfully captured the spirit of Eden.

The ideal society, the Eden, that Winthrop, Shepard, Cotton, Colman, Edwards, and others sought to establish in New England cannot be accurately encapsulated in any one of

\footnotetext{
${ }^{38}$ Genesis 5:22-24; Benjamin Colman, The Holy Walk and Glorious Translation of Blessed Enoch, (Boston: 1728), 9.

${ }^{39}$ Exodus 33:11; Colman, The Holy Walk and Glorious Translation of Blessed Enoch, 20.
} 
the terms typically used to describe such a construct. It was not a paradise, an arcadia, a perfect moral commonwealth, or a utopia. More problematically, the edenic ideal to which they aspired was never the subject of a full-length work produced by a writer who lived in New England; there is no single edenic blueprint for New England comparable to Thomas More's Utopia or Philip Sidney's Arcadia, which respectively provided utopian and arcadian prototypes for Old England. This is due, in part, to the fact that several excellent treatments of Eden already existed and were widely read in New England at various points in the seventeenth and eighteenth centuries: New Englanders did not necessarily need a new description of Eden to guide their efforts, only to implement the aspects of Eden they were already familiar with from available accounts. Genesis is the obvious and most authoritative source of information about life in Eden, and as we have already seen, other biblical narratives were also read as expositions of edenic perfection. In addition, the epic poem $L a$ Semaine ou Création du monde (1578) by Frenchman Guillaume de Saluste, Sieur du Bartas' was translated by Joshua Silvester and published in 1611 as The Divine Weeks and Works. In its English form and possibly in the original French, du Bartas' poem was read in New England; Anne Bradstreet's quaternions drew heavily on du Bartas and are arguably the most original and extensive treatment of Eden produced in colonial New England, though they, like Winthrop's “Modell,” do not present a full vision of edenic life. Milton’s Paradise Lost (1667, 1674) and Paradise Regained (1671) reflect some of the seventeenth-century beliefs about Eden shared on both sides of the Atlantic and shaped the ways in which eighteenthcentury New Englanders imagined the paradise of Genesis, but do not necessarily reflect in full the societal aspirations of Bay Colony immigrants who preferred to remain in the New World rather than return to England during the interregnum. Cotton Mather's Triparadisus 
provides a full description of the original Eden, but it was never published and did not circulate widely in manuscript form. ${ }^{40}$ Other English and European works also engage the topic of Eden, but there is no single source from which to draw a comprehensive portrait of the edenic model that early modern colonists worked to establish in New England.

Accordingly, I will begin this study by defining the Eden that these colonists envisioned in opposition to alternative conceptions of an ideal society: paradise, arcadia, perfect moral commonwealth, and utopia. While the Eden that New England immigrants hoped to realize incorporates elements from each of these ideal societies, it also differs from them substantially. Indeed, there is one difference between Eden and these other forms of ideal society that may not be obvious from a modern perspective but which is of paramount importance: Eden was an historical reality that early modern New Englanders sought to recover; each of the other forms of ideal society was what J. C. Davis calls "a fiction, a thing feigned or imagined." The colonists of New England believed in the historicity of Eden in a way and with a surety that they could not extend to their belief in other ideal societies. The Eden they sought to replicate and restore was an actual physical place where perfect physical bodies and minds had actually resided, not an imagined land or even an idealized form of being accessed through "the Platonic theory of reminiscence" described by Louis Martz, "whereby the soul retains and recovers memories of an earlier existence." ${ }^{41}$ Of equal

\footnotetext{
${ }^{40}$ More problematically, it places the millennial restoration of paradisiacal conditions after a worldwide conflagration that would destroy everything. In his published writings, Mather frequently speaks of achieving edenic ideals in mortality, but by the end of his life, he had abandoned this earlier, post-millennial position in favor of a belief in a corporal transformation of the saints that would enable them to survive the conflagration that preceded the millennium. While the bulk of Mather's work-and certainly his published work-supports the post-millennial premise, his most complete discussion of Eden was written too late to afford us extensive insight into his earlier views. For more, see the introduction by Smolinski to Cotton Mather, The Threefold Paradise of Cotton Mather, ed. Reiner Smolinski, (Athens: The University of Georgia Press, 1995).

${ }^{41}$ J. C. Davis, Utopia and the Ideal Society, (Cambridge: Cambridge University Press, 1981), 14; Louis L. Martz, The Paradise Within, (New Haven: Yale University Press, 1964), xvi. While colonists sought to achieve the internal perfections of Adam and Eve, they also worked to regain the physical and social perfections they
} 
importance, the concept of Eden as a perfect, divinely instituted ecological model was immediately relevant to both seventeenth-century England, which Ken Hiltner reminds us was "in the midst of an environmental crisis of unprecedented proportions," and to early modern New England, whose environmental crises were of a different, but no less pressing, nature. ${ }^{42}$ As a model of a perfect, historically remembered and prophetically anticipated relationship between man and nature, Eden served as a tangible, achievable ideal in a way that no Neo-Platonic anamnesis, no paradise, arcadia, perfect moral commonwealth, or utopia could. By situating Eden with respect to these other forms of society, we can articulate the relationship between colonial New England authors and others that imagined ideal societies more accurately.

\section{$\underline{\text { Paradise }}$}

Of all the alternatives to Eden, paradise is the one most frequently conflated with the home of Adam and Eve because it is a word frequently used to describe Eden itself. I use paradise here, however, as a synonym for the mythical land of Cockaygne, where the superabundance of the natural world provides "satisfactions enough to satiate the grossest appetite. ${ }^{, 43}$ While Eden and Cockaygne were never confused, the word paradise was used to describe both. The key to distinguishing between an edenic paradise and a paradise such as

enjoyed in their own bodies, companionship, and in the landscape that surrounded them. Hence, achieving the mental and spiritual states advocated by Neo-Platonic and Augustinian thinkers such as Henry Vaughan and Thomas Traherne was not an edenic aspiration in and of itself. As Charles Webster notes, even though the Puritans did not generally subscribe to an Augustinian ideology, other church fathers were still influential guides to eschatological thought. Instead, the Puritans "looked forward to the ultimate fulfillment of the prophecies of the scriptures and of the patristic sources Papias and Lactantius, that the waste places would be reclaimed and become as fruitful as the garden of Eden." See Charles Webster, The Great Instauration, (London: Duckworth, 1975), 466.

${ }^{42}$ Ken Hiltner, Introduction, to Renaissance Ecology, ed. Ken Hiltner, (Pittsburgh: Duquesne University Press, 2008), 1.

${ }^{43}$ Davis, Utopia and the Ideal Society, 21. 
Cockaygne is identifying whether the paradise in question requires work: a paradise that satisfies all needs without work vitiates and corrupts the soul in the manner of Cockaygne, but a paradise where wholesome, pleasant work is rewarded with superabundance is edenic. Thus, Ralegh explains that "we now find, that if there be any place upon the earth of that nature, beauty, and delight, that paradise had, the same must be found within that supposed uninhabitable burnt zone, or within the tropics" because "those regions have so many goodly rivers, fountains, and little brooks, abundance of high cedar, and other stately trees casting shade, so many sorts of delicate fruits, ever bearing, and at all times beautified with blossom and fruit, both green and ripe, as it may of all other parts be best compared to the paradise of Eden.” Nevertheless, Ralegh asserts, the tropics differ from Eden in one essential: they require no labor and therefore promote moral degeneration. In the tropics, "nature being liberal to all without labour, necessity imposing no industry or travel, idleness bringeth forth no other fruits than vain thoughts and licentious pleasures," and these fruits are more fitting of Cockaygne than of Eden. ${ }^{44}$ Labor is an essential component of the edenic experience.

While labor is frequently described as a penalty of the Fall, it was also an aspect of Adam and Eve's prelapsarian experience; Shepard taught his congregants that "Adam in Paradise must not be idle, but look to the garden; and in this land those that will be good husbands for God (least they discredit their profession by bringing themselves to a piece of bread) must be good husbands for themselves." Lest this responsibility of looking to the garden be misunderstood as a recreational pursuit, Cotton Mather explained that "Adam in Paradise had a Labour imposed on him." ${ }^{, 45}$ As a consequence of his disobedience in Eden,

\footnotetext{
${ }^{44}$ Walter Ralegh, The Works of Sir Walter Ralegh, Kt., Vol. II, ed. William Oldys and Thomas Birch, (Oxford: Oxford University Press, 1829), 88-90.

${ }^{45}$ Thomas Shepard, The Parable of the Ten Virgins Opened \& Applied, (London: J. Hayes, 1660), 159; Cotton Mather, Small Offers Towards the Service of the Tabernacle in the Wilderness, (Boston: R. Pierce, 1689), 77.
} 
God punished Adam by cursing "the ground for thy sake; in sorrow shalt thou eat of it all the days of thy life; thorns also and thistles shall it bring forth to thee; and thou shalt eat the herb of the field; in the sweat of thy face shalt thou eat bread, till thou return unto the ground." But seventeenth-century readers understood that Adam's Fall did not introduce labor; it only changed its nature. Before the Fall, God places Adam in "the garden of Eden to dress it and to keep it"; Milton describes this labor as a "delightful task ... which declares [humanity's] Dignity." After the Fall, work is no longer delightful because nature rewards the labor of Adam with thistles and thorns instead of flowers and fruit. Seventeenth-century colonists find a paradise in the New England landscape, but it is not the tropical paradise described by Ralegh, not a Cockaygne; it is a paradise where labor is rewarded with nature's abundance as the labors of Adam and Eve were rewarded in Eden. ${ }^{46}$ Because the word paradise was used to describe labor-free zones of natural abundance as well as edenic landscapes that "require / More hands than ours to lop thir wanton growth" in the early modern period, it is an unstable referent. ${ }^{47}$ In this study, however, since Eden was a paradise even though not all paradises were edenic, paradise will be used in the same way that religious writers of the early modern period used the term most frequently: as a synonym for Eden.

\section{$\underline{\text { Arcadia }}$}

Like the labor-free paradises associated with Cockaygne, the arcadian tradition emphasizes the cessation of hostilities between man and nature incident to the Fall. The

\footnotetext{
${ }^{46}$ Genesis 3:17-19, 2:15; Milton, Paradise Lost, IV.437, 619. In contrasting New England with the labor free paradises described by Ralegh, White explains that an absence of labor is only desirable if "men desire to have a people degenerate speedily, and to corrupt their mindes and bodies too, and besides to tole-in theeves and spoilers from aborad." For those who "desire that Piety and godlinesse should prosper; accompanied with sobriety, justice and love, let them choose a Countrey such as this is; even like France, or England, which may yield sufficiency with hard labour and industry." See John White, The Planters Plea, (London: William Iones), 32-33.

${ }^{47}$ Milton, Paradise Lost, 628-29.
} 
arcadian tradition presupposes that "satisfactions, at least material ones, are more abundant" and that "[n]ature is generously benevolent." In this respect, Arcadia is similar to Eden: "men work, but the burden is light and easy," and their labor is rewarded by nature. This core similarity notwithstanding, the arcadian pattern differs from Eden in several other respects. Whereas the arcadian mode "emphasises the integration of man and nature," Eden is a space in which man commands nature; the relationship is harmonious but hierarchical. ${ }^{48}$ In his first instructions to Adam and Eve after their creation, God enjoins them to "have dominion over the fish of the sea, and over the fowl of the air, and over every living thing that moveth upon the face of the earth," and Adam demonstrates his knowledge of and power over the natural world by naming each of the animals in turn. Of equal importance, the bounty of arcadian landscapes is often conditional, the product of an artificially low population, but theologians believed that the prelapsarian paradise inhabited by Adam and Eve could accommodate and support a numerous progeny. Indeed, these differences between Arcadia and Eden can be summed up in the divine injunction to "multiply, and replenish the earth, and subdue it.",99 The flora and fauna of Eden are the property of humanity, and they are plentiful enough to provide for all, without the regard for low population densities key to arcadian and pastoral societies.

The pastoral values associated with arcadian living emphasize a communion between man and nature; the harmony between human residents of Arcadia is at least partly due to the physical distance that separates them. In Eden, however, sociality is an integral part of the paradisiacal state; Milton's Satan recognizes that Adam and Eve, "Imparadis't in one

\footnotetext{
${ }^{48}$ Davis, Utopia and the Ideal Society, 22, 23, 24. For an in-depth consideration of the characteristics of pastoral—and anti-pastoral—societies, see Peter Lindenbaum, Changing Landscapes, (Athens: The University of Georgia Press, 1986), 1-21.

${ }^{49}$ Genesis 1:28, 2:19.
} 
anothers arms / The happier Eden, shall enjoy their fill"- their spiritual union and communion is a form of Eden far more precious than the surrounding physical environment. In edenic communities, then, interpersonal relationships transcend relationships with nature, and isolation is to be avoided, not pursued. Indeed, Howard Russell's description of living arrangements in seventeenth-century New England encapsulates perfectly this distinction between edenic and pastoral societies. In New England, as in Eden, social proximity trumps natural isolation and so a "closely settled village was almost uniformly the pattern. To a majority of the newcomers, the idea of scattered farmsteads on outlying disconnected sites would have been strange and repugnant." ${ }^{, 50}$ The edenic society is first and foremost a community, not a place for lone shepherds and homesteaders to lose themselves in nature.

In addition to the distinctions noted above, arcadian and edenic societies differ in the way that they portray and respond to human appetites. While "the arcadian simplifies human desires and at the same time throws great stress on their satisfaction," Eden satisfies human desires even as it emphasizes "a pattern of restraint." Simply put, there is no forbidden fruit in Arcadia, no need to curb consumption. In Eden, on the other hand, restraint and moral discipline are points of emphasis. When God placed Adam in the garden, he told him that "Of every tree of the garden thou mayest freely eat: but of the tree of the knowledge of good and evil, thou shalt not eat of it: for in the day that thou eatest thereof thou shalt surely die." ${ }^{, 51}$ Eden's abundance allowed Adam and Eve to satisfy their desires, but their stay was conditional on the performance of certain moral duties and the restraint of their appetites within the bounds the Lord had set. Just as the arcadian tradition largely ignores moral

\footnotetext{
${ }^{50}$ Milton, Paradise Lost, IV.506-07; Howard S. Russell, The Long, Deep Furrow, (Hanover: University Press of New England, 1976), 71.

${ }^{51}$ Davis, Utopia and the Ideal Society, 24; Genesis 2:17.
} 
strictures, it also renounces societal structure and "rejects all institutions whatsoever." While the original Eden was not governed by institutions, it did not explicitly reject them either, and men like Winthrop recognized that any return to Eden in early modern New England would be accomplished through the church as charity "gathers together the scattered [church members] or perfect old man Adam and knits them into one body againe in Christ whereby man is become againe a liueing soule"; as Adam first came to life in Eden ${ }^{52}$ Eden, as described in Genesis and imagined by New Englanders in the seventeenth and eighteenth centuries, is simultaneously more hierarchical, capacious, disciplined, and organized than any Arcadia.

\section{Perfect Moral Commonwealth}

The emphasis on discipline and restraint that distinguishes Eden from Arcadia is something Eden shares with the perfect moral commonwealth, in which society achieves harmony "by the moral reformation of every individual in society." This belief that the establishment of a community of individual saints will produce collective moral and social reform is, perhaps, the defining characteristic of the New England way and the means by which edenic temperance and harmony were to be realized. At the end of Bradstreet's poems, "The Four Elements" and "Of the Four Humours in Man's Constitution," the creation of Eden is only made possible when each of the contentious and contending parties-fiery choler, airy blood, earthy melancholy, watery phlegm—individually agree to cease quarelling and "be friends" so that it can no more "be discern'd, here's water, earth, aire, fire, / But here's a compact body, whole, entire. ${ }^{, 53}$ Only the individual reformation of each element and

\footnotetext{
52 Davis, Utopia and the Ideal Society, 24; Winthrop, “A Modell of Christian Charity,” 290.

${ }^{53}$ Davis, Utopia and the Ideal Society, 27; Anne Bradstreet, “Of the Four Humours in Man's Constitution," in The Complete Works of Anne Bradstreet, eds. Joseph R. McElrath, Jr. and Allan P. Robb, (Boston: Twayne Publishers, 1981), 35. Because McElrath and Robb-the best scholarly edition of Bradstreet's poems-do not
} 
humor makes it possible for them to achieve collective perfection, and only the individual reformation of each church member would produce the congregation to which Colman aspires, one in which every member of the church is capable of walking together in God's presence as Adam and Enoch did.

But the perfect moral commonwealth differs from Eden in two important ways. First, unlike Arcadia or Cockaygne, perfect moral commonwealths are not situated in idealized natural settings; their perfection consists entirely in the collective attainment of individual virtue. Second, the "perfect moral commonwealth tradition accepted existing social arrangements and political institutions," whereas those trying to recreate Eden work to restore primitive purity by reforming ecclesiastical and political institutions. ${ }^{54}$ The goal of ministers like Cotton and Colman was to provide a church atmosphere that would encourage the elect to achieve the spiritual state of Adam and Eve in Eden; for this reason fallen, anthropogenic traditions had to be stripped from the church. Depending on the degree to which individual ministers adhered to Puritan principles, this might involve abolishing the surplice, the Book of Common Prayer, instrumental accompaniment of psalm-singing or any number of other practices in which Adam, Eve, the apostolic church, and other models of

number the lines of her verse, and because the numbering of lines varies widely in other editions, I have chosen to refer to Bradstreet's poems by page number rather than using the customary practice of citing line numbers.

${ }^{54}$ Davis, Utopia and the Ideal Society, 25. Advocates of a perfect moral commonwealth argued that the form of government or other social institutions was irrelevant if the citizens were virtuous, a position that A. B.

Ferguson describes as characteristic of the Elizabethan age: "government remained for most of the commentators of this period personal rather than institutional - personal, that is, in the sense that it depended on the moral nature of men running it, not in the sense, more typical of renaissance thought, that it depended on the dynamic personality of the artist in politics." This position is consistent with the Hobbesian belief articulated by Quentin Skinner that there is no "connection between the establishment of free states and the maintenance of individual liberty." Hobbes argues that the widespread enjoyment of individual liberties is the functional equivalent of a free state, regardless of the form of government; likewise, those who imagine perfectly moral commonwealths suggest that their moral perfection is dependant on the individual virtue of its citizens and not on the institutions that govern those citizens. See A. B. Ferguson, The Articulate Citizen and the English Renaissance, (Durham: Duke University Press, 1965), 33; Quentin Skinner, Liberty Before Liberalism, (Cambridge: Cambridge University Press, 1998), 60. 
primitive purity did not engage. In addition to reforming the church so that it more accurately reflected the values and practices of primitive Christians, early modern New Englanders also worked to reform government so that it more closely adhered to the principles of natural law that governed the interactions of Adam and Eve in Eden. Philip Almond points out that the "more common Protestant position was the Augustinian one that in a world without sin government would, have been unnecessary and that therefore the ideal state of nature was one of equality between all," but the men and women who struggled to reinvent Eden in New England did so in an already fallen world and recognized that some form of government was necessary until their goal had been accomplished. ${ }^{55}$ Accordingly, they worked to establish the most perfect form of government possible: one in accord with natural law. To the perfect moral commonwealth's emphasis on individual virtue, these colonists added an insistence that the ecclesiastical and political structures under which they labored be reformed to reflect primitive purity.

\section{$\underline{\text { Utopia }}$}

Like a perfect moral commonwealth and unlike Eden, a utopia is rarely set in a physical paradise, but the primary difference between utopias and Eden is the ultimate aim of each society. Utopias "are concerned with dragooning men, far from ideal, into righteousness; with breaking out of the vicious cycle of pernicious social and political influences on weak men, into a situation where the pressures of institutional, legal and educational arrangements all lead in the direction that a rightly informed conscience should move anyway." But the strict controls of utopian societies never purport to correct the underlying problem: human depravity and a basic antagonism between humanity and nature.

\footnotetext{
${ }^{55}$ Philip Almond, Adam and Eve in Seventeenth-Century Thought, (Cambridge: Cambridge University Press, 1999), 103.
} 
They combat social problems of "crime, instability, poverty, rioting, war, exploitation and vice. None of these evaporate in utopias. They are controlled and where possible eliminated," but the cause of those problems remains ${ }^{56}$ Unlike perfect moral commonwealths, utopias are not concerned with the production of regenerate saints, only the containment of degenerate criminals and imperfect citizens. Furthermore, utopias rely almost wholly on the formation of institutions to effect social change, whereas edenic communities presuppose the innocenceor regeneracy—of their citizens as a necessary pre-condition to the reformation of institutions.

\section{$\underline{\text { Eden }}$}

Studies in the hexameral tradition of the early seventeenth century highlight three characteristics of Eden that distinguish it from the fallen world and the other societies I have considered. Eden was understood to be "a three-fold Paradise: an external garden of delight, a perfect body attuned to its harmonious surroundings, and a Paradise of perfections, natural or supernatural, within [the] soul" of Adam and Eve. ${ }^{57}$ Accordingly, New England colonists seeking to recover these three aspects of Eden's perfection and create an edenic community—as described by Genesis and other contemporary accounts and distinguished from alternative forms of ideal societies—needed to:

1. Find a landscape that offered the temperate climate and encyclopedic content of Eden, a land where pleasant labor is rewarded with bountiful harvests. Eden's bounty is absolute, not relative; its paradisiacal nature is not contingent on a low population count, so the land should support both propagation and immigration.

2. Exercise dominion over nature and regain the bodily temperance that Adam and Eve

\footnotetext{
${ }^{56}$ Davis, Utopia and the Ideal Society, 82, 37.

${ }^{57}$ Mary Irma Corcoran, Milton's Paradise with Reference to the Hexameral Background, (Washington, D.C. : Catholic University of America Press, 1945), 17. On the state of paradisiacal lands, bodies, minds and souls, see also Arnold Williams, The Common Expositor, (Chapel Hill: The University of North Carolina Press, 1948), 81-84 and 108-109; and J. Martin Evans, Paradise Lost and the Genesis Tradition (Oxford: Clarendon Press, 1968), 242-271.
} 
enjoyed in Eden through disciplined consumption and excretion and by relocating in an atmosphere where external influences promoted bodily temperance.

3. Reform individuals and institutions so that they reflect the intellectual, moral, and social perfections of Eden.

Because early modern New England colonists conceived of Eden as a state of geographical, physiological, intellectual, moral, and social perfection, I organize this study to reflect the ways in which they sought to recapture each of those edenic attributes.

But Eden was more than a set of attributes; it was a state of being that could only be restored in its fullness through divine intervention. In order to avoid "reducing the expulsion from Eden to a change in lifestyle, as though [shedding] shame and the consciousness of death were nothing more than learning a new dance step or developing a taste for chardonnay," colonists connected their pursuit of edenic perfection to a larger program of millennial restoration contingent on divine grace. ${ }^{58}$ While they took their responsibility to "work out your own salvation with fear and trembling" seriously, they also acknowledged that "it is God which worketh in you both to will and to do of his good pleasure" and depended on deity to make their quest for Eden a reality. Their attempts to temper and moderate their bodily humors, to achieve the spiritual sanctification of Adam and Eve, were “investigations conducted into secondary causes, and with utilitarian ends in mind": a program of action that would prepare them for the millennium, not a mortal circumvention of divine timetables. ${ }^{59}$ Eden was the goal they labored to realize, but it was a goal whose achievement was contingent on God's grace.

\footnotetext{
${ }^{58}$ Roger Lundin, From Nature to Experience, (Lanham: Rowman \& Littlefield, 2005), 31.
} 


\section{Invention: Discovery, Interpretation, and Innovation}

To claim that early modern New England men and women invented anything-much less edenic lands, bodies, minds, souls and governments - is to beg the question, "What does the term invention mean in this context?" My own approach to the colonial venture in New England as a process of invention is indebted to Edmundo O'Gorman's The Invention of America and Frank Lambert's Inventing the "Great Awakening”. As Lambert notes, invention has two meanings in the early modern period. The Oxford English Dictionary's primary definition for the term is: "The action of coming upon or finding; the action of finding out; discovery (whether accidental, or the result of search and effort)." As explorers and colonists in the New World repeatedly discover, the climate, flora, and fauna in the western hemisphere generally, and New England specifically, are compatible with their conceptions of Eden's landscape. As these sailors and settlers gave order to the novel attributes of the New World by comparing its features to landscapes and ecosystems that were familiar from personal experience or from written descriptions, they concluded, almost unanimously, that they had found Eden—or at least something like Eden. But the gradual evolution of a European belief in America's discovery that O'Gorman traces is a process in which the empirical experience of Eden is not only found; it is catalogued, organized, and contextualized as the unfamiliar is rendered familiar in a process of invention. What is more, the settlers who find and interpret evidence of Eden in the landscape of New England also contrive to imagine "a new method or means of doing something," exercising the "power of mental creation" to devise processes that will reproduce other features of the original Eden. This second $O E D$ definition for invention applies to my description of edenic bodies,

\footnotetext{
${ }^{59}$ Philippians 2:12-13; Webster, The Great Instauration, 22.
} 
language, wisdom, conversion, and government, as colonists exercised their imaginations to identify new projects and processes that would help them achieve their aspirations to primitive purity and millennial perfection through Eden's example.

For many seventeenth-century Puritans, of course, the idea of harnessing invention as a creative force was anathema; novelties and innovations were inherently corrupt because inextricably linked to the fallen men and women who produced them. Thus in 1604, when John Reynolds asked the newly crowned King James I, "May your Majesty be pleased that the Bible be new translated?" his Puritan companions took great pains to clear their proposal from the seventeenth-century condemnation of innovation, "describing themselves as 'Ministers of the Gospell, that desier not a disorderly innovation but a due and godlie reformation.'” In general, neither the Puritans nor the bishops they opposed condoned innovation; advocates of high and low church alike dissociated themselves from the term, with each side constantly accusing the other of introducing new doctrine even as both stressed the orthodox foundations of their respective beliefs. While the Puritans strove to frame their request for a new translation as a reformation intended to recover the primitive purity of the Hebrew text, Lancelot Andrewes, William Laud's mentor, described the opposing, prelatic view of Reynolds's request for a new translation. He complained that Puritan preachers filled religion "with 'new tricks, opinions and fashions, fresh and newly taken up," condemning those who wished "to be Authors, and inventors of somewhat, that so we may seem to be as wise as GOD if not wiser. ${ }^{, 60}$ For many of the men and women detailed in this study, the notion of inventing or reinventing Eden would have been deemed suspicious, if not heretical.

\footnotetext{
${ }^{60}$ As quoted in Adam Nicolson, God's Secretaries, (New York: HarperCollins, 2003), 57; Nicolson, God's Secretaries, 39, 30.
} 
In some sense, however, the extent to which any seventeenth-century Puritan would accept innovation or invention also depends on the term's definition. We might describe the acceptance of innovation in Puritan circles as a general support for the "pioneer thinking" which Geoffrey Nuttall identifies as characteristic of seventeenth-century Puritan England. This system is, in large part, the product of those "university educated elites [who] drifted toward complex, highly intellectual forms" of religion whom Jon Butler describes: "They did not deny Christianity; they sought to perfect it by unlocking its shackled secrets. ${ }^{, 61}$ Inasmuch as the guiding minds of New England Puritanism accepted innovation, they did so not to abandon or alter orthodox beliefs but to urge them forward, to meet scriptural ideals through godly innovation as a community without adopting the "individualistic position" of separatists such as Samuel Gorton, Roger Williams, and Anne Hutchinson. ${ }^{62}$ Acceptable innovation in early modern New England involved a minor variation on a widely accepted Puritan consensus rather than the completely new tunes of these extremists.

Even as they condemned innovation in broad strokes, New England divines like Cotton and John White also recognized that invention could occasionally serve as an instrument of godly reform. White defends colonization as a godly practice in part because "the husbanding of unmanured grounds, and shifting into empty Lands, enforceth men to frugalitie, and quickneth invention." ${ }^{63}$ White portrays invention, like frugality, as a quality to be sought after by the godly emigrating to New England. For his part, Cotton acknowledges the Fall and its corrupting effects, but his Briefe Exposition with Practicall Observations upon The Whole Book of Ecclesiastes (1654) also contends for the possibility of godly

\footnotetext{
${ }^{61}$ Geoffrey Nuttall, The Holy Spirit in Puritan Faith and Experience, (Chicago: University of Chicago Press, 1992), 6; Jon Butler, Awash in a Sea of Faith, (Cambridge: Harvard University Press, 1990), 24.

${ }^{62}$ Nuttall, The Holy Spirit in Puritan Faith and Experience, 12.
} 
innovation. On the one hand, he concedes that "Gods curse hath brought vanity upon the whole creature, and all the fruits of it, by reason of our sin."64 On the other hand, Cotton actively defends human creativity; in speaking of Solomon's charge that "there is nothing new under the Sun," he queries, "Are there not sundry Inventions of Art new, as Guns, Printing, and the use of the Loadstone?" History demonstrates to Cotton that man can, in fact, create something novel, but he admits that mere novelty and change do not make a thing truly new. In most cases, "the artificiall inventions of men, though they be new sometimes at first, yet for the kind many of them have been before; and generally none of them continue new long, but wax stale and old like other things." Because "only God our happinesse is alwaies the same [...] and ever is new," only those inventions of men which praise God or further his purposes can truly be considered new: "For Gods Predestination is above the Sunne; and things done here according to it, are new still under the Sunne."65 Only because the "new" art of printing contributes significantly to the divinely-directed propagation of scripture can Cotton make a claim for printing's newness in a religious sense, outside of its technological novelty.

From Cotton's viewpoint, believers can attain "true happiness" only in that knowledge capable "of yeilding satisfaction to the minde and of variety and newnesse," and they can find such newness "in the things we are conversant about" already—in a second or third look at spiritual things such as the word of God, the wisdom of Solomon or the innocence of Eden. In this way, Cotton's discussion of Ecclesiastes becomes an exhortation

\footnotetext{
${ }^{63}$ John White, The Planters Plea, (London: William Iones, 1630), 4-5.

${ }^{64}$ John Cotton, A Briefe Exposition with Practicall Observations upon the Whole Book of Ecclesiastes, (London: T. C., 1654), 38

${ }^{65}$ Ecclesiastes 1:9; Cotton, A Briefe Exposition with Practicall Observations upon the Whole Book of Ecclesiastes, 20-21.
} 
to innovation and invention—not those "inventions whereby we seek to start away from God, and to corrupt our selves" as in the case of Hutchinson or Gorton, but those which "made Adam righteous at first," inventions that might recover the primitive purity of a temperate edenic body, the Adamic language, or the system of natural law by which Eden was governed. ${ }^{66}$ In this sense, Cotton's Exposition of Ecclesiastes proposes a middle road for Puritan invention, one that allows for the creation of something new without abandoning the Calvinist suspicion of mortal artistry.

For those who investigate early American Puritan culture through the interpretive lens of poetry, the question of Puritan attitudes toward modern notions of invention and innovation has long shaped their attempts to trace a poetic lineage from the seventeenth to the nineteenth century. To Roy Harvey Pearce, "the history of American poetry is [...] the record of a gradual but nonetheless revolutionary shift in the meaning of 'invention': from ‘coming upon' something made and ordered by God, to ‘making' and ‘ordering' transforming — something, anything, into that which manifests above all man's power to make and to order." More recent work by Elisa New suggests that this Emersonian emphasis on innovation and the pursuit of "an original relation to the universe" ignores the centrality of Puritan belief, particularly belief in the Fall and the Preacher's report that "there is nothing new under the Sun."67 With a proper understanding of the Puritan emphasis on the Fall, "the

\footnotetext{
${ }^{66}$ Cotton, A Briefe Exposition with Practicall Observations upon the Whole Book of Ecclesiastes, 15, 17, 161. In his discussion of Ecclesiastes 7:29 and invention, Cotton references the twenty-sixth chapter of Second Chronicles as an example of human innovation, when Uzziah "made in Jerusalem engines, invented by cunning men, to be on towers and upon the bulwarks, to shoot arrows and great stones withal. And his name spread far abroad; for he was marvelously helped" by heaven until he later blasphemed by burning incense in the temple in the priest's stead. The inventions by which Uzziah defends Jerusalem are clearly sanctioned by and produced in collaboration with heaven's marvelous help; it is his pride in the process of invention, with which "his heart was lifted up to his destruction" and not the invention itself which condemned him. See 2 Chronicles 26:15-16.

${ }^{67}$ Roy Harvey Pearce, The Continuity of American Poetry, (Princeton: Princeton University Press, 1961), 41; Ralph Waldo Emerson, Nature, in Emerson's Prose and Poetry, eds. Joel Porte and Saundra Morris, (New York: W. W. Norton \& Co., 2001), 27; Ecclesiastes 1:9.
} 
Emersonian self-reliance is retuned in a lonelier key, resolving back into Augustine's, or Calvin's, more islanded solitude, the poet not creating so much as carrying the self, not inventing Eden so much as marking time outside it. [...] Whereas originality proper finds no register in the human voice, the sin that dogs it with relation is richly voiced. ${ }^{\prime 68}$ But in highlighting the faithfulness of seventeenth-century authors, New discounts Puritan originality unnecessarily, just as Pearce's focus on innovation underestimated the Fall's importance.

If we accept Cotton's views on invention, Puritan theology admits and even advocates the creativity and innovation which Pearce claims characterizes later American literature as long as that innovation lies within the faithful constraints described by New. Cotton's conceptualization of innovation as a means of introducing godly reform allows even those writers who are most conscious of their own Fall-induced depravity to strive for originality within the context of their faith. In this sense, then, the Puritan thinkers and writers described in this study anticipate the modern poet described by New, who "has left Ecclesiastes for Genesis" and who seeks "nothing less than to unwrite the Fall." ${ }^{\prime 99}$ Their writings constitute a via media between the diametrically opposed positions of Pearce and New: the Puritan quest to reinvent Eden that this study describes does not ignore or reject the Fall; it only seeks to mitigate or reverse the Fall's effects and to recapture prelapsarian purity. In describing the central place that Eden assumes in the culture and theology of early modern New England, I do not intend to suggest that this urge to purify and return to the primeval infected everyone. I recognize with Cotton Mather that for many of New England's inhabitants, the "main end of planting this wilderness" had nothing to do with the edenic

\footnotetext{
${ }^{68}$ Elisa New, The Regenerate Lyric, (New York: Cambridge University Press, 1993), 25.
} 
aspirations of "the people at the Bay"; for many, the "main end was to catch fish" and attain the economic prosperity that Smith promises. ${ }^{70}$ But Eden and its inhabitants were crucial figures in the theological aspirations of New England clergy; and, as we shall see, the contents of Genesis and the story of Adam and Eve really do matter for a substantial portion of the laity, who understood themselves and many of their cultural artifacts - their gardens, bodies, language, etc.- - in terms of Eden. Accordingly this study focuses on the writings of influential New England ministers including Cotton, Colman, Thomas Hooker, Cotton Mather, and Jonathan Edwards as well as prominent members of the New England laity whose interest in achieving edenic ideals signals their subscription to those ministerial ambitions.

\section{Intellectual Roots, Cultural Fruits: Grounding Intellectual History}

This study of Eden in New England also joins two important strands of criticism in early American literature, promoting "a conviction currently out of intellectual favor": the belief that "ideas have considerable power within history and, to some extent, over its course" to shape the "artifacts and labors of culture."71 By illuminating the ways in which the primitivist and millennial aspirations of New England colonists affected their understanding of the landscape and altered the ways in which they conceived of their physical and figurative bodies, it connects the work of eco-critics such as William Cronon and Timothy Sweet and humoral theorists such as Gail Paster and Michael Schoenfeldt to the intellectual history of Bozeman and Bercovitch. This task of tracing the ties between a theological

\footnotetext{
69 ibid, 17.

${ }^{70}$ Cotton Mather, Magnalia Christi Americana, ed. Thomas Robbins, Vol. 1, (Hartford: Silas Andrus and Son, 1855) I.66.
} 
evolution in England and the material manifestations of that theology's application on New World landscapes, bodies, and cultural artifacts presupposes that "ideas are often the causes rather than the effects of public events" and that "even if your professed principles never operate as your motives, but only as rationalisations of your behaviour, they will nevertheless help to shape and limit what lines of action you can successfully pursue."72 This study is not a history of ideas, but it is the history of an idea, of a persistent, pervasive belief in Eden's imminence, and the way in which that idea shaped the behaviors, cultural productions, and material circumstances of colonists in early modern New England.

\section{Experience and Ideology}

While Jim Egan argues persuasively that colonists cited experience as their authorization for revolution and other acts, his claim that "it was not ideology or theory that made America but experience" goes too far; colonial experience was informed and interpreted through lenses of ideology and theology before it was ever invoked as a source of authority. ${ }^{73}$ Though Columbus rejected contemporary belief that Eden was historically located in Asia, Africa or the Middle East because he had never "seen it in any world map, placed with authority based upon proof," and because his experiences in the New World provided him with what he considered empirical proof of Eden's location in the western hemisphere, his conclusions are the product of the very theological position that he ultimately rejected! $!^{74}$ As Tzvetan Todorov explains, Columbus had to rely on select points of conventional theology to overturn other, equally conventional beliefs about

\footnotetext{
${ }^{71}$ Lundin, From Nature to Experience, 4.

${ }^{72}$ Skinner, Liberty Before Liberalism, 104-05.

73 Jim Egan, Authorizing Experience, (Princeton: Princeton University Press, 1999), 3.

${ }^{74}$ Columbus, The Four Voyages II.36
} 
the earthly Paradise: the sign that fresh water constitutes (hence a great river, hence a mountain) is interpreted, after a momentary hesitation, 'in agreement with the opinion of those holy and wise theologians.' 'I am much more convinced in my own mind that the earthly Paradise is to be found there where I have said, and I rely upon the arguments and authorities given above.' Columbus performs a 'finalist' strategy of interpretation, in the same manner in which the Church Fathers interpreted the Bible: the ultimate meaning is given from the start (this is Christian doctrine); what is sought is the path linking the initial meaning (the apparent signification of the words of the biblical text) with this ultimate meaning. There is nothing of the modern empiricist about Columbus: the decisive argument is an argument of authority, not of experience. He knows in advance what he will find; the concrete experience is there to illustrate a truth already possessed, not to be interrogated according to preestablished rules in order to seek the truth. ${ }^{75}$

As with Columbus, so with his successors in the New World. The initial descriptions of New World landscapes provided by Columbus and others shaped the expectations and perceptions of immigrants who first experienced the New World in radically different climates and contexts; his widely adopted belief in the tempering influence of Eden on the New World permeated the public sphere and made the New World a place where perfection —or at least an approach to perfection-seemed possible. J. Martin Evans suggests that seventeenthcentury readers would have understood Milton's poetic revision of the first three chapters of Genesis as an implicit commentary on colonial practices in the New World because Genesis was "a text that was already thoroughly impregnated with the ideology of European imperialism"; I wish to invert his argument and contend that seventeenth-century immigrants to the New World would have understood their journey as a movement towards Eden and edenic purity because the land to which they traveled was already inextricably linked to the biblical paradise before they ever experienced it for themselves. ${ }^{76}$

During the seventeenth and eighteenth centuries New England colonists and writers turned and returned to the garden of Eden as a model of primitive purity, moral and physical

\footnotetext{
75 Todorov, The Conquest of America, 17.
} 
perfection, and millennial aspirations. Seventeenth-century ministers like Shepard pointed back to the innocence of Adam and Eve as a model of Christian sanctification; leaders of the Great Awakening looked forward to an edenic millennium; and eighteenth-century revolutionaries justified their rebellion against the British throne by referencing principles of natural law derived from hexameral exegesis. Indeed, though the specific aims of New England's inhabitants changed over time, their edenic aspirations remained constant. The use of Eden as a perfect model in and interpretive lens for New England thought and experience is chronologically consistent even after Calvinism's decline in the late eighteenth century, and the influence of the colonists' belief in and quest for Eden —in all its various manifestations—on early American life and letters can hardly be overstated.

In his study of Adam and Eve in Seventeenth-Century Thought, Almond discloses the ways in which clerical and lay understandings of Genesis shaped many facets of early modern life in England. He argues that

the story of Adam and Eve was seminal for all aspects of seventeenth-century cultural life. It had to be read, and by all, not merely by theologians. For it was the focus of heated debates on democracy versus monarchy, on nakedness, on richness of apparel and the use of cosmetics, on androgyny, on sexual libertinism, on the nature of marriage, and on polygamy. It was the fulcrum around which moved excited discussions on the place of Paradise, on the date of creation, on the nature of the Adamic language, on the identity of the forbidden fruit, on the provenance of the American Indians, on vegetarianism, on the stature and longevity of prediluvian people, on leveling and agrarian communism, on herpetology, on the delights of gardening and fruit-growing, and on the necessity and meaning of labour. ${ }^{77}$

For seventeenth- and eighteenth-century colonists in New England, this relationship between biblical history and everyday living was magnified: unlike the English writers Almond treats, they lived on a continent popularly identified by many as the site of Eden and dealt on a

\footnotetext{
${ }^{76}$ J. Martin Evans, Milton's Imperial Epic, (Ithaca: Cornell University Press, 1996), 6.

${ }^{77}$ Almond, Adam and Eve in Seventeenth-Century Thought, 2-3.
} 
regular basis with Indians who they believed spoke a language closely related to the Adamic tongue. While critics have noted the contemporary comparisons between New World landscapes and Eden, Eden's impact on other aspects of early modern thought has not received the same attention in New England that Almond provides in Old, an oversight this study remedies.

\section{Religious Historicity vs. Mythical Allegory}

In considering the edenic overtones in early American life and letters, I treat the nineteenth century, that period of American literature most commonly associated by the academy with Eden and its inhabitants, only briefly. Because R. W. B. Lewis and Judith Fryer, among others, have identified Natty Bumppo, Walt Whitman, and Captain Ahab as figures of Adam, and Elsie Venner, Hester Prynne, and Daisy Miller as representations of Eve, many studies of Eden's significance in United States culture focus on the literature of the nineteenth century. But when Lewis, Fryer, and their successors find depictions of Eden in nineteenth-century novels, they read and interpret these accounts in terms of myth, ignoring or effacing a legacy of belief in the Bible's historicity. This belief, vibrant in the seventeenth and eighteenth centuries but admittedly flagging by the middle of the nineteenth century, is what makes the story of Adam and Eve into "the dominant myth of American culture" in the first place, and it is this early modern belief in the reality of Adam and Eve

and in the relative geographical and temporal proximity of Eden that this study interrogates. ${ }^{78}$

By treating Adam and Eve as mythic archetypes rather than the religious figures alluded to and reinvented by antebellum writers who believed in their historicity, critics of nineteenth-century American literature have erroneously applied an Emersonian emphasis on

\footnotetext{
${ }^{78}$ Judith Fryer, The Faces of Eve, (New York: Oxford University Press, 1978), vii.
} 
individuality and self-reliance to Eden. For Lewis, whose influence continues to impact critical readings of masculinity and myth in nineteenth-century novels, isolation and autonomy are the primary characteristics of an American Adam; he is "an individual standing alone, self-reliant and self-propelling, ready to confront whatever awaited him with the aid of his own unique and inherent resources." ${ }^{, 79}$ But this image of the autonomous man does not reflect antebellum understandings of Adam; Jonathan Edwards, the most influential theologian of the eighteenth and nineteenth centuries, describes Adam in his original, solitary state as "incomplete because without his companion": only Eve's creation makes Adam whole. Antebellum writers commonly refer to Adam and Eve jointly as "our first parents," idealizing their union before the Fall and commonly blaming Adam's decision to eat the fruit on his uxoriousness ${ }^{80}$ Adam is consistently described in terms of his representative stature and his connection to and dependence on Eve, not as an autonomous individual.

In the first half of the nineteenth century, Adam and Eve were defined by their union, and contemporary novels reflect this view of Eden as a (small) social sphere. In Nathaniel Hawthorne's Blithedale Romance, Miles Coverdale ultimately fails to find solace in the Blithedale "scheme for beginning the life of Paradise anew" precisely because he is alone: he fails to attract an Eve to his Adam, though he cannot resist picturing Zenobia's "fine, perfectly developed figure, in Eve's earliest garment." ${ }^{, 11}$ His solitude is depressing, not paradisiacal. Even in James Fenimore Cooper's The Deerslayer, in which isolation and selfreliance are celebrated, Natty Bumppo's autonomy is something less than edenic; Lake

\footnotetext{
${ }^{79}$ R. W. B. Lewis, The American Adam, (Chicago: The University of Chicago Press, 1955), 5.

${ }^{80}$ Jonathan Edwards, "Miscellany 702.2," in The Works of Jonathan Edwards, Vol. 18, The "Miscellanies," ed. Ava Chamberlain, (New Haven: Yale University Press, 2000), 289; The Bible in Miniature, (New York: A. Brower Jun., 1791), 24.

${ }^{81}$ Nathaniel Hawthorne, The Blithedale Romance, (New York: Penguin Books, 1983), 9, 17.
} 
Glimmerglass fails to become "all creation" to Bumppo—as the garden was to Adam— precisely because he rejects Judith's plea to "turn this beautiful place into such a garden of Eden, for us. ${ }^{182}$ Even a champion of self-reliance such as Cooper conceived of Eden as a social sphere, a place where contemporary theology emphasized Adam and Eve's companionship and their mutual progress toward the idealized forms of God and his angels.

The critical consensus that depicts Adam and Eve as isolated individuals and Eden as a natural paradise in which to lose oneself attributes too much influence in the antebellum period to Ralph Waldo Emerson and his gospel of self-reliance. Philip Gura's reconsideration of the Transcendentalist movement refutes the premise that solitude translates into edenic experience: while Emerson "described Transcendentalists as few, and 'lonely' in their habits, conversation, and writing. ... many of Emerson's cohort, including some of his close friends, at that very moment were assiduously laboring around Boston to remedy the plight of the poor and others disadvantaged by circumstance." Ministers such as Orestes Brownson and George Ripley “adhered to Saint-Simon's maxim, 'Eden is before us, not behind us,"” and actively worked to perfect humanity through social reform. ${ }^{83}$ As Gura demonstrates, Emerson's centrality to antebellum American Transcendentalism is a retrospective critical construct produced by the revival and secularization of Emerson's philosophy after the Civil War as a key principle in the economic transformation that took place during the period of Reconstruction. The ethos of Brownson and Ripley, which saw social reform as the means toward an edenic era of perfection commonly conflated with the millennium, was the driving force of antebellum Transcendentalism, and that communal urge to reinvent Eden through social and religious reform constitutes a link to, if not a direct inheritance from, the

\footnotetext{
${ }^{82}$ James Fenimore Cooper, The Deerslayer, (New York: Penguin Books, 1987), 541, 376.
} 
seventeenth- and eighteenth-century inhabitants of New England who preceded them.

In a funeral sermon, the eighteenth-century minister Samuel Buell describes the sociality of Eden as one of its defining characteristics and a model for emulation. Exhorting his parishioners to strive for bonds of friendship qualitatively similar to the bond between Adam and Eve, Buell writes that

Life without Friendship and Society, tho' attended with the utmost Affluence of all other outward Comforts, in their rich Variety, would be a rayless Gloom. Perfect solitude would wither all the Glories of Eden, and turn it into a Desart, and a Palace into a Dungeon. Paradise itself appear'd in Part unbless'd, till joyous Friendship crown'd and consummated it's blooming Pleasures. Friendship is the Bond of Bliss in the upper World, where all is Harmony, all is Love; and in this our World, it affords a Sort of Life-sustaining Power. ${ }^{84}$

In this earlier period, Eden's convivial nature was its defining characteristic. As Samuel Willard explains, "Man was made a sociable creature; love and friendship were the bond of this society, and had he kept his innocency, there had never been" the disagreements that isolate members of the human race from one another. ${ }^{85}$

Perhaps more importantly, every facet of edenic life, including its congenial character, was considered worthy of emulation; the invocation of Eden provided Buell and others a link between heaven, or "the upper World," and "this our World" in all of its fallen corruption. Because Eden was the only place on earth where God dwelt with mortals for an extended time, it was the only physical model in which early modern men and women could ground their understandings of heaven's ethereal perfections. ${ }^{86}$ Thus, colonial New

\footnotetext{
${ }^{83}$ Philip Gura, American Transcendentalism: A History, (New York: Hill and Wang, 2007), 15-16, 78.

${ }^{84}$ Samuel Buell, The Divine Agency Acknowledged in the Death of Our Dearest Friends, (New York: J. Parker and W. Weyman, 1757), 5.

${ }^{85}$ Samuel Willard, A Compleat Body of Divinity, (Boston: B. Green and S. Kneeland, 1726), 226.

${ }^{86}$ Cotton's argument that "the same day that Adam was created he fell, or certainly soon after, but most probable the same day" represents an extreme contraction of Adam's stay in Eden; most theologians believed Adam and Eve remained in the garden for a more extended duration. Arnold Williams explains that many
} 
Englanders pressing forward together toward Peter's pearly gates aimed at Eden's

attainments as a sort of way station, a conceptually more concrete—because geographically locatable, physically tangible, and historically linked both to man's present corrupted nature and to his potential for exaltation—version of heaven's spiritual splendors.

\section{Inventing Eden: Methods and Materials}

When William Spengemann first advocated studying "some of the most historically and literarily important English writings of the Renaissance and the Enlightenment" as early American literature because those texts "helped to create the stylistic circumstances" in which English colonial authors wrote, his plea fell largely on deaf ears. ${ }^{87}$ Instead of pursuing inquiries into the linguistic genealogy of American literature, Spengemann's successor at Dartmouth, Ivy Schweitzer, launched a wave of comparative studies in her capacity as an editor of Blackwell's Companion to the Literatures of Colonial America. Examinations of the topical connections between literature in both halves of the western hemisphere provide rich insight to readers by exposing students of Anglophone literatures to a variety of new authors writing in Spanish, French, Portuguese, and other languages, but this shift in the study of early American literature has also resulted in an unnecessary neglect of the

commentators "protest that a period of nine or twelve hours is insufficient for the all the events between Adam's creation and his exile. Hence, Luther places the fall on the seventh day, Pererius conjectures that Adam and Eve remained in Paradise about eight days, and Pareus and Mersenne give them thirty-three and forty days, respectively." See John Cotton, An Exposition Upon the Thirteenth Chapter of the Revelation, (London: 1656), 189; Williams, The Common Expositor, 137.

${ }^{87}$ William Spengemann, A New World of Words, (New Haven: Yale University Press, 1994), 49-50. While Spengemann gestures toward the need for a consideration of other languages impacted by the idea of America in his afterword, his primary concern was with the conjunctions between what we now think of as British and American English. As Leonard Tennenhouse notes, this concern is only now "generating much new work in the field"; as Philip Gould notes, work in the field over the past two decades has gravitated toward the study of "non-English texts" that "rehabilitate the multicultural dimensions" of early American literature at the expense of the English links that were Spengemann's primary focus. See Leonard Tennenhouse, "Revisiting A New World of Words," Early American Literature 42.2 (2007): 363; Philip Gould, "The New Early American 
Anglophone linguistic connections Spengemann labored to illuminate. In an effort to reverse this unfortunate neglect I consistently contextualize the texts and artifacts of seventeenth- and eighteenth-century New England that this study considers with comparisons to early modern British texts and current secondary works on early modern British literature and culture. While New England's congregational emphasis and unique political status clearly provided the first colonists a sense of distinction, they uniformly retained their identity as English subjects and brought British beliefs about Eden with them across the Atlantic to the New World. In addition, the vast majority of the texts that early modern New England writers produced were framed in response to the literature and social concerns of readers in Old England; until the eighteenth century, most of the full-length books published by early American writers were even printed in England. As I move from a discussion of edenic lands to edenic bodies and then to the intellectual, moral, and social perfections possessed by Adam and Eve in the garden and sought after by New England colonists, I refer to texts produced on both sides of the Atlantic. The English examples are illustrative, not comprehensive, but their comparison to colonial visions of Eden fills significant gaps in the fields of inquiry traditionally restricted to the eastern shores of the Atlantic-as Anne Bradstreet's "Humours" challenges the gendered assumptions of humoral theorists working in the British Renaissance, for example.

This study follows the logic of early modern exegetes, who viewed Eden as a threefold paradise, because it makes good sense to describe the Eden that New Englanders sought to create in the same way that they envisioned it. My inquiry into the pursuit of Eden proceeds chronologically, but its organization is primarily topical. I begin with the 
paradisiacal character of the landscape because that is, at least in part, the impetus for the projection of England's eschatological vision onto the new world; I proceed with the physiological, intellectual, linguistic, spiritual, and social aspirations of early modern New Englanders because those are the categories of edenic perfection that they identified and sought to restore. The authors I examine are not selected for their canonicity or diversity; I include every New England author who exhibits a sustained interest in Eden without regard to race, gender, or class. If the authors included in this study are predominantly white, male professionals (and the occasional well-placed white woman), that is only because theirs is the demographic whose pursuit of Eden is best preserved in the historical record. While I offer a form of intellectual history, I make no pretense to having written a comprehensive history of the colonial period in New England. I include some important events—-the Great Awakening and Revolutionary War — while I mention others only briefly—the Salem witch trials and the French and Indian War. Again, the determination as to which historical events I include and which I exclude is largely a function of the internal logic of Eden itself. Certain historical and cultural events inspire, or are inspired by, contemplations of Eden, and those events have received a disproportionate share of attention in the chapters that follow.

In Chapter 1, I examine the ways in which early seventeenth-century colonial accounts of the New England landscape present its edenic attributes. In examining the early written accounts of the land, I focus on the natural artifacts and technological processes described by the authors. By doing so, I hope to avoid the pitfall described by Andrew Sluyter, who points out that "[w]hile ignoring material process might be appropriate in literary criticism, such ethereal analysis certainly falls flat when ingenuously transferred to the analysis of landscape transformations involving processes as clearly biophysical as 
growing food and clearing forests, no matter how indubitably they also involve social processes, including conceptual ones" such as Eden. ${ }^{88}$ While the ideas of paradise and wilderness are central to this chapter, those ideas emerge from and are tied to the physical artifacts and processes that colonists understood to be either paradisiacal or wild.

Between 1622 and 1637, at least fourteen accounts of New England's geographical possibilities and limitations were written by individuals with first-hand knowledge-or previously unpublished second-hand knowledge_ - of the American landscape. Of these relations, only one, William Bradford's Of Plymouth Plantation (1630-1650), characterizes the land as an actively hostile wilderness; the rest either explicitly identify the land as paradisiacal or describe it in such a way that readers in Old England might believe it so. By the second half of the seventeenth century, however, the potential paradise upon which colonists universally agreed had disappeared. This chapter examines the rationale behind early colonial hopes of obtaining a physical paradise in the New England landscape and chronicles the failure of English invention, as colonists gradually realized that the introduction of plows and other technological innovations would not tame or civilize what originally appeared an overgrown paradise. These agricultural failures combined with the Antinomian Controversy, Pequot War, and other early social disruptions to convince the colonists that they first needed to tame the wilderness within their own congregations and physiologies before Providence would provide the paradise for which they hoped.

The physiological self-fashioning in which New England colonists engaged allowed them to alter and, theoretically, to perfect the humoral balance of their bodies. Early modern ethnology presented temperance - the condition of Adam and Eve's physiologies in Eden,

\footnotetext{
${ }^{88}$ Andrew Sluyter, Colonialism and Landscape, (Lanham: Rowman \& Littlefield Publishers, 2002), 9.
} 
where all four humors were ideally balanced—as the perfect physiological state, and New England colonists worked to transform their own overly phlegmatic English constitutions into perfectly temperate physiologies. In Chapter 2, I discuss the evolution of two different types of humoral self-fashioning across the seventeenth and eighteenth centuries: the disciplining of both physical and figurative bodies. Anne Bradstreet and Benjamin Franklin were both socially disadvantaged, Bradstreet because she was a woman and Franklin because he was a poor member of the lower class who enjoyed few familial advantages. As Paster demonstrates, these social stigmas would have rendered Bradstreet and Franklin incapable of perfecting their physical bodies in Old England, but in New England Bradstreet and Franklin engage with greater success in projects of somatic self-fashioning. Bradstreet rewrites humoral hierarchies in her quaternions and paradoxically portrays her excessively phlegmatic (because both English and female) body as the vehicle to achieving edenic temperance. Franklin demonstrates an interest in disciplining the physical body similar to Bradstreet's, but by the late eighteenth century the acquisition of humoral temperance was no longer connected to Eden. Instead, physiological temperance became the first of Franklin's famous thirteen steps to moral perfection; the link between temperance and spiritual perfection remains, but the reason for that link—-the idealized prelapsarian physiologies of Adam and Eve-has faded into obscurity.

In addition to the interest in physical temperance that Bradstreet and Franklin literally embodied, early modern New Englanders were also interested in acquiring ecclesiastical temperance. Seventeenth- and eighteenth-century New England ministers consistently characterized their congregations as ecclesiastical bodies afflicted with distempers, humoral imbalances that lead to disease or, in this case, sin. To remedy these distempers preachers 
like Winthrop and Hooker prescribed Christian virtues such as charity—whose warming power would thaw the cold, phlegmatic hearts of their listeners and engender spiritual temperance. Ministers also worked to regulate the consumption of the ecclesiastical body in other ways. As David Hall notes, they appointed fast days that "carried people out of ordinary time_ - or out of time's decay—back to that moment when all things were 'new,' when time was everlasting, when the ideal coincided with reality" in Eden. ${ }^{89}$ In addition, New England ministers generally restricted entry to the ecclesiastical body and access to communion; while Solomon Stoddard dispensed the Lord's Supper to all of the visibly godly as though it were a sort of spiritual medicine that would promote conversion, Jonathan Edwards hoped to restore spiritual temperance to a Northampton congregation troubled with the Great Awakening's distempers by reversing Stoddard's policies and restricting access to communion. He describes himself as the mouth of the metaphorical ecclesiastical body over which he presides, accepting and digesting only those applicants whose savor identifies them as members of the elect. Just as Bradstreet and Franklin struggled to discipline their physical bodies, early modern ministers labored to promote an edenic temperance in the ecclesiastical body. They, like Franklin, recognized temperance as the physiological foundation upon which more ethereal intellectual, spiritual, and social perfections were predicated.

The seventeenth-century quest to recover the intellectual perfections of Adam in Eden was inextricably linked to Francis Bacon, whose Great Instauration (1620) provided a systematic program for the recovery of Adam's knowledge of the natural world. In his New Atlantis (1627) Bacon describes the island utopia of Bensalem, where a body of scholars known as Salomon's House, or the College of the Six Days Work, performs scientific

\footnotetext{
${ }^{89}$ David D. Hall, Worlds of Wonder, Days of Judgment, (New York: Knopf, 1989), 171.
} 
experiments designed to restore Adam's lost knowledge. The wisdom of Solomon and the knowledge of Adam were frequently connected in early modern thought, and Chapter 3 explores the ways in which seventeenth- and eighteenth-century New Englanders worked to recover the intellectual attainments of these two figures. Cotton justifies the Bay Colony's remove to the New World by citing the example of the Queen of Sheba, who traveled "from the utmost parts of the earth to heare the wisdome of Salomon," and the search for edenic or Salomonic wisdom was institutionalized at Harvard College. ${ }^{90}$ Harvard's founders described the college as a modern school of the prophets where a portion of Adam's wisdom had been preserved, and its first students adopted the new philosophy of Bacon to prove that paradise could, in fact, be restored. Harvard president Leonard Hoar would even have transformed the New England school into the first university wholly dedicated to Bacon's experimental methods if not for his untimely death. Bacon's edenic aims and inductive reasoning were a part of New England's official educational policies from the beginning.

Of course, higher education and Harvard College were off-limits to women, and the second half of Chapter 3 describes Bradstreet's interest in acquiring Solomonic wisdom outside official channels. Because Eve's quest for knowledge and wisdom led to the Fall, women such as Bradstreet were discouraged from harboring the intellectual aspirations of their male counterparts: wisdom was widely considered a masculine pursuit in seventeenthcentury New England. Bradstreet's poems reveal a woman committed to Puritan orthodoxy who is also interested in gender equality; rather than reject the Calvinist condemnation of Eve as a sinful temptress she reinscribes it, finding an alternative model for the pursuit of wisdom in the more modern example of Queen Elizabeth. Bradstreet even lays claim to the

\footnotetext{
${ }^{90}$ John Cotton, Gods Promise to His Plantations, (London: William Jones, 1630), 8.
} 
wisdom of Solomon, but her interest in wisdom was not imitated by her peers who, by and large, were content to obey the Solomonic and ministerial injunction to "Fear God, and keep his commandments. ${ }^{, 11}$ The effort to reclaim edenic and Solomonic wisdom was pursued almost exclusively by men—and highly educated men (e.g. ministers) at that—-throughout the early modern period. But the uneasy synthesis between Bacon's new philosophy and the Calvinist commitment to an inscrutable God came unglued as the Enlightenment progressed, and Jonathan Edwards was one of the last intellectuals in New England to treat Bacon and Calvin with equal seriousness.

Part of the early New England interest in Bacon was prompted by his call for linguistic reform, as expressed in George Herbert's Latin translation of the Advancement of Knowledge (1605). Since the language and wisdom of Adam were understood as inextricably linked, colonial pretensions to prelapsarian wisdom were necessarily accompanied by aspirations to linguistic purity. Enthusiastic millenarians such as John Eliot proposed establishing Hebrew as the lingua franca of New England because he, like most seventeenthcentury theologians, believed Hebrew was the language spoken by Adam in Eden, but most of his contemporaries spent their energies in support of a more practical pursuit: the purification of English. Chapter 4 presents Herbert's poems as exemplary models of Baconian language reform that shed light on the linguistic work done by New England poets with very different sensibilities. Herbert offers two diametrically opposed pathways to linguistic purity: in poems such as "Paradise" and "Jordan (2)," he advocates a plain aesthetics reminiscent of the Bay Psalm Book; in more metaphysical offerings such as "The Holy Communion" or "The Sacrifice," he connects prelapsarian perfection to alchemy,

\footnotetext{
${ }^{91}$ Ecclesiastes 12:13.
} 
where language is purified by the complex mystical rituals that Edward Taylor embraces. Hebrew and Herbert are complementary models of the edenic devotional language that New England poets sought into the early eighteenth century, when writers like Cotton Mather embraced Milton as an alternative pattern for paradisiacal language.

As the eighteenth century progressed, explicit and public references to Eden gradually diminished, but edenic ideals continued to shape the spiritual aspirations and religious culture of New England. Whereas seventeenth-century colonists described conversion as a life-long journey that would return the successful pilgrim to edenic innocence, eighteenth-century ministers and converts who participated in the Great Awakening emphasized a new birth that produced instantaneous sanctification. This shift in the discourse of conversion from pilgrimages, Eden, and innocence toward the new birth and sanctification was, ironically enough, the product of Jonathan Edwards's interest in Eve's regeneracy as a model for conversion. Edwards is widely recognized as a central influence on the evangelical and revival movements, and his emphasis on an immediate, physical new birth can be directly connected to his understanding of Eve's conversion experience at the birth of Cain. In Chapter 5 I contend that Eve, through Edwards, is responsible for a pivotal shift in New England morphology as ministers and converts made the new birth the primary trope of conversion, abandoning the metaphor of a temporally protracted pilgrimage for an emphasis on being born again in a more immediate experience compatible with the constrained timeframes of revivals. Her influence has long passed unnoticed because Edwards's musings on Eve were hidden in his private notebooks, but uncovering her contributions to the theological innovations that made the eighteenth-century revivals possible suggests edenic models continued to shape New England culture and experience long after the explicit 
references to Eden which distinguished seventeenth-century texts had stopped being so common.

This underground current of edenic thought resurfaced again during the American Revolution and in the formative years of the early republic, as the founding fathers relied on theories of natural law and balanced government indebted to the foundational narrative of Genesis. I argue in Chapter 6 that by fashioning a Constitution based on the Oceana of James Harrington, these national leaders openly announced their pretension to edenic governmentan ambition that was identified by and shared with a large portion of the nation's upper and middle classes, especially men initiated as Freemasons. The purpose of Freemasonry, as identified by eighteenth-century Masonic leaders, was the reversal of the Fall, and these leaders viewed the United States as the vehicle by which they could create a paradisiacal, postmillennial society. Not all shared their optimism; while descriptions of the new republic as an edenic space are almost ubiquitous in this period, citizens were more likely to fear a national Fall than to forecast a triumphant ascent to perfection. While some writers warned of the dangers of slavery or a Native American insurgency, others worried that religious declension would leave the nation without virtuous leaders. Whether the anticipated trouble involved race relations, a retreat from Calvinist doctrines, the specter of a national bank, female suffrage, or a number of other fears, these problems were consistently described as snakes in the national garden with the power to fascinate and destroy its innocent civilian inhabitants. The first citizens of the United States could—and did—point to the republic as an earnest of edenic perfection in a way that they could point to no other social achievement or institution, but by the early nineteenth century they had come to believe that the new republic was deeply flawed and that its fall was inevitable. The founding and formative years 
of the United States marked both the apogee and the end of mainstream edenic aspirations in New England and the nation. 


\section{CHAPTER 1}

FINDING PARADISE, CULTIVATING WILDERNESS:

THE GEOGRAPHICAL POSSIBILITIES AND AGRICULTURAL REALITIES OF COLONIAL NEW ENGLAND

When, in 1616, John Smith praised Massachusetts as an Eden in waiting, he wrote his Description of New England (1616) from a ship-side perspective. Smith made only limited and inconclusive forays inland, a fact that his praise for the fisheries and harbors off the New England coast often obscures. But in between his encomiums on the "Paradise of all those parts," Smith confesses that New England itself remains largely unexplored; he writes that of this 2000 miles more than halfe is yet vnknowne to any purpose: not so much as the borders of the Sea are yet certainly discovered. As for the goodness and true substances of the Land, wee are for most part yet altogether ignorant of them, unlesse it bee those parts about the Bay of Chisapeack and Sagadahock: but onely here and there we touched or have seene a little the edges of those large dominions, which doe stretch themselves into the Maine, God doth know how many thousand miles; whereof we can yet no more judge, then a stranger that saileth betwixt England and France can describe the Harbors and dangers by landing here or there in some River or Bay, tell thereby the goodnesse and substances of Spaine, Italy, Germany, Bohemia, Hungaria \& the rest. ${ }^{1}$

By his own admission, Smith was no more familiar with the actual character of the New England landscape than a Devonshire cod fisherman is with the plains of Spain, and the terrain of New England remained largely unknown until a company of Leiden Separatists arrived at Cape Cod on November 9, 1620 and established the first permanent European

\footnotetext{
${ }^{1}$ John Smith, "A Description of New England," in Captain John Smith: Writings with Other Narratives of Roanoke, Jamestown, and the First English Settlement of America, ed. James Horn, (New York: Library of America, 2007) 149, 135-36.
} 
settlement in New England at Plymouth. ${ }^{2}$

These colonists quickly came to several realizations about the New England landscape that Smith ignored or touched on only briefly in his Description-which they may not have read with as much care as they consumed reports about Virginia, since their charter was for "a Voyage to plant the first Colony in the Northerne parts of VIRGINIA." "3 Where Smith, based on his work as a gardener "in June and July," hypothesized that "winter is more colde in those parts," the Pilgrims experienced for themselves the "freezing cold weather" which "caused many to get colds and coughs" and "afterward turned to the scurvey, whereof many dyed." "The winter's lethal cold was a continuous source of concern for Plymouth settlers who had to march "up and downe the steepe hills, and deepe vallies, which lay halfe a foot thicke with snow" just to find a place suitable to build in; their experience was a far cry from Smith's promise that "this a most excellent place, both for health \& fertility." Even the seafood of which Smith boasts "made us all sicke that did eat." But if the winter was more deadly than Smith had warned, it was also more fruitful than the Pilgrims might reasonably have hoped; the Relation of G. Mourt, the earliest published account of life at Plymouth, indicates that they found "many kinds of hearbes" growing in the middle of "Winter, as Strawbery leaues innumerable, Sorrell, Yarow, Caruell, Brook-lime, Liver-worst,

\footnotetext{
${ }^{2}$ The Plymouth settlers quickly came to a more complete understanding of New England's climate and landscape than Smith, but they remained cognizant of their own ignorance as to the extent and content of New England's interior parts. In a sermon written one year after their arrival at Plymouth, Robert Cushman expressed a belief that New England "is an Iland, and neere about the quantitie of England" but acknowledged that the "secrets of [New England], we haue not yet so found as that as eye-witnesses we can make narration thereof." See Robert Cushman, A Sermon Preached at Plimmoth, (London: I. D., 1622), A2-A3.

${ }^{3}$ G. Mourt, Relation, (London: Iohn Bellamie, 1622) 3. While the Plymouth settlers may not have read Smith's Description before they departed, they were familiar with it by the end of their first year at Plymouth, when Cushman explains that he refers to his new home as "NEW ENGLAND ... because Captaine Smith hath so entituled it in his Description." See Cushman, A Sermon Preached at Plimmoth, A2.

${ }^{4}$ Smith, "A Description of New England," 143; Mourt, Relation, 3, 8.

${ }^{5}$ Mourt, Relation, 9; Smith, “A Description of New England,” 143.
} 
Water-cresses, great store of Leekes, and Onyons, and an excellent strong kind of Flaxe, and Hempe." 6 To the first permanent Old World residents of New England, the landscape was a paradox — deadly and delightful, perilous and promising.

The initial published accounts from Plymouth were fairly balanced in their assessment of New England's geographical limitations and possibilities. If they described New England as a "Wildernesse," they nevertheless recognized the beneficence of their Native American neighbors who "were wont to be the most cruelest and trecherousest people in all these parts, euen like Lyons, but to vs they haue beene like Lambes, so kinde, so submissiue, and trustie, as a man may truly say many Christians are not so kinde, nor sincere." Though the "Countrey is yet raw, the land vntilled, the Cities not builded" and therefore understood as a wilderness, it was also reminiscent of Isaiah's “new heavens and a new earth" where God has promised that "the lion shall eat straw like the bullock" and lie down with the lamb, just as the Native Americans had given up their "trecherous" ways to coexist peacefully with the Pilgrims, and where the elect "shall build houses, and inhabit them; and they shall plant vineyards, and eat the fruit of them" and "long enjoy the work of their hands." $" 7$ The settlers at Plymouth acknowledged both the risk of inhabiting an unfamiliar geographical space as well as the potential physical and spiritual harvests waiting to be reaped in their churches and fields. But later writers, who described these inaugural months of settlement with the benefit of hindsight, shifted to polarized view points in which the landscape was either lauded or demonized. From the same set of circumstances, writers

\footnotetext{
${ }^{6}$ Mourt, Relation, 2, 22.

${ }^{7}$ Cushman, A Sermon Preached at Plimmoth, A3, 14; Isaiah 65:17-25. Because Isaiah characterizes the millennial restoration of prelapsarian relations between predators and prey as a time when human labor will continue, it is possible for Cushman to view the remarkable transformation of the lion-like "Savages" into lamblike innocents as a sign of millennial promise despite the significant labor that remains to be done in civilizing them and the New England landscape.
} 
drew conflicting conclusions: using the Council for New England as his mouthpiece, Sir Ferdinando Gorges proclaimed that New England was "so temperate, as it seemeth to hold the golden meane" and was inhabited by "poore innocent creatures," while William Bradford found nothing more than "a hideous and desolate wilderness, full of wild beasts and wild men." ${ }^{8}$ This chapter examines the rationale behind those inconsistent positions and chronicles the gradual triumph of those who championed the wilderness perspective as the inhabitants of New England sacrificed their belief in a present paradise in the hope of recovering a future Eden, only to find their progress toward paradise interrupted by Indian warfare and an internal wilderness of religious dissension.

\section{Finding Paradise: "The More I Looked, the More I Liked It."}

Most critical treatments of early colonial responses to the New England landscape characterize it as a wilderness. Peter Carroll devotes an entire volume to Puritanism and the Wilderness (1969) and mentions only in passing that New England was also judged "a potential paradise" by some. Likewise, Richard Slotkin lumps in the Plymouth Pilgrims and Bay Colony Puritans with other groups of men who

tore violently a nation from the implacable and opulent wilderness-the rogues, adventurers, and land-boomers; the Indian fighters, traders, missionaries, explorers, and hunters who killed and were killed until they had mastered the wilderness; the settlers who came after, suffering hardship and Indian warfare for the sake of a sacred mission or a simple desire for land; and the Indians themselves, both as they were and as they appeared to the settlers, for whom they were the special demonic personification of the American wilderness. ${ }^{9}$

\footnotetext{
${ }^{8}$ Council for New England, An Historicall Discoverie and Relation of the English Plantations in Nevv England, (London: Iohn Bellamie, 1627), D1, B3; William Bradford, Of Plymouth Plantation, ed. Samuel Eliot Morison, (New York: Alfred A. Knopf, 2002), 62. Gorges obtained a patent for New England from forty to forty-eight degrees north latitude and established the Council for New England to administer affairs in the colony. The anonymously authored Historicall Discoverie is generally accepted as his work.

${ }^{9}$ Peter N. Carroll, Puritanism and the Wilderness, (New York: Columbia University Press, 1969), 15; Richard Slotkin, Regeneration Through Violence, (Middletown: Wesleyan University Press, 1973), 4.
} 
More recently, Timothy Sweet describes an American georgic tradition; he begins with Bradford's wilderness in the 1630s and moves directly to the seventeenth-century historian Edward Johnson's anticipation of a millennial landscape in 1652. Cecilia Tichi likewise acknowledges that there are "two opposing kinds of response to the New England geography, one celebrating fecundity (at least sufficiency) and the other announcing hardship or bare subsistence"; but she, like Slotkin, emphasizes the "inevitable voices of disillusionment" and insists that "the Puritans were unswayed by promises of new Edens." From the midseventeenth century onward, everyone acknowledges the Puritan "commitment to change the New World landscape, literally to re-form it" from wilderness to paradise. ${ }^{10}$ But what happened to the "Paradise" that John Smith claimed to have found in the first place? Why did the initial Pilgrim survey conclude that New England was "so goodly a Land"? What happened to the "hopefull Country" they settled in $1620 ?{ }^{11}$ Was there ever an edenic landscape in New England?

In the Introduction, the case for identifying the New England landscape of the 1620s as a present paradise is implicit in my description of Eden. An edenic landscape provides its inhabitants with

1. The resources and geographical space to support propagation and immigration;

2. Pleasant labor that is abundantly rewarded with year-round plenty;

3. A temperate climate; and

4. An encyclopedic collection of flora and fauna.

Those who looked for paradise in the New England landscape found all of these things. Their discovery, like Columbus's putative discovery of Eden in the West Indies, was a foregone

\footnotetext{
${ }^{10}$ Cecilia Tichi, New World, New Earth, (New Haven: Yale University Press, 1979), 20-21, 2-3.

${ }^{11}$ Smith, “A Description of New England," 149; Mourt, Relation, 1, B2.
} 
conclusion because they utilized the same "'finalist' strategy of interpretation"; for men like Gorges, the discovery of a paradise was the best way to "balance the concerns of centralized economic-environmental management and the individual production of wealth" that Sweet reminds us was at the center of every colonization project, and so the discovery of New England's paradisiacal nature was the inevitable result of Gorges's interpretation from London of first-person accounts in Plymouth. ${ }^{12}$ Similarly, the Scottish politician William Alexander portrays New England—but more especially Nova Scotia_-in paradisiacal terms primarily because geographical distance allows and financial interest compels him to do so. The initial attempt to colonize New Scotland, as Alexander named Nova Scotia before its cession to the French, was even less successful than the Separatist venture at Plymouthwhich saw half of its number die in the first winter-but Alexander still describes this northern portion of the New World as a land "gorgeously garnished with all wherewith pregnant nature ravishing the sight with variety can grace a fertile field." ${ }^{\prime 13}$ From across the Atlantic and in the expectation of an exceptional return on investment, it was easy for colonial financiers to read the reports of Plymouth Pilgrims as an overly cautious description of paradise.

\footnotetext{
${ }^{12}$ Tzvetan Todorov, The Conquest of America, trans. Richard Howard, (New York: Harper \& Row, 1984) 17;Timothy Sweet, American Georgics, (Philadelphia: University of Pennsylvania Press, 2002) 7-8.

${ }^{13}$ William Alexander, An Encouragement to Colonies, (London: William Stansby, 1624) 30-31. The first company of colonists financed by Alexander never even made it to Nova Scotia and abandoned the enterprise completely after their rescue from a brutal winter on Newfoundland. Alexander's description of New England as both pregnant and ravishing takes significant liberties with the opening scene of Mourt's Relation, where the pilgrims first see land after their voyage across the grim, wintry Atlantic and "the appearance of it much comforted vs, especially, seeing so goodly a Land, and woodded to the brinke of the sea." While Mourt never describes the land in the same glowing terms as Alexander, he does allow that "we are so farre from want, that we often wish you partakers of our plentie." See Mourt, Relation, 1, 61. Jorge Cañizares-Esguerra has shown that this imaginative leap made by Alexander is also an integral part of the Iberian-Catholic tradition in American literature; he argues that the ways in which both New England Puritans and Spanish conquistadors "imaginatively transformed their local landscapes into Holy Lands, sacred spaces, New Jerusalems," and, I might add, Edens, in order "to justify expansion and colonization" were strikingly similar. See Jorge CañizaresEsguerra, Puritan Conquistadors (Stanford: Stanford University Press, 2006), 30.
} 
That the colonists themselves did not regularly refer to the New England landscape as a new Eden, a paradisiacal land of plenty, was not a problem for the imperial aspirations of men like Gorges and Alexander because colonial accounts commonly described Eden, even if they did not name it. Moreover, Francis Bacon's The Advancement of Learning (1605) and New Atlantis (1627) had provided a new paradigm for the production of knowledge in the seventeenth century that divided responsibilities between colonial observers and imperial interpreters of the natural world. As Ralph Bauer explains, "[t]he secrets of nature would thus be unlocked in a prescribed order in which the eyewitness would surrender his first-hand observations to the detached 'speculator' to be refined into the 'true axioms' of modern knowledge." The colonial contributors to Mourt's Relation were not expected to draw any conclusions from their observations of the New England landscape; rather, they were subject to "the imposition upon experiential testimony of an authorial ideal that [Julie] Solomon calls 'epistemic self-distancing' - the effacement of the eye-witnesses's subjectivity in the delivery of facts." ${ }^{\prime 14}$ As a result of this imperial insistence on colonial objectivity, the earliest New England narratives written by settlers provided unvarnished accounts of the landscape that largely avoided conclusions about the possibilities and limitations of their natural setting. Robert Cushman, author of a 1622 sermon preached at Plymouth and published in London, concluded that "[i]t pertaineth not to my purpose to speake any thing, either in prayse, or dispraise of the country," only to provide essential details describing "the place where we liue" as a necessary context for readers of his sermon. Because the Plymouth authors were "better acquainted with planting then writing," their narrative was composed in an admittedly "plaine and rude manner," furnished with objective observations which metropolitan

\footnotetext{
${ }^{14}$ Ralph Bauer, The Cultural Geography of Colonial American Literatures, (New York: Cambridge University Press, 2003) 15-16. For a description of Bacon's imperial and hierarchical system of knowledge production, see Chapter 3, pp. 167-68.
} 
advocates of English colonization like Gorges, Alexander and the English preacher Richard Eburne construed as signs that New England was a new Eden where God "hath, as for Adam in Paradise, before he placed him there, Gen. 1. so for them, before he bring them thither, prouided so well."15

\section{The Population of Eden}

Because early modern men and women understood God's command to Adam and Eve in Eden to "[b]e fruitful, and multiply, and replenish the earth" as the original authorization for plantations, some Renaissance exegetes thought that Eden was a paradisiacal state encompassing the entire world, a garden capable of holding all of humanity. ${ }^{16}$ For preachers such as Eburne and John White, then, who took "their warrant [for the establishment of colonies] from Gods direction and command; who as soone as men were, set them theire taske, to replenish the earth, and to subdue it," it was important to show that these new plantations, like Eden, were both spacious and fruitful enough to sustain the population growth that justified their existence. They believed that England had degenerated because its population growth had overrun the available land and natural resources; an "excessiue multitude of people" such as currently inhabited England inevitably tended "to decline to idlenesse, riot, wantonnesse, fraud, and violence, the fruits of well-peopled Countryes, and of the abundance and superfluities of long setled States." ${ }^{17}$ In contrast, "the

\footnotetext{
${ }^{15}$ Cushman, A Sermon Preached at Plimmoth, A3-A4; R. G., "To His Much Respected Friend," in G. Mourt, Relation, (London: 1622), B; Richard Eburne, A Plaine Path-VVay to Plantations, (London: G. P., 1624), 25. Though the pilgrims who settled at Plimoth claimed to be plain country farmers, Howard Russell points out that "actual agricultural experience among the 102 people who embarked in the Mayflower was apparently not great.” See Howard S. Russell, A Long Deep Furrow, (Hanover: University Press of New England, 1976 ), 12.

${ }^{16}$ Genesis 1:28. Protestant commentators alternately embraced and rejected this position. For a brief survey of thinkers who believed in a paradisiacal earth, as opposed to a more geographically limited paradisiacal garden, see Alessandro Scafi, Mapping Paradise, (London: The British Library, 2006), 264-66.

${ }^{17}$ John White, The Planters Plea, (London: William Iones, 1630), 1, 5; Eburne, A Plaine Path-VVay to Plantations, A2.
} 
taking in of large Countreys presents a naturall remedy against couetousnesse, fraud, and violence; when euery man may enjoy enough without wrong or injury to his neighbour. Whence it was, that the first ages, by these helpes, were renowned for golden times." ${ }^{18}$ The establishment of plantations would recapture the "golden" character of those first ages, in which Adam and Eve set about the business of populating Eden and the world, and New England's expanse of empty fields provided an ideal opportunity for settlers to do so.

"[S]o long as there was no vast ground, howsoeuer men had beene willing, whereupon Plantations might haue beene made," it was impossible for men and women to establish a new Eden reminiscent of the original, from which "the world in her infancy, and innocency, was first peopled." But the discovery of the New World's "vast ground" and sparse native populations transformed the practice of colonization from a past ideal into a present possibility. Alexander suggests that the New England landscape approaches nearest to the puritie of these that (by an industrious diligence) in the infancie of the first age did extend the multiplying generations of Mankind, to people the then Desert Earth, for here [immigrants] may possesse themselues without dispossessing of others, the Land either wanting Inhabitants, or hauing none that doe appropriate themselues any peculiar ground but (in a straggling company) runne like beasts after beasts, seeking no soile but onely after their prey. ${ }^{19}$

The nomadic nature and abandoned dwellings of New England's native population were construed as an open invitation to fulfill God's command by establishing a permanent human presence in this remote corner of the earth. While New England's coastline was relatively sparsely settled at the time English immigrants arrived, we now know that colonial accounts overexaggerated the emptiness of the coast; as Charles Mann notes, "the Americas were immeasurably busier, more diverse, and more populous than" explorers believed them to

\footnotetext{
${ }^{18}$ White, The Planters Plea, 5.

${ }^{19}$ Alexander, An Encouragement to Colonies, 37.
} 
be. ${ }^{20}$ The empty American chaos that made immigration seem inviting were- to some degree—constructs of seventeenth-century European imaginations.

In the coastal regions of New England the supposedly pristine landscape was "thoroughly marked by humankind" but also apparently devoid of human inhabitants. ${ }^{21}$ Of course, the coast was uninhabited largely because its Indian residents had died from exposure to the diseases of European explorers; ironically, the diseases of England's degenerate, overcrowded cities - whose deteriorating conditions were an indication of the need to purge England of its excess population —-were the very means which enabled colonial pretensions to prelapsarian purity. As Andrew Sluyter explains,

Introduced diseases such as smallpox ultimately did more to materially and conceptually transform the landscape of the Americas than any other single process. As disease vastly reduced native population, desettlement resulted in changes in land use and vegetation patterning. Non-natives eventually recategorized the moribund cultural landscape that they had resettled, believing it to be a pristine wilderness. ${ }^{22}$

The former Indian population of the Massachusetts coast hardly left behind a culturally "moribund" landscape, but their deaths did facilitate the identification of New England as a potentially pristine Eden by creating the illusion of a land that could accomodate exponential population growth.

While a significant Indian population remained in New England, settlers apparently believed that the land could accommodate an almost unlimited growth. Alexander believed that "either Virigina, or New England, hath more bounds then all his Maiesties subiects are able to plant." William Wood, writing in 1634, was even more optimistic, arguing that "these two places [the towns Aogwamme and Merrimacke] may containe twice as many people as

\footnotetext{
${ }^{20}$ Charles C. Mann, 1491, (New York: Alfred A. Knopf, 2005), 15.

${ }^{21}$ ibid, 4.

${ }^{22}$ Andrew Sluyter, Colonialism and Landscape, (Lanham: Rowman \& Littlefield Publishers, 2002), 25.
} 
are yet in new England: there being as yet scarce any inhabitants in these two spacious places." 23 According to Wood, even if the entire European presence in New England had been concentrated in just one of these towns, there still would have been room for growth. He viewed New England's landscape as an unbounded expanse more than large enough to handle the pressures of immigration and propagation without placing strain on its natural resources. By establishing a plantation in New England, colonists could guarantee that the landscape would be fruitful because "we may guesse at [God's] intention and will, to have the earth replenished, by the extraordinarie frutifulnesse that he gave to mankinde in those first times.” Because God had rewarded early efforts to propagate and replenish the earth with abundant harvests, colonists could expect Him to reward New England plantations with a similar abundance.

\section{$\underline{\text { Labor and its Rewards }}$}

Adam was told that as a result of the Fall the ground would bring forth "thorns also and thistles," that cultivating the newly hostile soil will be hard work: "In the sweat of thy face shalt thou eat bread." Early modern readers of the Bible understood that these postlapsarian difficulties were part of Adam's curse but that work itself was not because Adam also worked while he lived within Eden's bounds. In the first sermon to emanate from New England, Cushman decries men who "thinke to haue more in this world then Adams felicitie in Innocencie, being borne (as they thinke) to take their pleasures, and their ease, let the roofe of the house drop thorow, they stirre not; let the field be ouer-growne with weeds, they care not, they must not soile their hand, nor wet their foote.” Cushman's insistence that those who avoid work seek more than "Adams felicitie in Innocencie" clearly substantiates

\footnotetext{
${ }^{23}$ Alexander, An Encouragement to Colonies, 32; William Wood, Nevv Englands Prospect, (London: Tho. Cotes, 1634), 44.
} 
his own belief that Adam worked in the Garden, a position widely shared by other Puritan ministers. John Smith explains that the prelapsarian "labour which [Adam] had before, was a delightfull, not a painefull or penall labour," and in the words of the late seventeenth-century minister Samuel Willard, work before the Fall "would have been a recreation and delight, without any weariness at all." ${ }^{24}$ Accordingly, promoters of New England's paradisiacal promise emphasized the redemptive and delightful character of the work awaiting immigrants and indicated that this labor would be rewarded with bounteous harvests from a cooperative landscape.

While work in New England was enjoyable, it was work nonetheless. Christopher Levett debunks the belief that the New England landscape would provide an unearned bounty in his 1624 account of the voyage he made with Sir Ferdinando Gorges's son, Robert. Levett promises that in his narrative he will not

doe therein as some haue done, to my knowledge speake more then is true: I will not tell you that you may smell the corne fields before you see the Land, neither must men thinke that corne doth growe naturally (or on trees,) nor will the Deare come when they are called, or stand still and looke one a man, until he shute him, not knowing a man from a beast, nor the fish leape into the kettle, nor on the drie Land, neither are they so plentifull, that you may dipp them up in baskets, nor take Codd in netts to make a voyage, which is no truer: then that the fowles will present themselues, to you with spits through them. ${ }^{25}$

New England, Levett assured his readers, is no land of Cockaygne, where cooked food presents itself to the eater without any exertion. Yet if, as William Cronon concludes, Levett warned against the "vision of a landscape in which wealth and sustenance could be achieved

\footnotetext{
${ }^{24}$ Genesis 3:18-19; Cushman, A Sermon Preached at Plimmoth, 6; John Smith, An Exposition of the Creed, (London: Felix Kyngston, 1632), 162; Samuel Willard, A Compleat Body of Divinity, (Boston: B. Green and S. Kneeland, 1726), 225. Arnold Williams summarizes the opinions of hexameral exegetes on the state of labor before and after the Fall: "Labor then existed in Paradise, but not hard, odious toil. That was the effect of the curse on Adam after the fall; not that he should work, but that his work should be irksome and painful." See Arnold Williams, The Common Expositor, (Chapel Hill: The University of North Carolina Press, 1948), 111.

${ }^{25}$ Christopher Levett, A Voyage Into New England, (London: William Iones, 1630), 22.
} 
with little labor," he did not deny that labor in New England was both easier and more productive than comparable labor in the Old World. ${ }^{26}$

The efforts of their Indian predecessors, who before being decimated by sickness had cleared and farmed much of the land subsequently settled by English immigrants, shaped the nature of the work that remained for these newcomers. Because so much land had been cleared, obtaining firewood "alwayes cost vs a great deale of labour," but the methods of Indian agriculturists also saved the settlers labor of a different sort. Wood explains that "whereas it is generally conceived, that the woods grow so thicke, that there is no more cleare ground than is hewed out by labour of man; it is nothing so; in many places, divers Acres being cleare ... it being the custome of the Indians to burne the wood in November, when the grass is withered, and leaves dryed, it consumes all the underwood, and rubbish, which otherwise would over grow the Country."27 The fires of Indian farmers and hunters allowed English colonists to travel through wooded territory unimpeded by underbrush and to plant land that was "of a character unusually easy to work." As a result, it was "not much troublesome for to cleere for the Plough to goe in, [and there was] no place barren." The labor they faced in hauling firewood across large open fields was more than mitigated by the fact that they did not have to clear the very fields across which they carried their kindling. More importantly, the labor provided to New England colonists was actually regenerative. In a letter attached to Francis Higginson's Nevv-Englands Plantation (1630), a colonist named Graves points out that "few or none doe heere fall sicke, vnlesse of the Scuruy that they bring from aboard the Shippe with them, whereof I haue cured some of my Companie onely by labour." Since no Protestant would dare to "dreame of an absolute ease" anyway, the relative

\footnotetext{
${ }^{26}$ William Cronon, Changes in the Land, (New York: Hill and Wang, 1983), 35.

${ }^{27}$ Mourt, Relation, 18; Wood, Nevv Englands Prospect, 15.
} 
delights of labor can only be judged "comparatiuely, according to the occasions more or lesse," and New England's empty fields and orderly woods, "which a pleasing industry may quickly bring to a perfection," provided immigrants with both the "guiltlesse labour" and the abundant harvests that Adam enjoyed in Eden. ${ }^{28}$

Colonial writers regularly praised the empty but fertile New England fields for the quality of their soil. The first settlers at Plymouth report that "the crust of the earth is a spits depth, excellent blacke mold and fat in some places" and subsequent groups also found "as fat blacke Earth as can be seene any where. ${ }^{, 29}$ European readers must have reacted with skepticism to these claims because later colonists defended the use of fish carcasses as fertilizer in fields whose excellent soil would seem to make this agricultural enhancement unnecessary. Wood explains that "although many deeme it barren, because the English use to manure their land with fish, which they doe not because the land could not bring corne without it, but because it brings more with it." Wood insists that the New England landscape was naturally fruitful, but he also notes that the landscape rewarded the labor of its inhabitants—not that catching these fish, which were "bigger than the English Shaddes and fatter," was hard work, since they "come up to the fresh Rivers to spawne, in such multitudes as is almost incredible"-with an additional abundance. ${ }^{30}$

The soil's abnormal fecundity was repeatedly praised by farmers who discovered that wild and cultivated crops alike grew to a greater size and with a higher quality in New England than in Old. Wild strawberries were "in abundance" and measured a remarkable

\footnotetext{
${ }^{28}$ Russell, A Long, Deep Furrow, (Hanover: University Press of New England, 1976), 11; Francis Higginson, Nevv-Englands Plantation, (London: T. \& R. Cotes, 1630), D2; Alexander, An Encouragement to Colonies, 27, 42,6 .

${ }^{29}$ Mourt, Relation, 22; Higginson, Nevv-Englands Plantation, B2.

${ }^{30}$ Wood, Nevv Englands Prospect, 12, 34.
} 
"two inches about." Wild grapes were even larger; the "[v]ines doe grow heere plentifully laden with the biggest Grapes that I ever saw," and some grapes measured an astounding "foure inches about." Such a claim stretches the modern imagination, and one cannot help but suspect that these reports were meant to resemble the biblical descriptions of Canaan, where a single cluster of grapes was so heavy that "they bare it between two [men] upon a staff." ${ }^{31}$ Crops imported from Europe also prospered in this paradisiacal country "whose endowments are by learned men allowed to stand in a parallel with the Israelite's Canaan"; once planted in New England soil, "Turnips, Parsnips and Carrots are here both bigger and sweeter then is ordinarily to be found in England." Even more impressive than the size of wild fruit or the improvements in their vegetable gardens, however, were the geometrically expanding returns that British farmers reaped from their experiments with maize. Graves claimed that "every thing that is heere eyther sowne or planted prospereth farre better than in Old England: the increase of Corne is here farre beyond expectation, as I haue seene here by experience in Barly, the which because it is so much aboue your conception I will not mention," but other farmers did quantify the effect of New England's climate on crop yields. From a single seed of maize, farmers could expect to reap far more grains of corn than they had ever received from planting individual stalks of wheat in England. With just one seed planted, harvests of "[t]hirtie, fortie, fiftie, sixtie are ordinarie here: yea Iosephs encrease in Aegypt is out-stript here with vs. Our planters hope to haue more than a hundred fould this yere: and all this while I am within compasse; what will you say of two hundred fould and vpwards?" By 1637, this initial optimism had ballooned, and "some of good credit now in this Kingdome ... affirmed that they had above 300. fold.” The New England soil was so

\footnotetext{
${ }^{31}$ ibid, 13; Higginson, Nevv-Englands Plantation, D2; Numbers 13:23.
} 
productive that only biblical comparisons could adequately express colonial "wonderment" at a degree of agricultural prosperity more befitting Canaan or Eden than England. ${ }^{32}$

This apparently exponential increase in grain yields was, for colonists, akin to the miracle Christ performed by multiplying seven loaves of bread to feed the five thousand; naturally, then, the animal populations of New England seemed to propagate as rapidly as the two fishes that his apostles served with those loaves. Gorges claimed that the wild deer of New England "bring forth two, three, and foure young at once, which is a manifest proofe of the fertility of the Soile, or temper of the Clime, or both together" and "which is not ordinarie in England." Higginson observes that this benefit extended to imported English stock: "It is scarce to be beleeued how our Kine and Goats, Horses and Hogges doe thriue and prosper here and like well of this Countrey." ${ }^{, 33}$ Indeed, the extraordinary fruitfulness of New England's landscape was actually described as a cause of colonial hunger and mishap; Edward Winslow explains that this "exceeding abundance was a great cause of increasing our wants. For though our Bay and Creekes were full of Basse, and other fish, yet for want of fit and strong Saynes, and other netting, they for the most part brake thorow and carried all away before them." Fish were so easy to catch in New England that Steve Nicholls reports "servants along the Connecticut River would only work on the condition that they were not fed salmon on more than two occasions each week," an astounding comment "on the abundance of salmon." The landscape was so productive that colonists had to adapt their Old World technologies and labor contracts to accommodate New England realities that made the

\footnotetext{
${ }^{32}$ Thomas Morton, New English Canaan, ed. Jack Dempsey, (Scituate: Digital Scanning, 1999), 54; Higginson, Nevv-Englands Plantation, B3, D2.

${ }^{33}$ Council for New England, An Historicall Discoverie and Relation of the English Plantations in Nevv England, D3; Higginson, Nevv-Englands Plantation B4, B2; Anon., A Treatise of New England, (London: 1643), 3 .
} 
landscape seem a "Grand-childe to earths Paradize" before they could fully realize the benefits of their new habitation. ${ }^{34}$

While colonial observers recognized that New England weather was not an eternally vernal autumn or autumnal spring, as Eden was thought to have been, they emphasized that the landscape provided a harvest of some sort all year round. Some crops, including strawberries, salad greens, and shellfish, were apparently available throughout the calendar year. ${ }^{35}$ Other natural resources were available seasonally: "In Winter time this Countrey doth abound with wilde Geese, wild Ducks, and other Sea Fowle, that a great part of winter the Planters haue eaten nothing but roastmeat of diuers Fowles which they haue killed," but "as the Fowle decrease, so Fish increase. ${ }^{, 36}$ As with the perception that labor in New England was "pleasing" and "guiltlesse" because less strenuous than expected, New England's natural resources could be considered edenic at least in relative terms. For those who wished to find a paradise in New England, the change in seasons was of less concern than the constant state of the larder. This was especially true for Puritan writers who distrusted pagan authors because as Ken Hiltner notes, "certain characteristics that we have come to associate with Eden, such as it being imagined as a perpetual springtime setting, do not explicitly occur in the biblical account at all, but instead were borrowed from classical portrayals of the golden

\footnotetext{
${ }^{34}$ Edward Winslow, Good Nevves from New-England, (London: I. D., 1624), 12; Steve Nicholls, Paradise Found, (Chicago: The University of Chicago Press, 2009), 13; William Morrell, New-England, (London: I. D., 1625), 13. Nicholls provides a species-by-species examination of the New World's abundance at the time of colonization that pays more particular attention to regions south of New England. Morrell is a party to and a celebrant of the Gorges enterprise in New England; his characterization of New England as an anti-type of Eden is dedicated to lords, knights, gentlemen and adventurers - the inhabitants of an imperial metropole, not the plain colonists he left in New England.

${ }^{35}$ The Plymouth settlers report seeing strawberry leaves and salad greens in the middle of winter, and Higginson indicates that turkeys "haue aboundance of feeding all the yeere long, as Strawberries." Alexander likewise claims that "all the yeere ouer they neuer want shellfish." See Mourt, Relation, 22; Higginsion, NevvEnglands Plantation, C2; Alexander, An Encouragement to Colonies, 18.

${ }^{36}$ Higginson, Nevv-Englands Prospect, C2-C3; Winslow, Good Nevves from New England, 12.
} 
age." ${ }^{37}$ Comparisons between Eden and New England could accommodate seasonal fluctuations as long as the land provided abundantly for its inhabitants throughout the year.

Though seasonal fluctuation was an acceptable characteristic of New England to proponents of the landscape's paradisiacal nature, the predominantly coniferous forests of northern New England also reflected a natural resistance to the changing of the seasons. In what is now New Hampshire and Maine, "on the sites of old forest fires [set by Indians], stood tracts of white pine containing trees as much as four to six feet in diameter, and 120 to 200 feet in height. Trees of such size and straightness were unknown in Europe," and these vast stretches of well-nigh perfect conifers constituted a natural reminder of Eden's perfection that contemporaries sought to replicate in England. In his Paradisi in Sole Paradisus Terrestris (1629), British Botanist John Parkinson proposes that "English gardens could be refashioned to resemble Eden" by en masse transplantations "of evergreen plants in the residential garden to mimic the Edenic state." Eden's "perpetual spring” could be reproduced without regard for variations in temperature and daylight by filling an ecological space with plants that remained green year round. ${ }^{38}$ The seasonal variation responsible for New England's diversion from the edenic pattern might have been at least partly mitigated for colonial interpreters by the constantly green and perfectly proportioned trees that made up its forests.

Though the land's plenty was at least partly seasonal, its evergreens were constant reminders of spring, and natural resources were so abundant that a labor-less existence was not beyond the realm of possibility, even if it was undesirable. Thomas Morton, a supporter

\footnotetext{
${ }^{37}$ Ken Hiltner, "Introduction," to Renaissance Ecology, ed. Ken Hiltner, (Pittsburgh: Duquesne University Press, 2008), 4.

${ }^{38}$ Cronon, Changes in the Land, 109-10; Hiltner, Introduction, to Renaissance Ecology, 5.
} 
of Gorges and his imperial ambitions, suggested that the Indians led such a life, where "food and raiment" were available "without overmuch carking," and wished that "our beggars of England should with so much ease as they furnish themselves with food, at all seasons." In New England, even "the least Boy in the Plantation may both catch and eat" as much shellfish as he wanted without straining himself, and Morton suggests that a group determined to avoid labor could easily take "for their maintaynance onely such things as the place it selfe did without labour freely afford." 39 Still, Morton acknowledges that such a course would threaten the permanency of a New England paradise because "there can be no hope of any constant dwelling where the people that inhabit doe not take a course to maintaine themselues by their owne Cornes, and pasture, as all there might doe, if they would respect their posteritie more then the present time." ${ }^{40}$ Eden was first and foremost a social sphere in which the landscape was a common heritage-goods were held in common and community fields were plowed jointly in the first days of Plymouth as well as in the early Christian church—and even a paradisiacal land would not support a laborless ease indefinitely. ${ }^{41}$ The colonists who inhabited New England had to work just as Adam worked in Eden, lest their descendants inherit a landscape and climate that did not reward their labor with an equal beneficence.

\section{$\underline{\text { New England's Temperate Climate }}$}

Colonial commentators almost universally agreed in the seventeenth century that New

\footnotetext{
${ }^{39}$ Morton, New English Canaan, 48; Higginson, Nevv-Englands Prospect, C; Alexander, An Encouragement to Colonies, 16. Carking: 'anxious toil.'

${ }^{40}$ Alexander, An Encouragement to Colonies, 26.

${ }^{41}$ Even after the dissolution of the original, “common course and condition" that Bradford compares to Plato's Republic, New England property is still held in common in some sense. Rather than planting their own, individual fields, "crops were usually planted under an agreed-on patter in individual strips in large common fields.” See Bradford, Of Plymouth Plantation, 120; Russell, The Long, Deep Furrow, 71.
} 
England's climate was temperate; only Bradford, whose history paints the landscape in

pessimistic colors, condemned it on those grounds. The relative temperance of New

England's climate — or of any climate for that matter—was assessed by considering the

duration and extreme temperatures of its seasons, the quality and balance of its elements, particularly its air, and its latitudinal location. ${ }^{42}$ While the writers who promoted New

England as a temperate land differed as to why it was temperate and what aspects of its

location, seasons, and air made it so, they agreed that its "Clime is found to bee so

temperate."43

Those who characterized New England as a paradise emphasized the mild nature of

the weather, but even writers who claimed that New England winters and summers reached temperatures more extreme than in Old England cited that variation as an indication of the climate's temperate quality. Morton claimed that temperatures in Old England "exceed that other in heat or cold" because as New England's "Coast lyeth, being circularly Northeast and

\footnotetext{
${ }^{42}$ The air is only the most remarked on element whose quality is related the temperance of a given landscape. The relative purity and balance of water, earth and fire were also of concern; thus Francis Higginson begins his exposition of New England's "discommodities as well as of the commodities" by noting that the welfare of "euerie Creature ... doth by the most wise ordering of Gods providence depend next vnto himselfe, vpon the temperature and disposition of the foure Elements, Earth Water Aire and Fire (For as of the mixture of all these, all sublunarie things are composed; so by the more or lesse injoyment of the wholesome temper and convenient vse of these, consisteth the onely well-being both of Man and Beast in a more or lesse comfortable measure in all Countreys under the Heauens) Therefore I will indeavour to shew you what New-England is by the consideration of each of these apart." Because I treat the quality of the soil in my discussion of the land's yield and because the quality of the air is typically discussed more prominently than the quality of the water or fire of New England, I treat air more extensively here. It is worth noting, however, that Higginson praises the presence of fire in New England as "proportionable to the rest of the Elements" and even suggests that "New-Englande may boast of this Element more then of all the rest." See Francis Higginson, Nevv-Englands Plantation, (London: T. \& R. Cotes, 1630), B, C3. Likewise, the water of New England is universally praised. The settlers at Plymouth praise the streams of New England as containing "the best water that ever we drunke," and later colonists agree (Mourt, Relation, 22). John White claims that New England water keeps "the body alwaies temperately soluble, and consequently helps much to the preventing, and curing of the Gout, and Stone, as some have found by experience." See John White, The Planters Plea, (London: William Iones, 1630), 24.

${ }^{43}$ Council for New England, An Historicall Discoverie and Relation of the English Plantations in Nevv England, D3. As the Leiden Separatists plan their departure for the New World some promote Guiana as an ideal site for colonization, but Bradford notes that "such hot countries are subject to grievous diseases and many noisome impediments which other more temperate places are freer from, and would not so well agree with our English bodies." See Bradford, Of Plymouth Plantation, 28.
} 
Southwest, opposite towards the Sun's rising which makes his course over the Ocean, it can have little or no reflecting heat of the Sunbeams, by reason of the continual motion of the waters, making the air there the cooler and the constanter." ${ }^{44}$ The low variance in New England temperatures from season to season was described by Morton as an indication of the land's temperance, but Wood made the opposite—and rather astonishing—case that a high variance in temperatures makes Massachusetts more temperate. Acknowledging that New England was both colder than England in the winter and hotter than England in the summer, Wood nonetheless insisted that "both Summer and Winter is more commended of the English there, than the Summer Winters, and Winter Summers of England; and who is there that could not wish, that Englands Climate were as it hath beene in quondam times, colder in Winter, and hotter in Summer?" This fluctuation in temperatures, Wood argues, is actually indicative of a "purer Climate," and if the relatively mild New England winter that greeted the first colonists at Plymouth killed many, "it was not because the Country was unhealthful, but because their bodies were corrupted with sea-diet." Indeed, Wood claimed that of all the western hemisphere New England, "that part of the Countrey wherein most of the English have their habitations: it is for certaine the best ground and sweetest Climate in all those parts ... agreeing well with the temper of our English bodies. ${ }^{, 5}$ Given their willingness to argue for the same conclusion from diametrically opposed lines of reasoning, it seems clear that

\footnotetext{
${ }^{44}$ Morton, New English Canaan, 12.

${ }^{45}$ William Wood, Nevv Englands Prospect, (London: Tho. Cotes, 1634), 8, 5, 3. To be fair Woods, like Morton, views some aspects of New England's climate as more moderate than that of Old England. He explains that "whereas in England most of the cold windes and weathers come from the Sea, and those situations are counted most unwholesome, that are neare the Sea-coast, in that Countrey it is not so, but otherwise; for in the extremity of Winter, the North-east and South winde comming from the Sea, produceth warme weather, and bringing in the warme-working waters of the Sea, loosneth the frozen Bayes, carrying away their Ice with their Tides, melting the Snow, and thawing the ground" (4). This New England moderation of English weather patterns is limited, however; he continues by noting that "the North-west winde comming over the Land, is the cause of extreame cold weather, being alwaies accompanied with deepe Snowes and bitter Frost" (4). New England is still colder than Old, but the weather patterns that bring about these extreme temperatures are more healthful because they come over land rather than from the sea.
} 
Wood and Morton both began their arguments with the same pre-determined conclusion.

Having already decided that New England was temperate, they each found weather patterns that supported this premise, even though those weather patterns were logically inconsistent with one another.

A second sign that the New England climate was sufficiently temperate to serve as a proxy for paradise is the quality of its air. Smith first remarked on the "moderate temper of the ayre" in his Description, and other accounts of New England agree that its air is both healthful and temperate. John White praises the air because of its "constant temper ... which seldome varies from cold to heate, as it doth with us," and Higginson provides a personal testimonial lauding the quality of New England air. ${ }^{46}$ He notes that

The Temper of the Aire of New-England is one speciall thing that commends this place. Experience doth manifest that there is hardly a more healthfull place to be found in the World that agreeth better with our English Bodyes. Many that haue beene weake and sickly in old England, by [ arvel hither haue beene thoroughly healed and growne healthfull and strong. For here is an extraordinarie cleere and dry Aire that is of a most healing nature to all such as are of a Cold, Melancholy, Flegmatick, Reumaticke temper of body. None can more truly speake hereof by their owne experience then my selfe. My Friends that knew me can well tell how verie sickly I haue been and continually in Physick, being much troubled with a tormenting paine through an extraordinarie weaknesse of my Stomacke, and aboundance of Melancholike humors; but since I came hither on this Voyage, I thanke God I haue had perfect health. ${ }^{47}$

Like Higginson, Wood identifies the dryness of this "sharpe Ayre" as the key to his own health, noting that although most New England "Townes border upon the Sea-coast, yet are they not often troubled with Mists, or unwholesome fogges" as in Old England. Because early modern medical thinkers believed that the English body was excessively phlegmatic and moist, this dry air that rarely fluctuated in temperature acted as a restorative, "drying vp

\footnotetext{
${ }^{46}$ Smith, “A Description of New England,” 138; John White, The Planters Plea, 24.

${ }^{47}$ Higginson, Nevv-Englands Plantation, C.
} 
the cold and crude humors of the Body: and therefore I thinke it is a wise course for all cold complections to come to take Physicke in New-England: for a sup of New-Englands Aire is better then a whole draught of old Englands Ale."48 Colonial writers not only believed that New England's air was temperate; they found it rejuvenating and invigorating in the same way that Eden's air was thought to have been. ${ }^{49}$

In his Description of New England, Smith explains that the "part wee call New England is betwixt the degrees of 41. and 45" latitude, and while Gorges' Council for New England was granted jurisdiction over all American territory from the fortieth to the fortyeighth north parallels, other writers largely accepted Smith's designation. ${ }^{50}$ The settlements at Plymouth and Boston are located at approximately 42 degrees latitude, and their position was idealized by writers emphasizing New England's paradisiacal nature. Gorge proclaimed that these settlements were "not onely seated in the temperate Zone, but as it were in the Center," a position that Thomas Morton rationalized by explaining that the "golden mean" of the temperate zone is

situated about the middle of those two extremes [the Torrida Zona or tropics and the Frigida Zona or arctic regions], and for directions you may prove it thus. Counting the space between the Line and either of the Poles in true proportion, you shall find it to be 90 Degrees: then must we find the mean to be near unto the Center of 90, and that is about 45 Degrees; and then, incline unto the Southern side of that Center, properly for the benefit of heat, remembering that Sol \& Homo generat hominem. And then keep us on that same side, and see what Land is to be found there; and we

\footnotetext{
${ }^{48}$ Wood, Nevv Englands Prospect, 3; Higginson, Nevv-Englands Plantation, C2. Wood actually enumerates the distempers that have been cured by the inhalation of New England air. Since his arrival in Massachusetts, he "never knew any that had the Poxe, Measels, Greene-sicknesse, Head-aches, Stone, or Consumptions, \&c. Many that have come infirme out of England, retaine their old grievances still, and some that were long troubled with lingering diseases, as Coughs of the lungs, Consumptions, \&c. haue beene restored by that medicineable Climate to their former strength and health" (9).

${ }^{49}$ Milton postulates that Eden's air promotes spiritual healing as well as physical health. When Satan first arrives on the outskirts of Eden, first "pure now purer air / Meets his approach, and to the heart inspires / Vernal delight and joy, able to drive / All sadness but despair" (Paradise Lost, IV.153-56).

${ }^{50}$ Smith, "A Description of New England," 137.
} 
shall easily discern that New England is on the south side of that center. ${ }^{51}$

The mathematical gymnastics in which Morton engages to prove that New England was perfectly situated, cartographically speaking, "made the land to [him] seem paradise." While the garden of Eden was traditionally located outside of any of the earth's five climactic zones - two polar, two temperate and the equatorial torrid zone-Morton and Gorges portrayed New England as a paradise, at least in part, because it is located "[v]nder the same climate and course of the Sunne that Constantinople, and Rome, the Ladies of the World; Italy, and France, the Gardens of Europe, haue their situation, within the limits of the fifth and sixt Climate." ${ }^{52}$ Since contemporary cartographers failed to agree on the Garden of Eden's latitude and longitude, Morton and Gorges turned to the gardens of Europe as indications of where an earthly paradise might be situated, even though they were not located in lands that anyone believed to have been the site of the biblical original.

\section{The Flora and Fauna of New England}

The efforts of Morton and Gorges to establish New England's latitude as evidencebased on the existence of botanical gardens at the same latitudes in Europe-of the

\footnotetext{
${ }^{51}$ Council for New England, An Historicall Discoverie and Relation of the English Plantations in Nevv England, D2; Thomas Morton, New English Canaan, ed. Jack Dempsey, (Scituate: Digital Scanning, 1999), 1112. While Morton has experience in the New World that Gorges and Alexander do not, his text promotes a similarly imperial attitude toward New England; it is a land whose bounty must be reaped, not a country whose inhabitants need converting. Indeed, Morton suggests throughout that the Indians are in many ways more civilized than his neighbors at Plymouth!

${ }^{52}$ Morton, New English Canaan, 54; Council for New England, An Historicall Discoverie and Relation of the English Plantations in Nevv England, D2. Alessandro Scafi's examination of maps that situate Eden in relation to the rest of the world indicates that zonal maps, which portrayed the temperate, frigid and torrid zones, "portrayed the inhabited northern hemisphere as neighbouring paradise." In these models, "it was difficult to associate paradise with any of the world's climatic zones" because "with its perpetually temperate weather, it fitted none of the climatic belts, unless it was some quite special area independent from 'normal' weather conditions." As a result, these zonal maps typically portrayed Eden as a region tangential to the known world rather than a specific location within it. (See Alessandro Scafi, Mapping Paradise, (London: The British Library, 2006), 165.) For those who, like Morton and Gorges, identified a region within the temperate zone as paradisiacal, the perpetually temperate weather of Eden seems to have been understood as a zonal reference instead of a comment on day-to-day weather.
} 
landscape's paradisiacal character drew on contemporary beliefs about the garden of Eden and spoke to the function of the botanical gardens they reference. John Prest's critical history of botanical gardens is entitled The Garden of Eden quite simply because seventeenthcentury "[c]ontemporaries interpreted the foundation of these encyclopaedic Gardens in a context of the re-creation of the earthly Paradise, or Garden of Eden." ${ }^{, 53}$ The hexameral tradition had interpreted Genesis' account of Eden, and in particular, God's promise that "I have given you every herb bearing seed, which is upon the face of all the earth, and every tree, in the which is the fruit of a tree yielding seed; to you it shall be for meat" as "suggesting the encyclopedic nature of Eden: every tree, every herb-bearing seed was present there. ${ }^{, 54}$ Prest explains that in the seventeenth century the creators of botanical gardens sought to recreate Eden by gathering every "new plant from the farthest corners of the world" and carefully placing them together in an aesthetically pleasing order because "[f]or the first time since the Fall, thanks to the discovery of America, a truly encyclopaedic collection of plants could now be made." ${ }^{55}$ The recovery of prelapsarian perfection—at least in a horticultural sense—was made possible by the discovery and ordering of all God's creation, especially the flora and fauna native to the American continents that were previously unknown in Europe.

While those who managed botanical gardens were more ambitious in their quest to produce an exhaustively encyclopedic collection of the world's plants than most other gardeners, their edenic aspirations were also associated with lesser efforts. Thus, Sir Hugh Plat's posthumously published "accurate Description of all Flowers and Fruits now growing

\footnotetext{
53 John Prest, The Garden of Eden, (New Haven: Yale University Press, 1981), 6.

${ }^{54}$ Genesis 1:29; Philip C. Almond, Adam and Eve in Seventeenth-Century Thought, (Cambridge: Cambridge University Press, 1999), 93.

${ }^{55}$ Prest, The Garden of Eden, 6, 10.
} 
in England" was also entitled The Garden of Eden (1654) even though he made no pretense of cataloguing and describing plants outside of England. According to Plat, even the compilation of an encyclopedic list of the natural resources available in a particular area was a form of participation in the project of edenic restoration that the botanic gardens represented, and imperial interpreters predisposed to view New England as a paradise would have understood the colonial catalogues of plants and animals contained in most descriptions of the landscape as an indication of New England's edenic character as well as an assessment of economic resources and opportunities in the region.

Extensive catalogues of the plants and animals native to New England appear in at least eight of the relations written between 1620 and 1637. They provide descriptions of the local wildlife, and readers familiar with the aims and theological roots of the botanical gardens popping up around Europe would have understood these compilations as more than mere lists of commodities. In his description of the third day of creation, Guillaume de Saluste, Sieur du Bartas, presents a catalog of the trees created by God:

...the loftie Pine

Distilling pitch, the Larche yeeld-Turpentine, Th'ever-greene Boxe, and gummie Cedar sprout And th'Airie Mountaines mantle round about: The Mast-full Oake, the use-full Ashe, the Holme, Coate-changing Corke, white Maple, shadie Elme, Through Hill and Plaine ranged their plumed Ranks. ${ }^{56}$

Du Bartas's trees are both commodities and religious symbols, reminders of God's power and encyclopedic knowledge. In some sense, however, their association with commodities is only a different type of religious symbol, a reminder of the injunction in Genesis to "subdue" the earth; the New England catalogs have been primarily understood as commercial

\footnotetext{
${ }^{56}$ Guillaume de Saluste, seigneur Du Bartas, The Divine Weeks and Works of Guillaume de Saluste, Sieur Du Bartas, trans. Joshua Sylvester (New York: Oxford University Press, 1979), I.545-51.
} 
advertisements, but their breadth is also a reminder of the capaciousness of Eden, which contains everything that Adam and Eve could possibly need. Collectively, these catalogs name more than sixty plants, thirty trees, twenty-five animals, fifty-five birds, and fifty-five fish, many of which were indigenous to the area and unknown to the European authors who described them. All told, they identify more than two hundred and thirty different species of flora and fauna found in seventeenth-century New England. The descriptions of famously new species such as maize, pumpkin, moose, porcupine, rattlesnake and turkey are well known, but the colonists also coined new words to describe new species that have never received significant attention: the plant saxifarilla, an herb known as carvell, an animal called the aroughcond, fish known as cole and freel, and a shellfish referred to as an othus. ${ }^{57}$ In creating these neologisms to translate their experience of New England wildlife into words, the colonists followed Adam's example when he exercised onomastic authority over all the beasts of the earth. New England was a storehouse of new species that European explorers believed lost since humanity's exile from Eden, and they acknowledged their own ignorance; in addition to the species they recognized or named, they also stated that there were many types of new species that they could not enumerate for their reading audience. There were "a great many of strange Fowles which we know not" and "other trees which we know not."58

Some colonial writers emphasized the completeness of New England's collection of flora and fauna. Regarding the local bird population, Higginson asserts that New England contains "all sorts as we haue in England as farre as I can learne," and Gorges boasts that New England soil produced an "infinite variety of nourishing roots, and other herbes, and fruits, common among them, but rare with us." Others pointed out that New England's

\footnotetext{
${ }^{57}$ For a comprehensive list of the flora, fauna and minerals listed in these catalogues, see Appendix A.

${ }^{58}$ Higginson, Nevv-Englands Plantation, C2 Mourt, Relation, 21.
} 
natural abundance would only be complete once the English had brought over key species that were missing from the North American landscape, especially "Horses, Cowes, and Sheepe, whereof neuer any was found in these parts," but also less important species such as “Magpies, Iackedawes, Coockooes, Iayes, Sparrows, \&c." ${ }^{, 59}$ But regardless of individual positions as to whether or not New England's collection of flora and fauna presently was or in the future would be encyclopedic, an emphasis on the diversity and broadly inclusive nature of New England wildlife was universal. For those who believed New England a paradise or wished so to portray it, the landscape's apparently unlimited variety was a sure sign of its potential. To them, New England “'twas Nature's Masterpiece: Her chiefest Magazine of all, where lives Her store."60

\section{Cultivating Wilderness: Importing English Order and Invention}

Despite Bradford's refusal to acknowledge the New England landscape's positiveand even paradisiacal - attributes; despite the fact that he contradicts the earliest account of life at Plymouth; despite the fact that his influence over the fate of New England began to wane with the arrival of the Bay Company; despite and perhaps because of these facts, his description of the New England landscape in 1630 as a "country, full of woods and thickets, [of] a wild and savage hue" has become the standard portrayal of early colonial experience. ${ }^{61}$

\footnotetext{
${ }^{59}$ Higginson, Nevv-Englands Plantation, C2; Council for New England, An Historicall Discoverie and Relation of the English Plantations in Nevv England, D3; Alexander, An Encouragement to Colonies, 41; Wood, Nevv Englands Prospect, 29.

${ }^{60}$ Morton, New English Canaan, 54.

${ }^{61}$ Bradford, Of Plymouth Plantation, 62. Most scholars fail to trace the shift in attitudes toward the landscape from early optimism in the 1620 s and 1630 s to a decided pessimism in the second half of the seventeenth century. They understandably ignore the horticultural hopefulness of the first settlers because their descendants and historians had already lost any hope that the landscape would soon achieve its edenic potential. My own description of edenic optimism among early explorers and settlers is, in large part, a history of fruitless hopes and failed prophecy, and criticism, like history, is generally more concerned with successes than with failures.
} 
To be sure, he was not the only one to characterize New England as a wilderness, but he seems to have meant something different by the term than his contemporaries. At the very least, men like Mourt, Cushman, Winslow, White, Higginson, and Wood seemed to believe that wilderness and paradise were not mutually exclusive; in successive paragraphs and without a hint of irony they describe both the edenic attributes of New England and the characteristics that made it a wilderness, while Bradford rarely identified any positive aspects of the land. For most of the settlers, wilderness was generally a negative state, a lack of grace, order and civilization; for Bradford, wilderness was a positive state, a surfeit of diseases, plants, animals, and men inimical to the religious mission of his Pilgrim companions.

There are at least four senses in which these writers describe New England as a wilderness. The term alternately means

1. A spiritual state of degeneracy in which an individual, group or even the entire world, including New England and Old, is wandering, estranged from God as Israel was estranged in the wilderness before their entry into Canaan;

2. The refuge of the elect described in Revelation, where the church, represented by a woman, "fled into the wilderness, where she hath a place prepared of God" in which to take refuge from the Antichrist;

3. A hostile landscape whose weather, flora, fauna and human inhabitants actively oppose English colonists; and

4. An empty landscape, devoid of the structures and agricultural activity characteristic of English country life.

Each of these types of wilderness serves a different rhetorical purpose when invoked, and all except the third are compatible with the Puritan "reconception of the primordial wilderness" as a necessary prelude to "the vision of a second Eden" described by George Williams. ${ }^{62}$

\footnotetext{
${ }^{62}$ George Williams, Wilderness and Paradise in Christian Thought, (New York: Harper \& Brothers, 1962), 6,
} 10. Williams provides an overview of the longstanding Judeo-Christian tradition that considers wilderness a 
Because I address the spiritual state of early modern New Englanders more fully in chapters two and five, I confine myself here to a consideration of the latter two definitions and the purposes for which the New England landscape was alternately described as a wilderness full of savagery and a wilderness devoid of civilization.

The stakes for both of these positions are clear. Bradford, by portraying New England as a wilderness full of obstacles to be overcome, engaged in a bit of colonial subterfuge against the financiers to whom the Pilgrims were in debt; by appropriating the power of interpretation from the metropole to the colony, he destabilized the imperial program of knowledge formation formulated by Bacon. Bauer reminds us that "these imperial epistemic economies, like their material counterparts, existed but as logo-centric utopias that engendered their own modes of geo-political resistance and were frequently undermined by colonial subjects," and by classifying the New England landscape as an actively hostile entity, Bradford sabotaged the efforts of men like Gorges and Alexander to portray New England as a place of paradisiacal possibilities. ${ }^{63}$ Gorges and the other backers of the Plymouth venture stood to profit from optimistic reports that would draw labor to the colonies, but they were not satisfied with a simple influx of labor; each good report, each load of commodities from New England, stoked the fires of their greed: "the more beaver and other commodities [the Pilgrims] sent to England, the more the debt grew." By exaggerating the difficulties and eliding the possibilities of the New England landscape, Bradford eventually lowered of expectations, convincing his creditors that there was no question of obtaining or cultivating a physical paradise- there was only a hope that he would someday

preparatory state for paradise. For most of the writers that Williams examines, the wilderness experience is actually believed to be a prerequisite to paradise.

${ }^{63}$ Bauer, The Cultural Geography of Colonial American Literatures, 4. 
pay off his debts and "bee translated from this wandring wildernesse, vnto that ioyfull and heauenly Canaan."64

In the first reports from Plymouth and the relations made by Puritan authors arriving in the 1630 s, claims that the landscape was an empty wilderness served to manage expectations in a different way. For these writers, the edenic landscape advertised publicly by imperial promoters was within the bounds of possibility; the land might not have been a fully developed paradise when they arrived, but it held the potential to become one. These men characterized New England as "a vast and emptie Chaos" at least in part because chaos is the state that precedes the creation of Eden; they extinguished their expectations of a present paradise in exchange for the prospect of a future Eden. ${ }^{65}$ By describing New England as a "vacant Wildernesse," they acknowledged the landscape's admittedly imperfect state without demonizing it and resigning all expectations of paradise in the way that Bradford did.

\section{Debunking the Demonic Wilderness}

Bradford's wilderness was full of obstacles to the establishment of civilization, not least of which were the unbalanced elements in the climate that so many of his countrymen claimed had been restorative and therapeutic. Bradford recalled worrying before their arrival in 1620 that

the miseries of the land which they should be exposed unto, would be too hard to be borne and likely, some or all of them together, to consume and utterly to ruinate them.

\footnotetext{
${ }^{64}$ Samuel Eliot Morison, Introduction, to William Bradford, Of Plymouth Plantation, ed. Samuel Eliot Morison, (New York: Alfred A. Knopf, 2003), xxv; Cushman, A Sermon Preached at Plimmoth, 19. The words are spoken by Cushman, but they might have come from Bradford's mouth. While most of the original Plymouth settlers are more optimistic regarding the landscape's potential than Bradford, they had universally stopped praising it in language that could be construed as edenic by 1624. Edward Winslow's statement that he "will not speake of the abundance of fowle, store of Venison, and varietie of Fish" again is representative; they abandoned forever whatever hopes they might have clung to that their New England home would prove to be "rich, fruitful, and blessed." The only paradise to which they aspired now was to a heavenly one. See Winslow, Good Nevves From New-England, 64; Bradford, Of Plymouth Plantation, 28.

${ }^{65}$ Mourt, Relation, 69.
} 
For there they should be liable to famine and nakedness and the want, in a manner, of all things. The change of air, diet and drinking of water would infect their bodies with sore sicknesses and grievous diseases.

In large measure these fears were realized — at least according to Bradford. He quantifies the death toll left unstated by Mourt; "half of their company died," and Bradford blames "the scurvy and other diseases which this long voyage and their inaccomodate condition had brought upon them." Sicknesses contracted aboard the Mayflower were largely responsible for the high mortality rate, but the very elements of New England - the air they breathed and the water they drank-were at least partially to blame for the hardships the Pilgrims suffered in their "inaccommodate condition," according to Bradford. ${ }^{66}$ Because his history contains letters and excerpts from published narratives, Bradford does include positive descriptions of the elements and landscape, but these are hurriedly discounted. Quoting a letter written by a Mr. Dermer to Gorges that praises the "blackish and deep mould" of New England soil, Bradford cut short Dermer's praise with the conclusion that the true-and apparently inadequate-virtues of the soil were "now better known than they were to him." The water was "as pleasant unto them as wine or beer had been in foretimes" but only because of their "great thirst." ${ }^{67}$ For Bradford, the elements were an obstacle to be surmounted, not the blessing they became in the relations of Gorges, Wood, or Higginson.

In addition to his concerns about the occasional hostility of the elements, Bradford complained that the "wild and savage hue" of New England's "woods and thickets" concealed a multitude of wild beasts that would prey on unwitting settlers. That the woods were "full of wild beasts" was a point for which Bradford derived a limited support from

\footnotetext{
${ }^{66}$ Bradford, Of Plymouth Plantation, 26, 77.

${ }^{67}$ ibid, 82-83, 65.
} 
other authors. ${ }^{68}$ Mourt recounts a time when the Pilgrims "heard as they thought two Lyons roaring exceedingly for a long time together, and a third, that they thought was very nere them" but ultimately admitted that "the wilde Beastes came not." ${ }^{, 69}$ Wood and Higginson likewise acknowledged the presence of unfriendly animals in the New England landscape but downplayed their impact. Higginson writes that "we are troubled much with little Flyes called Musketoes" but conceded that these were "the same they are troubled with in Lincolneshiere and the Fens: and they are nothing but Gnats," no different than the minor pests that annoyed civilized England. The rattlesnakes of New England were different from the adders of England in that they would "not flye from a man as others will, but will fly vpon him and sting him so mortally," yet the rattlesnake was really "nothing so bad as the report goes of him in England. For whereas he is sayd to kill a man with his breath, and that he can flye, there is no such matter, for he is naturally the most sleepie and unnimble creature that lives, never offering to leape or bite any man, if he be not troden on first." ${ }^{, 70}$ As for the "company of wolves or such like wild beasts" that terrified Bradford's Pilgrims with "a hideous and great cry," Wood states that they are "different from them of other countries; it was never knowne yet that a Woolfe ever set upon a man or woman. Neyther do they trouble horses or cowes." The only animals at risks were "swine, goates and red calves which they take for Deare," yet these selective predators were "the greatest inconveniency the Countrey hath." ${ }^{, 71}$ Bradford's contemporaries did not pretend that the New England woods were free from predators and pests—but they hardly reached the same dire conclusions about the

\footnotetext{
${ }^{68}$ ibid, 62.

${ }^{69}$ Mourt, Relation, 28.

${ }^{70}$ Higginson, Nevv-Englands Plantation, C3; Wood, Nevv Englands Prospect, 44.

${ }^{71}$ Bradford, Of Plymouth Plantation, 69; Wood, Nevv Englands Prospect, 23-24.
} 
wildlife that he did.

Bradford's fears about the quantity and savagery of the Indians he would encounter in New England were likewise overly dramatic in comparison to the descriptions of his contemporaries. He anticipates meeting

a savage people, who are cruel, barabarous and most treacherous, being most furious in their rage and merciless where they overcome; not being content only to kill and take away life, but delight to torment men in the most bloody manner that may be; flaying some alive with the shells of fishes, cutting off the members and joints of others by piecemeal and broiling on the coals, eat the collops of their flesh in their sight whilst they live, with other cruelties horrible to be related. ${ }^{72}$

But in the first decade at Plymouth, Bradford's Pilgrims met with few, if any, mortal acts of Indian aggression. The Pilgrims reported in Mourt's Relation that "we for our parts walke as peaceably and safely in the woods, as in the hie wayes in England."73 The New England woods were not full of bestial and cannibalistic savages; in fact, Bradford's contemporaries frequently could not find an Indian even when they wanted to.

\section{A Wilderness "Spatious and Void"}

Though Bradford remembered landing among "savage barbarians" who "were readier to fill their sides full of arrows than otherwise," contemporary accounts of the Pilgrims' first encounters with Native American culture in New England are notable precisely because there were no Native Americans_-no people_-in them, only artifacts. When an exploring party first landed, its members saw "fiue or sixe people, with a Dogge, coming towards them, who were Savages," but these Indians disappeared in the woods; they are ephemeral, marginaland rarely seen unless they want to be seen. ${ }^{74}$ The explorers followed the Indians' tracks into the woods, "yet could meete with none of them, nor their houses." When they selected

\footnotetext{
${ }^{72}$ Bradford, Of Plymouth Plantation, 26.

${ }^{73}$ Mourt, Relation, 61.

${ }^{74}$ Bradford, Of Plymouth Plantation, 62; Mourt, Relation, 4.
} 
Plymouth as the location for their permanent settlement, they traveled "along the coast in the woods, some 7. or 8. mile, but saw not an Indian nor an Indian house, only we found where formerly, had beene some Inhabitants, and where they had planted their corne.” They began building at Plymouth without having once spoken with an Indian face-to-face and reluctantly admitted that "what people inhabite here we yet know not, for as yet we haue seene none.,"75 The Native Americans that Bradford describes in such fearful terms were noted more for their absence than their presence.

During the first fifteen years of English colonization confrontations between Indians and Englishmen were rare and infrequently mortal; the one exception to this peaceful coexistence was an isolated fracas in which Indians sought to avenge themselves for the kidnapping of their countrymen by an English captain named Hunt. When the Pilgrims saw a burning house in Plymouth, they suspected that Indians had committed arson but subsequently discovered that "the house was fiered occasionally by a sparke that flew into the thatch." When a man walking through the woods saw "twleue Indians, marching towards our Plantation" he returned hurriedly to warn his neighbors of an impending attack, but when they went "abroad in the woods returned \& armed themselues, [they] saw none of them.,"76 The Indians were largely a phantom menace—not because they struck without the colonists' knowledge, but because they did not strike at all.

Even after the commencement of interpersonal relations between the settlers and the local tribes, colonists continued to describe the land as empty—and therefore a wilderness. Because New England Indian villages "were not fixed geographical entities" but migratory communities whose "size and location changed on a seasonal basis," English colonists did

\footnotetext{
${ }^{75}$ Mourt, Relation, 5, 21-22, 23.

${ }^{76}$ ibid, 29, 30.
} 
not believe that the landscape had been properly settled and domesticated. Not only had "a great and grieuous Plague" removed the vast majority of the Indians who used to live off of the land so that there were "verie few left to inhabite the Countrey," but the Indians who survived were "not able to make vse of the one fourth part of the Land" because they did not have "any setled places, as Townes to dwell in, nor any ground as they challenge for their owne possession, but change their habitation from place to place." ${ }^{, 77}$ For these colonists, the New England landscape was a wilderness only because it was "so rude and unmanaged a countrey," not because its climate or inhabitants were less than agreeable. ${ }^{78}$

This designation made the task of harnessing the landscape's paradisiacal promise relatively simple. Yes, the "Countrey is yet raw, the land vntilled, the Cities not builded, the Cattell not setled," but correcting these deficiencies was a matter of time and pleasantly productive labor, after which New England's temperate climate, bountiful harvests, and encyclopedic collection of flora and fauna would remain. ${ }^{79}$ In this sense, the predominant view of the New England landscape as a vacant wilderness in the 1620s and early 1630s mirrors Andrew Delbanco's description of the contemporary Puritan perspective on sin. Delbanco suggests that the

journey to America was in part an effort to conserve what was left of the conviction that sin, rather than being an entity implanted in the soul, was something more abstract: a temporary estrangement from God. Behind (in the double sense of impetus and abandonment) the Puritan journey lay an utterly un-Calvinist hope-not quite articulated, yet never fully suppressed — that Englishmen were not so much depraved as victims of a distorting experience.

For most of these early writers, the New England landscape was not depraved—the dwelling place of fiends and wild animals—in the way that Bradford's description might suggest; it

\footnotetext{
${ }^{77}$ Cronon, Changes in the Land, 38; Higginson, Nevv-Englands Plantation, C4.

${ }^{78}$ Wood, Nevv Englands Prospect, 47.

${ }^{79}$ Cushman, A Sermon Preached at Plimmoth, 14.
} 
was simply poorly managed by "a helplesse and idle people ... which cannot in any comely or comfortable manner helpe themselues, much lesse vs." ${ }^{\text {, }}$ They remained confident that English industry would unlock the land's edenic potential because there were already "many goodly fieldes" waiting to be planted; all that was wanted were "men to dresse and manure the same." The "Countrey wanted onely industrious men" and then these colonists "doubt not but by the blessing of God, the gayne will giue content to all." 81

\section{English Inventions in the Wilderness}

Once New England had been settled by industrious men and women, dotted with English houses and towns, and planted with English crops, colonists did not doubt that Smith's promise would be fulfilled and that Massachusetts would indeed become "the Paradice of New-England." 82 Some settlers did complain that New England was not "a rich land, a brave country" because "when they came there they could see nothing but a few Canvis Boothes \& old houses, supposing at the first to have found walled townes, fortifications and corne fields," but those who saw the empty wilderness as a paradise in waiting knew that no "townes could have built themselves, or corne fields have growne of themselves, without the husbandrie of man" and were willing to wait for New England to become rich and brave under their stewardship. After all, they rationalized, "where so great a work is begun with such small meanes, a little time cannot bring to perfection." ${ }^{\circ 3}$ The continual influx of colonists and the introduction of English innovations in the arts and sciences would bring the land's naturally abundant endowments to perfection-but only in

\footnotetext{
${ }^{80}$ Andrew Delbanco, The Puritan Ordeal, (Cambridge, MA: Harvard University Press, 1989), 79-80; Cushman, A Sermon Preached at Plimmoth, 14.

${ }^{81}$ Mourt, Relation, 43, 62-63.

${ }^{82}$ Levett, A Voyage into New England, 24.

${ }^{83}$ Wood, Nevv Englands Prospect, 47; Winslow, Good Nevves from New England, 39.
} 
due time.

The colonists divided their efforts at cultivating the land into two separate, but related, endeavors: the enclosed garden behind every house that contained vegetables, berries, and fruit trees, and the fields in which grain was sown. The care for these two areas had something in common; both had to be fenced, typically with rough-hewn boards known as paling, in order to keep wild deer and turkeys as well as domesticated chickens and cows from eating the crops. The enclosure of the gardens and fields was a practical measure taken to ensure that crops were not prematurely consumed but also a symbolic reminder of the land's edenic potential. Since the Middle Ages, Prest reminds us, the enclosed inner courtyards of Catholic monasteries had been known as "Paradise gardens, and in the later Cistercian order every monk was allotted his own little plot or Paradise to look after." This Catholic connection between enclosed gardens and paradise remained strong in seventeenthcentury Protestant England, because

at this period the Edenic ideal of peace among the animals was not attached to them. The enclosed garden behind its hedge of thorns, its wattle fence, its paling, or if it was to be really secure, its walls, was then left with an almost undisputed claim to represent the Garden of Eden. All the ideal qualities associated with ... the earthly Paradise thus came to be identified with the small contemporary, enclosed garden from which the animals were excluded altogether. ${ }^{84}$

By excluding animals whose tendency to consume and destroy both the crops and one another was less than edenic, New England gardeners followed in a monastic tradition that encouraged gardeners to imagine that their enclosed gardens and fields were small pieces of paradise restored to a prelapsarian perfection. After fencing in the land, they "digged our grounds, and sowed our garden seeds" and anticipated Eden's return. ${ }^{85}$ Edward Taylor,

\footnotetext{
${ }^{84}$ Prest, The Garden of Eden, 21-23. For a description of the practice of erecting paling around New England farms, see Russell, The Long, Deep Furrow, 35-38.

${ }^{85}$ Mourt, Relation, 35.
} 
writing at the turn of the eighteenth century, acknowledged that "Edens Garden" "doth excell all gardens here" but justified the comparison between earthly gardens and Adam's paradise because both spots were "Choicest Plots empalde with Palings rich." ${ }^{86}$ Surrounding the garden with paling produced edenic associations in the minds of seventeenth-century Puritan colonists.

Of course, when the seeds planted in these gardens and fields occasionally failed to produce fruits worthy of paradise, this was a major blow to the agricultural aspirations of men who thought of New England as "a most hopefull place." Like the creators of the botanical gardens of Europe, where "plants were thus allotted places, in order" because Eden itself represented "the ideal of a completely ordered world," the settlers of New England also set about to order the landscape. Crops native to New England required improvement, and the settlers hoped that in time, "English ordering may bring" native crops such as the wild cherry trees to produce "an English Cherrie," the tame fruit associated with Eden and "the order which existed before the Fall." ${ }^{87}$ In addition to modifying and taming the wildly abundant fruits of New England, the English settlers also needed to prepare the ground to receive English grains. When the Plymouth Pilgrims made their first planting, "twenty acres of corn brought a considerable harvest; a little barley and no pease at all was the result from

\footnotetext{
${ }^{86}$ Edward Taylor, "63" in Preparatory Meditations, Second Series, in Edward Taylor's Gods Determinations and Preparatory Meditations, ed. Daniel Patterson, (Kent: The Kent State University Press, 2003), p. 319, lines $13-14,9$.

${ }^{87}$ Mourt, Relation, 21; Prest, The Garden of Eden, 1; Almond, Adam and Eve in Seventeenth-Century Thought, 98; Wood, Nevv Englands Prospect, 18. The garden of Eden was understood to be a fruit orchard, and English exegetes such as Ralph Austen suggested that the very act of planting fruit trees was a return to "Adams imployment in his innocency," where he tended the fruit trees of Eden. Because "a Garden of Fruit-trees was the meetest place upon all the Earth, for Adam to dwell in, even in his state of perfection," it is naturally the setting in which edenic perfections are most likely to be recaptured on earth. Not surprisingly, then, "[h]ouseholders everywhere [in New England] were soon planting seeds of apples, pears, cherries, and other fruits about their dwellings. ... Connecticut's first comers from The Bay had scarcely sat down before they were starting apples." See Ralph Austen, A Treatise of Fruit Trees, (London: William Hall, 1665), 22; Russell, The Long, Deep Furrow, 90-91.
} 
the six acres of European grain." ${ }^{88}$ The New England soil was almost universally lauded for its fertility, but this praise was misdirected. Colonists were impressed with the superior crop yields harvested from each individual grain of maize and mistakenly assumed that it was the soil—and not the plant—that caused each kernel of corn to produce an ear with many more pieces of grain than an individual stalk of wheat or barley. Eventually they recognized that European grains did not grow as well in New England soil, but even this was—at least initially—assumed to be a temporary setback.

When the initial attempts to sow fields of oats and barley failed to produce the expected results, colonists resorted to planting the fields with maize and sowed their gardens with the European grain, where they could watch and tend it more carefully. Wood reported that in their gardens "there hath as good English Corne growne there, as could be desired; especially Rie and Oates, and Barly: there hath beene no great tryall as yet of Wheate, and Beanes; onely thus much I affirme, that these two graines grow well in Gardens.” He attributed this limited success to a careful husbandry of the soil, whose fertile abundance had to be adapted to European standards by agricultural practices. The grass of New England was "not at the first cutting so fine as our English Grasse, yet ... the oftener it is mowed, the finer it growth." Because the ground was so wet, Wood explains, "it must bee sowne the first yeare with Indian Corne, which is a soaking graine, before it will be fit for to receive English seede." But when colonists struggled to reproduce the limited success of European grains successfully grown in the garden in their fields, they blamed the ocean passage for ruining the seed. Therefore, they concluded, "it is not improbable, but when they can gather seede of that which is sowne in the countrey, it may grow as well as any other Graine: but commonly

\footnotetext{
${ }^{88}$ Russell, The Long, Deep Furrow, 13.
} 
the seede that commeth out of England is heated at Sea, and therefore cannot thrive at land. ${ }^{189}$ Having already convinced themselves that the New England climate and soil were at least proto-paradisiacal, the colonists blamed external factors for their crop failures and remained confident that English ingenuity would produce a better result in the future. White and Wood insisted that more time and labor were needed, because "[i]t were bootlesse to expect that all things will or can be at the first forming of a rude and incohaerent body, as they may be found in time to come," and "it is neyther impossible, nor much improbable, that upon improvements the soile may be as good in time as England." ${ }^{90}$ These improvements, they believed, would undoubtedly come with the introduction of English art and science into a wilderness increasingly resistant to the expected transition to paradise.

When the colonists first arrived in New England, they were initially forced to adopt strange agricultural practices in order to survive. Because "the Mayflower lading included not a single plow-everything had to be done with clumsy hand tools, and years were to pass before this soil would feel the tread of an ox to draw a plow of any kind." New England planters scraping weeds with clam shell hoes and turning over the soil with wooden shovels were confident that the introduction of English iron and technology would improve cultivation and allow them to grow European grains; as Edward Johnson notes, most "corn they planted before they had plows was Indian grain.” Just as importantly, colonists like White believed that the introduction of English technology would civilize the Indians

\footnotetext{
${ }^{89}$ Wood, Nevv Englands Prospect, 13, 12; Anon., A Treatise of New England, (London: 1643), 2.

${ }^{90}$ White, The Planters Plea, 66; Wood, Nevv Englands Prospect, 12.
} 
because the "example of our course of living, cannot but in time breed civility among

them."91 Wood suggests that the Indians,

being strangers to Arts and Sciences, and being unacquainted with the inventions that are common to a civilized people, are ravisht with admiration at the first view of any such sight. ... They doe much extol and wonder at the English for their strange Inventions, especially for a Wind-mill, which in their esteeme was little lesse than the worlds wonder, for the strangenesse of his whisking motion, and the sharpe teeth biting the corne (as they terme it) into such small peeces. ... The first plow-man was counted little better than a Iuggler: the Indians seeing the plow teare up more ground in a day, than their Clamme shels could scrape up in a month, desired to see the workemanship of it, and viewing well the coulter and share, perceiving it to be iron, told the plow-man, hee was almost Abamacho, almost as cunning as the Devill; but the fresh supplies of new and strange objects hath lessen' $d$ their admiration, and quickened their inventions, and desire of practising such things as they see." 92

The inventions of English technology not only promised to subdue the New England soil and promote the success of European grains; they would also aid in civilizing the Indians. And because "wee hardly have found a brutish people wonne before they had beene taught civility," White taught the colonists that they "must endeavour and expect to worke that in them first, and Religion afterwards." The inventions of the English were both a key to unlocking the land's edenic potential and a means toward the conversion of the Indians-an event that would signal the approach of the edenic millennium anticipated by Thomas Brightman and John Cotton, among others. ${ }^{93}$

A number of New England colonists worked to harness the power of innovation and bring order to the land. Russell notes that Joseph Jenckes, "by trade a swordmaker and die-

\footnotetext{
${ }^{91}$ Russell, The Long, Deep Furrow, 11; Edward Johnson, A History of New-England, (London: 1653), 56; White, The Planters Plea, 27.

${ }^{92}$ Wood, Nevv Englands Prospect, 77-78.

${ }^{93}$ White, The Planters Plea, 53. Even though some of the Puritan colonists in New England did not believe that the Indians were members of the lost ten tribes whose conversion would signal the millennial advent, they still viewed the Indians as Gentiles whose conversion was a necessary precondition to the Jews' conversion: "let it bee granted that the Iewes conversion is neare, and that the Gentiles, and consequently the Indians must needs bee gathered in before that day." For this reason, the colonization of New England "hath beene specially reserved for this later end of the world." See White, The Planters Plea, 16, 10.
} 
cutter, offered a foretaste of what was to happen in New Enland in a later era with respect to farm tools by inventing a greatly improved scythe. His blade was longer than that of the English scythe, yet rendered lighter and more effective by fastening the strip that furnished the cutting edge to a slender reinforcing bar." Other farmers also tested what appear to be new farm tools: "Thomas Minor mentions in 1654 in his diary a 'leading rake' as though pulled by a draft animal, [and] such a tool would certainly be unusual." 94 As Charles Webster notes, these farmers and the "puritan agricultural writers" who chronicled their efforts "represented a continuation and acceleration of a tradition of interest in innovation which extended back to the later sixteenth century." 95 To a limited extent, this New England extension of an English interest in agricultural innovation accomplished its purpose, allowing the users of these new tools to subdue the land, in fulfillment with the Adamic injunction in Genesis, far more effectively than those who persisted in using clam-shell hoes and other Indian technologies.

\section{English Ordering, English Eden}

With draft animals, plows and other iron tools, working the New England soil became both easier and more productive. Eventually, John Winthrop Jr. records that the English "found out an Easier way of raising Quantity of that Corne by the helpe of the Plough," using that implement to "turne in the Weeds" growing between hills of maize that they used to ignore when they planted in the Indian fashion. On this newly liberated soil the settlers "sprinkle Turnep-seed between the hills, and so have after Harvest a good crop of turneps in the same Field," reaping a doubly abundant harvest because of the importation of English "inventions" and plows. Settlers who used "to hill the Corne with the How" now use plows

\footnotetext{
${ }^{94}$ Russell, The Long, Deep Furrow, 83.

${ }^{95}$ Charles Webster, The Great Instauration, (London: Duckworth, 1975), 474.
} 
because "the Ground is better loosened then with the How, and the Rootes of the Corne have more Liberty to Spread"; not only was the labor easier and the harvest more abundant with the use of English inventions, but the very plants seemed more at ease. ${ }^{96}$

To their success in the fields, the colonists could add their triumphs in the kitchen. The first settlers at Plymouth consumed maize in much the same way that the Indians ate it. Winthrop Jr. writes that they baked

it among the Ashes, which they do so artificially, by putting it amongst the hott Embers, and continually stirring of it that it wilbe thoroughly parched without any burneing, but be very tender, and turned almost quite the inside outward, which wilbe almost white and flowry, this they sift very cleane from the Ashes, and then beate it in their wooden Morters with a long Stone for a pestle, into fine meale

which they ate wet or dry. In time, however, the colonists improved on this technique and learned that "to make good bread of it there is a different way of ordering of it, from what is used about the Bread of other Graine, for if it be mixed into stiff past, it will not be good as when it is made into a thinner mixture a little stiffer then the Battar for Pancakes, or puddings, and then baked in a very hott oven, standing all day or all Night therein. ${ }^{.97}$ English order and invention transformed wilderness into a civilized space, maize fields into a turnip harvest, and ash-cakes into baked bread.

Perhaps even more prominently than English plows, English piety played a large part in the ordering and civilizing of the New England wilderness. Winslow credits the prayers of English colonists with moderating the weather and notes that God looked more favorably on English prayers for rain than on the magical incantations of Indian powahs. He explained "the difference betweene their coniuration, and our invocation on the name of God for rayne; theirs being mixed with such stormes and tempests, as sometimes in stead of doing them

\footnotetext{
${ }^{96}$ John Winthrop Jr., “Indian Corne,” The New England Quarterly 10.1 (1937): 127-28.

${ }^{97}$ ibid, 129.
} 
good, it layeth the Corne flat on the ground, to their preiudice: but ours in so gentle and seasonable a manner, as they neuer observed the like." ${ }^{98}$ The substitution of English prayer for Indian conjurations had a moderating effect on the New England weather patterns that led to the landscape's reformation. These prayers and the plows that they supplemented were so effective in reforming the terrain that some who acknowledged that the region was once a wilderness even began to associate the New England landscape with Eden.

In his History of New England (1653), Edward Johnson reflected on the first twentyfour years of the Bay Colony's history and concluded that the remarkable transformation of the New England landscape was a testament to the world's impending return to a prelapsarian paradise. He looks back on the arrival of John Winthrop's colonists with a knowledge of the hardships that followed and writes that "here the onely encouragements were the laborious breaking up of bushy ground, with the continued toyl of erecting houses, for themselves and cattell, in this howling desart." With the advantage of hindsight, Johnson could see that the New England landscape so widely praised by its initial settlers had actually been an empty wilderness: Winthrop and the other settlers who first engaged "in this Wilderness-work" took "up a desolate Wilderness to be their habitation." ${ }^{99}$ The wilderness described by Johnson was hardly the landscape full of savage beasts and men that Bradford remembered, but its unforgiving and vacant terrain was—at least initially—devoid of the edenic attributes praised in so many early accounts.

Johnson insists that the New England landscape's desolate state was quickly reversed, however, after the arrival of Christ's church in that wilderness. God could not allow the elect of his church to arrive in a ready-made paradise because "[a]s it was necessary that there

\footnotetext{
${ }^{98}$ Winslow, Good Nevves from New England, 50.

${ }^{99}$ Edward Johnson, A History of New-England, (London: 1653), A2, 212, 206.
} 
should be a Moses and Aaron, before the Lord would deliver his people and destroy Pharoah lest they should be wildred indeed in the Wilderness; so now it was needful" for God to raise up political and ecclesiastical leaders in the New England wilderness "before Antichrist come to his finall ruine." With Old England safely in Puritan hands, however, God had unfurled the "glorious fabrick of his New-E. Churches" and revealed their New England home to be an Eden-in-waiting, a "Vineyard of the Lord" where "Christ among you takes his dayly walk" just as he did with Adam in the garden of Eden. ${ }^{100}$ Johnson explains that this transformation from wilderness into paradise was manifested in the sudden abundance of foodstuffs where there had previously been none. While the first settlers worried

that this would be no place of continued habitation, for want of a staple-commodity, but the Lord, whose promises are large to his Sion, hath blest his peoples provision, and satisfied her poor with bread, in a very little space, every thing in the country proved a staple-commodity, wheat, rye, oats, peas, barley, beef, pork, fish, butter, cheese, timber, mast, tar, sope, plank-board frames of houses, clabboard, and pipestaves, iron and lead is like to be also.

New England's prodigious abundance was such that colonists even "fed their Elder Sisters, Virginia, Barbados, and many of the Summer Islands that were prefer'd before her for fruitfulness" and as potentially edenic spaces. Though Eden was not typically associated with commercial traffic, Johnson's famous amazement that "this Wilderness should turn a mart" was, at least in part, an acknowledgment that the hitherto desolate New England landscape had turned into an edenic paradise. ${ }^{101}$

For Johnson, New England's status as a "mart" and center of commerce was actually less important than its status as a godly commonwealth where the millennial restoration of paradisiacal glory could occur. Thus, his description of New England's commodities and

\footnotetext{
${ }^{100}$ ibid, 231, 217, 206, 234. Regarding the perambulatory habits of God in Eden, see Genesis 3:8-“And they heard the voice of the LORD God walking in the garden in the cool of the day."

${ }^{101}$ Johnson, A History of New-England, 208.
} 
commercial activity was only a prelude to his conclusion that "the Lord [has] been pleased to turn one of the most hideous, boundless, and unknown Wildernesses in the world in an instant, as 'twere (in comparison of other work) to a well-ordered Commonwealth, and all to serve his Churches." Johnson describes the New England churches as the "golden Candlesticks" found in John's Revelation, among which Christ “walks in the midst." By linking the New England churches to the golden candlesticks of Revelation, Johnson updates and relocates the apocalyptic tradition of Brightman, who originally proposed that the church of England was the seventh church and candlestick of Revelation, the future home of a "newe Eden." 102 Forty years after Brightman's prophecy was first published, having witnessed the New England landscape's transformation from wilderness to paradise, Johnson was ready to shift the locus of Brightman's millennial restoration from Old England to New.

\section{Confronting Failure: The Inward Turn}

Johnson's optimistic identification of New England as a present paradise and the site of future millennial glory ultimately proved to be an isolated encomium, the product of inflated expectations following the establishment of Cromwell's Commonwealth after the English Civil War. The vast majority of the English colonists who placed their faith in God and the generally transformative power of English invention—and individual inventions such as the plow or Jenckes's scythe more specifically_to perfect the landscape were disappointed, as the land failed to change in the manner and within the time frame implicit in descriptions of the land published in the 1620s and 1630s. Early farmers blamed the failures of "English seed" that "came not to good" on inadequate technology that internal and

\footnotetext{
102 ibid, 209-10, 201; Thomas Brightman, A Revelation of the Revelation, (London: 1615) 51.
} 
imported inventions would eventually improve, yet these hopes were dashed by midcentury. ${ }^{103}$ By 1637 , "the Bay Colony could count up to thirty-seven plows, each able to turn over an acre or more a day of tilled land, and oxen had been trained to draw them," but while these plows made it easier to plant and harvest, they did not transform the New England soil in the way they were supposed to: they never made it possible for European grains to grow in New England soil. Russell explains that

Wheat seldom took kindly to soils along the [New England] coast, nor did barley become of importance in early times except in a few areas. ... Regardless of ill success, farmers continued to experiment with wheat as soon as land could be got into fit condition, for that was the grain for which English stomachs hankered. ... By midcentury it had become clear that for the great part of the colonies the combination of 'rye and Injun' must become New England's main reliance for bread. ${ }^{104}$

After the repeated failure of "civilized" European grains, men like Johnson still occasionally published reports of wheat's success in the colonies, but these reports were increasingly outnumbered by honest accounts of failure. Even in Johnson's text, fewer than "half the inventories mention the English bread grains: wheat, rye, or barley, except perhaps for a little in the house for cooking." ${ }^{105}$ European grains simply did not grow as well in coastal New England soil as the native species whose fertility had amazed explorers and colonists in the first place.

Compounding this agricultural failure, colonial settlement and husbandry also inadvertently destroyed the open forests so admired by the first settlers. Because many colonists considered the fires used by Indians to burn away the underbrush in forests to be uncontrollable and dangerous, they largely discontinued the practice and either used hand implements to clear brush or allowed the forest to grow unimpeded. But Sluyter points out

\footnotetext{
${ }^{103}$ Bradford, Of Plymouth Plantation, 85.

${ }^{104}$ Russell, The Long, Deep Furrow, 43, 41-42.

105 ibid, 98.
} 
that as "native land-use practices such as annual pruning" were replaced by colonial husbandry, "vegetation succession processes create a more closed forest" in which the order of the original forest was lost. ${ }^{106}$ English ordering not only failed to civilize the wild New England soil; it also allowed forests carefully ordered and preserved by the Indians to lapse into an overgrown wilderness state.

Of course, plows were not the only thing to fail New England colonists in the late 1630s; this was also the period of the Antinomian controversy and the Pequot War, when English ordering also failed_-at least temporarily_ to discipline the church and to civilize the Indians. In the wake of these and subsequent conflicts, the optimism attached to the land in the first two decades of permanent European colonization in New England began to fade. With New England's Native American population increasingly agitated over European land appropriation practices, colonists increasingly began to adopt Bradford's initially misguided view that the land was "full of wild beasts and wild men." Indian and wildlife populations actually decreased throughout the seventeenth century, but the increasingly invasive colonial practice of pushing inland to found new settlements englarged the contact zone between civilization and wilderness. As Indians resisted English efforts to civilize them, Sluyter notes that they became racialized, demonized, and "lumped with the landscape under the rubric of environment," leading providentially-minded settlers to view the New England landscape as a wilderness because of its diabolical inhabitants. Thus, in his 1662 poem, "God's Controversy with New-England," Michael Wigglesworth describes the landscape as

A waste and howling wilderness, Where none inhabited But hellish fiends, and brutish men

\footnotetext{
${ }^{106}$ Andrew Sluyter, Colonialism and Landscape, 23. For more on early New England forest management and its effects, see Cronon, Changes in the Land, 108-26.
} 
That Devils worshiped. $(5-8)^{107}$

Mary Rowlandson's account of her captivity in 1676 likewise refers to a "vast and desolate wilderness" full of "hell-hounds" and "ravenous bears" (epithets for her Indian captors). In a 1663 letter to Robert Boyle, Winthrop Jr. begs pardon "for detaining your honr with these Indian matters" and gives expression to what has become a commonplace belief, excusing his discussion of Indian affairs because he lives "in this Wildernesse amongst such a barbarous people."108 For Wigglesworth, Rowlandson and Winthrop Jr. wilderness was no longer a negative state but a positive one. The empty, potentially paradisiacal landscape described by Mourt, Cushman, Winslow, White, Higginson, and Wood had degenerated into Bradford's bestial terrain.

Winthrop Jr. is a useful figure in thinking through this change in perception because his own life and scientific endeavors illustrate the shift from colonial belief in New England as a potential paradise to an outpost in the wilderness. In preparation for his emigration to the Massachusetts Bay Colony, Winthrop Jr. arranged for the importation of several plant species to New England, including “Tansy," "Rockett," and "Clary," among others; he was an active participant in the cultivation of New England's horticultural possibilities. By the end of his life, however, Winthrop had become a net exporter of New England artifacts to Royal Society scientists. He sent cranberries and maize to Samuel Hartlib and other English scientists so that they could gather and unlock the secrets of nature rather than engaging in

\footnotetext{
${ }^{107}$ Andrew Sluyter, Colonialism and Landscape, 12; Michael Wigglesworth, "God's Controversy with New England," in Proceedings of the Massachusetts Historical Society, (Boston: Massachusetts Historical Society, 1873), 83. For an account of the racialization of the Indians, see Joyce Chaplin, Subject Matter, (Cambridge: Harvard University Press, 2001), 157-98.

${ }^{108}$ Mary Rowlandson, "The Sovereignty \& Goodness of God," in Puritans in the New World, ed. David D. Hall, (Princeton: Princeton University Press, 2004), 287, 285-86; John Winthrop Jr., Letter to Robert Boyle, Nov. 3 1663, in Proceedings of the Massachusetts Historical Society, Vol. 16, (Boston: Massachusetts Historical Society, 1878), 219.
} 
this Adamic enterprise himself. He continued to import English books and inventions, including New England's first telescope, but these inventions would not transform the New England landscape- they would only allow him to observe it. He anticipated transformative discoveries in Old England and directed his "quaeries" as to "[w]hether any reall invention be knowne" there, rather than seeking the answer in New England, because "we are heere as men dead to the world in this wildernesse." 109 The Indians had become an active hindrance to Winthrop's participation in the Great Instauration of Francis Bacon, and he grumbled repeatedly in his letters that they prevented him from engaging in the work of transforming New England from its wilderness state into a paradisiacal New Jerusalem. He complained of the "impossibility almost that full discoveries should be made, whiles these India warrs continue" and hoped that "[b]etter tymes may promote better discoveries, for wch we must waite." As to his previous labors, he "might have travailed further hopefully therein, had not the continued warres amongst the Indians wholy hitherto disapointed all such discoveries."110 Winthrop's hopes for transforming New England from a wilderness were thwarted, in large part, by the hostility of the Indians who now seemed to fill it.

From an initial belief in the possibility of recovering a landed paradise in the vacant

\footnotetext{
${ }^{109}$ John Winthrop Jr., Letter to Samuel Hartlib, Dec. 16 1659, in "Some Correspondence of John Winthrop, Jr., and Samuel Hartlib," Proceedings of the Massachusetts Historical Society, Vol. 72, (Boston: Massachusetts Historical Society, 1957-60), 40. On the plants imported by Winthrop, see Richard N. Mack, "Plant Naturalizations and Invasions in the Eastern United States," Annals of the Missouri Botanical Garden 90.1 (2003): 79. Although Walter Woodward might argue that Winthrop retained his hopes of a paradisiacal plantation in Connecticut until his death, he acknowledges Winthrop's place on the periphery of paradisiacal pretensions in the 1660s and beyond, noting that he "represented to the fellows [of the Royal Society] a type of natural philosopher who had been desired by reformers since Bacon's description of 'Solomon's House' in New Atlantis: the traveling elders (one third of Bacon's College) who gathered experimental information in other countries and returned, bringing their knowledge with them." See Walter W. Woodward, Prospero's America, (Chapel Hill: University of North Carolina Press, 2010), 270.

${ }^{110}$ John Winthrop Jr., Letter to Robert Moray, Aug. 18, 1668, in Proceedings of the Massachusetts Historical Society, Vol. 16, (Boston: Massachusetts Historical Society, 1878), 232-33; John Winthrop Jr., Letter to Henry Oldenburg, Nov. 12, 1668, in Proceedings of the Massachusetts Historical Society, Vol. 16, (Boston: Massachusetts Historical Society, 1878), 236.
} 
wilderness of New England, the Puritan inhabitants of that region shifted their focus more intensively to a cultivation of the wilderness within — the imperfections of their own bodies and souls. As Williams explains, the Puritans came to believe that any wilderness could, "through spiritual and moral subjugation and cultivation even more than physical conquest, tilling, and seeding become a garden or Eden of the Lord." ${ }^{111}$ After their failures to civilize the soil and reap the European grains they craved; after the Indians stopped cooperating with and started resisting the work of colonization; after the Antinomian controversy illuminated the fragility of their own spiritual strength, there was no longer any question of realizing a physical paradise in New England. Recovering the physiological, mental, and spiritual perfections of Adam and Eve would have to do.

This turn inward, away from external agricultural concerns, is one that occurred gradually as individual settlers and groups of settlers grew disenchanted with the landscape. Edward Winslow, in a 1622 letter attached to the back of Mourt's Relation, praised New England's fecundity and temperate climate, but two years later he refused to speak again "of the abundance of fowle, store of Venison, and varietie of Fish, in their seasons, which might incourage many to goe" to New England who lacked the physiological, mental and spiritual discipline required to thrive there. Familiar with men and women who alleged that New England was a wilderness of the type that Bradford described, he warned them not to "lay that imputation vpon the Country, and others, which themselues deserue": the land was not a wilderness so much as the colonists themselves were in a state of wilderness. Winslow suggests that men and women who fail to find the paradise that his original description of the landscape portrayed should first "see thine owne insufficiencie of thy selfe" and correct it

${ }^{111}$ Williams, Wilderness and Paradise in Christian Thought, 5. 
before seeking a physical paradise. ${ }^{112}$ Winslow's warning that settlers must cultivate the wilderness within before conquering the wilderness without was written in 1624, but many settlers did not come to share his viewpoint until the late 1630s. The year 1637 represents a significant turning point in conceptions of New Englands geographical possibilities — and not only because that year marks the beginning of the Pequot War and Antinomian controversy. The year 1637 was also the year in which the last substantive descriptions of New England's landscape appeared, as accounts of the terrain and its natural resources were subordinated to narratives of Indian conflict and defenses of the congregational system of church government. ${ }^{113}$ Though it was undoubtedly of little comfort to him in England, Thomas Morton could take some solace in having had the last word on the paradisiacal character of New England when his New English Canaan was published in 1637. For subsequent writers, the paradisiacal potential of the landscape was of less interest than the potential perfection of their own bodies, souls, and social spheres. ${ }^{114}$

\footnotetext{
${ }^{112}$ Winslow, Good Nevves from New England, 64, 66, 65.

${ }^{113}$ Early accounts of the New England landscape were republished-Wood's Prospect was reprinted in 1639, and the anonymously authored A Treatise of New England (London: 1637) was republished in 1645-but no substantive new accounts of the New England landscape appeared until the late seventeenth century, when John Josselyn's NewEngland's Rarities Discovered (1672) and An Account of Two Voyages to New-England (1674) were published. Indeed, there was so little new information published regarding New England's natural resources in the mid seventeenth century, and the accounts published in the 1620s and 1630s were considered so unsatisfactory that the London correspondents of John Winthrop Jr. practically begged him to publish a description and history of the New England landscape. Henry Oldenburg asks him repeatedly to "put in writing what you know of ye constitution and productions, etc., of New England" and to begin "the composure of a good History of New England, from the beginning of ye English arrival there, to this very time; containing ye Geography, Natural Productions, and Civill Administrations thereof." See Henry Oldenburg, Letter to John Winthrop Jr., Mar. 18, 1671, in Proceedings of the Massachusetts Historical Society, Vol. 16, (Boston: Massachusetts Historical Society, 1878), 249, 250.

${ }^{114}$ While the reformation of the New England landscape continued to be a matter of interest in the eighteenth century—for the Harvard professor who was John Winthrop's namesake, among others-it was never again the universal concern that it was in the first two decades of colonization. For a survey of eighteenth-century New England thought in "a nation that was hewing its habitat from the wilderness, slowly bringing the virgin continent under the sway of civilization," see Jan Golinski, "American Climate and the Civilization of Nature," in Science and Empire in the Atlantic World, ed. James Delbourgo and Nicholas Dew, (New York: Routledge, 2008), 156.
} 
When John Smith cautioned that "though the Coast be rockie, and thus affrightable; the Vallies, Plaines, and interior parts, may well (notwithstanding) be verie fertile" he spoke of New England's geographical interiority, but the settlers of the Bay Colony soon discovered the fruitfulness of their own psychosomatic interior parts. ${ }^{115}$ Their failure to convert the New England landscape into a civilized paradise was at least partially mitigated by their success in the regulation and reformation of their own bodies. In early modern narratives New England's transition from temperate paradise to howling wilderness was understood, at least in part, as the result of spiritual distempers among the colonists; the "Epidemicall" diseases that attacked colonial bodies resulted from a "change of our Manners in the wilderness from being heavenly to earthly and simply sincere and peaceable, to be cunningly sinfull and contentious, having changed our climate from Salubrious to unhealthy." ${ }^{116}$ Wigglesworth expressed this conviction in poetic form:

Our healthfull dayes are at an end, And sicknesses come on From yeer to yeer, becaus our hearts Away from God are gone.

New-England, where for many years You scarcely heard a cough, And where Physicians had no work, Now finds them work enough.

$$
* * *
$$

Our fruitful seasons have been turnd Of late to barrenness, Sometimes through great \& parching drought, Sometimes through rain's excess. Yea now the pastures \& corn fields

\footnotetext{
115 John Smith, “A Description of New England," in Captain John Smith: Writings with Other Narratives of Roanoke, Jamestown, and the First English Settlement of America, ed. James Horn, (New York: Library of America, 2007) 148.

${ }^{116}$ John Woodbridge, as quoted in Patricia A. Watson, The Angelical Conjunction, (Knoxville: The University of Tennessee Press, 1991), 19.
} 
For want of rain do languish:

The cattell mourn, $\&$ hearts of men

Are fill'd with fear \& anguish.

Before the colonists could regain the temperate, healthful climate that they enjoyed when

they first arrived, they needed to discipline their own bodies and souls; Wigglesworth warned that New England's inhabitants needed to "Repent, \& turn to God" before the land's paradisiacal potential could be fulfilled. ${ }^{117}$

${ }^{117}$ Wigglesworth, "God's Controversy with New England," 91-93. 


\section{CHAPTER 2}

\section{A BODY UNEMBARRASSED: HUMORAL EMPOWERMENT AND ASPIRATIONS TO EDENIC TEMPERANCE}

The shift that I describe at the end of Chapter 1, this turn inward from a focus on the cultivation of edenic landscapes to the cultivation of edenic bodies, would have seemed natural to early modern men and women because the vast majority of them believed in a cosmological connection between bodies and lands. As Gail Paster notes, "ordinary microcosmic man's flesh is earth and his passions are the seas" in the analogical framework of early modern England. ${ }^{1}$ Seventeenth-century poets like George Herbert proclaimed that "[Man] is in little all the sphere" (22), and natural philosophers such as Walter Ralegh described the body as a miniature copy of the macrocosm, relating human tissues to comparable geographical features: man's

blood, which disperseth itself by the branches of veins through all the body, may be resembled to those waters which are carried by brooks and rivers over all the earth; his breath to the air; his natural heat to the enclosed warmth which the earth hath in itself, which, stirred up by the heat of the sun, assisteth nature in the speedier procreation of those varieties which the earth bringeht forth; our radical moisture, oil, or balsamum, (whereon the natural heat feedeth and is maintained,) is resembled to the fat and fertility of the earth; the hairs of man's body, which adorns, or overshadows it, to the grass which covereth the upper face and skin of the earth. ${ }^{2}$

Because of the metaphorical framework constructed by seventeenth-century science and

\footnotetext{
${ }^{1}$ Gail Kern Paster, Humoring the Body (Chicago: University of Chicago Press, 2004), 4.

${ }^{2}$ George Herbert, "Man,” in The Complete English Poems, ed. John Tobin, (New York: Penguin Books, 2004), page 84; Walter Ralegh, The Works of Sir Walter Ralegh, Kt., Vol. II, ed. William Oldys and Thomas Birch, (Oxford: Oxford University Press, 1829), 59. For an overview of the seventeenth-century connections between physiology and geography, see J. B. Bamborough, The Little World of Man, (Darvey: Arden Library, 1980).
} 
theology, every aspect of the macrocosmic New England landscape that colonists worked to civilize was already understood in terms of their own microcosmic physiologies, which they cultivated and refined through alterations to diet, exercise, and other factors.

In addition to this metaphorical link between lands and bodies, of course, there was a very literal connection between the colonists' physical habitat and their physiological health. Men like Francis Higginson and William Wood promoted the belief that relocating in New England's temperate climate and reforming the landscape would prove restorative to body and spirit. ${ }^{3}$ According to William Cronon, these claims that the New England landscape conferred health benefits on its inhabitants were actually grounded in fact: "Disease was by no means absent from New England, as deaths from 'seasoning' and epidemics both showed, but the colonial population nevertheless remained for a while relatively isolated from the European disease environment. Large numbers of deaths in the occasional epidemics which did occur should not obscure the fact that New England mortality rates-for Europeanswere on average much lower than comparable rates in Europe.” Philip Greven calls colonial New England "a remarkably healthful place, conducive to the preservation of life and to the fecundity of the inhabitants," and the climate's friendliness to English physiologies was considered a key to their project of civilizing the landscape. ${ }^{4}$ As Joyce Chaplin notes, the continued health and fertility of English "bodies guaranteed overseas possession, both by creating a population that demonstrated territorial dominion and by generating many hands to improve the "wilderness' through labor." The New England wilderness ultimately proved

\footnotetext{
${ }^{3}$ For a discussion of the physiological benefits to be gained from the landscape, see Chapter 1, pp. 68, 77-78.

${ }^{4}$ William Cronon, Changes in the Land (New York: Hill and Wang, 1983), 24; Philip J. Greven, Four Generations, (Ithaca: Cornell University Press, 1970), 22. John Blake provides an earlier, contrasting view, contending that "the colonists were at all times subject to many ills." See John B. Blake, Public Health in the Town of Boston, 1630-1822, (Cambridge: Harvard University Press, 1959), 2.

5 Joyce Chaplin, Subject Matter (Cambridge, MA: Harvard University Press, 2001), 117.
} 
untamable, of course, but the leaky, phlegmatic, and lethargic bodies that English immigrants brought to the New World fared remarkably well and gave them hope that the perfectly temperate physiologies enjoyed by Adam and Eve in Eden could be regained there.

Hexameral commentators of the Renaissance agreed that the paradisiacal bodies of Adam and Eve were perfectly temperate. In Eden the four elements (fire, air, earth, water) and the four humors (blood, phlegm, black bile, or melancholy, and yellow bile, or choler) were ideally balanced; because the disparate components of his edenic body operated in harmony with one another, Milton explains that Adam's “sleep / Was Aery light, from pure digestion bred, / And temperate vapors bland." Maintaining this perfect physiological temperance was a matter of regulating consumption and excretion for Adam and Eve, and Raphael explains to the pair that if they eat well and care for their bodies appropriately, time may come when men With Angels may participate, and find No inconvenient Diet, nor too light Fare: And from these corporal nutriments perhaps Your bodies may at last turn all to spirit, Improv'd by tract of time, and wing'd ascend Ethereal, as wee, or may at choice Here or in Heav'nly Paradises dwell. ${ }^{6}$

The continued residence of Adam and Eve in Eden and their potential promotion to a heavenly paradise were contingent upon a continuation of an appropriate diet, one which excludes foods—such as the fruit of the tree of the knowledge of good and evil—that would disrupt their humoral temperance (among other deleterious effects). Mary Corcoran notes that God's injunction to Adam against eating the fruit of the tree of the knowledge of good and evil was viewed by seventeenth-century theologians as "a lesson of temperance in the use of the garden" because as soon as Eve disobeyed that commandment, she ceased to curb

\footnotetext{
${ }^{6}$ Milton, Paradise Lost, V.3-5, 493-500.
} 
processes of consumption and excretion, falling into intemperance. Milton writes that she “ingorg'd without restraint," so "in her Cheek distemper flushing glow'd."7

After the Fall Adam and Eve could not remain in Eden's perfectly temperate environment precisely because of the changing state of their physiologies. Milton's God explains that

... longer in that Paradise to dwell,

The Law I gave to Nature him forbids:

Those pure immortal Elements that know

No gross, no unharmonious mixture foul, Eject him tainted now, and purge him off As a distemper. ${ }^{8}$

This edenic state of humoral temperance which Adam and Eve forfeited at the Fall was the bodily ideal to which early modern men and women aspired. Mary Floyd-Wilson explains that "early modern ethnology values the good of temperance-an elusive, but theoretically achievable, balance of humors" enjoyed in Eden, and medical breakthroughs of the seventeenth century promised the recovery of this physiological perfection. Charles Webster describes Puritan thinkers, including John Winthrop Jr. and other New England physicians inspired by Francis Bacon, who "seriously believed [that] man's natural life was capable of more effective regulation than had been attained under traditional medicine" and that the average lifespan would soon be extended by a hundred years or more through medical innovations. ${ }^{9}$ For these English thinkers, the mutable nature of Native American physiologies

\footnotetext{
${ }^{7}$ Mary Irma Corcoran, Milton's Paradise with Reference to the Hexameral Background, (Washington, D.C. : Catholic University of America Press, 1945), 52-53; Milton, Paradise Lost, IX.791, 897.

${ }^{8}$ Milton, Paradise Lost, XI.48-53.

${ }^{9}$ Mary Floyd-Wilson, English Ethnicity and Race in Early Modern Drama, (Cambridge, UK: Cambridge University Press, 2003), 12. Charles Webster, The Great Instauration, (London: Gerald Duckworth, 1975), 24950. The medical breakthroughs described by Webster were Paracelsian in nature, and in England practitioners of Galenic medicine were adamantly resistant to the Paracelsian doctrine of iatrochemistry. In New England, however, medical practitioners - who were not licensed and therefore indoctrinated as graduates of the Royal College of Physicians-viewed the two systems as compatible and complementary. As Patricia Watson
} 
provided proof of the body's capacity for transformation.

English immigrants interested in physiological alteration were fascinated by the bodies of Native Americans, whose efforts to reform their own physiologies excited the eschatological hopes of colonists. European colonists regularly commented on the "tractable Nature" of New England's native inhabitants and the varied ways in which they modified their bodies; as Karen Ordahl Kupperman notes, they "wrote about the American Indians as if the attributes we subsume under the category of race were manipulable and constructed." 10 And because most Europeans believed that the Indians were descendants of the ten lost tribes of Israel who needed to be civilized, then converted, before the millennial restoration of prelapsarian perfection could occur, the pliable nature of their bodies and souls was a cause for celebration. ${ }^{11}$ New England colonists believed that this process of cultural and spiritual transformation would be facilitated by encouraging Indians to adopt English standards of dress and diet; Kupperman points out that "English writers describing American Indian life constantly attested to their belief in the link between changes in clothing and personality." Thus, when the colonists provided Massassoit with a scarlet robe from King James, colonial commentators depicted him instantly assuming some of the airs of an Old World monarch as he began to shed his identity as a tribal sachem. The conversion and civilization of the

explains, "adherents to these two systems formed opposing medical factions in England, [but] there is little evidence of such a debate in New England. Although they did not reject the basic tenets of Galenism (based on the balance of the four bodily humors), iatrochemical texts and remedies were very popular with Puritan divines." In New England, iatrochemistry was primarily a methodology for healing humoral bodies, not necessarily a new way of understanding the composition of those bodies. See Patricia A. Watson, The Angelical Conjunction, (Knoxville: The University of Tennessee Press, 1991), 5. For more a more recent perspective on the relationship between Galenic and Paracelsian medicine and an account of John Winthrop Jr.'s role as one of the most eminent physicians of the period, see Walter W. Woodward, Prospero's America, (Chapel Hill: University of North Carolina Press, 2010), 160-209.

${ }^{10}$ Thomas Morton, New English Canaan, ed. Jack Dempsey, (Scituate: Digital Scanning, 1999) 1; Karen Ordahl Kupperman, "Presentment of Civility: English Reading of American Self-Presentation in the Early Years of Colonization," The William and Mary Quarterly 54, no. 1 (1997): 194.

${ }^{11}$ See the Introduction, pp. 14-16. 
Indians_-necessary preconditions to the recovery of Eden promised by theologians such as Thomas Brightman and John Cotton-was made a matter of physiological alteration easily accomplished by modifications to native modes of clothing and consumption. ${ }^{12}$

This early modern belief in physiological mutability as a key to the recovery of edenic purity is powerfully captured in the frontispiece to John Bulwer's Anthropometamorphosis (1650), in which representatives of every nationality in the world are brought to be judged by the ghost of Galen in the presence of Adam and Eve, who preside in unadorned, naked perfection. Native Americans, Europeans, Africans, and Asians alike are condemned for the alterations they have made to the bodies they inherited from Adam and Even and directed to reform their physiologies so as to recapture the temperate perfections those two enjoyed. While Bulwer focuses on the ways in which cosmetics, dress, and jewelry have promoted physiological degeneration, his inclusion of Galen suggests that seventeenth-century men and women would also benefit from an application of Galenic medicine. Galen believed that the relative balance of the body's four humors determined the psychological and physiological well-being of every individual, and these key internal fluids fluctuated in response to a variety of outside factors including the external climate and an individual's emotions, diet, sleeping pattern, exercise regime, and habits of bodily excretion.

As Michael Schoenfeldt argues, this "understanding of self, not as an inert and alien body of knowledge, but rather as a vibrantly inconsistent but brilliantly supple discourse of

\footnotetext{
${ }^{12}$ Kupperman, "Presentment of Civility: English Reading of American Self-Presentation in the Early Years of Colonization," 222. In his Revelation of the Revlation (London: 1615), Brightman promises church members who "shall keep themselues pure from the corruptions of these tymes, and shall not forsake theire first loue" into "the true and free denizens of this holy Church, [who] shall haue liberty and power to eate of Christ who is that true tree of life in the mids of this newe Eden" (51). Similarly, in A Brief Exposition of the Whole Book of Canticles, or, Song of Solomon (London: 1642), Cotton explains that "as the garden of Paradise was the habitation of Adam in the estate of innocency, so is the Church of all those who are renewed into innocency," that the spiritual state of Adam and Eve in the garden of Eden is the reward of the regenerate (130).
} 
selfhood and agency [where] the consuming subject was pressured by Galenic physiology, classical ethics, and Protestant theology to conceive all acts of ingestion and excretion as very literal acts of self-fashioning," empowered early modern men and women in their quest to achieve humoral temperance- the condition enjoyed by Adam and Eve in Eden. ${ }^{13}$ For Calvinists, a belief in predestination made such efforts at purification ultimately ineffectual for anyone but the elect; nevertheless, both the degenerate and the regenerate alike were under divine command to purify themselves, body and soul. Accordingly, colonists in seventeenth-century New England repeatedly turned to the accounts of creation in Genesis, the physical bodies of Adam and Eve, and other aspects of Eden as reference points for their own concerns with disciplining and refiguring both physical and figurative bodies.

Chaplin has previously noted "the tremendously fraught relation between the body and power in early America" within the context of English interactions with Native Americans; Kupperman has described the colonial belief in seasoning, an involuntary "[c]hange in the balance of the humors" that affected most colonists in the New World; and Jim Egan has catalogued the ways in which New England "writers inadvertently revised early modern theories of the body politic"; but the religious implications of body theory in New England remain largely unexplored. ${ }^{14}$ In this chapter I argue that these apparently

\footnotetext{
${ }^{13}$ Michael Schoenfeldt, Bodies and Selves in Early Modern England, (Cambridge: Cambridge University Press, 1999) 9.

${ }^{14}$ Chaplin, 3; Karen Ordahl Kupperman, "Fear of Hot Climates in the Anglo-American Colonial Experience," The William and Mary Quarterly 41, no. 2 (1984): 215; Jim Egan, Authorizing Experience (Princeton, NJ: Princeton University Press, 1999), 8. Kupperman describes this humoral alteration, or "seasoning" as "a process commonly lasting about two years and thought necessary even in southern New England." While Kupperman notes that English colonists believed that Native Americans could and did manipulate skin color and other bodily characteristics, she does not address in detail the conscious attempts at self-fashioning engaged in by the colonists themselves. Egan devotes the bulk of his attention to the body politic in Authorizing Experience. When he does venture into the realm of the ecclesiastical body or the religious implications of temperate physical bodies, he makes an odd selection of primary texts. In discussing Bradstreet, for instance, Egan concludes that "Bradstreet renounces the experience of the [physical] body altogether" (84), despite her lengthy discussion of the physical body in the "Of the Four Humours." Egan's treatment of John Winthrop's A Short
} 
inadvertent alterations to body theory actually represent conscious reconfigurations of physical and spiritual bodies consonant with Schoenfeldt's conception of Renaissance bodies as potentially empowering resources. Early New England writers, by working to purify their weak and leaky English bodies, openly announced their interest in forging a new, "American" identity. In that sense, the bodies which come forward from seventeenth-century New England—whether literal or literary—actually reinvent the familiar creation myth of Genesis, producing the new ribs and wombs requisite in the establishment of a distinctly American physiology and literature. Without an appreciation for the psychological complexities of humoral discourse and Galenic medicine, Anne Bradstreet's discussion of "The Four Humors" falls flat, nothing more to literary critics than "a commonplace book put into iambic couplets, the historical scientific journal of a young woman with a taste for study." ${ }^{\prime 15}$ Properly framed by humoral theory, however, Bradstreet's poetic revision of Renaissance medicine turns into an articulation of colonial identity comparable to John Winthrop's “Modell of Christian Charity" or Benjamin Franklin's Autobiography. Humoral theory empowered both women and men, the poor and the wealthy as they collectively worked to reclaim the perfectly temperate bodies that Adam and Eve had lost in the Fall, and this socially inclusive quest for edenic temperance shaped the medical practice, theology, and culture of early modern New England.

Story of the Rise, reign and ruine of the Antinomians, Familists \& Libertines seems to dance around the idea of an ecclesiastical body and focuses more on the social implications of Anne Hutchinson's dissent and the disciplining of the social sphere.

${ }^{15}$ William C. Spengemann, A New World of Words (New Haven, CT: Yale University Press, 1994), 49-50; Adrienne Rich, "Foreword," in The Works of Anne Bradstreet, ed. Jeannine Hensley (Cambridge, MA: The Belknap Press of Harvard University Press, 1967), xiii. 


\section{Other-Fashioning: The Limits of Humoral Empowerment}

Although Schoenfeldt argues that humoral theory gave men and women an equal opportunity to fashion their own identities by controlling bodily intakes and expurgations, critics such as Paster and Thomas Laqueur place Galenic medicine and humoral theory "in collusion with patriarchal ideology to give a physiological 'explanation' to the asserted inferiority of women." Galenic medicine used somatics to justify gender hierarchies which described women as imperfectly evolved men whose temperature in utero never reached the boiling point necessary to convert the internal feminine genitalia into the external male sex organs, a concept which survives in the eighteenth-century writings of William Byrd, among others. While men frequently participated in the self-fashioning process successfully, women and lower-class citizens who lacked the bodily heat indicative of courage and resolve frequently could not "master their bodies [...] And the embarrassed bodies of wives, whores, rustics, and children, who predictably failed in such tasks, suffered humoral forms of embarrassment." ${ }^{16}$ In England, only male members of the upper class were considered capable of exerting sufficient control over their bodies. Peasants and wives who failed to exercise bodily discipline on their own required the help of a lord or a husband in order to fashion a body unembarrassed by humoral imbalances. These limitations of class and gender on English hopes for humoral regulation are the basis of the plot in Shakespeare's Taming of the Shrew.

In Shrew, a lord takes in the unconscious drunk Christopher Sly and instructs his

\footnotetext{
${ }^{16}$ Schoenfeldt, Bodies and Selves in Early Modern England, 36; Gail Kern Paster, The Body Embarrassed, (Ithaca: Cornell University Press, 1993), 7. Byrd describes the metamorphosis of a nun "who escaping out of a Nunnery, took post on Cavalier, and in Ten Miles hard riding had the good Fortune to have all the Tokens of a Man break out upon her," evincing a belief in the Galenic premise that the female genitalia is simply an inverted penis and that gender can be reversed even out of the womb. See William Byrd, The History of the Dividing Line Between Virginia and N. Carolina Run in the Year of Our Lord 1728 (Ms. S11160 American Philosophical Society Library, Philadelphia), 212.
} 
servants to treat the man like a noble. When Sly awakes in a nobleman's clothes, he cannot understand the signification of this apparent promotion in status, and the lord attempts to persuade Sly that his self-identification as a member of the lower class was the product of a deranged mind. Servants inform him that

... too much sadness hath congealed your blood, And melancholy is the nurse of frenzy.

Therefore [your doctors] thought it good you hear a play

And frame your mind to mirth and merriment

Which bars a thousand harms and lengthens life. ${ }^{17}$

The lord who deceives Sly would persuade him that literary and theatrical consumption determines identity by demonstrating Kate's own physiological and psychological transformation, but the play's ending does not record Sly's fate. Having first demonstrated the potential effects of changes in diet and exercise on Kate, Shakespeare allows the audience to decide whether the spoken words of his play might not produce a similar metamorphosis of character in Sly-or in themselves.

Kate, whose shrewish ways derive at least in part from her unnatural and manly heat, must literally cool off_-reduce the temperature of her physical body-before Petruchio can convince her to play the part of a good wife. To that end, Petruchio refuses to let Kate sleep, and instructs his servant Grumio to withhold all food items that might exacerbate her distemper by producing an excess of blood in her body:

Grumio: What say you to a neat's foot?

Kate: 'Tis passing good. I prithee, let me have it.

Grumio: $\quad$ I fear it is too choleric a meat.

How say you to a fat tripe finely broiled?

Kate: I like it well. Good Grumio, fetch it me.

${ }^{17}$ Shakespeare, Taming of the Shrew, Induction.ii.123-27. 
Grumio: I cannot tell. I fear 'tis choleric. ${ }^{18}$

After half starving her, Petruchio then threatens to embarrass Kate by keeping her home from her sister's wedding, symbolically removing her body from the event she most wishes to attend. Although Kate does not succumb to Petruchio's demanding standards of behavior until after this final threat, and Frances Dolan asserts that "Neither hunger nor weariness tames Katherine (directly)," Kate does eventually submit, and Shakespeare's explicitly humoral explanation for that submission emphasizes its importance. Paster argues that for Shakespeare, "in a cosmology governed by psychological materialism, where the psychological is not yet divorced from the physiological, Kate's soul is thus proved to have followed her body's temperature, whether the compliance is external or internal. ${ }^{, 19}$ Kate cannot regulate her own body; she obtains a physiology unembarrassed by humoral imbalances only through the disciplined consumption forced on her by a demanding husband.

Although Kate ultimately does obtain an idealized body which she proudly flaunts in the play's last major speech, she does not do so through her own agency; on the contrary, Kate's failure to discipline her temper and regulate her temperature constitutes the primary source of Shrew's conflict and comedy. ${ }^{20}$ Bodily discipline allows Kate to assume a new

\footnotetext{
${ }^{18}$ ibid, IV.iii.17-22.

${ }^{19}$ Frances E. Dolan, Introduction, in The Taming of the Shrew, William Shakespeare, ed. Frances E. Dolan (Boston: Bedford Books, 1996) 29. Paster, Humoring the Body, 134.

${ }^{20}$ The question of Kate's agency in the broader context of Shrew is a source of critical controversy. This essay does not enter into the question of whether Kate's final speech instructing her sister that "Such duty as the subject owes the prince, / Even such a woman oweth to her husband" (V.ii.155-56) is a text that Kate willingly endorses or not. I only recognize, with Lynda Boose, that "Petruchio controls access to all sustenance" and therefore assumes authority over the somatic fashioning of his wife (Lynda Boose, "Scolding Brides and Bridling Scolds: Taming the Woman's Unruly Member." Shakespeare Quarterly 42, no. 2 [1991]: 194.). Kate's subsequent choice "to please him and encourage his generosity rather than, as he says, continue ever more crossing him in futile imitation of birds whose wings have been clipped" is irrelevant, because that choice is the product of a body — and hence a decision-making process - fundamentally altered by Petruchio's attention to the humoral balance of Kate's food.
} 
identity, but that bodily discipline revolves around her own shaming, as when Petruchio leaves her waiting at the marriage altar and her father asks, "What says Lucentio to this shame of ours?" Kate replies, "No shame but mine" and bursts into tears, displaying an emotion other than anger for the first time. This imposition of shame by an outside agent begins the process of bodily discipline, but Kate's metamorphosis cannot be called selffashioning, since Kate does not initiate or moderate the process herself. Instead, Kate's taming mimics the type of rehabilitation offered Sly-the process in both cases might be described as "other-fashioning," where the self is conditioned and regulated by a social superior.

In England, as Paster shows, only upper-class men enjoyed the full freedom of selffashioning described by Schoenfeldt, and even he acknowledges the difficulty of finding "an example of a woman writer practicing the philosophically rigorous and literarily intense engagement with physiological inwardness that marks" the writings of male authors like Spenser, Shakespeare, Herbert and Milton. ${ }^{21}$ In this seventeenth-century setting, self-made men who participated in their own somatic self-fashioning may have been commonplace, but the idea of a self-made pauper or a self-made woman remained an oxymoron. As colonists worked to reform Native American bodies and souls in a manner analogous to that used by Petruchio to tame Kate, they too engaged in other-fashioning, imposing European cultural practices and dress on a people whose 'savage' ways identified them as incapable of the selffashioning in which the English engage. But while the invention of race-the racializing of Native Americans was a product of the 1640s, as Chaplin shows—-prevented Native Americans and African American slaves from taking a more active role in their own

\footnotetext{
${ }^{21}$ Shakespeare, Taming of the Shrew, III.ii.7,8; Schoenfeldt, Bodies and Selves in Early Modern England, 38.
} 
physiological and social reformation, humoral limitations based on gender and class were

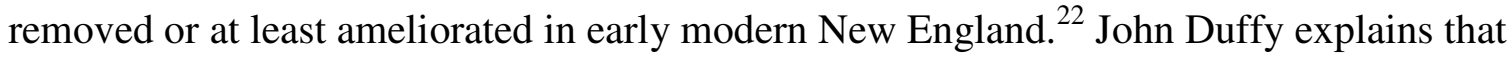
"[f]rontier conditions and the fluidity of American society soon tended to minimize, although not eliminate, distinctions [of education] among the various categories of medical practitioners" in New England, and this environment created conditions in which socially and sexually marginalized populations could appropriate medical knowledge to seize power available only to cultural elites in Old England. ${ }^{23}$ In New England the edenic ideal of a perfectly temperate body, one in which all of the humors are well balanced, was made accessible to the margins of society - to women and paupers as well as wealthy white men.

\section{Engendering Edenic Temperance: The Sexing of Medicine}

The wielding of medical knowledge provided power to its practitioners. Patricia Watson explains that a New England clergyman "hopeful of settlement in a particular community had to rely on other means to support himself" while the congregation debated his merits, and many relied on medicine as a second profession. The practice of medicine also allowed ministers to "maintain their elevated status within the community" and to feed their families during disagreements with congregations "intentionally attempting to 'starve' their ministers by withholding pay." 24 But ministers were not the only individuals to practice medicine in colonial New England; midwives and mothers also dispensed herbal remedies

\footnotetext{
${ }^{22}$ Chaplin, Subject Matter, 157-98. As Indians resisted the physiological improvements suggested by European colonists, "the English began to articulate this sense of innate corporeal difference," and "key to this shift, first evident in the 1640s," were the increased disease and mortality rates among Indians exposed for the first time to Old World plagues (157-58).

${ }^{23}$ John Duffy, From Humors to Medical Science, (Urbana: University of Illinois Press, 1993), ix. Duffy offers a comprehensive history of American medicine that focuses on medical theory and practice in the United States after the mid-eighteenth century; his discussion of seventeenth-century medicine is brief but establishes the egalitarian nature of the profession.

${ }^{24}$ Watson, The Angelical Conjunction, 67-68.
} 
and medical advice that enhanced their status and provided them social capital. While the college education of minister-physicians provided prestige unavailable to female practitioners, "women, who usually took on the role of healer in the home, also were known to possess their own copies of [Nicholas] Culpepper"- an English physician and the author of early modern New England's most popular medical treatise, The English Physitian (1652)—“and his works were often passed down from mother to daughter." Perhaps no woman's history demonstrates the power that mothers and midwives wielded via their medical expertise better than that of Anne Hutchinson. Eve LaPlante suggests that Hutchinson's scriptural opinions were accorded more weight because of "her role as a trusted midwife and nurse, on whom settlers depended at crucial moments of life and death."25 But Hutchinson's medical prowess was ultimately trumped by the minister-physicians whose educated opinions on the demonic nature of the hydatidiform mole that she miscarried fanned the flames of public opposition against her and led to her exile. Other women, however, were more successful in appropriating medical theory to become advocates for gender equality.

\section{$\underline{\text { A Self-Made Woman }}$}

Because John Woodbridge ostensibly took his sister-in-law's poetry to London and published it without her approval or revision, readers have long conceived of Anne Bradstreet as a woman confined and defined by her male contemporaries, subjected to the masculine other-fashioning that shamed Kate and condemned Hutchinson. Woodbridge bestowed on Bradstreet the title The Tenth Muse, Lately Sprung Up In America, and Ivy Schweitzer cites this exercise in naming as an example of cultural forces that sought to discipline and tame Bradstreet. From Schweitzer's point of view, “when brother John names

\footnotetext{
${ }^{25}$ ibid, 78; Eve LaPlante, American Jezebel, (San Francisco: HarperSanFrancisco, 2004), 46.
} 
his worthy sister Anne the 'tenth Muse,' he is deliberately attempting to 'manage' the threat of a woman quietly defying her culture's double messages about women's capabilities and women's roles, by putting her back into a feminine place."26 But any argument that revolves around outside impositions on Bradstreet's cultural identity presupposes that Bradstreet sought to escape "a feminine place," and her poems which most explicitly address gender politics—“The Foure Elements" and "Of the Foure Humours in Mans Constitution"wholeheartedly embrace both her femininity and her English identity.

This pair of poems lays the foundation for Bradstreet's examinations of natural and geo-political history in "The Four Ages of Man," "The Four Seasons of the Yeare," and "The Foure Monarchies"; they reinvent the biblical creation narrative and introduce Bradstreet's worldview in much the way Genesis introduces the Bible. In "Elements" and "Humours" Bradstreet challenges and overturns ethnographic and gender stereotypes. She does not cover up or paint over the weaknesses of the English constitution as in Ben Jonson's Masque of Blackness, where Queen Anne and her courtiers don blackface and appropriate the purifying heat of Ethiopian bodies, nor does she, like Shakespeare's Lady Macbeth, request that the “spirits / That tend on my mortal thoughts, unsex me here." ${ }^{, 27}$ Instead of covering up or stripping away the commonly perceived weaknesses that plagued English and female bodies, Bradstreet celebrates the virtues of those bodies. Her redaction of Genesis and the Eden

\footnotetext{
${ }^{26}$ Ivy Schweitzer, The Work of Self-Representation (Chapel Hill, NC: The University of North Carolina Press, 1991), 131.

${ }^{27}$ Shakespeare, Macbeth, I.v.45. Floyd-Wilson argues that "The Masque of Blackness stages a mythopoetic solution to the English fear that uniting with its northern neighbor [Scotland] would move England further from the origins of civilization and the civility of temperance" by emphasizing the ways in which "the Ethiopians' complexion not only [functions] in terms of the western aesthetics of 'great beauty's war,' but also as a temperament associated with the inner qualities of wisdom, civility, piety, constancy, and a contemplative nature." Though blackness was commonly associated with evil in early modern England, it also represented the humoral quality — dry heat - that the English lacked and therefore constituted a valuable potential corrective. See Floyd-Wilson, English Ethnicity and Race in Early Modern Drama, 114, 125.
} 
narrative valorizes the very qualities for which natural philosophers condemned the English and the female body and attributes to her own physiology the edenic, humoral and moral perfections which Milton later ascribed to the bodies of Adam and Eve.

Bradstreet serves notice that she will consider the edenic body by announcing in her "Prologue" that the quaternions will not tell "of Wars, of Captaines, and of kings," taking in their place the content of "Great Bartas sugar'd lines. ${ }^{28}$ Bradstreet refers to the French author, Guillame de Saluste, Sieur du Bartas, who described the creation of Eden in $L a$ Semaine ou Création du monde (1578), a poem translated into English by Joshua Sylvester and published as The Divine Weeks and Works (1611); du Bartas' hexameral effort proved influential with several English authors thinking about Eden, most famously in Milton's Paradise Lost. Imagining the chaos preceding creation, Du Bartas describes the nascent world as "a most forme-lesse Forme, / A confus'd Heape, a Chaos most diforme, / A Gulph of Gulphes, a Body ill compact.” For Du Bartas, the jumbled elements of earth, air, fire and water, which "The Lord high-Marshall, unto each his quarter / Had not [yet] assigned," resemble a physical body requiring medical treatment. For Bradstreet, those same elements "looked like a Chaos, or new birth" needing the attention of a skilled midwife to deliver Eden and the perfectly temperate, "glorious" bodies of Adam and Eve. As Cotton, Bradstreet's minister, taught, bodies in Eden "could be maintained for ever" because God kept the elements and humors "in a sweet temper and harmony." For both du Bartas and Bradstreet, the process of creating paradise revolves around the proper balancing of the elements;

\footnotetext{
${ }^{28}$ Anne Bradstreet, "The Prologue" in The Complete Works of Anne Bradstreet, ed. Joseph R. McElrath, Jr. and Allan P. Robb, (Boston: Twayne Publishers, 1981), 6. On the citation of Bradstreet's poetry, see the Introduction, p. 26f.
} 
likewise, the creation of edenic bodies revolves around the proper balancing of the humors. ${ }^{29}$

Because the heat of fire and choler promised to purify the other elements and humors, these related forces were valued more than their counterparts, but seventeenth-century medical thought still preferred an evenly balanced body, one that included even apparently undesirable humors such as phlegm, over bodies dominated by a single, more desirable humor such as choler. Nonetheless, temperance might have seemed a lofty goal for Bradstreet. Galenic medicine identified women's bodies as disadvantageously phlegmatic, cold and moist, and geohumoral theory similarly identified the English race as unnaturally phlegmatic, a cold and moist people. This twofold stigmatization of Bradstreet's female, English body poses two enormous hurdles to Bradstreet's project of recovering an edenic body; Floyd-Wilson explains that "[o]n a local level, English gentlemen would work to distinguish themselves from women and the lower orders as more temperate and selfcontained, but on the world stage, they found themselves characterized as excessively pale,

\footnotetext{
${ }^{29}$ Guillaume de Saluste, seigneur Du Bartas, The Divine Weeks and Works of Guillaume de Saluste, Sieur Du Bartas, trans. Joshua Sylvester (New York: Oxford University Press, 1979), I.247-49, 262-63; Bradstreet, "The Foure Elements" and "Contemplations" in The Complete Works of Anne Bradstreet, 8, 169; Cotton, A Briefe Exposition with Practicall Observations upon the Whole Book of Ecclesiastes, 12. Speculation on the extent of Cotton's relationship with Bradstreet is widespread, but there is no doubt that they associated closely and that Bradstreet was familiar with Cotton's religious views. Heidi Nichols notes that during her time in England, Bradstreet lived with Theophilus, Earl of Lincoln, who "often entertained the famed John Cotton, vicar of St. Botolph's Church in Boston, Lincolnshire, who was later to join the settlers in the New World. The earl's chapel in particular became a place where Puritans [like Cotton] often preached." This has led some, including Charlotte Gordon and Amanda Porterfield, to speculate that Cotton might have been the minister who prepared her for the possibility of death during her sickness with the smallpox and who later married her. More importantly, she would also have had contact with Cotton in New England; as Elizabeth White notes, Bradstreet undoubtedly had access to Cotton's sermons at least aurally, if not in written form: "It is likely that Anne Bradstreet attended [Cotton's] lectures and sermons as often as she could. After the move to Ipswich in 1635 she would have been able to read his teachings in manuscript copies, as they must have been widely circulated in the colony before being published in London." Laurel Thatcher Ulrich points out that there is, of course, another tie that is both indisputable and far more intimate than the ones named; Cotton's son Seaborn and Bradstreet's daughter Dorothy were married, which means that John Cotton and Anne Bradstreet would have been grandparents to the same children and met frequently at family gatherings. See Heidi L. Nichols, Anne Bradstreet, (Philipsburg: P\&R Publishing, 2006), 23; Charlotte Gordon, Mistress Bradstreet, (New York: Little, Brown and Company, 2005), 50; Amanda Porterfield, Female Piety in Puritan New England, (New York: Oxford University Press, 1992), 107; Elizabeth White, Anne Bradstreet, (New York: Oxford University Press, 1971), 170-71; Laurel Thatcher Ulrich, Good Wives, (New York: Oxford University Press, 1983).
} 
moist, soft-fleshed, inconstant, and permeable. The English, in a geohumoral context, were defined by intemperance," and as a woman, Bradstreet was doubly so. The "Elements" and "Humors" offer a solution to this intemperance, accomplishing a "discursive rearrangement of the inherited [humoral] knowledge" which inverts traditional value structures and privileges the feminine English body as a vessel ideally situated to reclaim the perfect temperance of Eden. ${ }^{30}$

Bradstreet's contemporaries and the first feminist critics read Bradstreet's quaternions as derivative productions mimicking du Bartas, but more recent criticism has recognized the complex original thought informing these poems. In his "Introductory Verses" to the Tenth Muse Nathaniel Ward labels Bradstreet "a right Du Bartas Girle," a woman who for once has done "ought that's good." ${ }^{31}$ Adrienne Rich, who laudably worked to save Bradstreet's work from “the catalogues of Women's Archives," nevertheless complains that Bradstreet's voice in these poems "was in large measure that of a neophyte bluestocking for a man of wide intellectual attainments.” More recently, Jean Marie Lutes, Tamara Harvey and Carrie Galloway Blackstock each have drawn attention to the quaternions as "important but underestimated early work[s]." These critics, however, focus on "Elements" and "Humours" as a "challenge [to] the Aristotelian belief that women are cooler than men and therefore inferior." 32 I would suggest that modern constructions of Bradstreet's gender have unnecessarily limited critical responses to the two poems, obfuscating Bradstreet's

\footnotetext{
${ }^{30}$ Floyd-Wilson, English Ethnicity and Race in Early Modern Drama, 12, 13.

${ }^{31}$ Nathaniel Ward, "Mercury shew'd Apollo, Bartas Book," in Anne Bradstreet, The Complete Works of Anne Bradstreet, ed. Joseph R. McElrath, Jr. and Allan P. Robb, (Boston: Twayne Publishers, 1981), 526-27.

32 Rich, "Foreword," xii; Carrie Galloway Blackstock, “Anne Bradstreet and Performativity: Self-Cultivation, Self-Deployment," Early American Literature 32, no. 3 (1997): 222; Tamara Harvey, “"Now Sisters...Impart your Usefulness and Force': Anne Bradstreet's Feminist Functionalism in The Tenth Muse (1650)," Early American Literature 35, no. 1 (2000): 6-7.
} 
concomitant concerns with her identity as both a woman and an English citizen.

\section{Phlegmatic, Ergo Edenic, Physiologies}

Because the English race collectively acknowledged their own reputation as "uncivil, slow-witted, and more bodily determined than those people living in more temperate zones," Floyd-Wilson suggests that the English people as a whole felt the "desire to reassess and reconceptualize notions of regional influence and ethnological inheritance." Bradstreet acknowledges national discontent with physical, spiritual, and political English bodies in her poem, "A Dialogue Between Old England and New, Concerning Their Present Troubles," and privileges New England as the temperate example and source of relief to which England must look. ${ }^{33}$ Old England queries, "dost not feele / My weakned fainting body now to reele?" She begs New England, "For my relief, now use thy utmost skill, / And recompence me good, for all my ill." New England, for her part, promises to play the "nurse, I once your flesh, / Your sunken bowels gladly would refresh." ${ }^{34}$ But Bradstreet provides the corrective which she, as a New Englander, promises for the physical English body in "Humours," not in "Dialogue"; there, Bradstreet describes phlegm as the key to a temperate constitution, reversing the traditional humoral hierarchy and redefining the English body as a vessel ideally suited to the pursuit of edenic temperance.

As Floyd-Wilson notes, other English authors of the period had attempted to valorize the English race's phlegmatic constitution, but none proved successful. Writing in 1587, William Harrison suggested that "he whose nature inclineth generallie to phlegme, cannot but be courteous: which joined with strength of bodie, and sinceritie of behavior [...] the

\footnotetext{
${ }^{33}$ Floyd-Wilson, English Ethnicity and Race in Early Modern Drama, 5. For a discussion of New England's reputation as a temperate land, see Chapter 1, pp. 74-79.

${ }^{34}$ Bradstreet, "A Dialogue Between Old England and New, Concerning Their Present Troubles" in The Complete Works of Anne Bradstreet, 141, 146.
} 
Britons doo excell such as dwell in the hoter countries." Courtesy alone cannot compensate for the multiple failings of phlegmatic bodies, and Harrison's "attempt to invest phlegm—a traditionally weak and effeminate humor-with 'courtesy' and 'sinceritie' was only one of many failed tactics in the ongoing construction of Englishness. ${ }^{35}$ Bradstreet also attributes positive qualities to phlegm, but she ultimately acknowledges that phlegm's faults apparently outweigh its virtues. When Flegme defends herself to her sisters, the other humors, she takes pride in her demonstration of patience, waiting until each of the other four humors had laid claims to superiority, but admits that "wit I want." Flegme contends that because "The Brain's the noblest member" of the body and because the brain relies on phlegm for its operation, her contribution to the body's decision-making organ outweighs her lack of individual intelligence, but Bradstreet's valorization of phlegm, like Harrison's, falls flat. ${ }^{36}$ Patience is not enough to make the phlegmatic English constitution desirable.

Yet Bradstreet makes it clear that phlegm contributes more than patience to the body—phlegm also unifies the body's disparate parts. "Humours" is, throughout the first five hundred eighty-nine lines, a vicious, spiteful quarrel between sisters, each personified humor insulting the others and announcing her own superiority. Flegme's speech, the last, contains far less vitriol than any of the others, and she ends her rather muted and laughable claim to superiority with the following admonition:

Let's now be friends, 'tis time our spight was spent, Lest we too late, this rashnesse do repent, Such premises wil force a sad conclusion, Unlesse we 'gree all fals into confusion. Let Sanguine, Choler, with her hot hand hold, To take her moyst my moistnesse will be bold;

\footnotetext{
${ }^{35}$ As quoted in Floyd-Wilson, English Ethnicity and Race in Early Modern Drama, 13; Floyd-Wilson, English Ethnicity and Race in Early Modern Drama, 14.

${ }^{36}$ Bradstreet, "Of the Four Humours in Mans Constitution," in The Complete Works of Anne Bradstreet, 32, 33.
} 
My cold, cold Melanchollies hand shal clasp,

Her dry, dry Cholers other hand shal grasp;

Two hot, two moist, two cold, two dry here be,

A golden Ring, the Posey, Unity:

Nor jars nor scoffs, let none hereafter see,

But all admire our perfect amity;

Nor be discern'd, here's water, earth, aire, fire,

But here's a compact body, whole, entire:

This loving counsel pleas'd them all so wel,

That Flegme was judg'd, for kindnesse to excel. ${ }^{37}$

Only Flegme's "kindnesse," humility, and persuasive rhetoric allow the humors to overcome their differences and create a temperate, "compact body, whole entire." Bradstreet transforms the very effeminate and weak nature of the English body into its greatest strength, a malleability that engenders edenic unity and temperance. Flegme causes the warring elements and humors to come together and coexist peacefully in "A golden Ring" just as God "kept the wild beasts from preying upon the tame" in the golden age of Eden. Isaiah promises a millennial return to the tranquility of Eden when "[t]he wolf and the lamb shall feed together, and the lion shall eat straw like the bullock: and dust shall be the serpent's meat," but Bradstreet seizes the promise of paradise for herself and her contemporaries, identifying the phlegmatic, English body as the key to recapturing edenic temperance and peace in the present. $^{38}$

While pointing out the positive aspects of a phlegmatic constitution serves primarily to redeem the English body, it also significantly eases the stigma attached to female bodies known for an overabundance of phlegm. But Bradstreet goes further in her defense of the feminine body; most obviously, she identifies all of the humors as feminine. Choler explains that she and her "mother," Fire, were

${ }^{37}$ ibid, 34-35.

${ }^{38}$ Cotton, A Briefe Exposition with Practicall Observations upon the Whole Book of Ecclesiastes, 12; Isaiah 65:25. 
...both once Masculines, the world doth know,

Now Feminines (a while) for love we owe

Unto your Sister-hood, which makes us tender

Our noble selves, in a lesse noble Gender. ${ }^{39}$

As Lutes points out, "Caring for bodies in seventeenth-century New England was in many ways a female calling," and by altering the designated gender of masculine humors,

Bradstreet draws attention to women's roles in both caring for and generating bodies. The masculine Choler must swap sexes before he can act as "midwife to thy birth," since male doctors generally left the medical aspects of childbirth to women in seventeenth-century New England. ${ }^{40}$ More importantly, Bradstreet creates a dialectic opposition between choler and phlegm which highlights the problems of achieving temperance in choleric_-or masculinebodies.

Though Choler identifies herself as feminine, she continues to act with masculine aggression; Blackstock notes that "the assumption of female form by Fire and Choler does not carry with it or bring about values and behaviors associated with the 'feminine.",41 Flegme's speech directly addresses Choler's failure to speak and act in moderation, and she spends thirteen lines chastising Choler because "Thy judgment is unsafe, thy fancy little, / For memory, the sand is not more brittle." In stark contrast to this substantive critique (though still half as long as the twenty-eight line tirade which Choler delivers on Flegme's inadequacies), Flegme glosses over any potential faults of the authentically feminine Blood and Melancholy: "I passe by what sister Sanguine said; / To Melancholy i'le make no reply." ${ }^{42}$ Bradstreet highlights Choler's divisive nature by contrast in Flegme's unifying

\footnotetext{
${ }^{39}$ Bradstreet, "Of the Four Humours in Mans Constitution," 21.

40 ibid, 23; Jean Marie Lutes, "Negotiating Theology and Gynecology: Anne Bradstreet's Representations of the Female Body," Signs 22, no. 2 (1997): 310.

${ }^{41}$ Blackstock, “Anne Bradstreet and Performativity: Self-Cultivation, Self-Deployment,” 225.

${ }^{42}$ Bradstreet, "Of the Four Humours in Mans Constitution," 34.
} 
speech, implicitly subordinating masculine aggression to a feminine talent for forging

alliances. Harvey suggests that this subordination mirrored contemporary political thought in the Bay Colony, where leaders experimented with new forms of republican government:

“The masculine monarchy of Choler is replaced by a more republican system with no single leader but most nobly legislated by the cool Brain.” Even in politics, Bradstreet implies, sexual "opposition is diametrical," and only one gender can effectively restore temperance to physical and political bodies. ${ }^{43}$ Choler's division and Flegme's unification of the four humors suggests that Bradstreet places the responsibility and opportunity of regaining an edenic constitution squarely in the hands of women.

In justifying the claims of phlegmatic English men and women to the temperate bodies lost in Eden, Bradstreet provides the American "example of a woman writer practicing the philosophically rigorous and literarily intense engagement with physiological inwardness" that Schoenfeldt and Paster fail to find in seventeenth-century England. Though modern readers may not consider Bradstreet's poems the aesthetic equals of verse by Spenser, Shakespeare, Herbert, or Milton, her deliberations on and revisions of physiological identity demonstrate a complexity of thought which merits the comparison. Confronting a

\footnotetext{
${ }^{43}$ Harvey, “'Now Sisters...Impart your Usefulness and Force': Anne Bradstreet's Feminist Functionalism in The Tenth Muse (1650)," 23; Bradstreet, "Of the Four Humours in Mans Constitution," 32. Obviously, there is more to be said about the attempts to purify the body politic and regain the natural law that ruled in Eden, but other scholars indicate that themes discussed here apply to the political realm. In Authorizing Experience, Jim Egan carefully chronicles the seventeenth-century dissociation from the diseased monarchical body politic and the formation of a new, unified governmental structure devoid of tyrannous corruption. Matthew Holland's Bonds of Affection traces the continuing impact of Winthrop's ideas about charity (which, I argue in the balance of the essay, like Phlegm's kindness, forms the basis on which ecclesiastical temperance and unity is to be built) to giants of American political thought such as Jefferson and Lincoln and twentieth-century politicians like John Kennedy and Bill Clinton. Holland argues that the Christian charity propounded by Winthrop evolves in the eighteenth century into the civic charity of John Locke, who "launches modern pluralism and secular liberal democracy in the name of charity itself," and whose theories give rise to the Declaration of Independence (Matthew S. Holland, Bonds of Affection, [Washington D.C: Georgetown Unviersity Press, 2007], 10). The demonstrably transformative and unifying power of charity in the early American body politic suggests that the search for edenic, humorally perfectible, physical and ecclesiastical bodies which I outline here also applies to the political bodies of early New England, a topic I address at greater length in chapter 6 of this study.
} 
New England landscape that her contemporaries conceived of as an empty chaos, Bradstreet's surroundings offered her an opportunity to reinvent Eden and the temperate bodies it produced in a way no seventeenth-century Englishwomen living in the cultured countryside could have. Williams notes that for New England Puritans, the landscape was "a symbol of the uncreated order and a surrogate in the poetry of the prophet and psalmist for the primordial abyss at the beginning of creation," and Bradstreet's poems bring a new order to that chaos in the same way that God brought order to the warring elements when he created the world and the garden of Eden. ${ }^{44}$ That new order and Bradstreet's creative reconfiguration of the four elements and humors allowed her to appropriate an edenic body, producing, in the process, the first self-made woman in New England.

\section{$\underline{\text { Ministerial Medicine }}$}

The minister-physicians of New England did not share Bradstreet's belief in the temperate nature of the English body, largely because they were more concerned with the effects of sin on bodily temperance than with the consequences of a phlegmatic constitution. To be sure, these men used Galenic medicine, but they thought of it of as a temporary corrective and not a full restoration to the bodily condition that "man in his innocency enjoyed." In an exposition of Genesis, Samuel Willard explains that "Man's body in the Creation was a stately, comely, majestick thing" but that because of sin "his health is lost, and from the very conception he is distempered and unhealthy, and so liable to all diseases." ${ }^{45}$ Humoral medicine combated the Fall's effects on the human body, but even when a physician "hath made the best of [humoral remedies], the stay and staff in them is

\footnotetext{
${ }^{44}$ Schoenfeldt, Bodies and Selves in Early Modern England, 38; Williams, Wilderness and Paradise in Christian Thought, 14.

${ }^{45}$ Samuel Willard, A Compleat Body of Divinity, (Boston: B. Green and S. Kneeland, 1726), 224.
} 
greatly impaired," and medicine "to remedy the maladies which are often seezing" the human body is generally good only "that so a dying life may be a while shored up." Sinners "now in health and life as sound as any other ... may be fetch'd away, and turned out of the world before an hour," but this condition applies primarily "whiles they are unregenerate." For the elect, however, Willard suggests that the temperate constitutions of Adam and Eve were still attainable through medical modifications to the body because "those who are in a state of grace are exempted"—at least in part—from the bodily "miseries" of the "natural estate" inaugurated by the Fall. ${ }^{46}$

Minister-physicians began their diagnoses by determining whether the underlying cause of a particular illness was physical or spiritual. Thomas Palmer, a Massachusetts minister and physician, always commenced the practice of medicine by deciding '... whether it [the illness] be a humoral Distemper \& what Humours are most afflictive, $\&$ what parts of the body are most distempered, \& where the seat of the disease lyes.' He then chose from an arsenal of remedies he had collected, of which 'there be sundry kinds. Some work chiefly by Vomit [emetics], some cheifly do work downward [purgatives], some work both ways; some are Violent and dangerous. ... Others are ... safe. ... Some purge Phlegm, some choler [yellow bile], some Melancholy [black bile], some most humours, \& some all humours. ${ }^{, 47}$

These remedies, or simples, were typically concocted of herbs and were applied both internally and externally. The attending physician could also order a patient bled, and while Watson reminds us that "it is impossible to determine the frequency with which clerics bled their patients, colonial diaries and letters indicate that the ministry performed venesection with a fair degree of regularity." Herbal remedies and bloodletting restored the subject to health and humoral temperance frequently enough that colonists maintained their faith in

\footnotetext{
${ }^{46}$ ibid, 225-26.

${ }^{47}$ Watson, The Angelical Conjunction, 79-80.
} 
Galenic medicine, but on many other occasions they proved either fatal or ineffective. ${ }^{48}$

When Galen failed, minister-physicians urged their patients to entreat God more insistently, to pray and fast until their health had been restored. Especially for those diseases "which in Men go under the Name of Splenitic, and in Women go under the Name of Hysteric," the root of the problem was understood by minister-physicians like Cotton Mather to be mental or spiritual. Such illnesses could still be diagnosed humorally, because the subject's "Urine is Clear, Limpid, and Copious," but "these Diseases are not [treated] mainly in the Humours; inasmuch as Evacuations do not releeve, but fearfully Produce and Increase the Diseases." Instead of humoral remedies, Mather recommends

Serious PIETY. Many Remedies have done Virtuously, (and had their Virtues) but thou Excellest them all. ... Lett this be Remembred: Moderate Abstinence, \& Convenient Exercise; and Some Guard against injurious Changes of the Weather, with an HOLY and EASY MIND, will go as far, in carrying us with undecay'd garments thro' the Wilderness, to the Promis'd and Pleasant Land, which we are bound unto, as all the Praescriptions with which all the Physicians under Heaven, have ever yett obliged us. ${ }^{49}$

Mather acknowledges the need to regulate the effect of outside influences-sex, ${ }^{50}$ exercise, weather, etc. - on the humoral body, but he considers these medicinal remedies secondary to upright living and the maintenance of morality. Only when humoral regulation is combined

\footnotetext{
${ }^{48} \mathrm{ibid}, 84$. On at least one occasion Palmer acknowledged that his bloodletting had killed a patient.

${ }^{49}$ Cotton Mather, The Angel of Bethesda, ed. Gordon W. Jones, (Barre: American Antiquarian Society and Barre Publishers, 1972), 36-38. These quotations are from the fifth chapter of Mather's medical magnum opus, the only portion of the work that was published in his lifetime, by Timothy Green of New Haven in 1722; the remainder was preserved in manuscript form until its publication two hundred and fifty years later.

${ }^{50}$ Moderating sexual activity was a key component of humoral regulation, because the ejaculation of sperm was understood to unbalance a man humorally and weaken him. Sex is not incompatible with temperance or with Eden; most early modern theologians assumed that Adam and Eve would have had children if they had not remained in the garden of Eden, and Milton, among others, depicts sex as an integral—and innocent—part of the prelapsarian experience. For more on Puritan attitudes toward intercourse itself (as opposed to what they conceived of as inherently immoral acts of intercourse, such as adultery and sodomy) see Richard Godbeer, Sexual Revolution in Early America, (Baltimore: Johns Hopkins University Press, 2002); The Puritan Origins of American Sex, eds. Tracy Fessenden, Nicholas F. Radel, and Magdalena J. Zaborowska, (New York: Routledge, 2001); and Edward Morgan, "The Puritans and Sex," The New England Quarterly 15.4 (1942): 591-607.
} 
with practical piety can the elect enjoy bodies that—like the Israelites' garments in Canaan or the bodies of Adam and Eve in Eden—are not subject to the decay and degeneration brought on by the Fall. As a physician, Mather is aware that death and disease are physiologically inevitable, but his theological aspiration to the prelapsarian purity of "the Promis' $d$ and Pleasant Land, which we are bound unto" coerce his imagination into a vision of an edenicbecause "undecay' $d$ "— body.

\section{Diabolical Distempers}

Most diseases in colonial New England were diagnosed and treated as humoral imbalances—even those "episodes of widespread sickness" that ministers interpreted "as evidence of God's mounting displeasure with his covenanted people. ${ }^{, 51}$ But when the illness of a given individual proved resistant to humoral remedies, it was occasionally seen as evidence of something more sinister than God's punishment for relatively minor transgressions. Men and women—mostly women—occasionally attributed their physiological ailments to the curses of witches or to demonic possession, and while the symptoms of these diseases responded to humoral treatments, their eradication was only possible through periods of intense spiritual cleansing.

Elizabeth Knapp, the servant of minister Samuel Willard, had experienced bouts of

illness and hallucinations for a week in late 1671 before she was seen by a physician

who judged a maine pt of her distempr to be naturall, arising from the foulnesse of her stomacke, \& corruptnesse of her blood, occasioning fumes in her braine, \& strange fansyes; whereupon (in order to further tryall $\&$ administration) shee was removed home, \& the succeeding weeke shee tooke physicke, \& was not in such violence handled in her fits as before; but enjoyed an intermission, \& gave some hopes of recovery.

The remedies provided by the physician relieved Knapp's symptoms, but they failed to cure

${ }^{51}$ Watson, The Angelical Conjunction, 17. 
her because the root cause of her illness was not a humoral imbalance but something much worse. Though she “exp'ssed hopes that ye Devill had left her, but yr was little ground to thinke soe" because the physician's humoral remedies had done nothing to address the root problem. ${ }^{52}$ When he came back, the physician altered his original diagnosis and "consented that ye distemper was Diabolicall, refused further to administer, advised to extraordinary fasting; whereupon some of Gods ministers were sent for." These ministers united in prayer, and by their collective spiritual exertions over a period of several months, Knapp was finally restored to good health and enabled to resume a normal life. ${ }^{53}$

For the objects of demonic possession and witchcraft—overwhelmingly female and consistently subjected to the examinations and judgments of male minister-physicians - there was little or no hope of obtaining the edenic body that Mather promised to those who practiced "Serious PIETY." Bradstreet's ability to restructure humoral hierarchies and valorize the phlegmatic female body as an ideal vehicle for the reclamation of edenic purity was an exception to this rule, yet the men who cajoled and condemned possessed girls such as Knapp were still able to read their distinctly un-edenic bodies as portents of an impending millennium that would restore paradisiacal conditions on the earth. Mather taught that in the coming millennium

the Raised Saints will there have a New Heaven, which, We expect according to the Promise of God. Now, a little before this thing, you'l be like to see the Devil, more sensibly and visibly Busy upon Earth perhaps, than ever he was before: You shall oftner hear about Apparitions of the Devil, and about poor people strangely Bewitched, Possessed and Obsessed, by Infernal Fiends. When our Lord is going to set up His Kingdom, in the most sensible and visible manner that ever was, and in a manner answering the Transfiguration in the Mount, it is a thousand to one, but the

\footnotetext{
52 Samuel Willard, A Briefe Account of a Strange \& Unusuall Providence of God, ed. Samuel A. Green, in Samuel A. Green, Groton in the Witchcraft Times, (Groton: University Press, 1883), 10.

${ }^{53}$ ibid, 11. On the recovery and subsequent life of Knapp, see David D. Hall ed., Puritans in the New World, (Princeton: Princeton University Press, 2004), 141.
} 
Devil will in sundry parts of the World, assay the like for Himself, with a most Aspish Imitation.

The demonic possession of Elizabeth Knapp and the experiences of other girls beset by Satanic influences were harbingers of Jesus Christ's Second Coming to Mather, and he promises that Christ's advent will transform New England. He speculates that "if we are not a Thousand Years yet short of that Golden Age, there is cause to think, that we are not an Hundred" and that the approach of this edenic restoration is cause for repentance and rejoicing, "particularly for His New-English Israel!" New England both possessed the potential for edenic temperance and, in their devilish distempers, signaled the inevitable storm before a fast approaching edenic millennium.

\section{Embarrassed By Sin: Humoral Correctives for Ecclesiastical Intemperance}

New England ministers cared for the individual bodies and souls of their congregants, but they were also charged with the well-being of the congregation as a whole, and they frequently described their congregations as ecclesiastical bodies, using the same anatomical and humoral terms that Bradstreet and Willard used to describe the physical body. Indeed, Cotton's description of a newly formed congregation bears a striking resemblance to Bradstreet's portrayal of the humors after Flegme has unified them; the newly formed assembly "professe their full purpose of heart, to cleave one to another in Brotherly love"in counterpoint to the sisterly love of Bradstreet's humors_- "and mutuall subjection ... till they all grow up to a perfect man in Christ Jesus." This perfection was corporate, not individual, since the church was "one Spouse unto Christ," and ministers derived this conception of the ecclesiastical body from Paul's representation of the church as "the body of

\footnotetext{
${ }^{54}$ Cotton Mather, The Wonders of the Invisible World, (Boston: Benj. Harris, 1692), 28, 36.
} 
Christ," where "by one Spirit are we all baptized into one body." ${ }^{55}$ Though spiritual leaders like Cotton and civic leaders like Winthrop understood that the ecclesiastical body possessed no corporeal materiality, they still conceived of congregational weaknesses and distempers in terms of humoral theory and contemporary Galenic medicine. As Giles Firmin, a Boston physician and clergyman, explains, “[c]ongregations must be mended by degrees: to purge per vices in foule bodies, is better then at first to give Hellebore, Scammony, and such strong workers; it will cost abundance of prayer, wisdome, labour, meeknesse, to bring these Congregations fallen" into the distempers of sin back to a state of ecclesiastical temperance. ${ }^{56}$ Schoenfeldt's work demonstrates "the empowerment that Galenic physiology and ethics bestowed upon the individual" in early modern England; I wish to emphasize that by appropriating these theories of somatic self-regulation and applying them to an imagined ecclesiastical body, the Puritan ministers of New England created a means by which their congregations could collectively reclaim Eden's temperance. The human body provided the leaders of Puritan New England a model in which self-regulation successfully produced ecclesiastical purification, and those leaders, like Bradstreet, pointed to kindness, or charity, as the key to achieving the physiological purity of Eden. ${ }^{57}$

\footnotetext{
${ }^{55}$ John Cotton, The Way of the Churches of Christ in New-England. Or, the Way of Churches walking in Brotherly Equality, or Coordination, without Subjection of One Church to Another, (London: Matthew Simmons, 1645), 4, 8; I Cor. 12:27, 13. As the extended title suggests, Cotton's entire treatise is concerned with the promotion of harmony among warring members of a single ecclesiastical body—just as Bradstreet's "Humours" is entirely concerned with the resolution of differences between the four components of the human body.

${ }^{56}$ Giles Firmin, Separation Examined, (London: R. I., 1652), 45.

${ }^{57}$ That New England's leaders identify charity as the key to achieving both an edenic purity and unity is ironic on two levels. First, as Reid Barbour points out, "Charity makes us conformable but somehow also equal, one communal person; yet inequality of persons is natural, even integral to charitable works." (147). Second, in seventeenth-century England, "the more zealous sort of English Protestant" interpreted an "emphasis on charity, harmony, and peace as code for crypto-popery and persecution": exactly those qualities that those who settled in New England for religious reasons moved in order to avoid. See Reid Barbour, Literature and Religious Culture in Seventeenth-Century England, (New York: Cambridge University Press, 2002), 147, 192.
} 
While thinking about the ecclesiastical body in physical terms made purification possible, it also posed a problem for non-Separatist emigrants from England. The original settlers of Plymouth who landed in Massachusetts Bay in 1620 did not emigrate from England; they had rejected the Church of England as corrupt earlier and left in 1609 for Amsterdam and Leiden, eleven years before they departed from Denmark for the New World. The founders of the Bay Colony, on the other hand, did not wholly condemn and desert the Church of England, and they conceived of their physical remove from that group as a temporary period of separation after which they would return to England with a pattern of purity that could be used to reform and restore the Anglican church.

But withdrawing to another continent brought charges of schism. William Ames, a Puritan divine who contemplated removal to New England but never actually went, noted the problems of schism and separation for settlers in the Bay Colony in 1630, immediately after the first settlers had left: "It is against the honour of Christ, in regard that after its manner, it destroyeth the Vnitie of Christs Mysticall body." The only applicable justification for breaking up the ecclesiastical body, Ames suggests, is "if a man cannot continue his communion without a communication of their sinnes." With this in mind, Cotton instructed emigrants that they did well to leave England before the sins of those who supported the English episcopacy could contaminate them, just as "a wise man forseeth the plague" coming and flees before it. Only the threat of bodily infection justified the division of the ecclesiastical body, and the Puritan remove to New England_-"a most excellent place, both for health and fertility" - naturally addressed fears of spiritual infection couched in physical terms. Immigrants to the Bay Colony, conscious that the ecclesiastical body had been embarrassed by sin just as Adam and Eve's physical bodies were embarrassed by 
physiological intemperance after the Fall, naturally turned from their metaphorical position "at the east of the garden of Eden" and looked westward for a return to purity. ${ }^{58}$

Though religious leaders felt a need to distance the nascent and vulnerable Puritan ecclesiastical body from the contaminated and contagious church of England, seventeenthcentury advice manuals warned against emigration because travel inevitably amplified the problems in a cold, phlegmatic English constitution. Floyd-Wilson explains that because English bodies were weak and effeminate, travel only “exacerbated the English people's imperfections." For travelers who recognized that they "were exceedingly impressionable" and had already begun the process of self-fashioning, however, emigration to a climate "as temperate and as fruitfull as any other parallel in the world" represented an opportunity at humoral "salvation" because travel also amplified positive somatic inclinations. Indeed, when preacher Thomas Weld wrote back to the congregations he left behind in England that "[t]he place well agreeth with our English bodies that they were never so healthy in their native country," he speaks both of physical bodies that no longer suffer from the "toothache cough and the like" as well as an ecclesiastical body freed from "oaths, swearers [and] railers." Though travel in general was perilous, Weld promised that travel to New England would produce salutary effects in physical and ecclesiastical bodies alike. ${ }^{59}$

\section{$\underline{\text { A Model of Edenic Temperance }}$}

The humoral anxieties inextricably linked to travel help to explain Winthrop's

\footnotetext{
${ }^{58}$ William Ames, Conscience with the Power and Cases Thereof (London: Edw Griffin, 1643), 140-141; John Cotton, God's Promise to His Plantations (London: William Jones, 1630), 10; John Smith, "A Description of New England," in Captain John Smith: Writings with Other Narratives of Roanoke, Jamestown, and the First English Settlement of America, ed. James Horn, (New York: Library of America, 2007), 139; Genesis 3:24.

${ }^{59}$ Floyd-Wilson, English Ethnicity and Race in Early Modern Drama, 8, 16; John Smith, "A Description of New England," 141; Floyd-Wilson, English Ethnicity and Race in Early Modern Drama, 16; Thomas Weld, "To His Former Parishioners at Terling," in Puritans in the New World, ed. David D. Hall (Princeton, NJ: Princeton University Press, 2004), 34-35.
} 
exhortations to his fellow emigrants in A Modell of Christian Charity. Before embarking for the New World, Winthrop belabored their collective need for increased charity, a quality Cotton calls one of the "gracious affections, that are not to be found in nature" and a "love which was as heat and fire to thaw and warme, cold and hard hearts," in their cold, phlegmatic, English bodies. ${ }^{60}$ Cotton, Winthrop, and other early modern men and women versed in basic humoral theory would have known that all humoral "Diseases are cured by their contraries, but all parts of the Body maintained by their likes. Then if the heat be the cause of the disease, give cold Medicine appropriated to it," and if cold hearts afflicted the English immigrants, then the warming and medicinal power of charity was needed. ${ }^{61}$ An earlier sermon delivered in Plymouth by Robert Cushman characterized the exercise of charity in precisely those terms; he stated that preachers who urge men "not to seeke their owne, but euerie man anothers wealth" prescribe a "Physicke ... as terrible to carnall professors, as abstinence from drink is to a man that hath the dropsie: and it is a sure note, that a man is sicke of this disease of selfe-loue, if this be grieuous to him ... yet surely this veine must bee pricked, and this humor let out, els it will spoyle all, it will infect both soule and body. ${ }^{, 62}$ By prescribing charity to their fellow colonists, Cushman and Winthrop conflate the physical and ecclesiastical bodies. Charity served to warm the ecclesiastical body, but it was the physical bodies of English colonists that needed warming, and their sermons reveal

\footnotetext{
${ }^{60}$ John Cotton, Christ the fountaine of life, or, Sundry choice sermons on part of the fifth chapter of the first Epistle of St. John (London: Robert Ibbitson, 1651), 119, 121.A cover note found on the earliest copy of this sermon indicates that Winthrop wrote and delivered the address during his voyage over the Atlantic while on board the Arbella, but Hugh Dawson provides convincing evidence that Winthrop delivered his sermon before departing for the New World. See Hugh J. Dawson, "John Winthrop's Rite of Passage: The Origins of the 'Christian Charitie' Discourse," Early American Literature 26, no. 3 (1991): 219-31. The timing matters in this instance, because the colonists needed to begin the process of self-regulation before the amplifying influence of travel affected their bodies.

${ }^{61}$ Nicholas Culpepper, as quoted in Watson, The Angelical Conjunction, 80.

${ }^{62}$ Robert Cushman, A Sermon Preached at Plimmoth, (London: I. D., 1622), 2.
} 
the extent to which political and ecclesiastical leaders leaving for the new world conceived of their congregations in somatic terms, bodies which could be perfected and made temperate through disciplined consumption and strategic relocation to idealized climates.

Winthrop demonstrates the interdependency of the ecclesiastical body's respective parts in explicitly corporeal terms. To those who argue that "it is not possible that love should be bred" in the ecclesiastical body, Winthrop responds that

in regard of the pleasure and content that the exercise of loue carries with it, as wee may see in the naturall body the mouth is at all the paines to receiue, and mince the foode which serues for the nourishment of all the other partes of the body, yet it hath noe cause to complaine; for first the other partes send backe by secret passages a due proporcion of the same nourishment, in a better forme for the strengthening and comforteing the mouthe. ${ }^{63}$

Winthrop suggests that just as the physical body achieves humoral temperance through the cooperation of discrete bodily units that aid one another, the ecclesiastical body likewise achieves a spiritual temperance through the exercise of charity. Charity produces benefits for both the giver and the receiver in the same way that chewing food benefits both the mouth and the stomach, even though nourishment seems to flow in only one direction.

Winthrop begins his sermon by extolling "the variety and difference of the Creatures," explaining that "some must be rich some poore, some highe and eminent in power and dignitie; others meane and in subieccion" so that God might exercise "his graces in them, as in the greate ones, theire loue mercy, gentlenes, temperance etc., in the poore and inferiour sorte, theire faithe patience, obedience etc." Winthrop then instructs his listeners to give to the poor because the physical act of giving will stimulate an increase in charity, just as contemporary physicians recommended choleric red meat to patients who need an increase

\footnotetext{
${ }^{63}$ John Winthrop, "A Modell of Christian Charity," in Winthrop Papers, Vol. 2, ed. Stewart Mitchell (Boston: Massachusetts Historical Society, 1931), 291-92.
} 
of choler. For Winthrop, as for Bradstreet, the ultimate goal is temperance, and the means to temperance is charity, or kindness. The prosperous must care for and embrace the economically challenged just as Choler must embrace Flegme, because neither Choler nor the prosperous can be perfected on their own, despite their apparent superiority; only through charity can the physiological and ecclesiastical bodies recover edenic temperance. Winthrop writes that "the severall partes of this body, considered aparte before they were vnited, were as disproportionate and as much disordering as soe many contrary quallities or elements" in the chaos that preceded Eden's creation, but charity makes it possible for people- the diverse elements of the ecclesiastical body_to bond together just as Bradstreet's Flegme makes it possible for the warring elements and humors to achieve a harmonious unity. ${ }^{64}$

Winthrop points both backwards, to Adam and Eve in Eden, and forwards, to the promise of Christ's millennial reign over the church, which will be like a new Adam made perfect, as models of ecclesiastical temperance, conflating the millennial and paradisiacal hopes of the Bay Colony. Winthrop locates, explicates, and systematizes a pattern-a "Modell"- in the Garden of Eden that church members can use to guide their collective quest for temperance: "Adam in his first estate was a perfect modell of mankinde in all theire generacions, and in him this loue was perfected in regard of the habit, but Adam Rent in himselfe from his Creator, rent all his posterity allsoe one from another.” The Fall notwithstanding, Winthrop promises his listeners that the perfect, tempering love which Adam possessed in Eden can be regained, that "this loue is the fruit of the new birthe." For church members who experience this saving grace, "it workes like the Spirit vpon the drie bones Ezek. 37. [7] bone came to bone, it gathers together the scattered bones or perfect old

\footnotetext{
${ }^{64}$ ibid, 282-83, 288.
} 
man Adam and knits them into one body againe in Christ." ${ }^{, 65}$ Though Winthrop here associates the acquisition of perfect, edenic love with God's irresistible grace and the unconditional process of election, he nonetheless provides several suggestions as to how church members might exercise their agency in pursuit of that love.

Winthrop points to marriage as an institution in which husbands and wives can develop the perfect love that Adam and Eve enjoyed in Eden. He begins by likening the marriage of Adam and Eve to the purification and unification of the ecclesiastical body: "Thus it is between the members of Christ, each discernes by the worke of the spirit his owne Image and resemblance in another, and therefore cannot but loue him as he loues himselfe: [...] it is like Adam when Eue was brought to him, shee must haue it one with herselfe this is fleshe of my fleshe (saith shee) and bone of my bone." This seemingly natural, narcissistic love requires work to obtain; it must "be bred" into church members, and they "must liue in the exercise of it, if wee would haue comfort of our being in Christ." While Winthrop points to Adam and Eve's union as a pattern for all his listeners, he also suggests that the type of love they exemplify may arise more naturally in married couples because, "In the State of Wedlock there be many comfortes to beare out the troubles of that Condicion; but let such as haue tryed the most, say if there be any sweetnes in that Condicion comparable to the exercise of mutual loue." ${ }^{66}$ To Winthrop love is an exercise, something tried and practiced, not a vague endowment bestowed only on the regenerate who recognize themselves as God's elect.

Though Winthrop's sermon provides the most famous instance in which a preacher advocated the reclamation of edenic temperance in the ecclesiastical body, others shared his

\footnotetext{
${ }^{65}$ ibid, 290.

${ }^{66}$ ibid, 290-92.
} 
interest. Thomas Hooker, who famously left the Bay Colony to establish a settlement in Connecticut, did so at least in part because he and Winthrop disagreed about matters of ecclesiastical government, but he also emphasized the need for perfect, edenic love to his congregation. Hooker told congregants that if "mercy should put a man into the same estate that Adam was" while in Eden, then Christ's grace would not allow "my corruptions [to] beare sway in me," but he, like Winthrop, provided his parishioners with a plan of action for acquiring Christ's grace and mercy. For Hooker, the human heart is like "a knife, if it be rubbed on a Loadstone, it will draw iron unto it; [...] the love of God is like the loadstone, and if the heart be rubbed thereupon and affected with the sweetnesse thereof, it will be able to close with that mercy and come to that mercy and go to God from whence that mercy comes." In Hooker's simile, individuals seeking that perfect love which will restore them to Adam's estate need only draw close to God by changing the "behaviour of the soul," and "as the soul closeth with that mercy and welcommeth it, and the heart is content to take up mercy upon those termes $[\ldots]$ the heart retaineth and hath wrought upon it by this grace and free favour of God made knowne" (my emphases). ${ }^{67}$ By emphasizing the aspects of Hooker's sermon that elevate individual agency, I do not mean to suggest that either he or Winthrop rejected the Calvinist doctrines of irresistible grace and unconditional election, only to demonstrate that they wanted so badly to believe in the possibility of recapturing Adam's prelapsarian perfections that they occasionally persuaded themselves and their listeners to adopt positions not completely aligned with the Calvinist emphasis on predestination. To congregations that cultivate charity, Cotton, Hooker, and Winthrop promised a pathway to an edenic plantation in the wilderness, a haven where the ecclesiastical body could achieve

\footnotetext{
${ }^{67}$ Thomas Hooker, The Danger of Desertion (London: G.M., 1641), 42, 46-48.
} 
temperance away from the spiritual diseases of Old England.

\section{$\underline{\text { Regulating Consumption and Communion }}$}

As David Hall has noted, this pursuit of ecclesiastical purity led most of the settlers in the Bay Colony to regulate their physical consumption on fast days, an empowering conflation of the physical and ecclesiastical bodies that explicitly connects Schoenfeldt's theories of consumption to ecclesiastical practice in New England. In 1630, when the newly arrived settlers gathered in Charlestown to agree on standards for church membership, they came fasting until "the hundreds who participated in the fast had dwindled to no more than thirty or forty who entered into covenant." These fasts continued regularly after the organization of individual congregations, allowing church members "to cleanse the self or the body social and renew covenantal obligations"; church members reported physiological benefits after fasting as well as an increased sense of unity. Hall links the union achieved through fasting thematically back to Eden, suggesting an implicit connection left unstated in fast-day sermons: "Fast days carried people out of ordinary time—or out of time's decay— back to that moment when all things were 'new,' when time was everlasting, when the ideal coincided with reality" in Eden. ${ }^{68}$ The spiritual highs of fast days allowed participants to imagine themselves in the positions of Adam and Eve, and by voluntarily depriving themselves of food in order to achieve the transcendent spiritual union their first parents had enjoyed in Eden, colonists made the ecclesiastical body subject to material forces and humoral discipline.

The physical connections between ecclesiastical and physiological bodies also manifested themselves in the Halfway Covenant that emerged from the Cambridge Synod of

\footnotetext{
${ }^{68}$ Hall, Worlds of Wonder, Days of Judgment, (New York: Knopf, 1989), 148, 167, 171.
} 
1662. The Halfway Covenant stipulates that the children of men and women who were baptized — but who had never related a conversion experience or received formal admission to church membership_-also have the right to be baptized. But conferring this right to baptism on the children of individuals who have not publicly related a conversion experience implicitly acknowledges a connection between the physical bodies of individual members and the ecclesiastical body, a connection that Increase Mather made explicit in his defense of the Halfway Covenant. Mather famously argued that "the vein of Election doth run through the loyns of godly Parents for the most part. Though it be not wholly, and only so, that Elect Parents have none but elect Children, or that elect Children are alwayes born of elect Parents yet God hath seen meet to cast the line of Election so, as that generally elect Children are cast upon elect Parents." ${ }^{69}$ For Mather, election to the ecclesiastical body makes an impact on the physical bodies of men and women which is hereditary and can be passed down to their posterity, who would then enjoy an inside track in the pursuit of purity, perfection, and Eden. In the words of Solomon Stoddard, "the Children are Ecclesiastically holy because one at least of their Parents are visible Believers."70 Just as the physical body was a model for the ecclesiastical body, so too an individual's position within the ecclesiastical body became an indication of the purity of his or her physical body.

But in the late-seventeenth century, progressive ministers like Stoddard began questioning even the new, relatively lax standards for admission to church sacraments defended by the Mathers. ${ }^{71}$ Stoddard argued that the practice of administering communion

\footnotetext{
${ }^{69}$ Increase Mather, A Call from Heaven to the Present and Succeeding Generations, (Boston: John Foster, 1679), 5 .

${ }^{70}$ Solomon Stoddard, An Appeal to the Learned, (Boston: B. Green, 1709), 90.

${ }^{71}$ For an overview of the communion controversy, see Philip Gura, The Crossroads of American History and Literature, (University Park: Pennsylvania State University press, 1996). Gura provides a longitudinal survey of Northampton's attitudes toward the Halfway Covenant in chapter two, tracing the ministerial continuities and
} 
only to those members of the church who had already given an account of their conversion contradicted the charitable principles preached by Cotton, Winthrop, Shepard and the other founding ministers of New England. He asked, "How can we deny Membership to those who are to Charity members of Christs Mysticall Body. Those who seem to Charity to be of Christs Invisible Church, are indeed of the visible" and ought to receive communion. Stoddard's charity extended to all "Adult Persons as are worthy to be admitted into the Church, or being in the Church are worthy to be continued without censure," and he proposed that such individuals "be admitted to the Lords Supper" without first having to relate a conversion experience. ${ }^{72}$ Stoddard justified this expansion of communion recipients by explaining that "the Lords Supper now is appointed for Conversion" of such individuals, "for the begetting of Grace as Well as for the Strengthening of Grace." The unconverted who acted piously were not to be kept back from communion as though it were "forbidden fruit" but encouraged to come and take the bread and wine. ${ }^{73}$ In Stoddard's view a minister's role was not that of the cherubim who, with a flaming sword, turned Adam and Eve away from the tree of life — the analogical antipode for forbidden fruit—but that of an exhorter who encouraged visible saints who have not recognized God's grace in their lives to come forth and do so. Stoddard's minister had to welcome back into Eden those with godly demeanors and hope that this act would render them fit to stay there.

For men and women who are visible saints, Stoddard believes that the act of taking

disjunctions between Stoddard and Eleazar Mather, his predecessor in Northampton. In chapter four, Gura deals with the relationship between Stoddard, Taylor and Increase Mather in more depth.

72 Solomon Stoddard, “Arguments for the Proposition," in Edward Taylor vs. Solomon Stoddard: The Nature of the Lord's Supper, eds. Thomas M. \& Virginia L. Davis, (Boston: Twayne Publishers, 1981), 73; Solomon Stoddard, The Doctrine of Instituted Churches, (London: 1700), 20.

73 Solomon Stoddard, "Stoddard's Sermon on Galatians 3.1," in Edward Taylor vs. Solomon Stoddard: The Nature of the Lord's Supper, eds. Thomas M. \& Virginia L. Davis, (Boston: Twayne Publishers, 1981), 131; Stoddard, An Appeal to the Learned, 
communion will do

a great deale to draw you to Christ; if you wanted awakening $\&$ had not a due sence of the wrath of God against sin, you might have bin terrified by this ordinance; here is represented unto you how terribly God dealt with his owne Son when sin was imputed to him, here you might have seen what was done to the green tree $\&$ gathered from thence what is like to be done to the dry, in this ordinance hath bin held forth before you the impartiall justice \& vengeance of God for sin.

Stoddard viewed the taking of communion as a sharp reproof to the unconverted, and he explained that "[s]harp reproofs are like tart medicins not very acceptable, but very wholsom. They are profitable to mens [spiritual] necessities, but not to their [physical] Humours."74 For Stoddard, the taking of communion by unconverted souls acts as a spiritual remedy for the distempers of the soul in the same way that bitter medicines-especially emetics-correct the humoral imbalances of the physical body; neither is enjoyable, but both are necessary for the reclamation of temperance. Additionally, Stoddard posits that salvation, or the acquisition of spiritual temperance, is made possible only through humoral discipline: "Gods blessing is to be expected in Gods way: if men act according to their own humours \& phansies, and don't keep in a way of Obedience, it is presumption to expect Gods blessing" when they take communion. $^{75}$

Even as they argued with him, Stoddard's opponents and conservative administrators of communion-most notably Increase Mather and Edward Taylor-described the bread and the wine of communion in similarly humoral terms. Taylor contends that " $[\mathrm{w}] \mathrm{here}$ there is no life"-among the unconverted, who are spiritually dead- "there is no provision of Food: to sett food to such as are dead, is paganish, who sett a mess of Beans, etc., in the Grave with

\footnotetext{
${ }^{74}$ Stoddard, "Stoddard's Sermon on Galatians 3.1," 141, 129.

${ }^{75}$ Stoddard, An Appeal to the Learned, 27-28.
} 
their dead." ${ }^{, 76}$ The physical emblems of Christ's death, the bread and the wine, are restorative only for the regenerate, because the spiritual purity that they inculcate is predicated on processes of digestion that only occur in living_converted—bodies.

While Taylor had no faith that communion could convert, he did have hope that the already converted "Catechumeni of the Church" who "eate the Flesh, \& drinke the Blood of the Son of man" will, through that ordinance, "in time be made fruitful Trees, \& be planted in the Paradise of God, i.e., the Church."77 This hope in a transformation from ecclesiastical piety to edenic purity was rooted in a humoral understanding of the sacrament best expressed in Taylor's Preparatory Meditations:

What? Bread, and Wine, My Lord! Art thou thus made?

And made thus unto thine in th' sacrament?

These are both Coridall: and both displai'd.

Food for the Living. Spirituall Nourishment.

Thou hence art food, and Physick rightly 'pli'de

To Living Souls. Such none for dead provide.

Stir up thy Appetite, my Soule, afresh,

Here's Bread, and Wine as Signs, to signify

The richest Dainties Cookery can Dress

Thy Table with, filld with felicity.

Purge out and Vomit by Repentance all

Ill Humours which thy Spirituall Tast Forestall. (1-12)

Like Stoddard, Taylor viewed the Lord's Supper as an emetic that restored spiritual temperance by purging the ecclesiastical body of undesirable humors in its members; unlike Stoddard, Taylor restricted access to this "Physick" to converted, "Living Souls." The communion administered by Taylor is a medicinal remedy whereby the converted "eate

\footnotetext{
${ }^{76}$ Edward Taylor, "Taylor's 'Animadversions,"” in Edward Taylor vs. Solomon Stoddard: The Nature of the Lord's Supper, eds. Thomas M. \& Virginia L. Davis, (Boston: Twayne Publishers, 1981), 93.

${ }^{77}$ Taylor, “Taylor's 'Animadversions,"” 107.

${ }^{78}$ Edward Taylor, "104," in Preparatory Meditations, Second Series, in Edward Taylor's God's Determinations and Preparatory Meditations, ed. Daniel Patterson, (Kent: The Kent State University Press, 2003), 396-97; hereafter (II.104.1-12).
} 
indeed / Fruites of the tree of Life" so that they "shall in a better temper bee" (I.37.27-28, 42). For Taylor and Stoddard both, the Lord's Supper was a metaphorical representation of the tree of life found in Eden whose consumption restored edenic temperance to participants; the chief point over which the two differed was whether that temperance was best regained by expanding or restricting access to communion.

Even after the deaths of Taylor and Stoddard, questions as to the propriety of allowing unconverted congregants to take the Lord's Supper lingered, and Jonathan Edwards eventually sacrificed his Northampton pulpit in an effort to retain control over the consumption of communion and to discipline the ecclesiastical body over which he presided. As Stoddard's grandson and the inheritor of his pulpit, Edwards spent the first two decades of his ministry reluctantly adhering to Stoddard's policies, but the excesses of the awakenings and the experience of editing David Brainerd's journals prompted Edwards to restrict access to the communion table. Norman Pettit argues for a "connection between the communion controversy and Brainerd's example in the diary," and Edwards comments on the connections between humoral regulation and communion in his Life of Brainerd (1749). ${ }^{79} \mathrm{He}$ notes that Brainerd is "one who by his constitution and natural temper was so prone to melancholy" that he was frequently despondent, but Brainerd's journal frequently presents the administering and taking of communion as a corrective for his humoral imbalances. When Brainerd suffers from melancholy and is "in a dejected, spiritless frame, that I could not hold up my head nor look anybody in the face," he "[a]dministered the Lord's Supper at Mr. Wales's desire: And found myself in a good measure unburdened and relieved of my

\footnotetext{
${ }^{79}$ Norman Pettit, "Editor's Introduction" to Jonathan Edwards, An Account of the Life of the Reverend Mr. David Brainerd, in The Works of Jonathan Edwards, Vol. 7, The Life of David Brainerd, ed. Norman Pettit, (New Haven: Yale University Press, 1984), 15.
} 
pressing load when I came to ask a blessing on the elements.. ${ }^{80}$ Brainerd's melancholy was repeatedly relieved by the experience of administering and receiving communion, and Edward directed editorial attention to scenes in which Brainerd "rejoic[es] in Christ as king of his church and king of his soul; in particular at the sacrament of the Lord's Supper."

Edwards diagnosed a distemper in the ecclesiastical body over which he presided at Northampton, but he did not seek to cure the ecclesiastical body in the same way that Brainerd obtained relief from his own melancholic distempers, by administering communion to it. Instead he sought to regulate its consumption of new members by admitting to the Lord's Supper only those individuals who both demonstrated their godliness in their actions and made a public profession of faith. He did so because "[t]his matter of making a public profession of godliness or piety of heart, is certainly a very important affair, and ought to be under some public regulation, and under the direction of skilfull guides, and not left to the management of every man, woman and child, according to their humor." Unlike Taylor, Edwards does not present himself as a physician; in rejecting Stoddard's claim that communion converted men and women who were morally upright but had not yet recognized God's grace, Edwards asked,

What has any visibility or hope of a person's being in health to do in admitting him into a hospital for the use of those means that are the proper appointed means for the healing of the sick, and bringing them to health? ... For on the principles which I oppose, there is no need of any sort of ground for treating them as saints, in order to admitting them to the Lord's Supper, the very design of which is to make 'em saints, any more than there is need of some ground of treating a sick man as being a man in health, in order to admitting him into a hospital. ${ }^{82}$

\footnotetext{
${ }^{80}$ Jonathan Edwards, An Account of the Life of the Reverend Mr. David Brainerd, in The Works of Jonathan Edwards, Vol. 7, The Life of David Brainerd, ed. Norman Pettit, (New Haven: Yale University Press, 1984), 91, 409.

${ }^{81}$ ibid, 305.

${ }^{82}$ Jonathan Edwards, An Humble Inquiry, in The Works of Jonathan Edwards, Vol. 12, Ecclesiastical Writings, ed. David D. Hall, (New Haven: Yale University Press, 1994), 323, 188.
} 
As far as Edwards was concerned, communion could not convert; if it was medicine, it was preventative medicine administered to those who were already spiritually temperate, not a miraculous corrective given to the corrupt.

As a "skilfull guide," who decides which applicants for church membership the ecclesiastical body should ingest, Edwards portrays himself as that body's mouth; he is a sort of spiritual gourmet whose palate is capable of judging whether or not an applicant's spiritual humors are properly balanced before receiving communion. Edwards has "a taste or relish of the amiableness and beauty of that which is truly good and holy" and, thanks to his "rectified palate, knows what is good food, as soon as he tastes it, without the reasoning of a physician about it." ${ }^{, 83}$ A spiritual gourmand, he alone can discern the propriety of offering or withholding communion from congregants who would otherwise take it "meerly from Humour." ${ }^{84}$ Indeed, it is Edwards's self-imposed task to prevent the unconverted from taking communion so that church members can enjoy "this oneness of mind, or being of one heart and soul, [which] is meant by that charity which the Apostle calls 'the bond of perfectness,' Col. 3:14. And represents as the bond of union between all the members of the body." Like Winthrop before him, Edwards sought to promote edenic temperance by establishing perfect unity between the diverse members of the ecclesiastical body. He regulated the consumption of the ecclesiastical body-its intake of new members-by regulating the consumption of communion by the physical bodies of Northampton's residents and making it available only to "those that had both a part in the New Jerusalem, and also their names written in the book

\footnotetext{
${ }^{83}$ Jonathan Edwards, Treatise Concerning Religious Affections, in The Works of Jonathan Edwards, Vol. 2 , Religious Affections, ed. Paul Ramsay, (New Haven: Yale University Press, 1959), 281.

${ }^{84}$ Jonathan Edwards, “A195. Letter to Joseph Hawley, November 18, 1754," in The Works of Jonathan Edwards Online, Vol. 32, Correspondence by, to, and about Edwards and His Family, ed. Jonathan Edwards Center, (Jonathan Edwards Center at Yale University, 2008), accessed June 29, 2009.
} 
of life. ${ }^{\circ 5}$ Only those destined for an eternal paradise were allowed to take communion, that earthly representation of "the tree of life ... in the church on earth"; unlike his grandfather, Edwards believed that access to the tree of life, to Eden, must be kept closely guarded. ${ }^{86}$

\section{The Humoral Inheritance: Pauper to Printer}

Of course, Edwards's experiment in other-fashioning - the regulation of his parishioners' consumption at communion-failed spectacularly and resulted in his dismissal. While Galenic medicine continued to influence spiritual discourse well into the eighteenth century, the ministerial elites who had disciplined the ecclesiastical body in the seventeenth century began to lose control of that body in the eighteenth century as voices from the religious fringe — especially the voices of slaves and women — acquired spiritual authority during the Great Awakening. But these individuals, whose influence over the direction of New England's ecclesiastical bodies accreted slowly into the mid-nineteenth century, were not the only marginal groups who engaged in somatic self-fashioning; lower-class white men also completed projects of bodily refinement with success. ${ }^{87}$ And although any connection between physiological perfection and the early seventeenth-century interest in regaining the perfectly temperate bodies that Adam and Eve enjoyed in the garden was largely effaced in this later period, Eden continued to manifest itself in muted forms.

Critics have argued that a unique and identifiably American notion of the self begins

\footnotetext{
${ }^{85}$ Edwards, An Humble Inquiry, 254, 196.

${ }^{86}$ Jonathan Edwards, Apocalypse Series, in The Works of Jonathan Edwards, Vol. 5, Apocalyptic Writings, ed. Stephen J. Stein, (New Haven: Yale University Press, 1977), 157.

${ }^{87}$ For an account of the spiritual enfranchisement of African Americans and women during the Great Awakening and reflections on the nineteenth-century legacy of that empowerment, see Nancy Ruttenberg, Democratic Personality, (Stanford: Stanford University Press, 1998) and Nathan Hatch, The Democratization of American Christianity, (New Haven: Yale University Press, 1989).
} 
to emerge only at the end of the eighteenth century with the work of Edwards's

contemporary, Benjamin Franklin, whose Autobiography inspired early national thinkers like Henry Clay and nineteenth-century authors such as Horatio Alger Jr. in their elaborations on the virtues of "self-made men." 88 Michael Warner contends that Franklin's attempt "to embody representational legitimacy" and a national identity hinges on his textual prowess "as a printer and man of letters" who shows "how certain ways of representing individuals could produce new individuals," but more recently, critics have recognized the important links between Franklin's physical body and his relationship to national identity. Betsy Erkkila and Colleen Terrell both examine Franklin's project of somatic self-fashioning, but their respective representations of Franklin's revolutionary and mechanical body focus almost exclusively on "the eighteenth-century belief in education's transformative potential," ignoring the traditions of Renaissance physiology that informed Franklin's understanding of the body. While "it is important to recognize the artfulness of his narrative and the ways its various parts are shaped by the exigencies of the different historical and critical moments in which they were written," it is even more important to recognize the origins of Franklin's narrative and place it in the context of attempts by Anne Bradstreet, John Winthrop, and Jonathan Edwards to discipline and perfect New England bodies. ${ }^{89}$

Franklin's portrayal of himself as a self-made man derives, at least in part, from his

\footnotetext{
${ }^{88}$ Some, like Sacvan Bercovitch in The Puritan Origins of the American Self (1975) and Mitchell Robert Breitwieser in Cotton Mather and Benjamin Franklin: The Price of Representative Personality (1984), have already elaborated on the ways in which Franklin's status as a national icon is derived from an earlier Puritan preoccupation with introspection. My own focus on the physical body of Franklin as the symbol of his status as a self-made man suggests that Bercovitch and Breitwieser both place too much emphasis on the Puritan nature of this inward focus; the Puritans have only preserved and passed down a Renaissance tradition applicable to men from a number of religious traditions.

${ }^{89}$ Michael Warner, The Letters of the Republic (Cambridge, MA: Harvard University Press, 1990), 73, xiii; Colleen Terrell, “'Republican Machines': Franklin, Rush, and the Manufacture of Civic Virtue in the Early Republic," Early American Studies 1, no. 2 (2003): 101; Betsy Errikla, "Franklin and the Revolutionary Body," English Literary History 67, no. 3 (2000): 719.
} 
reflections on the dietary advice of the seventeenth-century English author and entrepreneur Thomas Tryon and bears a suspicious resemblance to the popular Renaissance conceptions of self which Schoenfeldt discerns in seventeenth-century England. Living with his brother James, Franklin first gains a competitive advantage because he chooses to eat different food than James, turning to "a Vegetable Diet" recommended by Tryon. This new diet imparts "that greater Clearness of Head and quicker Apprehension which usually attend Temperance in Eating and Drinking" and "an additional Fund for buying Books." Franklin's immersion in and approval of Tryon's prescribed methods of consumption demonstrates the continuity of Renaissance physiological tenets in American somatics; Tryon's elucidation of The Way to Health, Long Life and Happiness, or a Discourse of Temperance (1697) revolves around the alteration and maintenance of "a Man's COMPLEXION, of which there are commonly reckon'd four kinds, viz. the Cholerick, the Phlegmatick, the Sanguine, and the Melancholy; and since the true understanding of each of these, does mainly conduce to a man's knowing and right regulating of himself, we shall therefore treat of them severally."${ }^{, 90}$ By subscribing to Tryon's vegetarian diet, Franklin also implicitly adopts the ancient and early modern conceptions of humoral bodies upon which Tryon bases his recommendations.

As Schoenfeldt points out, "bodily condition, subjective state, and psychological character are in this earlier regime fully imbricated," and Franklin's subscription to these notions of the physical body carries with it important implications about the spiritual or psychological self. In his introduction, Tryon warns that 'if the Body be distemper'd thro' disorder and superfluity, the Mind and all the Senses are presently afflicted; if the Harmony of the one be interrupted or destroy'd, the other cannot continue: For the Spirit is the original

\footnotetext{
${ }^{90}$ Benjamin Franklin, The Autobiography of Benjamin Franklin, ed. Leonard W. Labaree, et al. (New Haven, CT: Yale University Press, 2003), 63; Thomas Tryon, The Way to Health, Long Life and Happiness (London: T. Carruthers, 1697), 2.
} 
whence the Body proceeded, and is the Life of every visible Substance, and as the Properties or Qualities are in their degrees in the Spirit either strong or weak, so also they are in the Elements of the Body." Influenced, perhaps, by Tryon's combination of the physical and spiritual, Franklin's Autobiography likewise conflates the physical and spiritual self; Franklin's famous "Project of arriving at moral Perfection" makes the acquisition of humoral temperance the basis of all morality, the first of the thirteen virtues which Franklin seeks. ${ }^{91}$ Before his more recognizably spiritual aspirations to silence, order, resolution, frugality, industry, sincerity, justice, moderation, cleanliness, tranquility, chastity (which, because it concerned the regulation of sperm, or purified blood, also engendered bodily temperance), and humility can be realized, Franklin must first discipline his physical body and achieve humoral temperance.

Though Franklin's deist leanings might seem to separate his own quest for physiological perfection from the earlier attempts of Puritans to regain edenic temperance, Franklin's reliance on Tryon provides a theological link connecting his relatively secular search to these earlier theological traditions. For Tryon, the humors are only tools used to achieve temperance, that edenic "Simplicity" which Adam's Fall turned into "Animal and Bestial Nature." Tryon promises readers such as Franklin that temperance leads to the "innocent life" of biblical role models such as Moses, whose physiological purity prepared him to enter God's presence, where "the Face of Moses shin'd, and he could guide his Body as if it had been a Spirit." Tryon's emphasis on the purifying powers of temperance builds on common seventeenth-century understandings of Moses' experience; Bradstreet and Winthrop both would have heard John Cotton suggest from the pulpit that Moses' theophany represents

\footnotetext{
${ }^{91}$ Schoenfeldt, Bodies and Selves in Early Modern England, 1; Tryon, The Way to Health, Long Life and Happiness, 2; Franklin, The Autobiography of Benjamin Franklin, 148.
} 
a symbolic reclamation of Eden where God's presence "maketh the face of a man [Adam] to shine." 92 This doctrine continued in the eighteenth-century Boston sermons that surrounded Franklin in his boyhood, as Benjamin Colman-whose sermons Franklin was familiar withtaught his congregants that "Moses face shone in the Mount with God, [as] did Adam's in the Garden of God." 93 Franklin never framed his plan for perfect temperance in edenic terms, but his physiologic instructor did, and Franklin's careful regulation of consumption reflects a secularized continuation and adaptation of earlier attempts at self fashioning by men and women with aspirations of transforming New England into Eden.

Franklin famously takes pains to describe the methods by which he made himself appear industrious and virtuous, but the iconic image of his embarkation on a quest for moral perfection is one of consumption, not production. Hungry and alone in a new environment, Franklin found a bakery and "ask'd for Bisket, intending such as we had in Boston, but they it seems were not made in Philadelphia, then I ask'd for a threepenny Loaf, and was told they had none such: so not considering or knowing the Difference of Money and the greater Cheapness nor the Names of his Bread, I bad him give me three penny worth of any sort. He gave me accordingly three great Puffy Rolls." Franklin knew that in bread "the Forms and Qualities of Nature stand in more exact and prefect Equality" than in other foods and that bread was the preferred food of Christ himself; his consumption of a new type of bread

\footnotetext{
${ }^{92}$ Tryon, The Way to Health, Long Life and Happiness, 36, 41, 34; John Cotton, A Briefe Exposition with Practicall Observations upon the Whole Book of Ecclesiastes (London: Anthony Tuckney, 1654), 42. Inasmuch as Tryon presents his dietary recommendations as a pathway to the purity enjoyed by predecessors who enjoyed God's presence in mortality, he provides a reason to question the assertion of Andrew Wear that paradise "was of little use in the practical daily business of deciding which products one should select to eat and drink." While Tryon's criteria for food selection are based on empirical evidence- the size of yeast bubbles in bread, for instance- - the food selected by Tryon's empirical criteria are intended to restore the consumer to a state of paradisiacal health. See Andrew Wear, Knowledge \& Practice in English Medicine, 1550-1680 (Cambridge: Cambridge University Press, 2000), 203.

${ }^{93}$ Benjamin Colman, The Holy Walk and Glorious Translation of Blessed Enoch, (Boston: 1728) 20. Leo Lemay's Documentary History of Franklin's life connects the Franklin family and Benjamin to several Colman sermons delivered in the early eighteenth century.
} 
marks the inauguration of his quest for economic prosperity and for physical and spiritual temperance both literally and symbolically. His move away from heavy biscuits to lighter rolls likewise conveys Franklin's interest in humoral perfection. Tryon teaches that "that Bread is best that is light, and full of small Eyes, as they call it, being well kneaded and thoroughly bak'd," and by switching to a superior food item, Franklin makes himself into a superior man. ${ }^{94}$ Franklin takes pains to emphasize that he arrives in Philadelphia a poor Boston boy accustomed to expensive Boston biscuits; his metamorphosis into an apparently virtuous Philadelphia man of means stems — at least symbolically_from his decision to eat the right kind of roll.

This image of Franklin walking "with a Roll under each Arm, and eating the other" is the same one which nineteenth-century autobiographers such as the libertine George Thompson emphasize when they attempt to recreate Franklin's act of self-fashioning. Thompson, too, describes himself eating a new kind of bread in a new city; after arriving in New York, he also "entered the shop of a baker and purchased three rolls at the rate of one cent per copy." When Thompson subsequently decided to apprentice himself to a printer, he remembered "Franklin was one, and he, like myself, was fond of rolls, because he entered Philadelphia with one under each arm. Yes, I'll be a printer." 95 For Thompson, as for Franklin, regulating or modifying consumption is the key to becoming a self-made man. In this respect, the "American" notion of a carefully constructed selfhood shaped by

\footnotetext{
${ }^{94}$ Franklin, The Autobiography of Benjamin Franklin, 76; Tryon, The Way to Health, Long Life and Happiness, 133, 135. I do not intend to argue that Franklin sought out the puffy rolls as a means to perfection in the moment that he purchased them, only to suggest that this understanding is one his immersion in Tryon's philosophies would have provided him as he reflected on the experience during his composition of the Autobiography.

${ }^{95}$ Franklin, The Autobiography of Benjamin Franklin, 76; George Thompson, My Life: Or the Adventures of Geo. Thompson, in Venus in Boston and Other Tales of Nineteenth-Century City Life, ed. David S. Reynolds and Kimberly R. Gladman (Amherst, MA: University of Massachusetts Press, 2002), 325-26.
} 
consumption and inaugurated by Franklin actually relies on the earlier, humorally-based views of physiology and psychology that Schoenfeldt articulates.

Though Franklin and Thompson do not explicitly endorse humoral theory or Galenic medicine, their shared concern with consumption and digestion as an act of self-fashioning reflects the principles of these philosophies. Early modern New Englanders believed that eating a piece of bread or shedding tears could change an individual, body and soul, and in this context, Franklin's purchase and consumption of three large puffy rolls for only three pennies tells readers just as much about his quest for moral perfection as it does about the relative economic spheres of Philadelphia and Boston. For Franklin's seventeenth-century predecessors, new foods could change the way an eater's brain functioned by altering the humoral balance of their bodies; modern readers recognize that Franklin's moods and thoughts affected his choice of food, but early modern readers would have understood that Franklin's food also affected his subsequent moods and thoughts. This connection between digestion and cogitation offered early modern men and women the opportunity to mold their own characters by regulating consumption and lent added significance to seemingly mundane activities such as eating. Shakespeare's words to his beloved in the seventy-fifth sonnet, "So are you to my thoughts as food to life," may seem less than inspiring in a modern context; after all, comparing your loved one to a quarter-pounder with cheese hardly inspires romance. But for early modern men and women, food not only sustained life-it shaped life, and Shakespeare's words proclaimed that his beloved has the power to transform him, body and soul. For early modern men and women like Franklin, food for thought literally signified food that becomes and shapes thought. ${ }^{96}$ Franklin's bread, like Bradstreet's phlegm,

\footnotetext{
${ }^{96}$ Most frequently, men and women of the early modern period worried about food's potential to fog or cloud thought and engaged in activities that they believed would purge the undesirable humors from their body and
} 
Winthrop's charity, or Edwards's communion wine, was a transformative tool used to purify and perfect his own physiology; if he does not explicitly acknowledge his inheritance of their edenic aspirations, he at least recognizes the connection between humoral temperance and his own quest for spiritual perfection.

\section{Edenic Body, American Identity}

Colonists who thought of the New England landscape as a potential paradise were disappointed by the failure of English agriculture, but the colonists—or "Humorists" as John Smith disparagingly refers to the Puritans of the Bay Colony—quickly converted their search for an outward, landed Eden into more successful efforts to perfect and balance the humors of their physical and ecclesiastical bodies, to create an inward Eden. Though spiritual leaders insisted that outsiders should "Consider us not as if we went about to justify ourselves or dream of perfection," they also acknowledged that "we desire to breathe after perfection and to know what is the rule and to walk in it" as Adam and Eve walked in Eden. ${ }^{97}$ The lure of purity proved too much for Calvinist doctrine to constrain, and even orthodox clergy preached to their congregations about how to reclaim Eden's perfection. This passion for perfection naturally appropriated the humoral body as a potential catalyst because Galenic medicine empowered individuals who wanted to improve their literal and metaphorical bodies. In the as yet undefined social spaces of New England even women (Bradstreet) and paupers (Franklin) found room to engage in self-fashioning in ways that citizens of Old

thereby elevate their thoughts. Thus Richard Baxter exercises until he sweats or sits by a hot fire in order to remedy the "very troublesome Drowsiness" that would otherwise prevent him from thinking clearly and writing "all the Books that ever I wrote." See Richard Baxter, Reliquiae Baxterianae, ed. Matthew Sylvester (London: T. Parkhurst, et al., 1696), 11.

${ }^{97}$ John Smith, "Advertisements," in Captain John Smith: Writings with Other Narratives of Roanoke, Jamestown, and the First English Settlement of America, ed. James Horn (New York: Library of America, 2007), 780; Weld, "To His Former Parishioners at Terling," 35. 
England could not; their respective constructions of American identity diverge from previous formulations of English identity even as they draw on theories of self-fashioning which belong to the English Renaissance.

In this respect, the psychosomatic focus of New England Puritans both reinforces and revises the Puritan Origins of the American Self delineated by Sacvan Bercovitch, who traces the genesis of Franklin's "American success story" to a Puritan adaptation of Renaissance customs but fails to acknowledge the crucial role of Galenic medicine and body theory in the formation of an American identity. The New England quest for temperance and charity via the regulation of consumption in both food and goods also belies the claim of David Shields that the commercial nature of American identity must be traced to the imperial roots of the middle colonies. New England did not need to revise "its sense of self to absorb the Dutch mystique of commerce"; the interest of New England colonists in the processes of consumption was rooted in the very quest for purification that brought them to New England, where they hoped that phlegm would unify their bodily humors, that charity would regulate greed and $\sin .{ }^{98}$ To their physical and ecclesiastical temperance, they hoped to add mental, spiritual and social perfections - the all-encompassing wisdom of Adam, the spiritual purity of Eve, and a government administered by the natural laws under which they lived in Eden.

\footnotetext{
${ }^{98}$ Sacvan Bercovitch, The Puritan Origins of the American Self (New Haven, Yale University Press, 1975), 3; David S. Shields, Oracles of Empire (Chicago: The University of Chicago Press, 1990), 2.
} 


\section{CHAPTER 3}

\section{THE WISDOM OF SOLOMON: ADAM, EVE, AND BACON'S LEGACY IN NEW ENGLAND}

Early modern exegetes describe Adam in Eden as the possessor of intellectual treasures and capacities since lost with the Fall, and plans for recovering his prelapsarian wisdom proliferated in the seventeenth century. Belief in Adam's original intellectual superiority was largely based on the biblical account in which "the LORD God formed every beast of the field, and every fowl of the air; and brought them unto Adam to see what he would call them: and whatsoever Adam called every living creature, that was the name thereof." Scriptural commentators viewed Adam's performance as a demonstration of his powers of observation and of his encyclopedic knowledge of the natural world. Calvin explains that Adam "named them not at a venture, but of knowledge he gave to every one his owne and proper name,"1 and Benjamin Colman describes the event as a "wonderful Evidence of that natural Wisdom and Sagacity with which he was endued: That at the first Sight of any of the Creatures he could look into them, see their different Natures, and name them agreably." Before the Fall Adam enjoyed "a Flight and Compass of Thoughts ... beyond the Ken of Angels," but after he had sinned, he lost "the Powers

\footnotetext{
${ }^{1}$ Genesis 2:19; Jean Calvin, A commentarie of Iohn Caluine, vpon the first booke of Moses called Genesis, trans. Thomas Tymme, (London: 1578), 74. For a more extensive discussion of Renaissance commentaries on the nature and extent of Adam's knowledge before the Fall, see Arnold William, The Common Expositor, (Chapel Hill: The University of North Carolina Press, 1948), 80-84.
} 
of Reason in Perfection."2

This loss rendered men and women intellectually blind, unable fully to understand the natural world in which they lived. But as Peter Harrison explains, the "tradition according to which Adam was in possession of the perfect philosophy implies that human minds had originally been designed to know the truth, and that if those impediments that arose as a consequence of the Fall could be identified and neutralized, the mind would once again, of its own nature, arrive at truth." ${ }^{3}$ Early modern men and women believed that the intellectual gifts employed by Adam in Eden could be restored by the systematic improvement of observational and epistemological processes, and with the rise of empiricism and modern science in the seventeenth and eighteenth centuries came new plans for the recovery of humanity's prelapsarian perfections. ${ }^{4}$

Francis Bacon presented the most influential of these plans in his Great Instauration (1620), a text that outlines six steps by which "that commerce between the mind of man and the nature of things, which is more precious than anything on earth, or at least than anything that is of the earth, might by any means be restored to its perfect and original condition.” But the sixth step of Bacon's Great Instauration — "to which the rest is subservient and ministrant"-is frustratingly vague and fails to present a practical means by which "the legitimate, chaste, and severe course of inquiry which I have explained and provided is at

\footnotetext{
${ }^{2}$ Benjamin Colman, A brief dissertation on the three first chapters of Genesis, (Boston: S. Kneeland and T. Green, 1735), 20, 22. For a seventeenth-century opinion on Adam's intellectual gifts that illustrates the continuity of thought between Calvin and Colman, see Lancelot Andrewes, Apospasmatia Sacra, (London: R. Hodgkinsonne, 1657), 208.

${ }^{3}$ Peter Harrison, The Fall of Man and the Foundations of Science, (Cambridge: Cambridge University Press, 2007), 4.

${ }^{4}$ For a broader view of scientific efforts to recapture intellectual perfection, see Chapter 10, "The Perfecting of Man by Scientific Progress," in John Passmore, The Perfectibility of Man, (New York: Charles Scribner's Sons, 1971), 190-211. The continuation of this quest to restore "right" reason by eighteenth-century philosophers is more fully treated in Montague Brown, Restoration of Reason, (Grand Rapids: BakerAcademic, 2006).
} 
length developed and established." Bacon laments that the production of an actionable blueprint is "both above my strength and beyond my hopes" because without a series of guidelines as to how the logical tools and philosophical methods he has provided should be used, his plan for the restoration of Adam's prelapsarian intellectual perfections is impractical, to say the least; the missing sixth part is the key to the whole enterprise. ${ }^{5}$ However, as Jerry Weinberger notes, Bacon provided in the New Atlantis (1627) what he left out of the Great Instauration: "the picture of mankind's scientific liberation from natural necessity" and a description of the practical means by which that liberation was achieved. ${ }^{6}$ In the New Atlantis, Bacon depicts an island utopia geographically linked to the Americas whose leaders work to recover Adam's wisdom and support an institution of higher learning dedicated to that purpose; in this imagined intellectual enclave, the Great Instauration has already produced significant progress toward the recovery of edenic idealities.

Bacon's island nation of Bensalem revolves around the activities of a society known as Salomon's House or the College of the Six Days Works. The group is named for the biblical King Solomon in part because it possesses an otherwise unknown "Natural History which he wrote, of all plants," and its members work diligently to perfect this initial step towards recovering the knowledge of the natural world that Adam possessed at the end of the sixth day of creation. The members of Salomon's House are assigned to a variety of different tasks: a dozen men "sail into foreign countries, under the names of other nations, (for our own we conceal;) who bring us the books, and abstracts, and patterns of experiments of all other parts"; four groups of three "try new experiments"; another three men "draw the

\footnotetext{
${ }^{5}$ Francis Bacon, The Great Instauration, trans. James Spedding, in The Great Instauration and The New Atlantis, ed. J. Weinberger, (Arlington Heights: Harlan Davidson, 1980), 1, 31.

${ }^{6} \mathrm{~J}$. Weinberger, Introduction to The Great Instauration and The New Atlantis, ed. J. Weinberger, (Arlington Heights: Harlan Davidson, 1980), xi.
} 
experiments of the former four into titles and tables, to give the better light for the drawing of observations and axioms out of them"; and once all of these experiments with the natural world have been completed, the results are turned over to a final group of "three that raise the former discoveries by experiments into greater observations, axioms, and aphorisms. These we call Interpreters of Nature." ${ }^{, 7}$ Only through this repetitive process of observation and experimentation can the members of Salomon's House collectively hope to acquire the "pure knowledge of nature and universality," that Adam possessed naturally in Eden, "a knowledge by the light whereof man did give names unto other creatures in Paradise."

Bacon had also connected this pursuit of Adamic knowledge or wisdom to Solomon in his earlier work on The Advancement of Learning (1605). There Bacon interprets Solomon's declaration that "the eye is never satisfied with seeing, nor the ear with hearing" as a scriptural sanction of his program for the restoration of prelapsarian knowledge. "That this knowledge is possible Salomon is our surety," Bacon writes, because "those things are to be held possible which may be done by some person, though not by every one," and Solomon acquired his knowledge "of Wisdom or Sapience, as the Scriptures call it," when God gave him "a wise and an understanding heart." Salomon's House in the New Atlantis is a model for humanity's collective recovery of Adamic knowledge, a model named after the man who Bacon believes came closest to recovering that knowledge on his own.

Bacon's program for the restoration of prelapsarian intellectual perfections was quickly adopted by Puritan intellectuals in the late 1620s and early 1630s. Charles Webster explains that by the time Cromwell and the Rump Parliament came to power in England, "the

\footnotetext{
${ }^{7}$ Francis Bacon, New Atlantis in The Great Instauration and The New Atlantis, ed. J. Weinberger, (Arlington Heights: Harlan Davidson, 1980), 57, 79-80.

${ }^{8}$ Francis Bacon, The Advancement of Learning, ed. G. W. Kitchin, (Philadelphia: Paul Dry Books, 2001 ), 6.
} 
vocabulary of Bacon had been assimilated into the millenarian ideology" espoused by Puritan theologians in Old England (Thomas Brightman and Richard Bernard) and New (John Cotton and Ephraim Huit). Bacon's "philosophical programme, the Instauratio Magna, came to be regarded by [John] Beale's generation [1608-1683] as the authentic guide to intellectual regeneration," and Puritan leaders expected that their pursuit of the goals and policies of Salomon's House would "initiate a gradual improvement in social organisation which would ultimately lead to a replication of the conditions of life associated with the Garden of Eden. In this age of perfection man himself would recapture the intellectual attributes sacrificed by Adam at the Fall.." ${ }^{10}$ The influence of Bacon's program for the recovery of prelapsarian intellectual perfections on the policies and institutions of Puritan England have been ably documented by Harrison, Webster, and others, but scholars have consistently downplayed the impact of Bacon's new philosophy on New England intellectual culture despite the widespread acknowledgment of his importance to Puritan thought generally. Walter Woodward has ably documented John Winthrop Jr.'s participation in Bacon's project, but "[r]eacquiring the prisca theologica, the knowledge that had been lost at Adam's fall" was a pursuit that played "a central role in one or more aspects of early colonial New England's cultural formation," and the way in which other prominent colonists adopted Baconian processes of induction and promoted the pursuit of edenic intellectual perfections deserves further exploration. ${ }^{11}$

Bacon's influence on colonial New England was explicitly acknowledged infrequently at best, and it may even be that some New Englanders did not recognize Bacon

\footnotetext{
${ }^{9}$ Bacon, The Advancement of Learning, 175, 68, 35; I Kings 3:12.

${ }^{10}$ Charles Webster, The Great Instauration, (London: Gerald Duckworth, 1975), 12, 8.

${ }^{11}$ Walter W. Woodward, Prospero's America, (Chapel Hill: University of North Carolina Press, 2010), 40, 9.
} 
as the impetus behind the intellectual aspirations to which they subscribed; nonetheless, his ambition to recapture Adamic wisdom and his depiction of Solomon as a role model who attained that wisdom are mirrored in the texts and educational policies of early modern New England. Writers like John Cotton and Anne Bradstreet associated Solomon with edenic themes and aspired to his wisdom as a pathway back to primal purity while educational leaders such as Hugh Peter and Leonard Hoar worked to convert Harvard College into a Baconian institution that would create knowledge through induction and experimentation. My primary purpose in highlighting the parallels between the intellectual aspirations of New Englanders and Bacon is not to establish some form of causality. Indeed, the work of proving that Cotton or Bradstreet had actually read Bacon might well distract from the larger point that New England colonists appropriated a Baconian rhetoric of intellectual perfection commonly employed by their Puritan counterparts in England and used it to justify and fulfill their own errand into the wilderness. ${ }^{12}$

Perry Miller's foundational survey of early New England intellectual history argues that seventeenth-century Puritan thinkers who preferred the logical and rhetorical framework of Petrus Ramus more or less ignored Bacon. ${ }^{13}$ But as Norman Fiering notes, Miller and other early historians were unduly influenced by Samuel Johnson's personal discovery of Bacon in the early eighteenth century, which prompted Johnson's memorable but inaccurate

\footnotetext{
${ }^{12}$ While neither Cotton nor Bradstreet can be tied directly to Bacon, both were seriously interested in the sciences. Bradstreet's reflections on contemporary scientific thought are primarily contained in her quaternions; I discuss her interest in humoral medicine in Chapter 2, but little has been done in the way of a comprehensive treatment of her engagement with the sciences. For an overview of Cotton's scientific thought and the ways in which he attempts to reconcile Europes Aristotelian intellectual heritage with the discoveries of Copernicus and Galileo, see Theodore Hornberger, "Puritanism and Science: The Relationship Revealed in the Writings of John Cotton," The New England Quarterly 10.3 (1937): 503-15. Rose Lockwood provides an excellent overview of scientific thought in seventeenth-century New England but focuses almost exclusively on Copernican astronomy at the expense of discussing the reception of other new scientific ideas. See Rose Lockwood, "The Scientific Revolution in Seventeenth-Century New England," The New England Quarterly 53.1 (1980): 76-95.
} 
declaration that his copy of The Advancement of Learning was "perhaps the only copy in the country and nobody knew its value." 14 To be sure, the Puritan founders of New England had collectively adopted the plain style and logical emphasis of Ramus, but an endorsement of Ramist rhetoric and logic does not preclude a concomitant interest in the larger intellectual aims of Bacon or even the use of his methodologies. Miller actually concedes that William Ames and other Puritan divines committed to Ramist logic, such as John Preston, quoted Bacon approvingly, justifying their limited endorsement of induction "by an appeal to utility." 15 John Norton, a first-generation New England divine who took Cotton's spot as an Overseer at Harvard after he caught the cold that killed him while preaching to Harvard students, also employed Bacon's logic; Norton frequently drew theological conclusions in his sermons after the "induction of some particulars" at the pulpit. ${ }^{16}$

Despite the precedent set by Ames, Preston, and Norton, Miller contends that firstgeneration immigrants to New England "did not take easily or naturally to the inductive method," preferring to rely upon tradition and inherited formulae rather than firsthand observation of and experimentation with natural phenomena. But Miller, as Rose Lockwood notes, too often conflates Bacon's new philosophy with the new Copernican and Galilean astronomy that first-generation colonists largely rejected; he cites Cotton's refutation of “the

\footnotetext{
${ }^{13}$ On the differences between Baconian and Ramist rhetoric and logic, see Wilbur Samuel Howell, Logic and Rhetoric in England, 1500-1700, (Princeton: Princeton University Press, 1956), 146-281, 364-75.

${ }^{14}$ As quoted in Norman Fiering, "President Samuel Johnson and the Circle of Knowledge," The William and Mary Quarterly 28.2 (1971): 209. Fiering provides a brief overview of Bacon's reception in seventeenthcentury New England on pages 210-14.

${ }^{15}$ Perry Miller, The New England Mind: The Seventeenth Century, (Cambridge: Harvard University Press, 1939), 218. John Preston is another minister cited by the founders of New England who used Bacon's methods; in a sermon on I Corinthians, he instructs his parishioners that "[b]y induction of particulars what [a spiritual feast] is not, you shall finde what it is." See John Preston, The Cvppe of Blessing, in The Saints Qualification, (London: R. B., 1633), 87.

${ }^{16}$ John Norton, The Orthodox Evangelist, (London: John Macock, 1654), 167. See also John Norton, The Heart of N-England Rent at the Blasphemies of the Present Generation, (Cambridge: Samuel Green, 1659), 20.
} 
Copernican theory on the very solid, common-sensical grounds that if the earth were moving, when a man threw a stone in the direction of its rotation he would overtake his stone before it fell" as evidence that the early colonists generally distrusted the new scientific views that Bacon represented without acknowledging that Cotton's distrust of Copernicus does not necessarily equate to a distrust of Bacon and that his admittedly erroneous conclusions are based on the very principles of observation and experimentation that Bacon advocated. ${ }^{17}$ The first generation of New England intellectuals never became disciples of Bacon in the way that their English counterparts did, but their willingness to use Bacon's methods and their interest in acquiring the Adamic wisdom of Solomon betrays an early commitment to the work of Bacon's Instauration that was slowly but surely institutionalized at Harvard College.

\section{New England as New Atlantis: Cotton's Epistemological Mandate}

When Cotton delivered his Southampton farewell sermon to John Winthrop and the other emigrants who would join him aboard the Arabella, he engaged what was a familiar topic for preachers in the early seventeenth-century. In Gods Promise to His Plantations (1630), Cotton defends the practice of establishing colonies in foreign lands, but he supports his argument with unusual evidence. The traditional talking points for such an argument had been well established by previous writers, and the key scriptural text was a commandment from God to Adam and Eve in Eden: "Be fruitful, and multiply, and replenish the earth, and subdue it." Other preachers addressing the task that now occupied Cotton had elaborated on this divine injunction at length. English minister Robert Eburne's justification for the practice of colonization relies entirely "vpon warrant of that Grant which Adam had ... Replenish yee

\footnotetext{
${ }^{17}$ Miller, The New England Mind: The Seventeenth Century, 217-18; Lockwood, "The Scientific Revolution in Seventeenth-Century New England," 79.
} 
the earth, or fill it vp againe," and New England minister John White's very first words in The Planters Plea (1630) explain that "COLONIES (as other conditions and states in human society) have their warrant from Gods direction and command; who as soone as men were, set them their taske, to replenish the earth, and to subdue it, Gen. 1.28."18 Colonial apologetics revolved around Eden, and Cotton briefly acknowledges that tradition by noting that "the ground of this [argument] is from the grand Charter given to Adam and his posterity in Paradise, Gen. 1.28."19 But the bulk of his discourse substitutes Solomon for Adam as the source of divine endorsement for colonial activities; in Cotton's sermon, Solomon's example in building the temple replaces the edenic injunction of Genesis to subdue and populate the earth as authorization for Winthrop and his company of Puritan colonists to settle in New England.

Cotton elaborates on the connection between Solomon and Eden in other texts, especially his sermon series on Ecclesiastes, published posthumously in 1654 as A Brief Exposition with Practicall Observations Upon the Whole Book of Ecclesiastes. There Cotton observes that God gave Solomon "great Wisdome," exhorting his listeners "to seek after that wisedom, which maketh blessed, and addeth no sorrow with it, Prov. 3.17." By adding the reference to Proverbs, Cotton signals to his congregants that the wisdom of Solomon, which they seek, "is a tree of life to them that lay hold upon her." ${ }^{20}$ Solomon, by acquiring divine wisdom, figuratively reentered Eden and tasted of the tree of life; "Solomons eminency of wisdom" caused his face to shine just as "even in a mean man (as Adam is here meant, as

\footnotetext{
${ }^{18}$ Genesis 1:28; Richard Eburne, A Plaine Path-VVay to Plantations, (London: G. P., 1624), 18; John White, The Planters Plea, (London: William Iones, 1630), 1.

${ }^{19}$ John Cotton, Gods Promise to His Plantations, (London: William Jones, 1630), 5.

${ }^{20}$ John Cotton, A Brief Exposition with Practicall Observations Upon the Whole Book of Ecclesiastes, (London: T. C., 1654), 31, 33; Proverbs 3:17.
} 
also in Psalm 49.2) wisdom maketh his face to shine." Like Moses, whose audience with God on Sinai made "the skin of Moses' face sh[i]ne," Solomon was restored to the divine presence and the wisdom that emanates therefrom, the same wisdom that allowed Adam to name all of the animals in his innocency. ${ }^{21}$ Solomon was a model of Adamic wisdom for Cotton, as for Bacon, and his farewell sermon to the Massachusetts Bay Company presents Solomon as a model for imitation in much the same way that the New Atlantis does.

\section{Inheriting Salomon's House}

The text from which Cotton chooses to preach in his sermon to the departing Bay Company is not Genesis 1:28 but 2 Samuel 7:10, a verse in the three-way conversation between King David, the prophet Nathan, and God about the building of the temple: "Moreover I will appoint a place for my people Israel, and I will plant them, that they may dwell in a place of their owne, and move no more." In the verses that precede Cotton's selection, David comes to the realization that the Israelites have continued to worship Jehovah, their heavenly king, in the tabernacle_-an extremely old tent undoubtedly frayed and filthy from years of use-while he takes his rest in a luxurious and newly-built palace. Cotton explains that David decides to build a temple in which his God can dwell in similar comfort but that God instructs Nathan to dissuade David from his plans, "to shut up his speech with words of encouragement, and so he remoues his discouragement two wayes." 22 Enumerating the blessings promised by God to comfort David in his grief after the Lord has rejected his offer to build a temple, Cotton declares that the "first is in the 10. verse: I will appoint a place for my people Israell. Secondly, seeing it was in his heart to build him an

\footnotetext{
${ }^{21}$ Cotton, A Briefe Exposition with Practicall Observations Upon the Whole Book of Ecclesiastes, 165; Exodus 34:35.

222 Samuel 7:10; Cotton, Gods Promise to His Plantations, 2.
} 
house, God would therefore, build him an house renowned for ever. verse 11. Thirdly, that he would accept an of [sic] house from Salomon." In the second blessing listed by Cotton, God promises to reciprocate; just as Solomon builds his house, so God will build a house for Solomon, David's son. Cotton believes that these blessings apply to God's people in all dispensations, and he interprets them as a "blessing promised" to Winthrop and his departing party. Because Solomon—or Salomon, as both Bacon and Cotton spell it (though the posthumously published transcription of his sermon series on Ecclesiastes reverts to the standard spelling)—builds a house for God, Winthrop's Company will enter "into a forreigne land" and find "an house and land provided for thee." ${ }^{23}$ The establishment of Salomon's house, Cotton suggests, is a type of the blessings that the godly will receive as they establish colonies.

Cotton further promises that an edenic atmosphere comparable to the one enjoyed on Bensalem awaits Winthrop's company in New England. The general promises which Cotton extrapolates from God's specific blessing to David and extends to the faithful include:

First, the designment of a place for his people. Secondly, a plantation of them in that place, from whence is promised a threefold blessing. First, they shall dwell there like Free-holders in a place of their owne. Secondly, hee promiseth them firme and durable possession, they shall move no more. Thirdly, they shall have peaceable and quiet resting there, The sonnes of wickednesse shall afflict them no more. ${ }^{24}$

The last two blessings, in particular, are reminiscent of the lifestyle enjoyed by those under the protection of Salomon's House in Bacon's New Atlantis. There is no more permanent homeland than Bensalem because no one in the outside world knows that the island exists, and as for "our traveling from hence into parts abroad, our Lawgiver thought fit altogether to restrain it"; no one ever moves from Bensalem. The island is also a bastion of peace and

\footnotetext{
${ }^{23}$ Cotton, Gods Promise to His Plantations, 2, 13.
} 
righteousness in the fallen world. On Bensalem even the Jews, who "in other parts" of the world "hate the name of Christ, and have a secret inbred rancour against the people amongst whom they live: these (contrariwise) give unto our Saviour many high attributes and love."25 On Bensalem, there are no "sonnes of wickedness" to afflict God's people. The blessing which Cotton finds in the Bible for the Bay Company emigrants is a promise that their plantation will be a place like Bensalem —an isolated island refuge in the New World (in 1630 New England was still widely believed to be an island) where they will not be subject to the full range of the Fall's consequences and whose existence is made possible by the establishment of Salomon's House, the Lord's temple in Jerusalem.

\section{The Wisdom of Establishing Colonies}

Just as Cotton's choice of proof texts for the divine justification of colonial practices diverges from the rhetorical tradition of his predecessors, so too does his description of the practical reasons for emigrating and the responsibilities of immigrants to New England. Most early seventeenth-century English writers who defend colonial practices emphasize the need to civilize and convert the native inhabitants of the New World. As Robert Cushman—whose "Reasons \& considerations touching the lawfulnesse of remouing out of England into the parts of America" is the "first attempt that hath beene made (that I know of) to defend those enterprises"-argues, "a man must not respect only to liue, and doe good to himselfe, but he should see where he can liue to doe most good to others." Cushman condemns the man who "will not hazard a dram of health, nor a day of pleasure, nor an houre of rest to further the knowledge and saluation of the sons of Adam in the New world, where a drop of the knowledge of Christ is most precious," and urges those who "daily pray for the conuersion of

\footnotetext{
${ }^{24}$ ibid, 2.
} 
the heathens" to "consider whether there be not some ordinary meanes, and course for vs to take to convert them. ${ }^{, 26}$ With the exception of John Eliot, the first waves of settlers in New England actually did little to effect the conversion of the Indians, but the civilization and indoctrination of heathen natives was always the primary pretext given for acts of colonization. Ministers like Eburne and White elaborate on the need for settlers to convert the indigenous inhabitants of the New World at length, and even secular writers such as William Alexander and John Smith, who are generally more concerned with commercial interests, make the conversion of the Indians a primary goal of colonization. ${ }^{27}$ Here again, Cotton bucks the rhetorical tradition of colonial discourse; the conversion of the Indians seems to be something of an afterthought for Cotton, an aim he acknowledges only once in three short sentences in the penultimate paragraph of his sermon. Even then, the conversion of the New World's native inhabitants is presented only as a duty of those who have chosen to emigrate for other reasons—not the central purpose of establishing foreign plantations.

Indeed, before Cotton ever mentions the need to "make [the poore Natives] partakers of your precious faith," he outlines ten other, more pressing reasons for Winthrop's party to sail for New England. Cotton's primary justification for the establishment of colonial outposts is the acquisition of wisdom, especially the type of wisdom possessed by Salomon: "First, wee may remove for the gaining of knowledge. Our Saviour commends it in the Queene of the south, that she came from the utmost parts of the earth to heare the wisdome of

\footnotetext{
${ }^{25}$ Bacon, New Atlantis, 56, 63.

${ }^{26}$ R. C., "Reasons \& considerations touching the lawfulnesse of remouing out of England into the parts of America," in G. Mourt, Relation, (London: Iohn Bellamie, 1622), 65, 67-68.

${ }^{27}$ Eburne, A Plaine Path-VVay to Plantations, 3-8; White, The Planters Plea, 12-16; William Alexander, An Encouragement to Colonies, (London: William Stansby, 1624), A4, 44; John Smith, "A Description of New England," in Captain John Smith: Writings with Other Narratives of Roanoke, Jamestown, and the First English Settlement of America, ed. James Horn, (New York: Library of America, 2007), 160, 170-71.
} 
Salomon: Matth. 12.42. And surely with him she might haue continued for the same end, if her personall calling had not recalled her home. ${ }^{28}$ This is an extraordinary inversion of the customary ecclesiastical position regarding colonialism. Cushman and other advocates of English evangelism argue that the establishment of plantations serves primarily to "further the knowledge and saluation of the sons of Adam in the New world," to export English theology to New England; Cotton counters with the proposition that the primary benefit of colonial practices will be the absorption of New World knowledge about the natural world (What other knowledge could they possibly expect to find in the wilderness among supposedly ignorant natives?) and the resultant acquisition of Solomonic wisdom. He presents the experience of engaging with the reputedly exotic New England landscape as a type of world-class education best compared to the one offered the queen of Sheba, who saw "all Solomon's wisdom, and the house that he had built." ${ }^{, 29}$ According to Cotton, the wisdom of Salomon's House awaits the Bay Company in the New England wilderness.

The importance of wisdom to the colonial venture is underlined by other motives for emigration identified by Cotton. He condones the actions of those who "remove and travaile for merchandize and gaine-sake" because they possess "the wisedome of the [unjust Steward]" that Christ made an exemplar. Likewise, Cotton notes that "God alloweth a man to remove, when he may employ his Talents and gift better elsewhere," citing the example of Joseph, whose "wisedome and spirit was not fit for a shepheard, but for a Counsellor of State, and therefore God sent him into Egypt. ${ }^{, 30}$ Implicit in Cotton's description of Joseph is the inference that Winthrop also possesses wisdom more appropriate to the government of a

\footnotetext{
${ }^{28}$ Cotton, Gods Promise to His Plantations, 19, 8.

${ }^{29}$ R. C., "Reasons \& considerations touching the lawfulnesse of remouing out of England into the parts of America," 67; 1 Kings 10:4.
} 
colony than the management of a mere sheepfold or household. In these examples Cotton presents wisdom as both a cause and an incentive of colonization; wisdom both motivates and enables the colonial venture in New England.

To summarize: Cotton's foundational sermon, which literally launched the Massachusetts Bay Company, diverges from the apologetical norms of colonial discourse. He elides the edenic enterprise of establishing foreign plantations with the biblical establishment of Solomon's house and replaces the conversion of the Indians with the acquisition of Solomonic wisdom as the primary pretext for colonial practices. The New England portrayed in Gods Promise to His Plantations is a place where Solomon's house and the "vacant soyle" of Eden converge, a place where lost knowledge and wisdom can be recovered. It is, in short, a place of Baconian proportions and relations where, as Denise Albanese argues regarding the island of Bensalem, "the flow of knowledge typical of colonialism" is reversed; it flows instead "from the inhabitants to the seamen" as Cotton instructs Winthrop and his party to discover wisdom in the natural artifacts and native inhabitants of New England. ${ }^{31}$ If Cotton himself was not familiar with Bacon's Instauration or New Atlantis, he was—until his removal to New England in 1633 - a member of the Spiritual Brethren in England who adopted Bacon's works as a sort of blueprint for national perfection, and his farewell sermon converts the rudiments of Bacon's plan for the restoration of edenic wisdom into a pretext for the Puritan removal to New England. ${ }^{32}$

\footnotetext{
${ }^{30}$ Cotton, Gods Promise to His Plantations, 9.

${ }^{31}$ ibid, 5; Denise Albanese, New Science, New World, (Durham: Duke University Press, 1996), 114. Albanese provides an insightful examination of Bacon's connections to the New World and argues that the New Atlantis, like Cotton's sermon, must be understood as a commentary on and justification for colonial practices.

${ }^{32}$ For a discussion of Cotton's closeness to the Spiritual Brethren in England, see Janice Knight, Orthodoxies in Massachusetts, (Cambridge: Harvard University Press, 1994), 34-71. On the relationship between the Spiritual Brethren and Bacon's Instauration, see Charles Webster, The Great Instauration, (London: Gerald Duckworth, 1975), 32-99.
} 


\section{The Aims of a College: Harvard's Place in the Paradisiacal Tradition}

Once the Bay Company had arrived in New England, they demonstrated their continuing commitment to the pursuit of Solomonic wisdom enjoined upon them in Cotton's sermon by raising funds to establish a college in a timely manner. Winthrop's company sailed on April 8, 1630, and Cotton Mather's history of Harvard states that only four months later a "General Court, held at Boston, September 8, 1630, advanced a small sum (and it was then a day of small things), namely, four hundred pounds, by way of essay towards the building of something to begin a Colledge ... which might hereafter grown into an University." ${ }^{33}$ By speedily establishing a college which "was often referred to as "the School of the Prophets,"' Harvard's founders announced their interest in recapturing the paradisiacal intellectual perfections of Adam. As George H. Williams explains, early New Englanders who modeled Harvard after the Old Testament school of the prophets, implicitly adopted

the guarded theological surmise that, in some sense, what had been lost in Paradise by Adam's overweening grasp for the knowledge of good and evil had been partially restored in the disciplined fellowship of the school of the prophets. ... they thought of paradisic truth as being limited to duly ordained teachers. According to this view, the truth of Paradise as possessed by Adam before the Fall, a universal truth, had been safeguarded in the corporate custody of disciplined teachers devoted to Christ and his Church and dutifully communicated to posterity. Only in some such manner could a Christian institution of learning justify its existence in the face of the anti-intellectual implications of the biblical account of Adam's fall. ${ }^{34}$

In the seventeenth century, universities were understood to be places where a portion of

\footnotetext{
${ }^{33}$ Cotton Mather, Magnalia Christi Americana, ed. Thomas Robbins, trans. Lucuius F. Robinson, Vol. II, (Hartford: Silas Andrus \& Son, 1853), 9. In actuality, as Samuel Morison attests, the General Court wherein Harvard's beginnings were announced was held on September 8, 1636, six years after the date given by Mather. But Mather's error exaggerates the truth about Puritan interest in education only in relative, not absolute terms: "no other European colony managed actually to establish a college of liberal arts so shortly after its foundation as the Colony of Massachusetts Bay." See Samuel Eliot Morison, Three Centuries of Harvard, (Cambridge: Harvard University Press, 1936), 5. On the actual court session of 1636 in which the money for Harvard was appropriated, see Morison, The Founding of Harvard College, (Cambridge: Harvard University Press, 1935), $161-70$.

${ }^{34}$ Morison, Three Centuries of Harvard, 24; George H. Williams, Wilderness and Paradise in Christian Thought, (New York: Harper \& Brothers, 1962), 148.
} 
Adam's prelapsarian wisdom had been preserved, and leaders of the Bay Company were anxious "to form a COLLEDGE, wherein a succession of a learned and able ministry might be educated" so that their access to this wisdom would not be dependant on a stream of university-educated immigrants. ${ }^{35}$

In the Magnalia Christi Americana (1702) Cotton Mather compares Harvard to a "river, the streams whereof have made glad this city of God ... and a poor wilderness indeed it had been, if the cultivations of such a Colledge had not been bestowed upon it." Mather sees the college as an antitype of the irrigation channel described by John in Revelation,

a pure river of water of life, clear as crystal, proceeding out of the throne of God and of the Lamb. In the midst of the street of it, and on either side of the river, was there the tree of life, which bare twelve manner of fruits, and yielded her fruit every month: and the leaves of the tree were for the healing of the nations. And there shall be no more curse. ${ }^{36}$

The river running through the New Jerusalem is a means whereby edenic conditions are restored to the earth; as the waters go forth, the curses laid upon mankind in Eden are "healed; and every thing shall live whither the river cometh." ${ }^{37}$ For Mather, Harvard performs a similar function, preserving and disbursing a portion of Adam's intellectual attainments to local clergymen engaged in the work of restoring the New England wilderness to the paradisiacal state of that city of God, the New Jerusalem. Until the whole earth was restored to its original perfections-whether by Bacon's Instauration, the millennium's arrival, or both-Mather and other early New Englanders hoped that Harvard would be a bastion of edenic knowledge and idealism in a fallen world.

\footnotetext{
${ }^{35}$ Mather, Magnalia Christi Americana, 8.

${ }^{36}$ ibid, 19, 27; Revelation 22:1-3.

${ }^{37}$ Ezekiel 47:9.
} 


\section{$\underline{\text { The Monastic and Parisian Traditions }}$}

Although Harvard was located in the New World, it was designed to provide an Old World education and to produce graduates who would compare favorably with the alumni of Cambridge in quality, if not in number. "Yet, if Cambridge and her colleges were the immediate models, the ancestry of Harvard goes back through Oxford to Paris" and the tradition of monastic learning that had given rise to the first university of northern Europe. "It was not," as Samuel Eliot Morison notes, "that they knew no other way of conducting a school of higher learning," but rather that they aspired to the ideals espoused at the University of Paris. ${ }^{38}$ Indeed, Mather's characterization of Harvard as the river which flows forth from the New Jerusalem nicely parallels Pope Gregory's thirteenth-century description of the University of Paris. Gregory explains that the hand of the Almighty planted aforetime a Paradise of pleasures in Paris, a venerable gignasium of letters, whence arises the font of wisdom, which, channeled in the four faculties—namely theology, jurisprudence, medicine, and philosophy (rational, natural, and moral)—-like unto the four rivers of Paradise is distributed throughout the four climes, drains and irrigates the whole world, and from which, further, how much and diverse spiritual and temporal progress Christianity has experienced! $!^{39}$

Gregory's river originates in Eden ande Mather's springs in the New Jerusalem, but both rivers - and universities — serve to distribute the knowledge of paradise throughout the world.

\footnotetext{
${ }^{38}$ Morison, The Founding of Harvard, 5; Morison, Three Centuries of Harvard, 12. Nathaniel Eaton, the first teacher at Harvard, and other early New England founders were educated at Dutch universities that provided an alternative model for higher learning.

${ }^{39}$ As quoted in Williams, Wilderness and Paradise in Christian Thought, 167. Williams's note on the use of gignasium, as opposed to gymnasium, is instructive: "This is an occasional medieval variant of gymnasium; but the allusion to gigno [from the Latin verb gignere, meaning to beget] is inescapable and with it the implication that, though begetting was the physical occasion of the Fall, the generation of learning under the tutelage of faith may well be the spiritual means whereby Paradise will be restored."
} 
This association of the University of Paris with paradisiacal knowledge - and by extension Harvard's relationship to edenic ideals-was an inheritance from medieval monks who believed that the perfections of Eden could be restored within the monastery's walls through asceticism and intensive study. ${ }^{40}$ Jerome teaches that the monastery should imitate the first school of the prophets instituted by Samuel at Kirjath-sepher and maintained by his prophetic successors; monks should pattern their lives after the "sons of the prophets, whom we consider the monks of the Old Testament." These models of academic achievement "built for themselves huts by the waters of Jordan and, forsaking crowded cities, lived in these on pottage and wild herbs," and Jerome exhorts monastic imitators to "make your cell your Paradise, gather there the varied fruits of Scripture."41 The monks who sought to restore paradise through study also harvested the literal fruits of paradise; John Prest affirms that "Benedictine monasteries all possessed Paradise gardens, and in the later Cicstercian order every monk was allotted his own little plot or Paradise to look after.” The walled paradise gardens of medieval monasteries eventually led "to the equation of the enclosed garden with the Garden of Eden,"42 and College Yard-the original home for Harvard's students who, like their monastic predecessors, also "were called "the Sons of the Prophets"”-was transformed into just such an enclosed garden immediately after its purchase. Morison explains that under the direction of Nathaniel Eaton, the first professor at Harvard, College Yard "was enclosed in a six-foot pale fence, and thirty apple trees were set out." Though the Yard was then surrounded by cow pastures, its orchard and fencing were more symbolic of

\footnotetext{
${ }^{40}$ For a description of the relationship between the monastery and the university, see Williams, Wilderness and Paradise in Christian Thought, 38-46 and 158-83.

${ }^{41}$ As quoted in Williams, Wilderness and Paradise in Christian Thought, 159. The link between Samuel and Kirjath-Sepher is established in Morison, The Founding of Harvard, 5.

${ }^{42}$ John Prest, The Garden of Eden, (New Haven: Yale University Press, 1981), 21.
} 
the intellectual heritage they represented than a practical measure against the incursion of cattle; as Morison notes, "six-foot-and-a-half paling was excessive precaution against the most enterprising of bovine timber-toppers. ${ }^{, 43}$ If an astute Benedictine such as Brother Cadfael could have walked out of Edith Pargeter's novels and into the original College Yard, he might even have recognized that Harvard, with its devotion to religious learning and its enclosed garden, was indebted to monastic traditions of paradisiacal learning.

Just as medieval monks patterned their monasteries after the biblical example of Samuel's school of the prophets, so too observers of the universities in Paris and Cambridge imagined those communities to be modern renditions of the city Kirjath-Sephir, where Samuel's school was located. Mather describes Newtown (which would become Cambridge, Massachusetts in deference to the alma mater of most of Harvard College's first Overseers) as "being the Kiriath Sepher appointed for the seat" of Harvard, and Gregory also "wrote of Paris as Kirjath-Sepher.” Even Bernard of Clairvaux, a twelfth-century Cistercian abbot, acknowledged that the University of Paris had inherited the monastic tradition of Samuel:

Just as the Queen of Sheba is said to have come with a large retinue, that by the sight of her own eyes she might have surer knowledge of those things whose fame she had eagerly absorbed from afar, so you too [he writes to Hergald, a student] came to Paris and found, sought out by many, compressed as in a replica-Jerusalem. ... Here the wisdom of Solomon is open for the instruction of all who have converged upon the city. Here his treasure house is thrown open to eager students. ... it truly deserves to be called Kirjath-Sepher. ${ }^{44}$

Just as Cotton identifies New England as a place where Solomonic wisdom can be obtained by following the example of the Queen of Sheba and through obedience to the edenic injunction to colonize and subdue the world, Gregory and Bernard see the academic

\footnotetext{
${ }^{43}$ Morison, Three Centuries of Harvard, 24, 7; Morison, The Founding of Harvard, 229. For more on the association between paling and Eden, see Chapter 1, pp. 93-94.

${ }^{44}$ Mather, Magnalia Christi Americana, 9; Williams, Wilderness and Paradise in Christian Thought, 165, 164.
} 
community of Paris as a place where Solomonic and edenic ideals are mutually realized. The university itself is both the house of Solomon and an institution inextricably connected to project of edenic restoration, as Bacon understood when he named Bensalem's exemplary academic institution both Salomon's House and the College of the Six Days Works.

Later University of Paris administrators reinscribed this connection. In a sermon by John Gerson, a fifteenth-century chancellor, the personification of the University cries out, "Alas! I am she who was first breathed into Adam" in Eden; elsewhere Gerson argues that "[a]s a daughter of Solomon (at once the philosopher-king and the type of Christ), the University is the mother of sciences and may forthrightly speak by authority of the wisdom of Solomon." 45 The University of Paris—and, by extension, all institutions consciously modeled after it, including Harvard - was a place where the wisdom of Adam and of Solomon had been preserved; it was a reservoir from which small draughts of "the water of life" were carefully meted out to students. This was the heritage of Harvard College and the nature of the institution that the Bay Colony established in order "to advance Learning."46

\section{The Institutionalization of Induction}

While the advancement of learning was the stated purpose of Harvard, historians have mistakenly assumed that its first Overseers and President did not take Bacon's treatise of the same name seriously. Bacon was present and accounted for from Harvard's beginnings; his Essays and The Advancement of Learning were both included in the library bequeathed to the school in its first month of existence by John Harvard, and a 1620 edition of the Instauratio Magna, together with additional copies of The Advancement of Learning, were acquired from other sources. The catalogue of John Harvard's library also includes Bacon's Sylva Sylvarum

\footnotetext{
${ }^{45}$ As quoted in William, Wilderness and Paradise in Christian Thought, 178, 179.
} 
(1627), the natural history with which the New Atlantis was published—a text whose presence at Harvard was overlooked by Morison and others, presumably because the cataloguer lists it as a text by "Lord Verulam" instead of grouping it with Bacon's other works. ${ }^{47}$ This extensive collection of Bacon's works notwithstanding, Morison argues that "it is doubtful if anyone who had to do with the founding of Harvard, except John Winthrop, Jr., had accepted Bacon's inductive and experimental method which was destined to revolutionize science and indeed all learning." Yet I would present the sermons of Cotton and Norton as evidence that they were sympathetic to Bacon's cause, and there are two other clear exceptions to this generalization: John Eliot and Hugh Peter. Though Eliot was not formally attached to the College, his stature as a minister and the overseer of Harvard's feeder school at Roxbury allowed him to influence College policy; he was responsible for 1649 legislation regulating the length of Harvard students' hair. ${ }^{48}$ Eliot was also committed to Baconian aims, and in a letter to Richard Baxter he expressed hope for the "Advancement of Learning in these late Days," in which the edenic restoration prophesied in Revelation was to be accomplished "by putting Power and Rule into the Hands of the Godly, Learned in all Nations. ${ }^{, 49}$ Peter's connections to Harvard and Bacon are even more obvious. He was one of the first Overseers of Harvard College who, with Thomas Welde, led the College's first fundraising drive in London from 1641-42, and Webster states that "Peter was clearly in sympathy with Baconian reform of education. He commented favourably on schemes for the

\footnotetext{
${ }^{46}$ Revelation 22:1; Anonymous, New Englands First Fruits, (London: R. O. and G. D., 1643), 12.

${ }^{47}$ See Alfred C. Potter, "Catalogue of John Harvard's Library," in Publications of the Colonial Society of Massachusetts, Vol. XXI, (Boston: The Colonial Society of Massachusetts, 1920), 198, 212.

${ }^{48}$ Morison, The Founding of Harvard College, 77; for an account of Eliot's tirade against Harvard students who wear "long haire after the manner of Ruffians and barbarous Indians," see Morison, Harvard College in the Seventeenth Century, 88-89.

${ }^{49}$ As quoted in Richard Baxter, Reliquiae Baxterianae, ed. Matthew Sylvester, (London: 1696), 294.
} 
advancement of learning; and he believed that some tutors should be dispatched abroad, like the Merchants of Light of New Atlantis, to ensure that the universities were acquainted with the most recent discoveries." It seems all but certain that Eliot, Peter, and Winthrop Jr.—or some combination of all three-were responsible for the preparation of New Englands First Fruits, the anonymous 1643 tract that provides the first printed account of Harvard and in which the phrase "to advance learning" appears; from the beginning then, Bacon's The Advancement of Learning and the advancement of learning at Harvard were undoubtedly related educational programs. ${ }^{50}$

There are other reasons to consider the pessimism of Morison and Miller with regard to Bacon's place among Harvard's founders as being overblown. Even as Henry Dunster officiated over the first commencement exercises in 1642, there was "some reason to believe that, as President, Dunster was not expected to be the master of Harvard College." That position was intended for one of Bacon's heirs, a Czech educational reformer named Johannes Amos Comenius. Cotton Mather writes that Comenius was persuaded by Winthrop

\footnotetext{
${ }^{50}$ Webster, The Great Instauration, 193. Peter's Baconian leanings are evident in his Good Work for a Good Magistrate (1651), where he notes that "For the Advancement of Learning, Lord Verulam [Francis Bacon] hath propounded manie excellent things, and more may bee added by other learned men; for doubtless, Learning will mightily improve all other things, if so regulated, as self might bee less, and the publick more intended." See Hugh Peter, Good Work for a Good Magistrate, (London: William Du-Gard, 1651), 73-83. Winthrop Jr. joined the Harvard fundraising mission that left in 1641 and traveled with Peter and Thomas Welde to England. Since the information regarding Harvard is ostensibly from Boston and is dated September 26, 1642, Winthrop Jr. and Peter could only be considered an author if he had prepared an earlier, original draft of the account for publication. Eliot is clearly responsible for the description of Indian evangelism described in New Englands First Fruits, and it is possible he could have written the other sections as well. Worthington Ford attributes the authorship to Welde, who with Peter was in charge of the fund drive, but Winthrop Jr. and Peter seem equally likely possibilities. Peter was engaged in the same work as Welde, and Winthrop Jr. was also apparently entrusted with college business during his time in London-while there he offered the presidency of Harvard to Johannes Amos Comenius. As for Cotton-who may have been involved in preparing the account that was edited by one or more from the group of Welde, Peter and Winthrop Jr., Ford notes that he likely would have at least signed the original document that transcribed the commencement exercises in his capacity as an Overseer of the college. Moreover, Cotton, like Peter, had a good relationship with Henry Overton, who paid for the publication of New Englands First Fruits as well as Cotton's The Churches Resurrection (1642), three editions of A Modest and Cleare Answer (1642), five editions of The Keyes of the Kingdom of Heaven (1644), and two printings of Milk for Babes (1646). For more on the authorship of New Englands First Fruits, see Worthington
} 
Jr. "to come over into New-England, and illuminate this Colledge and country, in the quality of a President: But the solicitations of the Swedish Ambassador, diverting him another way, that incomparable Moravian became not an American. ${ }^{, 51}$ Morison explains that Winthrop Jr. was apparently "asked by the first Board of Overseers, when he went abroad in 1641, to invite some outstanding figure in education to be Master of Harvard College—someone whose name alone would advertise the College, and attract more students from England." The Czech scholar happened to be in London when Winthrop Jr. arrived because he had come at the behest of Samuel Hartlib, who hoped to make him the master of another new institution of higher learning whose pedagogical plans and aims Comenius had outlined in a private letter to Hartlib and then again in Conatuum Pansophicorum Dilucidatio (1638). Comenius's plans for this Pansophic College "had been given powerful stimulus by two works of Francis Bacon which greatly influenced Comenius-the Magna Instauratio Scientarum and the Novum Organum," and Daniel Murphy argues that these works provided Comenius a "synthesis of classical-humanist and realist principles [that] was strongly in evidence in De Disciplinis, the work in which he set out the main principles of his pedagogic philosophy." ${ }^{52}$ When Winthrop Jr. offered Comenius the presidency of Harvard, he sought the services of a man thoroughly committed to both the methods and aims of Bacon. Nor can it be assumed that Winthrop Jr.—supposedly Bacon's lone supporter among the founders of

C. Ford, "New Englands First Fruits," Proceedings of the Massachusetts Historical Society, Vol. XLIII, (Boston: Massachusetts Historical Society, 1909), 259-66.

${ }^{51}$ Morison, The Founding of Harvard, 243; Mather, Magnalia Christi Americana, 14. Morison provides a helpful elucidation of Mather's rather abbreviated account of this episode, including several factual corrections. Woodward argues that Winthrop actually wanted Comenius to found a college in Connecticut; see Prospero's America, especially chapters two, "The Republic of Alchemy and the Pansophic Moment," and three, "Founding a New London." For a full treatment of Comenius's connection to Harvard, see Albert Matthews, "Comenius and Harvard College," Publications of the Colonial Society of Massachusetts, Vol. XXI, (Boston: The Colonial Society of Massachusetts, 1920), 146-90.

${ }^{52}$ Daniel Murphy, Comenius, (Portland: Irish Academic Press, 1995), 20, 69. 
Harvard — acted alone. Welde and Peter, two of the College's Overseers, were with Winthrop Jr. in London at the time of his audience with Comenius, and there is no question that Peter gave his assent to the plan; Welde likely concurred as well. More importantly, perhaps, Winthrop Jr. must have known that his choice would need the approval of the full Board; he would not have offered the job to Comenius if he thought the other Overseers-Cotton, John Wilson, John Davenport, and Thomas Shepard—would have objected to Comenius on the grounds of his commitment to Bacon's Instauration.

Comenius, of course, did not come to Harvard, but a number of his books could be found, with Bacon's works, on the shelves of the first College Library and in the private collections of students. ${ }^{53}$ Like the College's first Overseers, the first graduates of Harvard also demonstrated a commitment to Baconian methods and were almost certainly introduced to Bacon during their time at the College; those who left documentary evidence of their leanings include Urian Oakes (A.B. 1649), Leonard Hoar (A.B. 1650), Thomas Shepard Jr. (A.B. 1653) and Increase Mather (A.B. 1656). These students, all of whom studied at Harvard under Dunster, the College's first president, relied on Bacon's logical processes. Oakes argues that "Wisedom lyes ... in the induction of particulars, and due Reasoning from it," and in another sermon he presents Solomon as a Baconian logician and model philosopher whose wisdom is proved in Ecclesiastes "by an Induction of Particulars." Shepard Jr. even uses the Baconian method to prove that God has provided his people in

\footnotetext{
${ }^{53}$ Comenius's Janua Linguarum (1631) was in wide circulation in early seventeenth-century New England; it was used to teach primary students at Boston Latin, and an edition that John Harvard referred to as Porta Linguarum Trilinguis was included in his personal collection that became the first College Library. Matthews provides evidence that Hartlib's 1642 English translation of Comenius's A Reformation of Schools reached Harvard, and Morison suggests that his Phsicae ad Lumen Divinum Reformatae Synopsis (1645) was in circulation among Harvard students well before 1665, when a Harvard scholar first signed his name to the volume. See Matthews, "Comenius and Harvard College," 184; Samuel Eliot Morison, Harvard College in the Seventeenth Century, (Cambridge: Harvard University Press, 1936), 234.
} 
New England with the experience of "not a wilderness nor a land of Darkness, but the contrary ... a fruitful Field," a spiritual paradise where wine, milk and honey flow (at least metaphorically). Similarly, Increase Mather argues that conversion reverses "the corruption of nature," producing "a new and another creature" who reflects "the Image of God" just as it was first reflected in Adam. For the new convert, "Heaven and Earth is new ... As in the first Creation" of Eden, and Increase Mather provides proof that this paradisiacal restoration is possible "by Induction of particulars." ${ }^{54}$ If Bacon's disciples failed to restore edenic conditions and intellectual perfection to the world at large, his methods were at least responsible for establishing the paradisiacal nature of New England and the edenic character of conversion in the minds of early Harvard graduates.

In Hoar the College found its third president and the first Harvard graduate to preside over his alma mater. Hoar arrived in 1672 with a plan to transform the school into a version of Salomon's House, and in a letter to Robert Boyle sent three days after he assumed the presidency, Hoar describes his vision of Harvard's future as a Baconian experimental laboratory. He writes that

A large well-sheltered garden and orchard for students addicted to planting; an ergasterium for mechanick fancies; and a laboratory chemical for those philosophers, that by their senses would culture their understandings, are in our design, for the students to spend their times of recreation in them; for readings or notions only are but husky provender. ${ }^{55}$

If Hoar's plans had come to fruition, Morison believes that New England would have been the seat of "the earliest university chemical laboratory in the English empire, if not in the

\footnotetext{
${ }^{54}$ Urian Oakes, New-England Pleaded With, (Cambridge: Samuel Green, 1673); Urian Oakes, The Soveraign Efficacy of Divine Providence, (Boston: 1682), 3; Thomas Shepard Jr., Eye-Salve, (Cambridge: Samuel Green, 1673), 8; Increase Mather, Some Important Truths Concerning Conversion, (Boston: Samuel Green, 1684), 2526.

55 As quoted in Morison, Harvard College in the Seventeenth Century, 645.
} 
world." Hoar thought that these facilities for experimentation would "encourage the country in its utmost throws for its resuscitation from ruin." Like Bacon, he hoped that the new philosophy would provide the means for transforming English society from its corrupt state (and New England Puritans had plenty to say about the corruptions of early Restoration England) into a prior, more perfect version of itself. ${ }^{56}$

Of course Hoar never realized his vision for Harvard. For an unknown reason, perhaps because he was a stern disciplinarian or offended his charges in some other way, the students of the College took exception to Hoar and sought "to ruine his reputation." Eventually, they even "deserted the Colledge," and in 1675 Hoar was forced to resign. But Bacon's influence continued at Harvard even without Hoar's help, leading Cotton Mather to proclaim in 1702 that "though the Ramæan discipline be in this college preferred unto the Aristotelæan, yet they do not so confine themselves unto that neither, as to deprive themselves of that libera philosophia, which the good spirits of the age have embraced, ever since the great Lord Bacon show'd 'em the way to the 'advancement of learning." ${ }^{57}$ At Harvard, Bacon and Eden were the texts from which students were taught about the natural world; as Charles Chauncy, the College's second president, explained, "the first \& second chapters of Genesis ... do afford excellent and sure grounds for natural Philosophy, and a just systeme thereof." ${ }^{58}$ The plain style of Ramus continued to influence Puritan rhetorical modes throughout the seventeenth century, but the examples of Norton, Cotton, Winthrop Jr., Oakes, and others demonstrate that the edenic aims and methods of Bacon were not necessarily inconsistent with the principles of New England Puritanism.

\footnotetext{
${ }^{56}$ Morison, Harvard College in the Seventeenth Century, 401; as quoted in ibid, 645.

${ }^{57}$ Cotton Mather, Magnalia Americana Christi, 15, 21.

${ }^{58}$ Charles Chauncy, Gods Mercy, (Cambridge: Samuel Green, 1655), 37.
} 


\section{The Wisdom of Anne Bradstreet: Imitating Elizabeth, Outdoing Solomon ${ }^{59}$}

Bacon's College of the Six Days Work is not an equal-opportunity institution of higher learning: men perform the experiments, men administer the College's affairs, and men are the only ones (as far as the text discloses) who even discuss its aims and methods. Early modern universities were also exclusively male, in part because of their monastic roots, and seventeenth-century Harvard was no exception, leaving women in search of Solomonic wisdom to find — or build from scratch—-their own pathway to Eden. Of course, Eden itself was the problem, the reason that women were denied access to wisdom in the first place. It was the wisdom of Adam that individuals like Solomon and institutions like Salomon's House worked to preserve and restore; the theologians of seventeenth-century New England generally condemned Eve as a sinful woman whose pursuit of knowledge and wisdom brought about the Fall of humanity. While later ministers such as Benjamin Colman and Jonathan Edwards praised Eve, early New England preachers found little to say about her that was positive. ${ }^{60}$ Else Hambleton titles her study of adultery in colonial Massachusetts Daughters of Eve, and she describes adultery as an activity commonly associated with Eve by New England Puritans. Ministers criticized her for being "unable [...] to practice sexual discipline" and taught that each woman's "hold on salvation was tenuous because of her relationship to Eve"; naturally, those who expressed approbation for Eve's behavior or imitated her quest for wisdom were seen as threats to the Puritan project of establishing an

\footnotetext{
${ }^{59}$ Many of the ideas and much of the language in this section will be published in the near future under the title, "The Wisdom of Anne Bradstreet: Eschewing Eve and Emulating Elizabeth," Modern Language Studies 40.1 (2010): (forthcoming). They appear here by the permission of Laurence Roth, editor of MLS.

${ }^{60}$ The notable exception here is John Winthrop who, though not a minister, delivered a lay sermon lauding Eve for her charity, as noted in the Introduction, pp. 5-7. For a discussion of Eve's place in early modern New England and the proto-feminist exegesis of Jonathan Edwards, see my article, "Edwards and Eve: Finding Feminist Strains in the Great Awakening's Patriarch," Early American Literature 43.3 (2008): 671-86. Select portions of this argument are also incorporated into Chapter 5 of the present work.
} 
ideal society. ${ }^{61}$ For women in seventeenth-century New England, the acquisition of edenic or Solomonic wisdom was not a matter of restoration but of appropriation. Wisdom was a trait to be wrested away from its male possessors by women, whose interest in intellectual progress was understood to be fraught with theological danger because of Eve's example.

\section{The Gender of Wisdom}

The Puritans recognized two different types of knowledge or wisdom—a godly wisdom which William Scheick calls sapientia, and a worldly wisdom he terms scientia. ${ }^{62}$ Cotton delineates the distinctions between these two forms of wisdom in his sermons on Ecclesiastes: scientia is "an acquisite wisdome, to wit, natural or civil wisdome, gotten from the observation of the creatures or of humane affaires" and necessary for governance; sapientia, on the other hand, consists in a process of spiritual and intellectual enlightenment brought about through "Christ and his grace, which is true wisedome" and made available only to prophets and preachers since the Fall. ${ }^{63}$ Because Bay Colony preachers frequently make no distinction between the two and use the word wisdom in referring to either, I have not previously distinguished between them; Cotton's exhortation to the departing Bay Company and the educational aims of Harvard College encompass both scientia and sapientia. In describing a woman's quest for wisdom in seventeenth-century New England, however, it is necessary to differentiate the two because while Puritan ministers encouraged women to obtain a measure of scientia by observing the natural world and reading from the

\footnotetext{
${ }^{61}$ Else L. Hambleton, Daughters of Eve, (New York: Routledge, 200), xiii, 8.

${ }^{62}$ William J. Scheick, Design in Puritan American Literature, (Lexington: University Press of Kentucky, 1992), 36. On the relationship between Cotton and Bradstreet, see Chapter 2, p. $127 f$.

${ }^{63}$ Cotton, A Brief Exposition with Practicall Observations Upon the Whole Book of Ecclesiastes, 32, 33. In prelapsarian Eden, of course, both Adam and Eve enjoyed sapientia because they resided in God's presence. In mortality, this true wisdom causes the face to shine as Moses' face shone after he descended from Mount Sinai and Jesus' shone on the mount of transfiguration. It symbolizes the recipient's entrance into God's presence and the regaining of an Eden-like communion with God.
} 
divine book of nature, these observations were intended to edify a woman personally, not to endow her with the temporal authority associated with scientia or the spiritual authority linked to sapientia.

Cotton and other Bay Company ministers taught that women were not suited for governance; each woman needed to learn "her due place: she is a second, not a first; she is not above her husband (for he is her head, Ephes. 5.23)." Nor did women enjoy the spiritual standing necessary to receive sapientia; while there was a "great scarcity of good men," there was "a greater scarcity of good women." Cotton does acknowledge the existence of at least one wise woman (David's wife Abigail), but the majority of his commentary on Ecclesiastes regards the prospect of a woman in possession of wisdom skeptically at best. Cotton teaches that women lack the spiritual aptitudes of men because of "their greater liability to deceit and temptation [...] their greater vehemency and impotency in their passions and lusts, not only on good objects, 2 Sam. 1.26 but on evil also, 1 Kings 21.25 [...] their great superstition."64 As the original victim of Satan's deceit and temptation, Eve epitomized frailty and weakness in seventeenth-century theology; her quest for scientia and sapientia in the garden of Eden set a terrifying precedent used to justify the exclusion of women from an ongoing masculine and ministerial quest for wisdom.

Anne Bradstreet's own search for a socially acceptable way in which women could gain wisdom has led modern critics to identify her with Anne Hutchinson (who nearly brought about the Fall of the Bay Colony) and John Milton's Eve alike, but her contemporaries found her to be utterly orthodox, and we mistake her feminist quest to

\footnotetext{
${ }^{64}$ ibid, 84, 158-59.
} 
acquire wisdom for heresy at our own peril. ${ }^{65}$ Bradstreet removes the stigma attached to women who seek wisdom without sacrificing her faith and while writing within the confines of an orthodoxy highly critical of Eve's decision to pursue the scientia and sapientia that Adam possessed naturally. In "Contemplations" Bradstreet acknowledges Eve's legacy and the problems that it creates for women, but she also expresses a longing to escape that legacy and reenter Eden's eternal spring. Then, in “In Honour of that High and Mighty Princess Queen Elizabeth," and in “The Vanity of All Worldly Things," Bradstreet codifies a via media that will allow women to access Solomonic wisdom without rejecting Puritan orthodoxy, carving out a pathway by which she can lay hold on the wisdom that Adam enjoyed but that Eve sought in vain. Ultimately, the wisdom of Anne Bradstreet does not lie in her reaction to the stringencies of Puritanism but in her original contribution to its complexities as she made the edenic and Solomonic wisdom that (real and hypothetical) institutions of higher learning purportedly provided to men available to women as well.

\section{$\underline{\text { Bradstreet and the Critics }}$}

Because Hutchinson combined her quest for gender equality with heterodox theology, critics continue to conflate the two issues when studying contemporary women such as Bradstreet, making Bradstreet's affirmation of orthodox doctrines into a pose of submission and her poetic objections to gendered hierarchies tantamount to heresy. ${ }^{66}$ But a close reading

\footnotetext{
${ }^{65}$ Hereafter, I will refer to this search as "feminine wisdom," not because it is a type of wisdom that is uniquely feminine but to describe a means by which women can gain the wisdom traditionally reserved for men. Obviously, the notion of a single, monolithic Puritan orthodoxy is somewhat archaic and obsolete; Janice Knight's Orthodoxies in Massachusetts clearly demonstrates that the social and religious community that outsiders identified as Puritans allowed individuals significant theological latitude in certain areas. Still, Brasdstreet's good social and ecclesiastical standing, as well as her publishing success (Bradstreet's volume rated highly in William London's 1658 Catalogue of the Most Vendible Books in England, and John Foster's 1678 second edition of her poetry was one of the first colonial imprints whose domestic commercial appeal made governmental sponsorship unnecessary) speak to her acceptability among these various orthodoxies.

66 Jeannine Hensley, in her 1967 introduction to Bradstreet's works, suggests that Bradstreet's "little book of verse has survived to gain some warm admirers in its third century" and that she deserves the wreath of
} 
of Bradstreet's poems reveals neither a writer who meekly accepts predominant Puritan views on gender nor one who wholly rejects the theological tradition in which she writes. Instead, many of Bradstreet's poems, both those labeled subversive and those labeled submissive, detail her negotiation for the edenic and Solomonic wisdom that her male counterparts sought within the walls of Cambridge and the paling of Harvard. Bradstreet does advocate gender equality and does innovate theologically, but she operates within the confines of her faith; the via media she prescribes encourages women to participate fully in

thyme her poem requests. Those first warm admirers appreciated Bradstreet primarily because she rebelled against Puritan doctrines and patriarchy, but subsequent readers such as Robert Daly and Jeffrey Hammond have found Bradstreet's poetry to be utterly orthodox. New work by Robert Boschman, among others, has sought to divest Bradstreet scholarship of the polarity which divides Bradstreet criticism, but even in the twenty-first century, work on Bradstreet remains split between critics who argue that she rebelled against the religious culture in which she lived and those who suggest that she submitted to it. Boschman suggests that Bradstreet's poems "disclose not so much the patterned musings of a woman fomenting rebellion as the kinds of contradiction and paradox typical of many members of the Puritan commnity that had migrated to the New World." But even this relatively moderate position is skewed by the claim that Bradstreet "defies her God in late poems such as her elegy for her granddaughter Elizabeth." Lee Oser (2000), Michael Ditmore (2007), and Tamara Harvey (2008) are just three of the most recent critics to portray Bradstreet as a woman who employs "resistant or subversive poetic practices" in order to challenge "misogynistic literary [and religious] traditions". On the other hand, all three of Bradstreet's recent biographers-Douglas Wilson (2001), Charlotte Gordon (2005), and Heidi Nichols (2006) — seem to agree that "Anne Bradstreet completely accepted the teaching" of her Puritan ministers and "did not shrink back from doctrinal ramifications" that might have been distasteful. See Jeannine Hensley, "Introduction," The Works of Anne Bradstreet, ed. Jeannine Hensley, (Cambridge: The Belknap Press of Harvard University, 1967), xxiii; Robert Boschman, In the Way of Nature, (Jefferson: McFarland \& Company, 2009), 35, 36; Tamara Harvey, Figuring Modesty in Feminist Discourse Across the Americas, 1633-1700, (Burlington: Ashgate, 2008), 18; Douglas Wilson, Beyond Stateliest Marble, (Nashville: Highland Books, 2001), 159.

In a discussion of "Contemplations" published forty years after Hensley first brought Bradstreet's poems back into the academic limelight, Michael Ditmore reminds readers that the poem "has generally been received as a forceful, exemplary instance of Bradstreet's professed Christian faith" but insists that "its theology does not reflect what critics have come to understand as having been normative seventeenth-century New England values." The question of Bradstreet's orthodoxy continues to shape scholarly considerations of her work by encouraging readers to categorize her poems as either a rebellion against her authoritarian Puritan environment or a submission to it. Anne Braude argues forcefully that this critical "assumption of an inherent conflict between faith and feminism [is still] erroneously embedded in narratives of U.S. history," and Bradstreet scholarship has yet to recover from the impact. The truth about Anne Bradstreet's faith and feminism lies outside a hermeneutics of extremes; as Nina Baym notes, any rebellion or submission on the part of Anne Bradstreet in relation to gender and theology is "more complicated and subtle than the simple binaries" still used to define her. See Michael G. Ditmore, "Bliss Lost, Wisdom Gained: Contemplating Emblems and Enigmas in Anne Bradstreet's 'Contemplations,"” Early American Literature 42.1 (2007): 31, 55; Anne Braude, "Faith, Feminism, and History," in The Religious History of American Women, ed. Catherine A. Brekus, (Chapel Hill: The University of North Carolina Press, 2007), 234; Nina Baym, "Revising the Legacy of 1970s Feminist Criticism, Constance Fenimore Woolson's Nineteenth Century: Essays, ed. Victoria Brehn, (Detroit: Wayne State University Press, 2001), 28. 
the Puritan theocracy, not to escape from it (as early feminist critics proposed) or submit to it (as advocates of Bradstreet's orthodoxy have affirmed).

By refusing to recognize Bradstreet's authorial right to experiment and innovate within the confines of her faith, literary critics have in many ways assumed an authorship of her poems and relegated her to the status of a figurehead or character within them. This tendency manifests itself most obviously in the poetry of John Berryman, as Ivy Schweitzer notes, but also appears in the more recent critical work of Jeffery Hammond and Avery Fischer. ${ }^{67}$ Both Fischer and Hammond suggest that Bradstreet is more "like Milton's Eve" than Milton himself; by identifying Bradstreet with Eve the character rather than Milton the author, these critics strip Bradstreet of her authorial subjectivity and render her an object of their own critical readings. Fischer's argument that "the questions Bradstreet hints at in these poems, had she stated them, would have shown her to possess the same qualities separating Milton's Eve from God, including a need to criticize Providence and a desire for immortality" might easily have been rephrased to indicate that Bradstreet possessed "the same qualities separating [Milton himself] from God," a comparison that would have accorded Bradstreet an equality with Milton—at least in terms of her status as an author able to consciously shape a text. Instead, Fischer insists that Bradstreet "echoes Eve's" critique of God, concerned more with the shared identity of Bradstreet and Eve as women than with Bradstreet's ability, like Milton, to imagine the possibility of regaining paradise—or at least the wisdom of paradise. ${ }^{68}$

\footnotetext{
${ }^{67}$ See Ivy Schweitzer, The Work of Self-Representation (Chapel Hill, NC: The University of North Carolina Press, 1991), 127-80.

${ }^{68}$ Jeffrey A. Hammond, Sinful Self, Saintly Self, (Athens: The University of Georgia Press, 1993), 110; Avery Fischer, "Bradstreet's 'On my Dear Grandchild Simon Bradstreet and 'Before the Birth of One of Her Children,"' Explicator 59.1 (2000): 13, 12.
} 
Current critical postures that render Bradstreet a character and object lacking in rationality (a lack embodied by Eve's "wanton ringlets" in Paradise Lost) rather than an author and subject making informed decisions also suggest a critical susceptibility to modern gender trends explicated by Elizabeth Maddock Dillon. She proposes that the notion of a feminized private sphere derives largely from

the way in which women are displayed (even when 'naked,' particularly when 'naked') in public at the very moment when their private identity is seemingly articulated. Thus to say that women are absent from the public sphere because they are consigned to the private sphere is incorrect: rather, powerful public images of femininity identify women as private. ${ }^{69}$

In other words, the public efforts of Hammond and Fischer to explicate Bradstreet by comparing her to Eve, the most celebrated naked woman in history, paradoxically identify Bradstreet as private and unknowable even as they putatively attempt to make her poetry more accessible. Similarly, "the widespread critical assumption of two Bradstreets" has been fostered in an attempt to make Bradstreet's poetry more meaningful to modern audiences even as it obscures her preoccupation with reversing the effects of Eve's Fall. ${ }^{70}$ Ironically, Bradstreet's claims to wisdom have been obscured by her position as a symbolic image of naked femininity; critics have made her into a figure of the very woman whose legacy she seeks to escape: Eve.

\section{Bradstreet's Bloody Eve}

In "Contemplations" Bradstreet surveys the natural world in which she lives, examining the glory of each feature in the New England landscape as a means of drawing closer to God and preparing herself to receive sapientia by examining his handiwork. The

\footnotetext{
${ }^{69}$ Milton, Paradise Lost, IV.306; Elizabeth Maddock Dillon, The Gender of Freedom, (Stanford: Stanford University Press, 2004), 5.

${ }^{70}$ Hammond, Sinful Self, Saintly Self, 107.
} 
poet's contemplation of nature turns heavenward, led by the vertical lines of "a stately Oak" to the sky in stanza four:

Then higher on the glistering Sun I gaz'd, Whose beams was shaded by the leavie Tree;

The more I look'd, the more I grew amaz'd, And softly said, what glory's like to thee?

Soul of this world, this Universes Eye, No wonder some made thee a Deity: Had I not better known, (alas) the same had I. ${ }^{71}$

Bradstreet's admission that she, like the biblical Israelites, is tempted to worship the glories of nature hardly seems proper for a devout Puritan woman. Bradstreet acknowledges the idolatrous tone her poem's "wandring feet" have assumed, and she praises the "great Creator [...] That nature had, thus decked liberally: / But Ah, and Ah, again, my imbecility!" in returning to nature, the source of her idolatry! Determined to master her wayward self by drawing on the accumulated human knowledge and experience passed down in the Bible, Bradstreet looks to that text for instruction as to how she might praise God with "higher layes" than those reflected in nature. Bradstreet must "turn to the Book of Scripture, the Book given to humanity to inform reason through faith, as a partial replacement for lost sapientia," lacking "hope of finding [scientia and] consolation in nature until she is guided through its logogic signs by the Bible."72 Only by reviewing the lessons of the Bible can Bradstreet hope to transform her vain and idolatrous observations of nature into a productive understanding of God's handiwork and attempt to regain the sapientia she lacks.

Conscious of her own wayward inclinations, Bradstreet turns next to three biblical examples of sin, searching for a pattern of repentance. She portrays Adam, Eve, and Cain in

\footnotetext{
${ }^{71}$ Anne Bradstreet, "Contemplations," in The Complete Works of Anne Bradstreet, ed. Joseph R. McElrath, Jr. and Allan P. Robb, (Boston: Twayne Publishers, 1981), 168. On the citation of Bradstreet's poems, see the Introduction, p. 26f.

${ }^{72}$ Bradstreet, "Contemplations," 169; Scheick, Design in Puritan American Literature, 37.
} 
sorrowful hues, pointing out their weaknesses and frailty rather than their capacity for right and acceptable behavior. Given Bradstreet's reputation as a feminist, readers might expect her to reject the Puritan notion of Eve as an archetype of transgression in order to relieve women of her legacy. Instead Bradstreet unflinchingly associates Eve with all the sin and pain incumbent in the Fall:

Here sits our Grandame in retired place, And in her lap, her bloody Cain new born, The weeping Imp oft looks her in the face, Bewails his unknown hap, and fate forlorn; His Mother sighs, to think of Paradise, And how she lost her bliss, to be more wise, Believing him that was, and is, Father of lyes.

Bradstreet covers Eve with Cain's blood and suggests that her new-born child cries when he looks in her face. This imagery condemns Eve for the conditions of mortality and sin; after all, her bloody babe will commit the first murder and introduce death into the world. It is Eve who leads Bradstreet to the conclusion that "Nor youth, nor strength, nor wisdom spring again" in man. ${ }^{73}$

\footnotetext{
73 Bradstreet, "Contemplations," 170, 171. Jean Marie Lutes attempts to construe Bradstreet's bloody portrayal of Eve positively by describing Eve as "less a perpetrator of evil than a victim" in the poem, but her own research indicates that Bradstreet views Eve as a source of evil. Lutes argues for Bradstreet's familiarity with medical beliefs common to the seventeenth century; "belief in maternal impression was common enough $[\ldots]$ in the 1600s" that Bradstreet certainly would have been aware that "the mother's imagination was seen as a potent force "which operates as a sort of seal stamping the image of the mother's fancy on the child she has conceived in the womb."' In effect, by documenting Bradstreet's familiarity with this medical belief, Lutes argues that Cain's "ghastly face" in "Contemplations" is a reflection of Eve's face, that Eve is in some sense responsible for Cain's sins specifically in addition to a more general responsibility for the state of original sin into which he was born. Seventeenth-century subscription to maternal imaging posited that the mother's spiritual and emotional state during her pregnancy were transferred to the child at birth, and Bradstreet conveys a sense of Eve's spiritual waywardness, of her loss of sapientia in the garden, through Cain's grim face. See Jean Marie Lutes, "Negotiating Theology and Gynecology: Anne Bradstreet's Representations of the Female Body" Signs 22.2 (1997): $328,330$.

Bradstreet also refers to Cain as an imp, a label fraught with condemnation; the OED defines an imp as "a 'child' of the devil, or of hell," a connection that suggests Bradstreet may have agreed with radical sectarians such as Jacob Boehme, John Reeve or Lodowick Muggleton. Philip Almond reports that the fringe sects represented by this triumvirate believed that Eve engaged in intercourse with an actual serpent into whose spirit the devil had entered and that this act produced Cain, a child whose wickedness exceeded that of original sin. Whether or not Bradstreet believed in a sexual fall, her portrayal of Eve and Cain gazing guiltily into the other's
} 
But if Eve's example strips Bradstreet of hope in a restoration of the bliss and wisdom she forfeited in Eden, Bradstreet finds a new reason for optimism in the form of a nightingale who perches above her head and "wisht me wings with her a while to take my flight." The nightingale's song opens up a vision of Eden's eternal spring for Bradstreet; as each bird

tunes his pretty instrument,

And warbling out the old, begin anew,

And thus they pass their youth in summer season,

Then follow thee into a better Region,

Where winter's never felt by that sweet airy legion.

Bradstreet longs to follow that nightingale into "a better Region" where winter is always

subordinate to spring and where life, like the nightingale's song, can begin anew without the taint of Eve's past transgressions; the nightingale "Reminds not what is past, nor whats to come dost fear."74 The nightingale's example inspires Bradstreet with the hope that she too can forget the past—Eve's failed quest for wisdom — and find a future in which she need not fear repeating the mistakes of her "Grandame."

\section{$\underline{\text { Replacing Eve with Elizabeth }}$}

Bradstreet's faithfulness to Calvinist conceptions of Eve as an archetype of sin signals her commitment to orthodoxy, but her praise for Queen Elizabeth indicates that Bradstreet does not consider Eve's Fall a binding precedent for modern women seeking wisdom. ${ }^{75}$ In

face clearly connects the sins of the parent to those of the child and vice versa; Bradstreet's awareness of a prevalent belief in maternal impression renders the connection between Eve's sinful state and Cain's sorry visage unavoidable. See Philip Almond, Adam and Eve in Seventeenth-Century Thought, (Cambridge: Cambridge University Press, 1999), 173-74.

${ }^{74}$ Bradstreet, “Contemplations,” 173.

75 In enumerating the ways in which Bradstreet's Eve conforms to the Puritan archetype, I do not intend to contradict Nancy Wright's description of Bradstreet as an advocate for women who "refutes the argument that gender justifiably differentiates the positions and agency allotted to men and women" (258). Indeed, Bradstreet's insistence on Queen Elizabeth's possession of scientia, indicates that women are as capable of obtaining wisdom as are men; Eve's weakness in believing the father of lies thus becomes a function of her 
her encomium "In Honour of [...] Queen Elizabeth," Bradstreet celebrates the various accomplishments of that regent and honors her because "She hath wip'd off th' aspersion of her Sex, / That women wisdome lack to play the Rex.” These lines describe women as a group whose dominant perceived fault is a lack of scientia, the natural wisdom needed to govern in temporal affairs, and also suggest that Queen Elizabeth's singular display of scientia demonstrates the collective capacity for governance of all women. Perhaps most importantly, Bradstreet's recognition of the Queen's wisdom presupposes the poet's own scientia. As Nancy Wright explains, Bradstreet's "In Honour of Queen Elizabeth" is an authorial statement confirming "that she, like the queen, is a rational being" capable of governance ${ }^{76}$ At least in part, Bradstreet's praise also removes the stigma of Eve's failed quest for wisdom in the Garden of Eden. When Eve "lost her bliss, to be more wise, / Believing him that was, and is, Father of lyes," she seems to have been in pursuit of scientia, in search of a way to enter into the discourse of governance enjoyed by Adam and God when "God formed every beast of the field, and every fowl of the air; and brought them unto Adam to see what he would call them." ${ }^{, 77}$ Bradstreet makes the consequences of Eve's apparent failure to gain scientia irrelevant with her tribute to Elizabeth; the Queen's success, Bradstreet argues, proves that women can fill roles traditionally occupied by men.

Her praise for Elizabeth also indicates that Bradstreet views Eve as an individual instead of an archetype, transforming Eve's legacy of sin from one based on gender to one

individual character rather than a condition inherent in women. Seen in this light, Bradstreet's search for sapientia in "Contemplations" becomes a pattern by which women can obtain wisdom of either sort without incurring the sins of Eve. Rather than listening to "him that was, and is, father of lies" (85) as did Eve, Bradstreet shows women that they must seek wisdom by reading the texts God has left for their instruction: the Book of Nature and the Book of Scripture.

${ }^{76}$ Bradstret, "In Honour of that High and Mighty Princess, Queen Elizabeth, of Most Happy Memory," in The Complete Works of Anne Bradstreet, 156; Nancy E. Wright, "Epitaphic Conventions and the Reception of Anne Bradstreet's Public Voice," Early American Literature 31.3 (1996): 257. 
based on an erroneous approach to wisdom. In other words, Bradstreet suggests that Eve's desire for and possession of wisdom was not inherently wrong because of her gender but because of the means by which she gained it. By portraying Eve as sinful, ${ }^{78}$ Bradstreet acknowledges that individual women, like individual men, are fallible and that women who pursue wisdom in an inappropriate manner must be held accountable for the consequences of their actions. Bradstreet's descriptions of Elizabeth and Eve create criteria against which women who, like Bradstreet, seek scientia may be judged. Although Bradstreet's criteria are subjective, their existence suggests that women who choose to imitate successful feminine models like Queen Elizabeth are worthy of a voice in the public sphere, while women who seek sapientia do not pursue that form of wisdom under an inherent disability of gender. In creating dichotomous paths to wisdom Bradstreet signals that a feminine pursuit of wisdom should no longer be considered reprehensible simply because of Eve's precedent.

\section{$\underline{\text { Assuming Solomon's Mantle }}$}

In “The Vanity of All Worldly Creatures,” Bradstreet catalogs the blessings offered by a beneficent God to devout individuals who reject the vain cares of this mortal world and

\footnotetext{
${ }^{77}$ Genesis 2:19.

${ }^{78}$ Even for readers unfamiliar with the theory of maternal imaging, Bradstreet's description of Eve would suggest a link between the child's grief and the mother's sin, connecting the baby's character to his mother's countenance: Cain, lying on his mother's lap, "oft looks her in the face," perhaps reading there a record of her sin in seeking wisdom and "Believing him that was, and is, father of lies." For Cain, an infant lying on Eve's lap, only her face can convey to him the understanding of "his unknown hap and fate forlorn" and cause him to cry. Read in the context of contemporary medical knowledge, Bradstreet's attribution of Cain's sinful nature to Eve is not "theologically awkward" as Ditmore argues; it is scientific fact. Bradstreet's description of Cain's bloody birth and Eve's reaction to that event recalls Cotton's description of "birth [as] the seed time of corruption" more than Lute's depiction of birth as a celebration of feminine power. Cotton preached that "birth putteth us into the hands of Midwives, and other weake women," and Bradstreet's portrayal of Eve mourning the Fall while holding a bloody, wailing infant seems calculated to emphasize Eve's weakness. Bradstreet does not seek to mitigate Eve's guilt, and her willingness to write negatively about the prototype of femininity must be accounted for by any discussion of "Contemplations" before we can accept gendered readings of the poem. See Ditmore, "Bliss Lost, Wisdom Gained: Contemplating Emblems and Enigmas in Anne Bradstreet's 'Contemplations,'" 37; Cotton, A Brief Exposition with Practicall Observations Upon the Whole Book of Ecclesiastes, 116-17.
} 
defends the right of women to seek after the sapientia traditionally limited to men such as

Solomon. The poem's scriptural content facilitates its dismissal as "conventionally

Puritan," ${ }^{, 79}$ but its structure and assertive tone suggest that Bradstreet contends for the advancement of a feminine wisdom within Puritan culture even as she reaffirms the salvific power of Puritan religious experience. Almost all Puritan poems include numerous scriptural references, and although a significant subset of those poems offer a paraphrase or new translations of scripture (most noticeably The Bay Psalm Book), Bradstreet's "Vanity" is somewhat unique in that the poem not only restates but also rewrites scripture and grants Bradstreet standing with canonized prophet-poets. The very opening line proclaims Bradstreet's pretensions to canonical authority: "As he said vanity, so vain say I." Bradstreet's repetition of "vanity," the central theme of Ecclesiastes, is perfectly conventional in and of itself, but by claiming to speak the words of Ecclesiastes de novo in the same inspired manner as Solomon, she inscribes her poem with the authority of the Holy Ghost. Only the Holy Ghost's inspiration could sanction Puritan poets in the retelling and revision of scripture; thus Milton invokes the aid of God's "Spirit, that dost prefer / Before all Temples th' upright heart and pure" at the beginning of his Paradise Lost and Cotton, in the preface of The Bay Psalm Book, explains that he will not include psalms which are new or which deviate from a literal translation of the Old Testament because the translators have

\footnotetext{
${ }^{79}$ Hammond, Sinful Self, Saintly Self, 104. As Perry Miller observes, in the mid seventeenth century "[i]t had become especially appropriate [...] to preach in Boston upon Ecclesiastes and to drive home its refrain of the vanity of the earth, because men 'that have left all to enjoy the Gospel, now (as if they had forgotten the end for which they came hither) are ready to leave the Gospel for outward things." Ann Stanford even refers to "Vanity" as "a low point" in Bradstreet's poetry because it is so obviously orthodox. Ditmore argues that "["Contemplations"] points more directly toward the wisdom of Ecclesiastes as the central influence in Bradstreet's theology" and suggests that her interest in Ecclesiastes is an indication of heterodoxy, but Bradstreet's treatment of Ecclesiastes is by no means unusual. Michael Wigglesworth, an iconically orthodox Puritan poet, devotes an entire poem to Ecclesiastes, and the cry of vanity which originates in Ecclesiastes echoed from New England pulpits throughout the period. See Miller, The New England Mind: The Seventeenth
} 
no claim on "the extraordinary gifts of the Spirit" available to early Christians. ${ }^{80}$ By

assuming Solomon's role, Bradstreet empowers herself, taking on the persona and sapientia of a biblical prophetess such as Anna or Deborah and opening the door for other women to play the same part.

Hammond notes that Bradstreet uses simile to play a role in "As Weary Pilgrim” also, "rewriting herself into a latter-day Job as the suffering saint," but in "Pilgrim" she does not assume the authority invested in Job as biblical author, only Job's role as an emblematic sufferer of the common woes of mortality. The two identities which Bradstreet assumes are completely different—-the speaker in "Vanity" is not, as Hammond suggests, "the speaker of 'Pilgrim' [...], Anne Bradstreet rewritten as the gracious metaself that she struggled to find within." The speaker in "Vanity" is Bradstreet rewritten as the Preacher, the possessor of Solomonic wisdom and a figure endowed with the authority and poetic license women lack in Puritan society. Hammond acknowledges that "the poet becomes virtually indistinguishable from the biblically shaped identity that she appropriates," yet he seemingly ignores the rather alarming implications of Bradstreet's assumed identity. By identifying herself with Solomon Bradstreet does more than "offer readers an experiential model" of the self-denial he preaches. ${ }^{81}$ She also assumes (if only in the context of the poem) Solomon's scientia, that attribute which "In Honour of Queen Elizabeth" hints is necessary for a woman's entry into public discourse.

Century, 473; Ann Stanford, Anne Bradstreet, (New York: Burt Franklin, 1974), 80; Ditmore, "Bliss Lost, Wisdom Gained: Contemplating Emblems and Enigmas in Anne Bradstreet's 'Contemplations,'” 33.

${ }^{80}$ Bradstreet, "The Vanity of All Worldly Creatures," in The Complete Works of Anne Bradstreet, 159; Milton, Paradise Lost, I.17-18; John Cotton, "Preface," The Psalms, Hymns and Spiritual Songs of the Old and New Testament, Faithfully Translated into English Metre, (Cambridge: Hezekiah Usher, 1648), 4.

${ }^{81}$ Hammond, Sinful Self, Saintly Self, 27, 104, 105. 


\section{"Wisdom 'tis my Wisdome to Conceal"}

Bradstreet's assumption of Solomon's wisdom and authority is not, however, as significant as her willingness to revise Ecclesiastes. The opening line indicates that the poem should be read as a new version of Ecclesiastes, and while the first half of "Vanity" follows that biblical text closely, the second half of the poem diverges from the text of Ecclesiastes and effectively writes a new ending for that book. Ecclesiastes attempts to answer the question, "For who knoweth what is good for man in this life, all the days of his vain life which he spendeth as a shadow?" a question which Bradstreet rephrases in her own poem: "Where shall I climb, sound, seek search, or find / That Summum Bonum which may stay my mind?" In both texts, the poet seeks fulfillment in "honour, beauty, age, treasure, / [...] learning, wisdome, youth, pleasure" but finds that these pursuits cannot satisfy. ${ }^{82}$ Neither Solomon nor Bradstreet remained contented with the rewards of pleasure or any of the other sought-after qualities of honor, beauty, etc, and Bradstreet's poem parallels Ecclesiastes to that extent: both Ecclesiastes and "Vanity" reject the possibility of finding contentment in earthly pursuits. The two texts differ only in their reactions to this realization.

Whereas Solomon derives from this common ground "the conclusion of the whole matter: Fear God, and keep his commandments: for this is the whole duty of man," Bradstreet suggests that there is another end whose attainment may bring satisfaction but shrouds that goal in secrecy. ${ }^{83}$ Instead of accepting Solomon's injunction to obedience, Bradstreet writes cryptically, "There is a path, no vultures eye hath seen. / Where lions fierce, nor lions whelps have been." At the end of this path Bradstreet places the "living Christall Fount" that medieval educators and Cotton Mather compared to the university as it disburses wisdom,

\footnotetext{
${ }^{82}$ Ecclesiastes 6:12; Bradstreet, "The Vanity of All Worldly Creatures," 160.
} 
but even this does not seem to be the ultimate object of her journey on the path. Bradstreet refuses to articulate this end in the poem itself, writing only that "where, and what it is, from heaven's declar' d. ${ }^{, 84}$ Bradstreet's mysticism is atypical of wisdom literature, the genre to which Ecclesiastes - and therefore her poem, as a rewriting of Ecclesiastes-belong, but as Rosamond Rosenmeier explains,

The biblical wisdom tradition valued by both women and men, constitutes an important key to understanding Bradstreet's feminism. [It] modifies, reclaims, and in some ways subverts biblical patriarchy. But in so doing wisdom by no means destroys the gospel; rather, it fills scripture with new and more inclusive meanings, ones that speak of and to women. ${ }^{85}$

Because wisdom literature is primarily concerned with providing practical counsel, any reading of "Vanity" as wisdom literature presupposes that the end of Bradstreet's path, "where, and what it is, from heaven's declared," does not represent a mystic gnosis, some unknowable communion with God's grace, but a nameable aspiration. Bradstreet undoubtedly considered the Bible to be a book declared from heaven, and she uses wellknown biblical references to point readers to the twenty-eighth chapter of Job for knowledge of "what it is" in which she finds lasting contentment.

Bradstreet quotes the Old Testament book of Job most frequently in the second half of the poem, using scriptural context to indicate her desire for wisdom. She lifts her description of the mysterious path to the crystal fountain directly from Job: "There is a path [...] which the vulture's eye hath not seen: The lion's whelps have not trodden it, nor the fierce lion passed by it." Likewise, when Bradstreet writes that "The depth, and sea, hath said its not in me, / With pearl and gold it shall not valued be," she paraphrases Job's response to

\footnotetext{
${ }^{83}$ Ecclesiastes 12:13.

${ }^{84}$ Bradstreet, "The Vanity of All Worldly Creatures," 160.

${ }^{85}$ Rosamond Rosenmeier, Anne Bradstreet Revisited, (Boston: Twayne Publishers, 1991), 6.
} 
the question "Whence then cometh wisdom? and where is the place of understanding?",86 Bradstreet acknowledges with Job that wisdom in both its forms cannot be found nor purchased but must be pursued in unknown paths, and by paraphrasing Job's discussion on wisdom Bradstreet presents that quality as "That summum Bonum which may stay [her] mind." As Bradstreet remarks elsewhere, "wisdom 'tis my wisdome to conceal," and she disguises her quest for and favorable opinion of wisdom beneath layers of scriptural interpretation. $^{87}$

This reading initially seems to conflict with an earlier denunciation of wisdom in "Vanity," but a close reading shows that Bradstreet does not actually condemn wisdom; her apparent criticism of wisdom marks the only instance in which Bradstreet fails to find anything inherently wrong with an earthly pursuit. Instead of describing the inevitable problems of wisdom as she does with regards to the pursuit of old age, youth, beauty, etc., Bradstreet questions

Where is [consolation] then, in wisdome, learning arts?

Sure if on earth, it must be in those parts;

Yet these, the wisest man of men did find, But vanity, vexation of mind. ${ }^{88}$

Bradstreet never condemns the pursuit of wisdom and learning as vain; she only says that Solomon did. In fact, Bradstreet almost seems to expect fulfillment in the pursuit of wisdom and the arts, certain that "it must be in those parts" if it is to be found on earth at all.

\footnotetext{
${ }^{86}$ Job 28:7-8, 12; Bradstreet, "The Vanity of All Worldly Creatures," 160. Job responds, "Man knoweth not the price thereof; neither is it found in the land of the living. The depth saith, It is not in me: and the sea saith, It is not with me. It cannot be gotten for gold, neither shall silver be weighed for the price thereof. It cannot be valued with the gold of Ophir, with the precious onyx, or the sapphire. The gold and the crystal cannot equal it: and the exchange of it shall not be for jewels of fine gold. No mention shall be made of coral, or of pearls: for the price of wisdom is above rubies. The topaz of Ethiopia shall not equal it, neither shall it be valued with pure gold." See Job 28:13-19.

${ }^{87}$ Bradstreet, "The Vanity of All Worldly Creatures," 160; Bradstreet, "Of the Four Humours in Mans Constitution" in The Complete Works of Anne Bradstreet, 32.
} 
In this light Bradstreet's apparent deference to Solomon's opinion seems less a condemnation of wisdom and learning than an underhanded jab at his accomplishments. She draws attention to Solomon's masculinity, referring to him as "the wisest man of men" as if to clearly differentiate between his abilities as the wisest man and the abilities of an implied wisest woman. Her paraphrase of Job suggesting that neither "Lion fierce nor lion's whelps have been" on the path to wisdom also reflects negatively on Solomon. As a Davidic king, Solomon inherits Jacob's characterizations of Judah, his forbear; Jacob states that "Judah is a lion's whelp," and though the book of Job does not suggest a connection between the descendants of Judah and the lion he describes, Bradstreet makes that connection inevitable for the biblically minded by quoting Job in a poem about Solomon. ${ }^{89}$ Bradstreet's poem, by conflating the books of Job and Ecclesiastes, encourages readers familiar with Judah's inheritance in Genesis to substitute Solomon for the lion's whelp. In this way, her statement that "There is a path, no vultures eye hath seen. / Where lions fierce, nor lions whelps hath been" transforms itself into a claim that Solomon has never been on the path leading to true wisdom, to "that living Christall fount." What is more, Bradstreet attempts her search for fulfillment within a poem, and her successful conclusion in that poetic endeavor only reinscribes the unspoken claim that a woman can find wisdom and consolation in the arts even when Solomon, "the wisest man of men," cannot.

Even as she outdoes Solomon and assumes his wisdom, Bradstreet writes devoutly enough that even the ultra-orthodox Michael Wigglesworth finds common ground with her. Wigglesworth's Day of Doom condemns sinners, castigating even the most marginal of transgressions, and his poem "Vanity of Vanities" follows the text of Ecclesiastes more

\footnotetext{
${ }^{88}$ Bradstreet, "The Vanity of All Worldly Creatures," 160.
} 
faithfully than Bradstreet's. Wigglesworth, whose poem arrived twelve years after Bradstreet's and exhibits similarities not necessarily incident to their shared subject matter, may have drawn on Bradstreet's reading of Ecclesiastes in composing his own reformulation of scripture. Certainly his poem follows a similar framework; he also condemns the pursuit of wealth and pleasure, among the other prohibitions of Solomon. More significantly, his condemnation of beauty echoes Bradstreet's language. Wigglesworth dismisses beauty by rationalizing that both "fair and foul unto the grave must come" (88) a line at least reminiscent of Bradstreet's "They'r foul enough to day, that once was fair." In addition, Wigglesworth fails to condemn wisdom in much the same manner as Bradstreet. He writes only that "Honor doth befool and blind the Wise" (67), suggesting that the improper exercise of wisdom can produce blindness without condemning wisdom itself..$^{90}$ Like Bradstreet, Wigglesworth offers what seems like a condemnation of wisdom and the arts (but is not) by including it in a list of fallen and earthly pursuits. That Bradstreet's defense of wisdom may have influenced even the most orthodox of Puritans only lends credence to her ability to straddle the religious fence, offering original interpretations to substantially correct doctrines. By successfully negotiating the difficulties of an orthodox path to feminine wisdom, Bradstreet revises her legacy as a daughter of Eve. She exercises her creative abilities within the theological constraints of seventeenth-century New England, disproving Solomon's claim that "there is no new thing under the sun" in the process. Elisa New has argued that the occupation of Puritan poets is "not inventing Eden so much as marking time outside it," but for Bradstreet, the mere marking of time is insufficient; Eve's failure in the garden forces her

\footnotetext{
${ }^{89}$ Genesis 49:9.

${ }^{90}$ Michael Wigglesworth, "Vanity of Vanities," in The Day of Doom, (Tucson: American Eagle, 1991), pp. 9598; Bradstreet, "The Vanity of All Worldly Creatures," 160.
} 
to reinvent a woman's approach to wisdom. She acts as a pioneer, creating a path by which women can attain wisdom and participate in public discourse without sacrificing their faith. In this sense, Bradstreet anticipates the modern poet who "has left Ecclesiastes for Genesis" seeking "nothing less than to unwrite the Fall," and if she does not keep faith with the Fall when she reframes Eve's pursuit of wisdom, she at least keeps faith with Puritanism generally. ${ }^{91}$ Her poems, especially "Contemplations," anticipate Emerson's question in Nature, "Why should not we also enjoy an original relation to the universe?" with the resounding affirmation that the natural knowledge and wisdom possessed by Adam at the world's origin is available to Eve's daughters as well as Solomon's sons. ${ }^{92}$

\section{An Edenic Enlightenment: The Science of Mather and Edwards}

Bradstreet's desire to appropriate Solomonic wisdom and her interest in replacing the legacy of Eve with the more positive precedent set by Queen Elizabeth are inspiring but sadly singular in the written record of early modern New England. Her female readership in the Bay Colony did not demand access to Harvard or other institutions dedicated to the preservation of Adam's knowledge in Eden; there were no picket lines outside College Yard. Indeed, even Bradstreet's feminist successors in Massachusetts did not aspire so high. Abigail Adams may have pleaded with her husband to "Remember the Ladies" when he drafted legislation, but her letters portray wisdom as a distinctively masculine trait, and she articulates the need for a man like "Soloman in wisdom, to guide and conduct this great people: at this critical acre, when the counsels which are taken, and the measures which are

\footnotetext{
${ }^{91}$ Ecclesiastes 1:9; Elisa New, The Regenerate Lyric, (Cambridge: Cambridge University Press, 1993), 17, 25.

${ }^{92}$ Ralph Waldo Emerson, Nature in Emerson's Prose and Poetry, eds. Joel Porte and Saundra Morris, (Norton: New York, 2001), 27.
} 
persued; will mark our future Character either with honour, and Fame, or disgrace, and infamy." Instead of seeking Solomon's wisdom for herself, Adams finds his likeness in Benjamin Franklin, "Whose Mentor like appearence, age and philosiphy must certainly lead the polite scientifick Ladies of France to suppose they are embraceing the God of Wisdom, in a Humane Form."93 By all accounts Bradstreet's female counterparts and feminist successors contented themselves with Solomon's counsel to "Fear God and keep his commandments.",94 It was male experimenters, scientists, and natural philosophers-categories that often included ministers as well as learned laymen such as Franklin—that escalated the moderate seventeenth-century New England interest in Bacon into a full-fledged pursuit of Solomonic wisdom and knowledge about the natural world in the eighteenth century.

As Miller notes, this more widespread embrace of induction and empiricism was, in some sense, long overdue. After all, even the strictest New England Puritans were

responding to the same impulses as their philosophical contemporaries [whom Miller identifies elsewhere as Bacon, Descartes, and Hobbes]. ...they could take many steps in the same direction once they had seized upon their fundamental discovery that God has voluntarily engaged Himself to regular, ascertainable procedures. The rest followed surely and easily from this premise: the validity of reason in man, the regularity of secondary causes in nature, the harmony of knowledge and faith, the coincidence of the arbitrary with inherent goodness, the intimate connection between grace and the incitements that generate grace, the necessity for moral responsibility and activity. Everywhere along the line the method of the divine dispensation, while authorized only by God and remaining under His constant control, is actually

\footnotetext{
93 Abigail Adams, "Letter from Abigail Adams to John Adams, 31 March - 5 April 1776," in Adams Family Papers: An Electronic Archive, (Massachusetts Historical Society), 28 July 2009

<http://www.masshist.org/digitaladams/aea/cfm/doc.cfm?id=L17760331aa\&archive=letter\&hi=on\&mode=\&no images $=\&$ numrecs=1\&query=remember\%20the \%20ladies\&queryid=\&rec=\&start=1\&tag=text $>$; Abigail Adams, "Letter from Abigail Adams to John Adams, 20 June 1783," in Adams Family Papers: An Electronic Archive, (Massachusetts Historical Society), 28 July $2009<$ http://www.masshist.org/digitaladams/aea/cfm/doc.cfm?id=L17830620aa\&numrecs=52\&archive=letter\&hi=on \&mode=\&query=wisdom\&queryid=\&rec=29\&start=21\&tag=text\#firstmatch>; Abigail Adams, "Letter from Abigail Adams to John Adams, 30 June 1778 draft," in Adams Family Papers: An Electronic Archive, (Massachusetts Historical Society), 28 July $2009<$

http://www.masshist.org/digitaladams/aea/cfm/doc.cfm?id=L17780630aa\&numrecs=52\&archive=letter\&hi=on $\&$ mode $=\&$ query=wisdom $\&$ queryid $=\& r e c=24 \&$ start=21\&tag=text $\#$ firstmatch $>$.

${ }^{94}$ Ecclesiastes 12:13.
} 
synchronized with a completely scientific account. ${ }^{95}$

For this reason, it is unsurprising to find that even those eighteenth-century New England ministers who wholeheartedly embraced their Calvinist roots were also interested in reconciling their theological positions with the empirical evidence of the Enlightenment.

In recognition of his letters on the natural history of New England Cotton Mather was awarded membership in the Royal Society, a body expressly dedicated to the aims of Salomon's House, and whose members, in the words of Abraham Cowley, "fain would be / Catching at the forbidden Tree" of the knowledge of good and evil in Eden because "The Orchard's open now, and free; / Bacon has broke that Scare-crow Deity." enthusiastically adopted the initials F.R.S as a token of his status as a Fellow of the Royal Society, and in a letter to his counterparts in London, he expressed his excitement at contributing in a small way to Bacon's project for the restoration of edenic intellectual perfections:

You have so encouraged me, by the kind Reception, which my former communications have had with you, and by your Means with my Illustrious Masters, that I cannot but in my poor way, continue them. I wish that they had been more valuable for Curiosity or Erudition. But they are what I have. And you will have the Goodness to consider me, as a man exceeding full of employments: Able but now \& then after a Mean Manner to express my zeal for your [Bacon's] Noble Design. Tis indeed nothing but that well-meaning Zeal, that can bespeak for me, the Room you are pleas'd to allow me in a SOCIETY which I esteem as one of the most Illustrious in the World. ${ }^{97}$

As far as Mather was concerned Bacon's aims and methods, as embodied in the Royal

\footnotetext{
95 Perry Miller, Errand into the Wilderness, (Cambridge: Belknap Press of Harvard University Press, 1956), 9293.

${ }^{96}$ Abraham Cowley, "To the Royal Society," in Thomas Sprat, The History of the Royal Society of London, $4^{\text {th }}$ ed., (London: 1734), xv-xvi. For a fuller treatment of Mather's contributions to the Royal Society and his induction to that body, see George L. Kittredge, "Cotton Mather's Election into the Royal Society," in Publications of the Colonial Society of Massachusetts, Vol. XIV, (Boston: The Colonial Society of Massachusetts, 1913), 81-114.

${ }^{97}$ As quoted in Kittredge, “Cotton Mather's Election into the Royal Society," 114.
} 
Society (but not, presumably, in Cowley's blasphemous lyrics), clearly did not conflict with the tenets of Calvinism or his identity as a minister. Mather's interest in scientific phenomena is evidence of a brief period of synthesis between the new philosophy and religion that lingered in New England for at least the first half of the eighteenth century.

Pehaps the last great mind—and certainly the last great American mind—-to treat Calvinist theology and empirical science with equal seriousness, Jonathan Edwards also viewed the natural world as a textbook from which the wisdom of Adam could be gleaned. Edwards subscribed to the new philosophy introduced by Bacon and worked to reconcile its emphasis on induction from nature with the Calvinist belief in a God whose freedom of will is absolute; he explains the regularity of nature by arguing that there "is a moral necessity in God's acts of will that can be said to govern the divine will, just as surely as his will is regulated by his divine wisdom. Yet his will remains arbitrary in the sense that no sort of necessity imposes itself upon him from the outside," from nature. ${ }^{98}$ God's wisdom leads him to act in regular, predictable patterns in the natural world, but he is not required in any way to uphold natural precedents; the "course of nature is demonstrated, by late improvements in philosophy, to be ... nothing but the established order of the agency and operation of the Author of nature." 99 Still, because divine wisdom is responsible for the regular patterns of natural phenomena, Edwards believes that the study of those phenomena will provide the observer with a measure of divine wisdom, the wisdom that Adam possessed and passed down to his posterity in a book containing "abundance of philosophy ... as well as those high flights of divine knowledge." Edwards suggests that this edenic inheritance was preserved

\footnotetext{
${ }^{98}$ Paul Ramsey, "Editor's Introduction," to Jonathan Edwards, The Works of Jonathan Edwards, Vol. 1, Freedom of the Will, ed. Paul Ramsey, (New Haven: Yale University Press, 1957), 111.

${ }^{99}$ Jonathan Edwards, Original Sin, in The Works of Jonathan Edwards, Vol. 3, Original Sin, ed. Clyde A. Holbrook, (New Haven: Yale University Press, 1970), 385.
} 
until Noah's day and that the "abundance of learning that was in the heathen world was the corrupted remains of what was delivered to mankind by them that came out of the ark," who had preserved Adam's philosophy and knowledge in its purity until that point. ${ }^{100}$

Because Adam's wisdom—his philosophical knowledge- - had been corrupted and lost, Edwards set out to recover a portion of it directly from nature. In a series of notes on "Natural Philosophy" that were originally intended to become the basis for a major scientific study, Edwards finds divine wisdom everywhere he looks (and even in the design of the eye with which he looks):

The wisdom of God appears in so ordering it that the weight of the atmosphere should never be very much altered. ... One thing very evidential of the wisdom of God in the contrivance of the eye, is that it should so easily, perfectly and distinctly perceive the stroke or impression of the rays of light... THE ROUNDNESS OF THE EARTH shews the wisdom of God. ... The wisdom of God appears in so ordering it, that the earth should be an OBLATE SPHEROI- that the surface of the earth at and near the equator should be longer than in the polar parts. ... The wisdom of God appears in so ordering it that, though the planets revolve all of them nearly in the same plane, the COMETS are disposed in very different ones and distributed over all parts of the heavens... The wisdom of God appears in placing of the PLANETS at a greater or lesser DISTANCE from the sun, according to their DENSITY. ${ }^{101}$

Edwards never completed his survey of the natural world, and he would have been the first to admit that his collection of notes on "Natural Philosophy" restored only the tiniest fraction of the knowledge that Adam possessed. Yet perhaps it is appropriate that the last American to combine an interest in the recovery of Adam's lost and corrupted philosophy with a sincere commitment to Calvinist principles left his most important treatise on the wisdom to be gleaned from the natural world unfinished; that is, after all, the state in which Bacon left his

\footnotetext{
${ }^{100}$ Jonathan Edwards, "Note 111," in The Works of Jonathan Edwards, Vol. 15, Notes on Scripture, ed. Stephen J. Stein, (New Haven: Yale University Press, 1998), 81-82.

${ }^{101}$ Jonathan Edwards, "Wisdom in the Contrivance of the World," in The Works of Jonathan Edwards, Vol. 6, Scientific and Philosophical Writings, ed. Wallace E. Anderson, (New Haven: Yale University Press, 1980), $307-10$.
} 
Great Instauration, the completion of which was "both above [his] strength and beyond [his] hopes." ${ }^{102}$ Bacon's plan for the restoration of edenic intellectual perfections never came to fruition in New England any more than it did in Old, but it was not for a lack of interest and effort - the wisdom of Adam and of Solomon was sought by Bay Colony emigrants on the shores of Southampton, within the walls of Edwards's Northampton home, and even, as Abigail Adams attests, in the throes of Revolution.

${ }^{102}$ Francis Bacon, The Great Instauration, 31. 


\section{CHAPTER 4}

\section{TRANSLATIONS OF EDEN: \\ HEBREW, HERBERT, AND THE NEW ENGLAND INTEREST IN LINGUISTIC PURITY}

Central to the project of recovering edenic wisdom is a concomitant interest in the recovery of the Adamic language, or lingua humana, which gave perfect expression to Adam's perfect understanding of the natural world. Words in the Adamic language were believed to have a one-to-one correspondence with the objects and ideas they represented, so the restoration of the lingua humana would naturally accompany—or perhaps even lead tomankind's ability to discern and enumerate the distinguishing characteristics of each species, as Adam did in Eden. For this reason Francis Bacon warned those who would pursue his program for the restoration of edenic wisdom that

before we can reach the remoter and more hidden parts of nature, it is necessary that a more perfect use and application of the human mind and intellect be introduced. ...words are the tokens and signs of notions. Now if the very notions of the mind (which are as the soul of words and the basis of the whole structure) be improperly and overhastily abstracted from facts, vague, not sufficiently definite, faulty in short in many ways, the whole edifice tumbles.

In other words, the intellectual perfections promised by Bacon both result in the ability to use language precisely and, paradoxically, are derived from the very linguistic precision that they promote. The words and wisdom of Eden are inextricably linked.

Naturally, then, the men and women who worked to bring about Bacon's Great

\footnotetext{
${ }^{1}$ Francis Bacon, The Great Instauration, trans. James Spedding, in The Great Instauration and The New Atlantis, ed. J. Weinberger, (Arlington Heights: Harlan Davidson, 1980), 13-14, 22.
} 
Instauration concerned themselves with the refinement of existing languages and the development of artificial languages that had the properties attributed to the lingua humana. As Rhodri Lewis notes, Bacon's Advancement of Learning (1605) became "the single most important work in defining the shape of English language planning in the seventeenth century"; ${ }^{2}$ Bacon's disciples worked to fulfill its mandate to "reintegrate [man] in those benedictions, from which by his fault he hath been deprived; and as he hath striven against the first general curse by the invention of all other arts, so hath he sought to come forth of the second general curse, which was the confusion of tongues, by the art of grammar." Bacon explains that grammar provides insight into "the power and nature of words," but "[u]nto grammar also belongeth, as an appendix, the consideration of the accidents of words; which are measure, sound, and elevation or accent, and the sweetness and harshness of them; whence hath issued some curious observations in rhetoric, but chiefly poesy." ${ }^{3}$ The grammar envisioned by Bacon would be a tool for the restoration of prelapsarian language, a tool providing insight into the nature of words—-their origins and meanings—as well as their musical and metrical properties, allowing its user to craft poetic language similar to that used by Adam and Eve in Eden.

As I noted in Chapter 3, the aims and "vocabulary of Bacon [were] assimilated into the millenarian ideology" of Puritan theology shortly after Bacon's death in 1626 and adopted by the Bay Colony in New England. ${ }^{4}$ While Puritans remained suspicious of human efforts to combat the Fall, Bacon's program to recover the Adamic purity of language was

\footnotetext{
${ }^{2}$ Rhodri Lewis, Language, Mind and Nature, (Cambridge: Cambridge University Press, 2007), 10. Lewis provides the definitive account of the artificial language movement and linguistic reform in the seventeenth century.

${ }^{3}$ Francis Bacon, The Advancement of Learning, ed. G. W. Kitchin, (Philadelphia: Paul Dry Books, 2001), 12930.

${ }^{4}$ Charles Webster, The Great Instauration, (London: Gerald Duckworth, 1975), 12.
} 
acceptable because it acknowledged the limitations of mortality. Puritan theology, here poetically expressed by Milton, discouraged the pursuit of knowledge "of things remote / From use, obscure and subtle, but to know / That which before us lies in daily life, / Is the prime Wisdom." Language was a tool used daily, whose perfection would bring worshippers closer to God without presuming too much of human capabilities. Thus, Bacon's conclusion that “'all knowledge is to be limited by religion, and to be referred to use and action' [...] was perfectly adapted to the puritan position; investigations conducted into secondary causes, and with utilitarian ends in mind, would incur no risk of transgression, but instead glorify God, and restore man's dominion over nature." ${ }^{5}$ Puritan language planners and others interested in reversing the Fall's corruption in preparation for an edenic restoration adopted the goals and strategies of Francis Bacon as they worked to purify language.

But what began with Bacon soon ballooned into a national enterprise for the purification of language that Lewis claims "spanned the entire social, religious and political gamut of intellectual life in seventeenth-century England." ${ }^{\prime 6}$ While many of Bacon's followers focused on the creation of a new, scientific, universal language with representational characters similar to those used in China and Egypt, others turned to Hebrew as a model for linguistic purity. As Paul Cornelius explains, for "commentators of the seventeenth century, the Lingua Humana had been 'Primitive Hebrew.' This sacred language, which God had given to the first man, had remained uncorrupted throughout the early history of the Hebrews—even after the rise of impiety." 7 Philip Almond notes that most of the church fathers, Augustine included, believed that "the language of Eden was Hebrew. This

\footnotetext{
${ }^{5}$ John Milton, Paradise Lost, VIII.191-94; Webster, The Great Instauration, 22.

${ }^{6}$ Rhodri Lewis, Language, Mind and Nature, 2.

${ }^{7}$ Cornelius, Languages in Seventeenth and Early Eighteenth-Century Imaginary Voyages, (Geneva: Librarie
} 
was the most commonly held opinion throughout the Middle Ages," and seventeenth-century English ministers on both sides of the seventeenth-century debate over the surplice and episcopal oversight maintained that Hebrew was the language of Adam. ${ }^{8}$ Lancelot Andrewes told his congregation "that the Hebrew tongue was the first and most ancient from the beginning, and that which Adam here used in giving names to all the Creatures." Hebrew's edenic origins were obvious to Andrewes because just as "Adams knowledge and wisdome being ancient, is most perfect and absolute, so is this tongue and language of Paradise, which Adam useth, most rich and sufficient of itself." "Notwithstanding their differences, Andrewes's Puritan adversaries agreed that Hebrew was the language of Eden and even found new evidence to support that belief while on their errand in the wilderness.

New England colonists who studied the languages of Native Americans almost universally concluded that the Indian dialects were direct descendants of Hebrew. In his Key into the Language of America (1643), Roger Williams explains that "others (and my selfe) have conceived some of their words to hold affinitie with the Hebrew."10 And even as he penned a repudiation of Williams's behavior and character, John Eliot reached the same conclusion regarding the Hebraic origins of Algonquian and other native languages. In a series of remarkable conjectures as to the genealogical origins of the Native Americans, he argued that native languages were derived from Hebrew and supported his argument with the

\footnotetext{
Droz, 1965), 8

${ }^{8}$ Philip Almond, Adam and Eve in Seventeenth-Century Thought, (Cambridge: Cambridge University Press, 1999), 129.

${ }^{9}$ Lancelot Andrewes, Apospasmatia Sacra, (London: R. Hodgkinsonne, 1657), 209.

${ }^{10}$ Roger Williams, A Key into the Language of America, ed. John J. Teunissen and Evelyn J. Hinz, (Detroit: Wayne State University Press, 1973), 86.
} 
claim that the Indians were descendants of Shem, the son of Noah. ${ }^{11}$ Shem's descendants, Eliot explains, left their father and brothers "to visit, and inhabit the land of Eden, where the garden of Eden had been.” Shem's great-grandson Eber eventually completed "this removal Westward, towards the land of Eden" and "the first planters of America were Ebrewes of Eber, who was of the line of Sem."12 Because "none of Sems family were in this rebellion" at the tower of Babel, when God confounded the languages, "the confusion of languages fell not upon Ebers family."13 It was because of Eber's faithfulness that the lingua humana which originated in Eden and prevailed throughout the world before Babel became known as Hebrew; Eliot writes that in the days after Babel's fall, when there were "many languages in the earth, the Fathers thought good to call the holy language, which still continued in the Church, by the name of Eber." Since they were Eber's descendants, the first inhabitants of the Americas spoke "Hebrew, which the old world, before the floud did universally speak, being necessary in the paternal government thereof."14

Ultimately, of course, the Indians did not preserve Hebrew in its original form because they too fell into apostasy. Linguistic purity, for Eliot, was closely related to ecclesiastical purity, and the confusion of languages was not an event so much as an ongoing process that took place among individuals and family groups "according as they apostatized from the Church, and from paternal government." Because

the holy language was kept for the Churches use, as it seemeth to be, thence it might

\footnotetext{
${ }^{11}$ For a comprehensive overview of the relationship between language and nationality in the early modern period, see Edward G. Gray, New World Babel, (Princeton: Princeton University Press, 1999). Gray discusses Eliot's translation of the Bible at some length in Chapter 3, pp. 56-84, arguing that Eliot wished to create a millennial state "above and beyond linguistic difference-it was to be a .kingdom wholly unified by the universal language of faith." See Gray, New World Babel, 62.

${ }^{12}$ As quoted in Thomas Thorowgood, Jews in America, (London: 1660), 4, 12.

${ }^{13}$ ibid, 12, 18.

${ }^{14}$ ibid, 11, 7-8.
} 
follow, that as [the Native Americans] degenerated from the Church, and the ancient government and the holy waies of God, so they fell under the reach of that confusion: and may it not be worth the searching after, whether all the Easterne world, the posterity of Eber, have not more footsteps of the Hebrew language, at least in the grammatical frame of the language, than the westerne world hath. It seemeth to me, by that little insight I have, that the grammatical frame of our Indian language cometh neerer to the Hebrew, than the Latine, or Greek do: and if so, then may it not be considerable, that the dispersion of the Ten Tribes to the utmost ends of the Earth ... hath lesse severity of punishment in it, being dispersed into the countries of Sem, and among the posterity of Eber, whose language and spirit was not wholely strange unto them. ${ }^{15}$

Eliot's formulation of Native history is remarkable in two respects. First, it posits that linguistic and ecclesiastical purity are closely connected, suggesting that a return to ecclesiastical purity—such as the one which the Puritans were then undertaking in New England—would naturally lead to linguistic purity, a return to Hebrew. Second, it proposes that the curse of Babel rests more lightly in the Americas than anywhere else; linguistically speaking, New England is naturally a sort of halfway house between Eden and the fallen world.

Occupied with the translation of the English Bible into Algonquian—-that closely related remnant of the Adamic tongue—and prompted by his belief in Baconian reform, Eliot came to the conclusion that the elect needed to prepare themselves for the Second Coming and their coming paradisiacal inheritance by purifying their language. In a letter to Richard Baxter Eliot expresses the hope that if only God will "direct his People into a Divine Form of Civil government, of such a Constitution, as that the Godly, Learned in all places, may be in all Places of Power and Rule, this would so much the more advance all Learning, and Religion, and good Government; so that all the world would become a Divine Colledge"

${ }^{15}$ ibid, 10, 18-19. 
such as Bacon's College of the Six Days Work. ${ }^{16}$ Since Hebrew was both "the purest Language, in the World" as well as "the Language which shall be spoken in Heaven," Eliot pushed Baxter and the learned godly in England to adopt it as their primary tongue, intimating that such a procedure would "advance the Kingdom of Jesus Christ" and hasten the arrival of this millennial scene. Eliot acknowledges, however, that the Hebrew currently in usage still requires refinement and points out that this defect is actually an opportunity to "make ready for Heaven in this Point, by making and fitting that Language, according to the Rules of the divine Artifice of it, to express all imaginable Conceptions and Notions of the Mind of Man, in all Arts and Sciences." ${ }^{17}$ The work of translation-not from English to Algonquian in this case, but rather from English to Hebrew-was insufficient. Joshua David Bellin argues that Eliot finds "the acts of translation through which [the Algonquian Bible and devotional tracts] were forged" to be "tortured and opaque, marring any claim of absolute authority over or immediate access to, the terms of encounter," and it is because of his experience with the difficulties of translation that Eliot recognized a simple shift from English to Hebrew would be inadequate to achieve the heavenly and edenic purity for which he longs. ${ }^{18}$ Translation had to be combined with linguistic refinement in order to produce the pure language he proposes that Baxter should establish in England.

When Baxter responded to Eliot's suggestion that his scheme for the adoption of Hebrew be realized in Old England instead of New, he promised to "communicate your

\footnotetext{
${ }^{16}$ John Eliot, "For the Reverend and his much honored Friend Mr. Baxter," in The Eliot Tracts, ed. Michael P. Clark, (Westport: Praeger, 2003), 433. On Eliot's Baconian leanings, see also chapter 3, p. 186.

${ }^{17}$ John Eliot, "For the Reverend and his much honored Friend Mr. Baxter," 432.

${ }^{18}$ Joshua David Bellin, “A Little I Shall Say': Translation and Interculturalism in the John Eliot Tracts,” in Reinterpreting New England Indians and the Colonial Experience, eds. Colin G. Calloway and Neal Salisbury, Publications of the Colonial Society of Massachusetts, Vol. 71, (Boston: The Colonial Society of Massachusetts, 2003), 55.
} 
Motion here about the Hebrew, but" admitted that "we are not of such large and publick Minds as you imagin.” The godly in Old England (and presumably New as well since there is no evidence that Eliot ever persuaded anyone in the Bay Colony to use Hebrew in their daily speech) were pragmatic as well as pious, and Eliot must have realized that Hebrew would never become the functional language of the elect in his lifetime. Instead Eliot's New England neighbors worked to purify — and, occasionally, Hebraize—-the English language. ${ }^{19}$ There were at least two very different approaches to the project of linguistic refinement and translation taken by Eliot's early modern New England countrymen. The translators of the Bay Psalm Book, whose stilted, broken verses are still the subject of critical mockery; and Edward Taylor, whose metaphysical Preparatory Meditations have been widely praised for their aesthetics, write in very different styles but with the same purpose: to bring their devotional English as close to the linguistic perfection that Adam enjoyed in Eden as possible. $^{20}$

The different approaches to the problem of linguistic purity taken by the authors of the Bay Psalm Book and Taylor are, perhaps, best illustrated by the following two seventeenth-century accounts of translation:

1. When John Reynolds approached King James on behalf of his fellow Puritans to petition for a new translation of the Bible, he asked "May your Majesty be pleased that the Bible be new translated, such as are extant not answering the Originall"

\footnotetext{
${ }^{19}$ Richard Baxter, "The Answer," in John Eliot, The Eliot Tracts, ed. Michael P. Clark, (Westport: Praeger, 2003), 434. It should be noted that while Eliot is the only individual to advocate the adoption of Hebrew as the primary language of the Bay Colony, the language's prominent place at Harvard College was unusual for the time. Early graduates from Harvard were all trained in Hebrew, something that administrators at Cambridge and Oxford could not claim.

${ }^{20}$ While I emphasize the divergent styles of these two collections of devotional verse, Raymond Craig has argued that "Taylor's inconsistent imagery and "roughness"” are actually in harmony with the "study of biblical poetics as understood by [John] Cotton" whose disdain for poetic polish is manifest in the broken language of the Bay Psalm Book. See Raymond A. Craig, "The 'Peculiar Elegance' of Edward Taylor' Poetics," in The Tayloring Shop, ed. Michael Schuldiner, (Newark: University of Delaware Press, 1997), 78.
} 
Hebrew $?^{21}$ Reynolds envisioned a process in which erroneous and corrupt words or phrases in the Bishop's Bible would be lopped off as translators rendered the English as closely after the Hebrew as possible; he describes translation as a methodical process of eliminating corruption and reproducing an extant, pure text.

2. In a Latin treatise on the art of translation, Frenchman Pierre Daniel Huet proposed that a "translator must therefore become like Proteus: he must be able to transform himself into all manner of wondrous things, he must be able to absorb and combine all styles within himself and be more changeable than a chameleon."22 Huet suggests that the act of translation is something like alchemy-purity would result from the introduction of a supernatural catalyst that renders the translator and the text into altogether different entities.

Though Bellin argues that Huet's treatise ran "counter to the interdictions of Puritan divines," both approaches to the translation and purification of language were employed by New England poets seeking paradisiacal purity in the English language. ${ }^{23}$ That two such dichotomous attitudes towards language could be contained within a single religious community should not surprise us; as the influential example of George Herbert demonstrates, they could also be contained within a single man. It is Herbert, as much as Eliot, who connects the New England Puritan interest in linguistic purification to the Baconian program for edenic restoration. A close friend of Bacon and the translator of his Advancement of Learning into the Latin volume De dignitate et augmentis scientiarum (1623) that Lewis lauds as the foundation of the artificial language movement, Herbert gives poetic expression to Bacon's edenic aspirations in The Temple (1633), providing a model for linguistic purification that New England writers imitated. ${ }^{24}$

\footnotetext{
${ }^{21}$ As quoted by Francis Fullwood, in The Church-History of Britain: The Tenth Book, (London: 1655), 14.

${ }^{22}$ Pierre Daniel Huet, "De optimo genere interpretandi," in Translation, History, Culture, ed. André Lefevere, (New York: Routledge, 1992), 89.

${ }^{23}$ Bellin, "“A Little I Shall Say': Translation and Interculturalism in the John Eliot Tracts,” 60.

${ }^{24}$ Many critics have connected Herbert to Taylor, and the critical consensus is that Herbert was a model for Philip Pain's Daily Meditations (1668). For an examination of Herbert's influence on a variety of other seventeenth-century poets, see John T. Shawcross, "Some Colonial American Poetry and George Herbert," Early American Literature 23.1 (1988): 28-51. While I have not been able to draw specific connections between the translators of the Bay Psalm Book and Herbert, it is almost inconceivable that none of them had sampled the
} 


\section{Entering The Temple: Two Paths Back to Paradisiacal Purity}

Puritan divines in early modern New England both appreciated and imitated Herbert's verses; they accepted his warning that "Religion stands on tip-toe in our land, / Ready to pass to the American strand" as divinely inspired prophecy. ${ }^{25}$ In "The Church Militant," Herbert envisions the westward migration of true religion from England to the Americas, a translatio ecclesiae that Reid Barbour notes was understood by many to be "a progression toward spiritual and ecclesiastical perfection in the New Jerusalem" that would be built in North America. And even if, as Barbour argues, Herbert's poetic vision of the church's migration "does not entail full restitution or perfection in a new Eden," his American readers consistently misread "The Church Militant" as a prophecy of an impending millennial restoration of prelapsarian perfections. ${ }^{26}$ In The Temple, Herbert explores multiple routes back to the primal purity that the Church of England has lost—or, at least, that he believes it will lose very quickly — and that the American churches will inherit. This edenic inheritance and the search for ecclesiastical purity is consistently tied to Herbert's interest in the

verses of such a prominent devotional writer, all the more so given the flourishing transatlantic manuscript culture that David Hall documents in Ways of Writing (2008). The more important point, which I make later in this chapter, is simply that they approached the project of linguistic purification in the same way as Herbert. On Herbert's relationship to Bacon, see Greg Miller, George Herbert's 'Holy Patterns,' (New York: Continuum, 2007), 107-118; Michael C. Schoenfeldt, Prayer and Power, (Chicago: University of Chicago Press, 1991), 234-36; Charles Whitney, "Bacon and Herbert: Bacon and Herbert as Moderns," in Like Season'd Timber: New Essays on George Herbert, ed. Edmund Miller and Robert DiYanni, (New York: Peter Lang, 1987), 231-40; Joseph Summers, George Herbert, (Cambridge: Harvard University Press, 1954), 195-97.

${ }^{25}$ George Herbert, "The Church Militant," in The Complete English Poems, ed. John Tobin, (New York: Penguin Books, 2004), 185; hereafter (“The Church Militant” 235-36). Joshua Scottow's history invokes Herbert's famous lines from "The Church Militant," and he was cited regularly by the Mathers; Cotton Mather quoted approvingly from his "Perirrhanterium" in the Magnalia. See Emory Elliott, American Colonial Writers, 1606-1734, (Detroit: Gale Research, 1984), 243; Joshua Scottow, A Narrative of the Planting of the Massachusetts Colony, (Boston: Benjamin Harris, 1694), 8; Cotton Mather, Magnalia Christi Americana, ed. Thomas Robbins, trans. Lucuius F. Robinson, Vol. II, (Hartford: Silas Andrus \& Son, 1853), 153.

${ }^{26}$ Reid Barbour, Literature and Religious Culture in Seventeenth-Century England, (Cambridge: Cambridge University Press, 2002), 42-43. On optimistic readings of Herbert by colonial Americans, see David S. Shields, "Herbert and Colonial American Poetry: Then Shall Religion to America Flee," in Like Season'd Timber: New Essays on George Herbert, eds. Edmund Miller and Robert DiYanni, (New York: Peter Lang, 1987), $281-96$. 
sanctification of language; for Herbert, as for Eliot, linguistic and ecclesiastical purity are inextricably linked.

The sequential ordering of poems in The Temple, as much as the careful placement of words within each of Herbert's shape poems, is intended to influence the reader's experience of that volume; the reader's movement from the The Church-Porch into The Church and up to "The Altar" mimics the experience of entering into and moving within an actual church. The poems that precede and follow a given selection of verse provide context for interpretation, and Herbert frequently creates one continuous reading experience out of two or more discrete poems. In the closing lines of "Misery," he mourns the Fall from Eden:

Indeed at first Man was a treasure, A box of jewels, shop of rarities,

A ring, whose posy was, My pleasure:

He was a garden in a Paradise:

Glory and grace

Did crown his heart and face.

But sin hath fooled him. Now he is A lump of flesh without a foot or wing

To raise him to the glimpse of bliss: A sick tossed vessel, dashing on each thing,

Nay, his own shelf:

My God, I mean myself. (67-78)

Herbert reflects on the lost paradisiacal glory of mankind in "Misery" and recognizes his own personal Fall; he is no longer "a garden in a Paradise" but a "sick tossed vessel."

In "Jordan (2)," the poem that follows "Misery," Herbert acknowledges and explores the consequences of this Fall from paradisiacal purity, noting that his language has been corrupted. He laments that

When first my lines of heav'nly joys made mention, Such was their luster, they did so excel, That I sought out quaint words, and trim invention; My thoughts began to burnish, sprout, and swell, 
Curling with metaphors a plain intention,

Decking the sense, as if it were to sell.

Thousands of notions in my brain did run,

Off'ring their service, if I were not sped:

I often blotted what I had begun;

This was not quick enough, and that was dead.

Nothing could seem too rich to clothe the sun,

Much less the joys which trample on his head.

As flames do work and wind, when they ascend,

So did I weave my self into the sense.

But while I bustled, I might hear a friend

Whisper, How wide is all this long pretence!

There is in love a sweetness ready penned:

Copy out only that, and save expense. (1-18)

Herbert sees in his devotional language a reflection of his own degeneracy, and he expresses a longing to remove the taint of transgression from his vocabulary, to purify his language and symbolically re-enter the Eden he left in "Misery," where "Glory and grace" will "crown his heart and face" once more. In other poems from The Temple, Herbert explores two different approaches to the linguistic purification that he longs for in "Jordan (2)". In "The Sacrifice" he experiments with the alchemical transformation advocated by Huet and in "Paradise"with the methodical excision of corruption described by Reynolds, but the goal in both poems is the same: a devotional language that approximates the purity of edenic speech.

\section{From Dust to Rest}

Herbert has illusions about the nature of his current, corrupt state. He presents himself as an exemplum of the Fall "because my lust / Hath still sewed fig-leaves to exclude thy light: / But I am frailty, and already dust" ("Sighs and Groans" 15-17). Sin and shame_-as represented by the fig leaves_-combine to obscure Herbert's perception of God in the same way that they separated Adam and Eve from the divine presence in Eden; Herbert describes the mortal dust from which his body has been formed as an obstacle blocking his return to 
and vision of Eden, and he can only imagine the day when his "eyes shall see thee, which before saw dust" ("Love [2]" 9-10). Herbert longs to escape from under the burden of Adam's curse in Genesis—“dust thou art, and unto dust shalt thou return”- and enjoy a relationship of prelapsarian purity with his Maker. ${ }^{27}$

Herbert knows that Jesus Christ is the means by which the Adamic curse has been circumvented, and he acknowledges edenic innocence can only be restored to mankind through the sanctifying power of his grace. But in "The Sacrifice," Herbert appropriates the persona of Christ and suggests that he, through Christ's grace and the refinement of his own language, has escaped the burden of the Fall. In the first stanza of the poem, before the reader can be certain of the speaker's identity, Herbert asks

$\mathrm{O}$, all ye, who pass by, whose eyes and mind To worldly things are sharp, but to me blind;

To me, who took eyes that I might you find:

Was ever grief like mine? (1-4)

Herbert serves notice that he will take "eyes"-or I's-in the remainder of the poem: that the speaker in "The Sacrifice" will be a representation of himself as well as Jesus Christ. It is this double identity that lends special significance to the narrative Christ's claim "that I the Temple to the floor / In three days razed, and raised as before. / Why he that built the world can do much more" (65-67). By merging his own identity with that of the narrative Christ, Herbert sanctifies his own Temple and associates it with the perfection of Eden, when the world was first built and it was "very good." As Douglas Thorpe argues, Herbert himself is "the temple that has been built ... as delight is alchemized to sacrifice"; Herbert's mysterious transformation into the persona of Christ, and the accompanying purification of his language,

\footnotetext{
${ }^{27}$ Genesis 3:19.
} 
is catalyzed by Christ's blood in an alchemical reaction. ${ }^{28}$

Herbert acknowledges his interest in alchemy most explicitly in "The Elixir," where he compares the eucharist, in which "All may of [God] partake" to "the famous stone / That turneth all to gold" $(13,21-22)$. This sacrament and the symbolic representation of Christ's blood allows Herbert to reenter Eden and the heavenly paradise that Eden foreshadowed; describing "The Holy Communion," Herbert explains that he, like Adam, "might to heav'n from Paradise go, / As from one room t'another" by symbolically partaking of "this thy heav'nly blood" when he drinks the communion wine (35-38). As Thorpe explains, Herbert believes that it is "in sacramental labor [that] the new earth is daily made visible, so that 'whether I flie with angels, fall with dust ... Thy power and love, my love and trust / Make one place ev'rywhere.' Here is the union of Thy and my" that existed in Eden-the original "new earth"-restored. ${ }^{29}$ Through the alchemy of communion, Eden is restored.

Roberta Albrecht identifies other alchemical allusions in "To John," a Latin poem in which Herbert demands that the beloved disciple cease "leaning on Jesus' bosom" so that Herbert might take his place at the Master's side. Albrecht argues that Herbert elides the image of John at Christ's breast with "the image of the alchemical virgin suckling her child during cibation," informing John that

He also shed his blood for me, And thus, having rightful Access to the breast, I claim the milk Mingled with the blood. ${ }^{30}$

\footnotetext{
${ }^{28}$ Genesis 1:31; Douglas Thorpe, A New Earth: The Labor of Language in Pearl, Herbert's Temple, and Blake's Jerusalem, (Washington, D.C.: The Catholic University of America Press, 1991), 84.

${ }^{29}$ Thorpe, A New Earth: The Labor of Language in Pearl, Herbert's Temple, and Blake's Jerusalem, 84.

${ }^{30}$ John 13:23; Roberta J. Albrecht, Using Alchemical Memory Techniques for the Interpretation of Literature, (Lewiston: The Edwin Mellen Press, 2008), 119; as quoted in Albrecht, Using Alchemical Memory Techniques for the Interpretation of Literature, 118.
} 
By suckling at Christ's breast, Albrecht suggests that Herbert hopes to undo the Fall and "regain all that is rightfully his by mixing his drink (as in the medieval tradition of mixing milk and blood), thereby getting double grace." ${ }^{31}$ This double grace would allow him to figuratively reenter Eden and reclaim the spiritual perfections forfeited when Adam and Eve left the garden.

Just as Christ's bloody milk is the medium by which Herbert regains his innocence in "To John," his blood is also the alchemical catalyst that purifies Herbert's language—and The Temple - in "The Sacrifice." The narrative Christ acknowledges "my blood to be the only way, / And cordial left to repair man's decay" (158-59). Christ's blood is the only elixir that will restore Eden, and Herbert douses The Temple's language in it; he counts out the meter of his poetry in the rhythm of Gethsemane, where Christ's "sweat was as it were great drops of blood falling down to the ground." Herbert describes the rhythm of Christ's bloody sweat falling on the ground as a substitute for the rosary; his "Drops [of] blood [are] (the only beads) my words to measure" (22). He also conflates the words of his own poetic language with the Word, Jesus Christ, who "was in the beginning with God" and by whom "All things were made.,"32 Just as "The tree of life" and the paradisiacal world "came in / By words" (203, 206-07), Herbert's words will, through the grace of Christ's blood, treat "the earth's great curse in Adam's fall" and "remove it all" (165-66). Having cleansed his language in the blood of Christ, Herbert attributes a salvific and restorative power to the poems of The Temple; although his words were little better than "a thorn" in their original form, they have "let me blood" and so will "restore / What I have lost with cordial fruit" in Eden ("The Collar" 7-9).

\footnotetext{
${ }^{31}$ Albrecht, Using Alchemical Memory Techniques for the Interpretation of Literature, 118.
} 
If dust is the symbol of humanity's Fall from Eden, rest is the promised blessing for all those who, like Herbert, regain that heavenly paradise of which Eden was a type. As Chana Bloch notes, "Rest is the gift of God the Creator" after he had formed Eve from Adam's rib in Eden, and rest is the essence of edenic perfection: "God himself 'rested on the seventh day from all his worke."” Bloch cites Genesis as proof that "Herbert uses the word [rest] with its full symbolic weight" in "The Pulley," a poetic account of "When God at first made man" (1). ${ }^{33}$ In Eden, God begins to bestow all "the world's riches" — strength, beauty, wisdom, honor, and pleasure-on humanity, but

When almost all was out, God made a stay, Perceiving that alone of all his treasure

Rest in the bottom lay. (8-10)

Rest is the only gift that God withholds from humanity, but this apparent imperfection in the edenic estate is, paradoxically, the very means by which the fallen faithful are restored to paradisiacal perfection. God withholds his rest, yet he allows man to

...keep the rest,

But keep them with repining restlessness:

Let him be rich and weary, that at least,

If goodness lead him not, yet weariness

May toss him to my breast. (16-20)

It is at Christ's breast, where the elect will imbibe bloody milk as an alchemically transformative catalyst, that they will find rest and, as Albrecht argues, "regain all that is rightfully [theirs]," all that was lost in Eden. ${ }^{34}$ It is through the purified language of his own poetry that Herbert can dust himself off, as it were, "That to the old man I may rest, / And be in [Christ] new dressed" ("Aaron” 19-20).

\footnotetext{
${ }^{32}$ Luke 22: 44; John 1:2-3.

${ }^{33}$ Chana Bloch, Spelling the Word: George Herbert and the Bible, (Berkeley: University of California Press, 1985), 49.
} 


\section{$\underline{\text { Paradisiacal Pruning }}$}

Herbert's poems abound with the sorts of metaphysical conceits and mystic transformations that convert the eucharist into a philosopher's stone and Herbert into Christ himself, but they also embrace an alternative aesthetic of plainness. In Jordan (1), Herbert rejects those who say "that fictions only and false hair / Become a verse" (1-2). He suggests that his poems are an appropriate medium for plain truths as well as complex alchemical transactions; not all poetry must "be veiled, while he that reads, divines, / Catching the sense at two removes" (9-10). Conscious that readers who gravitated toward an unadorned aesthetics might argue that plainness is inevitably subordinated by poetry, Herbert begs that they not "punish me with loss of rhyme, / Who plainly say, My God, My King" (14-15). James Boyd Whites explains the poem's paradoxical nature nicely: it is a "poem against poetry then, a complex text written to affirm the value of plain simplicity" in which Herbert demonstrates that poetry can be made to serve plainness, that the medium need not always obscure the message. ${ }^{35}$

Herbert shows that plainness, like the complex alchemical processes of "The Elixir" or "To John," is also a conduit to prelapsarian purity, and he presents a methodology for purging the corruptions of the Fall from language in "Paradise." Here Herbert describes himself as one of the trees in God's orchard whose purity and fruitfulness are the products of God's pruning shears:

I bless thee, Lord, because I GROW Among thy trees, which in a ROW To thee both fruit and order OW.

What open force, or hidden CHARM

\footnotetext{
${ }^{34}$ Albrecht, Using Alchemical Memory Techniques for the Interpretation of Literature, 118.

35 James Boyd White, 'This Book of Starres,' (Ann Arbor: The University of Michigan Press, 1994$), 50$.
} 
Can blast my fruit, or bring me HARM,

While the inclosure is thine ARM?

Inclose me still for fear I START

$\mathrm{Be}$ to me rather sharp and TART,

Than let me want thy hand and ART.

When thou dost greater judgments SPARE, And with thy knife but prune and PARE, Ev'n fruitful trees more fruitful ARE.

Such sharpness shows the sweetest FREND:

Such cutting rather heal than REND:

And such beginnings touch their END. (1-15)

Just as Herbert himself must be pruned and pared so that he can remain a productive member of God's paradisiacal garden, so too must his language be trimmed and cut back; Herbert employs the same processes used by God in purifying the faithful to purify his language.

Before he can become one with God and enjoy the divine presence, Herbert—and his language — must be stripped of corruption: in The Temple, there is "no way out of being broken if one seeks wholeness." Thorpe argues that the construction of a pure language is, paradoxically, a process of deconstruction, or paring down, because "[b]uilding, by necessity, Herbert claims at his most radical, must in fact be an 'unbuilding' operation by God; otherwise building is simply Babel." ${ }^{, 36}$ Babel's builders thought that they could build a tower high enough to breach the heavens; they sought to win back the perfections lost in Eden through human artifice. In "Paradise" Herbert argues that linguistic purity will be restored only when the corruptions introduced at Babel have been stripped away. Here the invention of a pure language is not about novelty but the discovery of primitive words hidden by linguistic accretions. God oversees paradise as a gardener, stripping the elect of impurities by painfully paring away their sins, and Herbert is the gardener of "Paradise" whose linguistic

\footnotetext{
${ }^{36}$ Thorpe, A New Earth: The Labor of Language in Pearl, Herbert's Temple, and Blake's Jerusalem, 73, 86.
} 
pruning restores prelapsarian purity to words.

Herbert produces the end rhymes of "Paradise" by removing the initial letter of the last word in the first line of each stanza and placing the new, shorter word at the end of the second line; "GROW" becomes "ROW" and "ROW" becomes "OW" as the process is repeated. As White notes,

The pattern in each case (after the first stanza anyway, though 'row' can mean altercation) is the same-first something good, then something bad, then something neutral - and an important part of the point is that this pattern is not made by the poet but found in the language, in the very words themselves. This sense of the language itself as a source of meaning and beauty outside the speaker, and of the similarly mysterious significance of the poetic form itself, counteracts the consciousness, so explicit in the "Jordan" poems, of the deep inadequacy of all language and art. ${ }^{37}$

Herbert does not reveal a new, more pure language in "Paradise"; rather, he presents a new way of using extant language and unlocking its paradisiacal potential. The symbolic progression —or regression-within each stanza from good to bad to neutral is a mimetic representation of post-Babel human attitudes toward language: the pagans celebrated their own language and human creativity; Christians recognized that their language had become corrupt; and seventeenth-century language reformers like Bacon worked to restore the natural relationship between words and things, to strip language of its positive and negative connotations and restore its denotative potential. Herbert's methodological removal of mortal corruptions restores language to its original state, allowing the speaker an unmediated relationship with deity.

Because Herbert presents The Temple as a devotional text by which the reader can draw closer to God by traversing The Church-Porch, entering The Church, and worshipping at "The Altar," the paradisiacal language that Herbert produces is socially inclusive. Cristina

\footnotetext{
${ }^{37}$ White, 'This Book of Starres,' 60.
} 
Malcolmson argues that in "Paradise,"

growth and productivity [are dedicated] to communal rather than individual purposes. The gardens use the dichotomy of nature and art to achieve this coordination, since the concept of art is used to suggest not only the incorporation of the individual into the social fabric by controlling his or her unruly nature, but also the improvement of an uncultivated nature in order to increase productivity. The aesthetic shaping of the garden proclaims moral, religious, and political reformation but obscures the development of private property, whether that of the land or of the self. ${ }^{38}$

"Paradise" is God's garden; its language is the language of God. The poet and the reader alike are only trees within the garden whose access to the neutral language of paradise is equal. Herbert's new devotional language erases social boundaries and private property, binding readers together in an edenic community of the elect.

Herbert's language also serves as a ligature in "The Dedication" to The Temple, where the poems he has written bind him and his readers to God. Herbert denies having authored the poems himself; they are his "first fruits" and

Yet not mine neither: for from thee they came, And must make return. Accept of them and me, And make us strive, who shall sing best thy name.

Turn their eyes hither, who shall make a gain:

Theirs, who shall hurt themselves or me, refrain. (2-6)

According to Herbert, the language of "Paradise" was not a product of his imagination but a transcription of divine speech returned to its original author, and the act of reading the poems creates a divine community; reading transforms "them" and " $m e$ " into " $u s$," allowing a community of the elect to "make return" into God's presence. "The Altar," Herbert's most famous poem, describes an altar built of hearts in which "sin turned flesh to stone" ("The Holy Communion” 29). These stones God's “hand did frame; / No workman's tool hath touched the same" ("The Altar" 3-4), and the language that brings those hearts together is the

\footnotetext{
${ }^{38}$ Cristina Malcolmson, Heart-Work, (Stanford: Stanford University Press, 1999), 179-80.
} 
cement that makes the community of the elect into a living altar which "to praise thee may not cease" ("The Altar" 14). The language of "Paradise" is as close to the language of paradise as Herbert believes English can be; it strips the corrupt connotations of human thought from neutral linguistic roots and creates an edenic community ready to reenter God's presence.

\section{"In the Beginning Was the Word": The Plain Language of the Bay Psalm Book}

When William Spengemann advocated studying writers like Herbert_- "some of the most historically and literarily important English writings of the Renaissance and the Enlightenment" - as early American literature because those texts "helped to create the stylistic circumstances" in which English colonial authors wrote, his plea fell largely on deaf ears. ${ }^{39}$ But Spengemann's work seems particularly relevant in light of an interdisciplinary renewal of interest in the Puritan plain style, with which the plain aesthetics of Herbert's "Paradise" and "Jordan" poems have much in common. In recent years, scholars have variously identified the plain style as an inspiration for nineteenth-century American poetry, a means of economic and transatlantic self-definition, and an aesthetic manifest in the physical objects of New England, yet each of these examinations of the Puritan plain style still defines the term largely as Perry Miller did the better part of a century ago: as a series of rhetorical proscriptions urging practitioners to an "unmediated transparency wherein rhetoric was homely and common, visual artifice anathema, and bodily performance shunned."40

\footnotetext{
${ }^{39}$ William Spengemann, A New World of Words, (New Haven: Yale University Press, 1994), 49-50.

${ }^{40}$ Matthew P. Brown, The Pilgrim and the Bee, (Philadelphia: University of Pennsylvania Press, 2007), 22.

I reference Brown; Elisa New, "Variety as Religious Experience: The Poetics of the Plain Style," Religion and Literature 38, no. 1 (2006): 9-25; and Michelle Burnham, Folded Selves (Hanover: University Press of New England, 2007), 46-67, respectively. Brown's explication of the "thick style" contributes substantially to our understanding of the aesthetics of the material objects and language used by New England Puritans but, like
} 
These practices illustrate the usage and delivery of the Puritan plain style, but they hardly offer readers a means of describing the actual language of which the plain style consists. An examination of the Bay Psalm Book's linguistic character-its lexical and etymological roots—suggests that its translators conceived of the plain style as an aesthetic with a distinctive vocabulary. As Zoltán Haraszti notes, the vocabulary of the Bay Psalm Book is its most enduring and important feature; even when Henry Dunster substantially rewrote the volume in 1651, "there were few changes in the vocabulary; only the rhymes were corrected. ${ }^{, 41}$

As Matthew Brown notes, critics have turned the Bay Psalm Book—and, implicitly, its vocabulary—into an icon marking the beginning of American literature and "the ground upon which the "plain style' is understood." Fortunately, the existence of earlier English psalmodies allows readers to view the Bay Psalm Book's exposition of the Puritan plain style as something more than a beginning; it is an end product of the linguistic evolution that prompted Reynolds to call for a new translation of the Bible and Herbert to translate Bacon's Advancement of Knowledge. The translators of the Bay Psalm Book set about to purify the English language in the same way that Herbert does in "Paradise," and their movement towards a plain English can be traced in the Bay Psalm Book's lexical divergence from the earlier, more ornate psalmodies of Sir Philip Sidney, Thomas Sternhold and others. ${ }^{42}$ Seen in this literary context, the Bay Psalm Book becomes more than "the 'first' American book"; it is a "selection and arrangement of English words attributable to the writer's efforts to take

Miller, neglects the actual language and vocabulary of the plain style.

${ }^{41}$ Zoltán Haraszti, The Enigma of the Bay Psalm Book, (Chicago: The University of Chicago Press, 1956), 29.

${ }^{42}$ Brown, The Pilgrim and the Bee, 37. The Sidney and Sternhold-Hopkins are used for comparison because of their representative nature; many other translations of the psalms in both plain and ornate language were produced in the sixteenth and seventeenth centuries. 
hold of "America," where "America" represents the alternately innovative and regenerative ideas about religion whose initial rejection in England forced Puritans like John Cotton to emigrate to the Bay Colony. ${ }^{43}$ In his examination of the neoclassical plain style, Richard Kroll suggests that "earlier forms of discourse and inherited vocabularies remain visible but assume different connotations and alliances; we witness the invention of new discourses to serve the needs of revived or new institutions," and the same is true of the Bay Psalm Book with relation to the English psalmodic tradition. ${ }^{44}$ Individual psalms may resemble earlier translations by Sternhold and Hopkins or Sidney, but a comparative analysis of the Bay Psalm Book's language reveals that the New England translators have pruned and trimmed devotional English into its most basic form. It is certainly possible that the Bay Psalm Book translators intentionally modeled their verses after Herbert's "Paradise"-after all, as John Shawcross notes, "it is [the straightforward poet Herbert, the unmetaphysical Herbert] we find reflected in the poetry of Colonial authors more often," who strictly adhere to "the concept of plainness in 'Jordan (I),' which Herbert himself does not unrelentingly follow." ${ }^{\text {,45 }}$ But establishing a direct influence is unnecessary; the salient points are that the Bay Psalm Book translators approach the task of purifying language in the same manner as Herbert and that "Paradise" should be understood as an exemplary text which illuminates and explicates the linguistic work done by the Bay Company psalter.

\footnotetext{
${ }^{43}$ Brown, The Pilgrim and the Bee, 37; Spengemann, A New World of Words, 49. As Amy Morris points out in her consideration of the politics of seventeenth-century psalmody, the Bay Psalm Book was a meaningful endpoint only for the colonists, who overwhelmingly favored the translation until Isaac Watts's 1719 Psalms of David Imitated eventually replaced it in the late eighteenth century (Amy Morris, "The Art of Purifying: The Bay Psalm Book and Colonial Puritanism" Early American Literature 42, no. 1 [2007]: 107-130). In England, the psalters of King James I (1631), George Wither (1632), Francis Rous (1643), William Barton (1644), and Henry King (1651), among others, were all promoted by various factions as the ideal replacement to the Sternhold and Hopkins (1562) translation most commonly used in the English church prior to its ultimate replacement by the Tate and Brady psalter in 1696.

${ }^{44}$ Richard W. F. Kroll, The Material Word (Baltimore, MD: The Johns Hopkins University Press, 1991), 39.
} 
In seeking an edenic English, Herbert and the translators of the Bay Psalm Book participated in a cultural project that transcended sectarian divides and engaged in a national pursuit that occupied both secular and religious writers. Seventeenth-century travel narratives by writers from a multitude of religious perspectives explored the potentiality of a "pure" language: "Whether based on real or imagined findings—-such as Chinese characters, the presumed Hebraic origins of Native American words, or the hieroglyphics of Thomas More's Utopians-these travel narratives evoke the possibility of recovering a prefallen language like that spoken in the Garden of Eden.” Thomas Sprat of the subsequently formed Royal Society urged his countrymen to alter the English language to adopt the virtues of these foreign tongues by returning "back to the primitive purity and shortness, when men deliver'd so many things, almost in an equal number of words [...] preferring the language of Artisans, Countrymen, and Merchants, before that, of wits, and scholars. ${ }^{46}$ It is in this context-a national movement toward linguistic reform that sought to recover the purity of the Adamic tongue- that the Bay Psalm Book's plain style must be examined.

\section{Linguistic Masonry}

Like the language of Herbert's "Paradise," the translations in the Bay Psalm Book are meant to engender a sense of community as they are "sung by a joynt consent and harmony of all the Church in heart and voyce." The poetry and music of the psalms unify the congregation as they sing, "all of us with one heart and one voyce." The translation of the psalms, like the composition of The Temple, is an act of linguistic masonry by which

\footnotetext{
${ }^{45}$ Shawcross, "Some Colonial American Poetry and George Herbert," 38.

${ }^{46}$ Burnham, Folded Selves, 56; Thomas Sprat, The History of the Royal Society of London (London: Printers to the Royal Society, 1667), 113. Though Sprat represents a scientific view of language and though the search for the Adamic language increasingly became a scientific pursuit, Puritans who worked on the Bay Psalm Book, including John Cotton, would have been familiar with the theories of a pure Adamic language from their studies of exegetical and hexameral literature.
} 
individual hearts are bound together into a living altar and returned to God's presence. In the

Preface to the Bay Psalm Book, Cotton makes the comparison explicit, explaining that

If therefore the verses are not always so smooth and elegant as some may desire or expect; let them consider that Gods Altar needs not our pollishings: Ex. 20. for wee have respected rather a plaine translation then to smooth our verses with the sweetnes of any paraphrase, and soe have attended Conscience rather then Elegance, fidelity rather then poetry, in translating the hebrew words into english language, and Davids poetry into english meetre; that soe wee may sing in Sion the Lords songs of prayse according to his owne will. ${ }^{47}$

The author of the Bay Psalm Book's preface and one of its most influential translators, John Cotton exerted more influence over the volume's devotional aims and stylistic innovations than anyone else involved in its preparation. Under his direction, the translations of the Bay Psalm Book were rendered as faithfully as possible to the original Hebrew, the language of Eden, allowing Cotton and his team of translators to unify their edenic community of the elect, their New Jerusalem or "Sion."

In his Briefe Exposition with Practicall Observations upon the Whole Book of Ecclesiastes (1654), Cotton turns to the church fathers as a model of the ways in which language can ameliorate the effects of original sin and restore edenic purity. He writes that "Original sin is fitly compared (by Epiphanius) to a wilde Fig Tree, rootted in the joynts of the stone-wall of a goodly Pallace, If it be cut and lopped (as it is by repentance and mortification) yet it sprouteth againe, but when the walls are taken downe, and the stones cast asunder, body and soul parted, then being built againe, the root is shaken out utterly."48 In the

\footnotetext{
${ }^{47}$ John Cotton, Preface to The Bay Psalm Book, facsimile (Chicago, IL: University of Chicago Press, 1956), 6, 9, 14-15. Although many originally supposed that Richard Mather wrote the "Preface" to the Bay Psalm Book, Zoltan Haraszti presents convincing evidence to the contrary in The Enigma of the Bay Psalm Book. Cotton apparently wrote the majority of the essay, then sent it to Thomas Shepard for editing and additions. As the manuscript evidence is incomplete and it is impossible to determine exactly who is responsible for various phrases, I refer to Cotton as the author of the Preface throughout.

${ }^{48}$ John Cotton, A Briefe Exposition with Practicall Observations upon the Whole Book of Ecclesiastes (London: Anthony Tuckney, 1654), 260. This analogy can be found in Epiphanius, The Panarion of Epiphanius of Salamis, trans. Frank Williams, in Nag Hammadi and Manichaean Studies, Vol. XXXVI, ed. J.M. Robinson \&
} 
surrounding discussion from which Cotton quotes, Epiphanius writes of the resurrection, recognizing that in mortality "sin is reduced and lulled to sleep by faith, and canont bear harmful fruit; but it has certainly not been destroyed roots and all." But even if the guilt of original sin cannot be wholly eliminated until death, Epiphanius argues that the effects of sin can be removed from the life of a true believer if, "like an ax the word chops sin's roots off as they grow below."49 In the borrowed framework of Epiphanius, Cotton suggests that the pure word can rip up the buried roots of sin below the ground and work to purify the soul from sin's effects even before the separation of body and spirit.

In an important addition to the framework established by Epiphanius, Cotton draws on Jesus's parable of the wheat and the tares, casting Satan as the sower of "our sin, and springing up in us, which is but cast into us by Satan [...] The weeds that are cast in over the pale, into a mans garden, are not the weeds of the garden, till the soyle give rooting to them, that is consent." ${ }^{, 50}$ Cotton's New Testament addition to the allegory of Epiphanius includes the notion that $\sin$ - even original sin-requires some measure of consent on the part of the soil or individual in which it takes root. His analogy implies that the effects of original sin are not inescapably embedded in mortal flesh; instead, the roots of sin are merely well buried in the interstices of body and soul as the roots of the fig tree are buried in the stone wall. Because sin requires some measure of consent on the sinner's part and even its deepest roots can theoretically be dug up, Cotton's conception of sin offers the hope that the regenerate might expunge sins effects from their lives so that they could enjoy their assured salvation in

H.J. Klimkeit (Leiden: Brill, 1994), 160-61, in Book Two, section IV, Heresy 64, paragraph 33, lines 1-7 of the Panarion, hereafter (64, 33, 1-7). The Panarion is a treatise condemning heretics, "exposing their unlawful deeds like poisons and toxic substances, matching the antidotes with them at the same time-cures for those who are already bitten, and preventatives for those who will have this experience" (Proem I, 1, 2).

${ }^{49}$ Epiphanius, Panarion, (64, 33, 6-7).

${ }^{50}$ Cotton, A Briefe Exposition with Practicall Observations upon the Whole Book of Ecclesiastes, 144. 
a type of renewed edenic state.

In describing Epiphanius's fig tree as a representation of original sin, Cotton states that the processes of repentance and mortification serve only to trim back the outward manifestations of sin, but elsewhere in A Briefe Exposition he indicates that repentance and mortification can actually remove the very root of sin, as Ephiphanius suggests that "the word chops sin's roots off." Ennumerating the reasons why individuals remain in sin, Cotton proposes that this continuation in sin mainly results from "Toleration of the root of it, without mortification of it." ${ }^{, 51}$ Cotton clearly believes in the possibility of rooting out sin and provides Jonah as an example of someone who could have accomplished the feat but chose not to. Sin first manifested itself in Jonah's heart when he refused God's call to Ninevah: "But Jonah rose up to flee unto Tarshish from the presence of the Lord." After famously being swallowed by "a great fish," Jonah repented for not traveling to Ninevah and agreed to "pay that that I have vowed" by returning to Ninevah and preaching. When the Ninevahites repent, however, Jonah begrudges them forgiveness and defiantly tells God, "I do well to be angry, even unto death." In backsliding to a blasphemous anger, Cotton writes that Jonah missed an opportunity to eliminate not only his anger but also the very root of sin: "Thus Jonah repenting of his forsaking his call, but not mortifying the pride of his heart (which was the root of it) brake forth againe." ${ }^{52}$ The implication of Cotton's biblical exegesis is that Jonah could have removed the root of pride from his heart but chose not to.

By adopting Epiphanius's characterization of original sin and highlighting Jonah's missed opportunity to uproot sin from his heart, Cotton makes the expulsion from Eden

\footnotetext{
${ }^{51}$ Epiphanius, Panarion, (64, 33, 7); Cotton, A Briefe Exposition with Practicall Observations upon the Whole Book of Ecclesiastes, 145.

${ }^{52}$ Jonah 1:3, 17; 2:9; 4:9; Cotton, A Briefe Exposition with Practicall Observations upon the Whole Book of Ecclesiastes, 145.
} 
reversible. The recovery of edenic purity is a matter of masonry, and in the Bay Psalm Book, the translators are metaphorical masons using linguistic stones to build God's altar. Cotton rejects the belief that "all English words are framed by English men, in corrupt nature, to wit, without the immediate assistance of the Holy Ghost in the framing of them" because the "English words [in psalms] are as much an invention of man as English Tunes" and "we have [from God] also the like liberty of inventing Tunes" for the psalms. In Cotton's conception, a man filled with the Holy Ghost can transcend his corrupt nature to invent English words and combinations of words that are both plain and pure. The English Cotton employs in the Bay Psalm Book is a halfway point between conventional language and Hebrew, the language of Eden. Though the psalms occasionally use "the Idioms of our owne tongue in stead of Hebraismes," these changes "are such as either the hebrew will unforcedly beare, or our english forceably calls for," and they "no way change the sence" of the original edenic speech from which they are translated. The Bay Psalm Book introduces the paradisiacal purity of the lingua humana into English. By excising "the corruptions in our common psalme books," the translators prune the devotional English of the psalms to its essentials in the same way that Herbert pares down the language of "Paradise," allowing Cotton to deconstruct Epiphanius's stone wall into its linguistic parts and replace the fig tree with an altar, a model of the English language's potential purity. ${ }^{53}$

\section{The Plain Style of Primers and Psalm Books}

When, in the Preface, Cotton famously stated "that Gods Altar needs not our pollishings Ex. 20," he introduced his ideal language as one composed of rough, unpolished words. The reference to Chapter 20 of Exodus discloses his familiarity with God's

\footnotetext{
${ }^{53}$ John Cotton, Singing of Psalmes a Gospel-Ordinance (London: Hannah Aleen and John Rothwell, 1647), 58; Cotton, Preface, 14.
} 
instructions in Exodus to those who would build him an altar: "And if thou wilt make me an altar of stone, thou shalt not build it of hewn stone: for if thou lift up thy tool upon it, thou hast polluted it." Altar builders could not polish or shape stones before using them in construction; they had to use "whole stones" or else God would not accept the altar. ${ }^{54}$ For Cotton and the other translators of the Bay Psalm Book, God's guidelines for construction represented a linguistic challenge; their poetic altars needed to be built with whole stones, with a language undefiled by mortal embellishments. Hannibal Hamlin explains that this meant the language of the newly translated psalms needed to avoid both the textual inaccuracies and "meaningless filler phrases typical of the 'Sternhold and Hopkins' psalms" as well as the artistic, polished phrases of translators like Sir Philip Sidney and the Countess of Pembroke. 55

Amy Morris argues that in promoting a translation of the psalms with linguistic whole stones Cotton works to construct linguistic "purity in the Reformation tradition, that is, not as an elitist cultural refinement but as a back-to-basics stripping away of unnecessary accretions." Seeking models of language in its most basic form, Cotton and his fellow translators undoubtedly would have been influenced by the primers and catechisms of children, texts which they learned either in church, at home or in an "English school." Undoubtedly, the Bay Psalm Book translators, who grew up singing the psalms of Sternhold and Hopkins, made the connection between the language of early primers and the psalms naturally. As early as 1583 , Ian Green explains that the catechisms in primers began to appear "in verse, which could also be sung to the same tunes as in Sternhold and Hopkins's

\footnotetext{
${ }^{54}$ Cotton, Preface, 14; Exodus 20:25; Deuteronomy 27:6.

${ }^{55}$ Hamlin, Psalm Culture and Early Modern English Literature, 20.
} 
metrical version of the psalms. ${ }^{, 56}$ Composers of these primers and metrical catechisms wrote "not in a lofty style or to have used hard words but to be especially suitable for 'poor, simple country-people," an apt description of the colonists "used to a plain country life" that Bradford describes settling in Plymouth and for whose consumption Cotton directed the translation of the psalms. ${ }^{57}$ Most importantly, by eschewing rhetorical flourishes and "hard words," the primers and catechisms anticipate Cotton's later attention to both language and rhetorical devices in the Puritan plain style. The New England Primer and the Royal Primer of King George, though printed more than eighty years after the Bay Psalm Book first appeared in 1640, still capture the avoidance of hard words and the approach to language prevalent in the early seventeenth century and exemplified by the most popular two primers of the time: The A.B.C. with the catechisme and The primer and catechisme.

In the 1636 edition of The A.B.C. with the catechisme, religious instructors presented children with "six sets of alphabets (in black letter, roman and italic type-faces, all in upper and lower case)" and a list of two letter pairings representing common syllables. The book offered no other language instruction; children apparently passed from syllabaries on to the

\footnotetext{
${ }^{56}$ Amy Morris, "The Art of Purifying: The Bay Psalm Book and Colonial Puritanism," Early American Literature 42.1 (2007): 111; Ian Green, The Christian's ABC: Catechisms and Catechizing in England c. 15301740 (Oxford: Clarendon Press, 1996), 172, 154. As Matthew Brown notes, the Bay Psalm Book is "the only English-language version widely circulated that reproduced the abecedary," inserting a reminder of the alphabetic basis of the $119^{\text {th }}$ Psalm where other translations effaced it. Indeed, Edmund Calamy referred to the psalm as "A holy Alphabet for Sions Scholars; the A.B.C. of godliness. Sixtus Senensis calls it, An Alphabetical Poem. The Jews are said to teach it their little Children the first thing they learn, and therein they take a very right course, both in regard of the heavenly matter, and plaine stile fitted for all capacities." Believing that Jews used the psalms as a primer, the translators of the Bay Psalm Book cannot have failed to consider their own psalmody an extension of the linguistic views expounded in their more formal primers. See Brown, The Pilgrim and the Bee, 40; as quoted in Brown, The Pilgrim and the Bee, 49.

${ }^{57}$ Ian Green, The Christian's ABC: Catechisms and Catechizing in England c. 1530-1740, 254; William Bradford, Of Plymouth Plantation 1620-1647, ed. Samuel Eliot Morison (New York: Alfred A. Knopf, 1966), 11. In actuality, many if not most of Bradford's party were, as Michelle Burnham points out, "artisans of one sort or another. Among those who eventually left Holland to settle in Plymouth were clothworkers, woolcombers, tailors, watchmakers, cabinetmakers, carpenters, tobacco pipemakers, and printers." Still, Bradford's characterization of the party as a group of plain country people indicates the group's collective appropriation of a rural persona. See Burnham, Folded Selves, 51-52.
} 
full sentences of the catechism. While the New England Primer and the Royal Primer provide intermediate steps, both preserve the syllable as the basic unit of language from which words and sentences proceed. This commitment to the syllable may derive at least in part from Luther's insistence that "the catechist should begin by teaching the young and unlearned to repeat and retain the exact words of the catechism 'in such a way that we do not alter a single syllable'; only then should the catechist go on to 'teach them what it means."' Primer writers may also have emphasized the syllable in reading because of the largely oral nature of catechetical instruction. As Green notes, "[t]he text of a catechism was probably taught in short stages, either by repeated oral repetition where most of the catechumens were illiterate, or by giving literate catechumens copies to master, or by a mixture of oral repetition and reading." ${ }^{58}$ Most students first learned the catechism orally, then matched the written text to their memorized performance, and in matching a set of memorized sounds to the appropriate graphs, students needed to rely on syllables in order for literacy skills to transfer over to a text with visually unfamiliar words. Then, using the memorized sounds attached to a syllabary, learners could sound out unfamiliar words and recognize them from oral experience.

The Royal Primer constructs its syllabary in a series of tables: Table 1 contains words "Consisting of One Vowel and One Consonant"; Table 2, words "Consisting of One Consonant and One Vowel"; Table 3 presents "Significant Syllables of Two Letters only"; and the remaining tables list words of three, four, five, six and seven syllables, respectively. At the end of these lists appear "Select Proverbs consisting of Words of One Syllable only, in easy Verse." These proverbs conclude that portion of the Royal Primer devoted strictly to

\footnotetext{
${ }^{58}$ Ian Green, The Christian's ABC: Catechisms and Catechizing in England c. 1530-1740, 174, 235, 241.
} 
language, but the subsequent religious instruction consistently divides polysyllabic words into their various parts, acting as a continuing reminder of the syllable's linguistic primacy. The New England Primer teaches English in a somewhat different manner but also emphasizes the syllable's importance as the basic unit of language. From an introductory list of two-letter pairings, the New England Primer moves on to lists of words with one, two, three, four or five syllables. It lists polysyllabic words twice, first with hyphens to indicate the conjunction of syllables (a-bu-sing), then without hyphens (abusing). Like the Royal Primer, the New England Primer frequently hyphenates its subsequent moral instruction; it breaks every word of its two most basic statements, "The Lord's Prayer" and "The Creed," into syllables. In these two primers, one-syllable words are the linguistic equivalent of whole stones, words in their most basic state that do not require a clarifying or explanatory hyphen to join them.

For the Puritan translators of the Bay Psalm Book, strings of one-syllable words represented a means of constructing a linguistic offering to God without presuming to "polish" syllables, the basic units of language in seventeenth-century English. The Bay Psalm Book's translators thought of syllables as the primary unit of psalmodic composition because "all Verses in all Poems doe consist of a certaine number, and measure of Syllables." Though the meter of the Bay Psalm Book varies from psalm to psalm, the majority employ alternating lines of iambic tetrameter and iambic trimeter. With a minimum of six syllables to a line, translators at least had the option of using polysyllabic words, but the "Preface" seems to indicate a preference for syllabic simplification in its explanation of synonyms: "Synonimaes we use indifferently: as folk for people, and Lord for Iehovah, and sometime (though seldom) 
God for Iehovah. ${ }^{, 59}$ In all three examples, Cotton substitutes a one-syllable word for a polysyllabic choice, and even when the translators used the polysyllabic Jehovah in order to preserve the purity of God's name in Hebrew, they frequently "put Jah for Jehovah," contracting the name of God "for the verse sake." In the same way that Herbert strips letters from words until they reach their smallest meaningful form (from FREND to REND to END), the Bay Psalm Book translators break polysyllabic words into their syllabic foundations, and their eagerness to simplify belies the subsequent claim that "somtime wee have contracted, somtime dilated the same hebrew word, both for the sence and the verse sake. ${ }^{60}$ More importantly, a comparison of the Bay Psalm Book with other translations reveals that the translators placed a premium on simplicity, striving to render the psalms as concisely as possible. By keeping translations brief and plain, the Puritan translators discouraged presumptuously artistic alterations of the original Hebrew text while also avoiding unwanted and unnecessary textual additions.

This interest in a simplified, predominantly monosyllabic English suggests that the Puritan plain style involves a distinctive vocabulary as well as a proscription of rhetorical devices such as metaphor and repetition. Elisa New's recent discussion of the plain style's impact on the nineteenth century suggests that the core of Miller's original description of the plain style has held up well, "and if Perry Miller's argument—-that plain-stylists relied on the logical method of Peter Ramus to deliver doctrinal truth without embellishment—has not worn well, yet Miller's essential observations—-that Puritans suspected 'harmony...as the lighter part of rhetoric...,' resisting 'likeness of sounds, measures and repetitions' in favor of similes, metaphors, illustrations and examples'—has.” But insofar as we limit our treatment

\footnotetext{
${ }^{59}$ Cotton, Singing of Psalmes a Gospel-Ordinance, 55; Cotton, Preface, 13.
} 
of the Puritan plain style generally and the Bay Psalm Book's style specifically to an examination of rhetorical devices or even the material objects described by Brown, we undervalue its vocabulary unnecessarily. Indeed, Cotton's insistence that the plain style permits even "Rhetorical elegancies" provided "that the Rhetorick be suitable to the matter" suggests that "the considerations of time and place" which determine the acceptability of stylistic ornamentations often stretch to the point that we cannot describe the plain style solely in terms of rhetorical devices. ${ }^{61}$ The flexibility of ornamental prohibitions only underlines the potential utility of an alternate means of describing and identifying the plain style, something an analysis of its vocabulary provides.

The obvious problem in attempting to differentiate the plain vocabulary used by Cotton and his translators from what Debora Shuger calls "the Christian grand style of the Renaissance [...] a passionate and lofty religious prose" or other more ornamental styles lies in selecting a text where linguistic discrepancies do not arise from the mere vagaries of subject matter. ${ }^{62}$ Fortunately, the Protestant emphasis on scripture provides us with a set of texts whose lexical differences depend solely on authorial preferences. English translators published five new editions of the English Bible in the century before Puritan settlers reached the Bay Colony, and the number of psalm translations exceeded that total by far. Rivkah Zim numbers ninety discrete translations of the psalms into English produced between 1530 and 1601, and each of these translations (ostensibly) worked from the same Hebrew text. This

\footnotetext{
${ }^{60}$ Cotton, Singing of Psalmes a Gospel-Ordinance, 60; Cotton, Preface, 13.

${ }^{61}$ Elisa New, "Variety as Religious Experience: The Poetics of the Plain Style," Religion and Literature 38.1 (2006): 10; Cotton, A Briefe Exposition with Practicall Observations upon the Whole Book of Ecclesiastes, 9; Perry Miller, The New England Mind: The Seventeenth Century (Cambridge: Harvard University Press, 1954), 352.

${ }^{62}$ Deborah K. Shuger, Sacred Rhetoric: The Christian Grand Style in the English Renaissance (Princeton, NJ: Princeton University Press, 1988), 7.
} 
proliferation of psalm translations provides ample opportunity to compare lexical tendencies; because each translator worked from the same text, any differences in vocabulary between translations must result from the linguistic preferences of the translators themselves. In this way, we can compare the New England version of the Puritan plain style in the Bay Psalm Book to the decidedly more ornamental style of Philip Sidney's psalms and an earlier version of the plain style as recorded by Thomas Sternhold and John Hopkins. ${ }^{63}$ According to Hannibal Hamlin, the founders of the Bay Colony used one or more of the "over 700 editions of all shapes and sizes" of the Sternhold and Hopkins psalter printed "[b]etween 1562 and 1596" in their worship up until 1640, when their dissatisfaction with this standard English psalter led to the Bay Psalm Book's publication. ${ }^{64}$ A comparison of Cotton's Bay Psalm Book to these two earlier translations reveals that the New England plain style innovates lexically as well as stylistically.

In their efforts to establish the Bay Colony as a bastion of primitive purity Cotton and his translators invent a new language of devotion, one which offers its users a means of accessing true wisdom and an Eden-like access to God. By the "helpe of Christ," this devotional English would enable its users to purify their "corrupt Nature" and "bring forth knowledge by Tongues" in the same way that Adam did when he first named the animals. Although "it little skilleth what the pen be, of a Goose or Swans quil, or Ravens," Cotton taught that edenic wisdom could not be obtained or expressed unless "God delighteth to use such an instrument" because He finds the writer's "style and phrase of speech meet," and the

\footnotetext{
${ }^{63}$ Rivkah Zim, English Metrical Psalms (Cambridge: Cambridge University Press, 1987). As Hannibal Hamlin notes, the Sternhold translations were not originally thought of as plain or particular to the lower classes at all. They were originally produced, performed and published for the court of Edward VI, and their socially elite origins "need to be stressed, given the much later tendency to associate 'Sternhold and Hopkins' with the simple devotions of the lower classes" (Hannibal Hamlin, Psalm Culture and Early Modern English Literature [Cambridge: Cambridge University Press, 2004], 25).
} 
Bay Psalm Book translators worked to refine English into a language of which God might approve. ${ }^{65}$

\section{The Vocabulary of the Bay Psalm Book}

In rendering the psalms as plainly as possible, the translators placed a premium on words, rarely using two where one would do. For the purposes of comparing the Bay Psalm Book with its psalmodic predecessors, I selected fifteen psalms from each collection, choosing fourteen psalms randomly (numbers $8,11,12,25,38,46,93,94,95,100,103,127$, 129 , and 131) and also examining the twenty-third psalm because "[a]mong the 150 psalms, few were translated, paraphrased, explicated, or alluded to as often as Psalm 23," and its special status seems to have encouraged translators to singular efforts in using an idealized language ${ }^{66}$ Since there are 150 psalms, the fifteen I examined in each volume represent a full ten percent of the content, and this randomly selected representative sample illustrates the ways in which the idealized plain style of the Bay Company consists of a unique vocabulary.

The first and most obvious finding of my analysis was the relative brevity of

\footnotetext{
${ }^{64}$ Hamlin, Psalm Culture and Early Modern English Literature, 38.

${ }^{65}$ Cotton, Singing of Psalmes a Gospel-Ordinance, 59; Cotton, A Briefe Exposition with Practicall Observations upon the Whole Book of Ecclesiastes, 5-6.

${ }^{66}$ Hamlin, Psalm Culture and Early Modern English Literature, 147. I used the random number generator at www.random.org to choose 14 numbers between 1 and 150 (the number of psalms). The etmological and syllabic breakdown of each psalm is illustrated in Appendix B. Drawing on random psalms to assess the overall linguistic character of the psalms is tremendously important; as Morris argues, "[i]t is possible to identify several metrical Psalters used as source texts by the compilers" of the Bay Psalm Book by selectively looking at individual psalms, but an appreciation of the volume's linguistic totality requires an unbiased selection of a representative sample of psalms. Morris notes that "Psalm 116, for instance, contains strikingly simpler, more monosyllabic diction than is found in the King James or Geneva versions" of the Bible but cannot make her analysis more general without testing her hypothesis against other, randomly chosen psalms. Sidney's psaltery contains only one translation of each psalm, whereas both the Sternhold and Hopkins version and the Bay Psalm Book occasionally present multiple translations for each psalm. Thus, I actually analyzed seventeen psalms from the Sternhold-Hopkins translation, sixteen from the Bay Psalm Book and fifteen from the collaborative efforts of Sidney and the Countess of Pembroke. See Morris, "The Art of Purifying: The Bay Psalm Book and Colonial Puritanism," 120.
} 
translations in the Bay Psalm Book. Each psalm was, on average, only 195 words long; the Sternhold-Hopkins translations averaged 253 words per psalm; and the Sidney-Pembroke translations averaged 219. By limiting the word count of each psalm, the Bay Psalm Book translators created a mechanism to address the tendency of both the Sternhold-Hopkins and the Sidney-Pembroke translations to make "addition to the words [of David]" which altered the literal meaning of the lingua humana. The low word count also made it more difficult for translators to engage in the artistic flourishes that distinguished Sidney's work. Sidney’s additions are frequently aesthetic in nature; instead of the "fowls of the air, fish in the sea" that both the Bay Psalm Book and Sternhold-Hopkins agree on in the eighth psalm, Sidney digresses in describing "The Bird, free-burgesse of the Aire; / The Fish, of sea the native heire." Lest they stray from the Hebrew text or take undue "poeticall licence," the Bay translators kept their words to a minimum. ${ }^{67}$

The Bay translators also made an effort to use monosyllabic words, the linguistic whole stones required by the Lord and shown to be the most fundamental building blocks of language in contemporary primers. On average, each translation in the Bay Psalm Book used fewer polysyllabic words than either of the other two translations. Assuming that the translators must use a certain number of polysyllabic words simply to convey an accurate Table 1: Words Per Psalm

\begin{tabular}{|c|c|c|c|}
\hline & Bay Psalm Book & Sternhold-Hopkins & Sidney-Pembroke \\
\hline Total & 195 & 253 & 219 \\
\hline Polysyllabic & 38.5 & 42.5 & 42 \\
\hline Polysyllabic \% & $19.8 \%$ & $16.8 \%$ & $19.2 \%$ \\
\hline
\end{tabular}

sense of the Hebrew text, the low polysyllabic count in the Bay Psalm Book might represent a minimal usage level. Of course, the additional monosyllabic words in each Sternhold-

\footnotetext{
${ }^{67}$ Cotton, Preface, 12, 11.
} 
Hopkins translation-words non-essential to the psalms' meaning such as "'eke' and 'aye"” that were largely excised from the Bay Psalm Book—creates the illusion of a style more monosyllabic than that used by the New England translators. ${ }^{68}$ Because each SternholdHopkins psalm contains more words than its Bay Psalm Book counterpart, the SternholdHopkins collection appears to use a strikingly lower percentage of polysyllabic words. Only $16.8 \%$ of the words used by Sternhold-Hopkins are polysyllabic, whereas these words account for $19.8 \%$ of the vocabulary used by the Bay Psalm Book translators. In reality, however, the inclusion of extraneous monosyllabic words in the Sternhold-Hopkins translations distort these statistics. While both translations use polysyllabic words sparingly, only the Bay Psalm Book combines an intensive use of monosyllabic words with an emphasis on overall brevity.

The cumulative differences of the various translations might best be emphasized by a comparison of the one instance in which they are most similar, the twenty-third psalm. Due to its fame, I conjecture that each translator took especial care to render the twenty-third psalm as carefully as possible; not surprisingly, both the Sternhold-Hopkins and Sidney translations of this psalm match the Bay Psalm Book closely. The Bay Psalm Book translates this psalm in 121 words, and while the other two versions use more words, they diverge from the Bay Psalm Book's example much less than in other instances. Because the Sternhold-

\section{Table 2: A Comparative Analysis of Three Versions of the $23^{\text {rd }}$ Psalm}

\begin{tabular}{|c|c|c|c|}
\hline & Bay Psalm Book & Sternhold-Hopkins (2) & Sidney-Pembroke \\
\hline Words & 121 & 132.5 & 125 \\
\hline Polysyllabic & $15 \%$ & $14 \%$ & $16 \%$ \\
\hline
\end{tabular}

Hopkins and Sidney-Pembroke collaborations approximate the Bay Psalm Book's total word count, they also approximate the percentage of polysyllabic words. The twenty-third psalm

\footnotetext{
${ }^{68}$ Hamlin, Psalm Culture and Early Modern English Literature, 20.
} 
arguably represents the pinnacle of the New England plain style; the 1652 revisers of the Bay Psalm Book made changes to every psalm but this and three others, an indication of subsequent translators' respect for the original. ${ }^{69}$ And if we assume that the twenty-third psalm employs an idealized language, it becomes apparent that the Puritan plain style theorized by Cotton in the Exposition and realized in the Bay Psalm Book values both a simple vocabulary and a minimalistic use of words.

In addition to its monosyllabic tendencies, the Bay Psalm Book's etymology disproportionately favors words with Old English or Proto-Indo European roots. Although Terttu Nevalainen states that "French borrowing reaches its peak in 1570-1620"- the period immediately preceding the Bay Psalm Book's composition and publication-the volume uses words borrowed from French and other languages relatively infrequently. While borrowed words made up 40-50\% of the lexicon in the Early Modern English Period, they comprise only $18 \%$ of the vocabulary in the Bay Psalm Book, a figure more in line with the etymological tendencies of English's most basic vocabulary. Indeed, the etymological composition of the Bay Psalm Book's vocabulary approximates that of English's thousand most commonly used words. The thousand most commonly used words are overwhelmingly Old English in origin, undoubtedly because later vocabulary expansions and borrowings from foreign languages consist primarily of words describing concepts or objects non-essential to Table 3: Etymological Composition of the Bay Psalm Book

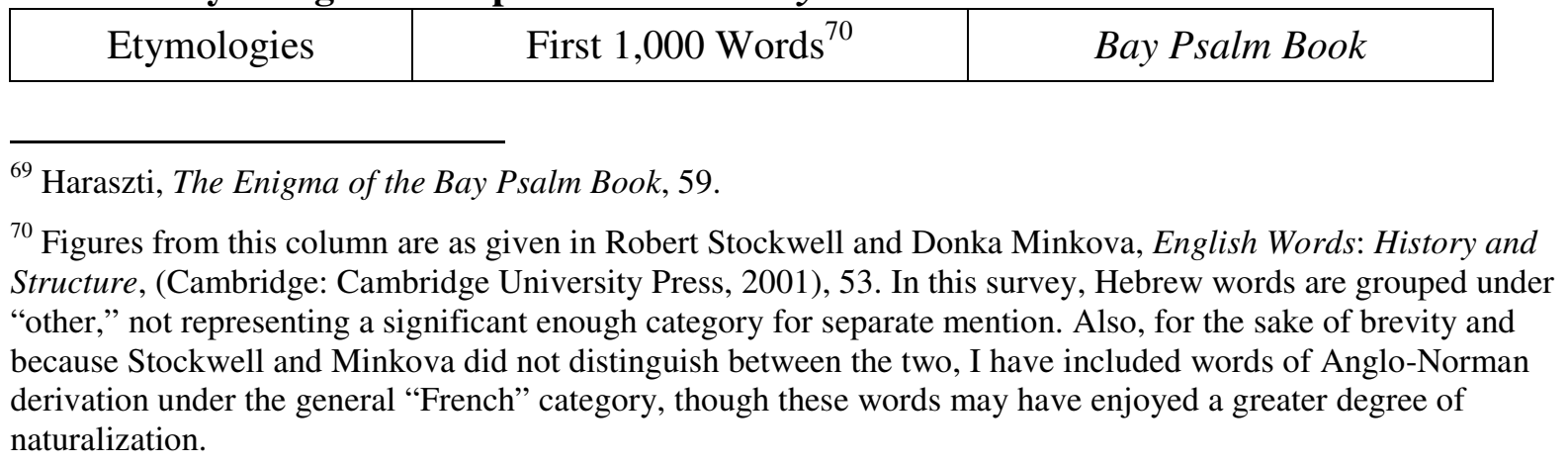




\begin{tabular}{|c|c|c|}
\hline Old English/PIE & $83 \%$ & $81.9 \%$ \\
\hline French & $11 \%$ & $11.0 \%$ \\
\hline Norse & $2 \%$ & $3.2 \%$ \\
\hline Hebrew & (Included in “Other”) & $1.2 \%$ \\
\hline Latin & $2 \%$ & $2.3 \%$ \\
\hline Other & $2 \%$ & $0.2 \%$ \\
\hline
\end{tabular}

survival. ${ }^{71}$ The Bay Psalm Book's etymological duplication of this basic vocabulary

emphasizes its plain language and its accessibility to all, even those with only a rudimentary grasp of English.

In addition to making the psalms accessible to all, eschewing words of foreign derivation might also have made the Bay Psalm Book more pure in the eyes of God and man. As Robert Stockwell and Donka Minkova note, "The inhabitants of Britain since Gerald of Wales in the twelfth century have been content with the paradoxical view that, although they speak a language which matches in its diversity the various origins of the people, fresh influence from outside is to be regarded as a form of corruption." While this belief has ancient roots, it intensified during the late sixteenth and early seventeenth centuries, when “opposition by the proponents of pure English to that which they saw as foreign defilement was to become a serious intellectual debate" embodied by the inkhorn controversy. ${ }^{72}$ During this debate, Thomas Wilson famously charged that "Some seke so farre for outlandishe Englishe, that thei forget altogether their mothers language," setting up what Werner Hullen calls "an obvious dichotomy here between strange, outlandish (i.e. French and Italian) speech

\footnotetext{
${ }^{71}$ Terttu Nevalainen, "Early Modern English Lexis and Semantics," in The Cambridge History of the English Language, ed. Roger Lass, Vol. 2 (Cambridge: Cambridge University Press, 1999), 368, 332. As Werner Hullen argues, "For these native speakers, the Latinate vocabulary of English [including borrowings from French and other romance languages] demands a certain understanding of the structural principles of word formation and, ideally, some knowledge of Latin," an education that the ostensibly plain country folk who used the Bay Psalm Book would not have enjoyed. See Werner Hullen, A History of Roget's Thesaurus: Origins, Development, and Design, (New York: Oxford University Press, 2004), 133.

${ }^{72}$ Stockwell and Minkova, English Words: History and Structure, 414; David Burnley, "Lexis and Semantics," in The Cambridge History of the English Language, ed. Norman Blake, volume 2 (Cambridge, UK: Cambridge
} 
and the commonly received mother tongue." This dichotomy privileged words with Old English roots as pristine and natural even as it designated words of alternative etymological backgrounds as artificial and unnecessary additions to the language. For New England divines, Chaucer's English was a symbol of linguistic purity; Thomas Hooker engages the central issues of the inkhorn controversy from across the Atlantic when he "invokes Chaucer as writing a pure and plain English, undefiled by French and Italian importations—an emblem, for Hooker, of an earlier national innocence." ${ }^{73}$ For the Bay Psalm Book to be considered an innocent language of whole stones unaffected by mortal artifice, the Puritan translators had to avoid foreign words as much as possible.

An etymological analysis of the Bay Psalm Book reveals that the translators excluded foreign borrowings from the psalms more successfully than either the Sternhold-Hopkins or Sidney-Pembroke collaborations. Cotton's translations employ fewer words of foreign derivation than either of the other two versions in every category except for Hebrew, an exception whose important implications I shall address momentarily. For now, it seems

Table 4: A Comparative Analysis of Three Psalter's Etymological Roots

\begin{tabular}{|c|c|c|c|}
\hline Words Per Psalm & Bay Psalm Book & Sternhold-Hopkins & Sidney-Pembroke \\
\hline Old English/PIE & 161.1 & 210.5 & 173.8 \\
\hline French & 21.6 & 27.5 & 29 \\
\hline Norse & 6.3 & 8.5 & 7.6 \\
\hline Hebrew & 2.4 & .5 & 1.8 \\
\hline Other & .5 & .9 & 1 \\
\hline
\end{tabular}

sufficient to state that The Bay Psalm Book's plain style emphasizes a language of Germanic origin, preferring words whose linguistic longevity have rendered them part of English's core vocabulary. Actually, this description of the etymological make-up of the Bay Psalm Book

University Press, 1992), 414-15.

${ }^{73}$ Hullen, A History of Roget's Thesaurus: Origins, Development, and Design, 129; Alan Heimert and Andrew Delbanco, eds. The Puritans in America (Cambridge: Harvard University Press, 1985), 63. 
probably emphasizes its foreign aspect too much. Though "only part of the new vocabulary in any language will find its way into the common core, which is shared by the written and spoken medium alike, by all registers, and by all social and regional varieties," a majority of the foreign borrowings seem to be of this type-words so commonplace that even a highly educated man may not have realized their foreign roots. ${ }^{74}$

Because of seventh-century Danish invasions and the Norman conquest of 1066, many of the Bay Psalm Book's borrowings from Old Norse and French come from words that had already been in the language for at least 400 years by the time the Bay Colony translators first imagined the plain style realized in that psalter. Old Norse, for instance, contributed English's third-person plural pronoun they, a word which neither Cotton nor modern speakers would identify as foreign and for which there exists no widely acceptable substitute. As to the naturalization of French borrowings, "contemporaries of Chaucer (d. 1400) would not have considered originally French words like very, river, city, mountain, anchor, close, glue, haste, ease, and so on as 'foreign'; such words had become an inseparable part of English." ${ }^{, 75}$ Puritan translators, writing 200 years after Chaucer, would hardly have considered that when they translated the eighth psalm's reference to "Foules of the ayre," they described birds flying through a gaseous substance named by the French.

In at least one case, the use of a French word even represents a conservative choice. In addition to the "Foules of the ayre," the translators also write about the "beasts of field" in the eighth psalm. ${ }^{76}$ Although beast is a French word adopted in Middle English as a

\footnotetext{
${ }^{74}$ Nevalainen, "Early Modern English Lexis and Semantics," 342.

${ }^{75}$ Stockwell and Donka Minkova, English Words: History and Structure, 38.

${ }^{76}$ While Sidney and the Sternhold-Hopkins translations also use beast instead of animal, I do not cite their example as conservative because they wrote just before animal began to be widely used. In this sense, the Bay Psalm Book is even more conservative in its etymological composition than at first supposed. Because it was written almost one hundred years after the Sternhold and Hopkins, the translators of the Bay Psalm Book could
} 
replacement for deer as a general reference to living creatures, it was already falling out of favor in the early seventeenth century. The new (and recognizably foreign) animal was in the process of being adopted from Latin, and beast may have seemed like a conservative choice. As Nevalainen argues, "the fact that the Franco-Latin animal successfully replaced the Middle English French loan beast in the general sense of 'living creature' in Early Modern English speaks for [the word beast's] naturalisation." 77 Thus, the use of beast in the Bay Psalm Book constitutes a conservative use of a naturalized word rather than a recognizable borrowing. While etymological analysis of the Bay Psalm Book's vocabulary indicates a relatively high proportion of words with Old English roots, that quantitative measure may actually understate the degree to which the translators and their readers perceived its language as natural because a large portion of the volume's "foreign" word stock had already become an indistinguishable part of English by the seventeenth century. By expunging foreign borrowings from English, the translators replicated one of the lingua humana's defining characteristics,

[f]or whereas all other tongues, even the Greek, doe shew their beggerlinesse, and argue and shew their imperfection in this, that they borrow words and names from their senior tongues, and because they are fain to make infinite compounds to expresse their minds, but this Hebrew and holy tongue on the other side, borroweth not of any tongue, but lendeth to all; and also consisteth in such simplicity of words, and yet hath such a grate and majestie in every phrase ... that God approveth all the names which Adam giveth to the Creatures." 78

The lack of foreign borrowings is proof of Hebrew's prelapsarian purity, and the Bay Psalm Book translators carefully eschewed foreign words as a means of replicating that purity.

have used a number of foreign words - particularly Latin — adopted into the English language after Sternhold and Hopkins first translated the psalms. That the vocabulary of the Bay Psalm Book is not significantly more Latinate is a testament to the translators' desire to retain the Germanic roots of the language.

${ }^{77}$ Nevalainen, "Early Modern English Lexis and Semantics," 362.

${ }^{78}$ Andrewes, Apospasmatia Sacra, 209. 
For this reason, the Bay Psalm Book's emphasis on the incorporation of Hebrew may represent the most significant lexical difference between the Bay Psalm Book and the compilations of Philip Sidney or Sternhold and Hopkins. Hebrew—even the relatively late Hebrew from which the psalms were translated-represented the last remaining link to the pure language God first gave to Adam. By incorporating Hebraisms into the English translations and giving expression to "all the artificiall elegancies of the Hebrew Text, so farre as we are able to imitate the same," Cotton and his other translators endowed the Bay Psalm Book with a measure of the primitive purity attributed to Hebrew even as they embraced the "elegancies" supposedly proscribed by the Puritan plain style. The Hebrew word included in the psalms most frequently is Iehovah, which often replaces either God or the Lord as a reference to deity. By substituting Iehovah for either of the English names for deity, the translators actually reversed the preference Cotton expressed in his "Preface" where he suggested that the translators might use "Lord for Iehovah, and sometime (though seldom) God for Iehovah. ${ }^{, 79}$ In retaining God's original Hebrew name, the Bay Psalm Book translators also recreate the covenantal relationship of the Old Testament, making the Bay Colony a type of the Israelites, God's covenant people.

Their inclusion of Hebrew calls attention to both the plainness and the purity of the Bay Psalm Book; Hebrew connects the psalmody's language to the purity of Eden, and allows its users to worship God without the corrupt connotations introduced at Babel. That the Bay Psalm Book became the platform for an attempt to recover edenic speech in New England is only natural. Isaiah explicitly connects the psalms to Eden, prophesying that "the Lord shall comfort Zion: he will comfort all her waste places; and he will make her

\footnotetext{
${ }^{79}$ Cotton, Singing of Psalmes a Gospel-Ordinance, 56; Cotton, Preface, 13.
} 
wilderness like Eden, and her desert like the garden of the Lord; joy and gladness shall be found therein, thanksgiving, and the voice of melody." The Hebrew word translated as melody in the Authorized Version is זמרה, commonly translated as psalm; the Hebraicists translating the Bay Psalm Book would have understood that the psalms were the natural music of a restored Eden. ${ }^{80}$ And even if, as William Scheick has argued, New England Puritans largely "doubted the capacity of fallen human reason to escape the convoluted muddle of connotative meanings in the temporal world" and adequately express "the ultimate denotative definitions of language from the deity's point of view," their efforts in purifying the language of the psalter suggest that they still retained a hope that such a restoration might be made possible. As Teresa Toulouse argues, this was precisely the aim of New England preachers like Cotton, who believed "that the language he employs, when preached by an elect preacher and heard by elect hearers, is not, in fact, figurative at all. God's 'literall' meanings are made manifest to his elect, even if they still appear figurative to the unassured and uncertain. 'But now the vaile is taken away, and we all behold the glory of the Lord with open face"" in the same way that Adam did in Eden and that Moses and Solomon did after the Fall. ${ }^{81}$

Understanding the ways in which writers on both sides of the Atlantic worked to recapture prelapsarian linguistic purity produces a broader concept of the Puritan plain style and American language in keeping with Stephen Foster's explanation of Americanness as an ideology and movement emerging over time, from the late sixteenth to early eighteenth

\footnotetext{
${ }^{80}$ Isaiah 51:3. The Authorized Version translators use psalm for זמרה in Psalms 81:2 and 98:5.

${ }^{81}$ William J. Scheick, Design in Puritan American Literature, (Lexington: University Press of Kentucky, 1992), 19; Teresa Toulouse, The Art of Prophesying, (Athens: The University of Georgia Press, 1987), 40.
} 
century. ${ }^{82}$ Like Bacon and Herbert, Cotton and the other translators of the Bay Psalm Book were all born in the age of Elizabeth and emerged from a shared literary tradition, but as William Spengemann notes, "the inclusion of [the psalms of the Bay Psalm Book] in American literature said less about their own literariness than about their historical relations to later, more evidently literary texts." Similarly, the exclusion of Bacon and Herbert from American literature says more about their perceived lack of influence on works written in the New World than it does about the literariness of their texts. But if the Bay Psalm Book is not "the American realization of English aspirations," it is at least the continuation of a philological project begun in England and shaped by English writers like Bacon and Herbert. Understanding the Bay Psalm Book's linguistic innovations requires contextualizing them within the broader sphere of English culture and those writers, like Bacon and Herbert, who shaped it. As scholars interested in print culture, inter-continental economics and literary theory continue to reference the Bay Psalm Book as a touchstone of the Puritan plain style and a symbol of the seventeenth-century, it is imperative that we understand both the linguistic features that distinguish that volume and the transatlantic context in which it was written. Only then can we meaningfully refer to the Bay Psalm Book "as the 'first' American book $[\ldots]$ and as the ground upon which the 'plain style' is understood." ${ }^{\prime 83}$

\section{“Make my Leaden Whittle, Metall Good": Edward Taylor and the Alchemy of Eden}

Whether or not any of the Bay Psalm Book translators ever read Herbert's "Paradise," they appear to have adopted the approach to linguistic purity exemplified in that poem,

\footnotetext{
${ }^{82}$ See Stephen Foster, The Long Argument: English Puritanism and the Shaping of New England Culture, 15701700, (Chapel Hill: The University of North Carolina Press, 1991).

${ }^{83}$ Spengemann, A New World of Words, 19; Foster, The Long Argument: English Puritanism and the Shaping of New England Culture, 1570-1700, xii; Brown, The Pilgrim and the Bee, 37.
} 
pruning away polysyllabic, unnecessary, and etymologically corrupt words from the psalms in the same way that Herbert trimmed letters from his end rhymes. Their methodical excisions produced a language of "native purity," an edenic English infused with Hebrew reminders of the lingua humana. ${ }^{84}$ And while the Bay Psalm Book has become a cultural touchstone whose rough rhymes and awkward language are generally assumed to represent the aesthetics of all New England Puritans, there was at least one Puritan poet who approached the problem of restoring prelapsarian linguistic purity from quite a different perspective. Edward Taylor, like the Bay Psalm Book translators, was committed to the pursuit of a pure, devotional English; the primary purpose of his Preparatory Meditations was to prepare him for the experience of taking and administering communion, when the emblems of Christ's body and blood would restore him to an edenic intimacy with and innocency before God. In his verse, Taylor "lin'de out a Paradise in Power" so that he could be grafted into "this Tree of Life within / The Paradise of God, that I may live" (I.33.19, 3738). ${ }^{85}$ But Taylor's meditations are full of elaborate conceits, rich with the foreign words and polysyllabic lexemes eschewed by the Bay Psalm Book translators-his pursuit of prelapsarian purity is not analogous to the plain model provided in "Paradise" or "Jordan (I)" but crafted in imitation of the alchemical and metaphysical language of "The Sacrifice" and

\footnotetext{
${ }^{84}$ Cotton, Preface, 12. The quotation in the subtitle is from Edward Taylor, "32" in Preparatory Meditations, Second Series, in Edward Taylor's Gods Determinations and Preparatory Meditations, ed. Daniel Patterson, (Kent: The Kent State University Press, 2003), p. 266, lines 61; hereafter (II.32.61).

${ }^{85}$ The tree of life is an important image in Taylor's poetry that received significant attention from early readers but which, like Taylor himself, has largely fallen out of fashion. For early readings of Taylor's edenic imagery, see Cecelia L. Halbert, "Tree of Life Imagery in the Poetry of Edward Taylor," American Literature 38.1 (1966): 22-34; Ursula Brumm, “The 'Tree of Life' in Edward Taylor's Meditations," Early American Literature 3.2 (1968): 72-87; Thomas Werge, "The Tree of Life in Edward Taylor's Poetry: The Sources of a Puritan Image," Early American Literature 3.3 (1968): 199-204.
} 
"The Holy Communion.",86

Critics have long debated the nature of the relationship between Taylor's verse and Herbert's; Shawcross and Barbara Lewalski have presented forceful evidence for a direct influence, while Scheick and Thomas Davis suggest that the apparent similarities between Taylor and Herbert should be attributed to their emergence from "a similar religious milieu." I am persuaded that "we do see Taylor exhibiting the influence of Herbert in the subject matter of his poetry, in the language, conceits, and images he employs, and in his structures and forms," but—as in the comparison between Herbert's language in "Paradise" and the language of the Bay Psalm Book-establishing a direct influence is less important than illustrating the ways in which Herbert's alchemical methods of linguistic reform shed light on Taylor's aspirations to a language of prelapsarian purity. ${ }^{87}$

Elisa New writes that by “[e]schewing originality, Taylor's poems instead strike for a state of renewal - a regeneracy," and his interest in an edenic restoration supports her argument; but Taylor hardly “keeps faith with the Fall” by waiting patiently outside Eden's gates as she suggests. Instead, when Taylor "lin'de out a Paradise in Power" (I.33.19), he asserts his claim to edenic purity as one of the elect. He writes "for a sight beyond the human prospect—for, if you will, Power - that is implicated and interrogated in the work of

\footnotetext{
${ }^{86}$ Walter Woodward notes in passing that "The concept of alchemical purification proved such an apt symbol for its spiritual counterpart that Edward Taylor, the Puritan minister-poet of Westfield, Massachusetts, wrote several poems employing alchemy as a metaphor for attaining grace," but an extensive examination of Taylor's linguistic alchemy has not, as yet, been offered. See Walter W. Woodward, Prospero's America, (Chapel Hill: University of North Carolina Press, 2010), 39.

${ }^{87}$ Thomas Marion Davis, A Reading of Edward Taylor, (Newark: University of Delaware Press, 1992), 211 (n. 9); Shawcross, "Some Colonial American Poetry and George Herbert," 46. See also William Scheick, "Typology and Allegroy: A Comparative Study of George Herbert and Edward Taylor," Essays in Literature 2.1 (1975): 76-86; and Barbara Kiefer Lewalski, Protestant Poetics and the Seventeenth-Century Lyric, (Princeton: Princeton University Press, 1979).
} 
[nineteenth-century] poets writing after" him. ${ }^{88}$ In this sense, Taylor's verse anticipates that of later American poets who strive to recover the linguistic mastery and onomastic authority of Adam and to become, in Emerson's words, a "Namer, or Language-maker, naming things sometimes after their appearance, sometimes after their essence, and giving to every one its own name and not another's." Taylor acknowledges his mortal condition in the Preparatory Meditations but remains confident in the affirmation he made to his Westfield congregants when the church was first organized. He and they have been "brought out of a state of Nature, into a State of Grace" and "made Free Denisons of the New Jerusalem"; their "first Entrance" into the congregational covenant was like "[w]hen Adam in the Glorious Shine of Gods Image upon him, was first placed in Paradise." 89

\section{The Polished Stones of Taylor's Temple}

For Taylor, as for Herbert and Cotton, masonry is a powerful metaphor for language; with a pen purified by grace, Taylor promises "To build there Wonders Chappell where thy Praise / Shall be the Psalms sung forth in gracious layes" (II.3.35-36). But whereas the whole stones of Cotton's psalter/altar must not be polished, Taylor asks whether "rubbish, Unpollisht Stones [are] fit matter for Christs Temple? If not, then prepare thyself." He insists that the polishing of oneself and of language is not only acceptable-it is necessary. The polish that Taylor prescribes, however, is not a methodical removal of corruption but a mystical infusion of grace whereby the elect and his own language are restored to "their first spirituall Excellency." He urges his congregants to "strive that you may be pretious Stones to

\footnotetext{
${ }^{88}$ Elisa New, The Regenerate Lyric, (Cambridge: Cambridge University Press, 1993), 18, 24.

${ }^{89}$ Ralph Waldo Emerson, “The Poet," in Emerson's Prose and Poetry, eds. Joel Porte and Saundra Morris, (New York: W. W. Norton \& Co., 2001), 190; Edward Taylor, The Revised Foundation Day Sermon, in Edward Taylor's “Church Records” and Related Sermons, eds. Thomas M. \& Virginia L. Davis, (Boston: Twayne Publishers, 1981), 283-84, 369.
} 
be laid in this Heavenly Building, Living stones, in this Spirituall Temple. Repent of Sin, Reform your Lives: put a way the old Leaven that you may be a New Lump." The agency is clearly human, but the means by which mortals may produce polish is unclear; the elect must "strive" and "Reform," but they cannot remove leaven from a lump of dough: it is chemically impossible..$^{90}$

Of course, it is also chemically impossible to transform lead into gold, but alchemy promised all manner of miracles. And Taylor, like Herbert, seizes on alchemy as a metaphor for the miraculous process by which grace allows him to polish his life and language so that he can become a living stone in God's temple. That grace was most frequently made available through the administration of communion, and in describing that sacrament, Taylor exclaims

Here's spirits of the spirits Chymistrie And Bisket of the spirits Backhouse best Emblems of sanctifying Grace most high Water and Bread of spirituall life up dresst. Here's Meat and Drinke to nourish grace in sum And feed the spouses infants in her womb. (II.149.31-36)

For Taylor, as for Herbert, the taking of communion is an alchemical—or chemical; the two disciplines were largely synonymous at this point—process that both purifies and feeds individual souls harbored in the "womb" of the church, Christ's "spouse." Christ's grace is made visible in the emblems of communion, and the sensory experience of handling and seeing the bread and water transforms Taylor's life and language to a state of primitive purity.

Taylor models this linguistic transformation in his twenty-second meditation, moving from a corrupt, self-centered language to an edenic speech in which "the union of Thy and

\footnotetext{
${ }^{90}$ Taylor, The Revised Foundation Day Sermon, 362, 315.
} 
my" that existed between Adam and God in paradise, and that Thorpe describes in Herbert's "The Temper (I)," is restored. ${ }^{91}$ In the first four stanzas, Taylor sees God's "shining Glory fall / Before mine Eyes"-not just his ocular organs but his self-referent $I$ as well: he refers to himself more than twenty-five times and to the God he is ostensibly praising less than half as frequently (I.22.15-16). In the fifth and sixth stanzas, however, the personal pronouns that represent Taylor's corruption disappear from the poem entirely, shifting the emphasis squarely onto God's "Glorious Righteousness" (I.22.33). This interlude of selfless song is the product of "filling Grace" as Taylor's anticipation of consuming the holy communion elevates him into a visionary state in which he is granted "One glimps, my Lord, of thy bright Judgment day" (I.22.40, 37). This grace and the glimpse it engenders provide a much needed corrective to Taylor's verse that ultimately allows God to "guild [his] Soule with thy bright Ray" (I.22.42). Taylor's eyes and $I$ return in the poem's final stanza, but his language is no longer obscured by the prior, corrupt focus on self; the references to self and to deity are brought into balance as the relationship between Taylor's human $m y$ and God's divine thy is "restored back into as desirable \& Commendable a state as it was in its first erection" in Eden and "as neer to its first beauty \& excellency as it can be." ${ }^{.92}$ Grace provides him with the ability to praise God appropriately, to say what was previously unutterable in a language appropriate to man's "first erection."

This return to primitive linguistic purity is the polish that Taylor plans to apply liberally to the stones of his own poetic temple. In the twenty-third and twenty-fourth meditations that follow, both written over the next five months, Taylor again imagines the temple walls of New Jerusalem and promises that if he were "but there, and could but tell my

\footnotetext{
${ }^{91}$ Thorpe, A New Earth: The Labor of Language in Pearl, Herbert's Temple, and Blake's Jerusalem, 84.
} 
story, / 'T would rub those Walls of Pretious stones more bright" (I.23.7-8). Taylor rejoices that he is "thy Bride Espousd by thee" (I.23.47) as "Thy Milke white Hand, my Glorious Lord, doth this: / It opes this Gate, and me Conducts into / This Golden Palace" (I.24.7-9). He laments that his "minde is Leaden in thy Golden Shine" but his access—as Christ's spouse - to "Thy Graces storehouse" allow him to become "the Golden Trumpet of thy Praise"; in an alchemical transformation catalyzed by Christ's grace, Taylor's poetics are translated from his own corrupt and leaden language into a golden dialect of the paradisiacal New Jerusalem.

\section{"This Sacred Adamick Stone" $" 93$}

Taylor repeatedly describes himself as "like lead" and pleads with the Lord to touch his tongue "with thine Altars quick, live Coale" which, like quicksilver, will transport him back to a golden age of paradisiacal purity and "make [him], Lord, one of thy garden beds;" but he also employs other alchemical images to depict the process of purification (II.86.6, 7, 31). Like Herbert, he longs for the double grace available to one who suckles Christ's bloody breast, and his transformation from leaden lump of clay to golden garden is aided by a draught of "thy Wine and Milk" (II.86.22). Eucharist wine is universally understood to represent the blood of Christ, but Taylor redoubles the drink's significance by making it into a symbolic representation of Christ's breastmilk as well. Taylor likens the administration of communion to a mother breastfeeding; the congregants who symbolically drink Christ's blood by drinking "the spirits Wine fat pure" are like "spirituall Babes [that] hang sucking of her breasts / And draw thence th'spirituall milk of these milk bowles" (II.149.42, 49-50). It is

\footnotetext{
92 Taylor, The Revised Foundation Day Sermon, 315.

${ }^{93}$ Paracelsus describing the philosohper's stone and as quoted in Robert Turner, Paracelsus, (London: 1657), 32.
} 
the simultaneous consumption of Christ's blood and milk that makes possible the movement from lead to gold.

The combination of blood and milk would have been understood by those like Taylor, who was familiar with the alchemical theories of Paracelsus and Ramon Llull, as a reference to the red and white elixirs whose joint virtues created the philosopher's stone that made transmutation possible. Karen Gordon-Grube has shown that Taylor was "a follower of Paracelsus" who prescribed mummy or mumia_-"medicinally prepared human flesh"—as a cure for bodily ailments, and it should be noted that seventeenth-century belief in the medicinal virtue of mummy was rooted in Eden. ${ }^{94}$ Andrea Tentzelius clarifies the Paracelsian belief in the potency of mummy, explaining that "the Knowledge of Good and Evil, was, by the mediation of the Mumy-spiritual of the Serpent, transplanted into the forbidden Tree; so also by the presidy of some other spiritual Mumy, eternal sanity, or immortality, was from God granted to the Tree of Life, That he that tasted thereof, should live for ever." Because Adam and Eve did not eat from the tree of life, they were denied God's divine knowledge of the macrocosm, but by eating of the fruit of the tree of the knowledge of the tree of good and evil, they acquired "the Mumy-spiritual of the Microcosm," and its virtues were transmitted through them into the flesh of all humanity, recycled by minister-physicians like Taylor who endorsed the cannibalization of cadavers as a medical treatment. ${ }^{95}$ If his "Dispensatory" shows that Taylor subscribed to the Paracelsian belief in the paradisiacal origins and restorative powers of mummies, his Preparatory Meditations suggest that Taylor also believed in the alchemical virtues of blood and milk, the red and white elixirs that produce

\footnotetext{
${ }^{94}$ Karen Gordon-Grube, “Evidence of Medicinal Cannibalism in Puritan New England: 'Mummy' and Related Remedies in Edward Taylor's 'Dispensatory,’” Early American Literature 28.3 (1993): 185.

${ }^{95}$ As quoted in Turner, Paracelsus, 88, 84.
} 
the philosopher's stone.

The red and white elixirs had to be "nourished, as the Child is in the Mothers wombe" and then "compounded" together like "the Sperm of the unperfect Bodies with her menstruum into her Body" before they could jointly "make perfect the Philosophers stone."96 According to Llullian alchemy, this combination of blood and sperm-the masculine equivalent of milk, in humoral terms - produced the philosopher's stone which, not coincidentally, resembled a woman's breast: "within the centre of compleat white, rests the red Stone of most delight." Like mummy, the power of the philosopher's stone is derived from Eden. Paracelsus teaches that "the matter of the Stone is understood to be Adamical," and the stone is a representation of the sexual union between Adam-whose Hebrew name is associated with redness - and Eve, when "the fair [white] Woman so loving the red Man, she became one with him, and yielded him all glory." For this reason, "the philosopher's stone is also "called their Adam, who beareth his occult and invisible Eve in his own body." "97 As a follower of Paracelsus, Taylor understood that blood and milk, red and white, were both symbols of paradisiacal perfection and the means of restoration; thus

Loves Milke white hand [The regenerate] takes and brings unto her Ewer of blood, Doth make Free Grace her golden Wisp, and Sand With which she doth therein them Wash, scoure, rub And Wrince them cleane untill their Beauty shows More pure, and white, than Lilly, Swan, or Rose.(II.34.37-42)

It is the conflation of milk and blood that produces paradisiacal purity because "purest White and red in spirituall sense / Make up [Christ's] Beauty to the spirituall Eye" of one versed in Paracelsian alchemy (II.116.25-26).

\footnotetext{
96 Turner, Paracelsus, 122-23.

${ }^{97}$ Paracelsus, as quoted in Turner, Paracelsus, 59, 27, 55, 27.
} 
When Christ "Wash[es] with his blood my blots out" and allows Taylor to "suck in / Thy Graces milk Pails some small drop," he permits the fallen poet to regain "the shine / Out Spouted so from Adams typick Streame" (II.3.28, 31-32, 8-9). Like Bacon and other writers interested in a return to Eden's perfection, Taylor cites Solomon as evidence that such a restoration is possible. Solomon is

The perfect'st piece that Nature ever bred.

Thy Human nature is the perfect'st jem

That Adams offspring ever brudled.

No Spot nor Wrinckle did it ever smite.

Adams in Paradise was ne're so bright. (II.13.20-24)

Solomon's transition from fallen man to paradisiacal perfection is made possible by his wisdom and alchemical knowledge because alchemy or "Philosophy is nothing but the study of Wisdom considered in a created Nature." Solomon's alchemical power comes “when Nature and Art make one perfection" and he becomes a type of Christ, with the power to transcend Adam's curse: ${ }^{98}$

Nature doth better work than Art: yet thine Out vie both works of nature and of Art. Natures Perfection and the perfect shine Of Grace attend thy deeds in ev'ry part. A Thought, a Word, and Worke of thine, will kill Sin, Satan, and the Curse. (II.57.43-48)

Through alchemy—-through the blood and milk of Christ, as symbolized in the sacramental wine-Taylor's language and person are purified, freed from the curse that expelled Adam from Eden.

Because the "Regeneration of Man, and the Purification of Metals, have like degrees of Preparation and Operation, to their highest Perfection," when Taylor ascends the "Scale or

\footnotetext{
${ }^{98}$ ibid, $52,56$.
} 
Ladder of Transmutation" he also gains access to the grace of Christ. ${ }^{99}$ Taylor purifies himself through alchemy, and that purification is embedded in the language of his Preparatory Meditations as "Grace most Choice / Comes spouting down from God to man of Clay / A Golden Stepping Stone to Paradise / A Golden Ladder into Heaven!" (I.The Return.25-28). Though Taylor takes a different approach to linguistic purification than the translators of the Bay Psalm Book, his object is the same: a language of prelapsarian purity. Alchemy is the ladder by which Taylor's language is lifted to sanctified heights, the stimulus that causes his thoughts—and his language—-to "run a Wooling over Edens Parke" whenever he sits down to meditate and write about the holy communion (I.29.2).

\section{Paradise Lost, Paradise Regain'd: The Eighteenth-Century Move to Milton}

Until his death in 1729 Taylor continued to write his private, Preparatory

Meditations, but the New England interest in linguistic purity generally, and in edenic language in particular, had cooled considerably by the midpoint of the eighteenth century. The most tangible sign of this declension was the brisk book trade, as the Bay Psalm Book was rapidly replaced by imported psalters from Isaac Watts and the partnership of Nahum Tate and Nicholas Brady. ${ }^{100}$ Recognizing that the New England translation lacked the metrical and musical properties that their congregants desired, ministers like Cotton Mather and Thomas Prince who wished to preserve or improve upon its linguistic purity produced

\footnotetext{
${ }^{99}$ ibid, 58, 3.

${ }^{100}$ James Raven documents the steady advance in book imports throughout the seventeenth and eighteenth centuries, noting that " $[\mathrm{w}] \mathrm{e}$ are unlikely to be surprised that the importation of books from the mother country was the mainstay of bookselling in the early, sparsely populated years of colonial settlement, but that this volume should have increased rather than declined with the growth of colonial production is not so easily explained." See James Raven, "The Importation of Books in the Eighteenth Century," in A History of the Book in America, Vol. I, The Colonial Book in the Atlantic World, eds. Hugh Amory \& David D. Hall, (Cambridge: Cambridge University Press, 2000), 183.
} 
new psalters, but these were largely ignored, sung only by their own congregations. ${ }^{101}$ Even if Mather's Psalterium Americanum (1718) had been widely adopted, however, that adoption still would have represented a divergence from the Herbertian tradition of linguistic purity evident in the Bay Psalm Book and the meditations of Taylor. As Shawcross explains, the “decline in Herbert's influence in the eighteenth century in England (there were no editions of the poems between 1709 and 1799) followed in the Colonies, where, as in England, Milton and Alexander Pope became the strongest influences as the century moved on."102 Mather was just as interested in linguistic purity as his forbears, but Milton's language in Paradise Lost and Paradise Regain'd was his preferred model of edenic speech—not Herbert's Temple.

Milton's aspirations to prelapsarian linguistic purity are openly acknowledged in his numerous invocations to the Holy Ghost in Paradise Lost: "Hail holy Light, offspring of Heav'n first-born, / Or of th' Eternal Coeternal beam / May I express thee unblam'd?" The various strategies by which he attempts to make his poetics conform to the imagined unblameable, innocent, and edenic speech of Adam and Eve have been discussed and debated at length, ${ }^{103}$ but most readers agree that Milton uses the following two techniques to imitate their unfallen language:

1. Like the Bay Psalm Book translators, Milton is concerned with etymologies-but not with removing words borrowed from foreign languages. Instead, Christopher Ricks argues, he uses borrowed words in their original etymological sense to "recreate something of the pre-lapsarian state of language." Thus, when Eve calls Adam “earth's hallow'd mould, / Of God inspir'd," she uses inspir'd in its Latin sense of “to

\footnotetext{
${ }^{101}$ Haraszti, The Enigma of the Bay Psalm Book, 29-30.

102 Shawcross, "Some Colonial American Poetry and George Herbert," 28.

${ }^{103}$ Milton, Paradise Lost, III.1-3. See, for instance, John K. Hale, Milton's Languages, (Cambridge: Cambridge University Press, 1997), 105-45 and 165-79; John Leonard, Naming in Paradise, (Oxford: Clarendon Press, 1990); Leonard Mustazza, “Such Prompt Eloquence,” (Lewisburg: Bucknell University Press, 1988), 69-89; and Robert L. Entzminger, Divine Word, (Pittsburgh: Duquesne University Press, 1985).
} 
breathe on," referring to the moment when God "breathed into [Adam's] nostrils the breath of life; and man became a living soul."104

2. Edenic language in Milton is both instinctive and eloquent. As John Leonard notes, Adam and Eve 'lacked 'neither various style / Nor holy rapture.' Alistair Fowler glosses the first of these terms as 'formal elaboration' and the second as 'inspired spontaneity.' In the fallen world one has to choose between set liturgical forms and spontaneous eloquence; for Adam and Eve there is as yet no antagonism between these ways of praising God." Paradise Lost, which Milton claimed came to him in the night as milk to a cow, is both formally sophisticated and "Unpremeditated."105

In Milton the language of Eden is original, eloquent, and instinctual, an unmediated expression of truth delivered with rhetorical flourish and without forethought.

But a different characteristic of Milton's edenic speech, one whose novelty critics sometimes now take for granted, was more widely recognized by his contemporaries. Both Paradise Lost and Paradise Regain'd are delivered in blank verse, and this is the defining trait of Milton's paradisiacal poetry that Mather appropriates for his Psalterium Americanum. In a prefatory note to Paradise Lost, Milton himself cites the poem's metrical signature and its lack of rhyme as factors that restore an "ancient liberty" to English verse. Rhyme, Milton argues, is "but the Invention of a barbarous Age, to set off wretched matter and lame Meter."106 While Milton's invocation of ancient liberty refers to Greek and Latin poetry rather than prelapsarian language, Mather understands Milton's blank verse as a key to the recovery of ancient religious and linguistic purity. The titlepage of the Psalterium visually links the phrases "B̉ank Verse" and "Pure Offering," suggesting a causal relationship between the two. They are the only two phrases on the title page set in black letter, and we know that Mather supervised the incorporation of black letter typeface because he explains its purpose

\footnotetext{
${ }^{104}$ Christopher B. Ricks, Milton's Grand Style, (Oxford: Clarendon Press, 1963), 110; Milton, Paradise Lost, V.321-22; Genesis 2:7.

${ }^{105}$ Leonard, Naming in Paradise, 245; Milton, Paradise Lost, IX.24.
} 
in an "An Admonition Concerning the TUNES." The use of black letter typeface provides singers musical and metrical flexibility; "by Taking or Dropping the Two Syllables of $\mathcal{B}$ lack fetter" in each verse of most psalms, the psalms are "fitted unto all the Common TUNES, the Notes whereof are Eight and Six" as well as "a well-known Longer Metre." And while Mather never names Milton as the inspiration for his decision to translate the psalms into blank verse, he does admit using "Some famous pieces of Poetry, which this Refining Age has been treated withal, [that] have been offered us in Blank Verse" as models for his own poetic endeavor. $^{107}$

We know that Mather was familiar with and cited Milton; George Sensabaugh notes that "in his Magnalia Christi Americana Mather paraphrased three times ... from Paradise Lost, once in order to enlarge his own exposition and twice to heighten particular scenes." Yet Milton's influence on Mather is, to Sensabaugh, relatively minor because "[i]n the vastness of his project his three citations from Milton are all but lost." ${ }^{108}$ The Psalterium suggests that Milton's influence on Mather was considerably more important than previously supposed. The psalter is Mather's most important linguistic experiment, and he believed that his translations of the psalms were so powerful that congregants could literally "recreate themselves with Singing them." The Psalterium's reader would inevitably, "like the Beloved Disciple ... be carried away in the Spirit into the wilderness, and be shown the Judgment of the Great Whore that sitteth upon many Waters. He shall also in these Visions of GOD, see

\footnotetext{
${ }^{106}$ John Milton, "The Verse," in Complete Poems and Major Prose, ed. Merritt Y. Hughes, (Indianapolis: Hackett Publishing, 1957), 210.

${ }^{107}$ Cotton Mather, Psalterium Americanum, (Boson: S. Kneeland, 1718), xxxv-xxxvi, vii. On Mather's attitudes toward contemporary singing practices, see David P. McKay, "Cotton Mather's Unpublished Singing Sermon," The New England Quarterly 48.3 (1975): 410-22.

${ }^{108}$ George F. Sensabaugh, Milton in Early America, (Princeton: Princeton University Press, 1964), 38, 41.
} 
the Holy City, New Jerusalem, coming down from God out of Heaven, prepared as a Bride adorned for her Husband." As worshippers "SING with such Thoughts," they "carry on the Wars of the Lord" and through their song will produce "wondrous Changes upon the World, will turn an horrid and howling Wilderness into a Paradise." The Psalterium captures the "Manly Christianity" and militant spirit of Milton's regicidal road back to paradise in blank verse set to music. ${ }^{109}$ Despite the evidence pointing to a connection between Milton and the blank verse of Mather's Psalterium, this link has been given critical attention only in a small note by Sacvan Bercovitch, who points out that Mather's condemnations of rhyme "seem unmistakably to echo those of Milton." But inasmuch as this connection illustrates a key disjunction in early American poetics at the same time that it highlights the continuation of a colonial quest for linguistic purity, it is worthy of greater attention; the Psalterium marks a transition in early American aesthetics as Mather rejected the Herbertian approach to "Paradise" presented in the Bay Psalm Book and became one of the first colonial poets to embrace and imitate Paradise Lost. This new eighteenth-century poetic model is radically and, one might say, revolutionarily different from its predecessor, but the aim—a speech that would make it possible to say "such Things as cannot be uttered"-remains the same. ${ }^{110}$ For Mather, as for the translators of the Bay Psalm Book, connecting English more closely to the lingua humana, to Hebrew, was an important part of producing sacred speech. ${ }^{111}$ Indeed, Mather actually accuses the Bay Psalm Book translators of diverging from

\footnotetext{
${ }^{109}$ Mather, Psalterium Americanum, iv, xxx, xxviii, xxxiv, viii.

${ }^{110}$ Sacvan Bercovitch, "Cotton Mather Against Rhyme: Milton and the Psalterium Americanum," American Literature 39.2 (1967): 191; Mather, Psalterium Americanum, viii.

${ }^{111}$ It could be argued that Mather's interest in Hebrew is also, in part, derived from Milton—or at least that his insistence on an Englished Hebrew is not inconsistent with his embrace of Miltonic language. Herbert Marks argues that "it is Hebrew itself, the language of Scripture, that returns to haunt the text of Milton's poem," and Douglas Brooks has provided persuasive documentation of "the intertext of Paradise Lost and the Hebrew Bible." But John Hale suggests that while "[t]here remain occasions where Milton does seize on Hebrew," the
} 
the Hebrew as a pretext for his own translation, arguing that "they leave out a vast heap of those rich things, which the Holy SPIRIT of GOD speaks in the Original Hebrew; and that they put in as large an Heap of poor Things, which are intirely their own. All this has been meerly for the sake of preserving the Clink of the Rhime." As he incorporates more and more of "the Golden and Massy Hebrew," Mather claims that his translations are "disencumbred from every thing that may give them any Humane Debasements." ${ }^{112}$ The beneficial effects of his purified verse are available even to those who cannot recognize the source of its power; although "They that can Examine the Original Tongues, have peculiar Advantages for their Discoveries" of hebraicisms in the psalter, "yet our Translation affords enough, to furnish the Illiterate Christian for This, and every Good Work." The incorporation of recognizably Hebrew words such as selah and Jehovah identify all of Mather's psalms as primitively pure, but he suggests that the underlying Hebrew is particularly transparent—and therefore particularly powerful—in the $119^{\text {th }}$ psalm. Here Mather reproduces the Hebrew abecedary, prefacing each section of the psalm with an English transliteration of the corresponding Hebrew letter: beth, gimel, daleth, etc. The mere consideration of these remnants from the lingua humana is enough to transport an elect reader to the incorruptions of Eden or heaven itself:

Consider, What Affections of Piety are plainly discernable in the Words now before you; And then, with a Soul Turning to the Lord, assay to utter the Language of the like Affections. Perhaps the CXIX Psalm, is as likely a Portion for this Purpose as any under Heaven, that the Experiment may be made upon. Friend, Ere thou art aware,

\footnotetext{
influence of other ancient tongues on Paradise Lost—Greek and Latin in particular-are much greater and that Hebrew was a relatively minor influence on the language of the poem. See Herbert Marks, "The Blotted Book," Re-Membering Milton, ed. Mary Nyquist and Margaret W. Ferguson, (New York: Methuen, 1988), 227;

Douglas A. Brooks, “'Ill-Matching Words and Deeds Long Past': Englished Hebrew and 'the Readmission of the Jews' in Paradise Lost," Philological Quarterly 81.2 (2002): 70; and John K. Hale, Milton's Languages, (Cambridge: Cambridge University Press, 1997), 124.

${ }^{112}$ Mather, Psalterium Americanum, vii, ix, viii.
} 
thou wilt be caught up into Paradise, in such an Exercise. ${ }^{113}$

Mather has forsaken the rhymed verse preferred by Herbert, Taylor, and the translators of the Bay Psalm Book for the blank verse of Milton, but his emphasis on hebraicized English as a pathway to paradise preserves at least one aspect of the early New England quest for linguistic purity.

Of course, whereas Philip Pain's Herbertian Daily Meditations (1668) and the Bay Psalm Book sold briskly enough that they were reprinted, Mather's conversion to Miltonic blank verse was either ignored or unappreciated by his contemporaries. The seventeenthcentury interest in linguistic purity was widely replaced, in eighteenth-century New England, with a desire for art-for the rhymes and rhythms of Watts and the heroic couplets of Pope. David Shields explains that the early eighteenth century marked a turning point in colonial language and literature because "New World poets embraced three developments in neoclassicism with great ardor: the religious sublime, belletrism, and Agustan neopaganism." ${ }^{114}$ As unsold copies of Mather's Psalterium gathered dust on store shelves behind imported works from Abraham Cowley, Edmund Waller, and John Dryden, the New England interest in recovering an Adamic language quietly came to an end.

\footnotetext{
113 ibid, xxvi, xxv-xxvi.

${ }^{114}$ David S. Shields, Oracles of Empire, (Chicago: University of Chicago Press, 1990), 7.
} 


\section{CHAPTER 5}

\section{FROM ADAM'S INNOCENCE TO EVE'S REGENERACY: ALTERNATIVE MODELS AND MORPHOLOGIES OF CONVERSION IN EARLY MODERN NEW ENGLAND}

As much as the geographical, physiological, intellectual, and linguistic perfections of Eden appealed to colonists living in early modern New England, it was the prelapsarian innocence of Adam and Eve that they most longed to recover. In the minds of some immigrants to the region, this return to innocence was merely a matter of following an extant spiritual impulse already within them; John Norton complains that after their arrival in 1656, the Quakers taught that "in all men, not one excepted, there is a light, which being followed is an infallible guide" to the restoration of Adamic innocence. ${ }^{1}$ Giving heed to this inner light famously allows George Fox to "come up in Spirit through the flaming Sword, into the Paradise of God. All things were New; and all the Creation gave another Smell unto me, than before, beyond what Words can utter. I knew I knew nothing, but Pureness, and Innocency, and Righteousness, being renewed up into the State of Adam, which he was in, before he fell." Fox promises that following this inner light will likewise bring all who are "faithful to [it] ... up into that State, in which Adam was before he fell," but Calvinist theologians in New England argued that this aspect of Quaker theology effectively denied the

\footnotetext{
${ }^{1}$ John Norton, The Heart of New-England Rent, (London: John Allen, 1660), 15.
} 
Fall. ${ }^{2}$ Norton explains that a universal inner light cannot lead humanity back to innocence because the "light of nature remaining in Adams posterity, since the Lapse, is so little, as that it is not to be mentioned the same day, with what was in Adam, before the fall." 3 The restoration of innocence that seemed so simple for Fox and his followers continued to be a torturous pursuit for New England's Calvinist orthodoxy.

Unlike their Quaker counterparts, Puritan theologians believed that the original innocence of Eden had been lost forever; salvation from the Fall was not just a restoration of guiltlessness and spiritual neutrality but a personal appropriation of the righteousness of Jesus Christ through the power of faith. In the garden, Adam and Eve lived under a covenant of works and were promised that obedience would preserve their innocence, but this reliance on works was replaced at the Fall with a covenant of faith, or grace. Thomas Shepard states that whereas "Adam and all his posterity was to be saved by his doing," by performing with exactness the duties prescribed in the law, "we are not to performe acts of obedience now as Adam was to doe, viz. by the sole power of inherent grace, but we are to live by faith, and act by faith ... we are not united to Christ our life by obedience as Adam was to God by it, but by faith." The problem with this new covenant of faith is that it requires something of Adam's descendants that they cannot offer, because "Adam had not [faith in the garden of Eden], nor could have in that estate; and therfore none of the Sons of Adam naturally can

\footnotetext{
${ }^{2}$ George Fox, A Journal or Historical Account of the Life, (London: 1694), 17-18. For a treatment of Quaker conversion narratives in colonial America, see the still relevant Daniel B. Shea, Jr., Spiritual Autobiography in Early America, (Princeton: Princeton University Press, 1968), 3-84.

${ }^{3}$ Norton, The Heart of New-England Rent, 16.

${ }^{4}$ Thomas Shepard, The Sincere Convert, (London: T.P. and M.S., 1641), 242; Thomas Shepard, The Sound Beleever, (London: 1645), 331-32.
} 
share in it." In Calvinist theology justification-a return to spiritual blamelessness which precedes an inevitable transition to a state of positive holiness or righteousness-is an external affair, the gift of an inscrutable God to his elect, and Adam's descendants are no longer able to earn or preserve innocence.

Guiltlessness under this new covenant of grace is also qualitatively different from original, Adamic innocence. Shepard explains that conversion is not "a means only, to make every man a first Adam; setting men to work for their living again" but a process that leaves the convert in a spiritual state superior to that enjoyed by Adam and Eve in Eden. ${ }^{6}$ Because "the righteousnesse of the second Adam exceeds the first" so too is the convert "more happy, more holy in the second Adam, than ever the first in himselfe was" in Eden. To leave behind the covenant of works that Adam subscribed to in Eden and "to come out of all duties truely to a Christ hath not so much as a coate in innocent, much lesse corrupted nature."7 Christ's righteousness - and not Adam's innocence-was the standard by which conversion should have been measured in colonial New England. Righteousness should have been the standard; but it was frequently supplanted by edenic innocence.

Despite the Puritan conviction that innocence had been replaced by righteousness, that "our sanctification is differing from the Image Adam had" in the garden, ministers nonetheless frequently contradicted themselves, instructing their congregants that "Sanctification is the restoring of us to the image of God we once had in Adam" and

\footnotetext{
${ }^{5}$ Thomas Shepard, The Parable of the Ten Virgins Opened \& Applied, (London: J. Hayes, 1660), I.205. Richard Mather also makes the point that faith was not an attribute acquired by Adam in Eden, noting that "faith is wholly supernatural, Math: 16.17. so that Adam in his innocency knew not this way of believing in, and trusting to the righteousness of a Redeemer \& mediator." See Richard Mather, The Summe of Certain Sermons Upon Genes: 15.6, (Cambridg: Samuel Green, 1652), 36.

${ }^{6}$ Thomas Shepard, The Parable of the Ten Virgins Opened \& Applied, I.19

${ }^{7}$ Shepard, The Sincere Convert, 32, 242.
} 
comparing the spiritual state of the converted elect to the original innocence of Adam and Eve. ${ }^{8}$ John Cotton taught that just "as the garden of Paradise was the habitation of Adam in the estate of innocency, so is the Church of all those who are renewed into innocency," that the spiritual state of Adam and Eve in the garden of Eden is comparable to that of the regenerate. ${ }^{9}$ Thomas Shepard told his congregants that "[w]hen Adam stood, and was for God, all creatures served him"; so too, he continues, "when we are set right for God ... The Lord will then command all creatures to be serviceable to his Church and people." Puritan ministers in New England consistently taught that the spiritual status, rights, and privileges of Adam were to be restored, and the language of conversion was always distinguished by the prefix re-; ministers emphasize renewal, regeneration, and the recovery of a lost, primitive, edenic purity. Like Cotton and Shepard a hundred years before him, Benjamin Colman explained in 1736 that "[i]n Regeneration Souls are recover'd to the true Love of Themselves. As God is glorious Self-love, so is Man in his primitive and saved State."10 Puritan theologians universally agreed with Increase Mather that "Believers are made happier than Adam was. . . That Heaven which Christ has prepared for Believers is a far better place than the earthly Paradise was," but the language of conversion was, nonetheless, a language of reversion—of returning to the spiritual privileges that the first Adam enjoyed in Eden. ${ }^{11}$ This emphasis on innocence rather than righteousness—on Adam's “Earthly

\footnotetext{
${ }^{8}$ Shepard, The Parable of the Ten Virgins Opened \& Applied, I.217; Shepard, The Sound Beleever, 216.

${ }^{9}$ John Cotton, A Brief Exposition of the Whole Book of Canticles, or, Song of Solomon, (London: 1642), 130. Jesper Rosenmeier argues that Cotton views conversion as a state of righteousness and Shepard sees only innocence, but both men clearly continued to use Adam as a model of Christian conversion even though they understood that Christ's righteousness was the ultimate destiny of the elect. See Jesper Rosenmeier, "New England's Perfection: The Image of Adam and the Image of Christ in the Antinomian Crisis," The William and Mary Quarterly 27.3 (1970): 435-59.

${ }^{10}$ Benjamin Colman, A Dissertation on the Image of God Wherein Man Was Created, (Boston: S. Kneeland and T. Green, 1736), 31, 25.
} 
Paradise" instead of Christ's "Caelestial Paradise"—was the natural result of ministerial attempts to reconcile corrupt human nature with Christ's divinity. ${ }^{12}$ The convert's spiritual state might be qualitatively different from Adam's in Eden because his or her salvation was derived from Christ's righteousness and not Adam's obedience, but Puritan preachers still knew that "[t]here is as much Difference between the Image of God in meer Men, and that in the Man Christ Jesus, as there is between Earth and Heaven, between God and his Creature. ${ }^{13}$ In other words, a degree of Christ's righteousness would be the heavenly inheritance of the elect, but while on earth their spiritual state could not be any more perfect than Adam's was in Eden. It would only be "[a]t the Resurrection [when] their Bodyes shall be spiritualiz'd, and immortalized, that they ... shall be filled with Divine Knowledge and Grace, beyond what the soul of Adam was in his first estate" 14 The heavenly paradise to which the elect would ascend at their resurrection would far surpass the first, terrestrial paradise of Adam and Eve, but Eden "had been as like to Heaven for Happiness, as could be on Earth," and since even the elect were bound to remain on earth for a time, Eden became a middle ground — the highest spiritual plane to which the Puritans could properly aspire in this terrestrial life. ${ }^{15}$ As ministers like Samuel Lee waited for God to shape and form "the new Adam within" them and their congregants, they hoped for a "renovation of the image of God" first reflected in "Adam in Innocency."16

\footnotetext{
${ }^{11}$ Increase Mather, The Mystery of Christ Opened and Applyed, (Boston: Richard Pierce, 1686), 155; see also Colman, A Dissertation on the Image of God Wherein Man Was Created, 25.

${ }^{12}$ Colman, A Dissertation on the Image of God Wherein Man Was Created, 20, 25.

${ }^{13}$ ibid, 39.

${ }^{14}$ Increase Mather, The Mystery of Christ Opened and Applyed, (Boston: Richard Pierce, 1686), 155; see also Colman, A Dissertation on the Image of God Wherein Man Was Created, 23.

${ }^{15}$ Benjamin Colman, A Brief Dissertation on the Three First Chapters of Genesis, (Boston: S. Kneeland and T. Green, 1735), 31.

${ }^{16}$ Samuel Lee, The Joy of Faith, (Boston: Samuel Green, 1687), 232, 142.
} 
In order to communicate the drastic difference between a fallen soul and one in which God's image had been restored to the original luster enjoyed by Adam, ministers used the contrasting images of wilderness and paradise. Increase Mather describes the soul as a plot of ground, and explains that every "Soul that was a desolate, parched, barren Wilderness, when once the Spirit from on high is poured upon it; doth become like a fruitful field." In Mather's formulation, the waters of grace heal the wounds of original sin and restore the heart to its edenic state, and he cites the promise in Ezekiel that "every thing that liveth, which moveth, whithersoever the rivers shall come, shall live [and] shall be healed" as scriptural support for his analogy. Grace, Mather's remedy for the "souls sickness" contracted in Eden, would transform the heart from a fallen wilderness to a spiritual paradise, and every Puritan regularly examined their life in an effort to find evidence of God's grace at work in their lives. ${ }^{17}$ The Puritan belief in the possibility of recapturing Eden in an inward, spiritual paradise of the soul is, perhaps, best expressed by Milton in Michael's promise to Adam that he "shalt possess / A paradise within thee, happier far" than the garden from which he was being driven. Barbara Lewalski explains that Adam—as a representative of every man and woman who faithfully seeks for signs of grace_-"is led by Michael to expect the transformation of his nature by faith and virtue, and with such transformation he might come to say, in reverse analogy to Satan, 'My self am Paradise.",18 The members of Mather's Boston congregation and every other devout inhabitant of Massachusetts hoped for that

\footnotetext{
${ }^{17}$ Increase Mather, A Call from Heaven to the Present and Succeeding Generations, (Boston: John Foster, 1679), 10; Ezekiel 47:9. This is, of course, the same metaphor that his son, Cotton Mather, used to describe the effect an edenic Harvard College would have on the wilderness of New England - that of a river of grace. See Chapter 3, p. 181. For more on transition from paradise to wilderness as a metaphor for conversion, see George H. Williams, Wilderness and Paradise in Christian Thought, (New York: Harper \& Brothers, 1962), pp. 65140.

${ }^{18}$ Milton, Paradise Lost, XII.586-87; Barbara Lewalski, “Milton's Paradises,” in Renaissance Ecology, ed. Ken Hiltner, (Pittsburgh: Duquesne University Press, 2008), 26.
} 
promise to be fulfilled in their own lives. Ever conscious of their fallen heritage as descendants of Adam and Eve, the men and women of New England longed for a supernatural cultivation of the soul that would renew in their hearts a state of spiritual perfection equivalent to the physical perfections enjoyed in Eden.

Just as the spiritual state of Adam and Eve in Eden was the goal of New England converts so, too, was reading the Genesis account of their creation, Fall, and the promise of their future redemption the means by which many colonists came to recognize their own need for grace and to experience conversion. Seventeenth- and eighteenth-century Protestant conversion narratives follow a pattern established more than a thousand years earlier by Augustine, who no sooner had read a verse of scripture "than the light of certainty flooded my heart and all dark shades of doubt fled away." ${ }^{, 19}$ While New England conversion narratives are not always as dramatic as that of Augustine, they too revolve around readings of scripture, and listening to or reading from the verses of Genesis was a transformative moment for a number of colonists.

When the citizens of Westfield, Massachusetts, decided to form a church and to appoint Edward Taylor as their minister, they required a conversion narrative from him and each of the founding members of that congregation as a testament to their spiritual worthiness. Taylor provided an account of his initial conviction and vocation that revolves around Eden, recalling that

As for the first time that every [sic] any beam of [Infinite Grace] did break in upon me, was when I was but small: viz, upon a morning a Sister of mine while she was getting up, or getting me up, or both, fell on the giving an account of the Creation of the world by God alone, \& of man especially, \& of the excellent state of man by Creation, as that he was created in the image of God, was holy \& righteous, \& how, Eve was made of Adams Rib, \& was the first woman, was Adams wife, how both

${ }^{19}$ Augustine, The Confessions, trans. Maria Boulding, (New York: Vintage Books, 1998), 168. 
were placed in paradise, the garden of Eden, a most curious place, $\&$ had liberty to eate of all the trees therein except the tree of knowledge of Good, \& evill. \& this God would not suffer them to eate of. But the serpent did betray them, \& drew them to eate of that fruite \& thereby they Sin'd against God: \& God was angrey, \& cast them out of the Garden of Eden, \& set Angels - Cherubims, \& a flaming sword turning every way to keep the tree of life. \& So man was made a Sinner, \& God was angrey with all men for Sin.

But, oh! this account came in upon me in such a Strang way, that I am not able to express it, but ever since I have had the notion of Sin, \& its naughtiness remain, \& the wrath of God on account of the same. ${ }^{20}$

It is the story of the Fall—of spiritual perfections lost in Eden—that prompts Taylor to begin his quest to recover prelapsarian innocence.

The conversion narratives of other New England inhabitants likewise turn around a consideration of the Fall, of Adam and Eve in their removal from Eden. John Root, another one of the founding members at Westfield, begins his account by remembering the teachings "of godly parents, who instructed me $\&$ told the danger all sons were in by Adams fall, \& that I was guilty of Sin thereby." When called upon to elaborate on her feeling of conviction, Isabell Jackson of Cambridge explained that the sin within her own heart "is a dishonor to the Lord, how as Adam did dishonor the Lord by breaking of the Commandments." ${ }^{21}$ It was only by grappling with Eden's past that the Puritans could find any hope in a future Eden. Conversion was necessarily preceded by an understanding expressed by Isaak Phelps, a knowledge that humanity was "involved in a fallen State \& insensible thereof." 22 This emphasis on Adam and the Fall from Eden was present in the earliest formulation of Congregational conversion narratives; in 1629 the Salem church outlined seven points of doctrine to which every applicant should subscribe in his or her narrative, and one of those

\footnotetext{
${ }^{20}$ Edward Taylor, The Public Relations, in Edward Taylor's "Church Records" and Related Sermons, eds. Thomas M. \& Virginia L. Davis, (Boston: Twayne Publishers, 1981), 98.

${ }^{21}$ ibid, 112; Thomas Shepard, The Confessions, in God's Plot, ed. Michael McGiffert, (Amherst: The University of Massachusetts Press, 1994), 216
} 
seven was a statement "Concerning the fall of Man." Every Salem applicant was to agree

"That Adam by transgressing the Command of God, fell from God and brought himself and his posterity into a state of Sin and death, under the Wrath and Curse of God, which I do believe to be my own condition by nature as well as any other." This statement of belief is, as Patricia Caldwell notes, "the only one [of the seven] to use the first-person" and asks each applicant to internalize the loss of Eden as a prerequisite for and stimulus to the restoration of edenic innocence. ${ }^{23}$ In early modern New England, Eden was both the means and the end of conversion.

To summarize this introduction to the role that Eden played in New England Puritan conversion narratives, the garden and its inhabitants were most commonly invoked during the discourse of conversion for the following three reasons:

1. Ministers taught that the state of the regenerate on earth was comparable to the innocence of Adam and Eve in Eden; prelapsarian innocence was considered the height of earthly spirituality, and aspirations to Christ's righteousness could not be fully realized until after the resurrection. ${ }^{24}$

2. Conversion was described as a transformation of the soul from wilderness to paradise, a topological metamorphosis made possible by the healing waters of grace.

3. Ministers and converts alike described their sense of the Fall—and the Genesis narrative of Eden-as integral to the conversion experience, a key to being convicted with a full understanding of personal sin and the need for grace.

References along these lines to Adam, Eve, and Eden in conversion narratives and sermons from this period are ubiquitous. But occasionally a minister or convert would invoke the

\footnotetext{
${ }^{22}$ Taylor, The Public Relations, 114.

${ }^{23}$ John Higginson, A Direction for a Publick Profession in the Church Assembly, (Cambridge: Samuel Green, 1665), 3; Patricia Caldwell, The Puritan Conversion Narrative, (Cambridge: Cambridge University Press, 1983), 62.

${ }^{24}$ John Cotton is the only individual who might have seriously challenged this assumption because of his view, outlined in The Churches Resurrection (1642), that the first resurrection was a sort of spiritual awakening and not the physical restoration that would take place after the Second Coming. But even Cotton, as previously noted, compared the spiritual state of the regenerate to that of Adam and Eve in Eden.
} 
garden for some other purpose in explicating the conversion process, and these other references to Eden deserve closer attention.

In describing Adam and Eve in their postlapsarian state as the first individuals to find a saving faith in Jesus Christ and become converted, Jonathan Edwards introduced the pair as models of Christian conversion. When he curses the serpent after the Fall, God promises Adam and Eve that he "will put enmity between [the serpent or devil] and the woman, and between thy seed and her seed; it shall bruise thy head, and thou shalt bruise his heel." Christian exegetes commonly understand this verse from the Hebrew Bible as a promise that Jesus Christ—-the "seed" of the woman—will "bruise" or destroy Satan, the serpent, and Edwards suggests that Adam and Eve became the first converts by exercising faith in this promise. As evidence of their faith, Edwards points to the new name given by Adam to his wife; after the Fall "Adam called his wife's name Eve; because she was the mother of all living," 25 and Edwards explains that this title is a symbol of Adam's faith in a Savior: "Adam, who from what God said concerning the seed of the woman, that was so very figurative, could understand, that relief was promised, as to the death which was threatened" and as a result he gave "his wife that new name, Eve, or Life, on the promise or intimation of the disappointment and overthrow of the tempter in that matter, by her seed."26 Edwards's belief that Adam and Eve were the first individuals to acquire a saving faith in Jesus Christ was atypical of the common descriptions of Adam and (especially) Eve in early modern New England, and it was exceptionally important because of Edwards's influential position as the

\footnotetext{
${ }^{25}$ Genesis 3:15, 20. For an overview of the exegetical tradition surrounding these verses and the somewhat unusual belief that Adam and Eve were the first Christians, see Philip Almond, Adam and Eve in Seventeenth Century Thought, (Cambridge: Cambridge University Press, 1999), 47-48.

${ }^{26}$ Jonathan Edwards, Original Sin, in The Works of Jonathan Edwards, Vol. 3, Original Sin, ed. Clyde A. Holbrook, (New Haven: Yale University Press, 1970), 243, 255.
} 
instigator of the Great Awakening.

The balance of this chapter is an examination of how Edwards's reflections on Eve's conversion as a type of all conversion experiences provided a catalyst that shifted the discourse of conversion in New England. While the pilgrimage was the dominant trope for conversion among Puritans in the seventeenth century, conversion narratives in New England gradually evolved into short accounts that revolved around brief transformative moments communicated through physical affect and associated with an individual's physiology. Notwithstanding this shift toward the timeframe and physicality of the new birth in conversion narratives, the pilgrimage continued to be the standard metaphor for conversion until Edwards and other evangelicals behind the transatlantic awakenings publicly embraced the new birth. At least in part because of Edwards's belief in Eve as the original prototype of the new birth, the Puritan emphasis on the pilgrimage as a metaphor for conversion in spiritual auto/biography was subordinated to the vocabulary of the new birth, which rapidly became the predominant metaphor for conversion in the eighteenth-century sermons and accounts of revival modeled on Edwards's A Faithful Narrative of the Surprising Work of God (1737). Through Edwards's influence Eve's regeneracy became a standard for the new birth in the eighteenth century just as Adam's innocence had been the goal sought by spiritual pilgrims in the seventeenth century.

\section{Exemplary Pilgrims: Seventeenth-Century Narratives of Conversion}

For English Protestants generally in the seventeenth century and for Puritans specifically, conversion - the process by which an individual becomes aware that he or she is one of God's elect and subsequently strives to live a life of sanctification-was conceived of 
in terms of a pilgrimage. The pilgrimage, according to Charles Hambrick-Stowe, is the "principal metaphor running through Puritan spirituality and devotional practice" in the seventeenth century. ${ }^{27}$ Seventeenth-century Calvinist conversion narratives and spiritual autobiographies are framed in the terms of a physical journey; thus, when Anne Bradstreet anticipates the end of her life's journey toward salvation, she describes herself "As weary pilgrim, now at rest" whose "wasted limbes, now lye full soft / That myrie steps, haue troden oft." Bradstreet thinks of herself as a metaphorical pilgrim traveling toward an ethereal heaven, but her spiritual progress is won through a literal and physical journey-just as her opportunity to worship as a nonconformist is won by a journey across the Atlantic from Old England to New. She sails in "stormy raines" and under the rays of "The burning sun," walks over "rugged stones" and through "bryars and thornes" on her way to "the bed Christ did perfume" for her in heaven. ${ }^{28}$ The conversion of Anne Bradstreet-her voyage "into this Covntry, where I fovnd a new World and new manners at wch my heart rose" until she "was convinced it was ye way of God"-is understood in both literal and metaphorical terms as a pilgrimage, a journey pursued by "a stranger in a strange land" looking for "a city which hath foundations, whose builder and maker is God."29

Although the pilgrimage was the dominant trope used to understand and describe the conversion process among seventeenth-century Puritans, it was not used exclusively; ministers also frequently related the process of conversion to a number of other topics,

\footnotetext{
${ }^{27}$ Charles E. Hambrick-Stowe, The Practice of Piety, (Chapel Hill: The University of North Carolina Press, 1982), 54.

${ }^{28}$ Anne Bradstreet, The Complete Works of Anne Bradstreet, eds. Joseph R. McElrath, Jr. and Allan P. Robb, (Boston: Twayne Publishers, 1981), 210.

${ }^{29}$ Bradstreet, The Complete Works of Anne Bradstreet, 216; Exodus 2:22; Hebrews 11:9-10. William Bradford was another prominent figure who described himself as a pilgrim in a poem on his deathbead, writing that "In Fears and Wants, through Weal and Woe, / As Pilgrim past I to and fro" (7-8). See William Bradford, "Certain
} 
including agriculture and childbirth. In a popular series of poems, Michael Wigglesworth elaborates on the similarities between agriculture and conversion, explaining that

Our Hearts are over-run

Much like a fallow Field,

Which must be broke and plowed up

Before it fruit can yield:

Afflictions are God's Plough

Wherewith he breaketh us,

Tears up our Lusts, those noisome Weeds,

And fitteth us for use. ${ }^{30}$

Because of their familiarity with biblical parables, farming was a concept that early New England colonists could readily relate to spiritual matters, and so too was childbirth. Thus, Increase Mather describes the conversion of his father, Richard Mather, as a physically painful process that disrupted his ability to eat, a process of becoming "a New Creature" that is best understood in terms of the nausea and labor pains suffered by pregnant women when they bring forth new life: "The pangs of the New-birth were exceeding terrible to him, inasmuch as many times when they were at Meals in the Family where he sojourned, he would absent himself to retire under hedges and other secret places, there to lament his misery before God. But after some time, the Lord revived his broken heart." ${ }^{, 31}$ Metaphors related to agriculture and childbirth were commonly used in conversion narratives, but the pilgrimage was unquestionably the most-used metaphor for conversion among seventeenth century Puritans. Even as Charles Cohen argues for the centrality of the new birth to seventeenth-century Puritanism, he reduces its importance by describing the "gate of

Verses," in American Poetry: The Seventeenth and Eighteenth Centuries, ed. David S. Shields, (New York: New York, The Library of America, 2007), 14-15.

${ }^{30}$ Michael Wigglesworth, Meat Out of the Eater, (Cambridge: S.G. and M.J., 1670), 12. For a full treatment of the image of the plowman as a figure of conversion in early modern Protestant thought, see Barbara A. Johnson, Reading Piers Plowman and The Pilgrim's Progress, (Carbondale: Southern Illinois University Press, 1992).

${ }^{31}$ Increase Mather, The Life and Death of that Reverend Man of God, Mr. Richard Mather, (Cambridge: S.G. and M.J., 1670), 6. 
conversion" as a mere milestone on the pilgrimage back to God along "the straight and narrow path to heaven." David Hall points out that some influential Calvinists, like Richard Baxter, even explicitly rejected an "agonizing, datable "new birth"” as an appropriate characterization of conversion. ${ }^{32}$ The new birth was of secondary importance during the seventeenth century, and the pilgrimage's preeminence as the primary trope in spiritual narratives was all but guaranteed by the popular devotional literature of the period.

\section{The Puritan's Pathway to Heaven}

Matthew Brown reminds us that popular devotional titles "have been overlooked by cultural critics and wholly neglected by literary scholars" despite their importance to critical understandings of early modern culture, literature, and theology in early modern New England. Reprinted twenty-five times before 1640 and forty times in press runs that had totaled more than 100,000 copies by 1704 , Arthur Dent's The Plaine Mans Path-way to Heauen (1601) was one of New England's "steady sellers" and, Elizabeth Hudson argues, quite possibly "the most popular piece of religious literature published in the first half of the seventeenth century." ${ }^{, 3}$ The book was written by a Puritan for Puritans, and its very title, as much as the spiritual instruction within its pages, taught readers to conceive of their reconciliation with God as a journey, a spiritual pilgrimage. Indeed, the language of the pilgrimage is even implicit in Dent's instructions to the reader; he asks

that thou woldest not reade two or three leaues of this booke, and so cast it from thee: but that thou wouldest reade it throughout euen to the end. For I do assure thee, if

\footnotetext{
${ }^{32}$ Charles Lloyd Cohen, God's Caress, (New York: Oxford University Press, 1986), 5; David D. Hall, The Faithful Shepherd, (Chapel Hill: The University of North Carolina Press, 1972), 62.

${ }^{33}$ Matthew P. Brown, The Pilgrim and the Bee, (Philadelphia: University of Pennsylvania Press, 2007), 9; David D. Hall, Worlds of Wonder, Days of Judgment, (Cambridge: Harvard University Press, 1989), 50; Elizabeth K. Hudson, "The Plaine Mans Pastor: Arthur Dent and the Cultivation of Popular Piety in Early Seventeenth-Century England," Albion 25.1 (1993): 26. On the publication history of The Plaine Mans Pathway to Heauen, see Maurice Hussey, “Arthur Dent's 'Plaine Mans Path-Way to Heaven,"” The Modern Language Review 44.1 (1949): 26.
} 
there be anything in it worth the reading, it is bestowed in the latter part thereof, and most of all towards the conclusion. Be not discouraged therefore at the harshnesse of the beginning, but looke for smoother matter in the middest: and most smoothe in the perclose \& wind up of al. ${ }^{34}$

Dent encourages his reader to move through the book linearly from beginning to end, to adopt what Brown calls a continuous reading style. "Central to the devotional literary culture, metaphors of journey and pilgrimage elaborate this vision of linear progress," and as New England "readers sat still with a text and moved through it: they were both ruminator and pilgrim.",35

But the pilgrimage outlined for the reader by Dent is not solely metaphorical or lexical; the dramatic dialogue that depicts the conviction and vocation of Asunetus both begins and ends in medius viaticus, in the middle of a physical journey. The dialogue opens as the pious Philagathus meets the minister Theologus during a "walke abroad in the fields," and as the two walk they meet the ignorant Asunetus and the unbelieving Antilegon, "a couple of neighbours of the next Parish," traveling towards them. The four men converse, and after Theologus explains that "there be some sparks and remnants left in us still of that excellent Image of God, which was in our first creation," Philagathus prays that God will "give vs his holy spirit, wherby we may be carried aboue this world into the mountaines of Spices" where they may "clime vp aboue the world, and . . conuerse in the chambers of peace." 36 This cleansing journey made possible by the "holy spirit" will restore travelers to the original image of God that existed in Adam before the Fall, and Asunetus is eager to start down the road to spiritual restoration; he begs Theologus for "some particular directions out of the word of God, for the good guiding \& ordering of my particular actions" and asks,

\footnotetext{
${ }^{34}$ Arthur Dent, The Plaine Mans Path-way to Heauen, (London: 1601), vii.

${ }^{35}$ Brown, The Pilgrim and the Bee, 30, 23.
} 
"What course would you wish me to take, that I may come" to this place of which Philagathus speaks? Theologus provides Asunetus with spiritual counsel, and The Plaine Mans Path-way to Heauen ends with the minister's prayer that “The Lord blesse you, and keep you in all your waies," as the four neighbors resume their peripatetic ways through the countryside. $^{37}$

The conversion process described by Dent is exactly that: a process or journey distinguished by movement and progression, not an event or destination experienced and arrived at in a single moment of time. ${ }^{38}$ The entire action of The Plaine Mans Path-way to Heauen takes place during a journey; there is no record of the journey's beginning or end points because it is the journey itself — the process of conversion and not the soul's final resting point — that matters. Since salvation was a matter of God's sovereign will and not human effort, it was impossible for an individual to determine the ultimate destination of his or her soul. All that a spiritual traveler could do was follow the signposts established by previous, successful pilgrims and wait for God's grace. Dent's Path-way to Heauen provided a well-used spiritual roadmap for Puritan readers. As Hudson notes, the "continuing popularity of The Path-way for a half century suggests that the route to heaven that it mapped out was familiar to a fairly broad segment of English society, and even when supplanted by later guides, such as Pilgrim's Progress, the spiritual signposts of personal repentance,

\footnotetext{
${ }^{36}$ Dent, The Plaine Mans Path-way to Heauen, 1-2, 7, 91.

${ }^{37}$ ibid, 363, 343, 416.

${ }^{38}$ While I emphasize the singularity of Dent's pathway, at least in part because this study is interested in tropes of conversion, as opposed to particular experiences, Christopher Haigh points out that Denth inspired a host of imitators whose pathways diverged in interesting ways; his study of lived religion in Post Reformation, preCivil War England, The Plain Man's Pathways to Heaven (Oxford: Oxford University Press, 2007), is an invaluable examination of the exceptions and singularities I gloss over here.
} 
conversion, and perseverance in the faith remained recognizable."39

\section{Bunyan's Personal Pilgrimage Allegorized}

Steady sellers from the first half of the seventeenth century-including Dent's Pathway to Heauen - were replaced in the second half of the century by newer titles, including works by John Flavel, Baxter, and John Bunyan, as a "new flood of devotional literature helped spiritualize the pilgrimage for the second and third generations" in New England. ${ }^{40}$ Flavel's A New Compass for Seamen (1664) was intended to help sailors—and all Christians_- "to Stear their true course to Heaven." Baxter, in his Call to the Unconverted (1658), provides "Directions" to "impenitent Unconverted sinners" and asks them, "If you were going on a journey that your life lay on, would you stop or turn again, because you met with some cross waies, or because you saw some travellers go the horse way, and some the foot way, and some perhaps break over the hedge, yea and some miss the way? or would you not rather be the more careful to enquire the way?"41 Flavel and Baxter both describe conversion as a journey; their texts are compass and chart to the wayward soul. References to the new birth are present, of course-Flavel compares "The Launching of a Ship" to a "second Birth" and Baxter's "Directions" chart a course to "a thorough and true Conversion, that [converts] miscarry not in the birth"- -but the overarching metaphor in both texts is that of the pilgrimage, as the author provides spiritual direction and guides the reader on his or her journey back to God's presence. ${ }^{42}$

Boston booksellers imported titles from Flavel and Baxter at impressive rates, but

\footnotetext{
${ }^{39}$ Hudson, "The Plaine Mans Pastor: Arthur Dent and the Cultivation of Popular Piety in Early SeventeenthCentury England," 36.

${ }^{40}$ Hambrick-Stowe, The Practice of Piety, 267.

${ }^{41}$ John Flavel, A New Compass for Seamen, (London: 1664), i; Richard Baxter, A Call to the Unconverted, (London: R.W., 1658), A3, 183.
} 
demand for Bunyan's The Pilgrim's Progress (1678) was apparently so much greater that importers simply could not supply enough copies in the years immediately following its release. ${ }^{43}$ Samuel Sewall-who served as the official printer of Boston from 1681 to 1684, after the death of John Foster-issued a New England edition of Bunyan's allegory in 1681, and in his verse introduction to part two of The Pilgrim's Progress (1684) Bunyan boasts that as for the first part of Christian's tale,

'Tis in New-England under such advance, Receives there so much loving Countenance, As to be Trim'd, new Cloth'd, \& Deck't with Gems, That it might shew its Features, and its limbs, Yet more, so comely doth my Pilgrim walk, That of him thousands daily Sing and talk. ${ }^{44}$

Emory Elliott explains that The Pilgrim's Progress and Bunyan's spiritual autobiography, Grace Abounding (1666), were popular in New England precisely because they followed the conventions of earlier devotional narratives, allowing the reader "to relate [his or her] personal experience to an accepted teleology." $" 45$ Bunyan's personal pilgrimage, like the representative pilgrimage of Christian, was exemplary, not innovative.

Bunyan famously attributes his own conversion to the influence of three women in Bedford whose "talk was about a new birth, the work of God on their hearts." ${ }^{46}$ Although it is talk of the new birth that inspires Bunyan to search for signs of God's grace in his own life,

\footnotetext{
${ }^{42}$ Flavel, A New Compass for Seamen, 1; Baxter, A Call to the Unconverted, A4.

${ }^{43}$ For an account of books imported into Boston during the late seventeenth century, see A History of the Book in America, Vol. I, The Colonial Book in the Atlantic World, eds. Hugh Amory and David D. Hall, (Cambridge: Cambridge University Press, 2000); Worthington Chauncey Ford, The Boston Book Market, (Boston: The Club of Odd Volumes, 1917).

${ }^{44}$ John Bunyan, The Pilgrim's Progress, ed. Cynthia Wall, (New York: W.W. Norton, 2009), 133.

${ }^{45}$ Emory Elliott, "New England Puritan Literature," in The Cambridge History of American Literature, Vol. 1, ed. Sacvan Bercovitch, (Cambridge: Cambridge University Press, 1994), 210.

${ }^{46}$ John Bunyan, Grace Abounding, ed. John Stachniewski with Anita Pacheco, (New York: Oxford University Press, 1998), 14.
} 
and even though he engages metaphorical representations of birth repeatedly, he consistently reformulates his conversion in the language of a pilgrimage. Immediately after his experience in Bedford, Bunyan has a vision in which he is figuratively born again; he must squeeze through the strait gate that leads to salvation in the same way that children wriggle their way into the world from their mother's womb. First Bunyan "did get in my head, \& after that by a side-ling striving, my shoulders, and my whole body" emerge into "the light and heat of their Sun," the Son, Jesus Christ. ${ }^{47}$ This portion of Bunyan's vision seems to be an obvious allegorical representation in which the correlation between his own conversion and the birthing process is highlighted, but Bunyan nearly elides the symbolism of this portion of his vision by situating it in a larger narrative that emphasizes his role as a traveler and pilgrim searching for the promised land.

Bunyan begins by noting the geography of his vision; he sees the elect "as if they were set on the Sunny side of some high Mountain ...; methought also betwixt me and them I saw a wall that did compass about this Mountain." Desiring to pass through the wall and enter "into the very midst of them," Bunyan travels "[a]bout this wall ... again and again, still prying as I went, to see if I could find some way or passage by which I might enter therein." The focus on Bunyan's birth into God's kingdom and his ultimate arrival at "the Mountain [that] signified the Church of the living God" is subsumed by a larger narrative that centers around his journey to, around and through the wall, a spiritual journey that he reenacts as he engages in the physical journeys inherent in his life as an itinerant tinker: Bunyan ponders on and prays about the vision "where ever I was, whether at home or abroad,

${ }^{47}$ Matthew 7:14; Bunyan, Grace Abounding, 19. 
in house or field." ${ }^{48}$ By citing Christ's teaching that "I am the way, the truth, and the life: no man cometh unto the Father, but by me," Bunyan privileges Christ's role as "the way," or the road which seeking pilgrims must follow, over his role as a midwife who makes it possible for every man to "be born again," even though both roles are equally applicable to the imagery of his vision. ${ }^{49}$ He elides the vocabulary of the new birth from his analysis of the vision in order to emphasize that of the pilgrimage.

Even in the climactic moment of his conversion, when Bunyan finally realizes that he is justified and begins "to take some measure of incouragement" from the Bible, a moment whose relative brevity makes the new birth a more natural metaphor than the temporally protracted language of a pilgrimage, Bunyan imagines his conversion in the terms of a traveler. He compares his own unwitting trespasses against Christ to the sin of manslaughter and takes comfort in Moses' promise that "the slayer that killeth any person unawares and unwittingly" can journey to one of six cities of refuge and receive sanctuary from "the avenger of blood." ${ }^{50}$ Bunyan is "convinced that I was the slayer, and that the avenger of blood pursued me, that I felt with great terrour; only now it remained that I enquire, whether I have right to enter the City of Refuge." Having resisted the temptation to sin "for a twelvemoneth before," Bunyan decides that his temporal progress toward the figurative city of refuge is sufficient and that "the Elders [of this city], which are the Apostles, were not to deliver me up" to the avenger of blood. ${ }^{51}$ While Bunyan's spiritual development is made possible by the Bedford women and their discussion of a new birth, he frames his own

\footnotetext{
${ }^{48}$ Bunyan, Grace Abounding, 18-19.

${ }^{49}$ John 14:6, 3:3. On Christ's role as a midwife in the Christian tradition, see Psalms 22:9-10.

${ }^{50}$ Joshua 20:3-5.

${ }^{51}$ Bunyan, Grace Abounding, 62-63.
} 
spiritual experiences in Grace Abounding and the spiritual experiences of every Christian in The Pilgrim's Progress in the language of a pilgrimage, a journey towards God.

Christian in The Pilgrim's Promise, like Bunyan in his vision, is a traveler on his way to a mountain. Christian's journey "to Mount Zion" is marked by his passage through a little wicket gate representing the new birth, after which he continues his travels "from the City of Destruction" to a city of refuge, "the Colestial City." Like Bunyan when he imagines himself to be in the same predicament as an Israelite convicted of manslaughter, Christian knows that to "go back is nothing but death" and thus presses onward to the Celestial City, where "I am sure to be in safety." toward conversion, The Pilgrim's Progress, as Kathleen Swaim and others have noted, "transposes into allegory Bunyan's own life and era, but the life and era themselves encapsulate the Puritan culture they inhabit." ${ }^{53}$ To be Puritan is to strive for conversion, and the struggle to become justified, sanctified, and glorified was universally understood throughout the seventeenth century as a pilgrimage. The converting journey back to God's presence did not end after a pilgrim had passed through the gate that represents a new birth; pilgrims still needed to surmount the Hill of Difficulty, pass through the Valley of the Shadow of Death, and resist the temptations of Vanity Fair before they could hope to arrive at the Celestial City and truly call themselves converted. ${ }^{54}$

\footnotetext{
52 John Bunyan, The Pilgrim's Progress, ed. Cynthia Wall, (New York: W.W. Norton, 2009), $23,36$.

${ }^{53}$ Kathleen M. Swaim, Pilgrim's Progress, Puritan Progress, (Urbana: University of Illinois Press, 1993$), 4$.

${ }^{54}$ My brief treatment of British conversion narratives is limited to texts written in the seventeenth century. For an excellent account of the genre's evangelical turn in eighteenth-century Britain, see D. Bruce Hindmarsh, The Evangelical Conversion Narrative, (Oxford: Oxford University Press, 2005).
} 


\section{First Stirrings: Preparing for the New Birth in New England}

At various points during his pilgrimage to the Celestial City, Christian pauses to converse with fellow pilgrims and with men like Evangelist, Good Will, and the Interpreter. In each of these encounters Christian provides a narrative of his journey up until that point, and when read collectively, these "self-examinations take shape as a church profession." As Christian reviews "his whole past in conversation with the catechizing inhabitants of House Beautiful," he

develops a progressively more integrated articulation of his history and begins to see the pattern within his past and for his future, the rhythms of repentance and hope. Each stage adds details and re-presents more and more earlier data in a widening circle of progressively interpreted and redesigned retelling. That narration becomes fully formed when Piety helps Christian select from his history his most significative providences or saving graces. 55

Bunyan's allegorical depiction of the conversion process is riddled with these self-reflective moments in which Christian and his auditors identify signs of grace in the narrative of his life. The larger narrative of Christian's conversion is consistently interrupted by his own conversion narratives, and this is, perhaps, at least one of the reasons why New England readers found The Pilgrim's Progress to be such a relevant cultural and theological model.

While it was not unusual for Puritans in Old England to review the signs of God's grace in their lives publicly as Christian does, the practice was never compulsory in the way that it was for New England Puritans living under the Congregational Way. For Bunyan's New England readers, the experience of conversion could hardly be distinguished from the narration of that experience because a congregant's claim that he or she was one of the elect always needed to be ratified by the members of the church before the individual could be admitted to the sacraments that would progressively sanctify him or her. New England

\footnotetext{
${ }^{55}$ ibid, 150.
} 
readers would have understood that Christian's conversion narratives are an essential part of his pilgrimage, necessary reflections on grace received in the past that precipitate his recognition of other, current blessings from God and that promote faith in his ability to "run with patience the race that is set before" him. ${ }^{56}$ Christian's conversion narratives also have a telescoping effect and provide the reader with a model for condensing the events of a lifetime into a brief, verbal relation.

\section{The Soul of Brevity, or Abbreviated Souls}

Conversion narratives of New England colonists from the early seventeenth-century anticipate the pattern made famous by Bunyan's spiritual autobiography and popular allegory, but the conditions in which they were delivered encouraged applicants for church membership to abbreviate their narratives even more than Christian does when he speaks with Evangelist, Good Will, and others. As John Allin's Brief History of the Church of Christ at Dedham explains, these conversion narratives were typically delivered orally and forced applicants to "declare the workings of God in their souls" so that "the whole company [could] approve or leave out as the Lord should guide us to judge of every one's condition or fitness for the work." ${ }^{, 57}$ This format naturally produces brief narratives that revolve around a single, paradigm-shifting moment of conversion. While each applicant for church membership describes events in his or her life that roughly correspond to the stages of conversion outlined by William Perkins and refined by Thomas Hooker, among others, emphasis is placed on vocation, that moment when "God so farre enlighten[s] the minde, as

\footnotetext{
${ }^{56}$ Hebrews 12:1.

57 John Allin, A Brief History of the Church of Christ at Dedham, in Puritans in the New World, ed. David D. Hall, (Princeton: Princeton University Press, 2004), 57.
} 
to buckle the heart and to turne it away from corruption to him." ${ }^{, 58}$ In their oral accounts, applicants for church membership in New England repeatedly identify a singular moment of vocation as evidence of their election, and because of the abbreviated nature of their narratives, this singular moment is even more prominent than it would be in a comparatively lengthy spiritual autobiography such as Grace Abounding.

Consider, for example, the brief 1638 narrative of Edward Hall (transcribed by

Thomas Shepard and quoted here in full), which follows a trajectory similar to that observed

in Bunyan's account of his own conversion:

The first means of his good was Mr. Glover's ministry, whereby he saw his misery from Jeremiah 7-the temple of the Lord-and that he was without Christ. But he went from thence to another place under the sense of an undone condition. But in that place he was deprived of the ordinances of God, and hence the scripture came oft to mind - what if a man win the world and lose his soul? Hence he desired to come to that place again, but the minister was gone. But Mr. Jenner came, and by him he saw more evil in himself. But Mr. S[hepard] came, and then the Lord did more clearly manifest himself to him from John 3 concerning the new birth. And here he saw more of his misery and that he had followed examples and duties and made them his Christ and lived without Christ. Hereby the Lord let him see he was Christless and built upon false foundations, and by this text he saw himself no new creature but only a mended man. Now when the Lord did humble him under this, he saw the want of Christ and that without him he must perish. And afterward John 5:40 was openedyou will not come to me to have life. And here he saw how freely Christ was offered, and hereby the Lord did stay and comfort his spirit and so was stirred up with more vehemency to seek Christ. And then that promise was opened-the son of man came to seek that which was lost. And he did not know but the Lord might seek him. And out of that text Peter 2:8, that unto you that believe he is precious, and here he saw his unbelief in cleaving to Christ by fits and starts. And since the Lord brought him to this place, he found his worldliness, and this bred many fears whether ever any work of Christ in him was in truth, and that he was one that might fall short of Christ and that he was humbled. But his heart was not deep enough, and hence he was put to more search whether ever he was humbled. Yet the Lord made it more clear from Ephraim's condition, Jer. 31:18, that the Lord had made him loathe himself, and this made him loathe himself. And here he hath found more enmity of his heart against the Lord than ever before. But hearing the Lord was willing to take away his enmity, he by Revelation 22:17 was brought nearer to the Lord. ${ }^{59}$

\footnotetext{
58 Thomas Hooker, The Soules Preparation for Christ, (London: 1632), 168.

59 Thomas Shepard, The Confessions, in God's Plot, ed. Michael McGiffert, (Amherst: University of Massachusetts Press, 1994), 149-50.
} 
Hall is initially interested in the process of salvation by Thomas Shepard's talk "concerning the new birth" in the same way that Bunyan would later be arrested by the discussion of the women at Bedford. And like Bunyan in Grace Abounding, Hall comes to understand his own sinfulness as a problem of transportation-Hall "will not come to [Christ] to have life." As a result, Hall abandons the language of the new birth, framing his conversion in terms of a journey or pilgrimage: "[T]he Lord brought him to" New England where he finally experienced vocation and was "brought nearer to the Lord" because he responded to Christ's invitation to "Come. And let him that heareth say, Come. And let him that is athirst come."60 Hall's conversion, like Bunyan's, is a matter of coming closer to God; it is a literal and spiritual journey.

I emphasize the similarities between Hall's 433-word narrative and Bunyan's booklength autobiography because the two texts transcribe the same basic events but provide markedly different perspectives on the chronology of a conversion experience. Bunyan's moment of vocation - the point at which he realizes that he has the "right to enter the City of Refuge"-occurs in the middle of a narrative that goes on to relate his struggle for sanctification. There is nothing about the structure of the text that distinguishes this or any other moment as a turning point, a moment of new birth. Bunyan's desire for vocation does not disappear; it simply shifts focus, becoming an earnest longing to recognize his own justification and to become sanctified. In Hall's narrative on the other hand, vocation is both climax and conclusion. The entire narrative builds to a single moment when he comes to Christ and is "brought nearer to the Lord." His examiners considered this moment sufficient proof that Hall was worthy to be admitted as a member of the Cambridge congregation; that

${ }^{60}$ Revelation 22:17. 
moment was the end of his narrative journey. Conversion was still understood as a spiritual pilgrimage in New England, but accounts of the journey back to God were commonly abridged and abbreviated.

Shepard's transcriptions of orally delivered conversion narratives from the laypeople of seventeenth-century Massachusetts confirm that the genre engenders accounts whose brevity promotes the identification of a single experience around which conversion hinges. For Edward Collins, conversion was a product of his immigration to New England, where "[a]t the first coming, seeing the great change from this and that place did much transport my heart" as "by a servant of [God] I was brought upon my knees." The journey across the Atlantic also propelled the conversion of John Stansby, who tells Shepard that "since I came hither, my heart hath been straitened for God." ${ }^{61}$ John Trumbull was a mariner "loath to go to prayer" in fair weather whose near death in a storm at sea prompted him to give more heed to God's word, and William Andrews also turned from his worldly ways in the middle of a storm while "naked upon the main topsail in very cold weather." 62 Each of these men condense the lifelong pilgrimage that Bunyan later allegorized into a single journey of a few months, or even a singular moment within that journey; in these accounts conversion does not appear to be a temporally protracted pilgrimage so much as a brief passage through adverse conditions.

Conversion also came in fleeting moments of change for colonial women. Alice Stedman first experienced a hope of conversion while reviewing one of John Cotton's sermons on Revelation with an elder of the church. Her narrative, like Hall's, concludes and climaxes with a moment of vocation; as she recalls, the elder "asked me what stuck upon my

\footnotetext{
${ }^{61}$ Shepard, The Confessions, 179, 181.
} 
spirit. I said, I was afraid it was not righteousness. And he encouraged me not to give way to those fears. And hearing John 13:20 — he that receives him that sent me-the Lord came in much by those words. And so was much confirmed, and many times since the Lord hath spoken to me to help me." The narrative of Gilbert Crackbone's wife (given and maiden names unknown) identifies an equally brief but significantly more dramatic experience as the crux of her conversion; she concludes her narrative by remembering that while "seeing [my] house burned down, I thought it was just and mercy to save life of the child and that I saw not after again my children there. And as my spirit was fiery to burn all I had, and hence prayed Lord would send fire of word, baptize me with fire. And since the Lord hath set my heart at liberty." ${ }^{63}$ The women of Massachusetts Bay, like the men, describe conversion as an event more than a process. Conversion is an occasion with identifiable-if flexible-time boundaries. Applicants might relate a number of experiences in their oral testimonies, but their vocation - the recognition of God's grace and their own status as one of his elect-is invariably associated with a single experience whose relative prominence in such a brief account would have encouraged listeners to understand conversion itself as an instantaneous phenomenon.

For those whose initial applications were rejected, the narratives that accompanied subsequent applications for church membership typically revolved around incidents that had occurred since the initial rejection, further compressing the perceived length of a conversion experience. In Dedham's examination of applicants, Anthony Fisher's “rash carriage and speeches savoring of self confidence, etc. had given some offence and the company thought it meet to seek the humbling and trial of his spirit with some serious admonition from the

\footnotetext{
${ }^{62}$ Thomas Shepard, "John Trumbull," in Puritans in the New World, 122, 125.
} 
Lord." In the "many meetings" that followed, Fisher continued to plead his case, but his application now depended on relating a new experience in which he came to see the error of his former ways, an experience which "at last the Lord by some pertinent scriptures" provided ${ }^{64}$ Even the illusion of longevity provided by Allin's allusion to "many meetings" is dispersed by the acknowledgment that they took place in less than a month. Fisher, forced to reinvent himself spiritually in less than thirty days, seizes upon an isolated session of scripture reading as the basis for his admission to the Dedham congregation, magnifying the importance of a single moment in time to his eventual conversion.

In curtailing their conversion narratives and emphasizing a single experience as the basis for their hopes of salvation, applicants to New England's churches did only what was asked of them. Thomas Shepard, instructing his congregants how best to describe their relationship with God, warned them not to tell "a long Storie of Conversion" because "an hundred to one, if some lie or other flip not out with it." Shepard encouraged his parishioners to cut short their accounts of conversion because

it is not fit that so holy and solemn an Assembly as a Church is, should be held long with Relations of this odd thing and tother, nor hear of Revelations and groundless joyes, nor gather together the heap, and heap up all the particular passages of their lives, wherein they have got any good; nor Scriptures and Sermons, but such as may be of special use unto the people of God, such things as tend to shew, Thus I was humbled, then thus I was called, then thus I have walked, though with many weaknesses since, and such special providence of God I have seen, temptations gone through, and thus the Lord hath delivered me, blessed be his Name, \&c.

Church members were to "Be alway converting" precisely because conversion was associated with a point in time that passes and fades; it was an experience both momentous

\footnotetext{
${ }^{63}$ Shepard, The Confessions, 189, 194.

${ }^{64}$ Allin, A Brief History of the Church of Christ at Dedham, 58-59.
} 
and momentary. ${ }^{65}$ As applicants for church membership in the congregational churches of New England recited the abbreviated narratives that the ministers had requested and they themselves had carefully rehearsed, conversion became associated with brief, singular moments of vocation that punctuated their lifelong struggle for justification and sanctification.

\section{Tears of Repentance, Sighs of Contrition}

In the same way that the unique ecclesiastical requirements of the Congregational Way promoted abbreviated conversion narratives, missionary efforts among New England's indigenous inhabitants encouraged the ministers responsible for evaluating the narratives of indigenous applicants to associate conversion with physical affect. Ministers had always understood appropriately modest displays of emotion (tears which were shed while no one was looking, but which left the eyes from which they fell red; choked or stifled sobs) as potential signs of grace; indeed, John Eliot suggested that a melancholic disposition was "a good servant to repentance," a belief later echoed by Edwards and other ministers. ${ }^{66}$ But when Shepard, Eliot, and other ministers attempted to assess the spiritual state of Indians for overseas audiences and for the purpose of admitting them to church membership, physical affect was disproportionately influential on their judgment. Among English applicants for church membership in New England, the most important criterion was the conversion narrative - the verbal account of contrition and vocation delivered to the minister and elders of the church. When ministers attempted to ajudicate the conversion narratives of Indians, however, they were forced to rely more heavily on physiological signs of emotion because of

\footnotetext{
${ }^{65}$ Shepard, The Parable of the Ten Virgins Opened \& Applied, I.183, II.200, II.201.

${ }^{66}$ John Eliot, The Day Breaking, if not The Sun-Rising of the Gospell, in John Eliot, The Eliot Tracts, ed. Michael P. Clark, (Westport: Praeger, 2003), 95.
} 
their inability to understand fully the narratives offered by Indian applicants.

The language barrier is cited repeatedly in the eleven published descriptions of English conversion efforts among New England Indians that are now known as the Eliot tracts. The earliest account of Indian evangelism, New Englands First Fruits (1643), begins by acknowledging both "the difficulty of their Language to us, and of ours to them" as well as "the diversity of their owne Language to it selfe; every part of that Countrey having its own Dialect, differing much from the other; all which make their comming into the Gospel the more slow. ${ }^{, 67}$ Eliot and other English ministers were eventually able to learn enough of the language to catechize the Indians, but serious communication barriers remained for Indians attempting to relate their effectual callings by delineating signs of God's grace in their lives. In 1652, Eliot assembled his community of praying Indians in front of a gathering of church elders and translated their conversion narratives into English for the assembled colonists. But as Eliot listened, "oft I was forced to inquire of my interpreter (who sat by me) because I did not perfectly understand some sentences." Eliot translated and transcribed each of the narratives as it was delivered, but admits that he has "rendered them weaker (for the most part) than they delivered them; partly by missing some words of weight in some Sentences, partly by my short and curt touches of what they more fully spake, and partly by reason of the different Idioms of their Language and ours." ${ }^{\text {,68 }}$ Eliot understands most of what is said, but he also acknowledges the limitations of his linguistic capabilities and that he relied on physiological clues to guide his interpretation of grace in the Indian narratives.

As an Indian named Waban professed that "I am ashamed of all I do, and I do repent

\footnotetext{
${ }^{67}$ New Englands First Fruits, in The Eliot Tracts, 58. On the authorship of this anonymously published pamphlet, see chapter 3, p. 185.

${ }^{68}$ John Eliot, Tears of Repentance in The Eliot Tracts, 282, 283.
} 
of all my sins, even of all that I do know of: I desire that I may be converted from all my sins, and that I might beleeve in Christ," Eliot carefully recorded his words. When Waban had finished, Eliot read the narrative out loud and then noted that objections were raised because Waban's confession "was not so satisfactory as was desired.” Eliot, who had only heard Waban's narrative, could say nothing in his defense, but John Wilson "testified that [Waban] spake these latter expressions with tears, which [Eliot] observed not, because [he] attended to writing." It is the sight of Waban's emotion that persuades Wilson of his sincerity, and Wilson's testimonial provokes Eliot to defend Waban—and, implicitly, all other Indians: "His gift is not so much in expressing himself this way [ie, in the Congregational Way and Calvinist rhetorical tradition], but in other respects." ${ }^{69}$ Eliot suggests that Waban's narrative should be satisfactory to the assembled elders despite its doctrinal and rhetorical flaws because he has communicated his contrition-and his vocation, since "those aboundant teares which wee saw shed from their eies, argue a mighty and blessed presence of the spirit of Heaven in their hearts"- - through the tears that punctuate his performance. ${ }^{70}$ It is the physical display of emotion that persuades Wilson and Eliot of Waban's conversion, and Eliot entitles the volume of Indian conversion narratives from which Waban's story is taken Tears of Repentance (1654) precisely because the visible tears of the Indians it describes are more convincing evidence of spiritual progress than their verbal professions of faith.

Waban's case is a characteristic example of the way in which Indian evangelism altered the criteria used to evaluate conversion narratives as ministers placed increased emphasis on physiological expressions of contrition. When Shepard examines applicants to the Cambridge church, he rarely_-if ever_comments on their emotional or physiological

${ }^{69}$ ibid, 271-72. 
state, focusing on the doctrinal content of their confessions and the catechistical question and answer sessions that followed several of the narratives. When he observes one of Eliot's sermons to the Indians, however, Shepard largely ignores the verbal participation and questions of the Indians "which received full answers from severall hands. But that which I note is this ... their gracious attention to the Word, the affections and mournings of some of them under it." Shepard is less impressed with one Indian man's “many expressions of wondring at Gods goodnesse" than he is "with [the] strong actings of his eyes and hands," which "did much also affect all of them that were present at this Lecture also."71 The stumbling confessions of Indians expressing their faith in a second language are only understood and believed when accompanied by tears or physical gestures; the anonymous author of New Englands First Fruits is convinced of one Indian's salvation because "his manner was to smite his hand on his breast, and to complaine sadly of his heart, saying it was much machet, (that is very evill) and when any spake with him, he would say, Wequash, no God, Wequash no know Christ." Among a people "well known not to bee much subject to teares, no not when they come to feele the sorest torture, or are solemnly brought forth to die," tears and other physical signs of emotion were seen as incontrovertible evidence of "some conquering power of Christ Jesus stirring among them.,"72

Of course, the same ministers who take such pride in the spirituality of emotionally volatile Indians are the very individuals who taught them to express their spirituality through emotion in the first place! Eliot, recognizing that the Indians would struggle to articulate their

\footnotetext{
${ }^{70}$ Eliot, The Day Breaking, if not The Sun-Rising of the Gospell, 94.

${ }^{71}$ Thomas Shepard, The Clear Sun-Shine of the Gospel Breaking Forth Upon the Indians in New-England, in The Eliot Tracts, 120-21.

${ }^{72}$ New Englands First Fruits, 62; Shepard, The Clear Sun-Shine of the Gospel Breaking Forth Upon the Indians in New-England, 133.
} 
relationship to God in the same terms as his Roxbury congregants, explained to them that "although they could not make any long prayer as the English could, yet if they did but sigh and groane .. . God would teach them Jesus Christ." Eliot teaches the Indians to express their spirituality through physical affect precisely because, as Kathleen Lynch argues, the postures, gestures, tears, and sighs of the Indians were "the only criteria of authenticity the witnesses"- who did not speak the various Indian dialects—“were equipped to judge. The persuasions of physical affect were a point of evaluation whenever such testimony was delivered orally." ${ }^{, 73}$ This ministerial emphasis on physical affect as a measure of conversion was a self-conscious response to linguistic barriers between Indian applicants and English examiners that shaped the reception of Indian confessions, but it also impacted the way in which English-speaking applicants, church members, and ministers understood conversion in the seventeenth century.

Eliot, comparing spiritually receptive Indians to hard-hearted colonists, suggests that "Indians shall weepe to heare faith and repentance preached, when English men shall mourne, too late, that are weary of such truths." ${ }^{, 74}$ The implication of Eliot's statement is that colonists should be weeping just as frequently as the Indians-and that the absence of tears on English cheeks indicates their degeneracy. Despite Eliot's encouragement, there is no evidence that colonists followed the example of his Indian converts and cried more frequently in the second half of the seventeenth century than they did in the first. To be sure, Increase Mather and other ministers promised church members that their "Prayers and Tears before the Lord" would produce conversion in their children-but there is no way to quantify

\footnotetext{
${ }^{73}$ Eliot, The Day Breaking, if not The Sun-Rising of the Gospell, 85; Kathleen Lynch, Writing from Experience, (book manuscript circulated in a Folger seminar on "Forms of Religious Experience in the 17th-Century British Atlantic World," February 2009), chapter 3, page 39.

${ }^{74}$ Eliot, The Day Breaking, if not The Sun-Rising of the Gospell, 94.
} 
the tears shed by second generation colonists as opposed to their first generation counterparts. ${ }^{75}$ There is evidence, however, that New England colonists came to understand conversion as a process intimately linked with individual physiologies, that they eventually accepted Eliot's belief in bodily excretions as a leading indicator of election.

\section{$\underline{\text { Sanctified Semen and the Half-Way Covenant }}$}

In his description of the Indian response to Puritan preaching Shepard emphasizes Indian tears as a measure of conversion, but he also connects other bodily excretions to the conversion process. When the Indians ask "Whither their little children goe when they dye," Shepard responds by teaching them about "the Covenant of God, which he hath made with all his people, and with their children, so that when God chooses a man or a woman to be his servant, he chooses all their children to be so also." This "doctrin was exceeding gratefull unto them" because the Indians who inquired undoubtedly dared to hope that they were among the elect and that their children would be saved with them. ${ }^{76}$ In reassuring these Indians about the eternal fate of their prematurely deceased children, Shepard teaches principles that would not be ratified by New England churches until the Half-Way Covenant was formally adopted by the synod of 1662 . Though he does not speak so frankly as Increase Mather later would, Shepard's claim anticipates and agrees with Mather's assertion that "Elect Parents have none but elect Children," and both men are making a claim about the bodies of the converted elect. According to their shared understanding of conversion and parentage, election is what we would now describe as a heritable genetic trait, part of the physiological inheritance present in the ovum and transmitted with semen as it was ejaculated from "the vein of Election ... through the loyns of godly Parents." And if the

\footnotetext{
${ }^{75}$ Increase Mather, Pray for the Rising Generation, (Boston: John Foster, 1679), 17.
} 
child of elect parents somehow failed to inherit saving grace, Mather conjectures that it could still be imparted after birth through breastmilk; he teaches women that "your Children (as Luther speaketh) may suck in Religion from their mothers breasts." ${ }^{, 77}$ Conversion was not only signified by bodily excretions (tears), it was also passed from parent to child through bodily excretions (ovum, semen, breastmilk).

In 1648, when Shepard articulated the doctrine that would later become the backbone of the Half-Way Covenant while responding to an Indian's question about the spiritual destiny of unbaptized infants, he spoke without pretending to clerical consensus. Indeed, the Cambridge Platform agreed to in that same year says only that baptized children "are in a more hopefull way of attayning regenerating grace," not that baptism is an implicit recognition of the inherent connection between the conversion of a parent and the future conversion of his or her biological offspring. But the Half-Way Covenant clearly connects biology and conversion. The basic premise of the Half-Way Covenant is that even when "the Lord cast off the immediate Seed" of elect parents, "he remembers his Covenant to others that are more remote." Thus, baptizing the children of baptized but unconverted church members is appropriate, because God always "remembers his Covenant made with blessed [biological] Ancestors"; the Half-Way Covenant presupposes that saving grace, like any other unexpressed trait on a recessive gene, is sure to pop up in a generation or two. ${ }^{78}$ Yet the genetic and heritable character of saving grace was an issue on which, as E. Brooks Holifield reminds us, the "clergy reached no consensus" until long after the synod of 1662. Not until the end of the seventeenth century did most of the ministers opposing the Half-Way

\footnotetext{
${ }^{76}$ Shepard, The Clear Sun-Shine of the Gospel Breaking Forth Upon the Indians in New-England, 129.

${ }^{77}$ Mather, A Call from Heaven to the Present and Succeeding Generations, 5, 23.
} 
Covenant die down or die off, but by the time Edwards inherited his pulpit in Northampton from his grandfather, Solomon Stoddard, the ministers in New England had collectively come to support the baptism of unconverted church members' children. Their belief that descendants of the elect had "the means of grace vouchsafed" in their very physiologies had become a commonplace of Congregational theology. ${ }^{79}$

\section{Labor and Delivery: Edwards, Eve, and the New Birth ${ }^{80}$}

By the beginning of the eighteenth century, and because of the unique circumstances that shaped Congregational theology in New England, conversion had become a process that had more in common with the circumstances and duration of childbirth than with the protracted nature of a pilgrimage. The orally-delivered and chronologically compressed confessions required of all applicants for church membership had associated conversion with a single brief moment of vocation, a spiritual metamorphosis communicated through physical affect to which the biological descendants of New England's elect were genetically predisposed. Conversion was now a phenomenon described in terms more closely related to childbirth—a (relatively) short, physical event — than to the timeframes and language associated with a pilgrimage. To be sure, ministers continued to use the language and metaphors of the pilgrimage as a metaphor for conversion; Henry Gibbs described "the Saints . . a as wearisome Pilgrims," and Thomas Foxcroft portrayed death as a welcome relief

\footnotetext{
${ }^{78}$ Cambridge Synod, A Platform of Church Discipline Gathered Out of the Word of God, (Cambridge: S.G., 1649), 18; Mather, A Call from Heaven to the Present and Succeeding Generations, 19.

${ }^{79}$ E. Brooks Holifield, Theology in America, (New Haven: Yale University Press, 2003), 54; Mather, A Call from Heaven to the Present and Succeeding Generations, 14. For a more detailed consideration of the debtate that ensued in the years following the synod of 1662, see E. Brooks Holifield, The Covenant Sealed, (New Haven: Yale University Press, 1974), 169-224.

${ }^{80}$ Some of the ideas-but none of the actual words-in this section were first presented in "Edwards and Eve: Finding Feminist Strains in the Great Awakening's Patriarch," Early American Literature 43.3 (2008): 671-86.
} 
for celestially bound saints from "the Fatigues and Troubles of their Pilgrim-State." ${ }^{81}$ But Foxcroft became a vocal defender for advocates of the new birth during the transatlantic revivals; and Gibbs, who was born in 1668, died before the revivals had even begun. Gibbs and Foxcroft are, in this sense, representative of two different populations of New England clergy in the early eighteenth century: a generation born in the seventeenth century for whom the pilgrimage remained preeminent until their deaths, and the first generation of ministers raised in the eighteenth century, a group that recognized the tradition of the pilgrimage but that eventually emphasized the new birth as a more central metaphor for conversion during the Great Awakening. The trope of the pilgrimage did not disappear from religious discourse in New England, but Thomas Kidd notes that it was supplanted by the new birth as the "principal metaphor" of New England "spirituality and devotional practice" as a growing evangelical movement placed "new emphases on the discernible moment of an individual's conversion, or the 'new birth,' and the simultaneous conversion of many individuals during revivals." $" 82$

At the center of this emergent evangelical movement stood Jonathan Edwards, whose Northampton revivals provided a pattern for ministers and the laity alike as they struggled to recognize and then describe the outpourings of grace that produced mass conversions across the upper Atlantic. In the structure and language of A Faithfull Narrative of the Surprising Work of God (1737) Edwards supplied his readers with what Philip Gura calls “a new grammar and sociology of religious revival ... and with each reprinting of the book, readers internalized the remarkable stories of Abigail Hutchinson, Phebe Bartlett, and other

\footnotetext{
${ }^{81}$ Henry Gibbs, Bethany: or, The House of Mourning, (Boston: T. Green, 1714), 26; Thomas Foxcroft, $A$ Funeral Sermon, in Cotton Mather, The Soul Upon the Wing, (Boston: B. Green, 1722), 46.

${ }^{82}$ Hambrick-Stowe, The Practice of Piety, 54; Thomas Kidd, The Great Awakening, (New Haven: Yale University Press, 2007), xiv.
} 
Northampton converts, making them their implicit role models." His advocacy for the new birth ultimately led to its ascension over the pilgrimage as the principal metaphor for conversion; Edwards's understanding of conversion shaped the individual and collective experiences of men and women caught up in the spirit of revival on both sides of the Atlantic, and his emphasis on the new birth is emphatic. Indeed, the entire purpose of the Faithfull Narrative is to show how the inhabitants of Northampton "appear to have been truly born again." ${ }^{83}$

\section{The Conversion of Jonathan Edwards}

As a religious leader whose preaching and writing led both directly and indirectly to the new birth of so many others, Edwards's own conversion narrative has been subjected to intense scrutiny, and Wilson Kimnach is quick to point out that Edwards fails to structure his experiences in what was still the traditional form of a pilgrimage with distinct stages back to God's presence. Edwards must have been aware that he was expected to shape his conversion experience into a spiritual travel narrative; "[o]n the issue of the proper morphology of conversion," his father, the Reverend Timothy Edwards was "a liberal traditionalist" who "tended to dominance, if not manipulation," forcing applicants for church membership to adhere to "a conventional structure, stressing the preparatory struggles and treating the joys of the new birth only briefly." But Edwards resisted his father's influence, and his own experience of conversion, as originally recorded in the "Diary" and later described in the "Personal Narrative," "did not have the conventional structure" of a pilgrimage. ${ }^{84}$ Whereas

\footnotetext{
${ }^{83}$ Philip Gura, Jonathan Edwards: America's Evangelical, (New York: Hill and Wang, 2005), 89-90; Jonathan Edwards, A Faithful Narrative, in The Works of Jonathan Edwards, Vol. 4, The Great Awakening, ed. C.C. Goen, (New Haven: Yale University Press, 1972), 159.

${ }^{84}$ Wilson H. Kimnach, "Preface to the New York Period," in Jonathan Edwards, The Works of Jonathan Edwards, Vol. 10, Sermons and Discourses 1720-1723, ed. Wilson H. Kimnach, (New Haven: Yale University Press, 1992), 271-72.
} 
Edwards's seventeenth-century predecessors received their vocation during journeys to and within the New World, travel draws Edwards further away from God. He complains in his journal that the "things, which take off my mind, when bent on religion, are commonly some remarkable change and alteration: journeys, change of place. ${ }^{85}$ To Edwards, travel is less a metaphor and catalyst for conversion than a distraction from pressing matters of the heart.

Edwards writes in his journal that the remedy for "such a lifeless frame" of mind and soul as that brought on by travel is "to go quick from one thing to another, and do ... things [e.g. reading the scriptures and praying] with vigor," to rely on a physical engagement with intellectual and spiritual tasks as a prompt to regeneracy. This emphasis on the physicality and immediacy of spiritual renewal would find public expression seven years later in his sermons; in a 1730 sermon entitled "Born Again," Edwards explains that the "change of man from a sinner to a saint is not a moral, but a physical change" and that this change is instantaneous, "a coming out of nothing into being" comparable to the ex nihilo creation of the world. ${ }^{86}$

\footnotetext{
${ }^{85}$ Jonathan Edwards, "Diary," in The Works of Jonathan Edwards, Vol. 16, Letters and Personal Writings, ed. George S. Claghorn, (New Haven: Yale University Press, 1998), 765.

${ }^{86}$ ibid, 765; Jonathan Edwards, "Born Again," in The Works of Jonathan Edwards, Vol. 17, Sermons and Discourses, 1730-1733, ed. Mark Valeri, (New Haven: Yale University Press, 1999), 187, 194. In the same sermon from which these quotes are taken, Edwards writes that conversion "is the same as a birth, rather than an immediate creation," apparently contradicting the suggestion of an instantaneous conversion. But this provision-if read in conjunction with Edwards's theory of childbirth and fetal development, on which more below-actually confirms, rather than contradicts, that conversion is what modern readers would understand to be "an immediate creation."

In his discussion of fetal development, Edwards writes that while physiological development proceeds gradually, the soul of a child is infused into its future body at a specific instant. Before that moment the fetus was an unliving mass of tissue; afterwards, it is a human being. Likewise, he writes in his sermon, "[t]here is in conversion infused a principle of spiritual understanding and spiritual action that is far above any principles that man had before, as the heaven is high above the earth. And this change of nature is such that he not only acts above what he did before, but contrary." The infusion of spiritual understanding is, like the infusion of a soul into the fetus, instantaneous; on that point, Edwards is clear. When he explains the new birth is not an immediate creation, he only points out that there is a "preparatory work" to conversion-just as the physiological growth of the fetus is a preparation for the reception of a soul. This preparatory work is not the event of conversion - the infusion of spiritual understanding that produces spiritual change-because such preparation does not necessarily result in conversion, but it is a necessary prerequisite. The infusion is
} 
Edwards's own conversion, as recounted in the "Personal Narrative," fits this pattern; it is both prompted by bodily experience and realized in a singular moment of physiological and intellectual change. He writes that "it pleased God, in my last year at college, at a time when I was in the midst of many uneasy thoughts about the state of my soul, to seize me with a pleurisy; in which he brought me nigh to the grave, and shook me over the pit of hell." This sickness leads him "to seek salvation, in a manner that I never was before," and that search culminates in a moment of understanding when, for the first time, "the doctrine of God's sovereignty" becomes palatable:

I remember the time very well, when I seemed to be convinced, and fully satisfied, as to this sovereignty of God, and his justice in thus eternally disposing of men, according to his sovereign pleasure. But never could give an account, how, or by what means, I was thus convinced; not in the least imagining, in the time of it, nor a long time after, that there was any extraordinary influence of God's Spirit in it: but only that now I saw further, and my reason apprehended the justice and reasonableness of it. However, my mind rested in it; and it put an end to all those cavils and objections, that had till then abode with me, all the preceding part of my life. And there has been a wonderful alteration in my mind, with respect to the doctrine of God's sovereignty, from that day to this.

That day—-that sudden now in which Edwards saw further—was marked by a new physiological sensation as "there came into my soul, and was as it were diffused through it, a sense of the glory of the divine being; a new sense, quite different from anything I ever experienced before." ${ }^{87}$ Significantly, Edwards's new appreciation for divine sovereignty is not just an intellectual understanding arrived at through reason over a period of time but a

instantaneous, but because it occurs "according to a fixed law of nature" and by "stated means" Edwards rejects the word immediate. Edwards uses immediate in the OED sense of an event occurring "without any intervening medium or agency," not in its current sense of an event "taking effect without delay or lapse of time." Because conversion is the product of God's laws and effected through natural means, Edwards's conception of conversion is not immediate in the autonomous sense, but it is instantaneous. See Edwards, "Born Again," 18789.

${ }^{87}$ My emphasis; Jonathan Edwards, "Personal Narrative," in The Works of Jonathan Edwards, Vol. 16, Letters and Personal Writings, ed. George S. Claghorn, (New Haven: Yale University Press, 1998), 791-93. 
physiological change experienced in an instant. ${ }^{88}$

Fueled by a physical illness, Edwards's chronologically brief and narratologically abbreviated spiritual search culminates and ends in a single transformative moment marked by physiological experience. His personal conversion is an instantaneous physical change, a new birth. Edwards's interest in the new birth represents a point of divergence from his father's emphasis on a temporally protracted spiritual pilgrimage and has traditionally been understood as a reflection of his grandfather's influence; after all, Edwards takes pains in the Faithfull Narrative to note that Stoddard had led several successful revivals before he ever arrived in Northampton. Stoddard's insistence that communion is a "converting ordinance" which should therefore be offered to the unconverted as "a Life-giving Bread" is certainly predicated on a belief in the physicality and immediacy of conversion consistent with Edwards's understanding of the new birth. ${ }^{89}$ But Edwards was always ill at ease with Stoddard's communion policies, and he eventually and infamously reversed them; his belief that the new birth was an instantaneous physiological change derived, at least in part, from a source more influential even than his grandfather: scripture. ${ }^{90}$

\section{Childbirth and the Conversion of Eve}

As his theology of the new birth moved toward its maturation in the 1730 "Born

\footnotetext{
${ }^{88}$ I emphasize the physicality and immediacy of Edwards's conversion, but without intending to efface the mental processes associated with it. Edwards clearly thinks and writes about his conversion-at least after the fact_-in Lockean terms, a point made by Perry Miller, among others. See Perry Miller, "The Rhetoric of Sensation" in Errand into the Wilderness (Cambridge: Harvard University Press, 1956), 167-83; Norman Fiering, Jonathan Edwards's Moral Thought and Its British Context, (Chapel Hill: The University of North Carolina Press, 1981); and William Sparkes Morris, The Young Jonathan Edwards (Brooklyn: Carlson Publishing, 1991).

${ }^{89}$ Solomon Stoddard, An Appeal to the Learned, (Boston: B. Green, 1709), 42.

${ }^{90}$ On Edwards's early disease with Stoddard's communion and conversion policies-even while Stoddard was still alive_-see Kenneth P. Minkema, "Sacramental Theology and Conversion," in The Works of Jonathan Edwards, Vol. 14, Sermons and Discourses, 1723-1729, ed. Kenneth P. Minkema, (New Haven: Yale University Press, 1997), 38-42.
} 
Again" sermon, a document whose theology he would ratify by repreaching it in 1753 , the young Edwards searched for scriptural examples of and experiential parallels to the new birth. In the winter months of 1726, just after he had arrived in Northampton and as he prepared himself to assume Stoddard's pulpit, Edwards considered the lives of Adam and Eve after their expulsion from the garden and made an entry in his Notes on Scripture identifying Cain's birth as the moment at which Eve was converted:

Genesis 4:1. "And Adam knew his wife; and she conceived and bare Cain, and said, I have gotten a man from the Lord." In Eve's expressing herself so, it is probable she had an eye to what God said, that her seed should break the serpent's head [Genesis 3:15]; for now, seeing she had a son, her faith and hope was strengthened that the promise should be fulfilled. $^{91}$

Edwards conjectures that the physical experience of childbirth leads Eve to a spiritual new birth - to a saving faith in the promise of a savior. Eve's conversion is both prompted by a physical event and experienced instantaneously; Edwards suggests that the vision of her male offspring allows Eve to understand in that moment the promise of redemption offered earlier in the garden.

Prompted by his insight into Eve's conversion experience, Edwards made another entry in his private notebooks only weeks later, at some point in the early months of 1727 , expanding on the parallels between childbirth and the new birth. Under a "Miscellanies" entry entitled "Regeneration," Edwards speculated that

It may be in the new birth as it is in the first birth. The vivification of the fetus in the womb is exceeding gradual; the vital operations of it arise from the most imperfect to the more perfect by an insensible increase, so that there is no determining at what

\footnotetext{
${ }^{91}$ Jonathan Edwards, "82," in The Works of Jonathan Edwards, Vol. 15, Notes on Scripture, ed. Stephen J. Stein, (New Haven: Yale University Press, 1998), 74. Stephen Stein, in conjunction with Thomas Schafer, has provided approximate dates for the composition of each of the Notes and states that "Note 82" was the fifteenth of eighty entries written during the four years 1726-1729. Assuming that the Notes were composed at a relatively consistent pace during this period, Edwards would have written "Note 82" some time in the late winter of 1726. See Stephen J. Stein, "Note on the Manuscripts," in The Works of Jonathan Edwards, Vol. 15, Notes on Scripture, ed. Stephen J. Stein, (New Haven: Yale University Press, 1998), 41-42.
} 
time it first begins to be [a] living creature and to have a rational soul. Yet there is a certain moment that an immortal spirit begins to exist in it by God's appointment ... In the new birth there is certainly a very great change made in the soul: so in the first birth there is a very great change when the rational soul is first infused, for the fetus immediately upon it becomes a living creature and a man, that before had no life; yet the sensible change is very gradual.

In the new birth — as in pregnancy and childbirth — there is a discernible moment of sensible change, a chronological point at which the convert experiences some "kind of new ... sensation." $" 92$ That new sensation may only be discerned gradually, as when Edwards failed to recognize "any extraordinary influence of God's Spirit in" his own conversion experience until "a long time after" the actual event, but it is, nonetheless, a physiological change attributable to a single instant.

Edwards's commentary on Eve's conversion and his subsequent, related reflection on the similarities of childbirth and regeneration are the earliest recorded formulations of his belief in the new birth as an instantaneous and physiological event. ${ }^{93}$ In other words, Eve was the inspiration for a theological innovation that made possible the Northampton revival of 1735 and that led indirectly to the transatlantic awakenings of the late 1730 s and 1740 s. This is, to be sure, a rather provocative claim—-but no more provocative than Edwards's own claim that since "Eve was the mother of all living universally ... [there is] not one, that has spiritual and eternal life, of all mankind, that in this sense is excepted, not Adam, nor Christ,

\footnotetext{
${ }^{92}$ Jonathan Edwards, "241. Regneration," in The Works of Jonathan Edwards, Vol. 13, The "Miscellanies": (Entry Nos. $a-z, a a-z z, 1-500$ ), ed. Harry S. Stout, (New Haven: Yale University Press, 1994), 357-58. For a chronology of "Miscellany" composition, see Kenneth P. Minkema, "A Chronlogy of Edwards' Life and Writings," The Jonathan Edwards Center at Yale University, Web. Edwards returned to this topic in his "Blank Bible"; see Jonathan Edwards, The Works of Jonathan Edwards, Vol. 24, The "Blank Bible," ed. Stephen J. Stein, (New Haven: Yale University Press, 1006), 604.

${ }^{93}$ Edwards makes an earlier entry on regeneration in the Miscellanies, but fails to articulate a clear understanding of conversion as both instant and physiological; the language of infusion is present in this earlier entry but without an explanation of conversion's chronology and physicality. See Jonathan Edwards, "78. Regeneration," in The Works of Jonathan Edwards, Vol. 13, The "Miscellanies": (Entry Nos. a-z, aa-zz, 1500), ed. Harry S. Stout, (New Haven: Yale University Press, 1994), 245-46.
} 
no, nor herself; for in this sense, as she was the mother of Christ, she was her own mother." ${ }^{\text {, }}$ Edwards stipulates that Jesus Christ's ministry and atoning sacrifice was only made possible by Eve's experience of childbirth and, therefore, that every conversion is already contingent on her maternity; it hardly seems a stretch to suggest that the scriptural account of Eve's delivery provided a biblical model of conversion on which Edwards based his own influential theories of the new birth.

\section{The After Birth: Eve's Impact on Edwards and the Awakenings}

If, as I have argued, Eve is the figure who inspired Edwards to think of conversion as a new birth datable to a discernible moment of physiological change, she is also an important factor in the evolving morphology of conversion among New England colonists and other participants in the transatlantic awakenings. The ecclesiastical structure and evangelical purpose of the Congregational churches in New England had already pushed the language of conversion away from the trope of a pilgrimage and towards the new birth, but Eve's influence on Edwards was something of a tipping point as the new birth found in him a powerful advocate: a brilliant theologian, a salesman who would describe the new births of the Northampton revival in memorable terms that stuck in the reader's mind, and a writer with connections to all of the most important ministers on both sides of the ocean. Edwards's emphasis on the new birth was imitated by his readers, and Eve is largely responsible for that emphasis; the language of his sermons changes markedly after his first recorded encounter with her. Between 1720 and 1727 Edwards's sermons betray no unusual focus on the new

\footnotetext{
94 Jonathan Edwards, “398. Genesis 1:27-30. COVENANT WITH ADAM,” in The Works of Jonathan Edwards, Vol. 13, The "Miscellanies": (Entry Nos. a-z, aa-zz, 1-500), ed. Harry S. Stout, (New Haven: Yale University Press, 1994), 397. For more on Edwards's views on Eve, see Hutchins, "Edwards and Eve: Finding Feminist Strains in the Great Awakening's Patriach.”
} 
birth. Indeed, his early sermons give equal time to the language of the pilgrimage, a balance between these two tropes of conversion that would not begin to tip in favor of the new birth until after he had recorded his private reflections on Eve and fetal development in the winter of $1726-1727$.

In a 1723 sermon entitled "The Way of Holiness," Edwards describes conversion as a spiritual journey in the conventional seventeenth-century manner, taking as his text a verse from Isaiah: "And an highway shall be there, and a way, and it shall be called The way of holiness; the unclean shall not pass over it; but it shall be for those: the wayfaring men, though fools, shall not err therein." While Edwards was already, at this time, rejecting travel as a means to and metaphor for his personal conversion in the "Diary," he continued to use the pilgrimage as a metaphor conducive to the conversion of his congregants. He exhorts them to follow the path prescribed by Isaiah and allegorized by Bunyan, warning that there is only one road back to God's presence: "Some don't go to heaven in a broad way, and others in a narrow; some in an easy and others in a difficult way; some in a way of self-denial and mortification, and others in a way of enjoyment of their lusts and sinful pleasures; some up hill and others down: but the way to heaven is the same, and it is the highway here spoken of." ${ }^{, 95}$ Another early sermon written in 1727—when he was still considering the lessons of Eve's conversion in his private notebooks—urges listeners to "consider your selves in this world as in a Journey and Consider heaven as your Everlasting home," asking "what great matter is it whether you have a smoth Road or no to Go home in" and inviting congregants to

\footnotetext{
${ }^{95}$ Isaiah 35:8; Jonathan Edwards, "The Way of Holiness," in The Works of Jonathan Edwards, Vol. 10, Sermons and Discourses, 1720-1723, ed. Wilson H. Kimnach, (New Haven: Yale University Press, 1992), 469.
} 
picture themselves as pilgrims returning to the celestial city. ${ }^{96}$ In these early sermons Edwards describes conversion as a "Journey," a lifelong pilgrimage to heaven in which the new birth is only one of many equally significant and incremental steps back to God.

After his encounter with Eve, however, the new birth becomes an increasingly important point of emphasis. In a sermon delivered in the fall and winter of 1728-1729, Edwards publicly declares for the first time that the new birth is accompanied by a physiological alteration. He exhorts his listeners to "examine therefore whether you feel a new nature in [deletion] your soul. what ones nature is may be felt and Perceived by one that observes. a man may feel which way his [deletion] soul naturally tends as ... his body by its weight tends Downwards. he that [deletion] is born again will feel a difference in himself from what he once was" and "feel new ... appetites." The new birth, Edwards explains, produces sensible physiological changes in weight and appetites; it is not solely a spiritual alteration. He reiterates the doctrine in 1732, rebuking those who "hold that there is no other Change in Conversion but only a Change of manners \& Customs only a moral not a Physical Change," noting that such individuals "never were sensible of the Corruption of mans [physiological] nature . . by the fall. ${ }^{, 97}$ In addition to these sermons and the 1730 "Born Agan" sermon, Edwards also delivered two others sermons on the new birth at some point during the years 1731 and $1732 ;{ }^{98}$ the occasional references in his early sermons to being

\footnotetext{
${ }^{96}$ Jonathan Edwards, "57. II Cor. 6:10 [1727]," in The Works of Jonathan Edwards Online, Vol. 42, Sermons, Series II, 1723-1727, ed. Jonathan Edwards Center, (Jonathan Edwards Center at Yale University, 2008), 30 Oct. 2009.

${ }^{97}$ Jonathan Edwards, "88. Luke 17:34 [1728-1729]," in The Works of Jonathan Edwards Online, Vol. 43, Sermons, Series II, 1728-1729, ed. Jonathan Edwards Center, (Jonathan Edwards Center at Yale University, 2008), 30 Oct. 2009; Jonathan Edwards, "230. Matthew 10:17 [1731-1732]," in The Works of Jonathan Edwards Online, Vol. 47, Sermons, Series II, 1731-1732, ed. Jonathan Edwards Center, (Jonathan Edwards Center at Yale University, 2008), 30 Oct. 2009.

${ }^{98}$ See Jonathan Edwards, “192. I Peter 2:9 [1731-1732]," in The Works of Jonathan Edwards Online, Vol. 46, Sermons, Series II, 1731-1732, ed. Jonathan Edwards Center, (Jonathan Edwards Center at Yale University,
} 
born again proliferated and were elaborated upon in the years after his initial reflections on Eve and in the period immediately preceding the Northampton revival.

By the time he sat down to record the events of the Faithful Narrative, Edwards's understanding of conversion had already undergone the pivotal shift that made the new birth a central feature of that work. In it, Edwards writes that "several Negroes ... appear to have been truly born again in the late remarkable season." He describes conversion in the terms of biological reproduction as saving grace "swiftly propagated from town to town," the new birth literally breeding as it renewed converts spiritually. Parents in Northhampton rejoiced "over their children as newborn, and husbands over their wives, and wives over their husbands." Those listening to Edwards's sermons took home "impressions that never wore off till they had hopefully a saving issue": their own new births. ${ }^{99}$ Edwards occasionally lapses into the language of pilgrimage—some of his congregants "wander about from mountain to hill, seeking rest and finding none: when they are beat out of one refuge they fly to another, till they are as it were debilitated, broken, and subdued with legal humblings" and "brought home to Christ"- but his primary emphasis has shifted to the new birth and the question of what distinguishes "those in whom the awakenings seem to have a saving issue." ${ }^{100}$ Those who have experienced the new birth, Edwards notes,

have a new sense of things, new apprehensions and views of God, of the divine attributes, and Jesus Christ, and the great things of the Gospel: they have a new sense of the truth of them, and they affect them in a new manner ... Their hearts are often touched, and sometimes filled, with new sweetnesses and delights ... there are new

2008), 30 Oct. 2009; Jonathan Edwards, "193. I John 3:9[1731-1732]," in The Works of Jonathan Edwards Online, Vol. 46, Sermons, Series II, 1731-1732, ed. Jonathan Edwards Center, (Jonathan Edwards Center at Yale University, 2008), 30 Oct. 2009

${ }^{99}$ Jonathan Edwards, A Faithful Narrative, in The Works of Jonathan Edwards, Vol. 4, The Great Awakening, ed. C. C. Goen, (New Haven: Yale University Press, 1972), 159, 151, 152.

${ }^{100}$ ibid, 166, 158, 168. 
appetites, and a new kind of breathings and pantings of heart, and groanings that cannot be uttered [Romans 8:26]. There is a new kind of inward labor and struggle of soul

which can best be understood by comparing it to the outward, physical labor of childbirth. Edwards's congregants have experienced the new birth, and through their conversion, "God has evidently made us a new people."101

In describing the new births of Hutchinson, Bartlett, and others in Northampton, Edwards made these women into models of conversion whose lives would be scrutinized and imitated across New England. But Hutchinson and Bartlett are only the most visible exemplars of the Great Awakening; the new birth that Edwards preached and that these women exemplified was first patterned after another exemplary woman whose influence has remained hidden in the pages of Edwards's private notebooks: Eve. When he urged his congregants to strive after an instantaneous and physically affecting new birth, Edwards made Eve's conversion experience during childbirth into the perfect pattern of regeneracy. In the same way that his seventeenth-century predecessors presented the original, edenic innocence of Adam as the highest attainable state of spirituality on earth, Edwards points to Eve's regeneracy—her experiences after the Fall as the first convert and the woman whose maternity made all other conversions possible—as the spiritual ideal to which all should aspire, and by prompting Edwards to emphasize the need for every individual to be born again, Eve vicariously helped to push the language of conversion in New England from the discourse of a temporally protracted pilgrimage to the language of a new birth. The overt references to Adam and Eden that punctuated seventeenth-century sermons and conversion narratives began to fade in the eighteenth century, but Eden remained, through Edwards, Eve,

101 ibid, 208, 209. 
and the evangelical movement they promoted, a central influence on New England religious experience. 


\section{CHAPTER 6}

\section{"OUT OF CHAOS AND CONFUSION": THE BELATED CREATION AND ANTICIPATED FALL OF HARRINGTON'S EDENIC REPUBLIC}

By the late eighteenth century New England colonists had largely ceased to look to an historical Eden as a model of the ideal society that they, like their seventeenth-century predecessors, sought to create; the founding fathers of the United States relied on philosophers like John Locke and Francis Hutcheson for guidance more than close readings of Genesis. In the eighteenth century, Eden was an ideal whose influence was more often hidden in the private notebooks of ministers like Jonathan Edwards than a standard openly invoked. But when participants in the Second Continental Congress cited principles of natural law to justify their separation from the British monarchy, and when delegates to the Constitutional Convention insisted that a separation of powers and a bicameral legislature be written into law, they endorsed a legal philosophy and a model of government that were both inextricably and recognizably linked back to Eden. Because of this indirect but unmistakable edenic influence on the laws and structure of the nascent United States and because of the lingering association between New World landscapes and the paradise of Genesis, citizens of the new republic characterized the budding state as a new Eden. Of course, for most of these individuals, Eden no longer carried the historical weight that it had in the sermons and narratives of Puritan writers from the seventeenth and early eighteenth centuries; writers of the revolutionary period generally describe the United States as a metaphorical Eden, not a 
place where the perfect physiologies, wisdom, language, and innocence of Adam and Eve will literally be restored.

This metaphorical Eden had become dissociated from many of the events and characteristics attributed to the paradise of Genesis by theologians, but the connection between Eden and the Fall was too strong to be severed. Writers who depicted the United States as a new, secular—or at least postsectarian—Eden almost invariably forecast an imminent fall from the republican and edenic ideals on which the country had been founded. They foresaw a number of apparently insurmountable problems, including the institution of slavery and the widely questioned assumption of republican theorists that education would produce virtuous citizens even without mandatory religious training. These problems, among others, were consistently and symbolically represented as snakes infesting the garden of the new republic, a metaphor appropriate to the analogical framework of Eden but also sadly ironic given the snake's history as an emblem of colonial and national unity. As citizens of the new republic transformed an icon of social solidarity into a portent of civil unrest they seem to have come to a collective realization that their secular Eden was an impossible dream, that they had sown the seeds of their own fall when they planned and planted their republican garden. In a way that they could point to no other social institution or achievement, colonists in New England and elsewhere pointed to the founding of the republic as tangible evidence that it was still possible to attain edenic ideals. Yet in the very moment that they celebrated the creation of a state analogous to the garden of Genesis, they seem also to have remembered the warning of Solomon in Ecclesiastes: "I made me gardens and orchards, and I planted trees in them of all kind of fruits: ... and, behold, all was vanity and 
vexation of spirit." ${ }^{, 1}$ With the formation of the United States, English colonists in North America had finally succeeded in inventing Eden after two centuries of trying, only to realize that their civic paradise, like the biblical original, was destined to fall.

\section{Declaring Eden: Jefferson, Grotius, and the Natural Law Tradition}

When Thomas Jefferson penned the Declaration of Independence in 1776, he called upon several "self evident" truths as proofs of the justice of his cause, including the assertions

that all men are created equal; that they are endowed by their creator with inherent and inalienable rights; that among these are life, liberty \& the pursuit of happiness; that to secure these rights, governments are instituted among men, deriving their just powers from the consent of the governed; that whenever any form of government becomes destructive of these ends, it is the right of the people to alter or to abolish it, $\&$ to institute new government.

If the truth of these claims was not immediately evident to the British crown, the claims themselves were at least based in a familiar, well-established legal and philosophical tradition. Jefferson's claim to "the separate and equal station to which the laws of nature and nature's god" had entitled the colonists points to the God of Genesis and the laws instituted at the founding of Eden as the ultimate source of political power; the argument of the Declaration is predicated on establishing a mutual understanding of God's actions and intent during the creation of the world, of nature. ${ }^{2}$ The Declaration of Independence is, in this sense, an ironic admission of Jefferson's dependence on the authority of the Bible and the exegetical commentaries that were an integral part of the natural law tradition.

The very notion of a law that is natural—derived from nature—depends on the ability

\footnotetext{
${ }^{1}$ Ecclesiastes 2:5, 11.

${ }^{2}$ Thomas Jefferson, “The Declaration of Independence as Originally Reported to Congress," as reprinted in Jay Fliegelman, Declaring Independence, (Stanford: Stanford University Press, 1993), 203.
} 
to imagine and describe a state of nature, a condition of being in which individuals interact

without the restraints or guidance of anthropogenic cultures, institutions, and customs.

Richard Tuck explains that

the idea of a state of nature ... was a creation of the seventeenth century, despite the various earlier accounts of the 'natural' life of man; the terms seems to be an invention of Hobbes, who remains the most clear-cut example of a state-of-nature theorist, but the idea seems to be present already in effect in the works of Hugo Grotius, the founder of the modern natural law school. One might suppose that the idea of a state of nature is simply a rather dramatic fictional device for making a point about the minimal character of the law of nature: strip away from agents all that is culturally specific, and one is left with merely the bare natural rights and duties which seem to be universal. ${ }^{3}$

Rather than attempt to imagine a state of nature completely on their own — an original and fictional picture of the world without inherited customs or institutions-most theorists, including Grotius and Hobbes, based their depictions of the state of nature on the biblical account of Adam and Eve as they existed both before and immediately after the Fall. ${ }^{4}$ Because Adam and Eve were the first human beings created by God, these theorists and their successors believed that their existence was ordered by divinely instituted and universally applicable natural laws untainted by the influence of fallen, artificial or unnatural—because manmade_-social traditions and that these laws applied both before and after the Fall. In this way the experience of Adam and Eve in and outside of Eden became the basis for theories of natural law that justified Jefferson's Declaration of Independence, the American Revolution, and, ultimately, the colonial confederacy that became the United States.

\footnotetext{
${ }^{3}$ Richard Tuck, The Rights of War and Peace, (Oxford: Oxford University Press, 2001), 6-7.

${ }^{4}$ Henrik Syse notes that for writers before the seventeenth century, "the state of nature is (to the extent that they employ the idea) the biblical state of innocence"; Grotius and Hobbes clearly break with this tradition by describing the state of nature as a post-Fall condition of universal war. Nevertheless, "Hobbes tries to find biblical backing for [his] views" of nature and natural law, and Genesis is the book to which he and others turn for support. See Henrik Syse, Natural Law, Religion, and Rights, (South Bend: St. Augustine's Press, 2007), $161,178$.
} 


\section{$\underline{\text { Grotius and Genesis }}$}

When Grotius first set out to codify the natural laws governing humanity, he did so in order to justify the militaristic commercial practices of the United East India Company, which in 1602 had seized a Portuguese ship whose costly cargo was of a value equivalent to the annual expenditure of the English government. This lucrative act of aggression by a trading company on the vessel of a sovereign state violated commonly understood standards of international relations, and Grotius responded to critics of Dutch actions and policy by arguing that in matters of war and peace the federated United Provinces of the Netherlands, which backed the United East India Company, were the equivalent of a sovereign statedespite the lack of a monarch—because they were formed by the voluntary union of sovereign individuals. Grotius explains in De Indis, his defense of the United East India Company and the United Provinces that was posthumously published as De Iure Praedae Commentarius, that "the law of nature, or law of nations, is the source from which the state receives" its power. He then proceeds to assert that this same law of nature is that which empowered Adam and his descendants, when 'God created man . . 'free and sui iuris,' so that the actions of each individual and the use of his possessions were made subject not to another's will but to his own." Grotius hypothesizes that all members of Adam's posterity were individually endowed with the rights traditionally reserved for states in the seventeenth century, and he argues that because each individual is "a miniature sovereign state" any voluntary collaboration between such entities should be understood as the equivalent of an act by a sovereign state, even if the body committing the act lacks a monarch and has not

\footnotetext{
5 As quoted in Tuck, The Rights of War and Peace, 82, 84. On the circumstances surrounding the development of Grotius as a legal jurist, see pp. 78-89.
} 
traditionally been recognized as a sovereign state by other nations. ${ }^{6}$ As the original man which "God created . . f free and sui iuris," Adam is, in De Indis, the model of sovereignty; his independence and authority are the common inheritance of humanity. ${ }^{7}$ In a logical extension of this conclusion Grotius claims that the loosely federated provinces of the Netherlands and their commercial/military representatives in the United East India Company possess the right to punish or wage war against the Portugese vessel they had seized.

Grotius largely relegates God and Genesis to the sidelines in De Indis and the first edition of De Iure Belli ac Pacis (1625), his most important treatise on natural law. He occasionally interprets events in sacred history but never allows moral or religious interests to subvert or distract from his principal end: the defense of Dutch sovereignty and aggression. His references to Adam and the creation are, in these texts, the exception rather than the rule, and he derives most of the principles of natural law from his observations of the nature itself. But when Grotius revised De Iure Belli ac Pacis in 1631, his changes to the text “were part of a campaign to make Grotius's views appear more acceptable to the Aristotelian, Calvinist culture of his opponents within the United Provinces," and in currying favor with his Calvinist opponents, Grotius allowed religious concerns to overshadow his belief in natural law as self evident in the workings of nature. Whereas the preliminary discourse to the 1625 edition proposed an examination of laws "proceeding from nature itself," the 1631 version of the same text described laws "proceeding from nature itself, or

\footnotetext{
${ }^{6}$ ibid, 84.

${ }^{7}$ While Tuck rightly notes that religion is largely ancillary in De Indis and the 1625 De Iure Belli ac Pacis, it would be a mistake to suggest that Grotius's early thought on natural law had not been shaped by close readings of Genesis. His Adamus Exul (1601), a Latin poem portraying the Fall, describes Adam as "ruler of the globe terrestrial / And emperor of ocean"; Adam was, long before Grotius wrote the legal treatises that made him famous, always the model of sovereignty to whom Grotius looked for insight into the foundations of natural law. See Hugo Grotius, Adamus Exul, trans. Watson Kirkconnell, in Watson Kirkconnell, The Celestial Cycle, (New York: Gordian Press, 1967), 149.
} 
established by divine laws. ${ }^{8}$ While his observations of nature suggested to Grotius in 1625 that "all men and the other animals are impelled by nature to seek their own interests," concerns about the religious acceptance of his work drove him to conclude in 1631 that "when it is said that nature drives each animal to seek its own interest, this ought not to be allowed as a universal truth." Because De Indis was not published during Grotius's lifetime and because the 1631 text of De Iure Belli ac Pacis was the edition referenced and reprinted by later generations, this inclusion of divine law—the Bible—as a primary source for the precepts of natural law was inherited by subsequent theorists, and no book of the Bible was more influential on thinkers in this tradition than Genesis.

Grotius seized on Adam's need for human companionship in 1631 as the basis for asserting that natural law obligates human beings to act sociably towards one another. The Bible states that "Adam gave names to all cattle, and to the fowl of the air, and to every beast of the field; but for Adam there was not found an help meet for him"; seventeenth-century exegetes interpreted this passage to mean that Adam, having failed to find a suitable companion among the animals, asked God for human companionship and that Eve's creation was evidence of a sociable drive in Adam's representative human nature. ${ }^{10}$ Grotius, elaborating on the attributes with which humanity was originally endowed by "our Creator," explains that "the Author of Nature was pleased, that every Man in particular should be weak of himself, and in Want of man Things necessary for living commodiously, to the End we might more eagerly affect Society." ${ }^{11}$ Adam's ability to see his insufficiency and his request

\footnotetext{
${ }^{8}$ Tuck, The Rights of War and Peace, 100.

${ }^{9}$ As quoted in ibid, 97, 99.

${ }^{10}$ Genesis 2:20.

${ }^{11}$ Hugo Grotius, The Rights of War and Peace: Book I, trans. Jean Barbeyrac, ed. Richard Tuck, (Indianapolis: Liberty Fund, 2005), 89, 93-94.
} 
for a companion more appropriate than the common animals demonstrates that "amongst the Things peculiar to Man, is his Desire of Society, that is, a certain Inclination to live with those of his own Kind, not in a Manner whatever, but peaceably, and in a Community regulated according to the best of his Understanding." "This Sociability . . . is the Fountain of Right," leading individuals to cooperate by elevating community concerns over individual interests, and Grotius associates it with the innocence of "Infants, in whom is to be seen a Propensity to do Good to others," as evidence that Adam's edenic social instinct has not yet been lost. ${ }^{12}$ Because of our inherently sociable natures, Grotius concludes,

it must therefore be agreeable to human Nature, that according to the Measure of our Understanding we should in these Things follow the Dictates of a right and sound Judgment, and not be corrupted either by Fear, or the Allurements of present Pleasure, nor be carried away violently by blind Passion. And whatsoever is contrary to such a Judgment is likewise understood to be contrary to Natural Right, that is, the Laws of our Nature.

To Grotius in 1631, natural law is the equivalent of natural right: the inevitable result of making judgments based on inherent social drives to form and work towards the good of a community. Natural law is the product of and revealed through Adam's experience in the garden of Eden. In this sense, "even the Law of Nature itself . . may notwithstanding be justly ascribed to God, because it was his Pleasure that these Principles should be in us."

The law of nature as outlined by Grotius in 1631 stipulates that all individuals are driven to form communities in which they willingly suborn their own interests in order to promote the common welfare. This interest "in the Maintenance of Society" then guides an individual's interactions with others, whether they are members of a particular community or not. Grotius recognizes that the Fall has introduced "exceedingly unruly" elements into

\footnotetext{
${ }^{12}$ ibid, 79-81, 83.

${ }^{13}$ ibid, 87, 91 .
} 
human nature and that amicable relations are more likely to exist between individuals with a natural interest in mutual self-preservation, so he returns to Eden for a final proof that the laws of nature foster a spirit of community even in a fallen world. Grotius acknowledges that the "Passions" introduced at the Fall lead men and women to act "contrary to our own Interest, and that of others, [that they] divert us from following the Rules of Reason and Nature" by cooperating with one another. But even as he admits the obstacles to living in accordance with natural law and our sociable nature, Grotius finds a solution in "Sacred History [which], besides the Precepts it contains to this Purpose, affords no inconsiderable Motive to social Affection, since it teaches us that all Men are descended from the same first Parents. So that in this Respect also may be truly affirmed ... that it is a Crime for one Man to act to the Prejudice of another." ${ }^{14}$ Because of their common relationship to Adam and Eve every individual has an additional, familial incentive to act according to the principles of natural law revealed in Genesis. Jesus Christ taught the precept that "all things whatsoever ye would that men should do to you, do ye even so to them: for this is the law and the prophets"; Grotius suggests that the legacy of Eden and our own interest in promoting the welfare of the human family teach the same message. ${ }^{15}$ This admonition against harming others and the exposition of a social drive that prompts community building in which individual interests are sacrificed for the communal good are the two edenic inheritances within the natural law tradition that later writers in the Grotian tradition responded to with their own edenic insights.

\section{Other English and European Influences on Natural Law}

Hobbes, writing in 1651, just a quarter century after De Iure Belli ac Pacis was first

\footnotetext{
${ }^{14}$ ibid, 91-92.

${ }^{15}$ Matthew 7:12.
} 
published, reinforced the central tenets of natural law which Grotius had already introduced, explaining that "From this Fundamentall Law of Nature, by which men are commanded to endeavour Peace, is derived this second Law; That a man ... be contented with so much liberty against other men, as he would allow other men against himself." For Hobbes, as for Grotius, the first principle of natural law is a declaration of man's sociable (peaceable) nature, and both men see the Golden Rule as a logical corollary to this foundational principle of natural law. Like Grotius, Hobbes supports his exposition of natural law with a close reading of Genesis; Hobbes explains that the laws of nature are discerned through the study of "the Art whereby God had made and governes the World" and that the establishment of a government based on natural law "resemble[s] that Fiat, or the Let us make man, pronounced by God in [Genesis 1:26 during] the Creation" of Adam and Eve. ${ }^{16}$ The state of nature described by Hobbes - a condition "of Warre, where every man is Enemy to every man ... And the life of man, solitary, poore, nasty, bruitish, and short"-is that of humanity after the Fall, and he points to "the savage people in many places of America" as evidence that "there are many places, where they live [in a state of nature] now." The purpose of natural law, as described by Hobbes, is to promote civility in "savage" places like the Americas, to reverse the Fall through the establishment of an edenic commonwealth: an institution created in imitation of the creation of Adam and Eve and a place where no man will come "to dispossesse, and deprive [another], not only of the fruit of his labour, but also of his life" in the way that Cain attacked Abel after their parents' expulsion from Eden. ${ }^{17}$

Other jurists made the connection between Eden and natural law even more explicit than Grotius and Hobbes. When Grotius invoked natural law to argue that humanity enjoys a

\footnotetext{
${ }^{16}$ Thomas Hobbes, Leviathan, ed. C. B. Macpherson, (New York: Penguin Books, 1988), 190, 81, 82.

${ }^{17}$ ibid, 186, 187, 184.
} 
negative community of goods in which the earth's resources are not naturally owned by a select few individals but freely available to all, John Selden responded in 1635 by asserting that Adam's divinely decreed ownership of the entire earth is an indication that humanity naturally existed in a positive community of goods where all natural resources have a rightful owner. Selden explains that

Adam . . . also received such a Donation from God, as wee have told you Noah and his Sons did afterward, and so became Lord of the whole World ... So that neither the Law Natural nor Divine ... hath expresly commanded or forbidden, but permitted both; that is to say, a common enjoiment, as well as a private dominion or possession of the Things of this Life. ${ }^{18}$

Selden claims that all natural resources are also private possessions because the whole world was originally owned by Adam, therefore each piece of the earth has theoretically been passed down as an inheritance by Adam and through Noah's sons to private individuals and the heads of sovereign states.

Just as Selden cites God's gift to Adam of dominion over the world as the best evidence that Grotius's conception of natural law was flawed, so too Samuel von Pufendorf views the creator and inhabitants of Eden as proofs regarding his own conceptions of natural law. In 1672 Pufendorf refutes Hobbes' claims regarding the naturally inimical state of nature by pointing to the paternal government of Adam; since "it's plain that Eve was subject to Adam, Gen. iii. 16. and those who were born of these primitive Parents, and so on, did immediately fall under paternal Authority and under Family Government" he concludes that Hobbes' inimical "State of Nature then did never naturally exist," even after the Fall. Pufendorf also returns to the issues of natural law and the positive community of goods posited by Selden, arguing that Adam's dominion over the earth does not imply a natural or

\footnotetext{
${ }^{18}$ John Selden, Of the Dominion or Ownership of the Sea, trans. Marchamont Nedham, (London: William DuGard, 1652), 19-21.
} 
divine preference for individuals rather than communities; he explains that "[w]hen God was pleased to give [Adam] a dear Partner and Companion, they agreed to hold this indefinite Right over things without dividing it: as being united to each other in the strictest Band of Society: For which Reason many Nations at this Day observe a Communion of Goods between the Husband and the Wife." ${ }^{19}$ While Pufendorf disagreed with much of what his predecessors had said regarding natural law, he agreed about the most fundamental point: that principles of natural law must be distilled from the biblical narrative of Genesis.

In addition to Grotius, Hobbes, Selden, and Pufendorf, students of political theory might also point to Edward Coke, Benedict Spinosa, Immanuel Kant, Jean Barbeyrac, and Jean-Jacques Burlamaqui as influences on the tradition of natural law as it was received by Jefferson and his contemporaries, but no philosopher was more important to American understandings of natural law than Locke. ${ }^{20}$ In his Two Treatises of Government (1690) Locke famously rejects the arguments of Robert Filmer and other political thinkers who viewed Adam's dominion over the earth as a divine endorsement of monarchical government, denying "That Adam had ... any such authority over his children, or dominion over the world, as is pretended" by advocates of a monarch's right to the throne through primogeniture from Adam. ${ }^{21}$ But Locke's arguments against Adam as a model of

\footnotetext{
${ }^{19}$ Samuel von Pufendorf, Of the Law of Nature and Nations, trans. Basil Kennet, (Clark: The Lawbook Exchange, 2004), 108, 374.

${ }^{20}$ For an overview of the transmission of modern theories of natural law into the colonies, see Charles F. Mullett, Fundamental Law and the American Revolution, (New York: Columbia University Press, 1933); Benjamin Fletcher Wright, Jr., American Interpretations of Natural Law, (New York: Russell \& Russell, 1962); and Andrew J. Wreck, "Natural Law in American Revolutionary Thought," The Review of Metaphysics 30.4 (1977): 686-714.

${ }^{21}$ John Locke, Two Treatises of Government and A Letter Concerning Toleration, ed. Ian Shapiro, (New Haven: Yale University Press, 2004), 100. For an overview of the positions of Filmer, Thomas Hayne, and others who supported the British monarchy based on their belief in the king's descent from Adam, see Philip Almond, Adam and Eve in Seventeenth-Century Thought, (Cambridge: Cambridge University Press, 1999), 104-108.
} 
monarchical government are not a rejection of edenic precedent as the basis for natural law.

Indeed, Locke relies on a close reading of Genesis to support his assertion that "this original

law of nature" provides every man an equal right to the pursuit and maintenance of property:

As much land as a man tills, plants, improves, cultivates, and can use the product of, so much is his property. . . . God, when he gave the world in common to all mankind, commanded man also to labour, and the penury of his condition required it of him. God and his reason commanded him to subdue the earth, i. e. improve it for the benefit of life, and therein lay out something upon it that was his own, his labour. He that, in obedience to this command of God, subdued, tilled, and sowed any part of it, thereby annexed to it something that was his property, which another had no title to, nor could without injury take from him.

Locke finds in "those grants that God made of the world to Adam" proof that all "men, being once born, have a right to their preservation, and consequently to meat and drink, and such other things as nature affords for their subsistence"; the commandments received by Adam and Eve in Eden are, to Locke, the basis for the "law of nature" that forbids one individual "to harm another in his life, health, liberty, or possessions."22

\section{Natural Law in Colonial New England}

New England readers of Grotius, Selden, Hobbes, Pufendorf, and Locke in colonial

New England appreciated the edenic origins of natural law. ${ }^{23}$ In The Selling of Joseph (1700), an anti-slavery tract written only ten years after Locke first published his Two Treatises of Government, Samuel Sewall invokes natural law and Eden's inhabitants in defense of a universal right to liberty:

\footnotetext{
${ }^{22}$ Locke, Two Treatises of Government and A Letter Concerning Toleration, 113-14, 111, 102.

${ }^{23}$ While the colonial figures discussed in this section were familiar with the writings of Grotius et al., their belief in and emphasis on the edenic origins of natural law is at least partly attributable to the earlier religious traditions that predate the political tradition outlined above. Thomas Shepard writes in his Theses Sabbaticae that the "Law of pure nature was the Law of God writ on Adams heart in innocency, which was nothing else but that holy bent and inclination of the heart within, to act according to the holy Law of God revealed, or Covenant made with him without, and thus Aquinas places the law of nature in this inclination." See Thomas Shepard, Theses Sabbaticae, (London: T. R. and E. M., 1749), 141. For a further discussion of these medieval conceptions of natural law, see Syse, Natural Law, Religion, and Rights, 121-45.
} 
It is most certain that all Men, as they are the sons of Adam, are Coheirs; and have equal Right unto Liberty, and all other Comforts of Life. GOD hath given the earth [with all its Commodities] unto the sons of Adam ... Now although the Title given by the last ADAM, doth Infinitely better Mens Estates, respecting GOD and themselves; and grants them a most beneficial and inviolable Lease under the Broad Seal of Heaven, who were before only Tenants at Will: Yet through the Indulgence of GOD to our First Parents after the Fall, the outward Estate of all and every of their Children, remains the same, as to one another. So that Originally, and Naturally, there is no such thing as Slavery... . This Law being of Everlasting Equity, wherein Man Stealing is ranked amongst the most atrocious of Capital Crimes: What louder Cry can there be made of that Celebrated Warning, Caveat Emptor! $!^{24}$

Like Locke in his own consideration of slavery, Sewall concludes that the enslavement of another human being is against the law "Originally, and Naturally" established by God with respect to Adam and Eve. In New England, as much as in Europe, natural law was the product of close readings of Genesis.

Throughout the eighteenth century, New England writers expounding on natural law generally remembered to acknowledge the edenic character of their topic. Arguing in 1717 that natural law vindicates the organization and government of New England's Congregational churches, John Wise followed the lead of Hobbes in describing a league of individuals joined together by a government to be "but one Man; in which the aforesaid Covenants may be supposed under Gods Providence, to be the Divine Fiat, Pronounced by God, let us make Man." Like Locke, however, he rejects the claim that Adam's dominion over the earth signifies a divine predisposition to monarchical government, noting that the original "Royal Family be wholly Extinct [as in Noah's Case, being not Heir Apparent from Descent from Adam]. ${ }^{25}$ Elisha Williams takes a different view of the relationship between Adam and Noah in ennumerating The Essential Rights and Liberties of Protestants (1744),

\footnotetext{
${ }^{24}$ Samuel Sewall, The Selling of Joseph, (Boston: Bartholomew Green and John Allen, 1700), 1.

${ }^{25}$ John Wise, A Vindication of the Government of New-England Churches, (Boston: J. Allen, 1717), 45-46, 3334.
} 
and he explains that man has "only the Law of Nature (or in other Words, of its MAKER) for his Rule. . . For which Purpose God was pleased to make a Grant of the Earth in common to the Children of Men, first to Adam and afterwards to Noah and his Sons." ${ }^{26}$ Williams and Wise disagreed as to whether Noah was a legitimate successor to Adam, but both men agreed that understanding Adam's role as the father of humanity was the key to the interpretation of natural law.

These early colonial reminders of Eden's importance in the natural law tradition were only reinforced by an influential pamphlet written by James Otis in the years leading up to the Revolution. Benjamin Wright and Bernard Bailyn, among others, argue that "Otis has [anticipatorily] summarized all of the essential principles found in the Declaration of Independence" in The Rights of the British Colonies (1764). This pamphlet, which was "to be of major importance in importing, modifying, and popularizing the doctrines" of the Declaration, argues that the powers of the English Parliament over the colonies extend only so far as the laws of nature permit. ${ }^{27}$ The power of Parliament, Otis explains,

is jus dicere only: jus dare, strictly speaking, belongs alone to God. Parliaments are in all cases to declare what is for the good of the whole; but it is not the declaration of parliament that makes it so: There must be in every instance, a higher authority, viz. GOD. Should an act of parliament be against any of his natural laws, which are immutably true, their declaration would be contrary to eternal truth, equity and justice, and consequently void. ${ }^{28}$

By subordinating the laws of Parliament to natural law Otis paved the way for Jefferson's claim that "the laws of nature and of nature's god" sanctioned a dissolution of the "political

\footnotetext{
${ }^{26}$ Elisha Williams, The Essential Rights and Liberties of Protestants, (Boston: S. Kneeland and T. Green, 1744), 3 .

${ }^{27}$ Wright, American Interpretations of Natural Law, 67, 69. See also Bernard Bailyn, Pamphlets of the American Revolution, 1750-1776, (Cambridge: Belknap Press of Harvard University Press, 1965), I.409-15, II.546-52.

${ }^{28}$ James Otis, The Rights of the British Colonies Asserted and Proved, (Boston: Edes and Gill, 1764), 47.
} 
bands" tying the colonies to Parliament. More importantly, at least in this context, Otis made it clear that the foundations of natural law and his dismissal of parliamentary authority lay in Eden:

The same omniscient, omnipotent, infinitely good and gracious Creator of the universe, who has been pleased to make it necessary that what we call matter should gravitate, for the celestial bodies to roll round their axes, dance their orbits and perform their various revolutions in that beautiful order and concert which we all admire, has made it equally necessary that from Adam and Eve to these degenerate days, the different sexes should sweetly attract each other, form societies of single families, of which larger bodies and communities are as naturally, mechanically, and necessarily combined, as the dew of Heaven and the soft distilling rain is collected by the all enliv'ning heat of the sun. Government is therefore most evidently founded on the necessities of our nature." 29

Like Grotius before him Otis viewed the sociable (and sexual) drives instilled into Adam in Eden as the basis for natural law_and, implicitly, the basis for establishing and disbanding governments.

When Jefferson sat down to author the Declaration, he drew on a tradition of natural law that originated in seventeenth-century Europe and that had been kept alive in New England during the eighteenth century. Indeed, although Jefferson was a Virginian, his reliance on natural law was more characteristic of a colonist from New England such as Otis or the Adams cousins, John and Samuel, both of whom repeated and expanded upon Otis's edenic arguments during the interval between the publication of The Rights of the British Colonies in 1764 and $1776 .{ }^{30}$ Because of his role in the Declaration's composition Jefferson, more than any of his contemporaries, has been associated with theories of natural law, but it was "New England writers," as Wright argues, who "seem to have been the leaders in

\footnotetext{
${ }^{29}$ ibid, 8 .

${ }^{30}$ See, for instance, Samuel Adams, "Resolutions of the House of Representatives of Massachusetts. October 29, 1765," in The Writings of Samuel Adams, ed. Harry Alonzo Cushing, (New York: The Knickerbocker Press, 1904), I.23-24; or John Adams, Novanglus and Massachusettensis, (Bedford: Applewood Books, 2009 ), 30.
} 
spreading the gospel of the inherent rights derived from the laws of nature," and it was New England writers who continued to invoke Eden as the precedent upon which their natural rights were based. As John Allen reminded his fellow New Englanders in 1773, just three years before Jefferson would pen the Declaration: "Freedom is that very breath of life that GOD breathed into man when he became a living soul: Therefore every man has the same natural and inherent right to every blessing of freedom and LIBERTY, as he has to his own existence ... for the law of nature is self preservation, which will never be relinqish'd by a people of any soul or spirit." 31 The Declaration makes no mention of Adam and Eve or of Eden, but its reliance on interpretations of Genesis could hardly have been more overt, and its text was heavily influenced by proponents of a New England school of natural law that had preserved the connection between hexameral theology and natural law. When Jefferson appealed to "the laws of nature and nature's god," he announced the colonies' collective intent to return to the laws that governed Adam and Eve in Eden, to form a new society that would allow a colonist like Benjamin Church to throw off the shackles of monarchical tyranny and "live according to his own just sentiments and innocent inclinations." 32 The Declaration of Independence is, in this sense, a declaration of innocence-a declaration of Eden.

\section{The Architecture of Eden: Right Reason and Republican Government}

By signing the Declaration of Independence Jefferson, John Hancock, and the other fifty-four men who affixed their name to that document signaled their intent to return to a

\footnotetext{
${ }^{31}$ John Allen, The American Alarm, (Boston: D. Kneeland, 1773), 6. This text has also been attributed to Isaac Skillman.

${ }^{32}$ Benjamin Church, An Oration; Delivered March $5^{\text {th }}, 1773$, (Boston: Edes and Gill, 1773), 10.
} 
state of nature before uniting under a new government more faithful to the laws of nature-of Eden—than the British monarchy. But the Declaration made no pretense of establishing such a government; rather, it marked the beginning of a war that many viewed as the disruption of an Eden already extant in colonial New England. In 1786 the Falmouth Gazette, Maine's first newspaper, published an anonymously authored poem supposedly "found in Bridgton, in the county of Cumberland, in the year 1776, written on the Bark of a Birch Tree," that portrays Maine as an edenic refuge from the military maneuvers to the south in Lexington and Concord. The poet describes Maine as a place

Where cannon, and the sound of war, Are only heard as news from far, No British troop disturbs my breast, Nor savage of the wilderness;

$[\ldots]$

Yet oft when I the forest rove, I think of Eden's sacred grove; The many blessings standing round Shew a resemblance of that ground. $(5-8 ; 19-22)^{33}$

While some colonists lamented that the American Revolution had disrupted an otherwise idyllic existence, they generally did not blame the revolutionaries for this Fall, preferring to cast King George as Satan and his loyal servants as serpents seeking to destroy a colonial Eden. In M'Fingal (1775-82) John Trumbull lampoons British General Thomas Gage and suggests that even this comparison is overly complimentary because

... Gage has bungled oft so vilely No soul would credit lies so silly, Outwent all faith and stretch'd beyond Credulity's extremest end.

Whence plain it seems tho' Satan once O'erlook'd with scorn each brainless dunce,

\footnotetext{
33 "All Ye that Love the Joys of Peace," Falmouth Gazette and Weekly Advertiser 14 Jan. 1786 (II.55): 4.
} 
And blund'ring brutes in Eden shunning,

Chose out the serpent for his cunning;

Of late he is not half so nice,

Nor picks assistants 'cause they're wise. ${ }^{34}$

Gage may not have been wise or deceitful enough to merit a comparison to the serpent of

Genesis, but there was no doubt that Massachusetts colonists viewed him—and the king he served — as the cause of their descent into warfare. In an elegy mourning the loss of colonial innocence, an anonymous poet describes the colonies as sunbeams on a glorious morning spoiled by King George, who is represented by tyrannical thunderheads:

... the glad prospect vanish'd from the sight, And the wing'd tempest o'er the Eden flew. Onward it swept, with wild destructive rage, And every beauty, tyrant-like, destroy'd. (15-18)

The poet hopes that his verses will "Teach [the reader] independence to implore" (47), presenting the liberty promised in the Declaration as a restorative that will redeem an edenic New England ravaged by tyranny and war. ${ }^{35}$

As the war drew to its conclusion in the early 1780s, former British colonists began to think of the United States as a new, edenic state. Even as patriot militias suffered a string of defeats at the hands of the British army Timothy Dwight wrote that

Perfumes as of Eden flow'd sweetly along, And a voice as of Angels enchantingly sung, Columbia! Columbia! To glory arise, The queen of the world, and the child of the skies. $(45-48)^{36}$

At the time Dwight's celebration of an edenic nation state must have seemed somewhat premature, but with the withdrawal of the last British troops from New York in 1783 came

\footnotetext{
34 "Canto First, or the Town Meeting," M'Fingal: A Modern Epic Poem, (Philadelphia: William and Thomas Bradford, 1775), 10.

35 “An Elegy,” The Federal Gazette, and Philadelphia Evening Post 13 Mar. 1790: 3.

36 “A New Song. Hail Americans," The Massachusetts Spy: Or, American Oracle of Liberty 2 Nov. 1780 (X.495): 3.
} 
opportunities for healing and restoration that would make his poem seem prophetic. By 1785 some of the Tories who had fled to Nova Scotia during the Revolution wished to return; they claimed that they had been deceived by New York's royalist printer: "Our friend Jemmy Rivington made [Nova Scotia seem like] an Eden" (53). They pled for permission to come back and realize their edenic aspirations in the newly formed United States, promising that

Now, if we return, as we're bone of your bone, We'll renounce all allegiance to George and his throne, And be the best subjects that ever were known. (70-72)

Having been deceived by the false Eden advertised in royalist propaganda, these former Tories now looked forward to forming a new Eden with the very men and women who had driven them from New York. These immigrants from Nova Scotia suggest that their reunion will be perfectly harmonious because they relate to "the Great-the Warlike-the Unitedthe Independent Americans" in the same way that Eve was related to Adam. They imply that upon their return, an American citizen might say that each of them "is now bone of my bones, and flesh of my flesh," as Adam once said with respect to Eve. ${ }^{37}$ Even the soldiers of the American army, with the bloodshed of war fresh in their minds, believed that the new country would be "free from envy, cank' ring care and strife" (1) and "sights of woe" (23). David Humphreys, a colonel and aide-de-camp to George Washington during the war, predicts that the United States will 'flourish in unfading prime, / Each age refining thro' the reign of time" until

Where now the thorn, or tangled thicket grows, The wilderness shall blossom as the rose, Unbounded deserts unknown charms assume, Like Salem flourish, and like Eden bloom. $(71-74)^{38}$

\footnotetext{
37 "To the Great — the Warlike—-the United—the Independent Americans!" The Freemen's Journal: or, the North-American Intelligencer 30 Mar. 1785 (IV.206): 3; Genesis 2:23.

${ }^{38}$ David Humphreys, "An ADDRESS to the Officers and Soldiers of the American Army, Concluded," The Massachusetts Centinel 11 Oct. 1786 (VI.7):28.
} 
The Revolutionary War may have disrupted an extant, colonial Eden, but the English subjects turned American citizens remained confident that the war was only the chaotic prelude to an impending perfection.

Once the war had ended, however, the citizens of the United States quickly realized that the establishment of Eden required something more than the cessation of hostilities. The Articles of Confederation, most agreed, were little more than the "shadow of a federal government." ${ }^{, 39}$ If the substance of Eden was to be restored in the United States, the charter that governed the new nation would have to be made more substantial. Delegates from twelve of the thirteen states (all except "Rogue" Island) gathered in Philadelphia from May to September in 1787 with the avowed intent of altering and strengthening the Articles, but participants almost immediately turned their attention to the creation of a new document that would bind the states together in a "more perfect Union." ${ }^{40}$ Dwight, who now recognized the insufficiency of a government that, in the throes of war and when compared to the British monarchy, had seemed to smell of Eden, saw in this Philadelphia Convention an opportunity to realize that earlier vision of edenic government. In a poem published in Philadelphia only days after the Convention had gathered, he exhorts the delegates to "Seize then, oh! seize Columbia's golden hour; / Perfect her federal system, publick power" (195-96). The key to this perfection, in Dwight's opinion, lay in a return to the sociality of Eden. Adam and Eve

\footnotetext{
${ }^{39}$ Alexander Hamilton, "No. XV," in The Federalist, ed. Henry Cabot Lodge, (New York: The Knickerbocker Press, 1902), 91. While Hamilton is responsible for this specific language, the sentiment he expresses is attributed to Henry Knox, reputed to have said of the articles that "Our present federal government is a name, a shadow, without power or effect."

${ }^{40}$ It should be noted that Rhode Island's refusal to send delegates to the Convention was one of the reasons that delegates focused their attentions on establishing a new government rather than fixing the Confederation; since any change to the Articles would have had to be unanimously adopted by the states and Rhode Island seemed unlikely to ratify proceedings in which they had no part, there was little incentive to work toward a reformation of the current system. When the Convention opened on May 25, 1787, only seven of the thirteen states were actually in attendance at the Convention - the remainder joined shortly.
} 
held their goods in common and became "one flesh"; Dwight instructs the delegates: "Each party view, each private good disclaim" (111) so that the citizens they serve might be "In thoughts, in arts, in life, in language join'd, / One faith, one worship, one politick mind" (6566). Having been formed from the dust of the earth and animated by the winds of heaven, Adam and Eve knew no divisions of race; Dwight announces that the citizens must no longer identify themselves as "Britons, Frenchmen, Germans, Swiss or Huns, [but] / Of earth the natives, and of Heaven the sons" (75-76). Having laid out a vision of the sociality that he hopes the Philadelphia Convention will codify, Dwight reminds the delegates that

'Tis yours to bid these scenes of Eden shine;

First then, and last, the federal bands entwine:

To this your every aim, and effort bend;

Let all your counsels here commence, and end. $(151-54)^{41}$

Dwight's call to establish a new Eden undoubtedly seemed daunting, but Jefferson, for one, believed that the delegates were up to the task. He saw in them "an assembly of demigods" fit for the divine work of creation appointed by Dwight. ${ }^{42}$

Of course the very notion of an edenic government would have been highly problematic for Calvinist theologians in New England and, more generally, the largely Protestant population of North America; government was seen by most Protestants to be a product of the Fall. Philip Almond explains that Protestants largely subscribed to the Augustinian position

that in a world without sin government would, [sic] have been unnecessary and that therefore the ideal state of nature was one of equality between all. In a sinful world, however, an hierarchical and coercive society was a necessity. Luther put it simply: 'And as to civil government (politia); before sin there was none; nor was it needed . .

\footnotetext{
${ }^{41}$ Timothy Dwight, "Address of the Genius of Columbia, to the Delegates of the Convention, at Philadelphia," TheMassachusetts Ceninel 6 June 1787 (VII.23): 92.

${ }^{42}$ Thomas Jefferson, "Jefferson to Adams," 30 Aug. 1787, in The Adams-Jefferson Letters, ed. Lester J. Cappon, (Chapel Hill: The University of North Carolina Press, 1959), I.196.
} 
. There would then have been no ravisher, no murderer, no thief, no slanderer, no liar. And therefore, what need would there have been of civil government. ${ }^{43}$

In The Tenure of Kings and Magistrates (1649) Milton also describes government as a consequence of the Fall, explaining that mankind

from the root of Adam's transgression falling among themselves to do wrong and violence, and forseeing that such courses must needs tend to the destruction of them all, they agreed by common league to bind each other from mutual injury, and jointly to defend themselves against any that gave disturbance or opposition to such agreement. Hence came cities, towns, and commonwealths.

But to suggest that the notion of an edenic government is inherently contradictory because governments are the product of the Fall would be to ignore the very purpose of popular government: to "invent laws, either framed or consented to by all, that should confine and limit the authority of whom they chose to govern them: that so man, of whose failing they had proof [in the Fall], might no more rule over them, but law and reason, abstracted as much as might be from personal errors and frailties." As Jonathan Scott explains, "To replace kingship, and with it dependence upon the will of fallen man, by the self-government of Godgiven reason, was the nearest mankind could come to the government of God." ${ }^{\text {"44 Popular and }}$ representative government might be thought of, in this way, as a means of circumventing the Fall by restoring the rule of perfect reason that had governed Adam and Eve in Eden.

\section{Right Reason and the Republic of Oceana}

As the delegates of the Philadelphia Convention worked to perfect the union binding their respective states together they naturally scoured the works of political theorists past and present for models of good government. Delegates were familiar with the Republic of Plato

\footnotetext{
${ }^{43}$ Almond, Adam and Eve in Seventeenth-Century Thought, 103.

${ }^{44}$ John Milton, The Tenure of Kings and Magistrates, in John Milton, Complete Poems and Major Prose, ed. Merritt Y. Hughes, (Indianapolis: Hackett, 2003), 754-55; Jonathan Scott, Commonwealth Principles, (Cambridge: Cambridge University Press, 2004), 60.
} 
and the Utopia of Sir Thomas More, but most seem to have agreed with David Hume, who claimed in 1754 that James Harrington's “Oceana is the only valuable model of a commonwealth, that has as yet been offered to the public." ${ }^{45}$ The delegates searched for idealized models of government such as the Oceana because, in the words of a 1787 letter to the editor of Boston's Independent Chronicle, they "anticipated a system of government too pure for a state of imperfection"-i.e., the state of government under the Articles—and wished to "reduce to practice the schemes which Plato and Harrington had only sketched upon paper." ${ }^{, 46}$ By the time of the Convetion, the Oceana had already been used to guide the construction of for several of the individual states' constitutions; citizens of Massachusetts were so taken with its precepts that in a 1779 convention to adopt a new state constitution, a delegate even proposed that the state change its name from the Commonwealth of Massachusetts to the Commonwealth of Oceana! ${ }^{47}$ Indeed, Oceana's relevance vis-à-vis the task of rewriting the federal Constitution was so obvious that the author of another widely reprinted letter urging "the present Convention" to "preserve and transmit to posterity the freedom of America" used Harrington as his penname, confident that readers would understand this pseudonym as an implicit endorsement of the structure and policies of James

\footnotetext{
${ }^{45}$ David Hume, Political Essays, ed. Knud Haakonssen, (Cambridge: Cambridge University Press, 2003), 222. On the influence of Hume's interpretation of the Oceana on the political thought of James Madison, see Douglass Adair, Fame and the Founding Fathers, (New York: Norton, 1974), 3-26, 93-108; and Edmund S. Morgan, "Safety in Numbers: Madison, Hume, and the Tenth Federalist," Huntington Library Quarterly 49 (1986): 95-112. In contending that Harrington's Oceana was a central influence on the Constitution, I do not intend to ignore other contributions (Montesquieu, Locke, etc.), only to highlight his importance.

${ }^{46}$ Camillus, "In Our Last Speculation," The Independent Chronicle and the Universal Advertiser 8 Mar. 1787 (XIX.958): 1. The anonymous author of this editorial actually argues strenuously against what he sees as a widely perceived desire to imitate Harrington's perfect constitution, urging readers instead to "cherish and defend our constitution" under the Articles of Confederation.

${ }^{47}$ For an account of the Massachusetts convention, see Smith, Harrington and His Oceana, 193-95; for a consideration of Harrington's influence on state constitutions generally, see John Adams, A Defence of the Constitutions of Government of the United States of America, (New York: Da Capo Press, 1971); and Willi Paul Adams, The First American Constitutions, trans. Rita and Robert Kimber, (Chapel Hill: The University of North Carolina Press, 1979).
} 


\section{Harrington's Oceana. ${ }^{48}$}

As James Madison and other leaders of the Convention worked to forge a consensus among the delegates, they did indeed replicate the major features of Harrington's idealized republic. ${ }^{49}$ Among other similarities to Harrington's nation of Oceana, they designed a legislative process divided among three units of government to achieve a balance of powers. Harrington had proposed "a government established upon an equal agrarian, arising into the superstructures or three orders, the senate debating and proposing, the people resolving, and the magistracy executing by an equal rotation through the suffrage of the people given by the ballot." The Constitution imitates this structure, providing for a deliberative body of the wise, intended to be a natural aristocracy (the Senate); a body whose composition is representative of the population that controls the power of the purse (the House); and a rotating magistracy determined primarily by a popular election (the President). ${ }^{50}$ Their reliance on Harrington was readily apparent, even to those not involved in the deliberative processes of the Convention. When, in The Power of Sympathy (1789), William Hill Brown defends the Convention's work, he does so by arguing that "the nature of the constitution seems to

\footnotetext{
${ }^{48}$ Harrington, "To the Freemen of the United States," The Independent Gazeteer 30 May 1787 (VI:457): 3.

${ }^{49}$ This is not, of course, to suggest that Harington was the only influence on the Constitution; indeed, M. N. S. Sellers suggests that Harrington's primary value was as an interpreter of Roman political ideologies, that participants in the Constitutional Convention viewed the Oceana primarly as a vehicle for the transmission of Roman republican ideals. See M. N. S. Sellers, American Republicanism, (Washington Square: New York University Press, 1994), 126-32. For a systematic examination of the ways in which Harrington's imaginary republic and the American Constitution coincide, see Samuel H. Beer, To Make a Nation, (Cambridge: The Belknap Press of Harvard University, 1993), 84-131.

${ }^{50}$ James Harrington, The Commonwealth of Oceana, in The Political Works of James Harrington, ed. J. G. A. Pocock, (Cambridge: Cambridge University Press, 1977), 181. Pocock points out in The Machiavellian Moment that several of the colonies had already attempted to adopt Harringtonian constitutions, including the Carolinas, New Jersey and Penn, so the adoption of Harringtonian assumptions about agrarianism, natural aristocracies, and rotating magistracies by delegates to the Convention are less than surprising. Pocock's predecessor H. F. Russell Smith, the man who first emphasized Harrington's importance to American systems of government in the modern era, is also still worth consulting. See J. G. A. Pocock, The Machiavellian Moment, (Princeton: Princeton University Press, 1975), 401-552; and H. F. Russell Smith, Harrington and His Oceana, (Cambridge: Cambridge University Press, 1914), 152-200.
} 
operate on the minds of all the people_-slavery is abolished_all men are declared free and equal." The mouthpiece for this defense? A republican convert known only as Harrington. In Brown's novel, as much as in the editorials of the day, the Constitution's dependence on James Harrington and his Oceana is unmistakable. ${ }^{51}$ Harrington's influence on delegates to the Convention was so transparent that when it came time for revolutionary republican leaders in France to draft a constitution, they translated the Oceana into French specifically so that they could understand the political theory behind the United States Constitution; as S. B. Liljegren notes, "it was the study of the American revolution which led the translator [of the Oceana] on to Harrington." ${ }^{52}$ Even observers an ocean away could see that the Constitution made a reality of the Oceana's imagined government.

Recognizing the Oceana's influence on the Constitution and the extent to which the educated citizenry of the United States was familiar with its contents ${ }^{53}$ is critical because

\footnotetext{
${ }^{51}$ William Hill Brown, The Power of Sympathy, ed. Carla Mulford, (New York: Penguin, 1996), 34. It should be noted that the Harrington depicted by William Hill Brown bears more than a passing resemblance to Harrington himself; Michael Downs describes the original as "a traitor to his king and his class and, because England for men of Lesley's ilk was no more than king and class, a traitor to his country, too.” Brown's Harrington might also be described as a traitor to his class and country, although for different reasons of course. See Michael Downs, James Harrington, (Boston: Twayne Publishers, 1977), 41. The pseudonym 'Harrington' was used more than once in the newspapers, presumably by different writers, to defend the Constitution in the weeks and months after its unveiling, with the intent of emphasizing the similarities between the model of government presented in Oceana and that proposed in the Constitution. See Harrington, "Federal Politicks," American Herald 15 Oct. 1787 (VII.314): 3; and Harrington, "For the Independent Chronicle," The Independent Chronicle 5 Feb. 1789 (XXI.1048): 2.

${ }^{52}$ S. B. Liljegren, Introduction to Théodore Lesueur, A French Draft Constitution of 1792 Modelled on James Harrington's Oceana, ed. S. B. Liljegren, (Acta Reg. Societatis Humaniorum Litterarum Lundensis XVII; London: Oxford University Press, 1932), 33. As evidence that "the United States in many cases transmitted the ideas of Oceana to France," Liljegren points to "a speech made by Boissy-d' Anglas in 1795. Here he refers to Samuel Adams, one of Harrington's followers in America, and to Adams' belief in the 'balance of power.' In another passage the same speaker dwells upon the fact that the legislative assembly was always divided into two chambers in America," as it was in Harrington's Oceana. Harrington was not the only seventeenth-century British writer introduced to French audiences by the American Revolution. Liljegren even suggests that "it is safest to say that the ideas of the English revolution did not always reach France directly but by way of America." See Liljegren, Introduction, 40-41. See also Smith, Harrington and His Oceana, 201-15.

${ }^{53}$ Aside from whatever copies may have been privately owned, copies of the Oceana were available in the second half of the eighteenth century, to students at Harvard and to members of the Library Company of Philadelphia, the New York Society Library, the Charleston Library Society, and the Loganian Library. Copies
} 
Harrington openly presents his idealized republic as a corrective to the Fall, and supporters of the United States' Harringtonian Constitution clearly saw that document as a charter establishing an edenic government. The nation of Oceana is a paradisiacal refuge from the ravages of the Fall; Harrington opens his text with an encomium praising the fruitful and innocent landscape in which his idealized republic is situated:

O the most blessed and fortunate of all countries Oceana! How deservedly hath nature with the bounties of heaven and earth endowed thee, the ever fruitful womb not closed with ice, nor dissolved by the raging star; where Ceres and Bacchus are perpetual twins. Thy woods are not the harbour of devouring beasts, nor thy continual verdure the ambush of serpents, but the food of innumberable herds and flocks.

The natural bounty of the landscape is harvested by the delightful work of farmers whose labor is untainted by the curse laid on Adam; a farmer "produceth the most innocent and steady genius of a commonwealth, such as is that of Oceana." 54

In addition to situating his idealized republic in an edenic landscape farmed by innocent laborers, Harrington also stipulates that Oceana must be governed by right reason, the perfect logic possessed by Adam and Eve in Eden prior to the Fall; he longs, as Blair Worden argues, "for a world purged of sin and corruption where all will be made new" as it

of the Oceana were offered for sale by booksellers in most metropolitan areas, and references to the text occur in a wide variety of genres, including sermons, political tracts, and poetry.

${ }^{54}$ Harrington, The Commonwealth of Oceana, 157, 159 (my emphasis). My identification of Oceana as an Eden challenges the assertion of J. C. Davis that Harrington's republic is, in fact, a utopia. This description of the landscape of Oceana sounds suspiciously like an arcadia, but Harrington's emphasis on the need for good governance (described in the following paragraphs) is more reminiscent of a utopia. It is the combination of these two features in concert with an emphasis on replicating the character of life in Eden that distinguishes an edenic society. Edens are, of course, frequently described as the product of millennial intervention, and Arihiro Fukuda detects "a millennarian streak" in Oceana. But, even if, as Charles Blitzer argues, Harrington "did not advocate or look forward to the terrestrial rule of the Saints," his interest in establishing an ideal society governed by right reason, based on biblical models of Eden, and situated in a physical paradise would identify his commonwealth as an edenic society. See J. C. Davis, Utopia and the Ideal Society, (Cambridge: Cambridge University Press, 1981), 205-40; Arihiro Fukuda, Sovereignty and the Sword, (Oxford: Clarendon Press, 1997), 160; Charles Blitzer, An Immortal Commonwealth, (New Haven: Yale University Press, 1960), 282; and the Introduction, pp. 17-30. 
was in Eden. ${ }^{55}$ Referring to the wealth of the landscape as the "goods of fortune" and to right reason as the "goods of the mind," Harrington suggests that the combination of these two attributes will result in the re-creation of Eden: "the legislator that can unite [the goods of the mind] in his government with those of fortune, cometh nearest unto the work of God, whose government consisteth of heaven and earth." Such a government would preside over "a commonwealth made by the same hand that made the world." 56 The goods of fortune "are external," naturally, the product of fortune or outside circumstances, but the goods of the mind are the product of intentional strivings as individuals "ascend, as I said, nearer heaven, or to the image of God which is the soul of man," and Harrington provides a plan for recovering "the image of God" as it was first stamped onto the souls of Adam and Eve in the creation narrative of Genesis. ${ }^{57}$ Harrington explains that "whatever was passion . . is vice and the bondage of sin" by the Fall; conversely, "whatever was reason. . . is virtue and the freedom of soul" as it existed in Eden. All men are subject to passion, which means that neither a monarchy, nor an aristocracy, nor a democracy—each of which are ruled by a man or men—could reinstate the rule of reason that allowed Adam and Eve to reflect God's image. Right reason could, theoretically, be captured in a perfect system of laws, but "seeing they that make the laws in commonwealths are but men, the main question seems to be how a commonwealth comes to be an empire of laws and not of men?",58

Harrington finds an answer to his own question in the "law of nature," or "that reason which is the interest of [all] mankind." He concludes that despite the individual corruptions

\footnotetext{
${ }^{55}$ Blair Worden, "James Harrington and 'The Commonwealth of Oceana,' 1656," in Republicanism, Liberty, and Commercial Society, 1649-1776, ed. David Wooton, (Stanford: Stanford University Press, 1994), 94.

${ }^{56}$ Harrington, The Commonwealth of Oceana, 169, 177.

${ }^{57}$ ibid, 169; Genesis 1:27.

${ }^{58}$ Harrington, The Commonwealth of Oceana, 169, 171.
} 
of any particular man or group of men, humanity collectively retains the image of God originally reflected in Adam and that therefore "the reason of mankind must be right reason. Now compute well, for if the interest of popular government come the nearest unto the interest of mankind, then the reason of popular government must come the nearest unto right reason." ${ }^{59}$ Rather than endorse a simple majority rule, however, Harrington proposes a sort of bi-cameral legislature in which representatives of the people vote on the recommendations of a natural aristocracy that are then enforced by an elected, rotational magistracy. This balance of powers, he suggests, will avert a tyranny of the majority and prevent the corrupt passions of any single individual or party from undermining the collective interests of society, allowing the commonwealth in question to governed by the right reason of Eden.

Oceana's popular government, with its balance of power and bi-cameral legislature, is still recognizable in the United States government, and early supporters of the Constitution were aware of its edenic origins. Writing only weeks after New Hampshire became the ninth state to ratify the Constitution (which, in accordance with Article VII of that document, made the charter legally binding), an anonymous poet exulted that "A new Constitution its laws has extended; / so noble, so pure, that the world they confound" (65-66). It is because of those laws that " $T$ ' a beautiful Eden, our countrymen go" with "The streamers of union, triumphantly dancing" overhead $(34,43) .{ }^{60}$ After Virginia and New York became the tenth and eleventh states to ratify the Constitution, another poet hailed the paradisiacal potential of a nation newly bound together by that document:

Eleven twin'd in one, Second Eden divine; Peace and plenty be thine,

\footnotetext{
${ }^{59}$ ibid, 171-72.

60 “Anniversary Ode, for July 4, 1788,” The New-Hampshire Spy 22 Jul. 1788 (IV.26): 104.
} 
Forever, forever.-Amen. (33-36)

This new, edenic nation governed by right reason would be "FREEDOM's TEMPLE" (28), ${ }^{61}$ and contemporary commentators urged the nation's "political architects" to "consult the plans of ... Harrington" so that their "masterly hands [could] rear a grand temple of federal liberty." ${ }^{62}$ It was evident to all that Harrington had been the designer of this temple; he had issued "the first call of beautiful order out of chaos and confusion [by devising] the architecture of a well-ordered commonwealth": Oceana. ${ }^{63}$

\section{The Masonry of Freedom's Temple}

61 "Federal Sacred Ode," The Herald of Freedom, and the Federal Advertiser, 18 Sep. 1788 (I.ii): 8. A third poem described the new nation as an edenic space in the first year of George Washington's presidency:

$\mathrm{G}$ reat God! Columbia boasts from thee

E mpire and independency!

$\mathrm{O}$ 'er fair realms thy goodness pours

$\mathrm{R}$ ich blessings in unceasing show'rs;

$\mathrm{G}$ ives plenty, peace, and liberty;

E earth's choicest gifts to crown the FREE.

W here erst wild monsters prowl'd for prey,

A nd men more savage far than they,

$\mathrm{S}$ ee Eden's smiling vallies bloom,

$\mathrm{H}$ ear notes celestial cheer the gloom:

I mmortal pleasures in her train,

$\mathrm{N}$ ow hail blest Freed'm's glorious reign!

G rant, Pow'r Divine, that while we sing

$\mathrm{T}$ he joys that from such sources spring,

O ur patriot virtues may be shown,

$\mathrm{N}$ or THEE forget-nor WASHINGTON.

See “Acrostic," The Gazette of the United States 12 Aug. 1789 (XXXV): 138.

62 "An Essay on the Means of Promoting Federal Sentiments in the United States, by a Foreign Spectator," The Independent Gazeteer 4 Sep. 1787 (VI.540): 2.

${ }^{63}$ Harrington, The Commonwealth of Oceana, 341. Harrington attributes the previous line, "the art of man, being the imitation of nature which is the art of God" to Hobbes; he both understood the link between Eden and natural law in Hobbes and reproduces that link in the Oceana. 
If, by virtue of Oceana's influence, Harrington might be said to have been the metaphorical architect of the United States, then men like Jefferson, George Washington, and Benjamin Franklin were the master craftsmen and masons who actually constructed the nation that he had designed. This analogical framework captures a reality that has been both promoted and distorted by pop culture artifacts like Dan Brown's The Lost Symbol and Nicholas Cage's National Treasure franchise; Jefferson, Washington, and Franklin were master masons-Freemasons—whose "masterly hands" constructed a "republican edifice" in which "the people are not inanimate materials, but living stones." ${ }^{64}$ The edenic character of Harrington's Oceana may no longer be blatantly obvious, but it would have been readily apparent to members of a fraternity which, as Peter Levenda writes, viewed each of its lodges or temples as representations of "the universe; not the universe in a chaotic [or fallen] state but as an ordered cosmos, created and designed by the Great Architect." These are men who, in their regular meetings at Masonic temples designed to represent a newly created, edenic world, sang lyrics such as "The fruit of Eden's tree we taste, / Its balmy joys are our repast" (19-20); the restoration and enjoyment of Eden is the entire purpose of Freemasonry. ${ }^{65}$ The Masons who attended the Convention and signed the Constitution—including Gunning Bedford Jr., John Blair, David Brearly, Daniel Carroll, Jonathan Dayton, John Dickinson, Benjamin Franklin, Nicholas Gilman, Rufus King, James McHenry, William Paterson, and George Washington—could not have failed to appreciate the edenic character of

\footnotetext{
64 “An Essay on the Means of Promoting Federal Sentiments in the United States, by a Foreign Spectator," 2. This description sounds suspiciously like an advertisement for the edenic temple that George Herbert wished to construct (pp. 228-237 in chapter 4) and the paradisiacal New Jerusalem which Masons hoped to build in America. John Eliot explained to his fellow Freemasons in Boston that "It hath been my design throughout this discourse, to ... prepare us for the sublime entertainments of the new Jerusalem." See John Eliot, A Sermon, (Boston: Brother N. Willis, 1782), 13.

${ }^{65}$ Peter Levenda, The Secret Temple, (New York: Continuum, 2009), 11; “Song II" in Bennett Wheeler, The Young Mason's Monitor, (Providence: 1791), 13-15.
} 
Harrington's Oceana as they incorporated its principles into a charter for the new nation they would create. ${ }^{66}$

Freemasons in the early republic anticipated a form of the translatio ecclesiae to which the Puritans of the seventeenth century had looked forward. James Varnum, one of Washington's officers, taught his fellow Masons that

The Royal Art began in the East, and like the rising Glory of the World proceeded Westward, and diffused its irradiating Beams to those who sat in Darkness, and saw no Light. At length it has sought an Abode in America, the Center of this terraqueous Fabric, where the Rays of Truth converge, and will encrease, till the great Purposes of Humanity shall be compleated! ${ }^{67}$

The establishment of the United States—that "grand temple of federal liberty"—was inevitably understood as a step in this process as ministers and Masons such as Ezra Stiles both supported the American Revolution and "brought the splendid light from the East to this Western hemisphere! and with the assistance of the Brethren, are employed in erecting the great TEMPLE of MASONRY." ${ }^{68}$

Eighteenth-century Freemasons supported the Revolution and Constitution in their capacity as Freemasons, notwithstanding Masonic regulations that strongly discourage

\footnotetext{
${ }^{66}$ As identified in Nicholas Hagger, The Secret Founding of America, (London: Watkins Publishing, 2007), 160-63. Given the edenic thrust of Freemasonry, it should be noted that others have suggested that the Constitution is heavily indebted to the federal system of Masonic government. Henry Clausen writes that "Since the Masonic federal system of organization was the only pattern for effective organization operating in each of the original Thirteen Colonies, it was natural that patriotic Brethren should turn to the organizational base of the Craft for a model. Regardless of the other forces that affected the formation of the Constitution during the Constitution Convention in 1787, the fact remains that the federalism created is identical to the federalism of the Grand Lodge system of Masonic government created in Anderson's Constitutions of 1723." Those looking for evidence supporting Clausen's view will be interested in Masonic records from Massachusetts. John Warren opines that "The constitutions of Free Masonry are perhaps the most admirably adapted to the promotion of regularity and harmony in a society, that were ever invented by human sagacity," and a convention of Massachusetts lodges in 1785 seems to be organized along the same lines as - and reach conclusions anticipating - the Philadelphia Convention. See Henry C. Clausen, Masons Who Helped Shape Our Nation, (Washington: Masonic Service Association, 1976), 82; John Warren, A Charge, in John Eliot, A Sermon, (Boston: Brother N. Willis, 1782), 11; At a Convention of Delegates from the Following Lodges of Ancient Free and Accepted Masons, (Charlestown: 1785).

${ }^{67}$ James M. Varnum, An Oration, (Providence: John Carter, 1779), 11.

${ }^{68}$ Ezra Stiles, An Oration, (Westminster: Judah P. Spooner, 1782), 7.
} 
members from supporting a specific political party or religious sect. American Masons seem to have respected the charge to avoid "calling ourselves Lutherans, Calvinists, Arminians, Baptists, or Anabaptists" without abandoning what they saw as "the essence of true religion or real christianity," but this postsectarian Christian fraternity overwhelmingly supported the cause of the Revolution and, later, the Constitution. ${ }^{69}$ Claims that "We have no idle prating, / Of either Whig or Tory" (1-2), can hardly have been made in good faith; the minutes of a 1777 meeting at the Masonic temple in Philadelphia reveal that more than twenty men "highly inimical to the Cause of America" because "they consider themselves as Subjects of the King of Great-Britain, the Enemy of this and the other United States of America" were "imprisoned in the Free Mason's Lodge in this City." ${ }^{, 70}$ Pretensions to political neutrality were apparently suspended when it came to the founding of the United States, as Masons overwhelmingly supported the revolutionary and, later, the federal cause. ${ }^{71}$ William Weisberger notes that this exception also applied to the French Masonic Lodge of the Nine Sisters, which functioned "as a center for Masonic supporters of the American Revolution. These activities flagrantly violated Masonic regulations, but for unknown reasons were never questioned by Grand Orient authorities. ${ }^{, 72}$ Conspiracy theorists and, reportedly, even respected academics such as the late Charles Eliot Norton have pointed to this exceptionalism as evidence that the founding of the United States was intentionally

\footnotetext{
${ }^{69}$ Bulkley Olcott, Righteousness and Peace, the Way to Be Acceptable to God, and Approved of Men, (Windsor: Hough and Spooner, 1783), 9.

70 “Song XVI" in Bennett Wheeler, The Young Mason's Monitor, (Providence: 1791), 34-35; T. Matlack, Mason's Lodge, September $9^{\text {th }}$, 1777, (Philadelphia: Robert Bell, 1777).

${ }^{71}$ As Steven Bullock notes, some Masons did, in fact, support the British cause-but many of those individuals "left with the British" in the early years of the war, leading "to Masonry's later reputation as a strongly patriotic organization." See Steven C. Bullock, Revolutionary Brotherhood, (Chapel Hill: University of North Carolina Press, 1996), 111.

${ }^{72}$ R. William Weisberger, "Parisian Masonry, the Lodge of the Nine Sisters, and the French Enlightenment," Heredom 10 (2002): 175.
} 
engineered by secret leaders of the Freemason movement, but supporting or challenging such an allegation is well beyond the scope of this argument. ${ }^{73}$ The more important and clearly defensible point is that Masons of the late colonial and early republican periods unabashedly and publicly supported the United States as a government that would facilitate the accomplishment of their edenic aims.

Masonic visions for the future of the United States revolved around the reversal of the Fall and hopes that Freemasons could collectively transform the American continent into a prelapsarian paradise. Writing in the immediate aftermath of the Consitution's ratification, one Mason celebrated the order's annual festival of St. John by telling his brethren that "I can anticipate, with joy, the happy period, when influenced by an efficient FEDERAL GOVERNMENT, even the remote wilds around us will become the habitations of a virtuous people, and the fertile gardens of plenty." ${ }^{, 74}$ While the federal government established by the Constitution would facilitate this metamorphosis, the Masonic craft was actual means by which Eden would be restored. Masons believed "the Lodge almost coeval with Creation" because Adam had practiced the craft even before the Fall in Eden. ${ }^{75}$ John Marrant, an African American Mason proud to be a descendant of Cain because he believed him the recipient of Adam's knowledge of the craft, preached that Freemasonry "is a society which God himself has been pleased to honour ever since he breathed into Adam the breath of

\footnotetext{
${ }^{73}$ Norton is reputed to have written that "Not only were the founders of the United States Government Masons, but they received aid from a secret and august body existing in the East, which helped them to establish this country for a peculiar and particular purpose known only to the initiated four. The Great Seal is the signature of this Exalted Body." The quote can be found in Eugene Milne Cosgrove, Letters to a Disciple 1935, (Chicago: Gerson B. Deutsch, 1935), 238, and in Ganna Walska, Always Room at the Top, (New York: R. R. Smith, 1943 ), 477, but as neither of these authors give a satisfactory source for the quotation, I reprint it here with some doubts as to its authenticity. Norton's comments may have come from a statement quoted (in part) by Gaillard Hunt. There, Norton states that the great seal is "a dull emblem of a masonic fraternity." See Gaillard Hunt, The History of the Seal of the United States, (Washington D.C: Department of State, 1909), 55.

${ }^{74}$ Charles Smith, An Oration, (Philadelphia: 1788), 28.

${ }^{75}$ Samuel Magaw, A Sermon, Preached in Christ-Church, Dover, (Philadelphia: David C. Claypoole, 1781), 11.
} 
life."76 Masons freely acknowledged that "How far the pure inhabitants of Eden heightened their bliss, by an attention to the principles of Architecture, and Geometry, cannot be ascertained," but they insisted that Freemasonry was present in Eden because "Uninfluenced by the social virtues of this institution, our first parents would have been equally void of happiness, whether doomed to range the uncultivated desert, or permitted to remain within the blissful seat of Paradise."77 Such thinkers maintained, in effect, that there could be no happiness—no Eden-without Freemasonry. ${ }^{78}$

Eighteenth-century Masons may have struggled to articulate the function of Freemasonry in Eden precisely because they understood the craft as a means of combating the Fall. One Massachusetts Mason wrote in 1780:

That the principles of Masonry existed with the Great Architect, when he formed the constellations of the Pleiades, Mazarothi, Arcturus, and Orion, none can deny.Afterwards, when he laid the foundations of the Earth, and extended a Compass over the face of the deep, the Genius of Masonry stood before him, and was his delight.When the Angel of the Lord drove Adam and Eve out of Eden, he made known its theory in some measure to alleviate the distress of the wretched. ${ }^{79}$

As understood by American Masons, the craft that they practiced, with its emphasis on architecture, geometry, and other mathematical arts, was something like an eighteenthcentury rendition of Francis Bacon's Great Instauration: a scientific circumvention of the

\footnotetext{
${ }^{76}$ John Marrant, A Sermon Preached on the $24^{\text {th }}$ Day of June 1789, (Boston: Thomas and John Fleet, 1789), 1112. On his approbation for Cain, see page 10. Marrant belonged to Prince Hall's African Lodge No. 459, the first Masonic lodge to be run by and for African Americans.

${ }^{77}$ Christopher Gore, An Oration, (Boston: 1783), [5]-7.

${ }^{78}$ This quotation is particularly provocative given the language of Jefferson's Declaration. Given the fact that Jefferson was a Mason and the claims of William Still that 53 of the 56 signers of the Declaration were also Masons, it is tempting to imagine Jefferson's right to the "pursuit of happiness" might have implicitly laid claim on a right to practice Freemasonry. See William T. Still, New World Order, (Lafayette: Huntingdon House, 1990), 61. Manly Hall has made the claim that 51 of the 56 were Masons, a slightly lower-but still fantastically high—number. See Manly Palmer Hall, America's Assignment With Destiny, (New York: Philosophical Research Society, 1951), 96-97.

${ }^{79}$ Israel Keith, A Charge, (Boston: N. E., 1780), 5.
} 
Fall. ${ }^{80}$ John Warren, the brother of Freemason Joseph Warren and a Mason himself, ${ }^{81}$

explained that

We need but advert to the wants and necessities attendant upon human life, for the origin of an Art [the Masonic craft] that is every way adapted to the purpose of diminishing them; weak and helpless as we are, as individuals, the comfort and security of each most essentially depend upon the labours and inventions of the whole. The maledictory sentence pronounced upon the first parent of the human race, 'in the sweat of thy brow shalt thou eat bread,' has been greatly mitigated by the almost infinite variety of means that have been, in different ages of the world, discovered, to facilitate the performance of the task assigned us. ${ }^{82}$

Freemasons anticipated that the United States, under the Constitution, would facilitate this amelioration of the Fall and looked forward "in hope delighted, and expectation joyoustowards the approaching, mild, completed glories of the Land we live in." ${ }^{, 83}$ The reason for their optimistic expectations of the new federal government? "great George's mild reign (8). ${ }^{84}$

\section{$\underline{\text { Second Adam and Grand Master }}$}

Masons took pride in the knowledge that Washington, one of their own, had engineered the military defeat of the British and served as the president of the Philadelphia Convention. Their hopes that the new nation and its Constitution would provide conditions in which the craft and a future Eden would flourish revolved around a belief in Washington's ability and willingness to guide the nation according to the ideals of Freemasonry. Masons

\footnotetext{
${ }^{80}$ Freemasonry has consistently been linked back to Bacon and a number of other prominent Renaissance intellectuals. For an overview of his alleged involvement, see Hagger, The Secret Founding of America, 85-89.

${ }^{81}$ Warren was a Major-General who fought as a private and was hailed as a martyr by Masons after his death in the Battle of Breed's Hill. A poem commemorating his death hailed the return of "His mantle ... / To Solomon's Temple" with music from "The lyres of Eden" $(111,115,85)$. See L. G. S., "Commemorative Ode," Massachusetts Centinel 14 Jun. 1788 (IX.26): 104.

${ }^{82}$ John Warren, A Charge, in John Eliot, A Sermon, (Boston: Brother N. Willis, 1782), 4.

${ }^{83}$ Samuel Magaw, A Sermon, Preached in Christ-Church, Dover, (Philadelphia: David C. Claypoole, 1781), 16.

84 “The Deputy-Grand-Master's Song," in Bennett Wheeler, The Young Mason's Monitor, (Providence: 1791), 23-24.
} 
were highly conscious, under the Articles of Confederation in the early 1780s, that the fraternity lacked a centralized, national authority; minutes from a 1785 convention of Massachusetts lodges note that "an union and correspondence of all Ancient Lodges through the United States is an event much to be wished for by all good Masons, and that they think an opportunity is now offered for such union and correspondence by the letter from the Grand Lodge of Pennsylvania." 85 Masons like Oliver Lewis looked forward to the "prospect of having a GRAND MASTER appointed for the American Continent" because the "prosperity of Masonry would doubtless be greatly promoted by such an establishment; and I am happy to find, that the Lodges in the several States, are using every constitutional measure, to accomplish so desirable an event." ${ }^{86}$ Lewis speaks here regarding James Anderson's The Constitutions of the Free-Masons (1723, reprinted for American readers by Franklin in 1734), but Masons working for federal reform also sought a constitutional means of unifying the country under Washington, then Grand Master of Alexandria Lodge No. 22 in Virginia.

Steven Bullock notes that Philadelphia Masons sought to unify all colonial lodges under Washington in1780. He was nominated for the honor in the letter mentioned by the Massachusetts convention; for "the general grand master, [the Pennsylvania ancient grand lodge] proposed a brother who had attended the Morristown meeting, General George Washington." ${ }^{, 87}$ Whether or not Freemasons aspired to combine the office of national Grand Master and federal chief executive before the Convention is far from certain, but writers reflecting on Washington's presidency after his election clearly saw him in both roles. One

\footnotetext{
${ }^{85}$ At a Convention of Delegates from the Following Lodges of Ancient Free and Accepted Masons, (Charlestown: 1785), 5.

${ }^{86}$ Oliver Lewis, An Oration, (Hartford: Hudson and Goodwin, 1783), 14.

${ }^{87}$ Bullock, Revolutionary Brotherhood, 116.
} 
poet writes:

Genius of Masonry, oh hither come,

Nor hover round demolish'd Eastern piles;

Come Goddess, come, and with us make thy home,

Grace with thy presence great Columbia's isles.

Fame spread thy pinions, tell yon distant clime,

Great WASHINGTON beams forth our Master Grand;

Whose name immortal shall out-live old Time,

The pride, the glory of Columbia's land.

See on his brow calm reason reigns secure,

His sapient temples see with olive crown'd;

An heart that's free from ev'ry thought impure,

While ev'ry virtue doth the same surround.

His reverend head now silver'd o'er by time,

With flying ensigns of proud pomp and state

Is crown'd---But Masonry sublime,

Within his breast proclaims him truly great.

His martial sword now rests within its sheath,

Nor more in bloody war it shall engage:

Immortal fame has crown'd him with her wreath,

And marked the hero on her sacred page.

Hail Royal Art, once more, how blooming fair,

Nurs'd in the bosom of our Master Grand;

Henceforth shall Masons, ev'ry blessing share,

While dove-ey'd peace unites the social band.

Thrice honor'd, great, mysterious Art,

The pride of Kings, and garter'd sons of fame,

Companions to the gen'rous noble heart,

Which boasts no honour, but a Mason's name. ${ }^{88}$

While Washington was never formally given the post of national Grand Master, his fellow

Masons clearly thought of him as such. Their willingness to view him in that role is hardly

surprising given the fact that Washington's presidential inauguration ceremony could very

\footnotetext{
88 "Ode to Masonry" in Bennett Wheeler, The Young Mason's Monitor, (Providence: 1791), 42. In addition to this and other poetic tributes in The Young Mason's Monitor, Washington was also the dedicatee in a number of published Masonic orations. See Magaw, A Sermon, Preached in Christ-Church, Dover, A2; and James M. Varnum, An Oration, (Providence: John Carter, 1783), iii.
} 
well have been mistaken for an affair explicitly designed to recognize him as the national leader of Freemasonry in the United States. Nicholas Hagger reports that the "oath of office was administered by Robert Livingston, Grand Master of New York's Grand Lodge. The Marshall of the day was a Freemason, General Jacob Morton. Washington's escort was General Morgan Lewis, a Freemason. The Bible used for the oath was a Masonic edition from St. John's Lodge no. 1 of New York." ${ }^{89}$ Whether or not the average citizen of the United States knew of or cared about Washington's affiliation with Freemasonry, his fellow Masons certainly believed that their Grand Master's loyalty to the "Royal Art" would sway national policy in their favor; Masons fully expected to "ev'ry blessing share" under Washington's rule.

This expectation certainly seems justified, given the manner in which Washington set about constructing the new nation's Capitol. Contemporary newspaper accounts described the procession to the site of the Capitol as follows:

Two Sword Bearers, Masons of the First degree, Bibles, \&c. on Grand Cushions, Deacons with Staffs of Office, Masons of the Second Degree, Stewards with Wands, Masons of the Third Degree, Wardens with Truncheons, Secretaries with Tools of Office, Pay-Masters with their Regalia, Treasurers with their Jewels. Band of Music.

Lodge No. 22, of Virginia, disposed in their own order, Corn, Wine, and Oil, Grand Master, Pro. Tem.

Brother George Washington, W[orshipful]. M[aster]. No. 22, Virginia,

\footnotetext{
${ }^{89}$ Hagger, The Secret Founding of America, 163.
} 


\section{Grand sword-bearer. ${ }^{90}$}

This is remarkable! An account widely republished for a general audience of civilians in newspapers across the nation offers a list of the individuals participating in the cornerstone ceremony for the center of civilian, federal, national government, and the chief civilian and military officer of the nation is identified only in terms of his affiliation with an exclusive semi-religious fraternity. To be sure, none of the readers were likely to forget Washington's other roles in the federal government, but by privileging his identity as a Mason, Washington—who "wore full Masonic regalia" and "used the square and level, and of course the trowel, to lay the stone according to traditional Masonic rites"91_ and the newspapers effectively converted the new Capitol building into an edenic temple of Freemasonry. The commemorative silver plate read aloud before it was laid under the cornerstone by Washington even noted that the stone "was laid on the $18^{\text {th }}$ day of September 1793 , in the thirteenth year of American Independence . . and in the year of Masonry 5793, by the grand lodge of Maryland, several lodges under its jurisdiction, and lodge No. 22, from Alexandria, Virginia." 92

It is the lodges themselves—not Washington or any other officer of the governmentthat are credited with the laying of the cornerstone. Indeed, according to this report, it is a Freemason outside of government, Joseph Clark—the "Grand Master Pro. Tem." of the Maryland lodges_-who delivers the commemorative address; Washington's verbal contribution to the event is presumably limited to his participation in "Masonic chaunting

\footnotetext{
90 “The Surveying Department of the City of Washington," Columbian Centinel 5 Oct. 1793 (XX.8): 2.

${ }^{91}$ Hagger, The Secret Founding of America, 165.

92 “The Surveying Department of the City of Washington" 2.
} 
honours." 93 That address makes the Capitol's representative status as an edenic, Masonic temple explicit, as the Maryland Grand Master compares the Capitol to "that ever memorable temple to our order erected by our ancient G. M. Solomon.” The Masons who participate in its construction are "like innumerable hives of bees bestowing their industrious labour on this second Paradise," a "delightful city" situated in "a climate the most serene and salubriousequal of access from all the cardinal and intermedial points, as any place that kind nature ever formed, even beyond conception of art." ${ }^{, 94}$ This extraordinary speech subjugates national interests to Masonic destiny and replaces the national legislative center with an edenic New Jerusalem built by inspired artisans in a natural paradise. Washington, as the symbolic patriarch of the nation and its ruling fraternity, is portrayed as a second Adam whose leadership will make it possible to convert the United States into a restored Eden.

While Washington was the acknowledged lynchpin of Masonic pretensions to prelapsarian perfection, Freemason orators made it clear that the effort to purify and refine the nation would require the concerted efforts of all the Brethren. A poem that acknowledges Washington's Adamic stature among Freemasons also calls for his fellow Masons to support the policies he introduces into law:

Then in our songs be justice done,

To those who have enrich'd the art:

From ADAM to great WASHINGTON, And let each brother bear a part. $(25-28)^{95}$

Part of this duty to "bear a part" involved "avoiding those personal Animosities, and Party Altercations, which disturb the Happiness of Society." 96 Since Masons "call that only a

\footnotetext{
93 ibid, 2.

94 “Oration,” Columbian Centinel 9 Oct. 1793 (XX.9): 1.

95 “The Fellow-Craft's Song,” in Bennett Wheeler, The Young Mason's Monitor, (Providence: 1791), 24-25.

96 James M. Varnum, An Oration, (Providence: John Carter, 1783), 10.
} 
perfect system, which, by an admirable check of the component parts upon each other, is preserved from arbitrary power on the one hand, and from factions and popular phrenzy on the other," they were predisposed to uphold and support the Harringtonian government over which their Grand Master presided even before they had been explicitly instructed to do so, but Masons were also explicitly charged to actively support the Constitution. Speaking to a group of Masons in 1788, Charles Smith encourages them "to pay a due obedience to the power and authority constitutionally set over them, in return for that liberty, protection and happiness they enjoy from a good government" and "to promote and support every measure which can be of public utility." 97 With Washington at their head and the collective support of Freemasons in every state, Eden would surely be rebuilt. Only a spirit of disunity could prevent the Brethren from accomplishing their goals, a pitfall against which John Eliot warned his fellow Masons: "Let not calumny, the vice of little souls, and which is sure to poison the enjoyments of social beings, spread its baneful effects among a Brotherhood united as we are, in amity and friendship. Let not the snakes of envy hiss." ${ }^{\text {"98 }}$ Eliot's warning against allowing the "snakes of envy" to disrupt the fraternal unity of the Masons appropriately identifies a serpent as the primary allegorical threat to their paradisiacal pretensions; but it also transforms the snake from a symbol of colonial and national union into one of faction, turbulence, and disunion - the omen of an impending Fall for the newly established, edenic republic.

\section{A Snake in the Garden: Portents of the Fall}

The snake first appears as a symbol of colonial unity in the editorial writings of

\footnotetext{
${ }^{97}$ Charles Smith, An Oration, (Philadelphia: 1788), 24, v, 15.

98 John Eliot, The Charge, in Christopher Gore, An Oration, (Boston: 1783), 18.
} 
Benjamin Franklin during the 1750s. In reaction to the news that Samuel Saunders, a felon transported from the British isles to the American colonies for earlier crimes, had committed murder in the colonies, Franklin complains about the practice of transportation with a biblical reference: "We do not ask Fish, but thou givest us Serpents, and worse than Serpents!"99 A month later, in May 1751, Franklin suggests that the colonies should jointly oppose this injustice, proposing that the colonies, in return for Britain's convicts, export rattlesnakes to the mother country:

In some of the uninhabited Parts of these Provinces, there are Numbers of these venomous Reptiles we call Ratttle Snakes; Felons-convict from the Beginning of the World: These, whenever we meet with them, we put to Death, by Virtue of an old Law, Thou shalt bruise his Head. But as this is a sanguinary law, and may seem too cruel; and as however mischievous those Creatures are with us, they may possible change their Natures, if they were to change the Climate; I would humbly propose, that this general Sentence of Death be changed for Transportation. ${ }^{100}$

Franklin's call to export these descendants of the serpent that had disrupted Adam and Eve's paradisiacal union was resurrected as a symbol of colonial unity exactly three years later.

Already anticipating, in 1754, the consequences of hostilities that would become the French and Indian War, Franklin printed Jonathan Belcher's speech soliciting “a strict Union among all His Majesty's Colonies ... to ward off from yourselves and your Posterity, the fatal Consequences that must attend the present unjustifiable Violences and Insults of the French (in Conjunction with the Indians)." ${ }^{101}$ To illustrate the Belcher's call for colonial unity Franklin returned to the image of the rattlesnake-whose earlier appearance Henry Preble

\footnotetext{
99 "Philadelphia, April 11," The Pennsylvania Gazette 11 Apr. 1751 (1165): 2. Franklin here paraphrases the words of Christ in Matthew 7:9-10, where Jesus asks, "Or what man is there of you, whom if his son ask bread, will he give him a stone? Or if he ask a fish, will he give him a serpent?" Franklin's message is clear: the colonies have not asked for Britain's aid, much less her interference, and the British excuse for transportationthe "Improvement and Well Peopling of the Colonies"-comes as in answer to a need that was never expressed publicly by the colonies.

${ }^{100}$ Americanus, "Philadelphia, May 9," The Pennsylvania Gazette 9 May 1751 (1169): 2.

${ }^{101}$ Jonathan Belcher, "The Speech of His Excellency Jonathan Belcher," The Pennsylvania Gazette 9 May 1754 (1324): 1 .
} 
argues "could scarcely have been forgotten" by his readers-in a woodcut widely recognized as the first political cartoon published in America. ${ }^{102}$ Franklin depicts a rattlesnake divided into eight labeled segments—one each for $\mathrm{N}[\mathrm{ew}]$. E[ngland]., $\mathrm{N}[\mathrm{ew}]$. Y[ork]., $\mathrm{N}[\mathrm{ew}]$. J[ersey]., P[ennsylvania]., M[aryland]., V[irigina]., N[orth]. C[arolina]., and S[outh]. C [arolina]—with the legend "Join, or Die" below. ${ }^{103}$ In this woodcut, as in his satirical attack on the practice of transportation, Franklin presents the rattlesnake as a reminder of the need for colonial unity in opposing a foreign enemy.

Over the next twenty years Franklin's woodcut was adopted, adapted, and widely reprinted by newspapers from South Carolina to Massachusetts, and by the time of the Revolution the original, segmented serpent had been replaced by a single, whole snake with thirteen rattles to symbolize the effectual "union of the colonies" in the United States. ${ }^{104}$ This representation of national unity was characteristically accompanied by the warning, "Don't Tread on Me," and during the war for independence the rattlesnake became an official symbol of the United States military. Marc Leepson notes that Charles Gadsden mounted the snake and motto on a field of yellow silk and gave it to Esek Hopkins, commodore of "the first Continental Navy fleet in December 1775."105 The Gadsden flag, as it became known, was apparently the banner raised by John Paul Jones when he "hoisted the flag of America, with his own hands, the first time it was ever displayed," and Gadsden later presented a

\footnotetext{
${ }^{102}$ Geo. Henry Preble, Origin and History of the American Flag, (Philadelphia: Nicholas L. Brown, 1917), 214.

103 “Join or Die,” The Pennsylvania Gazette 9 May 1754 (1324): 2.

${ }^{104}$ Schuyler Hamilton, History of the National Flag of the United States of America, (Philadelphia: Lippincott, Grambo, and Co., 1852), 74.

${ }^{105}$ Marc Leepson, Flag, (New York: St. Martin's Press, 2005), 12. Hamilton offers a fascinating insight into the symbolical portent of Gadsden's flag, arguing that the black snake centered on a yellow field was intended to mimic "the quarantine flag of the mother country [which] was a yellow flag with a dark spot, a representation of the plague-spot in the middle." Hamilton goes on to suggest that "those colors were, doubtless, chosen for the rattlesnake flag, to indicate the deadly character of the venom of the rattlesnake, and the danger of treading on it." See Hamilton, History of the National Flag of the United States of America, 83.
} 
second flag to the Continental Congress, which hung the standard "in the southwest corner of that room, at the left hand of the President's chair."106 A 1775 flag employed at Bunker Hill displayed the snake on a crimson field with a Union Jack in the canton, ${ }^{107}$ and other flags depicted the rattlesnake stretched from the bottom right to the top left corner against a field of red and white, or sometimes red and blue, stripes. ${ }^{108}$ A rattlesnake even graced the 1778 seal of the War Department. ${ }^{109}$ By the end of the Revolutionary War, the rattlesnake may have been the single most widely recognized symbol of national unity, and yet those who questioned the viability of this new, edenic republic quickly converted it and other species of snakes into representations of the nation's imperfections, omens of an imminent Fall.

\section{The Fascinating Dangers of an Interracial Union}

The rattlesnake was adopted as a national symbol, at least in part, because it was a species indigenous to North America whose introduction to European settlers caused something of a stir. In addition to their curiosity regarding the serpent's rattles, colonial observers were keenly interested in the snake because they believed it possessed the power to incapacitate its victims by fascinating them with its eyes. Herbert Leventhal argues that colonial credence in the fascinating powers of common rattlesnakes probably emerged originally from the belief of Cherokee, Delaware, and Creek Indians, among others, "in certain mythical serpents—not the common everyday variety of rattlesnake or blacksnake which one could find in the woods - which possessed a power very similar to that of

\footnotetext{
${ }^{106}$ As quoted in Hamilton, History of the National Flag of the United States of America, 79; Preble, Origin and History of the American Flag, 216.

${ }^{107}$ Preble, Origin and History of the American Flag, 205.

${ }^{108}$ Milo M. Quaise, Melvin J. Weig, and Roy E. Appleman, The History of the United States Flag, (New York: Harper \& Row, 1964), 37.

${ }^{109}$ Hamilton, History of the National Flag of the United States of America, 74.
} 
fascination." ${ }^{110}$ Women were believed to be particularly susceptible to this power, a point made by the Algonquin tale "of a woman who fell in love with Atosis the Serpent while he was in human form. 'One day while the woman cut away the ice, she saw in the water a bright pair of eyes looking steadily at her. They charmed her so that she could not move.' Eventually, it was said, she gave birth to blacksnakes!" rattlesnake fascination was consistently associated with Native Americans, even by those who did not believe in the phenomenon; when De Witt Clinton proposed that "the fascination of serpents, should be banished from our natural, and the Welch nations of Indians from our civil, history," he preserved that connection between fascination and Indians even as he tried to extinguish belief in rattlesnake fascination and expurgate certain tribes of Native Americans from a national history. ${ }^{112}$

The link between fascinating serpents and peoples native to North America made the rattlesnake a natural symbol for colonial rebels struggling to differentiate themselves from their European past to appropriate, but citizens of the new republic also linked their concerns about future relations with Native Americans to the phenomenon of rattlesnake fascination. Those who believed that racial diversity would pose potentially insurmountable challenges to the continued existence of the United States expressed their concerns regarding the dangers of sharing a physical space with Native Americans in the language of fascination. One writer worried that the French would, from Canada, incite Indians living inside the borders of the

\footnotetext{
${ }^{110}$ Herbert Leventhal, In the Shadow of the Enlightenment, (New York: New York University Press, 1976), 163-66. On colonial — and contemporary American — belief in serpent fascination, see Richard M. Hurst, "Snakelore Motifs in the Writings of J. Hector St. John de Crevecoeur and Other Colonial Writers," New York Folklore Quarterly 9.3-4 (1983): 68-77.

${ }^{111}$ Leventhal, In the Shadow of the Enlightenment, 165.

${ }^{112}$ De Witt Clinton, “Orinthology,” The Newport Mercury 30 Sep. 1815 (LIV.2791): 1. For a speculative history of the possibility that groups of Welsh settlers colonized North American before Columbus's discovery and intermarried with Native American tribes, see William L. Traxel, Footprints of the Welsh Indians, (New York: Algora., 2004).
} 
United States to rebel; he warned that these agents of popery will, "serpent-like, fascinate the rude Indians" and make them the "good and faithful servants of the would-be demigod of Europe." ${ }^{" 113}$ Indian uprisings were particularly frightening because Indians themselves were believed to possess the power to fascinate. In an account of the French and Indian War that circulated in the early republic, when tensions between Native Americans and white settlers were still high, Captain Baker, the white protagonist, catches sight of Tumelek, his Indian foe, but "before he could well determine that he really was in sight, he had vanished without a visible motion, like the head of the black snake in the high grass.-The hunter felt in the encounter something of the fascination that is felt from the eye of a serpent, and began to doubt" whether he would survive. ${ }^{114}$ A second narrative from the early nineteenth century describes an Indian with a gun in his hand poised over a sleeping man. When the sleeping man wakes, he sees that the Indian's "eye was as brightly and as silently upon me. It was like fascination. I could only look at him and breathe softly, as if I feared to disturb the warrior." ${ }^{115}$ Not only were the Indians themselves potentially subject to the fascinating influence of the Pope's imperial agents, but they also, in their attacks on the citizens of the United States, possessed the power to fascinate and immobilize their victims. Native Americans were, in their role as allegorical serpents within the republican Eden established by Washington, far more terrifying to the white populace than the serpent ever had been to Eve.

As much as the prospect of war with Native American tribes may have frightened the male inhabitants of the early republic, they were still more distressed by the prospect of their

\footnotetext{
113 “The Gazette. 'Be Just—And Fear Not,”, Concord Gazette 14 Jan. 1812 (5.33): 3.

114 “Baker's Fight," The Farmers' Cabinet 17 Oct. 1829 (28.6): 1.

115 "First and Last Sacrifice," New-Hampshire Sentinel 30 Oct. 1829 (XXXI.44): 1.
} 
women being fascinated and killed—or, even worse, seduced—by Indians. Sarah Josepha Hale's short story "The Frontier House" (1828) climaxes as "the light fell full on the pale face of Rebecca; her eyes, as if by the power of fascination was rivetted on the Indian, his firery [sic] glance, was raised toward her, and their gaze met." ${ }^{, 16}$ This interlocking gaze was the object of considerable angst on the part of white men and women. In Rebecca's case, the danger was death, but other writers feared miscegenation more than massacre. While Indian eyes sometimes fascinated and terrified the gazer with their "dark ferocity," they could also display a "placid regard which always fascinates and attracts attention" from the fairer sex. ${ }^{117}$ It was the effect of this gaze that white writers feared most.

The 1824 marriage of Sarah Northrop to John Ridge, an Indian, prompted an editorial warning published across New England that white young women gazing at Indians were subject to "hallucination" as "their spiritual eyes discover [celestial charms] in those tawny sons of the forest." As a result, "the Cherokee youth" of the Foreign Mission School in Cornwall, Connecticut were instructed that they "must not look at a [white] young woman." ${ }^{118}$ Elias Boudinot, an Indian student at the school, disobeyed and proposed marriage to Harriet Gold, whose friends and family accused her of reacting with "animal feeling" to his "black eyes." They could imagine no fate worse than her marriage to an Indian and said so boldly: "if H[arriet]. must die for an Indian or have him, I do say she had as well die. ${ }^{, 119}$ In addition to their general disapproval of the match, they harbored a deep fear that Harriet's marriage would prompt a rash of interracial unions. Instead of simply suggesting

\footnotetext{
${ }^{116}$ Sarah Josepha Hale, “The Frontier House,” as reprinted in Eastern Argus 18 July 1828 (IV.396): 1.

117 “Indian Genius,” Daily National Intelligencer 21 Aug. 1816 (IV.1129): 3.

${ }^{118}$ As quoted in To Marry an Indian, ed. Theresa Strouth Gaul, (Chapel Hill: The University of North Carolina Press, 2005), 14, 19.

${ }^{119}$ ibid, 89, 137, 121-22.
} 
that she will be unhappy with her new husband, her family and friends attempt to dissuade her from marrying Boudinot with an allegory that illustrates the impact that her marriage might have on the larger community:

your Father has a perfect right to kindle a fire on his own land; but if his neighbor comes \& expresses his fears that that fire so kindled, will be driven by the wind into his fields, \& if there is indeed manifest reason to fear that such fire will injure his neighbour's property, then, though it be on his own ground, your Father cannot kindle such a fire without doing that which, in such circumstances, becomes absolutely wrong; ... Before you kindle the fire, which if once kindled may burn, we know not how far, nor how long, O Harriet, before you kindle the fire, remember . . . that God will hold you accountable to Him, for all the injury which His cause may thus receive. $^{120}$

From this perspective, Harriet's love for Boudinot is a spark that will ignite an interracial wildfire, consume Connecticut, and destroy public support for proselyting organizations such as the Foreign Mission School. The fascinating eyes of Indian young men were understood as a danger to society itself, not just to individual young women.

Lydia Maria Child capitalized on this fear in her novel Hobomok, which was published in 1824, the same year as the Northrop-Ridge marriage. Living in "a perfect Eden of fruit and flowers," Child's Mary Conant eventually falls into a "stupefied state" upon news that her lover has been lost at sea. ${ }^{121}$ It is in this condition that the Indian Hobomok finds and marries her; she is "unconscious of any change in her situation" during and even after the marriage. Her father, like Harriet Gold's relations, declares, "I find I could more readily have covered her sweet face with the clods, than bear this" and treats Mary as dead. Child foreshadows Mary's loss of willpower and effectual death in an earlier description of animal fascination; when Hobomok takes Mary and Mr. Conant on a deer hunt despite the

\footnotetext{
${ }^{120}$ ibid, 93.

${ }^{121}$ Lydia Maria Child, Hobomok, ed. Carolyn L. Karcher, (New Brunswick: Rutgers University Press, 2004), 5, 135 .
} 
father's objections that this spectacle will “entice [women's] wandering hearts," torchlight attracts and holds the attention of a passing animal. Though the deer recognizes the hunters as enemies, "so powerful was the fascination of the torches, that his majestic antlers seemed motionless as the adjacent shrubbery." 122 Mary might similarly have recognized in Hobomok's pagan nature an enemy to her Anglican faith, but when he leads her to his wigwam by "the rays of a bright October moon" she, like the deer, remains "pale and motionless." As Hobomok draws his bow to slay the deer, Mary "touched his shoulder, as she said, 'Don't kill it, Hobomok—don't;' but the weapon was already on the wing." So too, when Hobomok "asked his intended bride whether she was willing to be married in the Indian form," proposing her spiritual slaughter (at least from her father's perspective) with verbal missiles no less deadly than his arrows, his own mother intercedes, objecting that "She is mad." ${ }^{23}$ Neither Mary's entreaty nor the old squaw's objection saves the victims, and Mary's Fall from the Eden in which she lives is, at least by analogy, the product of fascination.

If the dangers of serpent-like fascination were, because of the perceived link between rattlesnakes and Native Americans, most commonly associated with Indians, they were also, at least occasionally, attributed to other non-English racialized groups. James Madison, in an address promoting Jeffersonian agrarianism, explains that "fascination ... belongs to that uncivilized state"; it is not a danger exclusively associated with the Indians of North America, but one attached to all "of our savage neighbors," including the Tartars,

\footnotetext{
122 ibid, 125, 133, 87, 89.

${ }^{123}$ ibid, 123, 89, 124.
} 
Greenlanders, and Peruvians. ${ }^{124}$ Other ethnic groups were associated with the power of fascination in direct proportion to their identity as wild or uncivilized peoples. One anonymous commentator notes that " $[\mathrm{t}]$ here is a sort of fascination and peculiarity to the Scottish character" directly related to the "wild, grand and magnificent scenery of their country." 125 Spaniards, with their "swarthy complexion" and their "black hair and eyes" are likewise "fascinating in their manners" precisely because those manners are considered to be "uncultivated." ${ }^{26}$ The Irish are "certainly more fascinating" to a United States citizen than the British because their similarities to "the natives of this barbarous country" are "an irresistable lure to every kind of attention." ${ }^{127}$ Racialized and uncivilized peoples were consistently linked to the phenomenon of fascination, and this connection was emphasized by writers who stressed the moral and physical perils that slavery posed to the new republic.

In his Letters from an American Farmer, J. Hector St. John de Crèvecœur praises American society as paradisiacal but in his discussion of slavery also cautions of an impending Fall. In America, Crèvecœur writes, “[e]very things has tended to regenerate," and the citizens have "escaped the miseries which attended our fathers!" Under the careful cultivation of European immigrants, the country develops into a type of paradise, where "the labours of its inhabitants [are] singularly rewarded by nature ... with barren spots fertilized, grass growing where none grew before; grain gathered from fields which had hitherto produced nothing better than brambles;" but Crèvecœur warns that slavery will quickly and

\footnotetext{
${ }^{124}$ James Madison, “Address by Mr. Madison,” American Advocate and Kennebec Advertiser 29 Aug. 1818 (IX.33): 2 .

125 “Matters and Things in General," Newburyport Herald 25 Mar. 1823 (XXVI.103): 2.

126 “Miscellany,” The Farmers' Cabinet 20 July 1838 (36.47): 1.

127 Sydney Owenson, The Wild Irish Girl (1806), as quoted in "London and Dublin Contrasted," The Guardian 6 Feb. 1808 (I.12): 48. Owenson was an Irish novelist, but her description of the Irish-as a wild people that had more in common with the Indians than the English-was consonant with American opinion in the early nineteenth century.
} 
inevitably lead to the downfall of this edenic space. ${ }^{128}$ Letter IX depicts Charleston, warning of "the poison of slavery," and Crèvecœur's next epistle provides an allegorical illustration of the dangers that poison could pose. Letter X portrays the slave-holding South as a blacksnake "whose stings are mortal" and whose eyes "display a fire which I have often admired, and it is by these they are enabled to fascinate birds and squirrels." ${ }^{129}$ This blacksnake attacks "a water-snake, nearly of equal dimensions" which represents the states opposed to slavery; "their untied tails" are "mutually fastened together, by means of the writhings, which lashed them to each other" in the same way that the pro-slavery and anti-slavery interests were united by the violence of the Revolutionary War. In Crèvecœur's allegory, however, this union is fatal, as the fascinating blacksnake, whose "eyes seemed on fire" eventually "stifled and sunk" the water snake, drowning it in a river. ${ }^{130}$ Inherent in Crèvecœur's metaphorical "critique of an Atlantic sphere of commerce fundamentally defined by slavery" is a fundamental pessimism regarding the republic's future that has led some, as Ed White notes, to call the Letters a "dystopian novel." 131 At the center of Crèvecœur's cynicism is a concern about the dual dangers of slavery and fascination and the ways in which they threatened, together, to destabilize an otherwise edenic republic.

The association between African American slaves and fascinating serpents would have seemed natural to Crèvecœur's contemporaries. Africa was the only Old World

\footnotetext{
${ }^{128}$ J. Hector St. John de Crèvecœur, Letters from an American Farmer, ed. Susan Manning, (New York: Oxford University Press, 1997), 42, 83-85.

${ }^{129}$ ibid, 161, 166, 169.

${ }^{130}$ ibid, 171, 172. The connection between slaves and snakes is transparent in this letter; when Crèvecœur describes a series of farmers who die from the fangs of a snake that become embedded "in the leather" of a pair of boots, he slyly hints that it is the institution of slavery itself that is responsible. On the morning that the first farmer to die leaves his house, he goes "to mowing, with his negroes, in his boots." Only the comma between negroes and in hides the passage's symbolic meaning; the poison that kills the farmer is his choice to own slaves, not snake venom. See pp. 167-68.

${ }^{131}$ Ed White, "Crèvecœur in Wyoming," Early American Literature 43.2 (2008): 380.
} 
continent where snakes seemed to possess the fascinating powers of their New World counterparts, and some African Americans, like the Native American tribes noted above, worshipped a snake god with power over its adherents. ${ }^{132}$ Citizens of the early republic believed that African American slaves retained a special relationship with the snake, which in Africa, "infests . . the dwellings of the negroes." 133 One slaveholder claimed to own "a negro who could from the acuteness of his smell, at all times discover the rattlesnake, within a distance of 200 feet when in the exercise of his fascinating power."134 Their association with snakes even seemed to endow African Americans, "whose fascinating smiles were more penetrating through an ebony complexion than under an alabaster forehead," with some of power and allure attributed to rattlesnakes and other serpents. ${ }^{135}$

But white men and women of the early republic never feared the fascinating powers of slaves in the same way that they feared Native Americans. Instead, much of their fear revolved around the possibility that fascination would lead to the liberation of the slaves and an interracial Union of ostensible equals. Supporters of slavery supported the exportation of free African Americans because they feared "the effects produced [on slaves] by the

\footnotetext{
${ }^{132}$ Leventhal's history of "The Fascinating Rattlesnake" emphasizes the home-grown nature of colonial belief in rattlesnake fascination. While New World accounts had convinced European scientists of the snake's powers by the mid eighteenth century, all European discussion of the subject clearly relies on earlier North American observations; "not only did many seventeenth-century [European] accounts of the rattlesnake not mention the power of fascination, but ... many Renaissance and seventeenth-century works discussed fascination without mentioning rattlesnakes." See Leventhal, In the Shadow of the Enlightenment, 138, 139-40. Examples of snake fascination from Africa come to light in the late eighteenth and early nineteenth century, in travel narratives by François Le Vaillant and Martin Lichtenstein. See "Power of Serpents," City Gazette and Daily Advertiser 30 Aug. 1797 (XV.3144): 2; and "Fascinating Power of Snakes," Connecticut Mirror 2 Dec. 1822 (XIV.24): 2. It should also be noted that Africans were credited with having discovered the same secrets of animal fascination that allowed Indians such as Hobomok to fascinate deer. Africans taught European hunters and explorers to take advantage of the "overmastering effect of the human eye" on wild animals. See "Natural History," Eastern Argus 15 Nov. 1824 (I.14): 1.On the central role of the serpent in African American voodoo culture, see Alice Eley Jones, "Sacred Places and Holy Ground: West African Spiritualism at Stagville Plantation," in Keep Your Head to the Sky, ed. Grey Gundaker, (Charlottesville: University Press of Virginia, 1998), 102-104.

133 “From Paine's Geographical Extracts," The Washingtonian 2 Oct. 1810 (II.87): 1.

134 "Fascinating Serpents," The Weekly Recorder 21 Aug. 1818 (V.2): 14.

135 “Miscellany," Hancock Gazette 24 Aug. 1820 (I.8): 1.
} 
fascinating, but delusive appearance of happiness, exhibited in persons of their own complexion, roaming in idleness and vice among them. ${ }^{, 136}$ An 1806 New York editorial warns of the "fascinating charm at first assumed by innovation" and cautions that the "best political writers have traced the fall of Roman liberty to the sudden emancipation of slaves" and similar "innovating measures in extension of the popular or democratic authority." "137 Slaveholders admonished their abolitionist neighbors that nothing would lead to the Fall of the United States sooner than the efforts of "your right liberty and equality men," who sought "to carry the fascinating doctrine of the new school to greater length, than even the most enthusiastic of his democratic brethren" by the "immediate and universal emancipation of the blacks." ${ }^{138}$ Advocates of the status quo chided those who believed that the abolition of slavery and the establishment of

uncircumscribed liberty, unalterable equity, eternal causation, with much more such shrubbery of the imagination, are to flourish together, and with their unfading blossoms to perfume a terrestrial paradise. The world has been much amused with such speculations of late. But, for myself, whenever I see a propagator of such nonsense, however meek his external demeanour, my mind involuntarily has a vision of the incendiary rage of a Cataline, and the bloody proscriptions of a Robespierre. ${ }^{139}$

First articulated by Crèvecœur even before the Revolutionary War had officially ended, this fear that some combination of fascination and slavery would doom the nascent republic to a bloody civil war like those which plagued the Romans and the French continued to haunt citizens of the United States until it was realized in 1861 at Fort Sumter. Notwithstanding the edenic encomiums lavished on the new republic by the Masons and others, the interracial character of the United States was recognized by most as a potential obstacle to paradisiacal

\footnotetext{
136 "South Carolina Opinions of the Colonization Society," Daily National Journal 20 Jan. 1831 (VII.4021): 2.

137 “Speculations of Dectus," New-York Spectator 7 June 1806 (IX.886): 1-2.

138 "Judge Bowen," Commercial Advertiser 10 May 1804 (VII.2041): 3.

139 “Speculations of Dectus," 2.
} 
pretensions from the inception of the republic.

Fascination, the Abandonment of Religion, and the Failure of Education

All manner of threats to national prosperity—and not just those associated with racialized communities - were framed in terms of serpentine fascination. Writers of the early republic worried that "power was fascinating" and would transform some future president into a despot whose "fascinating cant" would sound like "the hissing of the serpent"; ${ }^{140}$ that the monarchical tradition was "too fascinating ... to be resisted," even by "friends of representative government"; ${ }^{141}$ that supporters of hereditary rule would "fascinate [citizens'] eyes and make them view Aristocracy, as some harmless little creature" and then, "in the course of a few years, those officers should, like Pharoah's magicians, convert their wands into serpents"; ${ }^{142}$ that "FACTION, more frightful than Medusa, with her thousand grisly snakes" would infect the nation with "the poison of party principle" as men like Aaron Burr and his "fascinating friends" exerted a "fascinating influence" and lured "citizens to form a third party"; ${ }^{143}$ that female suffrage would endow "the fair-sex ... interesting, fascinating, with power to direct us at their will, and exercise a despotic sway over our affections"; ${ }^{144}$ that the national bank, that "monstrous engine of fraud and taxation, is weighing with the iron pressure of ruin, upon this devoted, this fascinated country"; ${ }^{145}$ and that "fascinating novels and romances, which bewilder their heads and poison their hearts," would replace "[m]oral

140 "Translated for the Newport Herald," Newport Herald 27 Aug. 1789 (III.131): 1; "From the Ulster Gazette," The Spectator 31 Aug. 1803 (VI.634): 1. The rise of a Bonapartian leader was the most feared outcome for such citizens; see, for example, "Political," Northern Whig 14 Feb. 1809 (I.7): 1.

141 “The Citizen,” American Citizen and General Advertiser 19 Dec. 1801 (II.549): 2.

142 "When, in the very hot-bed...," The Argus 16 Sep. 1791: 3.

${ }^{143}$ Benjamin Gleason, "Extracts of an Oration," The Democrat 23 Aug. 1806 (III.68): 2; “The following Toast is...," The Patriot 11 Apr. 1803 (I.7): 2.

144 “Fellow Citizens," Washington Federalist 14 Aug. 1801 (I.138): 3. See also "From the (Staunton) Republican Farmer," Federal Republican 4 Apr. 1815 (IX.1210): 2.

145 “Congress the Bank and the People No IV," Weekly Aurora 14 Dec. 1818 (IX.XLIII): 338. 
and religious education," resulting in a "national death," from which "there are no specifics which can renew its energies, and restore its pristine state." ${ }^{146}$ Almost any danger to the pristine, edenic nation could be-and was-described in the terms of rattlesnake fascination. Underlying most of these warnings, however, lay a common fear. Citizens of the early republic worried that the postsectarian Eden established by Masons such as Franklin and Washington was not just postsectarian but also secular, that the novus ordo seclorum was a new secular order and not just a new order of the ages. ${ }^{147}$ William Baker and other early editorialists gloomily prophesied that United States "Republicanism attired in all the charms of innocence" would submit to "the fascinating mantles of peace, and reason" as Deists and Masons, led by Thomas Paine and Thomas Jefferson, “destroy religious worship and set up their Temples of Reason."148

Because the widely accepted Calvinist doctrines of original sin and predestination precluded universal virtue and because contemporary political theory posited that a republic could only thrive if its citizens were universally virtuous, writers like Baker worried that the

\footnotetext{
146 "The Sham-Patriot Unmasked," The Post-Boy, and Vermont \& New-Hampshire Federal Courier 8 Oct. 1805 (I.41): 324.

${ }^{147}$ Although seventeenth-century colonial government and twenty-first century republican institutions of the United States now seem inseparable from religious influences, authors in the late eighteenth and early nineteenth centuries conceived of republicanism as inherently atheistic. Because the "deliberate, if tentative, exercise in republican state formation" which Michael Winship identifies in the devout Bay Colony ended with the revocation of Massachusett's charter in 1684 (para 43, 60), constituents of the early republic could not point to a single successful precedent in Christian republicanism. Even in eighteenth-century Massachusetts, "republican served as a smear word." See Michael P. Winship, "Godly Republicanism and the Origins of the Massachusetts Polity," The William and Mary Quarterly 63.3 (2006), <http://www.historycooperative.org/cgibin/justtop.cgi?act=justtop\&url=http://www.historycooperative.org/journals/wm/63.3/winship.html>, (27 Jan. 2010), para. 43, 60.
}

According to Mark Noll, the majority of the country agreed that "it was only when Christian orthodoxy gave way that republicanism could flourish." Fifty years after the formation of the United States, de Tocqueville still felt it necessary to remark on the "two perfectly distinct elements that elsewhere have often made war with each other, but which, in America, ... they have succeeded in incorporating somehow into another and combining marvelously. I mean to speak of the spirit of religion and the spirit of freedom." See Mark A. Noll, America's God, (Oxford: Oxford University Press, 2002), 60, 92.

${ }^{148}$ Wm. Baker, "For the Washington Federalist," Washington Federalist 8 July 1803 (III.492): 2. 
citizens of a secular United States would not learn to be virtuous enough to overcome their own depravity. ${ }^{149}$ A secular republic that failed to remove the taint of original sin from its citizens through education had already failed, ipso facto, so the American experiment in republicanism was, in some sense, predicated on the belief that education and an enlightened use of agency would disprove the Calvinist insistence on immutable human depravity. ${ }^{150}$ While the founding fathers were generally more than willing to abandon Calvin's insistence on total depravity for Locke's tabula rasa, the average citizen of the early republic seemed less certain that it was education — and not grace — that produced virtue. The representative protagonists of novels published in the early republic are not saved by education; on the contrary, they fall prey to an immobilizing power of fascination precisely because they rely too heavily on their own agency and the redemptive power of education, forgetting the depraved natures of their tempters and themselves. ${ }^{151}$

When Marion Rust pointedly asked, "What's Wrong with Charlotte Temple?" she easily could have extended the question to Charlotte's fellow female protagonists in other

\footnotetext{
${ }^{149}$ It should be noted that the Masons themselves were very insistent that the fraternity was both Christian and committed to the promotion of virtue; Steven Bullock highlights this emphasis, arguing that "virtue was the essence of the fraternity itself." Because Masons "followed Enlightenment theories about pedagogy," leaders like Jefferson undoubtedly saw the fraternity as a means of fulfilling the Lockean mandate to instill virtue into the citizens of the republic, but perceptions of Masonry's religious valence "would change dramatically after the Revolution" as some "sectarian religious groups explicitly forbade fraternal involvement." See Bullock, Revolutionary Brotherhood, 139, 163, 164.

${ }^{150}$ The newly formed United States included a religiously diverse population, and reconciling the spirit of religion with the spirit of freedom required citizens of the republic to put aside the Calvinist argument that no one "could have the civic virtues necessary for magistracy without being a saint." Instead of relying on the predestined morality of an elect few to ratify the religious standing and moral behavior of government officials, the republic rested firm in the belief that an adequate education could teach any individual to uphold freedom and behave virtuously. In the early republic, education replaced predestinarian thinking as the primary explanation for human behavior, empowering individuals with the knowledge necessary to correctly employ their own agency. See Winship, "Godly Republicanism and the Origins of the Massachusetts Bay Polity," para. 49.

${ }^{151}$ The indigenous roots of rattlesnake fascination have been elided by readers like Gillian Brown, who describe feminine fascination only in the terms of an imported mesmerism, the dangerous ability for one person to control the will of another through mental influence first described by the German Franz Mesmer. See Gillian Brown, The Consent of the Governed, (Cambridge: Harvard University Press, 2001), 123-47.
} 
novels of the early republic. Despite the Scottish Enlightenment's emphasis on individual agency, early American novelists consistently portray their female characters as women subject to the power of fascination, immobilized and unable to exercise their agency or take advantage of their educations. ${ }^{152}$ If Charlotte "is fond of "lying softly down" rather than making crucial decisions and thereby exhibits a "terrifying absence of self-direction," so too is Child's Mary, Brown's Harriot, Nathaniel Hawthorne's Priscilla in The Blithedale Romance, his Phoebe in The House of the Seven Gables, or Harriet Beecher Stowe's Madame de Frontignac in The Minister's Wooing. Each of these women "has virtually no say over how her life unfolds." ${ }^{153}$ Living in various renditions of a newly invented American Eden these Eves, like the original, discover that a serpent inhabits the new republic and learn-to their dismay - that it possesses power to provoke their respective falls. ${ }^{154}$ All five women

\footnotetext{
${ }^{152}$ Rust's essay extends the earlier claims of Jay Fliegelman regarding female protagonists, who notes that "the novel of seduction offered a refashioned account of the myth of the Fall and of the culpability of Eden's children. Because her reason is not yet fully formed nor her education complete, the fallen woman in this new myth is far less accountable than she is victimized." See Jay Fliegelman, Prodigals and Pilgrims, (Cambridge: Cambridge University Press, 1982), 88.

${ }^{153}$ Marion Rust, "What's Wrong with Charlotte Temple?" The William and Mary Quarterly 60.1 (2003), http://www.historycooperative.org/cgibin/justtop.cgi?act=justtop\&url=http://www.historycooperative.org/journals/wm/60.1/rust.html, (27 Jan. 2010), para. 1,5 .

${ }^{154}$ The language of Eden pervades early American novels. In Hawthorne's The House of the Seven Gables, Phoebe Pyncheon, like Eve, spends her time in a garden with a "rose-bush [that] looked as if it had been brought from Eden that very summer, together with the mould in which it grew." In Brown's The Power of Sympathy, we discover the tale of Henry, who "saved all his little stock of money to begin the world by himself" like Adam (50) but who discovers, like Adam, that his beloved has been transported by the deceit of a being outside his society. In Child's Hobomok, the villages of Naumkeak and Plymouth constitute "a perfect Eden of fruit and flowers" (1) carved from the wild expanse of untamed nature, and women are responsible not only for "that great tree of sin planted by Eve; but I say they are the individual cause of every branch and bud from that day downwards" (25). Given the extent to which the images and themes of Eden invade the work of early republican writers, critics might be excused if they take the presence of such language for granted. Discussing Catharine Sedgwick's Hope Leslie, for instance, Judith Fetterly suggests that "Sedgwick positions Hope as the original American, Eve preceding Adam in the garden" (497). Fetterly makes this assertion without citing a single instance in which Sedgwick either describes the New World as an edenic paradise or refers to Hope in terms reminiscent of Eve, but this apparent omission of evidence passes largely unnoticed because novelists and critics alike consistently refer to colonial America and the early Republic as a second Eden without identifying specific instances of this connection - an omission whose implications this project seeks to illuminate. See Nathaniel Hawthorne, The House of the Seven Gables, (New York: Signet Classic, 2001), 68;
} 
succumb to the power of fascination, and, in Jay Fliegelman's words, the "daughter of Eden becomes an innocent martyr." Each, like Charlotte, fails to "become an agent, as opposed to an instrument of her destiny," becoming instead "the centerpiece of national identity [...] a complete product of her surroundings," a victim of fascination and her own depravity. ${ }^{155}$

The link between rattlesnake fascination and the Calvinist doctrines subtly present in these novels was only made explicit in 1861, with the publication of Oliver Wendell Holmes's novel, Elsie Venner. When Catalina Venner is bitten by a rattlesnake while pregnant, her daughter- the eponymous main character-inherits the characteristics of the snake, occasionally hissing and assuming distressingly serpentine mannerisms. Holmes's novel is written at the turning-or end-point of American Calvinism, and dramatizes the injustices of the Calvinist doctrines of original sin and predestination. As R. W. B. Lewis has noted, Catalina passes on the rattlesnake poison to her daughter despite the fact that Elsie "was not morally present at the moment of the prenatal accident; she participated in it by no act of will," and Holmes suggests that she can "not be held responsible for the actions which flowed from it" any more than the rest of humanity could be held responsible for Eve's fall. ${ }^{156}$ Elsie Venner makes the connection between rattlesnake fascination and Calvinist doctrines more obvious than earlier texts, but fascination—and the resulting curtailment of moral agency-is a phenomenon present there also.

In The Blithedale Romance, Priscilla confesses that "I never have any free-will;" she has fallen sway to "Hollingsworth's magnetism" and to Westervelt, whose power "over the will and passions of another" Hawthorne symbolically captures in his "stick with a wooden

Brown, The Power of Sympathy, 50; Child, Hobomok, 1, 25; Judith Fetterly, “'My Sister! My Sister!': The Rhetoric of Catharine Sedgwick's Hope Leslie," American Literature 70.3 (1998): 497.

${ }^{155}$ Fliegelman, Prodigals and Pilgrims, 88; Rust, "What's Wrong with Charlotte Temple," para. 10.

${ }^{156}$ R.W.B. Lewis, The American Adam, (Chicago: The University of Chicago Press, 1955), 36. 
head, carved in vivid imitation of that of a serpent." ${ }^{157}$ Phoebe Pyncheon narrowly avoids her cousin Jaffrey's kiss in The House of the Seven Gables, receiving instead that "benevolence, which this excellent man diffused out of his great heart into the surrounding atmospherevery much like a serpent, which, as a preliminary to fascination, is said to fill the air with his peculiar odor.” Escaping Jaffrey Pyncheon's influence, Phoebe instead loses her agency to the merciful Holgrave, who, with a "glance, as he fastened it on the young girl," and a "wave of his hand $[\ldots]$ could complete his mastery over Phoebe's yet free and virgin spirit" but who chooses not to exercise his power. ${ }^{158}$ Similarly, Madame de Frontignac escapes the fascinating pursuit of Aaron Burr in Stowe's The Minister's Wooing. Burr “once asserted that he never beguiled a woman who did not come half-way to meet him,--an observation much the same as a serpent might make in regard to his birds," and de Frontignac seems receptive to Burr's seductive schemes but is saved by Mary Scudder's example of purity and goodness. ${ }^{159}$ Madame de Frontignac, Phoebe and Priscilla fortuitously evade the clutches of Burr, Westervelt and Jaffrey, but their novelistic predecessors do not fare so well; ${ }^{160}$ Child's

\footnotetext{
${ }^{157}$ Nathaniel Hawthorne, The Blithedale Romance, (New York: Penguin Books, 1983), 171, 134, 198, 92. Hawthorne's accounts of fascination are undoubtedly influenced by the work of Mesmer, but they also return to an earlier tradition of "animal magnetism" which is native to North America and which involves actual animals. Mesmer describes animal magnetism primarily as a force allowing one human being to influence the mental and physical state of another, but Hawthorne adapts Mesmer's theroy to American traditions of fascination by incorporating the image of the serpent. As Timothy Powell notes, American authors such as "Charles Brockden Brown self-consciously discussed [their] use of Indian subject matter to derive a uniquely 'American' cultural identity," and Hawthorne's novels, like those of Brockden Brown, deal with a "field of investigation, opened to us by our own country" that "differ[s] essentially from those which exist in Europe." See Timothy B. Powell, Ruthless Democracy, (Princeton: Princeton University Press, 2000), 40; Charles Brockden Brown, Edgar Huntly; or, Memoirs of a Sleep-Walker, eds. Philip Barnard and Stephen Shapiro, (Indianapolis: Hackett Publishing, 2006), 3. For more on Mesmer's influence in New England, see Charles Poyen, Progress of Animal Magnetism in New England, (New York: Da Capo Press, 1982).

${ }^{158}$ Hawthorne, The House of the Seven Gables, 108, 187.

${ }^{159}$ Harriet Beecher Stowe, The Minister's Wooing, ed. Susan K. Harris, (New York: Penguin Books, 1999), 177.

${ }^{160}$ In the American Renaissance Calvinist influence was seriously diminished. By the mid nineteenth century, even staunchly Edwardsean theologians had acknowledged the impact of individual agency, and more liberal denominations had absolved humanity from the effects of original sin entirely. Not surprisingly, then, the
} 
Mary and Brown's Harriot both fall prey to a fascination which leaves them dead, the first spiritually and the second physically.

Harriot Fawcet commits no moral atrocities in The Power of Sympathy, but she suffers an untimely death nonetheless. Sensible of Harrington's finer qualities—-He is extremely generous_-polite_-gay"—she allows herself to contemplate "the pleasures of [wedded] life" and accepts his proposal of marriage. Despite her continued chastity, death claims Harriot when she learns that Harrington is both her lover and her brother; unable to bear the mental and spiritual weight of this revelation, she sinks into the grave. Brown implies that Harriot's death follows as an inevitable consequence of her familial connection to Harrington, that a natural and innate sympathy robs both Harrington and Harriot of their free will in the matter, forcing them into love. To emphasize the involuntary character of their mutual attraction, Brown reminds readers that:

It is said of some species of American serpents, that they have the power of charming birds and small animals, which they destine for their prey. The serpent is stretched underneath a tree-it looks steadfastly on the bird-their eyes meet to separate no more - the charm begins to operate - the fascinated bird flutters and hops from limb to limb, till unable any longer to extend its wings, it falls into the voracious jaws of its enemy: This is no ill emblem of the fascinating power of pleasure. ${ }^{161}$

Harriot could not resist her innocent attraction to Harrington even if she wanted to, nor could Harrington temper his affection for Harriot; their mutually respectful behavior cannot prevent

heroines of Hawthorne and Stowe found education a more adequate tool in overcoming their own innate depravity than did their turn of the century predecessors.

${ }^{161}$ Brown, The Power of Sympathy, 12, 86, 75. If pleasure fascinates Harrington and Harriot in The Power of Sympathy, it likewise forces Eliza Wharton and Major Sanford to choose between a virtuous town life and an exciting city life in The Coquette. Sanford questions Eliza: "Do you intend to give your hand to Mr. Boyer?" She responds: "I do not intend to give my hand to any man at present. I have but lately entered society; and wish, for a while, to enjoy my freedom, in the participation of pleasures, suited to my age and sex." For both Sanford and Eliza, the quest for pleasure leaves them with limited agency. See Hannah Webster Foster, The Coquette, in William Hill Brown, The Power of Sympathy, ed. Carla Mulford, (New York: Penguin, 1996), 144; and Kristie Hamilton, “An Assault on the Will: Republican Virtue and the City in Hannah Webster Foster's The Coquette," Early American Literature 24.3 (1989): 135-51. 
a fall into the serpent's jaws.

Although I have focused on "the question of woman's powerlessness in the new Republic" because scholarship by Rust and Kristie Hamilton, among others, portrays powerlessness primarily as a feminine problem, Harrington's death serves to remind readers that education and virtuous behavior did not protect men in the early United States from fascination any more than it did women. ${ }^{162}$ The focus on feminine agency in the new republic stretches back to the "classical Greek thought" which Linda Kerber reminds us influenced the early republic. Greek women "were understood to lack the civic virtue that enabled men to function as independent moral beings," and the new republic focused on feminine education as a remedy. ${ }^{163}$ But both sexes were susceptible to the power of fascination, and a man's innate virtue did not preserve him from trouble any more than a woman's virtuous education; indeed, in Charles Brockden Brown's Wieland, Clara proves less vulnerable to the seemingly supernatural voice of Carwin than her brother, Theodore. Though Clara hears an apparently disembodied voice speaking from her closet command her to "Hold! Hold!" she "was able to deliberate and move" purposefully against that command. When, however, the same voice commands Theodore to "render me thy wife" as a sacrifice, he is "dazzled. [His] organs were bereaved of their activity." In Wieland, Theodore acts under the fascinating

\footnotetext{
${ }^{162}$ Hamilton, "An Assault on the Will: Republican Virtue and the City in Hannah Webster Foster's The Coquette," 135. Poe later reverses the typical presentation of fascination in portrayal of "The System of Doctor Tarr and Professor Fether." In the insane asylum under the care of Tarr and Fether, Monsieur Maillard remarks that "we could not do at all without the women; they are the best lunatic nurses in the world; they have a way of their own, you know; their bright eyes have a marvelous effect;--something like the fascination of the snake, you know." Poe, like the editorialists who warned of the dangers of female suffrage, transforms women from objects of fascination to agents who charm men into docility. See Edgar Allan Poe, Collected Works, ed. Thomas Ollive Mabbott, (Cambridge, MA: Harvard University Press, 1978), 1016.

${ }^{163}$ Linda K. Kerber, “Separate Spheres, Female Worlds, Woman's Place: The Rhetoric of Women's History,” The Journal of American History 75.1 (1988): 18.
} 
influence of Carwin's voice, from which rebellion "was impossible;", 164 in The Power of Sympathy, Harrington's innate virtue and education fail to direct his agency properly, allowing him to fall in love with his sister; and in Hannah Webster Foster's The Coquette, "the male seducer [Sanford], admits that he is not free to do as he wishes." ${ }^{165}$ Male characters in novels of the early republic clearly experience restrictions on their agency in much the same manner as female characters, and if - unlike their female counterparts—-they do not end up pregnant, they do—-like their female counterparts—frequently end up dead (Harrington, Wieland) or cast out from society (Sanford).

Authors in the early republic consistently tout the virtues of education and apparently reject Calvinist notions of original sin and predestination, but the characters in their novels rarely appear to experience the benefits and guidance of education when faced with paralyzing moral dilemmas. In the preface to his novel, Hill Brown describes The Power of Sympathy as an exposition on "the Advantages of FEMALE EDUCATION" and posits that the "proper cultivation of her intelligent powers" will allow a woman to become virtuous and accomplished. He presents "the human mind as an extensive plain" which "the river [of knowledge] that should water it" can make fruitful, eventually blooming "into a general efflorescence" if cultivated within the "high banks" of moral rectitude. Brown's belief in the efficacy of education notwithstanding, Harriot's presumably adequate education and demonstrably virtuous behavior do not save her from an incestuous entanglement with her brother Harrington or help her deal with it effectively. ${ }^{166}$ As Elizabeth Maddock Dillon notes,

\footnotetext{
${ }^{164}$ Charles Brockden Brown, Wieland, ed. Jay Fliegelman, (New York: Penguin Books, 1991), 97, 98, 190, 193.

${ }^{165}$ Hamilton, “An Assault on the Will: Republican Virtue and the City in Hannah Webster Foster's The Coquette," 137.

${ }^{166}$ Brown, The Power of Sympathy, 7, 29, 22. Even if readers question Harriot's education, they cannot question Harrington's; his susceptibility to the Power of Sympathy demonstrates education's inadequacy. In addition,
} 
"the central trauma of the novel—unwitting sibling incest-is one that could not have been

avoided with increased deliberation, increased virtue, or increased reading of novels."167

Education is powerless to prevent the problems of the republic, and the subsequent suicide of

Harrington suggests that education also fails to prepare citizens to cope appropriately with

the moral dilemmas it cannot eliminate.

The character Harrington is both advocate and embodiment of the new, Harringtonian

republic, and his suicide is a less than ringing endorsement of the nation's future. ${ }^{168}$ Through

both Charlotte Temple and Eliza Wharton of The Coquette received excellent educations, but the education of neither enabled her to avoid immoral masculine advances.

${ }^{167}$ Elizabeth Maddock Dillon, "The Original American Novel, or, The American Origin of the Novel," in A Companion to the Eighteenth-Century English Novel and Culture, eds. Paula R. Backscheider and Catherine Ingrassia, (Malden, MA: Blackwell Publishing, 2005), 253.

${ }^{168}$ Influential critics like Elizabeth Maddock Dillon and Paul Giles now challenge "the neat conjunction of nation and novel that has guided critical work" (Dillon 235) on earlier novelists such as Hill Brown. Rather than interrogate Brown and others "as representative of a particularly American set of concerns regarding nationformation," Dillon argues that "the literary genre of the novel and the political form of the nation remain in tension and dialogue with colonialism, the global market, and imperialism" (251). Dillon's emphasis on international content almost suggests that novels of the early United States fail to distinguish themselves from contemporary British texts except in geographical terms, a position in keeping with the emerging critical emphasis on transatlantic studies but one which effaces the distinctions which authors in the new United States consciously strove to draw between their own work and that of their British peers. See Dillon, "The Original American Novel, or, The American Origin of the Novel," 235, 251. While American literary scholarship can and must engage "the specter of postcolonialism, where the oratory of independence is forced unwillingly to recognize how it is bound inextricably to voices that are constitutionally weak," that engagement should not allow the nationalistic rhetoric that characterizes early American novels and other postcolonial texts to be wholly subsumed by the language of imperialism. Our own interest in the promotion of globalism must not be allowed to efface the explicitly nationalistic aims of authors in the early republic. See Paul Giles, "Antipodean American Literature: Franklin, Twain, and the Sphere of Subalternity," American Literary History 20.1-2 (2008): 45.

As Benedict Anderson argues, "nationality, or as one might prefer to put it in view of that word's multiple significations, nation-ness, as well as nationalism, are cultural artefacts of a particular kind. To understand them properly we need to consider carefully how they have come into historical being, in what ways their meanings have changed over time, and why, today, they command such profound emotional legitimacy." This essay investigates the ways in which American nationalism came into being from the perspective of a theological tradition unique to the United States and argues that to read these novels strictly as part of an international or colonial discourse is to efface the central concern of the writers, whose plots revolve around the consequences of abandoning Calvinist precepts for a liberal belief in the redemptive powers of education-a uniquely American concern. The elision of nationalistic positions from a reading of early American novels would be akin to reading Paradise Lost without understanding it as a comment on the English Civil War; while you can profitably read Paradise Lost as an epic poem and early American novels as colonial productions without historicizing them, to do so is, in effect, to ignore the very reason that the texts were written. I conclude, with Anderson, that the "reality is quite plain: 'the end of the era of nationalism,' so long prophesied, is not remotely in sight." Notwithstanding the current nationalistic rhetoric produced by the exportation of American 
him Brown examines the American experiment in republicanism; by "considering [the path of] a single soldier" Brown determines the ultimate destination of "an army composed of a great number of men, mov[ing] slowly on at a distance. ${ }^{, 169}$ When Harrington agrees to marry the lower-class Harriot, he uses his agency to embrace still-emerging social fluidity while relying on innate virtue and proper education to produce a morally acceptable outcome in a new and unknown social setting. The problem for Harrington and most other characters in

jobs to other countries, this is perhaps more true even in literature than in practical politics; inasmuch as we conceive of the nation as "an imagined political community" rather than a real state, nationalism becomes an integral component of novels that present their imagined communities in explicitly political terms. See Benedict Anderson, Imagined Communities, (New York: Verso, 1991), 4, 3, 6.

If the "insistently domestic and familial content" of the United States' early novels seems a reason to treat them as a product of British, imperial, transatlantic discourse as Dillon and Giles suggest, their collective concern with republican class structures and religious innovations unique to the United States provide a reason for critics to claim them as American texts. Indeed, when Brown's Mrs. Holmes describes the "ridicule sometimes leveled at those who are called learned ladies" as a "transatlantick idea," she uses the term almost as a pejorative, carefully distinguishing between the false portrayals of an "English Novel or Magazine" and the very real and virtuous "American ladies of this class, who [...] we know to be justly celebrated as ornaments to society, and an honour to the sex." While Brown's discussion of feminine education liberally references both English and continental literature throughout, he also takes pains to emphasize that any discussion of an American education in republican virtue is exactly that-an American education. Even Brown's use of the word "transatlantick" hints at a cultural separation between England and America, an acknowledgment that the ocean creates a barrier which must be overcome. In that sense, the OED's first documented appearance of the word in 1779 assumes additional significance. Only as the American Revolution drew to a close did it become politically necessary to label ideas which both sides of the ocean agreed upon as "transatlantic." Prior to 1779, transatlanticism might have been the status quo; after 1779, writers like Brown use the word to signal a European diversion from American norms. See Dillon, "The Original American Novel, or, The American Origin of the Novel," 236; Brown, The Power of Sympathy, 56.

Early American disdain for the transatlantic influence which Dillon and Giles advocate aside, there are very real weaknesses in the traditional conjunction between the seduction narrative and the early republic. By enumerating the similarities between the incest-ridden plot twists of Wells Brown's The Power of Sympathy and Daniel Defoe's Moll Flanders, Dillon weakens an often incestuous seduction narrative's position "as the basis for a critical account of the allegorical relation between the US nation and the early novel" (253). Proponents of The Power of Sympathy's nationalism cannot claim that the novel's examination of incest and seduction differs substantially from British texts. In this sense, then, Dillon is within her rights to dismiss the "nation-seduction allegory" (253), especially because the foundation upon which the association lies falls apart in light of Rust's reminder that so-called seduction narratives frequently do not contain an identifiable or central instance of seduction. The feminine protagonist in early American novels often "does not so much surrender her chastityin the sense of giving up under duress something she values - as lose track of it altogether, along with every other aspect of her being" (Rust para 4). The seduction-nation allegory lacks credibility, if only because early American novels frequently lack convincing seduction scenes. This rejection of the nation-seduction allegory does not preclude a nation-novel conjunction, however; it only necessitates a new framework: that of fascination. See Dillon, "The Original American Novel, or, The American Origin of the Novel," 253; Rust, "What's Wrong with Charlotte Temple?" para. 4.

${ }^{169}$ Brown, The Power of Sympathy, 32. 
novels of the period is that education fails. The enlightened use of reason does not protect men like Harrington from incest, and education certainly does not protect women like Charlotte Temple from seduction-it is her school tutor, La Rue, who urges her to succumb to her lover! As Eric Wolfe explains, in "republican politics, the possibility of social unity [was] founded not upon the overt coercion of monarchical power but upon the more 'natural' influence of oratorical persuasion" in education. ${ }^{170}$ Theoretically, freedom from the constraints of Calvinist doctrines would allow citizens to rely on education as a natural guide to virtue. Yet education always fails, and its failure leaves no safeguard for the citizens of a secular republic. Having rejected Calvinist notions of predestination and depravity, they cannot rely on God to unconditionally prosper and protect them. But why does education fail in these novels? Why does the force of fascination overcome moral training and betray republican agents into untenable situations?

In reading Wieland, Jane Tompkins suggests that these novelistic critiques of the republican social order function as "a plea for the restoration of civic authority in a postRevolutionary age," but I would suggest that her emphasis on civic unrest does not properly account for the religious instability of the new nation. Wieland and other novels portraying the failure of education do offer "a direct refutation of the Republican faith in men's capacity to govern themselves without the supports and constraints of an established social order," but that missing social order is as much religious as it is political. ${ }^{171}$ The victims of fascinationthose who suffer from this disruption in the social order-typically belong to a heterodox sect or lack religion altogether. Theodore Wieland's search "for the revelation of [God's]

\footnotetext{
${ }^{170}$ Eric A. Wolfe, "Ventriloquizing Nation: Voice, Identity, and Radical Democracy in Charles Brockden Brown's Wieland," American Literature 78.3 (2006): 439.

${ }^{171}$ Jane P. Tompkins, Sensational Designs, (Oxford, Eng: Oxford University Press, 1985), 61, 49.
} 
will" begins with the singular religious beliefs of his father, "a fanatic and a dreamer" and ends with "such absolute possession of my mind" by an outside influence that he slaughters his own wife and children. ${ }^{172}$ The Conant family in Hobomok live in Naumkeak rather than Plymouth because Mr. Conant cannot support the Plymouth elders, and Mary's Anglican faith distances her even further from her already estranged family. Charlotte Temple appears religiously orthodox, but after "she descend[s] from the church" in the novel's first page, Montraville makes her "forget [her] duty to [her] Creator," and she neglects "the morning sacrifice of prayer and praise;" having once left the church, she never darkens God's doorway again. ${ }^{173}$ The only mention of religion in The Power of Sympathy refers to "the clergy as so many Philosophers, the Churches as Schools, and their Sermons as Lectures for the improvement and information of the audience," a realization of William Baker's nightmare prediction that Paine and Jefferson would transform the nation's churches into temples of reason, turning houses of God into mere meeting places for educational lectures. ${ }^{174}$ The victims of fascination may practice an alternative religion, neglect God completely or only incorporate reason and philosophy into religion, but they all suffer for departing from orthodox paths.

In her Coquette, Foster illustrates the consequences of abandoning Calvinist orthodoxy for reasonable religion - the seemingly inevitable result of establishing a republic_-more explicitly than her contemporaries. When, having rejected Sanford and having been rejected by Boyer, Eliza Wharton writes to Lucy Sumner asking her "to share

\footnotetext{
${ }^{172}$ Brown, Wieland, 187, 13, 189.

${ }^{173}$ Susanna Rowson, Charlotte Temple, ed. Ann Douglas, (New York: Penguin Books, 1991), 3, 49.Though a tomb for Charlotte Temple now stands in New York's Trinity Churchyard, Susanna Rowson does not place the burial in a church-only at a grave of unknown location.

${ }^{174}$ Brown, The Power of Sympathy, 55.
} 
and alleviate my cares," Lucy replies with the following counsel: "Let reason and religion erect their throne in your breast; obey their dictates and be happy." Up until Lucy advises her to act according to "reason and religion," Eliza seems to have trusted in religion alone, in an ineffable, deterministic God who controlled her fate:

If wand'ring through the paths of life I've run; And backward trod the steps, I sought to shun, Impute my errors to your own decree; My feet were guilty, but my heart was free. ${ }^{175}$

But after Lucy's counsel inserts reason into Eliza's life, “a new scene [opens] upon us" in which she increasingly relies upon "the dictates of [her] own judgment" and reason, rationalizing her association with Major Sanford by the justification that "since he is married; since his wife is young, beautiful and lovely, he can have no temptation to injure me." ${ }^{\prime 16}$ This exercise in reason results in repeated visitations from Sanford, and those visitations leave Eliza a pregnant, fallen woman.

Even as Eliza's reason facilitates her fall, Foster reassures readers that her increasing abandonment of predestinarian notions does not determine Eliza's downfall in and of itself; rather, Eliza's reliance on reason only becomes dangerous when she simultaneously ceases to believe in the degeneracy of human nature. Early in the novel, Eliza notes her own "natural disposition [toward] a participation of those pleasures" which fascinated and destroyed both Harrington and Harriot. After receiving Lucy's counsel, Eliza seems either to forget her own nature or at least to think that it has changed; she certainly believes in Sanford's capacity to change his own nature. She writes to Lucy that "he wept! Yes, Lucy, this libertine; this man

\footnotetext{
${ }^{175}$ Foster, The Coquette, 190-92.

${ }^{176}$ ibid, 199, 204-05.
} 
of pleasure and gallantry wept! I really pitied him from my heart." ${ }^{177}$ Eliza's pity implies a belief that Sanford has rejected his life as a "man of pleasure," and her identification of that quality as something apart from herself likewise suggests that she no longer believes herself naturally disposed to pleasure. But Sanford has not changed his nature and neither has Lucy—their subsequent affair demonstrates the immutability of their "natural disposition" toward pleasure. The problem with Lucy's counsel is that a rational and republican religion carries with it a belief in the power of education to change human nature. Acting rationally is fine as long as reason acknowledges the inherently degenerate state of human nature. Eliza's companion, Julia Granby, who "is all that I once was" before this "new era of life" and possesses a mind "well cultivated" by reason, sees through Sanford's scheme because she understands "how prone to error is the human mind" and can read Sanford's "vices in his very countenance." Granby realizes that neither marriage nor education nor reason have “changed [Sanford's] disposition" to do evil and tries to convince Eliza of the same, but to no avail. ${ }^{178}$ Eliza's reason and her belief in the ability of education to overcome the degeneracy of human nature lead her to trust both herself and Sanford too far.

Education fails in novels of the early republic because the authors still believe in the "wickedness and depravity of the human heart" even though their characters do not. ${ }^{179}$ Does any reader really believe Clara Wieland's claim that "if Wieland had framed juster notions of moral duty, and of the divine attributes; or if I had been gifted with ordinary equanimity or foresight, the double tongued-deceiver would have been baffled and repelled"? ${ }^{180}$ Could

\footnotetext{
177 ibid, 113, 201.

178 ibid, 192, 191, 207, 194, 202, 209.

${ }^{179}$ Brown, The Power of Sympathy, 37.

${ }^{180}$ Brown, Wieland, 278.
} 
further education have changed and saved Harrington? Harriot? Eliza? Sanford? Mary Conant? No- - these early novelists place their protagonists in nearly impossible situations whose negative outcomes seem foreordained, the inexorable result of a human depravity which they do not recognize. Even Charlotte Temple, whose "mind is not depraved" and who Rowson describes as "pure and innocent by nature," possesses a natural "inclination" to elope with her seducer. Though Charlotte cannot imagine Montraville betraying her trust, Rowson knows that "a man may smile, and smile, and be a villain"; she knows that "the heart is deceitful" and wicked. ${ }^{181}$ Even the strictest Calvinist theologians of the eighteenth-century United States acknowledged human agency, but the doctrines of original sin and total depravity were not popularly abandoned until much later.

While Ann Douglas asserts that "the vitiation and near-disappearance of the Calvinist tradition" commences only around 1820, orthodox Calvinists in the late eighteenth century had already begun to accept the necessity of individual moral agency in the new republic. ${ }^{182}$ Timothy Dwight, Jonathan Edwards's grandson and theological heir, conceded education's power "to persuade men to become virtuous; or, in other words, to persuade them with the heart to believe and obey the Gospel," implicitly recognizing that men could act virtuously despite their inherent degeneracy. Dwight did not, however, suggest that education and agency alone could overcome corrupt human nature; every man still needed to "discern the nature, and extent, of his guilt; the strength of his evil propensities; the obstinacy of his unbelief, and impenitence; the uniformity of his disobedience; the completeness of his ruin;

\footnotetext{
${ }^{181}$ Rowson, Charlotte Temple, 66, 24, 47, 76, 93.

${ }^{182}$ Ann Douglas, The Feminization of American Culture. New York: The Noonday Press, 1998.
} 
his exposure to final condemnation; and his utter indisposition to return to God." ${ }^{, 183}$ Even Dwight's relatively liberal successor, Nathaniel Taylor, who, as Douglas Sweeney notes, "changed the face forever of New England Calvinism," and whose ministry divided Edwardsian theologians, wrote in 1828 that "the entire moral depravity of mankind is by nature." ${ }^{184}$ Not until the middle of the nineteenth century did Horace Bushnell's claim that "the child is [not] to grow up in sin, to be converted after he comes to a mature age; but that he is to open on the world as one that is spiritually renewed" gain substantial ground among formerly Calvinist congregations. ${ }^{185}$ Notwithstanding the Lockean rhetoric of national leaders, most citizens of the late eighteenth-century and early nineteenth-century republic remained committed to notions of original sin and human depravity.

In this context, the novels of Brockden Brown, Hill Brown, Child, Foster, and Rowson emerge as authorial attempts to imagine an as yet unknown reality in which the collective consciousness of human depravity has vanished, not depictions of a society in which this had already happened. In Wieland, The Power of Sympathy, Hobomok, The Coquette and Charlotte Temple, we see projections of the Edenic myth onto the United States' uncertain future as an experiment in secular-or at least postsectarianrepublicanism. As Adam and Eve receive an education from God which forbids the fruit but does not mention the presence of a dangerous tempter, so too do the novelist's imagined

\footnotetext{
${ }^{183}$ Timothy Dwight, Theology; Explained and Defended, in a Series of Sermons, $10^{\text {th }}$ ed, Vol. 4, (New Haven: T. Dwight \& Son, 1839), 247, 174.

${ }^{184}$ Douglas A. Sweeney, Nathaniel Taylor, New Haven Theology, and the Legacy of Jonathan Edwards, (Oxford: Oxford University Press, 2003), 3; Nathaniel Taylor, "Concio ad Clerum: A Sermon," in Sydney E. Ahlstrom, ed., Theology in America, (Indianapolis: Hackett, 1967), 214. Sweeney explains that Taylor's emphasis on the natural —as opposed to the willful, moral—degeneracy of humanity is actually a rejection of the conservative Calvinist belief in the immediate transmission of original sin for a belief in the mediate imputation of Adam's guilt. See Sweeney, Nathaniel Taylor, New Haven Theology, and the Legacy of Jonathan Edwards, 69-90.

${ }^{185}$ Horace Bushnell, Christian Nurture, (New York: Charles Scribner, 1861) 10.
} 
republican citizens receive moral imperatives in their education without an enduring understanding of the dangers inherent in dealing with depraved human beings. As Adam and Eve find their initial resolutions to obey God ineffective when confronted by the serpent's fascinating influence, so too do the novelist's imagined republican citizens find themselves powerless to act virtuously when confronted with moral dilemmas. This fascinated powerlessness defines the protagonists of the early American novel and looms large as the potential fate of a nation.

While the Douglas-Tompkins debates have turned sentiment into the defining characteristic of these early American seduction novels, their plots revolve around questions of fascination and human depravity as much as they do concerns of sympathy and affect. Indeed, readers of The Power of Sympathy: or, The Triumph of Nature have too long elided the second half of the novel's title. By choosing to fixate on the volume's treatment of sympathy and sentiment, they have erroneously assumed that the or conjoining the first and second halves of the title serves as an indication of correlativity rather than an alternative between two competing forces. There is, of course, a sense in which the terms sympathy and nature can be used synonymously: the OED defines sympathy as an "affinity between certain things, by virtue of which they attract each other," and two of the OED's twenty-seven different definitions for nature describe that force as "sexual desire" or a "natural feeling or affection, especially that between parent and child." Harriot, the most obvious victim of both sympathy and nature in Brown's book, even acknowledges that she feels "the endearments of the lover" even as she begs that lover, Harrington, to "be him, on whom I could never yet call by the tender, the endearing title of parent." She undeniably relates to Harrington both sexually and filially, yet I would argue that Brown's use of the term nature alludes not to an 
affinity between Harriot and Harrington but to the OED's more widely applicable and Calvinistic definition of human nature: "A fallible character or disposition [...] this impulse as contrasted with the perceived influence of God on man.” Thus, when Mrs. Holmes writes to Myra that Harriot's downfall comes through "the operation of NATURE—and the power of SYMPATHY!" she is not repeating herself but suggesting that Harriot's fallible, depraved human nature has allowed the filial and sexual love encapsulated in the word sympathy to overcome both her reason and education. ${ }^{186}$

Sympathy only causes Harriot's downfall because she possesses an unregenerate nature whose influence cannot be curtailed by educational enlightenment. Education cannot prevent her incestuous preference for Harrington, and without an authoritarian deity to guide her steps, she falls a helpless victim to the fascinating power of pleasure. For Harriot and Harrington, as for other citizens of the early United States, fascination — an inability to act, much less act virtuously_looms as the inevitable consequence of abandoning Calvinist doctrines. The republic appears to offer social mobility and increased choice, but early American novels warn of fascination's power in the absence of Calvinist strictures.

\section{The Conclusion of the Whole Matter: Vanity of Vanities, All is Vanity}

Both the founders and the citizens of the United States recognized the edenic character of natural law, the Constitution, and the new republic. While some-and especially Masons-saw this new Eden as the precursor to a postmillennial future, most of the nation's inhabitants seemed more interested in comparing the republic's prospects to the past; they foresaw another Fall and described the nation as an antitype of the original, primitive Eden

\footnotetext{
${ }^{186}$ Brown, The Power of Sympathy, 86-87, 63.
} 
from which Adam and Eve were expelled. ${ }^{187}$ These pessimists could not agree on the future cause of a national Fall, but deteriorating race relations and religious declension were the problems most frequently identified as potentially fascinating and serpentine sources of strife. They were sure that the nation would eventually succumb to one moral hazard or another, and the internecine bloodshed of the Civil War fulfilled those expectations as brother fought against brother in the same way that Cain and Abel had battled on Eden's outskirts. The founding of the United States was the most visible, successful attempt to establish Eden in American history; but it was also the end of the widespread edenic aspirations that had characterized much of seventeenth and eighteenth century New England religious culture. Never again would such a large portion of the mainstream United States population display a sustained interest in the invention - whether by discovery or creationof a second Eden. By the end of the eighteenth century the New England pursuit of Eden had, like Solomon at the end of Ecclesiastes, come to "the conclusion of the whole matter" and found that "[v]anity of vanities . . all is vanity."

\footnotetext{
${ }^{187}$ Steven Bullock disagrees as to the relative balance of Masons who believed in a coming, edenic Millennium and more skeptical citizens worried about the dissolution of religion; he argues that "even among the most evangelical denominations, large numbers of believers came to view Masonry as what one brother termed, "the herald of universal peace and tranquillity,' the harbinger of the coming millennium." But even if the nation did, as he suggests, collectively embrace Masonic millennialism in the years after the Revolution, the republic's relationship to the fraternity changed dramatically for the worse as a result of William Morgan's mysterious disappearance in 1826 and the accompanying "vigorous religious attack on Masonry." See Bullock, Revolutionary Brotherhood, 164.

${ }^{188}$ Ecclesiastes 12:13, 8.
} 


\section{APPENDIX A}

\section{A COMPENDIUM OF NEW ENGLAND FLORA AND FAUNA CATALOGUED IN ACCOUNTS OF THE 1620s AND 1630s}

Sources: William Alexander, An Encouragement to Colonies, (London: William Stansby, 1624), 17-19, 35-36; G. Mourt, Relation, (London: 1622), 2-3, 13, 21-22, 25, 28, 34, 44-45, 62; William Wood, Nevv Englands Prospect, (London: Tho. Cotes, 1634), 13-36; John Smith, "A Description of New England," in Captain John Smith: Writings with Other Narratives of Roanoke, Jamestown, and the First English Settlement of America, Ed. James Horn, (New York: Library of America, 2007) 144-145, 148, 150-51; William Morrell, NewEngland, (London: I. D., 1625), 15-16; Francis Higginson, Nevv-Englands Plantation, (London: T. \& R. Cotes, 1630), B2-C3, D2; Thomas Morton, New English Canaan, (Scituate: Digital Scanningy, 1999), 56-88; Council for New England, An Historicall

Discoverie and Relation of the English Plantations in Nevv England, (London: 1622), D3.

\section{$\underline{\text { Plants }}$}

1. Alexanders

2. Alkermes (Bugs erroneously thought to be berries; Smith, 145)

3. Anise

4. Balm

5. Barley

6. Bay

7. Bean

8. Bilberry

9. Black Grape

10. Brooklime

11. Calamus

12. "Caruell" (Herb? Mourt 22; Higginson B3)

13. Corrance (berry? Possibly an alternate spelling of 'currants'? Higginson B3)

14. Cucumber

15. Currant

16. Damask rose

17. Flax

18. Gooseberry

19. Gourd

20. Grass

21. Ground-nut

22. Hemp

23. Hindberry

24. Holly

25. Honeysuckle

26. Hurtleberry

27. Leek

28. Liverwort 
29. Maize

30. Marjoram

31. Musk rose

32. Muskmelon

33. Myrtle

34. Onion

35. Pea

36. Pennyroyal

37. Pumpkin

38. Purslane

39. Rape

40. Raspberry

41. Raspis

42. Red grape

43. Red rose

44. Rye

45. Wild Sarsaparilla

46. Saxifarilla (Saxifrage? Wood, 13)

47. Saxifrage

48. Smalnut (Higginson B3)

49. Sorrell

50. Strawberry

51. Thyme

52. Tobacco

53. Treackleberry (Wood, 14)

54. Violet

55. Watercress

56. Wheat

57. White grape

58. White rose

59. "a kind of red Wineberie" (Alexander 35)

60. Winter savory

61. Yarrow

$\underline{\text { Trees }}$

1. Alder

2. Ash

3. Aspen

4. Black oak

5. Black plum

6. Birch

7. Cedar

8. Cherry

9. Chestnut

10. Cypress 
11. Elder

12. Fir

13. Hawthorn

14. Hazel

15. Hornbeam

16. Juniper

17. Maple

18. Mulberry

19. Osier

20. Palm

21. Pine

22. Plane

23. Red beech

24. Red oak

25. Red plum

26. Sassafrass

27. Spruce

28. Sumac

29. Sycamore

30. Walnut (4 sorts; Morton, 57)

31. White beech

32. White oak

33. Yellow plum

$\underline{\text { Land Animals }}$

1. Aroughcond (animal, Smith 151)

2. Bear

3. Beaver

4. Black fox

5. Elk

6. Fallow deer

7. Ferret

8. Flying squirrel

9. Gray fox

10. Gray squirrel

11. Hare

12. Lion

13. Lynx

14. Marten

15. Moose

16. Muscat (probably an alternate spelling of muskrat?; Morrell 15)

17. Muskrat

18. Otter

19. Porcupine

20. Rabbit 
21. Raccoon

22. Red deer

23. Sable

24. Skunk

25. Small squirrell

26. Wildcat

27. Wolf

$\underline{\text { Flying Animals }}$

1. Bittern

2. Black Duck

3. Blue Teal

4. Brant-goose

5. Cormorant

6. Crane

7. Crow

8. Culver

9. Curlew

10. Dabchick

11. Eagle

12. Goshawk

13. Gray duck

14. Gray goose

15. Green Teal

16. Gripe

17. Hawk (5 sorts-Morton 66)

18. Heath-cock

19. Heron

20. Hummingbird

21. Kite

22. Knot

23. Lark

24. Loon

25. Madge

26. Mallard

27. Mew

28. Oldwife

29. Partridge

30. Pheasant

31. Pied duck

32. Pigeon

33. Plover

34. Quail

35. Rattlesnake

36. Raven 
37. Reindeer

38. Sandpiper

39. Screech owl

40. Sea-lark

41. Seagull

42. Sheldrake

43. Snipe

44. Sparrowhawk

45. Speckled owl

46. Stare

47. Swallow

48. Swan

49. Tassel

50. Thrush

51. Turkey

52. Turtle

53. Turtledove

54. White goose

55. Widgeon

56. Woodcock

\section{Marine Animals}

1. Alewife

2. Bass

3. Bream

4. Carp

5. Catfish

6. Clam

7. Cockle

8. Cod

9. Cole (Fish? Wood 32; Smith 151)

10. Crab

11. Crayfish

12. Cunner

13. Cusk

14. Eel

15. Freel (Morton 88)

16. Frost-fish

17. Grampus

18. Greedigut (Fish? Wood 32)

19. Haddock

20. Hagfish

21. Halibut

22. Hake

23. Herring 
24. Lamprey

25. Lampron

26. Ling

27. Lobster

28. Mackerel

29. Mullet

30. Mussel

31. Othus (Shellfish, Mourt 62)

32. Oyster

33. Perch

34. Periwig

35. Pike

36. Pilchard

37. Pinack (fish, Smith 151)

38. Porpoise

39. Razorfish

40. Roach

41. Salmon

42. Seal

43. Shad

44. Shark

45. Skate

46. Skote (Skate? Mourt 21)

47. Smelt

48. Sturgeon

49. Tench

50. Thornback

51. Tortoise

52. Trout

53. Turbot

54. Whales

55. Whelk

\section{$\underline{\text { Minerals }}$}

1. Alum

2. Brimstone

3. Chalk

4. Clay

5. Copper

6. Crystal

7. Gold

8. Graphite

9. Gravel

10. Iron

11. Lead 
12. Limestone

13. Loadstone

14. Marble

15. Salt

16. Sandstone

17. Seacoal

18. Silver

19. Slate

20. Smooth-stone (type of stone; Higginson, B2)

21. Tin

22. Vermillion 


\section{APPENDIX B}

\section{A COLOR-CODED ETYMOLOGICAL AND SYLLABIC ANALYSIS OF THREE PSALTERS}

Words derived from Old English are colored green

French are colored yellow

Anglo-Norman are colored red

Hebrew are colored dark green

Latin are colored

Norse are colored

Scandinavian are colored purple

Dutch are colored pink

German are colored turqoise

Greek are colored gray

\section{Sternhold \& Hopkins}

8

O God our Lord how wonderful are thy works euery where?

Whose fame surmount in dignitie aboue the heauẽs cleare.

Euẽ $n$ by the mouths of sucking babes yu wilt cõfoũd thy foes:

For in these babes thy might is sene, thy graces they disclose.

And when I see the heauẽs high, the works of thine own hand,

The sunne, the mone, and all the starres in order as they stand:

What thing is man, Lord, thinke I then, that yu doost him remẽber?

Or what is mans posteritie that thou doost it consider?

For thou hast made him little lesse then angels in degree:

And thou hast crown'd him also with glory and dignitie.

Thou hast preferd him to be Lord of al thy workes of wonder,

And at his fete hast set al things, that he should keep the under.

As shepe, and neat, and al beastes els that in the fieldes do fede:

Foules of the ayre, fish in the sea, and al that therein brede.

Therefore must I say once again, O God, that art our Lord:

How famous \& how wỡderful, are thy workes through ye world?

\section{Total: 192}

Polysyllabic: 29

\section{Sternhold \& Hopkins}

\section{1}

I Trust in God, how dare ye then, say thus my soule vntil:

Flee hence as fast as any foule, and hide you in your hil? 
Behold ye wicked bẽd their bowes, \& make their arrowes prest to shote in secret \& to hurt ye soũd \& harmles brest.

Of worldly hope al stayes wer shrũke, \& clerely brought to nought

Alas the iust and rightuous man, what euil hath he wrought?

But he that in his temple is, most holy and most hye:

And in the heauens hath his seat, of royal maiestye:

The poore and simple mans estate, considereth in his mynde:

And searcheth out ful narowly, the maners of mankynde.

And with a chereful countenance, the righteous man wil vse:

But in his hart he doth abhorre, al such as mischief muse.

And on the sinners casteth snares, as thicke as any rayne:

Fire \& brimstone, \& whirlwindes thick, apointed for their payne.

Ye see then how a righteous God, doth righteousnes embrace:

And to the iust and vpright men, shewes forth his pleasant face.

\section{Total: 178}

Polysyllabic: 38

\section{Sternhold \& Hopkins}

12

HElpe Lord, for good and godly men, do perish and decay: And faith \& truth frõ worldly men, is parted cleane away.

Who so doth wt his neighbour talk, his talk is al but vaine:

For euery man bethinketh how, to flatter, lye and faine.

But flatteryng and deceitful lippes, and tonges that be so stout:

to speak proud words \& make great brags, y lord soone cut the out. For they say stil, we wil preuayle, our tonges shal vs our tongs are ours, we ought to speak, what lord shal vs controll?

But for the great complaint and cry, of poore and men opprest:

Arise wil I now (saith the lord) and them restore to rest.

Gods worde is lyke to siluer pure, that from the earth is tride:

And hath no lesse then seuen tymes, in fyre bene purifide.

Now since thy promise is to helpe, Lord keepe thy promise then:

And saue vs now and euermore, from this il kind of men.

For now the wicked world is full of mischiefes manifold:

When vanitie with mortal men, so highly is

\section{Total: 186}

Polysyllabic: 32

\section{Sternhold \& Hopkins}

23-W.W. 
The Lord is onely my support, and he that doth me fede:

How can I then lacke any thyng, wherof I stand in nede?

He doth me fold in coats most safe, the tender grasse fast by:

And after driues me to the streames, which runne most pleasantly

And when I fele my selfe nere lost, then doth he me home

Conducting me in his right pathes, euẽ for his own names sake.

And though I wer euẽ at deathes dore, yet would I feare none ill:

For with thy rod and shepherdes crooke, I am comforted stil.

Thou hast my table richly deckt, in despite of my fo:

Thou hast my head with baulme refresht, my cup doth ouerflo.

And finally while breath doth last, thy grace shal me defend:

And in the house of God wil I my life for euer spend.

\section{Total: 145}

\section{Polysyllabic: 19}

\section{$23-$ T.S.}

My shepherd is the lyuing Lord, nothing therfore I need:

In pastors fayre, with waters calme, he sets me for to fede.

He did conuert \& glad my soule, \& brought my mind in frame,

To walke in pathes of rightuousnes, for his most holy name.

yea though I walke in vale of death, yet will I fear none il:

Thy rod, thy staff doth comfort me, and thou art with me stil.

And in the presence of my foes, my table thou shalt spred:

Thou shalt (O Lord) fil ful my cup, And eke annoynt my head.

Through all my life thy fauour is, so frankly shewde to me:

That in thy house for euermore, my dwelling place shalbe.

\section{Total: 120}

Polysyllabic: 18

\section{Sternhold \& Hopkins}

\section{5}

I Lift mine hart to thee, my God \& guide most iust, now suffer me to take no shame, for in thee do I trust.

Let not my foes reioyce, nor make a scorne of me,

and let them not be ouerthrowen that put their trust in thee.

But shame shal them befal, which harme them wrongfully:

Therfore thy pathes \& thy rightwayes, vnto me Lord descry.

Direct me in thy truth, and teach me I thee pray:

Thou art my God and sauiour, on thee I wayt alway.

Thy mercyes manifold, I pray thee Lord remember:

And eke thy pitie plentiful, for they haue ben for euer. 
Remember not the fautes, and fraylty of my youth:

Remember not how ignoraun, I haue ben of thy truth:

Nor after my deserts, let me thy mercy find,

But of thine own beningnity, Lord haue me in thy mynd.

His mercy is ful swete, his truth a perfect guide

Therfore the Lord wil sinners teach, \& such as go aside.

The humble he wil teach, his preceptes for to kepe:

He wil direct in al his wayes the lowly and the meke,

For al the wayes of God, are truth \& mercy

To them that kepe his testament, the witnes of his troth.

\section{The second part.}

Now for thy holy name, O Lord I thee intreat,

To graunt me pardõ for my sinne, for it is wõdrous great.

Who so doth feare the Lord, the Lord doth him

To lead his life in such away, as he doth best accept.

His soule shal euermore, in goodnes dwel and stand,

His sede and his posterity, inherite shal the land.

Al those that feare the Lord, know his secret

And vnto them he doth declare, his wil and

Mine eyes and eke my hart, to him I wil aduaunce

That pluckt my feete out of the snare, of sinne \&

With mercy me behold, to thee I make my mone:

For I am poore and desolate, and comfortles alone.

The troubles of mine hart, are multiplied in dede:

Bring me out of this misery, necessity and nede.

Behold my pouerty, mine anguish and my payne

Remit my sinne \& mine offence, \& make me cleane agayne.

O Lord behold my foes, how they do stil increase:

Pursuing me wt deadly hate, that faine would liue in peace.

and kepe my soule, and eke deliuer me:

And let me not be ouerthrowen, because I trust in the.

Let my simple purenes, me from mine enmies shend:

Because I looke as one of thine, that yu shouldst me defend.

Deliuer Lord thy folke, and send them some relief:

I meane thy chosen Israel, from al their paine and grief.

\section{Total: 456}

Polysyllabic: 87

\section{Sternhold \& Hopkins}

38

PVt me not to rebuke O Lord, in thy prouoked ire:

$\mathrm{Ne}$ in thy heauy wrath $\mathrm{O}$ lord, correct me I desire. 
Thine arrowes do sticke fast in me, thy hand doth presse me sore

And in my flesh no health at al, appeareth any more

And al this is by reason of, thy wrath that I am in:

Nor any rest is in my bones, by reason of my sinne.

For loe, my wicked doings Lord, aboue my head are gone:

As greater lode thẽ I can beare, they lye me sore vpon.

My wounds stinck and are festred sore, and lothsom is to see:

Which al through mine own folishnes, betideth vnto mee.

And I in careful wise am brought, in trouble and distres:

That I go wayling al the day, my doleful heauines.

My loynes are fild with sore disease, my flesh hath no whole part:

I feble am and broken sore, I rore for griefe of hart.

Thou knowst Lord my desire, my grones, are open in thy sight:

my hart doth pãt, my strẽgth hath faild, my eies haue lost their light

My louers and my wonted frends, stand looking on my wo:

And eke my kinsmen far a way, are me departed fro.

They y did seeke my life, laid snares, \& they that sought the way

To do me hurt, spake lies, \& thought on treason all the day.

\section{The second part.}

But as a deafe man I became, that connot heare at al:

And as one dum that opens not, his mouth to speake withal.

For al my confidence O Lord, is wholy set on thee:

O Lord yu Lord that art my God, thou shalt geue eare to mee.

This did I craue that they my foes, triumph not ouer mee:

For when my foote did slip, then they, did ioy my fal to see.

And truely I poore wretch am set, in place a woful wight:

And eke my griefful heauines, is euer in my syght.

For while that I my wickednes, in humble wyse confesse:

And while I for my sinful deedes, my sorrowes do

My foes do stil remayne aliue, and mighty are also:

And they that hate me wrongfully, in number hugely grow.

They stand against me that my good, with euil do repay:

Because that good and honest thinges, I do ensue alway.

Forsake me not O Lord my God, be thou not far away:

Hast me to helpe, my Lord my God, my safety and my stay.

Total: $\mathbf{4 2 0}$

Polysyllabic: 74

\section{Sternhold \& Hopkins}

46

THe Lord is our defence and ayde, the strength wherby we stand:

when we with wo are much dismayd, he is our helpe at hande. 
Though th earth remoue, we wil not feare, though hilles so high and stepe:

be thrust and hurled here and there, within the sea so depe.

No, though the waues, do rage so sore, that al the bankes it spils:

And though it ouer flow the shore, \& beat down mighty hils.

For one fayre floud, doth send abrod, his pleasaunt streames a pace:

To fresh the citie of our God, and wash his holy place.

In midst of her the Lord doth dwel, she can no whit decay:

Al things agaynst her that rebel, the Lord wil truly stay.

The Heathẽ folcke, the kingdomes feare, the people make a noyse:

The earth doth melt, \& not appeare, whẽ god puts forth his voyce.

The Lord of hostes, doth take our part, to vs he hath an eye:

Our hope of health, with al our hart, on Iacobs God doth lye.

Come, here, \& se, with mind and thought, the working of our God:

What wõders he himself hath wrought, throughout the earth abrod.

By him al warres are husht, and gone, which coũtryes did

Theyr bowes he brake, \& speares eche one, theyr Charets brẽt wt fire.

Leaue of therfore (saith he) \& know, I am a God most stout:

Among the Heathen high \& low, and al the earth throughout

The Lord of hostes doth vs defend, he is our strength and tower:

On Iacobs God, do we depend, and on his mighty power.

\section{Total: 272}

Polysyllabic: 39

\section{Sternhold \& Hopkins}

93

THe Lord as king alof doth raign, in glory goodly dight: and he to shew his strẽgth \& main, hath girt himself wt might.

The Lord likewise the earth hath made, \& shaped it so sure:

No might can make it moue or fade, at stay it doth endure.

Ere yt the world was made or wrought, thy seat was set before:

Beyond al time that can be thought, thou hast bene euermore.

The flouds (O Lord) the flouds do rise, they rore and make a noyce:

The floudes (I say) did enterprise, and lifted vp theyr voyce.

Yea, though y stormes before in sight, though seas do rage and swel:

The Lord is strong and more of might, for he on hye doth dwel.

And loke what promise he doth make, his houshold to defend:

For lust and true they shal it take, al tymes withouten end.

\section{Total: 148}

Polysyllabic: 17

\section{Sternhold \& Hopkins}


O Lord thou doost reuẽge al wrong, that office longes to thee:

Sith vengeãce doth to thee belong, declare that al may see.

Set forth thy self, for thou of right, ye erth doost iudge \& gide:

Reward the proud \& men of might, accordyng to their pride.

How long shal wicked mẽ beare sway, with lifting vp their voyce?

How long shal wicked men I say, thus triumph and reioyce?

How long shal they with brags burst out, \& proudly prate their fil?

Shal they reioyce which be so stout, whose workes are euer

Thy flock (O Lord) thine heritage, they spoyle and vexe ful sore:

against thy people they do rage, still daily more and more.

The widowes which are comfortles, and straungers they destroy:

They slea the children fatherles, and none doth put them by.

And whẽ they take these things in hãd, this talk they haue of thee:

Can Iacobs God this vnderstand? tush no he cannot see.

O folke vnwise \& people rude, some knowledge now discerne:

(ye fooles) among the multitude, at length begin to learne.

The lord which made y eare of man, he nedes of right must heare:

He made y eyne, al things must then, before hys syght appeare.

The Lord doth al the world correct, and make them vnderstand:

Shal he not then your dedes detect, how can ye scape his hand?

The lord doth know y thoughts of mã, his hart he seeth ful playn:

The Lord I say mẽs thoughts doth frame, \& findeth thẽ but vain

But Lord that man is happy sure, whom thou doost kepe in

And through correction doost procure, to teach him in thy law.

Wherby he shal in quiet rest, in tyme of trouble sit:

When wicked men shalbe supprest, and fal into the pit.

For sure the Lord wyl not refuse, hys people for to

His heritage whom he dyd chuse, he wil no tyme forsake.

Vntil that iudgement be decreed, to iustice to conuert:

That al may follow her with spede, that are of vpright hart.

But who vpon my part shal stand, against the cursed trayne:

Or who shal rid me from theyr hand, y wicked works maintain?

Except the Lord had bene mine ayde, mine enemies to

My soule and life had now bene layd, almost as low as hel:

When I did say my fote doth slyde, and now am like to fal:

Thy goodnes Lord did so prouyde, to stay me vp withal.

When with my selfe I mused much, and could no comfort fynde:

Then Lord thy goodnes did me touch, and that did ease my mind

Wilt thou enhaunt thy self and draw, with wicked men to sit?

which with pretence instede of law, much mischief do

For they consult against the life, of righteous men and good:

and in their counsels they are ryfe, to shed the giltles blood

But yet the Lord he is to me, a strong defence or locke:

He is my God, to him I flee, he is my strength and rocke. 
And he shal cause their mischiefs al, themselues for to annoy:
and in their malice they shal fal, our God shal them destroy.

Total: 541

Polysyllabic: 92

\section{Sternhold \& Hopkins}

95

O Come let vs lift vp our voyce, and syng vnto the Lorde, in hym oure rocke of health reioyce, let vs wyth one accord.

Yea let vs come before hys face, to geue hym thanks and prayse, in syngyng Psalmes vnto his grace, let vs be glad alwayes.

For why? the Lord he is no doubt, a great and mighty God:

A kyng aboue al gods throughout, in al the world abrode.

The secrets of the earth so depe, and corners of the land:

The tops of hils that are so stepe, he hath them in his hand.

The sea and waters al are his, for he the same hath wrought:

The earth and al that therin is, his hand hath made of nought.

Come let vs bow and prayse the Lord, before hym let vs fal:

and knele to hym with one accord, the which hath made vs al.

For why? he is the Lord our God, for vs he doth prouyde?

We are his folke, he doth vs fede, his shepe and he our guide.

To day if ye his voyce wil heare, then harden not your hart:

as ye with grudging many a yeare, prouokte me in desert.

Where as your fathers tempted me, my power for to proue:

my wõdrous works whẽ they did see, yet stil they wold me moue

Twise twenty yeares they did me greue, and I to them did say:

They erre in hart and not beleue, they haue not known my way.

Wherfore I sware, whẽ that my wrath, was kindled in my brest:

That they should neuer tread the path, to enter to my rest.

Total: 276

Polysyllabic: 33

\section{Sternhold \& Hopkins}

$100-$ J.H.

Al people yt on earth do dwel, sing to ye Lord with chereful voice:

him serue wt fear, his praise forth tel, come ye before him \& reioice.

The Lord ye know is god in dede, wtout our ayde he did vs make:

We are his folke he doth vs fede, \& for his shepe he doth vs

Oh enter thẽ his gates wt praise approch with ioy, his courts vnto

praise, laud, and bles his name alwayes, for it is seemely so to do. 
For why? the Lord our God is good, his mercy is for euer sure:

His truth at al times firmly stood, and shall from age to age indure.

\section{Total: 114}

\section{Polysyllabic: 14}

100-J.R.

In God the lord be glad and light, praise him throughout the earth

Serue him \& come before his sight, with singing and with mirth

Know that the Lord our God he is, he did vs make and kepe:

Not we our selues, for we are his, owne folke and pasture shepe.

$\mathrm{O}$ go into his gates alwayes, geue thanks within the

Within his courts set forth his prayse, and laud his holy name.

For why the goodnes of the Lord, for euermore doth raigne:

from age to age throughout the world, his truth doth stil remain

\section{Total: 98}

\section{Polysyllabic: 12}

\section{Sternhold \& Hopkins}

103

MY soule geue laud vnto the Lord, my sprite shall do the same: and all the secrets of my hart praise ye his holy name.

Geue thanks to God for al his gifts, shew not thy self vnkind, \& suffer not his benefites to slyp out of thy mynde. That gaue thee pardon for thy faults, and thee restord again: For al thy weak and frayle disease, and heald thee of thy paine.

That did redeme thy life from death, frõ which thou couldst not flee His mercy and cõpassion both, he did extend to thee. That fild with goodnes thy desire, and did prolong thy youth: Like as the Egle casteth her vil, wherby her age renueth.

The Lord with iustice doth repay, al such as be opprest: So that their suffring \& their wrõgs, are turned to the best. His wayes \& his cõmaundements, to Moyses he did shew: His counsels and his valiant actes, the Israelites did know. The Lord is kind and merciful, when sinners do hym greue:

The slowest to conceyue a wrath, and rediest to forgeue.

He chides not vs continually, though we be ful of stryfe: Nor kepes our faultes in memory, for al our sinful lyfe. Nor yet according to our sinnes, the Lord doth vs regard: Nor after our iniquities, he doth not vs reward But as the space is wondrous great, twixt heauen and earth aboue So is his goodnes much more large, to them that do hym loue. 
God doth remoue our sinnes from vs, and our offences al: as far as is the sunne rising, ful distant from his fal.

\section{The second part.}

And looke what pitie parents deare, vnto their children beare: Like pitie beares the Lord to such, as worship him in feare:

The Lord yt made vs knoweth our shape, our mould \& fashion how weake and frayle our nature is, and how we be but dust. And how the tyme of mortal men, is lyke the withering hay: Or like the floure right fayre in field, that fades ful soone away. Whose glosse \& beauty stormy winds, do vtterly disgrace: and make that after their assaults, such blossoms haue no place. But yet the goodnes of the Lord, with his shal euer stand:

their childrens children do receyue his righteousnes at hand. I meane which kepe his couenant, with al their whole desyre: and not forget to do the thyng, that he doth

The heauẽs hye are made the seat, and footestoole of the Lord: And by his power imperial, he gouernes al the world. Ye angels which are great in power, prayse ye and bles the Lord: Which to obey and do hys wyl, immediatly accord. ye noble hostes and ministers, cease not to land him stil: Which ready are to execute, his pleasure and hys wil. ye all his works in euery place, prayse ye his holy name: My hart, my mynd, and eke my soule, prayse ye also the

\section{Total: 499}

Polysyllabic: 98

\section{Sternhold \& Hopkins}

\section{7}

the Lord the house do make

And thereunto do set his hand

What men do build it can not stand,

Likewise in vayne men vndertake,

Cities and holds to watch and ward

Except the Lord be their safegard.

\footnotetext{
Though ye rise early in the morne,

And so at night go late to bed,

Fedyng ful hardly with browne bread, yet were your labour lost and worne

But they whom God doth loue and kepe

Receyue al thynges with quiet slepe.
} 
Therefore marke wel when euer ye see

That men haue heyres t' enioy theyr land

It is the gift of Gods own hand

For God him selfe doth multiply

Of hys great

The blessyng of posterity:

And when the children come to age

grow in strength and actiueness

In person, and in comelines,

So that a shaft shot with courage,

Of one that hath a most strong arme,

Flyeth not so swift, nor doth lyke arme.

Oh wel is hym that hath his quiuer,

Furnished with such artilery:

For when in peril he shalbe,

Such one shal neuer shake nor shiuer,

when that he pleadeth before the iudge:

Against his foes which bear him grudge.

\section{Total: 198}

Polysyllaic: 37

\section{Sternhold \& Hopkins}

129

OFt they now Israel may say, me from my youth assayled,

Oft they assailed me frõ my youth, yet neuer the

Vpon my back the plowers plowed, \& forrowes long did

The rightous lord hath cut the cordes, of wicked foes at last.

They that hate hym shal be shamed, and turned back also:

And made as grasse vpon the house, which withereth ere it grow

Wherof the mower cannot fynd, inough to fil his hand:

Nor he can fil hys lap that goeth, to gleane vpon the land.

Nor passers by pray God on them, to let his blessing fal:

Nor say we blesse you in the name, of God the Lord at al.

Total: 117

Polysyllabic: 22

\section{Sternhold \& Hopkins}

131 
O Lord I am not puft in mynd, I haue no scorneful eye:

I do not exercyse my selfe, in thynges that he to hye.

But as a child that wayned is, euen from his mothers brest:

So haue I Lord behaued my selfe, in sylence and in rest.

O Israel trust in the Lord, let hym be all thy stay:

From thys tyme for euermore, from age to age I say.

Total: 72

Polysyllabic: 9

\section{Sternhold \& Hopkins Syllables: Summary}

Total Words: 3793.5

Total Polysyllabic Words: 638.5

Psalms: 15 (17)

Total Words per Psalm: 253

Total Polysyllabic Words per Psalm: 42.5

Polysyllabic: $16.8 \%$

\section{Sternhold \& Hopkins Etymology: Summary}

Total Words: 3792

OE/PIE: $3158.5(83.2 \%)$

French + Anglo-Norman : 412.5 (10.8\%)

French : $347.5(9.1 \%)$

Anglo-Norman : 65 (1.7\%)

Hebrew : 8

$: 70.5(1.8 \%)$

: $128.5(3.2 \%)$

scandinavian : 9

Dutch : 4

German : 1

Greek : 0

\section{Sidney \& the Countess of Pembroke}

8

O Lord that rul'st our mortall lyne,

How through the world thy name doth shine:

That hast of thine unmatched glory

Upon the heav'ns engrav'n the story.

From sucklings hath thy honor sprong,

Thy force hath flow'd from babies tongue, 


\section{Whereby thou stopp'st thine en'mies prating}

Bent to revenge and ever -hating.

When I upon the heav'ns do look, Which all from thee their essence took;

When Moon and Starrs, my thoughts beholdeth,

Whose life no life but of thee holdeth:

Then thinck I: Ah, what is this man

Whom that greate God remember can?

And what the race, of him descended,

It should be ought of God attended?

For though in lesse than Angells state

Thou planted hast this earthly mate:

Yet hast thou made ev'n hym an owner

Of glorious crown, and crowning honor.

Thou placest hym upon all landes

To rule the workes of thine own handes:

And so thou hast all things ordained,

That ev'n his feete, have on them raigned.

Thou under his dominion plac't

Both sheepe and oxen wholy hast;

And all the beasts for ever breeding,

Which in the fertill fieldes be feeding.

The Bird, free- burgesse of the Aire;

The Fish, of sea the native heire;

And what things els of waters traceth

The unworn pathes, his rule embraceth.

O Lord, that rul'st our mortall lyne,

How through the world thi name doth shine!

\section{Total: 232}

Polysyllabic: 44

\section{Sidney \& the Countess of Pembroke}

\section{1}

\section{Since I do trust Jehova still,}

Your fearfull wordes why do you spill?

That like a bird to some strong hill

I now should fall a flying. 
Behould the evill have bent their bow,
And sett their arrowes in a row,
To give unwares a mortall blow
To hartes that hate all lyeng.

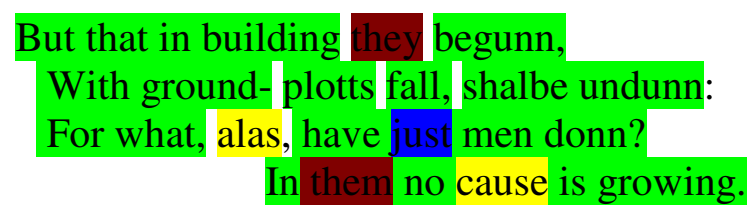

God in his holy temple is:

The throne of heav' $n$ is only his:

Naught his all -seeing sight can misse;

His ey- lidds peise our going.
The Lord doth search the just mans reynes, But hates, abhors, the wicked braines;
On them stormes, brimstone, coales he raines: That is their share assigned.

But so of happy other side
His lovely face on them doth bide,
In race of life their feet to guide
Who be to God enclined.

Total: 156

Polysyllabic: 29

\section{Sidney \& the Countess of Pembroke}

\section{2}

Lord, helpe, it is hygh tyme for me to No men are left that charity doe love: Nay, ev'n the race of good men are decai'd.

Of things vaine with vaine mates they babble all; Their abject lipps no breath but flattry move, Sent from false hart, on double meaning staid.

But thou (O Lord) give them a thorough fall: Those lyeng lipps, from cosoning head remove, In falshood wrapt, but in their pride displaid.

Our tongues, say they, beyond them all shall goe: 
We both have pow'r, and will, our tales to tell:

For what lord rules our brave emboldned brest?

Ah! Now ev'n for their sakes, that tast of wo,

Whom troubles tosse, whose natures need doth quell;

Ev'n for the sighes, true sighes of man distrest-

I will gett up, saith God, and my help show

Against all them that against hym do swell:

Maugre his foes, I will him sett at rest.

These are Gods wordes, Gods words are ever pure:

Pure, purer than the silver throughly tride,

When fire seav'n tymes hath spent his earthy parts.

Then thou (O Lord) shalt keepe the good still sure:

By thee preserv'd, in thee they shall abide:

Yea, in no age thy blisse from them departes.

Thou seest each side the walking doth endure

Of these badd folks, more lifted up with pride,

Which, if it last, wo to all simple hartes.

\section{Total: $\mathbf{2 3 5}$}

\section{Polysyllabic: 38}

\section{Sidney \& the Countess of Pembroke}

\section{3}

The Lord, the Lord my shepheard is,

And so can never I

Tast misery.

He rests me in greene pasture his:

By waters still, and sweete

He guides my feete.

Hee me revives: leades me the way,

Which righteousnesse doth

For his names sake.

Yea though I should through valleys stray,

Of deathes dark shade, I will

Noe whitt feare

For thou, deere Lord, thou me besett'st:

Thy rodd, and thy staff be 
To comfort me;

Before me thou a table sett'st,

Even when foes envious ey

Doth it espy.

Thou oil'st my head thou fill'st my

more thou endlesse good,

Shalt give me food.

To thee, I say, ascended up,

Where thou, the Lord of all,

Dost hold thy hall.

Total: 125

Polysyllabic: 17

\section{Sidney \& the Countess of Pembroke}

25

To thee, O Lord most just,

I lift my inward sight:

My God, in thee I

Lett me not ruine quight:

Lett not those foes, that me annoy

On my complaint build up their joy.

Sure, sure, who hope in thee,

Shall never suffer shame:

Lett them confounded be

That causelesse wrongs doe frame.

Yea, Lord, to me thy waies doe show;

Teach me, thus vext, what path to goe.

Guide me as thy truth guides;

Teach me; for why thou art

The God in whom abides

The saving me from smart.

For never day such changing wrought,

That I from trust in thee was brought.

Remember, only King,

Thy mercies tendernesse:

To thy remembrance bring

Thy kindnesse, lovingnesse.

Let those things thy remembraunce grave, 


\section{Since they eternall essence have.}

But, Lord, remember not

Sinns brew'd in youthfull glasse:

Nor my rebellions

Since youth, and they, do passe:

But in thy kindnesse me record

Ev'n for thy mercies sake, O Lord.

Of grace and righteousnesse

The Lord such plenty hath:

That he deignes to

To sinning men his path:

The meeke he doth in judgment leade,

And teach the humble how to tread.

And what, thinck you, may be

The pathes of my greate God?

Ev'n spottlesse verity,

And mercy spredd abroad,

To such as keepe his covenaunt,

And on his testimonies plant.

O Lord, for thy names sake,

Lett my

Of thee some mercy take,

Though it be greate in me:

$\mathrm{Oh}$, is there one with his feare fraught?

He shalbe by best teacher taught.

Lo, how his blessing buds

Inward, an inward rest;

Outward, all outward goodes

By his seede eke possest.

For such he makes his secrett know,

To such hee doth his cov'nant show.

\section{Total: 292}

Polysyllabic: 54

\section{Sidney \& the Countess of Pembroke}

38

Lord, while that thy rage doth bide,

Do not chide 


\section{Nor in anger chastise me,}

For thy shafts have peirc'd me sore;

And yet more

Still thy hands upon me be.

No sound part caus'd by thy wrath My flesh hath,

Nor my synns lett my boanes rest;

For my faults are highly spredd

On my hedd,

Whose foule weights have me opprest.

My woundes putrify and stinck,

In the sinck

Of my filthy folly laid:

Earthly I do bow and

With a look

Still in mourning cheere araid.

In my Reynes hott torments raignes;

There remaines

Nothing in my bodie sound:

I am weake and broken sore, Yea, I roare,

In my hart such griefe is found.

Lord before thee I do lay

What I pray:

My sighes are not hid from thee,

My hart pants, gon is my might,

Even the light

Of myne eyes abandons me.

From my plague, kinne, neighbour, frend

Farre off wend;

But who for my life do waite,

They lay snares, they nimble be Who hunt me,

Speaking evill, thincking deceite.

\section{But I, like a mann become}

Deafe and dumb,

Little hearing, speaking lesse,

I, even as such kind of wight,

Sencelesse quite,

Word with word do not represse. 
For on thee, Lord, without end

I attend:

My God, thou wilt heare my voice

For I said, heare, least they be

Gladd on me,

Whome my fall doth make rejoice.

Sure, I do but halting goe,

And my woe

Still my orethwar neighbour is.

Lo, I now to moorne beginner,

For my sinne

Telling mine

But the while, they live and grow

In greate show,

Many, mighty, wrongfull foes:

Who do evill for good, to me

Enimies be;

Why? because I vertue chose.

Do not, Lord, then, me forsake,

Doe not

Thy deere presence farre from me,

Haste, O Lord, that I be staid

By thy aid,

My salvation is in thee.

\section{Total: 322}

\section{Polysyllabic: 50}

Sidney \& the Countess of Pembroke

46

God gives us strength, and keepes us sounde,

A present help when dangers call;

Then feare not wee lett quake the grounde,

And into seas let mountains fall,

Yea soe lett seas withal,

In watry hills arise,

As maie the earthlie hills appall,

With dread and dashing cries.

For lo, a river streaming joy, 
With purling murmur saflie slides,

That cittie washing from annoy,

In holy shrine where God resides.

God in her center bides:

What can this cittie shake?

God earlie aides and ever guides,

Who can this cittie take?

When nations goe against her bent

And kings with siege her walls enround:

The voide of aire his voice doth rent,

Earth failes their feete with melting ground.

To strength and keepe us sound,

The God of armies armes:

Our rock on Jacobs God wee found

Above the reach of harmes.

$\mathrm{O}$ come with me, $\mathrm{O}$ come and view

The trophes of Jehovas hand:

What wracks from him our foes pursue,

How cleerly he hath purg'd our land.

By him warrs silent stand:

He brake the archers bow

Made charretts wheele a firy brand,

And speare to shivers goe.

Bee still saith he; know, God am I:

Know I will be with conquest croun'd,

Above all nations raised high,

High rais'd above this earthy round.

To strength and keepe us sound

The God of armies armes:

Our rock on Jacobs God we found,

Above the reach of harmes.

Total: 239

Polysyllabic: 53

\section{Sidney \& the Countess of Pembroke}

93

Cloth'd in state and girt with might,

Monark -like Jehova raignes:

He who Earthes foundation pight,

Pight at first, and yet sustaines; 


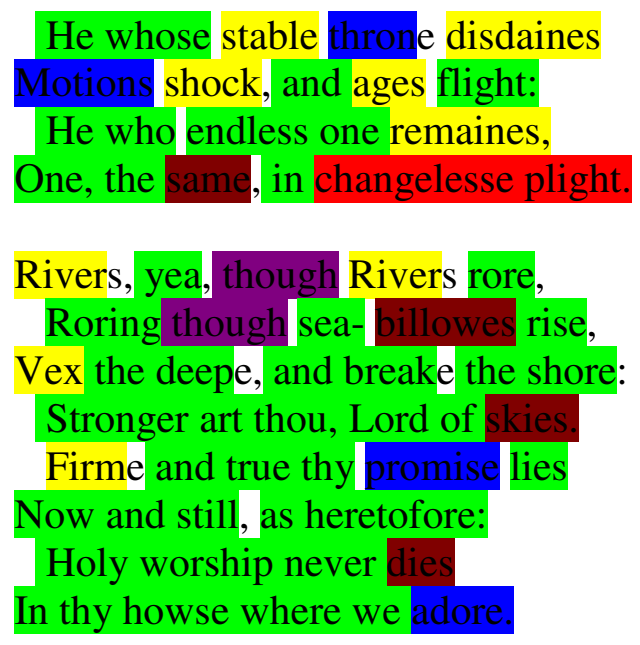

\section{Total: 87}

\section{Polysyllabic: 22}

\section{Sidney \& the Countess of Pembroke}

\section{4}

God of revenge, revenging God, appeare:

To recompense the proud, Earthes judge arise.

How long, O Lord, how long, unpunisht, beare

Shall these vile men their joyes, their jollities?

How long thus talk, and talking tiranize?

Cursedly doe and, doing, proudly boast;

This people crush, by thee affected most?

This land afflict, where thy possession lies?

For these, the widow and the stranger slay:

These work the orphan deadly overthrow.

God shall not see, then in their thoughts they say,

The God of Jacob he shall never know.

O fooles, this folly when will you forgoe,

And wisdome learne? who first the eare did plant,

Shall he him self not heare? Sight shall he want,

From whose first workmanshipp the eye did grow?

Who checks the world, shall he not you reprove?

Shall knowledge lack, who all doth knowledge lend?

ev'n the thoughtes of men who raignes above,

He knows, and knows they more than vainly end.

Then, blest, who in thy schoole his age doth spend,

Whom thou O Lord, dost in thy law

Thy harbor shall him shrowd from ruines storme, 
While pitts are dig'd where such men shall descend.

For sure the Lord his folk will not forsake,

But ever prove to his possession true;

Judgment, againe, the course of Justice And all righthartes shall God, their guide, ensue.

See, if you doubt: against the canckred crue,

Those mischief -masters, who for me did stand?

The Lord, none els: but for whose aiding hand,

Silence by now had held my soule in mew.

But Lord, thy goodness did me then uphold,

Ev'n when I said now, now I faint, I fall:

And, quailed in mind-combats manifold,

Thie consolation did my joyes recall.

Then what society hold'st thou at all,

What frendshipp with the throne of missery?

Which law

And Justice doth

ds

but

To counsel where conspired caitives flock

The just to slay, and faultlesse bloud to spill?

O no: my God Jehova is my Rock,

My rock of refuge, my defensive hill,

He on their heades shall well repay their ill

Jehova, loe! the God in whome we joy,

Destroy them shall, shall them at once destroy:

And what the meane? Their owne malicious will.

\section{Total: $\mathbf{3 7 8}$}

\section{Polysyllabic: 81}

\section{Sidney \& the Countess of Pembroke}

95

Come, come lett us with joyfull voice

Record and raist

Jehovas praise:

Come lett us in our safties Rock rejoice.

Into his presence lett us goe

And there with Psalmes our gladness show;

For he is God, a god most greate,

Above all gods a king in kingly seate.

What lowest lies in earthy 
What highest stands,

Stands in his hands:

The Sea is his, and he the Sea- wright was.

He made the Sea, he made the shore:

Come let us fall, lett us

Come let us kneele with

e:

grace

Before the Lord, the Lord our makers face.

He is our god, he doth us keepe:

We by him ledd,

And by him fedd,

His people are, we are his pasture sheepe.

Today if he some speach will use,

Doe not, O doe not you refuse

With hardened hartes his voice to heare,

As Masha now, or Meriba it were,

Where me your fathers, God doth say,

Did angring move.

And tempting prove:

Yet oft had seene my workes before that day,

Twise twenty times my poast, the sunn,

His yearly race to end had runn,

While this fond Nation, bent to

Did tempt, and try, and vex, and greeve me still.

Which when I saw, thus said I, loe,

These men are madd,

And too too bad

Erre in their harts; my waies they will not know.

Thus, therefore, unto them I sweare:

(I angry can noe more forbeare)

The rest for you I did ordaine,

I will soe work you never shall obtaine.

Total: 260

Polysyllabic: 38

\section{Sidney \& the Countess of Pembroke}

100

$\mathrm{O}$ all you landes, the treasures of your joy

In mery shout upon the Lord bestow:

Your service cheerfully on him imploy,

With triumph song into his presence goe. 
Know first that he is God; and after know

This God did us, not we our selves

We are his flock, for us his feedings grow:

We are his folk, and he upholds our state.

With thankfullnesse $\mathrm{O}$ enter then his gate:

Make through each porch of his your praises ring,

All good, all grace, of his high name relate,

He of all grace and goodnesse is the spring.

Tyme in noe termes his mercy

From age to age his truth it self extends.

\section{Total: 115}

Polysyllabic: 22

\section{Sidney \& the Countess of Pembroke}

103

My soule, my hart,

And every inward part,

Praise Jehova, praise his holy name:

My hart, my soule,

Jehovas name

What gratious he

Doth, and hath done for thee,

Be quick to mind, to utter be not lame.

For his free grace

Doth all thy sinnes deface,

He cures thy sicknesse, healeth all thy harme.

From greedy grave

That gaspes thy life to have,

He setts thee free:

And kindly makes on thee

All his Compassions, all his mercies swarme.

He doth thee still

With flowing plenty fill:

He eagle -like doth oft thy age renew,

The Lord hys right

Unto the wronged wight

Doth ever yeld:

And never cease to shield

With Justice them, whom guile and fraude pursue.

His way and trade 


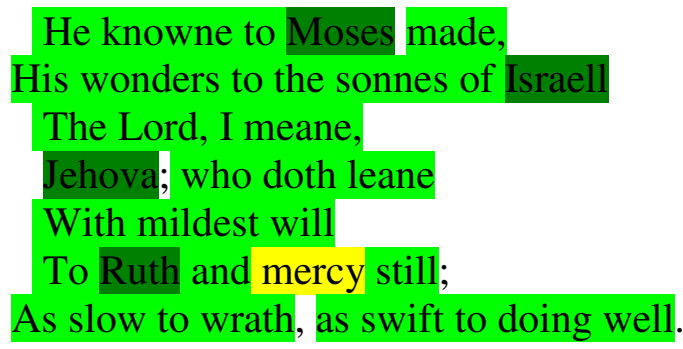

When he doth chide

He doth not chiding bide:

His anger is not in his treasures laide.

He doth not serve

Out synnes, as sinnes deserve:

Nor recompence

Unto us each offence

With due revenge in equall balance weighd.

\title{
For looke how farre
}

The Sphere of farthest starre

Drownes that proportion earthly Center beares:

Soe much, and more

His never empty store

Of grace and love

Beyond his synnes doth prove

Who ever hym with due devotion feares.

\author{
Nay looke how farre \\ From east removed ar \\ The westerne lodgings of the weary sunne: \\ Soe farre, more farre, \\ From us removed are, \\ By that greate love \\ Our faultes from him doe prove, \\ What ever faultes and follies we have done.
}

And looke how much

The nearly touching touch

The father feeles towards his sonne most deare,

Affects his hart,

At ev'ry froward part

Plaid by his child:

Soe mercifull, soe mild,

Is he to them that beare him awfull feare.

Our potter he

Knowes how his vessells we 
In earthy matter lodg'd this fickle forme:

Fickle as glasse

As flowres, that fading passe,

And vanish soe,

No not their place we know,

Blasted to death with breath of blustring storme.

Such is our state;

But farre in other

Gods endlesse Justice and his mercy stand,

Both on the good,

And their religious brood;

Who uncontrol'd

Sure league with him doe hold,

And doe his lawes not only understand.

Jehova greate

Sits thron'd in starry seate:

His kingdome doth all kingdoms

You angels strong,

That unto him belong,

Whose deedes accord

With his commanding word,

Praises and thanks upon Jehova spend.

Spirits of might,

You that his battails fight,

You ministers that willing work his will:

All things that he

Hath wrought, where soe they be,

His praise

Thou with the rest, my soule,

Praises and thanks spend on Jehova still.

Total: 474

Polysyllabic: 104

Sidney \& the Countess of Pembroke

127

The house Jehova builds not,

We vainly strive to build it:

The towne Jehova guards not,

We vainly watch to guard it. 
No use of early rising:

As uselesse is thy watching:

Not aught at all it helpes thee

To eate thy bread with anguish.

As unto weary sences

A sleepie rest unasked:

Soe bounty commeth uncaus'd

From him to his beloved.

Noe not thy children hast thou

By choise, by chaunce, by nature;

They are, they are Jehovas

Rewardes from him rewarding.

The multitude of infants

A good man holdes, resembleth

The multitude of arrowes,

A mighty Archer holdeth.

Hys happiness triumpeth

Who bears a quiver of them:

Noe countenance of haters

Shall unto him be dreadfull.

Total: 118

Polysyllabic: 36

Sidney \& the Countess of Pembroke

129

Oft and ever from my youth,

Soe now, Israel may say:

Israel may say for truth,

Ofte and ever my decay

From my youth their force hath sought:

Yet effect it never wrought.

Unto them my back did yield

Place and paine (O height of woe)

Where as in a plowed field,

Long and deep did furrowes goe.

But O just Jehova, who

Hast their plow- ropes cutt in two! 
Tell me you that Sion hate,

What you thinck shall be your end?

shall your mindes amate:

Blushe and shame your faces shend.

Mark the wheate on howses top:

Such your harvest, such your cropp.

Wither shall you where you stand;

Gather'd? noe: but, wanting sapp,

Filling neither reapers hand,

Nor the binders inbow'd lapp.

Nay who you shall reape or bind

Common kindnesse shall not find.

Such as travail by the way,

Where as they their paines imploy,

Shall not once saluting say,

God speed frendes, God give you joy:

He in whome all blessing raignes,

Blesse your selves, and blesse your paines.

\section{Total: 175}

Polysyllabic: 31

\section{Sidney \& the Countess of Pembroke}

131

\section{A lofty hart, a lifted ey}

Lord thou dost know I never bare:

Lesse have I borne in things too hygh

A meddling mind, or clyming care.

Looke how the wained babe doth fare,

$\mathrm{O}$ did I not? yes soe did I:

None more for quiet might

Ev'n with the babe that wain'd doth ly.

Heare then and learne, O Jacobs race,

Such endlesse trust on God to place.

Total: 70

Polysyllabic: 12

Sidney \& the Countess of Pembroke Syllables: Summary

Total Words: 3278

Total Polysyllabic Words: 631 
Psalms: 15

Total Words per Psalm: 218.5

Total Polysyllabic Words per Psalm: 42

Polysyllabic: $19.2 \%$

\section{Sidney \& the Countess of Pembroke Etymology: Summary}

Total Words: 3278

OE/PIE: 2608 (79.5\%)

French + Anglo-Norman : 435 (13.2\%)

French : $372(11.3 \%)$

Anglo-Norman : 63 (1.9\%)

Hebrew $28(0.8 \%)$

Latin : $76(2.3 \%)$

: $115(3.5 \%)$

Scandinavian : 5

Dutch : 6

German : 4

Greek : 1

\section{Bay Psalm Book}

8

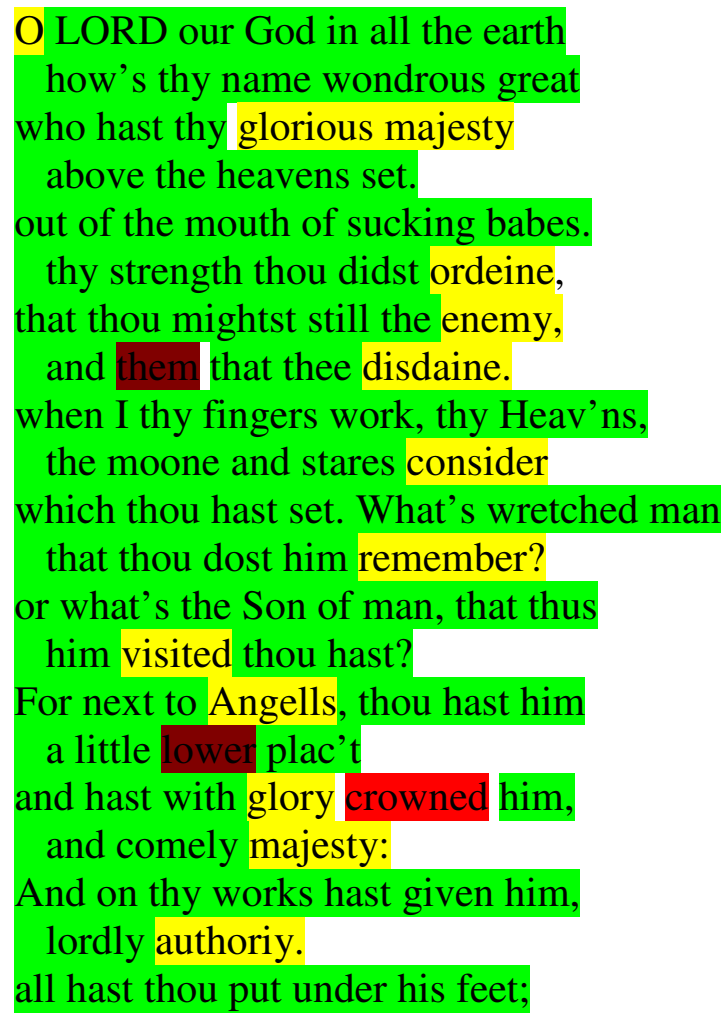


all sheep and oxen, yea

and beasts of field. Foules of the ayre, and fishes of the sea,

and all that passé through paths of seas.

O Iehovah our Lord,

how wondrously-magnificent

is thy name through the world?

Total: 156

Polysyllabic: 29

\section{Bay Psalm Book}

\section{1}

I in the Lord do trust; how then

to my soule doe ye say,

as doth a little bird unto

your mountaine flye away?

For loe, the wicked bend their bow,

on string; to shoot in dark at them

in heart that upright are.

If that the firme utterly ruin'd bee:

as for the man that righteous is,

what then performe can hee?

The Lord in 's holy temple is, the Lords throne in heaven:

his eyes will view, and his eye lids

will prove the Sonnes of men.

the man that truly- righteous is

ev'n him the Lord will prove;

his foule wicked hates, \& him that violence doth love.

Snares, fire, \& brimstone he will raine, ungodly men upon:

and burning tempest; of their shall-be their portion.

For Iehovah that righteous is, all righteousness doth love:

his countenane the upright one beholding, doth approve.

\section{Total: 151}

Polysyllabic: 34 


\section{Bay Psalm Book}

12

Helpe Lord: for godly men doe cease:

faithfull faile men among.

Each to his freind speaks vanit;

with flattring lips, and tongue

and with a double heart the speake.

All flatt'ring lips the LORD

shall cut them of, with every tongue

that speaketh boasting word.

Thus have they sayd, we with our tongue,

prevailing pow 're shall

are not our lips our owne for Lord

who over us is set?

Thus saith the Lord, for sighs of them

that want, for poor opprest,

I' le now arise, from such as puffe,

will set him safe at rest.

Pure are the words the Lord doth speak:

as silver that is tryde

in earthen furnace, seven times

that hath been purifyde.

Thou shalt them keep, o Lord, thou shalt

preserve them ev'ry one,

For evermore in safety from

this

The wicked men on evry side

doe walk

when as the vilest sons of men

are on hye.

Total: 158

Polysyllabic: 28

\section{Bay Psalm Book}

23

The Lord to mee a shepheard is,

want therefore shall not I.

Hee in the folds of tender-grasse,

doth cause mee downe to lie:

To waters calme me gently leads 
Restore my soule doth hee:

he doeth in paths of righteousnes:

for his names sake lead mee.

Yea though in valley of deaths shade

I walk, none ill I'le feare:

because thou art with mee, thy rod,

and staffe my comfort are.

for mee a table thou hast spread,

in presence of my foes:

thou dost annoynt my head with oyle, my cup it over-flowes.

Goodnes \& mercy surely shall

all my dayes follow mee:

and in the Lords house I shall dwell

so long as days shall bee.

\section{Total: 121}

Polysyllabic: 18

\section{Bay Psalm Book}

25

I lift my soule to thee o Lord. My God I trust in thee,

let me not be asham'd: nor let

my foes joe over mee.

Yea, all that wait on thee shall not,

be fill'd with fhamefulness:

but they shall be ashamed all, who without cause

Thy wayes, Iehovah, make mee know,

thy paths make me discerne.

Cause mee my steps to order well,

in thy truth, \& mee learne,

For thou God of my saving health,

on thee I wait all day.

Thy bowels, Lord, \& thy mercyes minde; for they are for

Sinnes of my youth remember not, neither my trespasses:

after thy mercy minde thou mee o Lord for thy goodnes.

Good and upright God is, therefore will sinners teach the way. 


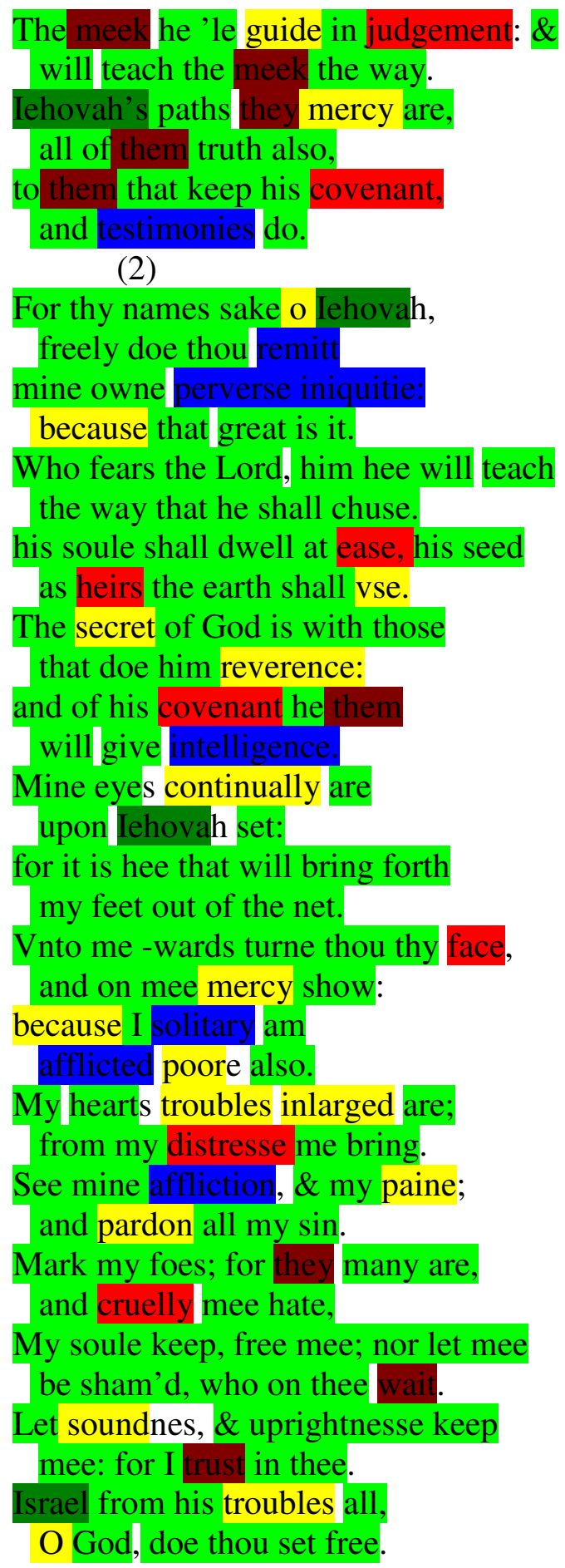

\section{Total: $\mathbf{3 3 5}$}

Polysyllabic: 54

\section{Bay Psalm Book}




\footnotetext{
LORD, in thy wrath rebuke me not:

nor in thy hot rage chasten me.

Because thine hand doth presse me sore:

and in me thy shafts fastened bee.

There is no soundnes in my flesh,

because thine anger I am in:

nor is there any rest within

my bones, by reason of my sin.

Because that mine

ascended are above my head:

like as an heavy burden, they

to heavy upon me are layd.

My wounds stink, and

my foolishnes doth make it so.

I troubled am, \& much bow'd downe,

all the day long I mourning goe.

For with soule sores my loynes are fill'd:

$\&$ in my flesh $i$ s no soundnes.

I' me weak \& broken sore; I roar'd

because of my hearts restlessnes.

All my desire 's before thee, Lord;

nor is my groaning hid from thee.

My heart doth pant, my strength me fails:

$\&$ mine eye sight is gone from mee.

My friends \& lovers from my sore stand off: off stand my kinsmen eke. And they lay snares that seek my life, that seek my hurt, they mischief speak,

And all day long imagin guile,

But as one deafe, I did not heare,

and as a dumb man I became

as if his mouth not open were.

Thus was I as man that heares not,

$\&$ in whose mouth reproofes none were.

Because o Lord, in thee I hope:

o Lord my God, thou wilt mee heare.

For sayd I, lest or'e me they joy:

when my foot slips, they vaunt the more

themselves 'gainst me. For I to halt

am neere, my grief 's still mee before.

For my transgression I' le declare;

I for my sins will sorry bee.

But yet my lively foes are strong,

who falsly hate me, multiplie.
} 


\section{Moreover they that doe repay \\ evill in stead of good to mee,}

because I follow what is good,

to me they adversaryes bee.

Iehovah, doe not mee forsake:

my God o doe not farre depart

from mee. Make hast unto mine ayd,

o Lord who my salvation art.

\section{Total: 350}

\section{Polysyllabic: 57}

\section{Bay Psalm Book}

46

GOD is our refuge, strength, \& help

in troubles very neere.

Therefore we will not be afrayd,

though th' earth removed were.

Though moutnaines move to midst of seas

Though waters roaring make

and troubled be, at whose wellings

although the mountaines shake. Selah.

There is a river streames whereof

shall rejoyce Gods city:

the holy place the tent wherein

abideth the most high.;

God is within the midst of her,

moved shee shall not bee:

God shall be unto her an help,

in the morning early.

The nations made $t$ noyse,

the kingdomes moved were:

he did give forth his thundering voyce

the earth did melt with feare.

The God of Armies is with us

th' eternall Iehovah:

the God of Iacob is for us

a refuge high. Selah.

O come yee forth behold the works

which Iehovah hath wrought,

the fearfull

which on the earth he brought.

Vnto the utmost ends of th' earth

warres into peace hee turnes: 
the speare he cuts, the bowe he breaks,

in fire the chariots burnes.

Be still, \& know that I am God,

be will I

among the heathen: though the earth

I' le be

The God of armyes is with us,

th' eternall Iehovah:

the God of Iacob is for us

a refuge high. Selah.

Total: 219

Polysyllabic: 54

\section{Bay Psalm Book}

93

The Lord reigns, cloth'd with majesty:

God cloath'd with strength, doth gird

himselfe: the world so stablisht is,

that it cannot be stir'd.

Thy throne is stablished of old:

from aye thou art. Their voyce

the flouds lift up, Lord, flouds lift up,

the flouds lift up their noyse.

The Lord on high then waters noyse

more strong then waves of sea:

Thy words most sure: Lord, holines

becomes thine house for aye.

Total: $\mathbf{7 3}$

Polysyllabic: 11

\section{Bay Psalm Book}

94

O LORD God, unto whom there doe revenges appertaine:

o God, to whom vengeance belongs,

clearly shine forth againe.

Exalt thy selfe, o thou that art

Iudge of the earth throughout:

render a recompence unto

all those that are so stout. 
Iehovah, o how long shall

that doe walk wickedly?

how long shall those that wicked are rejoyce triumphingly?

How long shall those men utter forth \& speake things that hard bee?

$\&$ shall all such thus boast themselves

that work

Lord, they thy folk in pieces break:

$\&$ heritage oppress.

They stay the widdow, \& stranger, $\&$ kill the fatherlesss.

The Lord they say, yet shall not see:

nor Iacobs God it minde.

Learne vulgal Sots: also yee fooles

when will yee wisdome finde?

Who plants the eare, shall he not heare?

who formes the eye, not see?

Who heaten smites, shall he not check? mans teacher, knows not hee?

(2)

The Lord doth know the thoughts of man,

that they are very vaine.

Blest man whom thou correcist, o Lord;

$\&$ in thy law dost traine.

That thou mayst give him quiet from dayes of

untill the pit be digged for such as doe wickedly.

Because Iehovah he will not

his people cast away,

neither will hee forsake his owne inheritance for aye.

But judgement unto righteousnes

it shall returne agen:

also all upright ones in heart

they shall pursue it then.

Against the evill doers, who will up for mee arise?

who will stand up for mee 'gainst them

that work miquityes?

Had not the Lord me helpt: my soule had neere in silence dwel'd.

When as I sayd, my foot slips: Lord,

thy mercy mee upheld.

Amidst the multitude of thoughts 


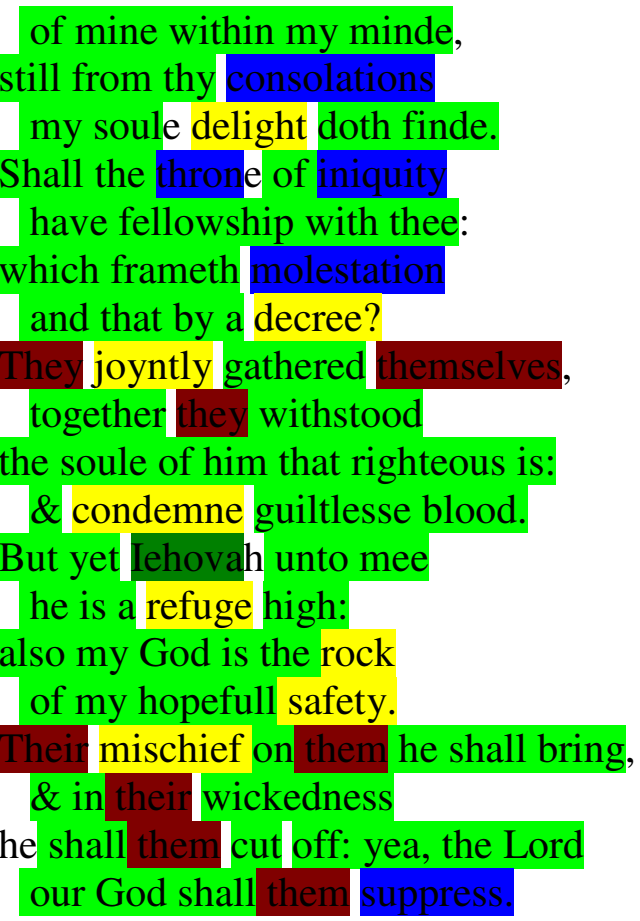

Total: $\mathbf{3 8 0}$

Polysyllabic: 90

\section{Bay Psalm Book}

95

O Come, let us unto the Lord

shout loud with singing voyce.

to the rock of our saving health let us make joyfull noyse.

Before his presence let us then approach with thanksgiving:

also let us triumphantly with Psalmes unto him sing.

For the Lord a great God: \& great King above all gods is.

In whose hands are deepes of the earth,

$\&$ strength of hills are his

The sea to him doth appertaine, also he made the same:

$\&$ also the drye land is his for it his hands did frame.

O come, \& let us worship give, $\&$ bowing down adore:

he that our maker is, the Lord 
o let us kneele before.

Because he is our God, \& wee

his pasture people are,

\& of his hands the sheep: to day

if ye his voyce will heare,

As in the

o harden not your heart:

as in the day of

within the

desart.

Whẽ mee your fathers tryde, \& pro'vd, \& my works lookt upon:

Fourty yeares long I griev'd was with this

And sayd, this people erre in heart: my wayes they doe not know.

To whom I sware in wrath: if thes into my rest should goe.

Total: 207

Polysyllabic: 35

\section{Bay Psalm Book}

$100 \mathrm{a}$

Make yee a joyfull sounding noyse unto Iehovah, all the earth:

Serve yee Iehovah with galdnes:

before his presence come with mirth. Know, that Iehovah he is God, Who hath us formed it is hee,

\& not ourselves: his owne people

$\&$ sheepe of his pasture are wee.

Enter into his gates with prayse, into his Courts with thankfullnes:

make yee confession unto him,

$\&$ his name reverently blesse.

Because Iehovah he is good, For evermore is his mercy:

\& unto generations all

continue doth his verity.

Total: 87

Polysyllabic: 28

$100 \mathrm{~b}$ 
Make yee a joyfull noyse unto Iehovah all the earth:

Serve yee Iehovah with gladnes: before him come with mirth. Know, that Iehovah he is God, not wee our selves, but hee hath made us: his people, \& sheep of his pasture are wee.

$\mathrm{O}$ enter yee into his gates with prayse, \& thankfullnesse into his Courts: confesse to him, $\&$ his Name doe yee blesse.

Because Iehovah he is good,

his bounteous-mercy

is everlasting: \& his truth

is to eternity.

\section{Total: 82}

Polysyllabic: 19

AVG TOTAL (for $100 \mathrm{a} \& \mathrm{~b}$ ): 84.5

AVG POLY (for 100 a \& b): 22.5

\section{Bay Psalm Book}

103

O Thou my soule, Iehovah blesse,

$\&$ all things that in me

most inward are, in humbleness

his Holy- Name blesse ye

The Lord blesse in

o thou my soule: also

put not out of thy

all 's bounties, thee unto.

For hee it is who pardoneth

all thine

he it is also who healeth

all thine

Who thy life from

redeems: who crowneth thee

with his tender

$\&$ kinde benignitee.

Who with good things

doth satisffie thy mouth: 
so that like as the Eagles bee

renewed is thy youth.

The Lord doth judgement \& justice

for all oppressed ones.

To Moses shew'd those wayes of his: his acts of Isr'ells sonnes.

(2)

The Lord is mercifull also

Hee 's very gracious:

and unto anger hee is slow,

in mercy plenteous.

Contention he will not maintaine

to

nor he his anger will retaine

unto eternity.

According to our sins likewise

to us hee hath not done:

nor hath he our

rewarded us upon.

Because even as the heavens are

in height the earth above:

so toward them that doe him feare

is his love.

Like as the East \& West they are

farre in their

he hath remov'd away so far

from us our trespasses.

A fathers pitty like unto, which he his sonnes doth beare:

like pitty doth Iehovah show

to them that doe him feare.

For he doth know this frame of ours:

he minds that dust wee bee.

Mans dayes are like the grasse: like flowrs

in field, so flourisheth hee.

For over it the winde doth passe,

\& it away doth goe;

also the place whereas it was

noe longer shall it know.

(3)

But yet Gods mercy ever is,

shall be, \& aye hath been

to them that feare him; and 's justice

unto childrens children.

To such as keepe his covenant,

that doe in minde up lay 
the charge of his commandment

that it they may obey.

The Lord hath in the heavens hye established his

and over all his Royallty

doth beare dominion.

$\mathrm{O}$ yee his Angells that

in strength, blesse yee the Lord,

that doe his word, that harken well

unto the voyce of 's word.

All yee that are the Lords armies, o blesse Iehovah still:

$\&$ all yee ministers of his,

his pleasure that fullfill.

Yea, all his works in places all

of his dominion,

blesse yee Iehovah: o my Soul,

Iehovah blesse alone.

Total: 414

Polysyllabic: 95

Bay Psalm Book

127

If God build not the house, vainly

who build it doe take paine:

except the Lord the city keepe, the watchman wakes in vaine.

I'ts vaine for you early to rise, watch late, to feed upon

the bread of grief: so hee gives sleep

to his beloved one.

Loe, the wombs fruit, it's Gods reward

sonnes are his heritage.

As arrows in a strong mans hand, are sons of youthfull age.

$\mathrm{O}$ blessed is the man which hath

his quiver fill'd with those:

shall not be asham'd I'th gate

when they speake with their foes.

Total: 96

Polysyllabic: 13 


\section{Bay Psalm Book}

129

From my youth, noy may Isr'ell say,

oft have they mee assaild:

They mee assaild oft from my youth, yet 'gainst mee nought

The ploughers plough'd upon my back,

their furrows long they drew:

The righteous Lord the wickeds cords he did asunder- hew.

Let all that Sion hate be sham'd, and turned back together.

As grasse on house tops, let them be, which ere it 's grown, doth wither:

Whereof that whcih might fill his hand

the mower doth not finde:

nor therewith hee his bosome fills

that doth the sheaves up binde.

Neither doe they that passe by, say, Iehovah's blessing bee

on you: you in Iehovahs Name a blessing wish doe wee.

\section{Total: 115}

Polysyllabic: 26

\section{Bay Psalm Book}

\section{1}

My heart 's not haughty, Lord, nor lofty are mine eyes:

in things too great, or high for mee,

is not mine exercise.

Surely my selfe I have compos'd, and made to rest,

like as a child that weaned is, from off his mothers brest:

I m'e like a weaned child.

Let Israell then stay

with expectation on the Lord, from henceforth and for aye.

Total: 65 


\section{Polysyllabic: 11}

\section{Bay Psalm Book Syllables: Summary}

Total Words: 2924.5

Total Polysyllabic Words: 578.5

Psalms: 15 (16)

Total Words per Psalm: 195

Total Polysyllabic Words per Psalm: 38.5

Polysyllabic: $19.8 \%$

\section{Bay Psalm Book Etymologies: Summary}

Total Words: 2949

OE/PIE: 2416.5 (81.9\%)

French + Anglo-Norman : 324.5 (11.0\%)

French : 278.5 (9.4\%)

Anglo-Norman : 46 (1.5\%)

Hebrew : $36(1.2 \%)$

: $69(2.3 \%)$

: $95(3.2 \%)$

Scandinavian : 5

Dutch : 2

German : 0

Greek : 1 


\section{BIBLIOGRAPHY}

\section{$\underline{\text { Primary Sources }}$}

Adams, Abigail. "Letter from Abigail Adams to John Adams, 31 March - 5 April 1776." in Adams Family Papers: An Electronic Archive. Massachusetts Historical Society. Accessed 28 July 2009.

$<$ http://www.masshist.org/digitaladams/aea/cfm/doc.cfm?id=L17760331 aa\&archive=letter\& hi=on\&mode $=\&$ noimages $=\&$ numrecs $=1 \&$ query=remember\%20the\%20ladies\&queryid=\&re $\mathrm{c}=\& \operatorname{star} \mathrm{t}=1 \& \operatorname{tag}=$ text $>$.

---. "Letter from Abigail Adams to John Adams, 30 June 1778 draft." in Adams Family Papers: An Electronic Archive. Massachusetts Historical Society. Accessed 28 July 2009. $<$ http://www.masshist.org/digitaladams/aea/cfm/doc.cfm?id=L17780630aa\&numrecs=52\&ar chive $=$ letter $\&$ hi $=$ on $\&$ mode $=\&$ query $=$ wisdom $\&$ queryid $=\&$ rec $=24 \&$ start $=21 \&$ tag $=$ text $\#$ firstm atch>.

---. "Letter from Abigail Adams to John Adams, 20 June 1783." in Adams Family Papers: An Electronic Archive. Massachusetts Historical Society. Accessed 28 July 2009.

$<$ http://www.masshist.org/digitaladams/aea/cfm/doc.cfm?id=L17830620aa\&numrecs=52\&ar chive $=$ letter $\&$ hi $=$ on $\&$ mode $=\&$ query $=$ wisdom $\&$ queryid $=\&$ rec $=29 \&$ start $=21 \&$ tag $=$ text $\#$ firstm atch>.

Adams, John. A Defence of the Constitutions of Government of the United States of America. New York: Da Capo Press, 1971.

---. Novanglus and Massachusettensis. Bedford: Applewood Books, 2009.

Adams, Samuel. "Resolutions of the House of Representatives of Massachusetts. October 29, 1765." in The Writings of Samuel Adams. ed. Harry Alonzo Cushing. New York: The Knickerbocker Press, 1904.

Alexander, William. An Encouragement to Colonies. London: William Stansby, 1624.

Allen, John. The American Alarm. Boston: D. Kneeland, 1773.

Allin, John. A Brief History of the Church of Christ at Dedham. in Puritans in the New World. ed. David D. Hall. Princeton: Princeton University Press, 2004. pp-pp.

Alsted, Johann Heinrich. The Beloved City. London: 1643.

Ames, William. Conscience with the Power and Cases Thereof. London: Edw Griffin, 1643.

Andrewes, Lancelot. Apospasmatia Sacra. London: R. Hodgkinsonne, 1657. 
Augustine. The Confessions. trans. Maria Boulding. New York: Vintage Books, 1998.

Austen, Ralph. A Treatise of Fruit Trees. London: William Hall, 1665.

Bacon, Francis. The Advancement of Learning. ed. G. W. Kitchin. Philadelphia: Paul Dry Books, 2001.

---. The Great Instauration and The New Atlantis. trans. James Spedding. ed. J. Weinberger. Arlington Heights: Harlan Davidson, 1980.

Baker, Wm. "For the Washington Federalist." Washington Federalist 8 July 1803 (III.492):

2.

Baxter, Richard. A Call to the Unconverted. London: R.W., 1658.

---. Reliquiae Baxterianae. ed. Matthew Sylvester. London: T. Parkhurst, et al., 1696.

---. “The Answer.” in John Eliot. The Eliot Tracts. ed. Michael P. Clark. Westport: Praeger, 2003.

Belcher, Jonathan. "The Speech of His Excellency Jonathan Belcher." The Pennsylvania Gazette 9 May 1754 (1324): 1.

Bradford, William. "Certain Verses." in American Poetry: The Seventeenth and Eighteenth Centuries. ed. David S. Shields. New York: New York, The Library of America, 2007. 1415.

---. Of Plymouth Plantation. ed. Samuel Eliot Morison. New York: Alfred A. Knopf, 2002.

Bradstreet, Anne. The Complete Works of Anne Bradstreet. eds. Joseph R. McElrath, Jr. and Allan P. Robb. Boston: Twayne Publishers, 1981.

Brightman, Thomas. A Revelation of the Revelation. London: 1615.

Broughton, Hugh. A Require of Agreement. Middelburg: 1611.

Brown, Charles Brockden. Edgar Huntly; or, Memoirs of a Sleep-Walker. eds. Philip Barnard and Stephen Shapiro. Indianapolis: Hackett Publishing, 2006.

---. Wieland. ed. Jay Fliegelman. New York: Penguin Books, 1991.

Brown, William Hill. The Power of Sympathy. ed. Carla Mulford. New York: Penguin, 1996.

Buell, Samuel. The Divine Agency Acknowledged in the Death of Our Dearest Friends. New York: J. Parker and W. Weyman, 1757. 
Bunyan, John. Grace Abounding. ed. John Stachniewski with Anita Pacheco. New York: Oxford University Press, 1998.

---. The Pilgrim's Progress. ed. Cynthia Wall. New York: W.W. Norton, 2009.

Bushnell, Horace. Christian Nurture. New York: Charles Scribner, 1861.

Byrd, William. The History of the Dividing Line Between Virginia and N. Carolina Run in the Year of Our Lord 1728. Ms. S11160 American Philosophical Society Library, Philadelphia.

Calvin, Jean. A commentarie of Iohn Caluine, vpon the first booke of Moses called Genesis. trans. Thomas Tymme. London: 1578.

Chauncy, Charles. Gods Mercy. Cambridge: Samuel Green, 1655.

Child, Lydia Maria. Hobomok. ed. Carolyn L. Karcher. New Brunswick: Rutgers University Press, 2004.

Church, Benjamin. An Oration; Delivered March $5^{\text {th }}$, 1773. Boston: Edes and Gill, 1773.

Clinton, De Witt. “Orinthology.” The Newport Mercury 30 Sep. 1815 (LIV.2791): 1.

Colman, Benjamin. A brief dissertation on the three first chapters of Genesis. Boston: S. Kneeland and T. Green, 1735.

---. A Dissertation on the Image of God Wherein Man Was Created. Boston: S. Kneeland and T. Green, 1736.

---. The Holy Walk and Glorious Translation of Blessed Enoch. Boston: 1728.

Columbus, Christopher. The Four Voyages of Columbus. ed. Cecil Jane. Vol. I. New York: Dover Publications, 1988.

---. The Libro de las Profecías of Christopher Columbus. trans. Delno C. West and August King. Gainesville: University of Florida Press, 1991.

Cooper, James Fenimore. The Deerslayer. New York: Penguin Books, 1987.

Cotton, John. A Brief Exposition of the Whole Book of Canticles, or, Song of Solomon.

London: 1642.

---. A Briefe Exposition with Practicall Observations upon the Whole Book of Ecclesiastes. London: T. C., 1654.

---. An Exposition Upon the Thirteenth Chapter of the Revelation. London: 1656. 
---. Christ the fountaine of life, or, Sundry choice sermons on part of the fifth chapter of the first Epistle of St. John. London: Robert Ibbitson, 1651.

---. Gods Promise to His Plantations. London: William Jones, 1630.

---. Preface. The Psalms, Hymns and Spiritual Songs of the Old and New Testament, Faithfully Translated into English Metre. Cambridge: Hezekiah Usher, 1648.

---. Singing of Psalmes a Gospel-Ordinance. London: Hannah Aleen and John Rothwell, 1647.

---. Sixteene Questions of Serious and Necessary Consequence. in The Antinomian

Controversy, 1636-1638. $2^{\text {nd }}$ ed. ed. David D. Hall. Durham: Duke Univerity Press, 1999.

---. The Way of Life. London: M.F., 1641.

---. The Way of the Churches of Christ in New-England. Or, the Way of Churches walking in Brotherly Equality, or Coordination, without Subjection of One Church to Another. London: Matthew Simmons, 1645.

Cowley, Abraham. "To the Royal Society." in Thomas Sprat. The History of the Royal Society of London. $4^{\text {th }}$ ed. London: 1734.

Cushman, Robert. A Sermon Preached at Plimmoth. London: I. D., 1622.

de Crèvecœur, J. Hector St. John. Letters from an American Farmer. ed. Susan Manning. New York: Oxford University Press, 1997.

Dent, Arthur. The Plaine Mans Path-way to Heauen. London: 1601.

Du Bartas, Guillaume de Saluste, seigneur. The Divine Weeks and Works of Guillaume de Saluste, Sieur Du Bartas. trans. Joshua Sylvester. New York: Oxford University Press, 1979.

Dwight, Timothy "Address of the Genius of Columbia, to the Delegates of the Convention, at Philadelphia.” The Massachusetts Ceninel 6 June 1787 (VII.23): 92.

---. Theology; Explained and Defended, in a Series of Sermons. $10^{\text {th }}$ ed. Vol. 4. New Haven: T. Dwight \& Son, 1839.

Eburne, Richard. A Plaine Pathway to Plantations. London: G. P., 1624.

Edwards, Jonathan. The Online Works of Jonathan Edwards. Vols. 27-73. Jonathan Edwards Center, Yale University. 
---.The Works of Jonathan Edwards. Vols. 1-26. New Haven: Yale University Press, 19572008.

Eliot, John (1604-90). The Eliot Tracts. ed. Michael P. Clark. Westport: Praeger, 2003.

Eliot, John (???-???). A Sermon, (Boston: Brother N. Willis, 1782), 13.

Emerson, Ralph Waldo. Emerson's Prose and Poetry. eds. Joel Porte and Saundra Morris. New York: W. W. Norton \& Co., 2001.

Epiphanius. The Panarion of Epiphanius of Salamis. trans. Frank Williams. in Nag Hammadi and Manichaean Studies. Vol. XXXVI. ed. J.M. Robinson \& H.J. Klimkeit. Leiden: Brill, 1994.

Firmin, Giles. Separation Examined. London: R. I., 1652.

Flavel, John. A New Compass for Seamen. London: 1664.

Foster, Hannah Webster. The Coquette. in William Hill Brown. The Power of Sympathy. ed. Carla Mulford. New York: Penguin, 1996.

Fox, George. A Journal or Historical Account of the Life. London: 1694.

Foxcroft, Thomas. A Funeral Sermon. in Cotton Mather. The Soul Upon the Wing. Boston: B. Green, 1722.

Franklin, Benjamin. "Philadelphia, April 11.” The Pennsylvania Gazette 11 Apr. 1751 (1165): 2.

---. The Autobiography of Benjamin Franklin. ed. Leonard W. Labaree, et al. New Haven, CT: Yale University Press, 2003.

Fullwood, Francis. The Church-History of Britain: The Tenth Book. London: 1655.

Gibbs, Henry. Bethany: or, The House of Mourning. Boston: T. Green, 1714.

Gleason, Benjamin. "Extracts of an Oration.” The Democrat 23 Aug. 1806 (III.68): 2.

Gore, Christopher. An Oration. Boston: 1783.

Grotius, Hugo. Adamus Exul. trans. Watson Kirkconnell. in Watson Kirkconnell. The Celestial Cycle. New York: Gordian Press, 1967.

---. The Rights of War and Peace: Book I. trans. Jean Barbeyrac. ed. Richard Tuck. Indianapolis: Liberty Fund, 2005. 
Hale, Sarah Josepha. "The Frontier House." as reprinted in Eastern Argus 18 July 1828 (IV.396): 1.

Hamilton, Alexander. "No. XV." in The Federalist. ed. Henry Cabot Lodge. New York: The Knickerbocker Press, 1902.

Harrington, James. The Commonwealth of Oceana. in The Political Works of James Harrington. ed. J. G. A. Pocock. Cambridge: Cambridge University Press, 1977.

Hawthorne, Nathaniel. The Blithedale Romance. New York: Penguin Books, 1983.

---. The House of the Seven Gables. New York: Signet Classic, 2001.

Hobbes, Thomas. Leviathan. ed. C. B. Macpherson. New York: Penguin Books, 1988.

Hooker, Thomas. The Danger of Desertion. London: G.M., 1641.

---. The Soules Preparation for Christ. London: 1632.

Higginson, Francis. Nevv-Englands Plantation. London: T. \& R. Cotes, 1630.

Higginson, John. A Direction for a Publick Profession in the Church Assembly. Cambridge: Samuel Green, 1665.

Hume, David. Political Essays. ed. Knud Haakonssen. Cambridge: Cambridge University Press, 2003.

Humphreys, David. "An ADDRESS to the Officers and Soldiers of the American Army, Concluded." The Massachusetts Centinel 11 Oct. 1786 (VI.7): 28.

Jefferson, Thomas. "Jefferson to Adams." 30 Aug. 1787. in The Adams-Jefferson Letters. ed. Lester J. Cappon. Chapel Hill: The University of North Carolina Press, 1959.

---. "The Declaration of Independence as Originally Reported to Congress." as reprinted in Jay Fliegelman. Declaring Independence. Stanford: Stanford University Press, 1993.

Johnson, Edward. A History of New-England. London: 1653.

Keith, Israel. A Charge. Boston: N. E., 1780.

Kidd, Thomas. The Great Awakening. New Haven: Yale University Press, 2007.

Lee, Samuel. The Joy of Faith. Boston: Samuel Green, 1687.

Levett, Christopher. A Voyage Into New England. London: William Iones, 1630. 
Lewis, Oliver. An Oration. Hartford: Hudson and Goodwin, 1783.

Locke, John. Two Treatises of Government and A Letter Concerning Toleration. ed. Ian Shapiro. New Haven: Yale University Press, 2004.

Madison, James. "Address by Mr. Madison." American Advocate and Kennebec Advertiser 29 Aug. 1818 (IX.33): 2.

Magaw, Samuel. A Sermon, Preached in Christ-Church, Dover. Philadelphia: David C.

Claypoole, 1781

Marrant, John. A Sermon Preached on the $24^{\text {th }}$ Day of June 1789. Boston: Thomas and John Fleet, 1789.

Mather, Cotton. Magnalia Christi Americana. ed. Thomas Robbins. Vols. 1 \& 2. Hartford: Silas Andrus and Son, 1855.

---. Psalterium Americanum. Boson: S. Kneeland, 1718.

---. Small Offers Towards the Service of the Tabernacle in the Wilderness. Boston: R. Pierce, 1689.

---. The Angel of Bethesda. ed. Gordon W. Jones. Barre: American Antiquarian Society and Barre Publishers, 1972.

---. The Wonders of the Invisible World. Boston: Benj. Harris, 1692.

Mather, Increase. A Call from Heaven to the Present and Succeeding Generations. Boston: John Foster, 1679.

---. Pray for the Rising Generation. Boston: John Foster, 1679.

---. Some Important Truths Concerning Conversion. Boston: Samuel Green, 1684.

---. The Life and Death of that Reverend Man of God, Mr. Richard Mather. Cambridge: S.G. and M.J., 1670.

---. The Mystery of Christ Opened and Applied. Boston: Richard Pierce, 1686.

Mather, Richard. The Summe of Certain Sermons Upon Genes: 15.6. Cambridg: Samuel Green, 1652.

Matlack, T. Mason's Lodge, September $9^{\text {th }}$, 1777. Philadelphia: Robert Bell, 1777.

Milton, John. Complete Poems and Major Prose. ed. Merritt Y. Hughes. Indianapolis: Hackett Publishing, 2003. 
Morrell, William. New-England. London: I. D., 1625.

Morton, Thomas. New English Canaan. ed. Jack Dempsey. Scituate: Digital Scanning, 1999.

Mourt, G. Relation. London: Iohn Bellamie, 1622.

Norton, John. The Heart of N-England Rent at the Blasphemies of the Present Generation. Cambridge: Samuel Green, 1659.

---. The Orthodox Evangelist. London: John Macock, 1654.

Oakes, Urian. New-England Pleaded With. Cambridge: Samuel Green, 1673.

---. The Soveraign Efficacy of Divine Providence. Boston: 1682.

Olcott, Bulkley. Righteousness and Peace, the Way to Be Acceptable to God, and Approved of Men. Windsor: Hough and Spooner, 1783.

Oldenburg, Henry. Letter to John Winthrop Jr., Mar. 18, 1671. in Proceedings of the Massachusetts Historical Society. Vol. 16. Boston: Massachusetts Historical Society, 1878.

Otis, James. The Rights of the British Colonies Asserted and Proved. Boston: Edes and Gill, 1764.

Owenson, Sydney. The Wild Irish Girl. as excerpted in "London and Dublin Contrasted." The Guardian 6 Feb. 1808 (I.12): 48.

Poe, Edgar Allan. Collected Works. ed. Thomas Ollive Mabbott. Cambridge, MA: Harvard University Press, 1978.

Poyen, Charles. Progress of Animal Magnetism in New England. New York: Da Capo Press, 1982.

Preble, Geo. Henry. Origin and History of the American Flag. Philadelphia: Nicholas L. Brown, 1917.

Preston, John. The Cvppe of Blessing. in The Saints Qualification. London: R. B., 1633.

Ralegh, Walter. The Works of Sir Walter Ralegh, Kt. Vol. II. ed. William Oldys and Thomas Birch. Oxford: Oxford University Press, 1829.

Rowlandson, Mary. "The Sovereignty \& Goodness of God." in Puritans in the New World. ed. David D. Hall. Princeton: Princeton University Press, 2004.

Rowson, Susanna. Charlotte Temple. ed. Ann Douglas. New York: Penguin Books, 1991. 
Scottow, Joshua. A Narrative of the Planting of the Massachusetts Colony. Boston: Benjamin Harris, 1694.

Selden, John. Of the Dominion or Ownership of the Sea. trans. Marchamont Nedham. London: William Du-Gard, 1652.

Sewall, Samuel. The Selling of Joseph. Boston: Bartholomew Green and John Allen, 1700.

Shakespeare, William. Macbeth. ed. William C. Carroll. Boston: Bedford Books, 1999.

---. The Taming of the Shrew. ed. Frances E. Dolan. Boston: Bedford Books, 1996.

Shepard, Thomas. "John Trumbull." in Puritans in the New World. Ed. David D. Hall. Princeton: Princeton University Press, 2004.

---. The Clear Sun-Shine of the Gospel Breaking Forth Upon the Indians in New-England. in John Eliot. The Eliot Tracts. ed. Michael P. Clark. Westport: Praeger, 2003.

---. The Confessions. in God's Plot. ed. Michael McGiffert. Amherst: The University of Massachusetts Press, 1994.

---. The Parable of the Ten Virgins Opened \& Applied. London: J. Hayes, 1660.

---. The Sincere Convert. London: T.P. and M.S., 1641.

--. The Sound Beleever. London: 1645.

---. Theses Sabbaticae. London: T. R. and E. M., 1749.

Shepard Jr., Thomas. Eye-Salve. Cambridge: Samuel Green, 1673.

Smith, Charles. An Oration. Philadelphia: 1788.

Smith, John. Captain John Smith: Writings with Other Narratives of Roanoke, Jamestown, and the First English Settlement of America. ed. James Horn. New York: Library of America, 2007.

Sprat, Thomas. The History of the Royal Society of London. London: Printers to the Royal Society, 1667.

Stiles, Ezra. An Oration. Westminster: Judah P. Spooner, 1782.

Stoddard, Solomon. An Appeal to the Learned. Boston: B. Green, 1709.

---. The Doctrine of Instituted Churches. London: 1700. 
Stowe, Harriet Beecher. The Minister's Wooing. ed. Susan K. Harris. New York: Penguin Books, 1999.

Taylor, Edward and Solomon Stoddard. Edward Taylor vs. Solomon Stoddard: The Nature of the Lord's Supper. eds. Thomas M. \& Virginia L. Davis. Boston: Twayne Publishers, 1981.

Taylor, Edward. Edward Taylor's Gods Determinations and Preparatory Meditations. ed. Daniel Patterson. Kent: The Kent State University Press, 2003.

---. Edward Taylor's “Church Records” and Related Sermons. eds. Thomas M. \& Virginia

L. Davis. Boston: Twayne Publishers, 1981.

Taylor, Nathaniel. "Concio ad Clerum: A Sermon.” in Sydney E. Ahlstrom, ed. Theology in America. Indianapolis: Hackett, 1967.

Thompson, George. My Life: Or the Adventures of Geo. Thompson. in Venus in Boston and Other Tales of Nineteenth-Century City Life. ed. David S. Reynolds and Kimberly R.

Gladman. Amherst, MA: University of Massachusetts Press, 2002.

Thorowgood, Thomas. Ievves in America. London: W. H., 1650.

Trumbull, John. "Canto First, or the Town Meeting." M’Fingal: A Modern Epic Poem. Philadelphia: William and Thomas Bradford, 1775.

Tryon, Thomas. The Way to Health, Long Life and Happiness. London: T. Carruthers, 1697.

Turner, Robert. Paracelsus. London: 1657.

Twisse, William. "Fourth Letter to Mr. Mede." in Joseph Mede. Works. London: James Flesher, 1664.

Varnum, James M. An Oration. Providence: John Carter, 1779.

von Pufendorf, Samuel. Of the Law of Nature and Nations. trans. Basil Kennet. Clark: The Lawbook Exchange, 2004.

Ward, Nathaniel. "Mercury shew'd Apollo, Bartas Book." in Anne Bradstreet. The Complete Works of Anne Bradstreet. eds. Joseph R. McElrath, Jr. and Allan P. Robb. Boston: Twayne Publishers, 1981.

Warren, John. A Charge. in John Eliot. A Sermon. Boston: Brother N. Willis, 1782.

Weld, Thomas. "To His Former Parishioners at Terling." in Puritans in the New World. ed. David D. Hall. Princeton, NJ: Princeton University Press, 2004. 
Wheeler, Bennett, ed. The Young Mason's Monitor. Providence: 1791.

White, John. The Planters Plea. London: William Iones, 1630.

Wigglesworth, Michael. "God's Controversy with New England." in Proceedings of the Massachusetts Historical Society. Boston: Massachusetts Historical Society, 1873.

---. Meat Out of the Eater. Cambridge: S.G. and M.J., 1670.

---. The Day of Doom. Tucson: American Eagle, 1991.

Willard, Samuel. A Briefe Account of a Strange \& Unusuall Providence of God. ed. Samuel A. Green. in Groton in the Witchcraft Times. ed. Samuel A. Green. Groton: University Press, 1883.

---. A Compleat Body of Divinity. Boston: B. Green and S. Kneeland, 1726.

Williams, Elisha. The Essential Rights and Liberties of Protestants. Boston: S. Kneeland and T. Green, 1744.

Williams, Roger. A Key into the Language of America. ed. John J. Teunissen and Evelyn J. Hinz. Detroit: Wayne State University Press, 1973.

Winslow, Edward. Good Nevves from New-England. London: I. D., 1624.

Winthrop, John. "A Modell of Christian Charity." in Winthrop Papers. Vol. 2. ed. Stewart Mitchell. Boston: Massachusetts Historical Society, 1931.

Winthrop Jr., John. “Indian Corne.” The New England Quarterly 10.1 (1937): 121-33.

---. Letter to Henry Oldenburg, Nov. 12, 1668. in Proceedings of the Massachusetts Historical Society. Vol. 16. Boston: Massachusetts Historical Society, 1878.

---. Letter to Robert Boyle, Nov. 3 1663. in Proceedings of the Massachusetts Historical Society. Vol. 16. Boston: Massachusetts Historical Society, 1878.

---. Letter to Robert Moray, Aug. 18, 1668. in Proceedings of the Massachusetts Historical Society. Vol. 16. Boston: Massachusetts Historical Society, 1878.

---. Letter to Samuel Hartlib, Dec. 16 1659. in "Some Correspondence of John Winthrop, Jr., and Samuel Hartlib." Proceedings of the Massachusetts Historical Society. Vol. 72. Boston: Massachusetts Historical Society, 1957-60.

Wise, John. A Vindication of the Government of New-England Churches. Boston: J. Allen, 1717. 
Wood, William. Nevv Englands Prospect. London: Tho. Cotes, 1634.

\section{$\underline{\text { Anonymously- and Corporately-Authored Primary Sources }}$}

"A New Song. Hail Americans." The Massachusetts Spy: Or, American Oracle of Liberty 2 Nov. 1780 (X.495): 3.

A Treatise of New England. London: 1643.

“Acrostic.” The Gazette of the United States 12 Aug. 1789 (XXXV): 138.

"All Ye that Love the Joys of Peace." Falmouth Gazette and Weekly Advertiser 14 Jan. 1786 (II.55): 4.

Americanus. “Philadelphia, May 9.” The Pennsylvania Gazette 9 May 1751 (1169): 2.

“An Elegy.” The Federal Gazette, and Philadelphia Evening Post 13 Mar. 1790: 3.

"An Essay on the Means of Promoting Federal Sentiments in the United States, by a Foreign Spectator." The Independent Gazeteer 4 Sep. 1787 (VI.540): 2.

“Anniversary Ode, for July 4, 1788.” The New-Hampshire Spy 22 Jul. 1788 (IV.26): 104.

At a Convention of Delegates from the Following Lodges of Ancient Free and Accepted Masons. Charlestown: 1785.

“Baker's Fight.” The Farmers' Cabinet 17 Oct. 1829 (28.6): 1.

Cambridge Synod. A Platform of Church Discipline Gathered Out of the Word of God. Cambridge: S.G., 1649.

Camillus. "In Our Last Speculation." The Independent Chronicle and the Universal Advertiser 8 Mar. 1787 (XIX.958): 1.

“Congress the Bank and the People No IV.” Weekly Aurora 14 Dec. 1818 (IX.XLIII): 338.

Council for New England. An Historicall Discoverie and Relation of the English Plantations in Nevv England. London: Iohn Bellamie, 1627.

“Fascinating Power of Snakes.” Connecticut Mirror 2 Dec. 1822 (XIV.24): 2.

“Fascinating Serpents.” The Weekly Recorder 21 Aug. 1818 (V.2): 14.

"Federal Sacred Ode." The Herald of Freedom, and the Federal Advertiser, 18 Sep. 1788 (I.ii): 8. 
"Fellow Citizens." Washington Federalist 14 Aug. 1801 (I.138): 3.

"First and Last Sacrifice." New-Hampshire Sentinel 30 Oct. 1829 (XXXI.44): 1.

“From Paine's Geographical Extracts.” The Washingtonian 2 Oct. 1810 (II.87): 1.

"From the (Staunton) Republican Farmer." Federal Republican 4 Apr. 1815 (IX.1210): 2.

“From the Ulster Gazette.” The Spectator 31 Aug. 1803 (VI.634): 1.

Harrington., "Federal Politicks." American Herald 15 Oct. 1787 (VII.314): 3.

Harrington. "For the Independent Chronicle." The Independent Chronicle 5 Feb. 1789 (XXI.1048): 2.

Harrington. "To the Freemen of the United States." The Independent Gazeteer 30 May 1787 (VI:457): 3.

"Indian Genius." Daily National Intelligencer 21 Aug. 1816 (IV.1129): 3.

“Join or Die." The Pennsylvania Gazette 9 May 1754 (1324): 2.

"Judge Bowen." Commercial Advertiser 10 May 1804 (VII.2041): 3.

L. G. S. “Commemorative Ode.” Massachusetts Centinel 14 Jun. 1788 (IX.26): 104.

"Matters and Things in General." Newburyport Herald 25 Mar. 1823 (XXVI.103): 2.

"Miscellany." Hancock Gazette 24 Aug. 1820 (I.8): 1.

“Miscellany." The Farmers' Cabinet 20 July 1838 (36.47): 1.

“Natural History.” Eastern Argus 15 Nov. 1824 (I.14): 1.

New Englands First Fruits. London: R. O. and G. D., 1643.

“Oration.” Columbian Centinel 9 Oct. 1793 (XX.9): 1.

"Political." Northern Whig 14 Feb. 1809 (I.7): 1.

"Power of Serpents." City Gazette and Daily Advertiser 30 Aug. 1797 (XV.3144): 2

"South Carolina Opinions of the Colonization Society." Daily National Journal 20 Jan. 1831 (VII.4021): 2.

“Speculations of Dectus.” New-York Spectator 7 June 1806 (IX.886): 1-2. 
The Bible in Miniature. New York: A. Brower Jun., 1791.

“The Citizen.” American Citizen and General Advertiser 19 Dec. 1801 (II.549): 2.

“The following Toast is...” The Patriot 11 Apr. 1803 (I.7): 2.

“The Gazette. 'Be Just-And Fear Not."” Concord Gazette 14 Jan. 1812 (5.33): 3.

"The Sham-Patriot Unmasked." The Post-Boy, and Vermont \& New-Hampshire Federal Courier 8 Oct. 1805 (I.41): 324.

"The Surveying Department of the City of Washington. Columbian Centinel 5 Oct. 1793 (XX.8): 2.

To Marry an Indian. ed. Theresa Strouth Gaul. Chapel Hill: The University of North Carolina Press, 2005.

"To the Great — the Warlike—the United—the Independent Americans!" The Freemen's Journal: or, the North-American Intelligencer 30 Mar. 1785 (IV.206): 3.

“Translated for the Newport Herald.” Newport Herald 27 Aug. 1789 (III.131): 1.

"When, in the very hot-bed..." The Argus 16 Sep. 1791: 3.

\section{Secondary Sources}

Adair, Douglass. Fame and the Founding Fathers. New York: Norton, 1974.

Adams, Willi Paul. The First American Constitutions. trans. Rita and Robert Kimber. Chapel Hill: The University of North Carolina Press, 1979.

Albanese, Denise. New Science, New World. Durham: Duke University Press, 1996.

Albrecht, Roberta J. Using Alchemical Memory Techniques for the Interpretation of Literature. Lewiston: The Edwin Mellen Press, 2008.

Almond, Philip. Adam and Eve in Seventeenth-Century Thought. Cambridge: Cambridge University Press, 1999.

Amory, Hugh and David D. Hall, eds. A History of the Book in America, Vol. I. The Colonial Book in the Atlantic World. Cambridge: Cambridge University Press, 2000.

Anderson, Benedict. Imagined Communities. New York: Verso, 1991. 
Bailyn, Bernard. Pamphlets of the American Revolution, 1750-1776. Cambridge: Belknap Press of Harvard University Press, 1965.

Ball, Bryan. A Great Expectation. Leiden: Brill, 1975.

Bamborough, J. B. The Little World of Man. Darvey: Arden Library, 1980.

Barbour, Reid. Literature and Religious Culture in Seventeenth-Century England. New York: Cambridge University Press, 2002.

Bauer, Ralph. The Cultural Geography of Colonial American Literatures. New York: Cambridge University Press, 2003.

Baym, Nina. "Revising the Legacy of 1970s Feminist Criticism." Constance Fenimore Woolson's Nineteenth Century: Essays. ed. Victoria Brehn. Detroit: Wayne State University Press, 2001. 21-29.

Beer, Samuel H. To Make a Nation. Cambridge: The Belknap Press of Harvard University, 1993.

Bellin, Joshua David. “'A Little I Shall Say': Translation and Interculturalism in the John Eliot Tracts." in Reinterpreting New England Indians and the Colonial Experience. eds. Colin G. Calloway and Neal Salisbury. Publications of the Colonial Society of Massachusetts. Vol. 71. Boston: The Colonial Society of Massachusetts, 2003.

Bercovitch, Sacvan. "Cotton Mather Against Rhyme: Milton and the Psalterium Americanum," American Literature 39.2 (1967): 191-93.

---. The American Jeremiad. Madison: University of Wisconsin Press, 1978.

---. The Puritan Origins of the American Self. New Haven: Yale University Press, 1975.

Blackstock, Carrie Galloway. "Anne Bradstreet and Performativity: Self-Cultivation, SelfDeployment." Early American Literature 32.3 (1997): 222-48.

Blake, John B. Public Health in the Town of Boston, 1630-1822. Cambridge: Harvard University Press, 1959.

Blitzer, Charles. An Immortal Commonwealth. New Haven: Yale University Press, 1960.

Bloch, Chana. Spelling the Word: George Herbert and the Bible. Berkeley: University of California Press, 1985.

Boose, Lynda. "Scolding Brides and Bridling Scolds: Taming the Woman's Unruly Member." Shakespeare Quarterly 42.2 (1991): 179-213. 
Boschman, Robert. In the Way of Nature. Jefferson: McFarland \& Company, 2009.

Bozeman, Theodore Dwight. To Live Ancient Lives. Chapel Hill: University of North Carolina Press, 1988.

Braude, Anne. "Faith, Feminism, and History." in The Religious History of American Women. ed. Catherine A. Brekus. Chapel Hill: The University of North Carolina Press, 2007.

Breitwieser, Mitchell Robert. Cotton Mather and Benjamin Franklin: The Price of Representative Personality. Cambridge: Cambridge University Press, 1984.

Brooks, Douglas A. "'Ill-Matching Words and Deeds Long Past': Englished Hebrew and 'the Readmission of the Jews' in Paradise Lost." Philological Quarterly 81.2 (2002): 53-80.

Brown, Gillian. The Consent of the Governed. Cambridge: Harvard University Press, 2001.

Brown, Matthew P. The Pilgrim and the Bee. Philadelphia: University of Pennsylvania Press, 2007.

Brown, Montague. Restoration of Reason. Grand Rapids: BakerAcademic, 2006.

Brumm, Ursula. "The 'Tree of Life' in Edward Taylor's Meditations." Early American Literature 3.2 (1968): 72-87.

Bullock, Steven C. Revolutionary Brotherhood. Chapel Hill: University of North Carolina Press, 1996.

Burnham, Michelle. Folded Selves. Hanover: University Press of New England, 2007.

Burnley, David. "Lexis and Semantics." in The Cambridge History of the English Language. ed. Norman Blake. Vol. 2. Cambridge, UK: Cambridge University Press, 1992.

Butler, Jon. Awash in a Sea of Faith. Cambridge: Harvard University Press, 1990.

Caldwell, Patricia. The Puritan Conversion Narrative. Cambridge: Cambridge University Press, 1983.

Cañizares-Esguerra, Jorge. Puritan Conquistadors. Stanford: Stanford University Press, 2006.

Carroll, Peter N. Puritanism and the Wilderness. New York: Columbia University Press, 1969.

Chaplin, Joyce. Subject Matter. Cambridge: Harvard University Press, 2001. 
Clausen, Henry C. Masons Who Helped Shape Our Nation. Washington: Masonic Service Association, 1976.

Cohen, Charles Lloyd. God's Caress. New York: Oxford University Press, 1986.

Corcoran, Mary Irma. Milton's Paradise with Reference to the Hexameral Background. Washington, D.C.: Catholic University of America Press, 1945.

Cornelius, Paul. Languages in Seventeenth and Early Eighteenth-Century Imaginary Voyages. Geneva: Librarie Droz, 1965.

Cosgrove, Eugene Milne. Letters to a Disciple 1935. Chicago: Gerson B. Deutsch, 1935.

Craig, Raymond A. "The 'Peculiar Elegance' of Edward Taylor' Poetics.” in The Tayloring Shop. ed. Michael Schuldiner. Newark: University of Delaware Press, 1997.

Cronon, William. Changes in the Land. New York: Hill and Wang, 1983.

Davis, J. C. Utopia and the Ideal Society. Cambridge: Cambridge University Press, 1981.

Davis, Thomas Marion. A Reading of Edward Taylor. Newark: University of Delaware Press, 1992.

Dawson, Hugh J. "John Winthrop's Rite of Passage: The Origins of the 'Christian Charitie' Discourse.” Early American Literature 26.3 (1991): 219-31.

Delbanco, Andrew. The Puritan Ordeal. Cambridge, MA: Harvard University Press, 1989.

Dillon, Elizabeth Maddock. The Gender of Freedom. Stanford: Stanford University Press, 2004.

---. "The Original American Novel, or, The American Origin of the Novel." in A Companion to the Eighteenth-Century English Novel and Culture. eds. Paula R. Backscheider and Catherine Ingrassia. Malden, MA: Blackwell Publishing, 2005.

Ditmore, Michael G. "Bliss Lost, Wisdom Gained: Contemplating Emblems and Enigmas in Anne Bradstreet's 'Contemplations." Early American Literature 42.1 (2007): 31-72.

Dolan, Frances E. Introduction. William Shakespeare. The Taming of the Shrew. ed. Frances E. Dolan. Boston: Bedford Books, 1996.

Douglas, Ann. The Feminization of American Culture. New York: The Noonday Press, 1998.

Downs, Michael. James Harrington. Boston: Twayne Publishers, 1977.

Duffy, John. From Humors to Medical Science. Urbana: University of Illinois Press, 1993. 
Egan, Jim. Authorizing Experience. Princeton: Princeton University Press, 1999.

Elliott, Emory. American Colonial Writers, 1606-1734. Detroit: Gale Research, 1984.

---. "New England Puritan Literature." in The Cambridge History of American Literature.

Vol. 1. ed. Sacvan Bercovitch. Cambridge: Cambridge University Press, 1994.

Entzminger, Robert L. Divine Word. Pittsburgh: Duquesne University Press, 1985.

Errikla, Betsy. "Franklin and the Revolutionary Body." English Literary History 67.3 (2000): $717-41$

Evans, J. Martin. Milton's Imperial Epic. Ithaca: Cornell University Press, 1996.

---. Paradise Lost and the Genesis Tradition. Oxford: Clarendon Press, 1968.

Ferguson, A. B. The Articulate Citizen and the English Renaissance. Durham: Duke University Press, 1965.

Fessenden, Tracy, Nicholas F. Radel, and Magdalena J. Zaborowska, eds. The Puritan Origins of American Sex. New York: Routledge, 2001.

Fetterly, Judith. “'My Sister! My Sister!': The Rhetoric of Catharine Sedgwick's Hope Leslie." American Literature 70.3 (1998): 491-516.

Fiering, Norman. Jonathan Edwards's Moral Thought and Its British Context. Chapel Hill: The University of North Carolina Press, 1981.

---. "President Samuel Johnson and the Circle of Knowledge." The William and Mary Quarterly 28.2 (1971): 199-236.

Firth, Katharine R. The Apocalyptic Tradition in Reformation Britain. Oxford: Oxford University Press, 1979.

Fischer, Avery. "Bradstreet's 'On my Dear Grandchild Simon Bradstreet and 'Before the Birth of One of Her Children." Explicator 59.1 (2000): 11-14.

Fixler, Michael. Milton and the Kingdoms of God. London: Faber and Faber, 1964.

Fliegelman, Jay. Prodigals and Pilgrims. Cambridge: Cambridge University Press, 1982.

Floyd-Wilson, Mary. English Ethnicity and Race in Early Modern Drama. Cambridge, UK: Cambridge University Press, 2003. 
Ford, Worthington C. "New Englands First Fruits." in Proceedings of the Massachusetts Historical Society. Vol. XLIII. Boston: Massachusetts Historical Society, 1909. 259-66.

---. The Boston Book Market. Boston: The Club of Odd Volumes, 1917.

Foster, Stephen. The Long Argument: English Puritanism and the Shaping of New England Culture, 1570-1700. Chapel Hill: The University of North Carolina Press, 1991.

Fryer, Judith. The Faces of Eve. New York: Oxford University Press, 1978.

Fukuda, Arihiro. Sovereignty and the Sword. Oxford: Clarendon Press, 1997.

Giles, Paul. "Antipodean American Literature: Franklin, Twain, and the Sphere of Subalternity.” American Literary History 20.1-2 (2008): 22-50.

Godbeer, Richard. Sexual Revolution in Early America. Baltimore: Johns Hopkins University Press, 2002.

Golinski, Jan. "American Climate and the Civilization of Nature." in Science and Empire in the Atlantic World. ed. James Delbourgo and Nicholas Dew. New York: Routledge, 2008.

Gordon, Charlotte. Mistress Bradstreet. New York: Little, Brown and Company, 2005.

Gordon-Grube, Karen. "Evidence of Medicinal Cannibalism in Puritan New England: 'Mummy' and Related Remedies in Edward Taylor's 'Dispensatory." Early American Literature 28.3 (1993): 185-221.

Gould, Philip. “The New Early American Anthology.” Early American Literature 38.2 (2003): 305-17.

Gray, Edward G. New World Babel. Princeton: Princeton University Press, 1999.

Green, Ian. The Christian's ABC: Catechisms and Catechizing in England c. 1530-1740. Oxford: Clarendon Press, 1996.

Greven, Philip J. Four Generations. Ithaca: Cornell University Press, 1970.

Gribben, Crawford. The Puritan Millennium. Milton Keynes: Paternoster, 2008.

Gura, Philip. American Transcendentalism: A History. New York: Hill and Wang, 2007.

---. Jonathan Edwards: America's Evangelical. New York: Hill and Wang, 2005.

---. The Crossroads of American History and Literature. University Park: Pennsylvania State University Press, 1996. 
Hagger, Nicholas. The Secret Founding of America. London: Watkins Publishing, 2007.

Haigh, Christopher. The Plain Man's Pathways to Heaven. Oxford: Oxford University Press, 2007.

Halbert, Cecelia L. "Tree of Life Imagery in the Poetry of Edward Taylor." American Literature 38.1 (1966): 22-34.

Hale, John K. Milton's Languages. Cambridge: Cambridge University Press, 1997.

Hall, David D., ed. Introduction. Puritans in the New World. Princeton: Princeton University Press, 2004.

---. The Faithful Shepherd. Chapel Hill: The University of North Carolina Press, 1972.

---. Worlds of Wonder, Days of Judgment. New York: Knopf, 1989.

Hall, Manly Palmer. America's Assignment With Destiny. New York: Philosophical Research Society, 1951.

Hambleton, Else L. Daughters of Eve. New York: Routledge, 2004.

Hambrick-Stowe, Charles E. The Practice of Piety. Chapel Hill: The University of North Carolina Press, 1982.

Hamilton, Kristie. "An Assault on the Will: Republican Virtue and the City in Hannah Webster Foster's The Coquette." Early American Literature 24.3 (1989): 135-51.

Hamilton, Schuyler. History of the National Flag of the United States of America. Philadelphia: Lippincott, Grambo, and Co., 1852.

Hamlin, Hannibal. Psalm Culture and Early Modern English Literature. Cambridge: Cambridge University Press, 2004.

Hammond, Jeffrey A. Sinful Self, Saintly Self. Athens: The University of Georgia Press, 1993.

Haraszti, Zoltán. The Enigma of the Bay Psalm Book. Chicago: The University of Chicago Press, 1956.

Harrison, Peter. The Fall of Man and the Foundations of Science. Cambridge: Cambridge University Press, 2007.

Harvey, Tamara. Figuring Modesty in Feminist Discourse Across the Americas, 1633-1700. Burlington: Ashgate, 2008. 
---. “'Now Sisters...Impart your Usefulness and Force': Anne Bradstreet's Feminist

Functionalism in The Tenth Muse (1650)." Early American Literature 35.1 (2000): 5-28.

Hatch, Nathan. The Democratization of American Christianity. New Haven: Yale University Press, 1989.

Heimert, Alan and Andrew Delbanco, eds. The Puritans in America. Cambridge: Harvard University Press, 1985.

Hensley, Jeannine. Introduction. Anne Bradstreet. The Works of Anne Bradstreet. ed. Jeannine Hensley. Cambridge: The Belknap Press of Harvard University, 1967.

Hiltner, Ken. Introduction. Renaissance Ecology. ed. Ken Hiltner. Pittsburgh: Duquesne University Press, 2008.

Hindmarsh, D. Bruce. The Evangelical Conversion Narrative. Oxford: Oxford University Press, 2005.

Holifield, E. Brooks. The Covenant Sealed. New Haven: Yale University Press, 1974.

---. Theology in America. New Haven: Yale University Press, 2003.

Holland, Matthew S. Bonds of Affection. Washington D.C: Georgetown Unviersity Press, 2007.

Hornberger, Theodore. "Puritanism and Science: The Relationship Revealed in the Writings of John Cotton." The New England Quarterly 10.3 (1937): 503-15.

Howell, Wilbur Samuel. Logic and Rhetoric in England, 1500-1700. Princeton: Princeton University Press, 1956.

Hudson, Elizabeth K. "The Plaine Mans Pastor: Arthur Dent and the Cultivation of Popular Piety in Early Seventeenth-Century England." Albion 25.1 (1993): 23-36.

Huet, Pierre Daniel. "De optimo genere interpretandi." in Translation, History, Culture. ed. André Lefevere. New York: Routledge, 1992.

Hullen, Werner. A History of Roget's Thesaurus: Origins, Development, and Design. New York: Oxford University Press, 2004.

Hunt, Gaillard. The History of the Seal of the United States. Washington D.C: Department of State, 1909.

Hurst, Richard M. "Snakelore Motifs in the Writings of J. Hector St. John de Crevecoeur and Other Colonial Writers.” New York Folklore Quarterly 9.3-4 (1983): 55-97. 
Hussey, Maurice. "Arthur Dent's 'Plaine Mans Path-Way to Heaven."” The Modern Language Review 44.1 (1949): 26-34.

Hutchins, Zachary. "Edwards and Eve: Finding Feminist Strains in the Great Awakening's Patriarch," Early American Literature 43.3 (2008): 671-86.

Johnson, Barbara A. Reading Piers Plowman and The Pilgrim's Progress. Carbondale: Southern Illinois University Press, 1992.

Jones, Alice Eley. "Sacred Places and Holy Ground: West African Spiritualism at Stagville Plantation." in Keep Your Head to the Sky. ed. Grey Gundaker. Charlottesville: University Press of Virginia, 1998.

Jue, Jeffrey K. Heaven Upon Earth. Dordrecht: Springer, 2006.

Kadir, Djelal. Columbus and the Ends of the Earth. Berkeley: University of California Press, 1992.

Kerber, Linda K. "Separate Spheres, Female Worlds, Woman's Place: The Rhetoric of Women's History." The Journal of American History 75.1 (1988): 9-39.

Kimnach, Wilson H. "Preface to the New York Period." in Jonathan Edwards. The Works of Jonathan Edwards. Vol. 10. Sermons and Discourses 1720-1723. ed. Wilson H. Kimnach. New Haven: Yale University Press, 1992.

Kittredge, George L. "Cotton Mather's Election into the Royal Society." in Publications of the Colonial Society of Massachusetts. Vol. XIV. Boston: The Colonial Society of Massachusetts, 1913. 81-114.

Knight, Janice. Orthodoxies in Massachusetts. Cambridge: Harvard University Press, 1994.

Kroll, Richard W. F. The Material Word. Baltimore, MD: The Johns Hopkins University Press, 1991.

Kupperman, Karen Ordahl. "Fear of Hot Climates in the Anglo-American Colonial Experience." The William and Mary Quarterly 41.2 (1984): 213-40.

---. "Presentment of Civility: English Reading of American Self-Presentation in the Early Years of Colonization." The William and Mary Quarterly 54.1 (1997): 193-228.

LaPlante, Eve. American Jezebel. San Francisco: HarperSanFrancisco, 2004.

Leepson, Marc. Flag. New York: St. Martin’s Press, 2005.

Leonard, John. Naming in Paradise. Oxford: Clarendon Press, 1990. 
Levenda, Peter. The Secret Temple. New York: Continuum, 2009.

Leventhal, Herbert. In the Shadow of the Enlightenment. New York: New York University Press, 1976.

Lewalski, Barbara Kiefer. "Milton's Paradises." in Renaissance Ecology. ed. Ken Hiltner. Pittsburgh: Duquesne University Press, 2008.

---. Protestant Poetics and the Seventeenth-Century Lyric. Princeton: Princeton University Press, 1979.

Lewis, R. W. B. The American Adam. Chicago: The University of Chicago Press, 1955.

Lewis, Rhodri. Language, Mind and Nature. Cambridge: Cambridge University Press, 2007.

Liljegren, S. B. Introduction. in Théodore Lesueur. A French Draft Constitution of 1792

Modelled on James Harrington's Oceana. ed. S. B. Liljegren. Acta Reg. Societatis

Humaniorum Litterarum Lundensis XVII; London: Oxford University Press, 1932.

Lindenbaum, Peter. Changing Landscapes. Athens: The University of Georgia Press, 1986.

Lockwood, Rose. "The Scientific Revolution in Seventeenth-Century New England." The New England Quarterly 53.1 (1980): 76-95.

Luciano, Dana. Arranging Grief. New York: New York University Press, 2007.

Lundin, Roger. From Nature to Experience. Lanham: Rowman \& Littlefield, 2005.

Lutes, Jean Marie. "Negotiating Theology and Gynecology: Anne Bradstreet's

Representations of the Female Body." Signs 22.2 (1997): 309-40.

Lynch, Kathleen. Writing from Experience. Book manuscript circulated in a Folger seminar on "Forms of Religious Experience in the 17th-Century British Atlantic World," February 2009.

Mack, Richard N. "Plant Naturalizations and Invasions in the Eastern United States." Annals of the Missouri Botanical Garden 90.1 (2003): 77-90.

Malcolmson, Cristina. Heart-Work. Stanford: Stanford University Press, 1999.

Mann, Charles C. 1491. New York: Alfred A. Knopf, 2005.

Marks, Herbert. "The Blotted Book." Re-Membering Milton. ed. Mary Nyquist and Margaret W. Ferguson. New York: Methuen, 1988.

Martz, Louis L. The Paradise Within. New Haven: Yale University Press, 1964. 
Matthews, Albert. "Comenius and Harvard College." in Publications of the Colonial Society of Massachusetts Vol. XXI. Boston: The Colonial Society of Massachusetts, 1920. 146-90.

McKay, David P. “Cotton Mather's Unpublished Singing Sermon.” The New England Quarterly 48.3 (1975): 410-22.

Miller, Greg. George Herbert's 'Holy Patterns.' New York: Continuum, 2007.

Miller, Perry. Errand into the Wilderness. Cambridge: Belknap Press of Harvard University Press, 1956.

---. The New England Mind: The Seventeenth Century. Cambridge: Harvard University Press, 1939.

Minkema, Kenneth P. "A Chronlogy of Edwards' Life and Writings." The Jonathan Edwards Center at Yale University. Accessed April 8, 2010.

http://edwards.yale.edu/files/JE\%20Chronology.pdf.

---. "Sacramental Theology and Conversion." in Jonathan Edwards. The Works of Jonathan Edwards. Vol. 14. Sermons and Discourses, 1723-1729. ed. Kenneth P. Minkema. New Haven: Yale University Press, 1997.

Morgan, Edward S. “The Puritans and Sex.” The New England Quarterly 15.4 (1942): 591607.

---. "Safety in Numbers: Madison, Hume, and the Tenth Federalist." Huntington Library Quarterly 49 (1986): 95-112.

Morison, Samuel Eliot. Harvard College in the Seventeenth Century. Cambridge: Harvard University Press, 1936.

---. Introduction. William Bradford. Of Plymouth Plantation. ed. Samuel Eliot Morison. New York: Alfred A. Knopf, 2003.

---. The Founding of Harvard College. Cambridge: Harvard University Press, 1935.

---. Three Centuries of Harvard. Cambridge: Harvard University Press, 1936.

Morris, Amy. "The Art of Purifying: The Bay Psalm Book and Colonial Puritanism." Early American Literature 42.1 (2007): 107-30.

Morris, William Sparkes. The Young Jonathan Edwards. Brooklyn: Carlson Publishing, 1991. 
Mullett, Charles F. Fundamental Law and the American Revolution. New York: Columbia University Press, 1933.

Murphy, Daniel. Comenius. Portland: Irish Academic Press, 1995.

Mustazza, Leonard. “Such Prompt Eloquence.” Lewisburg: Bucknell University Press, 1988.

Nevalainen, Terttu. "Early Modern English Lexis and Semantics." in The Cambridge History of the English Language. ed. Roger Lass. Vol. 2. Cambridge: Cambridge University Press, 1999.

New, Elisa. The Regenerate Lyric. New York: Cambridge University Press, 1993.

---. "Variety as Religious Experience: The Poetics of the Plain Style." Religion and Literature 38.1 (2006): 9-25.

Nicholls, Steve. Paradise Found. Chicago: The University of Chicago Press, 2009.

Nichols, Heidi L. Anne Bradstreet. Philipsburg: P\&R Publishing, 2006.

Nicolson, Adam. God's Secretaries. New York: HarperCollins, 2003.

Noll, Mark A. America’s God. Oxford: Oxford University Press, 2002.

Nuttall, Geoffrey. The Holy Spirit in Puritan Faith and Experience. Chicago: University of Chicago Press, 1992.

O'Gorman, Edmundo. The Invention of America. Bloomington: Indiana University Press, 1961.

Passmore, John. The Perfectibility of Man. New York: Charles Scribner's Sons, 1971.

Paster, Gail Kern. Humoring the Body. Chicago: University of Chicago Press, 2004.

---. The Body Embarrassed. Ithaca: Cornell University Press, 1993.

Pearce, Roy Harvey. The Continuity of American Poetry. Princeton: Princeton University Press, 1961.

Peter, Hugh. Good Work for a Good Magistrate. London: William Du-Gard, 1651.

Pettit, Norman. Editor's Introduction. in Jonathan Edwards. An Account of the Life of the Reverend Mr. David Brainerd. in The Works of Jonathan Edwards. Vol. 7. The Life of David Brainerd. ed. Norman Pettit. New Haven: Yale University Press, 1984.

Pocock, J. G. A. The Machiavellian Moment. Princeton: Princeton University Press, 1975. 
Porterfield, Amanda. Female Piety in Puritan New England. New York: Oxford University Press, 1992.

Potter, Alfred C. "Catalogue of John Harvard's Library." in Publications of the Colonial Society of Massachusetts. Vol. XXI. Boston: The Colonial Society of Massachusetts, 1920.

Powell, Timothy B. Ruthless Democracy. Princeton: Princeton University Press, 2000.

Prest, John. The Garden of Eden. New Haven: Yale University Press, 1981.

Quaise, Milo M. Melvin J. Weig, and Roy E. Appleman. The History of the United States Flag. New York: Harper \& Row, 1964.

Ramsey, Paul. Editor's Introduction. to Jonathan Edwards. The Works of Jonathan Edwards. Vol. 1. Freedom of the Will. ed. Paul Ramsey. New Haven: Yale University Press, 1957.

Raven, James. "The Importation of Books in the Eighteenth Century." in A History of the Book in America. Vol. I. The Colonial Book in the Atlantic World. eds. Hugh Amory \& David D. Hall. Cambridge: Cambridge University Press, 2000.

Rich, Adrienne. Foreword. in The Works of Anne Bradstreet. ed. Jeannine Hensley. Cambridge, MA: The Belknap Press of Harvard University Press, 1967.

Ricks, Christopher B. Milton's Grand Style. Oxford: Clarendon Press, 1963.

Robinson, Douglas. American Apocalypses. Baltimore: Johns Hopkins University Press, 1985.

Rosenmeier, Jesper. "New England's Perfection: The Image of Adam and the Image of Christ in the Antinomian Crisis." The William and Mary Quarterly 27.3 (1970): 435-59.

Russell, Howard S. A Long, Deep Furrow. Hanover: University Press of New England, 1976.

Rust, Marion. "What's Wrong with Charlotte Temple?" The William and Mary Quarterly 60.1 (2003). Accessed 27 Jan. 2010. http://www.historycooperative.org/cgibin/justtop.cgi?act=justtop\&url=http://www.historycooperative.org/journals/wm/60.1/rust.ht $\mathrm{ml}$.

Ruttenberg, Nancy. Democratic Personality. Stanford: Stanford University Press, 1998.

Sanford, Charles L. The Quest for Paradise. Urbana: University of Illinois Press, 1961.

Scafi, Alessandro. Mapping Paradise. London: The British Library, 2006. 
Scheick, William J. Design in Puritan American Literature. Lexington: University Press of Kentucky, 1992.

---. "Typology and Allegory: A Comparative Study of George Herbert and Edward Taylor." Essays in Literature 2.1 (1975): 76-86.

Schoenfeldt, Michael. Bodies and Selves in Early Modern England. Cambridge: Cambridge University Press, 1999.

---. Prayer and Power. Chicago: University of Chicago Press, 1991.

Schweitzer, Ivy. The Work of Self-Representation. Chapel Hill, NC: The University of North Carolina Press, 1991.

Scott, Jonathan. Commonwealth Principles. Cambridge: Cambridge University Press, 2004.

Sellers, M. N. S. American Republicanism. Washington Square: New York University Press, 1994.

Sensabaugh, George F. Milton in Early America. Princeton: Princeton University Press, 1964.

Shawcross, John T. "Some Colonial American Poetry and George Herbert." Early American Literature 23.1 (1988): 28-51.

Shea, Jr., Daniel B. Spiritual Autobiography in Early America. Princeton: Princeton University Press, 1968.

Shields, David S. Oracles of Empire. Chicago: The University of Chicago Press, 1990.

---. "Herbert and Colonial American Poetry: Then Shall Religion to America Flee." in Like Season'd Timber: New Essays on George Herbert. eds. Edmund Miller and Robert DiYanni. New York: Peter Lang, 1987. 281-96.

Shuger, Deborah K. Sacred Rhetoric: The Christian Grand Style in the English Renaissance. Princeton, NJ: Princeton University Press, 1988.

Skinner, Quentin. Liberty Before Liberalism. Cambridge: Cambridge University Press, 1998.

Slotkin, Richard. Regeneration Through Violence. Middletown: Wesleyan University Press, 1973.

Sluyter, Andrew. Colonialism and Landscape. Lanham: Rowman \& Littlefield Publishers, 2002. 
Smith, H. F. Russell. Harrington and His Oceana. Cambridge: Cambridge University Press, 1914.

Smolinski, Reiner. "Apocalypticism in Colonial North America." The Encyclopedia of Apocalypticism. Vol. 3. ed. Stephen J. Stein. New York: Continuum, 1998.

---. General Introduction. The Kingdom, the Power, \& the Glory. ed. Reiner Smolinski. Dubuque: Kendall/Hunt, 1998.

---. Introduction. Cotton Mather. The Threefold Paradise of Cotton Mather. ed. Reiner Smolinski. Athens: The University of Georgia Press, 1995.

Spengemann, William. A New World of Words. New Haven: Yale University Press, 1994.

Stanford, Ann. Anne Bradstreet. New York: Burt Franklin, 1974.

Stein, Stephen J. "Note on the Manuscripts." in Jonathan Edwards. The Works of Jonathan Edwards. Vol. 15. Notes on Scripture. ed. Stephen J. Stein. New Haven: Yale University Press, 1998.

Still, William T. New World Order. Lafayette: Huntingdon House, 1990.

Stockwell, Robert and Donka Minkova. English Words: History and Structure. Cambridge: Cambridge University Press, 2001.

Summers, Joseph. George Herbert. Cambridge: Harvard University Press, 1954.

Swaim, Kathleen M. Pilgrim's Progress, Puritan Progress. Urbana: University of Illinois Press, 1993.

Sweeney, Douglas A. Nathaniel Taylor, New Haven Theology, and the Legacy of Jonathan Edwards. Oxford: Oxford University Press, 2003.

Sweet, Timothy. American Georgics. Philadelphia: University of Pennsylvania Press, 2002.

Syse, Henrik. Natural Law, Religion, and Rights. South Bend: St. Augustine's Press, 2007.

Tennenhouse, Leonard. "Revisiting A New World of Words." Early American Literature 42.2 (2007): 363-68.

Terrell, Colleen. "'Republican Machines': Franklin, Rush, and the Manufacture of Civic Virtue in the Early Republic.” Early American Studies 1.2 (2003): 100-32.

Thorpe, Douglas. A New Earth: The Labor of Language in Pearl, Herbert's Temple, and Blake's Jerusalem. Washington, D.C.: The Catholic University of America Press, 1991. 
Tichi, Cecilia. New World, New Earth. New Haven: Yale University Press, 1979.

Todorov, Tzvetan. The Conquest of America. trans. Richard Howard. New York: Harper \& Row, 1984.

Tompkins, Jane P. Sensational Designs. Oxford, Eng: Oxford University Press, 1985.

Toulouse, Teresa. The Art of Prophesying. Athens: The University of Georgia Press, 1987.

Traxel, William L. Footprints of the Welsh Indians. New York: Algora, 2004.

Tuck, Richard. The Rights of War and Peace. Oxford: Oxford University Press, 2001.

Tuveson, Ernest Lee. Millennium and Utopia. Berkley: University of California Press, 1949.

---. Redeemer Nation. Chicago: University of Chicago Press, 1968.

Ulrich, Laurel Thatcher. Good Wives. New York: Oxford University Press, 1983.

Walska, Ganna. Always Room at the Top. New York: R. R. Smith, 1943.

Warner, Michael. The Letters of the Republic. Cambridge, MA: Harvard University Press, 1990.

Watson, Patricia A. The Angelical Conjunction. Knoxville: The University of Tennessee Press, 1991.

Wear, Andrew. Knowledge \& Practice in English Medicine, 1550-1680. Cambridge:

Cambridge University Press, 2000.

Webster, Charles. The Great Instauration. London: Duckworth, 1975.

Weinberger, J., ed. Introduction. to Francis Bacon. The Great Instauration and The New Atlantis. Arlington Heights: Harlan Davidson, 1980.

Weisberger, R. William. "Parisian Masonry, the Lodge of the Nine Sisters, and the French Enlightenment." Heredom 10 (2002): 155-202.

Werge, Thomas. "The Tree of Life in Edward Taylor's Poetry: The Sources of a Puritan Image." Early American Literature 3.3 (1968): 199-204.

White, Ed. “Crèvecœur in Wyoming." Early American Literature 43.2 (2008): 379-407.

White, Elizabeth. Anne Bradstreet. New York: Oxford University Press, 1971.

White, James Boyd. 'This Book of Starres,' Ann Arbor: The University of Michigan Press, 
1994.

Whitney, Charles. "Bacon and Herbert: Bacon and Herbert as Moderns." in Like Season'd Timber: New Essays on George Herbert. ed. Edmund Miller and Robert DiYanni. New York: Peter Lang, 1987. 231-40.

Williams, Arnold. The Common Expositor. Chapel Hill: The University of North Carolina Press, 1948.

Williams, George. Wilderness and Paradise in Christian Thought. New York: Harper \& Brothers, 1962.

Wilson, Douglas. Beyond Stateliest Marble. Nashville: Highland Books, 2001.

Winship, Michael P. "Godly Republicanism and the Origins of the Massachusetts Polity." The William and Mary Quarterly 63.3 (2006). Accessed 27 Jan. 2010.

$<\mathrm{http}: / / \mathrm{www} \cdot$ historycooperative.org/cgi-

bin/justtop.cgi?act=justtop\&url=http://www.historycooperative.org/journals/wm/63.3/winshi p.html>.

Wolfe, Eric A. "Ventriloquizing Nation: Voice, Identity, and Radical Democracy in Charles Brockden Brown's Wieland." American Literature 78.3 (2006): 431-57.

Woodward, Walter W. Prospero's America. Chapel Hill: University of North Carolina Press, 2010.

Worden, Blair. "James Harrington and 'The Commonwealth of Oceana,' 1656." in Republicanism, Liberty, and Commercial Society, 1649-1776. ed. David Wooton. Stanford: Stanford University Press, 1994.

Wreck, Andrew J. "Natural Law in American Revolutionary Thought." The Review of Metaphysics 30.4 (1977): 686-714.

Wright, Jr., Benjamin Fletcher. American Interpretations of Natural Law. New York: Russell \& Russell, 1962.

Wright, Nancy E. "Epitaphic Conventions and the Reception of Anne Bradstreet's Public Voice." Early American Literature 31.3 (1996): 243-63.

Zim, Rivkah. English Metrical Psalms. Cambridge: Cambridge University Press, 1987. 